Universidad Politécnica de Valencia

Facultad de Bellas Artes

Departamento de Conservación y Restauración de Bienes Culturales

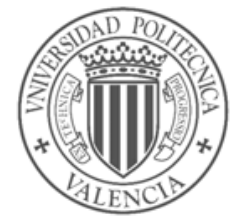

\title{
La creación contemporánea además de la materialidad. \\ Los artistas y los límites en la conservación y restauración del arte contemporáneo.
}

Tesis doctoral presentada en el Departamento de Conservación y Restauración de Bienes Culturales de la Universidad Politécnica de Valencia

Programa: Conservación y Restauración del Patrimonio Pictórico

Doctoranda Joana Cristina Moreira Teixeira

Directora de tesis Rosario Llamas Pacheco 

Aos mais novos da família, Pedro e André. Que tenham a oportunidade de conhecer a arte de hoje tal como é, e que a desfrutem tanto quanto eu.

Aos meus pais, por fazerem da arte um ingrediente na minha vida. 



\section{Agradecimientos}

Sin margen para dudas, el primer e inmenso obrigada está dirigido a mis padres que desde siempre me mostraron que existían otros mundos si cruzase la frontera; a ellos un verdadero obrigada por haberme enseñado a luchar y creer en algo tan imperceptible como la fuerza, acompañada de aquel fuerte abrazo que siempre ha estado presente desde mi primer viaje a Valencia hace 5 años.

Agradezco a la Universidad Politécnica de Valencia, a la Dra. Pilar Roig y al Departamento de Conservación y Restauración de Bienes Culturales, y en especial a mi orientadora Dra. Rosario Llamas Pacheco por acompañar y apoyar mis ideas y por su paciencia con mi castellano. A sus alumnos de los años lectivos, 2004/05, 2005/06 y 2006/07 por haber dispensado parte del material que necesité para realizar el estudio estadístico presente en esta investigación.

Mi expreso agradecimiento a la Fundação para a Ciencia e Tecnología, del Ministerio para a Ciencia, Tecnología e Ensino Superior del Governo Portugués, que ha financiado y confiado en este proyecto durante 4 años.

A los artistas plásticos portugueses y también amigos que se mostraron orgullosos de participar en esta investigación, cediendo todo el material e información que fue solicitado. A Ana Cardoso, a Carlos Mesquita, a Isaque Pinheiro, a João Pedro Rodrigues y a Rui Pedro Fonseca muchas gracias.

Otros fueron los abrazos y eternos apoyos que tanto agradezco, a mi hermana Raquel que siempre rompió los momentos de más cansancio, a mis abuelos, Emilia y Agostinho por su orgullo, a mi especial amigo Domingos Jorge por su entusiasmo y fe. 
Los amigos siempre nos traen en sus brazos y en especial agradezco a Antonio Fernando por su comprensión, saber y cómo no a su grandiosa experiencia en este mundo del patrimonio.

Agradezco igualmente a todos los amigos y familia -y que orgullosamente puedo decir que llenaba esta página si fuera a nombrarlos a todos- que creyeron en mi perseverancia, sin olvidar especialmente a Ana, Sofia, Maria, Ana Vasques y Ernesto que vivieron y se alegraran como si de su recorrido se tratase.

Al Instituto Valenciano de Arte Moderna, el IVAM y más concretamente al Departamento de Restauración por darme la oportunidad de desarrollar, durante tres meses, prácticas de restauración y participar de la realidad a la cual estaba vinculada teóricamente, y sin más, un especial agradecimiento a Isabel Alvaréz e a Isidro Sabater por la amistad y la ayuda primordial en las correcciones lingüísticas.

No puedo dejar de agradecer a la Dra. Eduarda Moreira que me animó a dar el primer paso hacía esta lucha, y a Dra. Carolina Barata que fue mi primera profesora de conservación/restauración y que tanto admiro por su rigor y ética profesional.

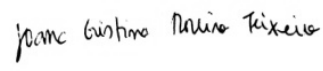

Valencia, Junio de 2009 


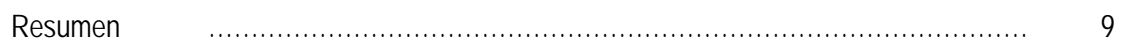

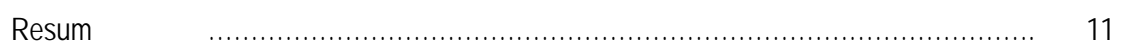

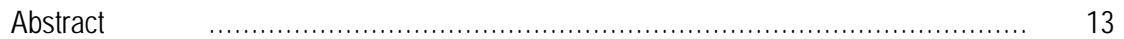

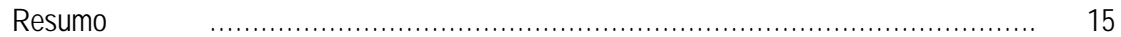

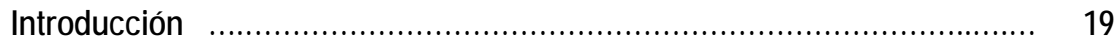

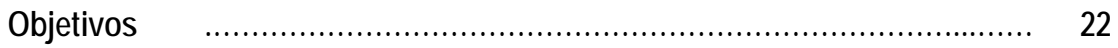

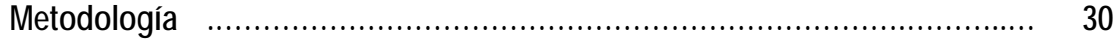

Capítulo I El arte y el artista: concepto y entorno............................ 33

1. Los antecedentes del arte contemporáneo: relación arte y artista a lo largo de la historia............................................. 37

1.1. La Revolución Francesa, el Siglo XIX y las Guerras Mundiales...... 37

1.2. El artista como el agente de la ruptura con la tradición.............. 56

1.3. El mercado del arte.................................................. 73

2. Lo aparente y lo oculto como contenidos de la creación artística... 81

2.1. La idea y la materia de las obras de arte contemporáneo............ 81

2.2. Lo efímero y la temporalidad en el arte contemporáneo.............. 97

\section{Capítulo II La herencia teórica de la conservación/restauración ante la} creación artística contemporánea.................................... 101

1. La teoría como base fundamental para la práctica y desarrollo de la conservación/restauración

1.1. La creación y evolución de la disciplina de conservación/restauración.

1.2. La Teoria del Restauro en el contexto del arte contemporáneo......

2. La nueva visión y noción de las creaciones contemporáneas

2.1. Lo efímero y la temporalidad de la idea versus materia: sus repercusiones en la conservación/restauración

3. El poder persuasivo del mercado del arte y las exposiciones temporales

Capítulo III Las normas jurídicas y su papel en la conservación/restauración del arte contemporáneo

1. El artista además de la creación. 
1.1. Derecho de autor y la Ley de Propiedad Intelectual.

1.1.1. Reseña histórica, convenciones y tratados internacionales 208

1.2. Los creadores visuales como autores................................ 215

1.2.1. Selección de artículos del Texto Refundido de la Ley de Propiedad Intelectual............................................ 219

1.2.1.1. Comentarios a los artículos seleccionados......... 221

1.3. Aspectos jurídicos de la relación autor y propietario................... 228

2. La obra como Patrimonio cultural y artístico........................ 234

2.1. La protección legal para los bienes culturales......................... 234

2.1.1. Constitución Española........................................... 238

2.1.2. Ley del Patrimonio Histórico Español............................. 240

2.1.2.1. Artículos seleccionados............................... 242

3. La conservación/restauración..................................... 246

3.1. Las Cartas de Restauro, convenciones y directrices internacionales........................................................... 249

Capítulo IV La realidad artística y la práctica actual......................... 257

1. Trabajo de campo y estudio estadístico ........................... 261

1.1. Nota introductoria.................................................... 261

1.2. Objetivos y metodología............................................ 263

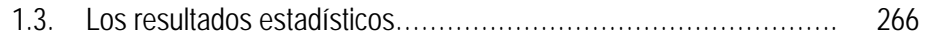

1.4. Conclusiones del estudio ......................................... 275

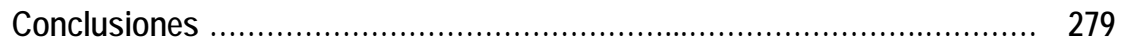

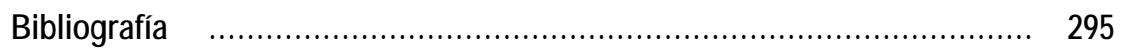

Arte: historia, artistas y mercado ..................................... 297

Conservación, restauración y patrimonio............................... $\quad 305$

Leyes y normas jurídicas............................................. 314

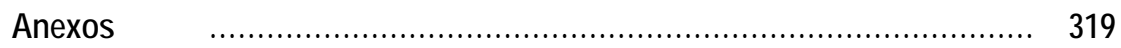

Entrevista a cinco artistas plásticos portugueses...................... 321

Ana Cardoso................................................................ 322

Carlos Mesquita.......................................................... 326

Isaque Pinheiro................................................................... 333

João Pedro Rodrigues..................................................... 337

Rui Pedro Fonseca........................................................ 341

Índice de figuras ......................................................................... 347 


\section{Resumen}

El panorama del arte contemporáneo, además de estar compuesto por una diversidad infinita de manifestaciones y creaciones artísticas heterogéneas, polifacéticas y provocadoras jugando con los conceptos de temporalidad y efímero, de idea versus materia, entre lo que es aparente y oculto, se revela a través de varios agentes culturales y sociales inevitables para su pleno desarrollo como son el mercado del arte y sus maniobras comerciales. En este contexto coexiste la disciplina de la conservación/restauración, la cual tendrá que aportar e imponer normativas profesionales y criterios éticos ante factores que parecen contradecir la lógica de una actividad guiada teóricamente pero que a veces parece perder aliento ante tan avasalladoras creaciones. ¿Cuál es el papel del artista y cuáles los límites de su actividad en la conservación/restauración de su obra?, es sin duda la cuestión principal sobre la cual la presente investigación se desarrolla, con el fuerte deseo de encontrar una respuesta concreta. Por ello, ha sido fundamental estudiar los contextos históricos, sociales y culturales de la disciplina de conservación/restauración, así como percibir los cambios en el contexto artístico y la entidad del artista, agregando un punto innovador y aún poco desarrollado, pero que se cree esencial para establecer los límites, a través de las normativas legales y la distinta legislación para cada campo de acción. Con el objetivo de dignificar una profesión y de percibir los cambios generados a lo largo del siglo XX, se pone en evidencia la Teoría de la Restauración, el documento que estableció durante varios años los fundamentos de la actividad de conservación/restauración y a través del cual se podrá también orientar la actividad para la compleja y diversificada conservación/restauración del arte contemporáneo. 



\section{Resum}

El panorama de l'art contemporani, a més d'estar compost per una diversitat infinita de manifestacions i creacions artístiques heterogènies, polifacètiques i provocadores jugant amb els conceptes de temporalitat i efímer, d'idea versus matèria, entre el que és aparent i ocult, es revela a través de diversos agents culturals i socials inevitables per al seu ple desenvolupament com són el mercat de l'art i les seves maniobres comercials. En aquest context coexisteix la disciplina de conservació/restauració, la qual tindrà d'aportar i imposar normatives professionals i criteris ètics davant factors que semblen contradir la lògica d'una activitat guiada teòricament però que a vegades sembla perdre alè davant tan avassalladores creacions. Quin és el paper de l'artista i quins els límits de la seva activitat en la conservació/restauració de la seva obra?, és sens dubte la qüestió principal sobre la qual la present investigació es desenvolupa, amb el fort desig de trobar una resposta concreta. Per això, ha estat fonamental estudiar els contextos històrics, socials i culturals de la disciplina de conservació/restauració, així com percebre els canvis en el context artístic i l'entitat de l'artista, agregant un punt innovador i encara poc desenvolupat, però que es creu essencial per establir els límits, a través de les normatives legals i la diferent legislació per a cada camp d'acció. Amb l'objectiu de dignificar una professió i de percebre els canvis generats al llarg del segle XX, es posa en evidència la Teoria de la Restauració, el document que va establir durant diversos anys els fonaments de l'activitat de conservació/restauració i a través del qual es podrà també orientar l'activitat per a la complexa i diversificada conservaciólrestauració de l'art contemporani. 



\begin{abstract}
The overview of contemporary art, besides to be made up of an infinite diversities to manifestations and heterogeneous, multifaceted and provocative artistic creations playing with the concepts of temporary and ephemeral, of idea versus matter, between which it is apparent and hidden, is revealed through several inevitable cultural and social agents for its total development as the art market and its commercial maneuvers. In this context the conservation/restoration discipline coexists, which will have to contribute and impose professional norms and ethical criterions before factors that, theoretically, seem to contradict the logic of a guided activity but that sometimes it seems to lose breath before such overwhelming creations. Which is the role of the artist and which are the limits of his activity in the conservation/restoration at his work?, without any doubt, this is the main question which the present investigation develops, with the strong desire to find an concrete answer. For that reason, it was fundamental to study the historical, social and cultural contexts of the conservation/restoration discipline, as well as to understand the changes in the artistic context and the entity of the artist. It has also been added an innovator point which remains undeveloped, but that are believed to be essential to establish those limits, through legal norms and different legislation for each subject field. With the goal of bringing dignity to a job and understanding the changes generated throughout century $\mathrm{XX}$, evidence is given to the Theory of the Restoration, the document that has established, during several years, the foundations of the activity of conservation/restoration and that enables one to be oriented through the complex and diversified conservation/restoration of the contemporary art.
\end{abstract}





\section{Resumo}

O panorama da arte contemporânea, além de estar composto por uma diversidade inifinita de manifestações e criações artísticas heterogênas, polifacéticas e provocadoras jogando com os conceitos de temporalidade e efémero, de idea versus matéria, entre 0 aparente e 0 oculto, revela-se através de vários agentes culturais e sociais inevitavéis para o seu pleno desenvolvimento como são o mercado da arte e as suas manobras comerciais. Neste contexto coexiste a disciplina de conservação/restauro, a qual terá de aportar e impor normativas professionais e critérios éticos perante factores que parecem contradizer a lógica de uma actividade guiada teoricamente, mas que por vezes parece perder alento frente a tão avasaladoras criações. Qual é o papel do artista e quais são os limites na actividade de conservação/restauro da sua obra?, é sem dúvida a questão principal sobre a qual a presente investigação se desenvolve, com o forte desejo de encontrar uma resposta concreta. Como tal, foi fundamental estudar os contextos históricos, sociais e culturais da disciplina de conservação/restauro, assim como perceber as mudanças no contexto artístico e sobre a entidade de artista, acrescentando um ponto inovador e ainda pouco desenvolvido, mas que se crê essencial para establecer tais limites, através das normativas legais e da distinta legislação para cada campo de acção. Com o objectivo de dignificar uma profissão e perceber as mudanças geradas ao longo do século XX, evidencia-se a Teoría de Restauro, o documento que estableceu durante vários anos os fundamentos da actividade de conservação/restauro e através do qual se poderá orientar a actividade para a complexa e diversificada conservação/restauro da arte contemporânea. 



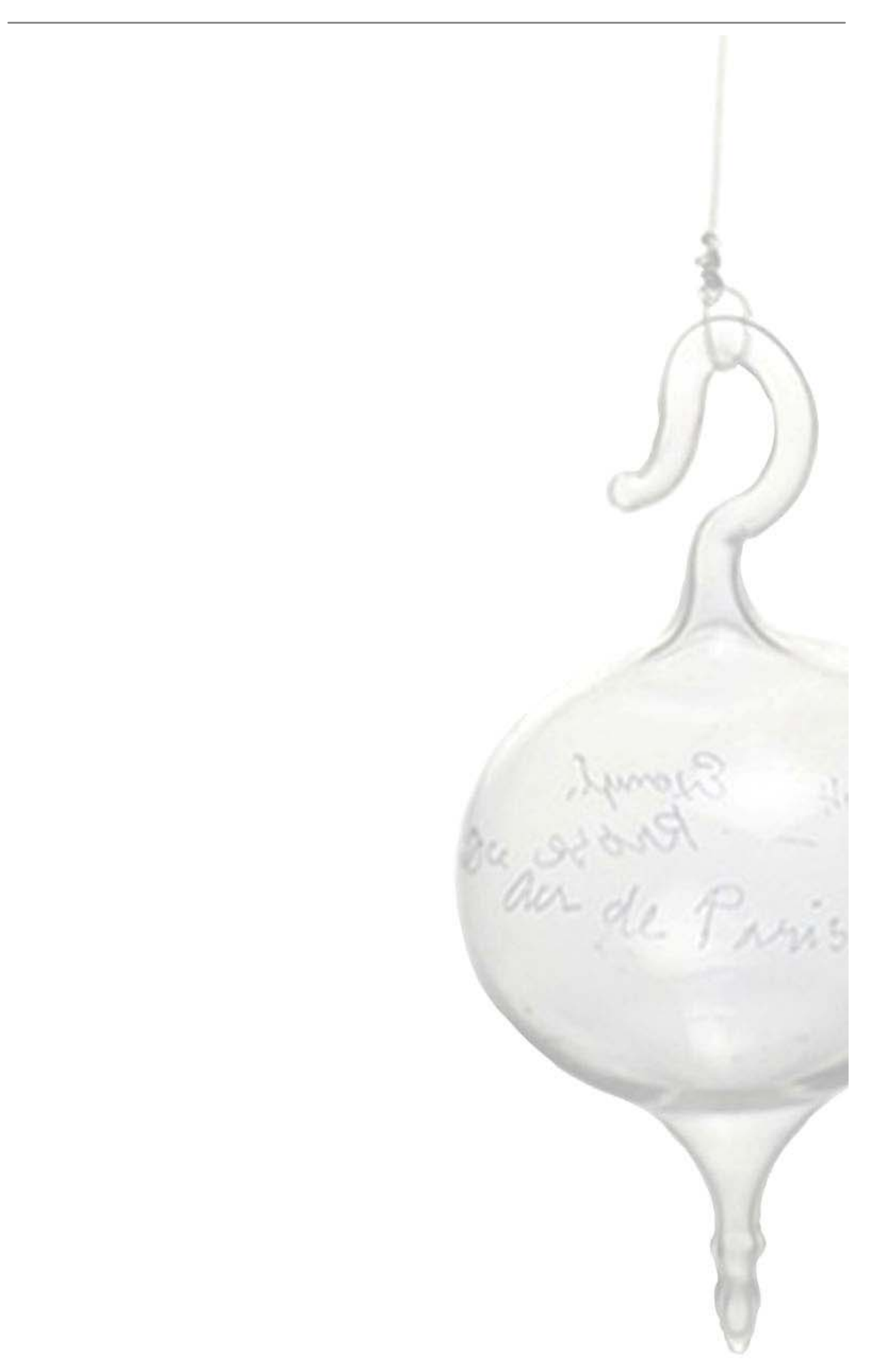



Introducción

Entre el renacimiento y la segunda mitad del siglo XIX, el mundo es conocido a través de su representación (su sujeto artístico es de conocimiento); entre el siglo XIX y el $X X$, el mundo es objeto de transformación y realización de la ficción (su sujeto artístico es el productor de realidad); en la actualidad, el mundo es ya objeto de administración para su consumo. Su sujeto artístico es el que consigue gestionar la realidad habiendo sido ésta realizada en sus imágenes. ${ }^{1}$

La historia, sea social, cultural o artística se desarrolla en base a los distintos valores que la componen, siguiendo un camino que muchas veces es cíclico. La historia del arte se construye a través de la formación de círculos viciosos, en una lucha constante, generalmente contra los valores y cánones vigentes. El arte contemporáneo traza, desde los años 60 un trayecto determinante, bajo influencias del pasado y oportunamente del presente, luchando contra corriente: se sobrentiende que cuanta más controvertida sea la lucha mejor será el resultado, hecho que muchas veces pierde fuerza. Mientras tanto su fundamento se deja llevar por varios factores externos, pero que inevitablemente se tornarán intrínsecos, interceptando los valores estéticos y artísticos, como el tan dominante mercado del arte. En estas pocas líneas se intuye el objetivo principal de la presente tesis doctoral, de título La creación contemporánea además de la materialidad. Los artistas y los limites en la conservación y restauración del arte contemporáneo, una investigación que subraya las influencias constantes y vigentes a lo largo de los siglos hasta llegar a las creaciones actuales.

La investigación nace cuando fue iniciado el Doctorado en Conservación y Restauración del Patrimonio Pictórico en la Universidad Politécnica de Valencia, y a lo

${ }_{1}^{1}$ PUELLES, Luis Romero. Entre imágenes: experiencia estética y mundo versátil, p.138. 
largo de cinco años con asumida dedicación se concreta la investigación como el medio para encontrar muchas de las cuestiones planteadas en la conservación y restauración del diversificado arte contemporáneo. Mientras tanto, la experiencia que forma y es parte de cada individuo está evocada en cada día de trabajo, y es uno de los medios, para que con la máxima claridad posible, se observen e interpreten correctamente las distintas realidades que existen en un determinado contexto y su alrededor. Por ello, es fundamental referir la anterior formación académica, una licenciatura en Artes Plásticas/Pintura, realizada en Portugal. Y se hace hincapié en este punto, por las distintas características de la trayectoria, tratándose de una formación totalmente dedicada a la práctica de la pintura además de un variado número de asignaturas, teóricas y prácticas, en que se señala hasta hoy el recuerdo de las clases de estética por su enorme contribución y apertura al cuestionamiento, fundamentales para la maduración y educación artística; pero sin olvidar que ésta, consistió en primera instancia en un recorrido completamente independiente de la formación de conservación y restauración. La formación posterior en el área de conservación/restauración junto a la experiencia académica vivida, fueron las primeras señales para vislumbrar la necesidad de establecer el puente entre las disciplinas de conservación/restauración y las artes plásticas.

La primera fase de esta investigación tuvo como punto de partida la realización del trabajo de investigación bajo el tema: inter-relación entre creación artística contemporánea y su conservación y restauración, con el título: el artista y su papel en la conservación del arte no convencional. Como objetivos principales, una primera aproximación a los criterios de intervención en las obras de arte contemporáneo, focalizar las relaciones entre la producción artística y la conservación/restauración y subrayar el papel del artista, los cambios conceptuales en el arte y consecuentemente en la conservación/restauración.

Todavía dos son las pasiones que sustentan este trabajo y que lo hicieron crecer poco a poco. Por un lado, el arte contemporáneo por sí mismo, que constituye un mundo fascinante. Su sinfín de propuestas no facilita su descripción y su definición. Se trata de obras atrevidas, provocadoras, inofensivas, arriesgadas, asumidas, tentadoras, contradictorias, desinteresadas, etc.... Pueden ser físicas, inmateriales, delicadas 0 
brutas. Pueden herir, aproximar, aislar, reflexionar, actuar... o simplemente, pueden ser miradas, observadas e interiorizadas. Pueden ser ese sinnúmero de sensaciones, cosas y formas, representaciones o ausencia de ellas, pero siempre serán algo perteneciente a alguien. Lo fueron del artista, son parte de él, y también forman parte de cada uno de nosotros. La otra pasión, el gusto por las teorías, y el deseo creciente de intentar percibir en profundidad las estructuras, las bases y los pilares que sustentan la actividad de la conservación/restauración, así como la entendida ética profesional. No obstante, algunos de los caminos podrán ser más agrestes, dejando de lado el más vivaz entusiasmo, pero del todo necesarios, cuando inevitablemente se tiene que encontrar la respuesta a la cuestión clave de la tesis ¿Cuáles son los límites en la actuación del artista para la conservación/restauración de su obra? Para ello, fue indispensable abordar un área desconocido y novedoso y recurrir a la legislación vigente y las normativas teóricas para la conservación/restauración de los bienes culturales.

Aún en el siglo XXI, se entrecruzan infinitas dudas y un elevado grado de incomprensión ante de las creaciones contemporáneas. Al final, ¿cómo entender tales manifestaciones? No es fácil dejarse seducir por un arte que rompe todos los estereotipos y que parece existir subordinado a la manipulación mercantil. Percibir un arte que parece andar a la deriva, con base en valores que no son característicos de la estética creativa tradicional, hace de la universalidad un factor fundamental, una puerta abierta sin presencia de límites, cosa que parece hacer de algo que ha muerto, algo más vivo que nunca. Sin duda es el mercado el regulador de los valores artísticos, que da voz a los artistas y que destaca unas creaciones más que otras. Estar en el interior del mercado es como "vivir en paz consagrada", donde el mundo del arte es más propiamente una maquina social y económica, y el arte en su última instancia, es más un valor económico que artístico. Pero, al final, ¿qué es lo que pretendemos de los objetos artísticos, de los bienes culturales? Aquí, inevitablemente, entra la conservación y restauración y todos los agentes que aseguran la materialidad e inmaterialidad de la vasta designación de Arte. 


\section{Objetivos}

Antes de presentar y desarrollar los objetivos para lo que fue propuesta esta investigación, existe la necesidad de ser consciente de dos premisas, y tener en cuenta que es una tesis totalmente teórica y que parte del camino está trazado en las líneas tangenciales de la historia del arte y de la estética. Si por un lado, en el Arte, teóricos y críticos intentan concretar una definición, reestructurando el concepto Arte; por otro, los artistas inician una incesante búsqueda de nuevas expresiones y lenguajes, con la intención de alcanzar nuevas experiencias. Pero es cierto que en los días de hoy la multiplicidad de acciones consideradas artísticas torna difícil encontrar una definición idónea, tal como afirma George Rickey: os artistas prosperaram, mas não se torna mais claro o que é arte². En contrapunto, la conservación/restauración es llevada a adaptarse a tal búsqueda y como consecuencia de la falta de objetividad del arte actual, desprovisto de su corolario tradicional, surge la necesidad de revisar su metodología y redefinir conceptos. En todo caso, la primera premisa es dejar explícito que ninguno de los objetivos propuestos tiene la intención de procurar y establecer una definición de arte 0 , con otras palabras, teniendo en cuenta el panorama contemporáneo, determinar lo que se entiende por obras de arte. Es dejada de lado esa cuestión, puramente retórica, en que simplemente son analizados los cambios conceptuales que nos ofrecen las nuevas propuestas artísticas introducidas desde el arte moderno hasta nuestros días, con determinadas consecuencias para la conservación/restauración. La segunda premisa, consiste en subrayar que evidentemente no es la disciplina de la conservación/restauración la que denomina el objeto de obra de arte, y como tal, todo lo que es tratado teóricamente en esta investigación está bajo ese reconocimiento social y cultural. El conservador/restaurador tiene la suerte de poseer una consciencia libre de conceptos predeterminados y definiciones incompletas, y el lujo de trabajar sobre objetos que ya llegarán al final del recorrido del reconocimiento: es más que un objeto debido al status adquirido en y por la sociedad, por su valor artístico, que no es establecido

2 George Rickey, Observações e refleções, 1964. en CHIPP, Herschel B. Teorias da Arte Moderna, p.599.

T. A.: ...los artistas prosperarán, pero no se torna más claro lo que es el arte. 
únicamente por su creador, pero en el interior del sistema del arte a través de los distintos agentes que intervienen en el mismo.

Además, se colocará en un segundo plano el delimitar de la terminología y la definición de la palabra contemporáneo, dado que sólo esta cuestión implicaría una reflexión historiográfica profunda y extensiva en la que no sería sencillo llegar a una conclusión. De cualquier forma, es un arte que se concreta en plena mitad del siglo XX donde los términos 'arte contemporáneo' se evidencian grandemente a partir de los años 60, siendo seguro que el arte producido en los años 70 ya está bien lejos de ser considerado un arte bajo la denominación de arte moderno. A pesar, de no haber todavía un límite riguroso de su presencia en la cronología, su denominación engloba el arte de ayer, de hoy y seguramente el de mañana, puesto que es algo vivo, en continuo devenir, y precisamente en estos mismos días, en estas mismas horas ${ }^{3}$, al cual se tendrán que añadir otras palabras del historiador y crítico de arte, Enrico Crispolti,

No es improbable que en un cierto momento se verifique algún cambio en el plano de la investigación, tal que haga que el arte que todavía consideramos "contemporáneo", razonablemente en su complejidad, se convierta únicamente en "arte del siglo XX". Y esto sucederá verosímilmente cuando nos sintamos ya, en un sentido nuevo, suficientemente instalados en una diversidad específica del siglo XXI. Hasta ahora no creo que sea posible cortar los puentes entre un hoy y un ayer de varios decenios, casi secular ya, considerados todavía como segmentos de la continuidad evolutiva de la fenomenología de lo contemporáneo. ${ }^{4}$

Cronológicamente, la investigación está centrada en la actividad artística del siglo XX hasta nuestros días, una vez que las cuestiones instaladas están subordinadas a los nuevos lenguajes y metodologías empleadas con mayor evidencia a partir de los años 60 , pero siempre teniendo en cuenta el contexto en que se crean y se desarrollan y con la conciencia de las varias revoluciones no sólo socio-cultural, sino también materiales. Como tal, en términos artísticos la primera referencia cronológica en esta investigación es dada por el Impresionismo, por el simple hecho de que este movimiento ha traído grandes cambios ideológicos.

${ }^{3}$ CRISPOLTI, Enrico. Cómo estudiar el arte contemporáneo, p.27.

${ }^{4}$ Ibídem. p.36. 
De esta forma, está trazado el principal objetivo: establecer un abordaje teórico para la práctica de la conservación/restauración del arte contemporáneo, pues en definitiva se opina fundamental la reflexión teórica y crítica necesaria para una práctica consistente y coherente. Todas las cuestiones planteadas a lo largo de esta tesis, tienen directa 0 indirectamente un enfoque práctico, y el deseo de estimular la discusión es desde luego fundamental debido a los obstáculos que las propias creaciones pueden presentar. No se cree que la conservación/restauración del arte contemporáneo sea un problema en sí mismo, sino un nuevo planteamiento. Si realmente se habla de problemática en la conservación/restauración del arte contemporáneo, ésta debería estar relacionada únicamente con la materialidad de las obras. O sea, no pueden ser considerados problemas, algunas de las características de las propias expresiones: la mutación, lo heterogéneo, la novedad, los materiales degradados, etc. Las expresiones contemporáneas son sin duda un abanico dispar de materialización, en que la diversidad de las acciones serán el centro de la actividad de conservación/restauración, y que se desarrollará bajo distintas perspectivas: pueden ser objetos comparados a las obras de arte tradicional; o objetos que crean y presentan nuevos cuestionamientos con la necesidad de adaptar los métodos, técnicas y materiales presentes en la conservación/restauración del arte tradicional, llegando a la introducción de nuevos métodos y técnicas; o por último, objetos que obligan a la creación de un nuevo concepto teórico de conservación/restauración, basado en la evolución conceptual e ideológica, tanto del arte como de la conservación/restauración y en el que es esencial el análisis profundo de la obra hasta el contacto con su creador.

Por ello, la presente tesis se divide en cuatro capítulos donde se desarrolla un planteamiento especifico de acuerdo con su área de acción, teniendo en cuenta que el arte contemporáneo lleva al estudio de diversas temáticas, en que de forma general se elabora un análisis teórico de todas las evoluciones de concepto que el arte ha vivido en el siglo XX y consecuentemente, el impacto que estas transformaciones y mutaciones, a niveles distintos, han tenido en la disciplina de la conservación/restauración. Es fundamentalmente una investigación teórica de la conservación/restauración del arte contemporáneo, pero para ello es esencial repasar 
algunos de los fenómenos socio-culturales y sus repercusiones, sin olvidar y subrayando que la teoría tiene un papel verdaderamente importante en una disciplina basada en la práctica.

En este sentido, el primer capítulo, de título, El arte y el artista: concepto y entorno, está únicamente dedicado a la contextualización de las creaciones contemporáneas, teniendo en cuenta las evoluciones sociales y culturales y todas las influencias que se tornan clave para entender el propio lenguaje de las obras, en el cual, la revolución francesa marca el inicio de la Edad Contemporánea. En paralelo a esta sintética aproximación del contexto histórico, es fundamental comprender el papel y desarrollo de la figura del artista, así el renacimiento marca la primera etapa en la historia occidental donde se tiene conciencia del pasado, adoptando medidas para tratar de recuperar 0 conservar muestras de tiempos más lejanos. Es evidente el papel reivindicativo del artista a lo largo de los siglos, y las grandes rupturas con el pasado, como claves para discernir la relación del artista con la sociedad, en que la individualización creativa, si por un lado desvirtúa los cánones artísticos, por otro presenta una digna representación del trabajo personal. Otros son los factores que se conjugan en el capítulo, como elementos fundamentales para que el mecanismo del arte funcione como una máquina bien afinada, como es el mercado del arte. Mientras tanto, el presente capítulo, aún tiene un segundo objetivo enteramente conectado al lenguaje expresivo, y que es determinante para comprender e interpretar las obras de arte contemporáneo. El estudio y análisis de conceptos como idea versus materia, efímero y temporalidad son determinantes para establecer el contacto y aproximarse correctamente a las heterogéneas creaciones contemporáneas.

El segundo capítulo, La herencia teórica de la conservación/restauración ante la creación artística, se presenta con el principal objetivo de comprender los índices teóricos de la disciplina de conservación/restauración, así como analizar conceptos y criterios de actuación. El siglo XIX fue fundamental para la disciplina de conservación y restauración, en que dos aspectos han favorecido especialmente la evolución en la conservación del patrimonio histórico y artístico: el respeto por la autenticidad o integridad de las obras, y la incorporación de las ciencias experimentales y la utilización del método científico en las intervenciones. A la par de estos fundamentos, 
se afirma que la conservación/restauración tiene obligatoriamente que regirse por una buena base teórica. Pero al final, ¿Cuáles son esas bases teóricas a las que todos se refieren?, ¿Cuáles son los procedimientos que llevan a restablecer la base teórica necesaria? Subrayando que con una base teórica se fundamenta la práctica de conservación/restauración, es evidente la necesidad de abordar las varias cuestiones que se plantean en el momento de intervenir una obra de arte contemporáneo, una vez que se es consciente de que muchas de las tipologías que pertenecen al contexto de este arte no se encuadran en las tenidas como artes tradicionales, asumiendo comportamientos y actitudes completamente novedosos.

Partiendo del principio de que todo lo que es subjetivo inquieta, existe constantemente la necesidad de definir normas y métodos, en que se impone la búsqueda de objetividad, de trazar un camino al encuentro de la realidad objetiva. Por ello, es defendida la imposibilidad de establecer una buena base teórica para la conservación/restauración del arte contemporáneo si no se parte de la buena teorización y profunda comprensión del mismo arte. Y como no, dejarse envolver por ese mundo fascinante que no siempre es tan complejo como parece visto de fuera 0 en un primer contacto. Es cierto que el arte contemporáneo plantea un abanico de cuestiones por su heterogeneidad material, pero ante todo, por su diversidad conceptual, donde se lucha con conceptos de autenticidad, originalidad e intención del artista.

En esta investigación es patente el deseo de encontrar respuestas, entre las cuales surge una directamente relacionada con los criterios teóricos de la disciplina de conservación/restauración. Si por un lado la disciplina de conservación/restauración está constituida por aspectos meramente técnicos, por otro existen los fundamentos teóricos, de los cuales se ocupará esta investigación, y que supuestamente justifican los anteriores. Comprenderla como ciencia implica ir mucho más allá de la intuición. Sabiendo que los valores presentes en la Teoría de la Restauración han sido la base para establecer criterios de actuación durante décadas, con la presencia del arte contemporáneo se debate su eficacia y ¿será que estos mismos criterios ya no son válidos para las creaciones del siglo XX y XXI? Cuestión para la cual hay intención de encontrar respuesta, pues parece fundamental establecer una normativa teórica o por 
lo menos un vínculo teórico en que se homogenicen criterios de intervención, o con otras palabras y de forma más práctica, ¿Cómo podíamos hacer frente a la fórmula de que si lo limpio es bello, más limpio es más bello y superlimpio es lo más bello de todo?5

Defiendo con ahínco que el arte contemporáneo, ante todas las cuestiones materiales y las diferencias que presenta comparado al arte tradicional, deberá ser visto bajo el concepto de que no todas las creaciones tendrán de ser restauradas, o sea, que no se debe analizar un objeto artístico partiendo del principio que éste tiene obligatoriamente que pasar por un proceso de restauración, porque no todos los objetos tienen que sobrevivir materialmente. Cada obra sigue un determinado deambular metodológico, en que la unicidad permanece en cada objeto creado, de singularidad expresiva y simbólica, con posible preservación 0 no, de su concretización material. El racionalizar es una forma de distanciarse de lo subjetivo, 0 mejor, en pura contradicción, el distanciamiento es uno de los caminos para la aproximación. Es imprescindible que en esta aproximación se evidencie el funcionamiento simbólico de cada obra de arte, para el cual el conservador/restaurador tiene como responsabilidad última, mantener la coherencia de la obra con base en ese ciclo vivo. Mirar la obra y percibirla como tal es la respuesta que se busca para la correcta, coherente y verdadera intervención de conservación/restauración, pensamiento que se intentará demostrar a lo largo de esta tesis, cuando el restaurador tiene que asegurar la durabilidad y la legitimidad de la obra y respetar la integridad y autenticidad de la misma. Además del estudio de las teorías para la restauración, este segundo capítulo se involucra en la comprensión de los conceptos esenciales del arte contemporáneo, demostrados anteriormente en el Capítulo I, que se refieren como fundamentales: la idea versus la materia; lo efímero y la temporalidad; el mercado de arte y las exposiciones temporales; además del profundo deseo de discernir conceptos como copia, imitación, réplica, facsímiles, múltiples, falsificación, reproducción, reconstrucción, repinte, restablecimiento y restitución, no sólo en el vocabulario del arte sino también fundamentalmente en el contexto de la conservación/restauración.

${ }^{5}$ BECK, James y DALEY, Michael. La restauración de obras de arte: Negocio, cultura, controversia y escándalo, p.215. 
En el tercer capítulo, Las normas jurídicas y su papel en la conservación/restauración del arte contemporáneo, se tornó fundamental su desarrollo en complemento de las cuestiones planteadas en esta investigación, a pesar de las dificultades que presenta por el escaso dominio del vocabulario jurídico. Sin embargo, es esencial analizar las condiciones legales de objetos tan valorados como los bienes culturales. Imposible de disociarlos del mundo de la especulación y del valor de consumo, el objetivo de este capítulo es establecer límites en la actuación del artista vivo ante la conservación y restauración de su obra. Sin duda, fue necesario recurrir a distintos dominios legislativos y atender a la dificultad de limitar el campo de acción. Es cierto que socialmente existe la necesidad de establecer normas jurídicas y parámetros legales de actuación, por el deseo de concretar comportamientos y acciones. Todavía, en respuesta a tal necesidad hay fundamentalmente que profundizar en determinados contextos y establecer planteamientos a los cuales se buscan respuestas concretas. En esta tesis, se parte de un planteamiento teórico para una solidificación práctica, para lo cual aún no hay seguridad cuanto a su eficacia, porque es objetivo acceder a un campo insípido de manifestaciones.

El cuarto y último capítulo, La realidad artística y la práctica actual, comporta un estudio estadístico, con el objetivo de concretar la realidad contemporánea de creación, 0 sea, aproximar las cuestiones prácticas de la expresión plástica a las teorías de la conservación/restauración. Con ello, se tiene la intención de presentar datos concretos sobre la realidad artística, para encontrar posibles respuestas para las actuaciones en la conservación/restauración. Como toda la investigación, también este capítulo tiene el objetivo de comprender la producción artística, para lo cual se optó por el contacto directo con la misma.

A parte de los objetivos presentados y desarrollados a lo largo de las páginas que preceden, es importante referir una última idea que origina gran parte de las cuestiones presentadas. Lo cierto es que pensar en arte en la mayoría de las veces remite mentalmente a las paredes de los muesos, centros públicos con un papel fundamental para el mantenimiento, protección y conservación del patrimonio cultural y su identidad. Sin embargo, el arte es mucho más que las obras que están protegidas bajos esos techos, y gran parte de las cuestiones e interrogantes que se 
asoman ante la conservación/restauración, están directamente asociadas a los objetos que ya han tenido el reconocimiento social y cultural y son denominados obras de arte, pero para los cuales no están establecidas y controladas todas las acciones, las mismas que se concretan después de ese reconocimiento, y que habitan en otros centro culturales que no son los museos o en colecciones privadas, por presentar algún ejemplo. Pues es en estos medios, donde esencialmente se vislumbra la falta de concretización de criterios, y donde necesariamente se destacan los que están vinculados a las prácticas de conservación y restauración.

Insistiendo en los objetivos prioritarios y con la intención de destacarlos por la importancia que representan en una investigación de esta índole, se señalan y resumen los puntos más significativos en:

- Realizar un acercamiento teórico a la práctica de la conservación/restauración del arte contemporáneo;

- Comprender el papel, evolución y desarrollo de la figura del artista a lo largo de los siglos y hasta la actualidad;

- Estudiar y analizar conceptos como idea versus materia, efímero y temporalidad caracterizadores de las creaciones contemporáneas;

- Comprender los índices teóricos de la disciplina de la conservación/restauración y analizar los conceptos y los criterios de actuación;

- Estudiar la base teórica para la conservación/restauración del arte contemporáneo, para una buena teorización y profunda comprensión del mismo arte;

- Establecer límites en la actuación del artista vivo ante la conservación y restauración de su obra;

- Aproximar las cuestiones prácticas de la expresión plástica a las teorías de la conservación/restauración. 


\section{Metodología}

Como fue previamente presentado, la investigación está dividida en cuatro partes y de acuerdo con sus objetivos, la metodología seguida para su concreción pasó por una investigación bibliográfica exhaustiva de acuerdo con las varias áreas de estudio. En un primer momento fue necesario contextualizar y definir el periodo cronológico abarcado en el estudio, por ello fue indispensable recurrir a varios manuales de historia del arte y estética, método también seguido para percibir y comprender los factores y hechos que conllevan las diversas revoluciones y rupturas. Es evidente que con la conciencia de los antecedentes y contexto cultural se obtienen informaciones fundamentales a la hora de conservar y restaurar una obra de arte contemporáneo.

El segundo punto de análisis consistió en la percepción de todo el panorama de la disciplina de conservación/restauración, su contextualización como ciencia que se estructura a lo largo de los siglos. Es importante el discernimiento de la diversidad de materiales, técnicas e intenciones que constituyen el universo tan variado y complejo del arte contemporáneo, para que posteriormente se establezcan criterios de actuación. Para ello, se definen con exactitud los cambios de algunos de los conceptos en el campo de la conservación/restauración, teniendo en cuenta las diferencias de intervención entre el arte tradicional y el arte contemporáneo, a través de una bibliografía especializada, en que juegan un papel destacable la Teoría de la Restauración de Cesari Brandi, la Teoría de restauración y unidad metodológica de Umberto Baldini, el libro Restauración de la pintura contemporánea. Tendencias, materiales y técnicas de Heinz Altöfer o el libro Conservare l'arte contemporánea. Probemi, metodi, materiali, ricerche, de Oscar Chiantore y Antonio Rava, entre otras.

El tercer punto de la investigación con aproximación a las normas jurídicas y legales, basa su metodología en la búsqueda bibliográfica de varias normativas teóricas como las Cartas de Restauro, además de la interpretación y análisis de las leyes que conllevan los temas de estudio, como la Constitución Española, la Ley del Patrimonio Histórico Español y la Ley de la Propiedad Intelectual. Es cierto que en España la 
actividad se rige a través de las normativas internacionales, la normativa estatal y las normativas de las comunidades autónomas, pero en esta investigación el análisis solo abarcará las normativas internacionales y estatales de forma a establecer límites en el estudio, señalando la escasa formación en el área.

Y por último, con la intención de completar la investigación realizada, se presenta un cuarto punto en que se deja aparte la pesquisa bibliográfica partiendo hacia un análisis de campo. Para ello, se realiza un estudio estadístico con la elaboración y consulta de 100 entrevistas a artistas plásticos españoles y portugueses. En anexo se presentan 5 ejemplos de las encuestas realizadas con la especial participación de los artistas plásticos portugueses: Ana Cardoso, Carlos Mesquita, Isaque Pinheiro, João Pedro Rodrigues y Rui Pedro Fonseca. A través de la realización de las entrevistas, fue posible percibir conceptos como: transporte, almacenamiento y exposición, enfocando el papel desempeñado por el artista, y la importancia atribuida a las obras y sus ubicaciones específicas. En este sentido, la investigación aporta un conjunto de datos y factores presentes en ambas áreas de estudio, que podrán ayudar a mejorar la metodología desarrollada en las intervenciones de conservación/restauración del arte actual, fuertemente caracterizado por su diversidad estructural y conceptual.

De acuerdo con los planteamientos de esta investigación no cabe duda de que la pesquisa bibliográfica es la gran herramienta para conjugar los diversos factores que envuelven la conservación/restauración, sin olvidar la densidad de información que la consulta por internet puede proporcionar. De forma a facilitar la consulta bibliográfica, se presenta la bibliografía dividida en las tres áreas de estudio: Arte: historia, artistas y mercado; Conservación, restauración y patrimonio; y por último, Leyes y normas jurídicas.

Por último y en relación a la selección de las imágenes que ilustran la investigación, se añade que a pesar de ser una investigación totalmente teórica se subraya la necesidad del contacto directo con el mundo artístico actual. Por ello además de adjuntar un estudio estadístico, también se optó, específicamente, por ilustrar toda la investigación con obras de cuatro de los cinco artistas plásticos entrevistados. De este modo y de acuerdo con el contenido y la diversidad del arte contemporáneo, se añade a la estructura teórica varios ejemplos de creaciones actuales, encajando y 
complementando el tema desarrollado. Algunas imágenes presentadas son ya conocidas del gran público, por su prestigio como marcos indiscutibles en la historia del arte, una situación que se justifica puntualmente cuando en el texto se remite específicamente al artista presentado en la imagen. 


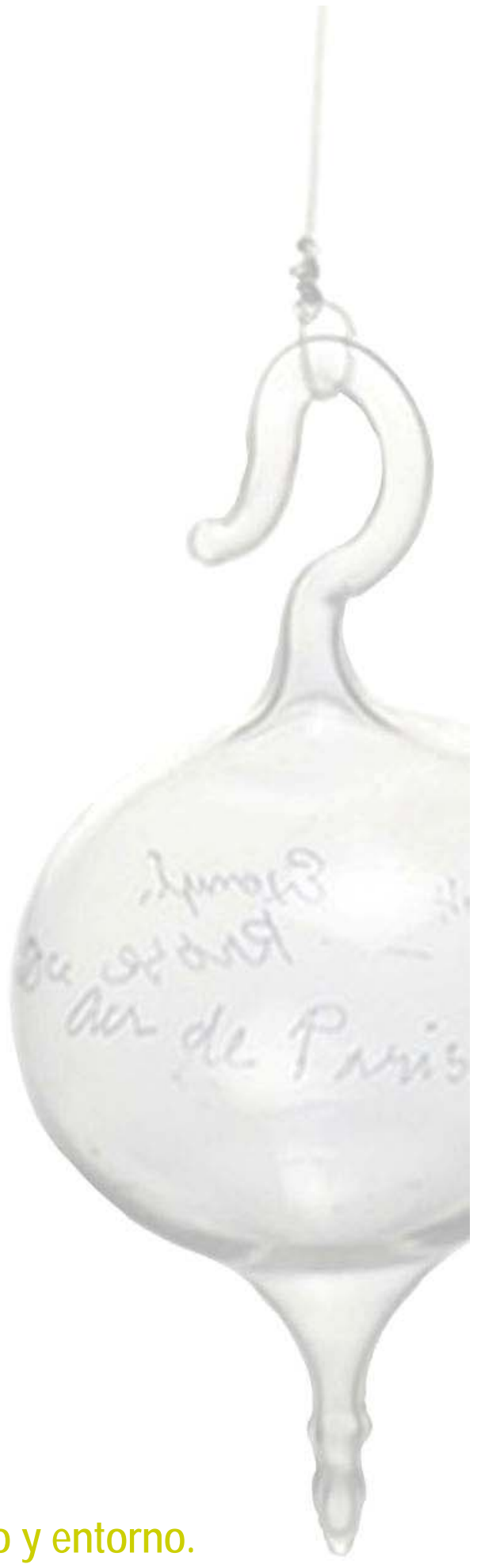

El arte y el artista: concepto y entorno. 

¿Cuáles son las influencias que hay en el arte moderno y contemporáneo? Y ¿Qué impacto han tenido tales influencias en las creaciones contemporáneas?

¿Qué papel desempeña el mercado en el contexto del arte contemporáneo?

¿Qué se desea encontrar en una obra de arte? O ¿Cómo se interpreta el contenido y la forma de una creación artística contemporánea?

¿Cuál es el valor de lo aparente y de lo oculto de una obra de arte contemporánea? 



\section{Los antecedentes del arte contemporáneo: relación arte y artista a lo largo de la historia.}

1.1. La Revolución Francesa, el Siglo XIX y las Guerras Mundiales.

La revolución científica, con sus amenazas, beneficios y promesas, parecía abrir una ventana emocional. Básicamente, yo sentí que ese mundo que la ciencia estaba haciendo visible contenía los símbolos esenciales para la reconstrucción del contorno físico, y para la reestructuración del mundo de las sensaciones, sentimientos y pensamientos, (...). Me vi así orientado hacia las contribuciones convergentes de arte y ciencia, y hacia la destilación de imágenes comunes a nuestra interioridad expansiva y al mundo exterior. ${ }^{7}$

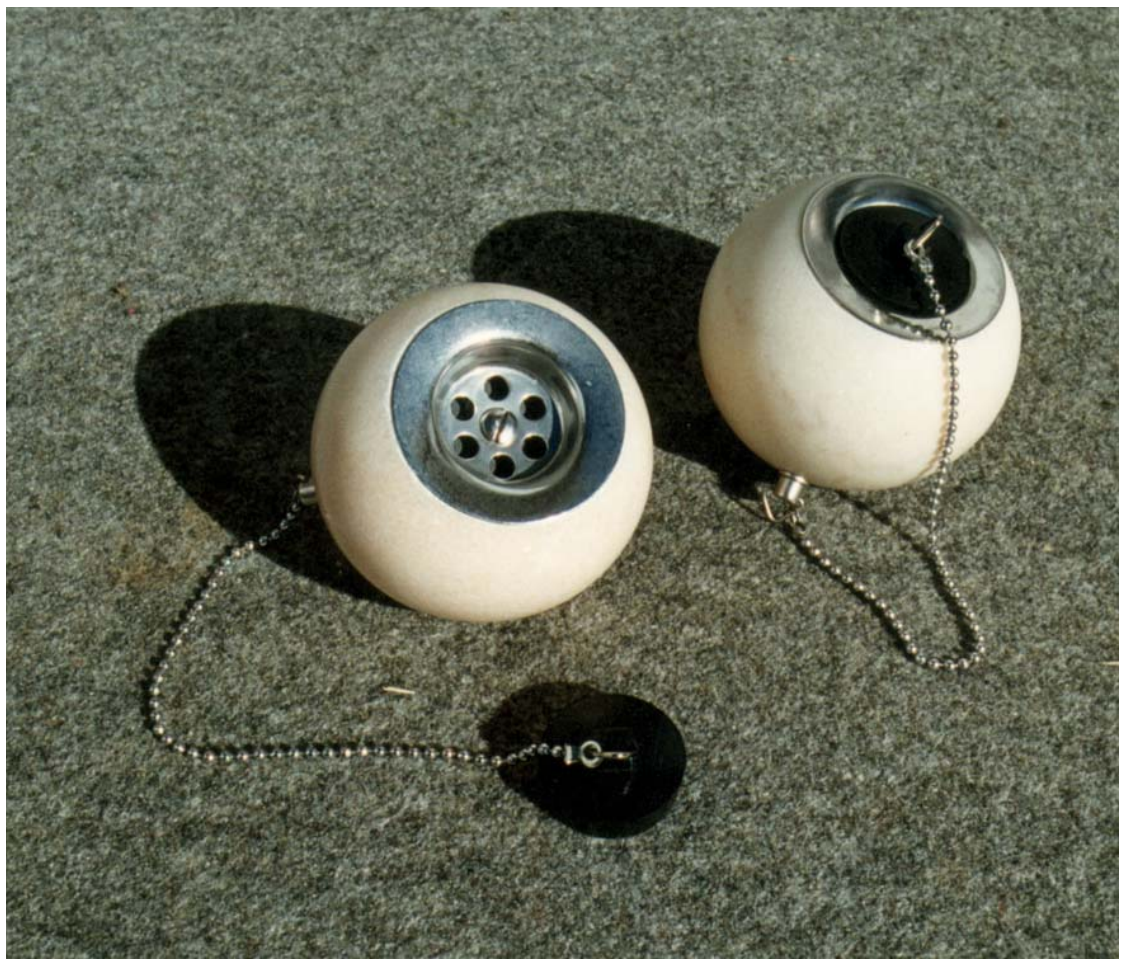

Figura 1: Isaque Pinheiro, Adanarg, 2000. Mármol, inox y borracha, 10x 10x 10cm

${ }^{7}$ Introducción de Gyorgy Keps, en La situación actual de las artes visuales, p.11-12. 
El artista al manifestar su particular visión del mundo y de la vida a través de imágenes y formas, hace que el objeto artístico retenga información indispensable al conocimiento del hombre y de los distintos modelos de vida en sociedad. La obra de arte como documento de un determinado momento de la historia, no se limita únicamente al hecho de ser una creación reconocida social y culturalmente, asume también un lenguaje mutante que refleja los beneficios, las creencias, las promesas y los prejuicios de diferentes índoles. Además de un bien artístico y cultural es un documento histórico donde está almacenada gran parte de la información fundamental sobre la época en la que fue creada, así como de todas en las que ha vivido y sobrevivido. Es reflejo y resultado de un proceso de creación y producción y,

sabiéndola interrogar, la obra de arte nos informará sobre la concepción del arte en esa fase de la historia, sobre las relaciones sociales de un determinado período histórico, posición y papel del artista, exigencias del comitente, organización del trabajo del taller, sobre las técnicas y materiales usados para su elaboración, sobre la vida política y el sistema de creencias religiosas, y así sucesivamente. ${ }^{8}$

Hay una comunicación constante entre la creación y la vida, en la que el hombre y el arte dejan un rastro de caminos paralelos o inseparables, y la constante influencia de los varios ejes de la acción humana dibuja un ciclo vicioso: el hombre dando existencia al arte y el arte dando identidad al hombre..$^{9}$ En ese ciclo se confirma que nada es fruto de la casualidad, puesto que el fenómeno artístico nace y se desarrolla, en el interior de la estructura cultural y social, aunque sea una lucha contra esa misma estructura.

No cabe duda de que las condiciones socioculturales tienen un papel importante en varios campos de la acción humana, y es obvia su influencia sobre la expresión artística, siendo de fácil percepción las características bien marcadas en el desarrollo de algunos movimientos y tendencias artísticas, existiendo un paralelismo, unas veces más acelerado otras menos, entre la evolución sociocultural y la creación artística. Es inevitable la influencia transmitida y en ese sentido cada corriente y movimiento son el reflejo directo de la época, de los contextos históricos y sus

${ }^{8}$ GONZÁLES- VARAS, Ignacio. Conservación de bienes culturales. Teoría, historia, principios y normas, p.51.

${ }^{9}$ CALLE, Román de la. En torno al hecho artístico, p.31. 
controversias, además de sus características intemporales que se asientan en los códigos universales de representación.

En consecuencia, para entender el arte contemporáneo es necesario estudiar sus momentos clave y sus antecedentes en la historia, no sólo sociales y culturales sino también industriales y científicos. Todavía en el siglo XVIII, la Revolución Francesa dibuja el inicio de la Edad Contemporánea y deja las primeras señales de ruptura: una incursión política, cultural e ideológica para el mundo contemporáneo. Es en 1789 cuando se inicia una ruptura con la tradición como respuesta social, permutando la forma de trabajar y vivir de los artistas y derribando premisas que habían estado presentes durante siglos. Se alcanza la autonomía del arte, una secesión en paralelo con la emancipación del saber científico. Llegados al final del siglo XIX, marcado por un progreso industrial, en el que los materiales ya no eran solamente producidos en el taller sino fabricados industrialmente; y tras la II Guerra Mundial, se ha pasado al empleo definitivo de los materiales industriales, así como de los objetos que antes no estaban dotados de cualidades estéticas o artísticas como los de uso cotidiano. Del mismo modo, la revolución industrial comenzó a destruir las mismas tradiciones del sólido quehacer artístico; la obra manual dio paso a la producción maquinista, el taller a la factoría ${ }^{10}$.

Lo cierto es que, entre finales del siglo XVIII y mediados del siglo XIX, el mundo occidental vivió una onda avasalladora de revoluciones industriales, agrícolas, liberales, demográficas, etc. De esta forma, se implantaron una serie de cambios, donde en la segunda mitad del siglo XIX se asentaron tales estructuras y se dio el perfeccionamiento progresivo en las sociedades, como verdaderas demostraciones de vida moderna en la que la actividad artística no ha podido dejar de lado los llamados mitos modernos: la trasgresión como método revolucionario, la inmediatez y necesidad como legitimidad popular, y la evolución como un hecho irrefutable ${ }^{11}$, referidos por Juan Luis Moraza.

${ }_{10} \mathrm{GOMBRICH}, \mathrm{E}$. H. Historia del arte, p.411.

${ }^{11}$ MORAZA, Juan Luis. Ornamento y Ley. Procesos de contemporización y normatividad en arte contemporáneo, p.21. 
Los mejores ejemplos del desarrollo y adhesión del progreso técnico-científico e innovación fueron las exposiciones universales que a partir de 1851 se realizaron, con regularidad, en las principales ciudades mundiales, sin olvidar que París realizó cinco, y se afirmó como capital cultural y artística durante el último cuarto del siglo XIX. En seguimiento de tal progreso, en París se vivió una búsqueda incesante, la necesidad de encontrar, por así decir, lo nuevo, cuando en pleno final del siglo XIX se consolidó simultáneamente con la revolución industrial la llamada modernidad. Y para entender el término modernidad, una vez más se buscan referentes sociales y culturales detectados en determinados momentos de la historia. En cualquier lugar y en cualquier época existe la posibilidad de vivir la modernidad, puesto que consiste en una actitud innovadora que busca lo nuevo de forma persistente. Además, se puede hablar de la obra de Friedrich Nietzsche, desarrollada entre 1869 y 1889, como un ejemplo de determinación en la historia de la cultura y en la historia de las ideas. Precursor de la modernidad, efectúa rupturas revolucionarias con la tradición cultural dando a la Edad Contemporánea respuestas decisivas. Nietzsche defendió que el arte era el instrumento fundamental para esclarecer la vida, porque el valor de los individuos y de las generaciones se mide por su vitalidad artística y mitológica, por la fuerza cultural con que imprime a cada uno sus gestos y sello de eternidad. El arte surge para estimular la vida y se asienta en la necesidad de la apariencia, del error y de la perspectiva, siendo fundamentalmente la actividad metafísica en la vida humana, y Nietzsche subraya porque a vida, essa, existe na aparência, na arte, na ilusão, na óptica, na necessidade de perspectiva e erro ${ }^{12}$.

Si por un lado existían artistas interesados en satisfacer el gusto tradicional y convencional del público, por otro estaban los que se satisfacían con su aislamiento y determinación; pero ambos sentían la brutal llegada de la industria, a través de la decadencia del oficio, la aparición de una nueva clase media sin tradición ${ }^{13}$, además de contribuir a una desvalorización de las obras, para la desmitificación del arte en sí mismo, y todo reflejado en un gusto poco exigente del público.

12 NIETZSCHE, Friedrich. A origem da tragédia, p.27-28.

T.A.: ...porque la vida, esa, existe en la apariencia, en el arte, en la ilusión, en la óptica, en la necesidad de perspectiva y error.

${ }_{13} \mathrm{GOMBRICH}$, op. cit. p.414. 
Uno de los grandes cambios encontrados en la pintura del siglo XIX es que ya no sólo los grandes maestros poseen el don de una técnica superior. El pintor desea pintar lo que ve, quiere representar la realidad, y lo hace de forma frenética, abandonando las exigencias de un maestro, o incluso de un público. Pero es en la segunda mitad del siglo XIX donde se presencian importantes cambios en el campo del arte, más concretamente en la actitud de los artistas y del público ante las obras de arte. Si por un lado el arte se libera de lo institucional acercándose más a sus verdaderos interesados: los creadores y los usuarios, por otro se alarga el consumo de los objetos artísticos, que también son económicos, instalándose el mercado del arte y gestándose la presencia de figuras como la del crítico del arte con su peso cultural y posición social. En consecuencia se imponen nuevos objetivos para la producción artística, distinguiendo corrientes de estilos y revolucionando técnicas y metodologías.

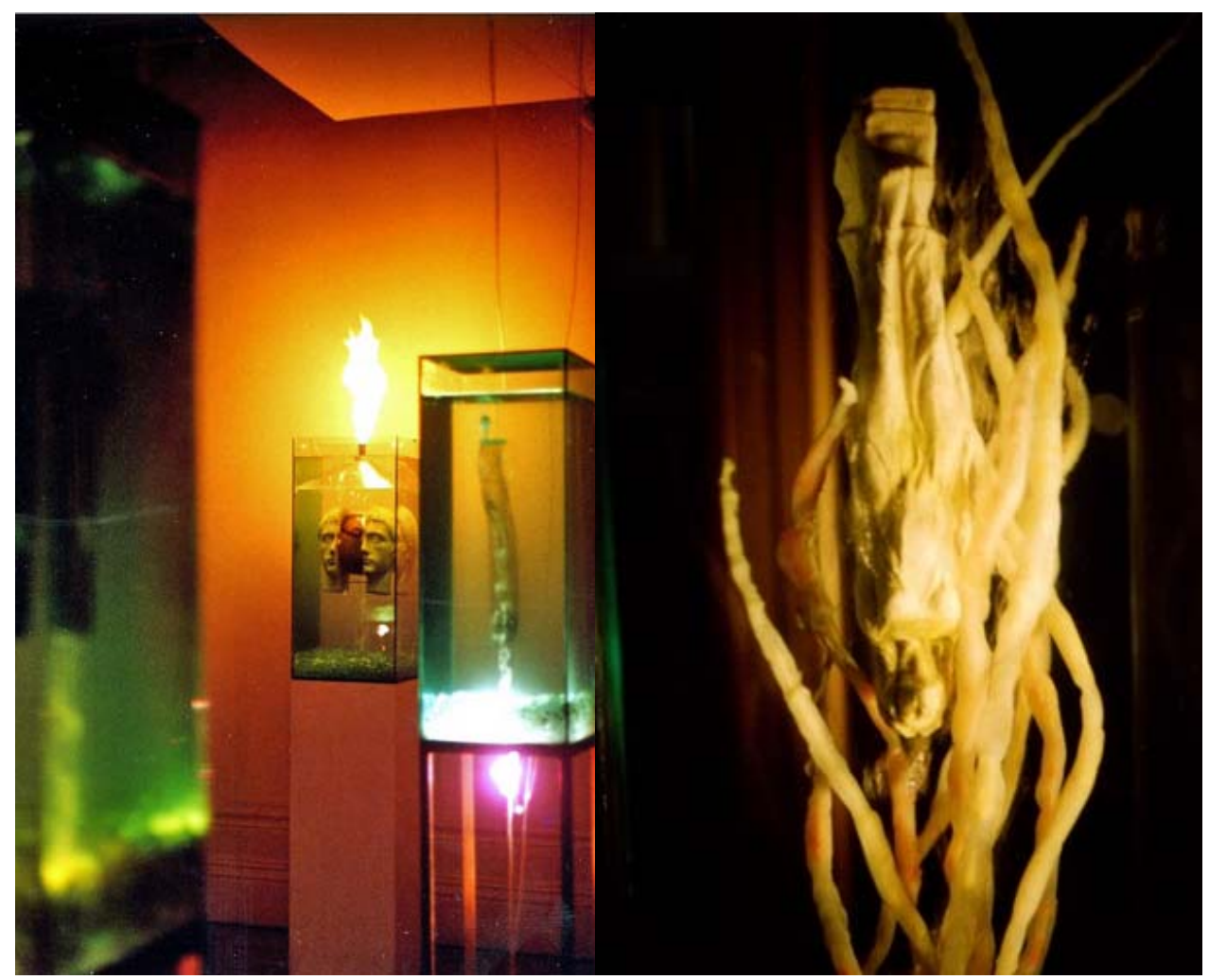

Figura 2: João Pedro Rodrigues, instalación Duplicidades. Técnica mixta, dimensiones variables. Figura 3: Detalle de la instalación Ar e terra. Vidrio, agua, silicona y pasta de cerámica, 177 X 30 X 30 cm. 
Con todos estos cambios socioculturales, se dio un paso hacia la vida moderna, tal como afirma anticipadamente Baudelaire, es cierto que la gran tradición se ha perdido y que la nueva aún no está hecha14. Todo esto resulta de una época llena de contrastes, retomando en un momento clave de la historia, un orgullo patente que no esconde las contradicciones, los choques entre la conciencia colectiva y la conciencia individual. Hay una lucha entre el espíritu social y el industrial, y es en este entorno donde surgen las pinturas impresionistas, rompiendo el ciclo histórico e iniciando el camino hacia las vanguardias. Hablar del Impresionismo implica partir del principio de que éste fue el movimiento de oposición al Romanticismo, al academicismo con todos sus cánones y al intelectualismo social del Realismo, porque volvió los ojos hacia el presente, y contempló las cosas ordinarias sin reticencias, por feas que fuesen. ${ }^{15} \mathrm{El}$ pintor impresionista buscó la realidad tal como era, arrebatando protestas y acusaciones como consecuencia de la incomprensión de los demás.

Sin que se concluya esta ruptura, los impresionistas abren paso a un grupo de artistas diversos, los llamados post-impresionistas, que buscan nuevos caminos para la pintura, en el sentido de separar definitivamente la pintura de la representación mimética de la naturaleza, en un enlace heterogéneo donde se agregan diferentes tendencias expresivas y diferentes autores, siendo éstos considerados los precursores del arte del inicio del siglo XX. Lo cierto es que el arte del siglo XX reivindicó autonomía frente a la sociedad con relación a las cuestiones ideológicas, técnicas y temáticas, y los artistas empezaron a recrear sus temas en vez de registrar sus apariencias. Lo que se había dibujado a finales del siglo XIX, ganó un nuevo aliento más independiente e individual, y como dijo con otras palabras Theodor Adorno, de categoría ameaçadora do novo irradia incesantemente a fascinação da liberdade, mais forte do que o que nela há de inibitório e, por vezes, de esteril. ${ }^{16}$

El artista se mueve en un mundo en constante mutación, rompiendo con los estereotipos y los modelos de taller. Los parámetros tradicionales entre la relación

\footnotetext{
${ }^{14}$ BAUDELAIRE, Charles. El Salón de 1846, p.197.

15 FISCHER, Ernst. La necesidad del arte, p.86-87.

${ }^{16}$ ADORNO, Theodor W. Experiência e criação artística, p. 26.

T.A.: ... de la categoría amenazadora de lo nuevo irradia incesantemente la fascinación de la libertad, más fuerte de lo que en ella hay de inhibitorio, de nivelador y, a veces, de estéril.
} 
arte-técnica cambian, originando una valoración distinta de la actividad manual. Fenómenos como la aparición de la fotografía o el estudio del color no pueden pasar desapercibidos. La óptica y las constataciones de los contrastes simultáneos de color aportaron informaciones concretas para el mundo artístico y la tan desconfiada aparición de la fotografía originó distintas posiciones ante la producción de una imagen de la realidad captada en todas sus dimensiones: por un lado, a un cierto sentimiento de frustración y, por otro, a que algunos artistas no se sintieran capaces de luchar contra el éxito demostrado por la máquina.

La fotografía es uno de los factores fundamentales que contribuyen al cambio de las reglas en la pintura, dado que con su aparición no será necesario el medio pictórico como representación fidedigna de la realidad. Los lenguajes comportan cambios acentuados, cuando el objetivo primero del arte se creía limitado a la imitación de la realidad, pasando a un segundo momento donde se propone el arte como la propia realidad, caracterizada por todos sus fenómenos de mutación. El arte en su expresión pictórica ha tenido que buscar algo distinto, hasta el punto de alcanzar un nuevo concepto, rechazando la idea de arte como pura representación.

Ciertamente, el arte moderno no sólo nace de la evolución del arte del siglo XIX, más bien es fruto de la ruptura de sus valores y reglas presentadas en ese mismo siglo. Una ruptura no solamente de los valores estéticos, sino también que interfirió con las cuestiones ideológicas e históricas, como una tendencia revolucionaria, una acción por la libertad, en la cual se organizan los pensamientos filosóficos, literarios y políticos, así como obviamente en el pensamiento y producción artísticos.

A finales de los años cuarenta del siglo XIX, se destaca la unidad histórica, política y cultural; y sobre la ruptura de esta unidad nacen, pasados treinta años, el arte de vanguardia y parte del pensamiento contemporáneo. Si bien es cierto que el artista impresionista deja atrás la tradición academicista en el tratamiento del color, como la liberación del lenguaje figurativo, a través del contacto directo con la realidad, también es verdad que éste ha influido largamente en la formación de los artistas de las primeras vanguardias. Los primeros vanguardistas tenían como objetivo principal el desarrollo de lo experimental, un crédito también derivado del contexto científico de la 
época, en la medida que tales avances científicos y su repercusión en el progreso industrial abrieron nuevas puertas e influyeron en las nuevas manifestaciones artísticas.

A arte moderna, para ter alguma significação, tem necessidade de permanecer no estado de pesquisa experimental. Os pintores devem pintar para a sua própria edificação e prazer e 0 que eles têm que dizer - não aquilo que são forçados a sentir - é o que irá interessar aos que se interessem por elos. 0 pensamento do instante é a emoção do instante..$^{17}$

En el mundo moderno, la pintura asume la espontaneidad y las cualidades físicas de la expresión pictórica, sin embargo, es necesario referir la contribución e influencia del pensamiento filosófico sobre la creación artística. Cierto es que a comienzos del siglo $X X$, se introduce el concepto de modernismo, algo que implica, claramente, innovación y cambio ante el pasado reciente. Gracias al modernismo, comprendido como estado o cualidad del que es de su tiempo o avanzado, y de su homogeneidad, surgen a partir de 1905, a través de una diversidad de movimientos y corrientes, las llamadas primeras vanguardias. Bajo la consigna de destrucción y oposición al arte del pasado, o más bien la negación de la tradición como punto de referencia obligatoria, la obra busca transponer fuera del espacio de la realidad una dimensión irrecuperable en el plano de la vivencia social e individual.

La modernidad marca un punto en el arte, antes del cual los pintores se dedicaban a la representación del mundo, pintando personas, paisajes y eventos históricos tal como se les presentaban o hubieran presentado al ojo. Con la modernidad, las condiciones de la representación se vuelven centrales, de aquí que el arte, en cierto sentido, se vuelve su propio tema. ${ }^{18}$

El siglo XX ha sido el siglo de la controversia en todas las áreas, y en el arte se ha convertido en un periodo de crítica y auto-reflexión, transmitido por varios movimientos y estilos, que envolvieron un largo abanico de fenómenos creativos, materializados sobre una variedad infinita de medios, desde la más simple hoja de papel hasta las tecnologías más avanzadas, pasando por la apropiación del cuerpo 0 del paisaje. Época de cuestionamiento y radicalismo, donde la crítica mordaz de los

${ }^{17}$ Marsden Hartley, A arte - e a vida privada, 1928. en CHIPP, Herschel B. Teorias da Arte Moderna, p.535.

T. A.: El arte moderno, para tener alguna significación, tiene necesidad de permanecer en estado de búsqueda experimental. Los pintores deben pintar para su propia edificación y placer y lo que ellos tienen que decir -no aquello que son forzados a sentir- es lo que interesará a los que se interesan por ellos. El pensamiento del instante es la emoción del instante.

${ }^{18}$ DANTO, Arthur, C. Después del fin del arte. El arte contemporáneo y el linde de la historia, p.29. 
artistas ha alcanzado tal grado que ha puesto en juego la propia esencia del arte, revisando su concepto y definición.

Lo cierto es que Francia, sobre todo París, durante las cuatro primeras décadas del siglo XX ha tenido una importancia crucial, pues la historia del arte moderno no puede estar desasociada de su historia. Si por un lado la época anterior a la I Guerra Mundial fue extremadamente fértil en términos de innovaciones y sus repercusiones sobre el discurrir del arte hasta influir en el arte contemporáneo, los años de la Guerra fueron como una introducción a la búsqueda de las nuevas tendencias. Ya en los años contiguos a la posguerra surgieron varios impulsos estéticos innovadores que hicieron mirar la tradición como algo obsoleto, surgiendo en los años treinta una nueva generación que sintió la guerra y que rechazó lo que podría ser una estética intelectualizada buscando un contacto simple y directo con la naturaleza.

Tras la I Guerra Mundial, y con mayor evidencia a partir de mediados de los años 40, se impone la ruptura con la estética del pasado, siendo necesario romper a toda costa con los valores formales, conceptuales y de estilo en que el artista tiene que ser necesariamente vanguardista, en una lucha con el objetivo de salvaguardar los nuevos valores trazados desde los primeros años del siglo.

Los medios de producción se multiplican y la nueva noción de obra se extiende y amplía. La pintura parece romper con el pasado definitivamente, por sus investigaciones, como se puede observar en la estética expresionista. El Expresionismo no es una corriente únicamente artística y literaria, sino más bien una forma de sentir el mundo, que se desarrolla en el primer decenio del siglo XX y que anuncia la ruptura total con el sistema artístico del siglo precedente.

Las grandes tendencias de la pintura del siglo XX, surgen en Francia y Alemania, marcadas por un dinamismo y euforia artísticos que se reforzaron debido a la multiplicación de las actividades creativas, hechas por comerciales y críticos, revistas especializadas, exposiciones realizadas al margen del arte oficial, frente a la búsqueda de la pureza en los medios de expresión. En el seno de una sociedad ciudadana llena de contradicciones, los artistas tenían la libertad suficiente para dar 
cuerpo a sus impulsos y sentimientos, rechazando las ideas y las formas antiguas y basando su actitud en principios autónomos, revolucionarios y, ante todo, individuales.

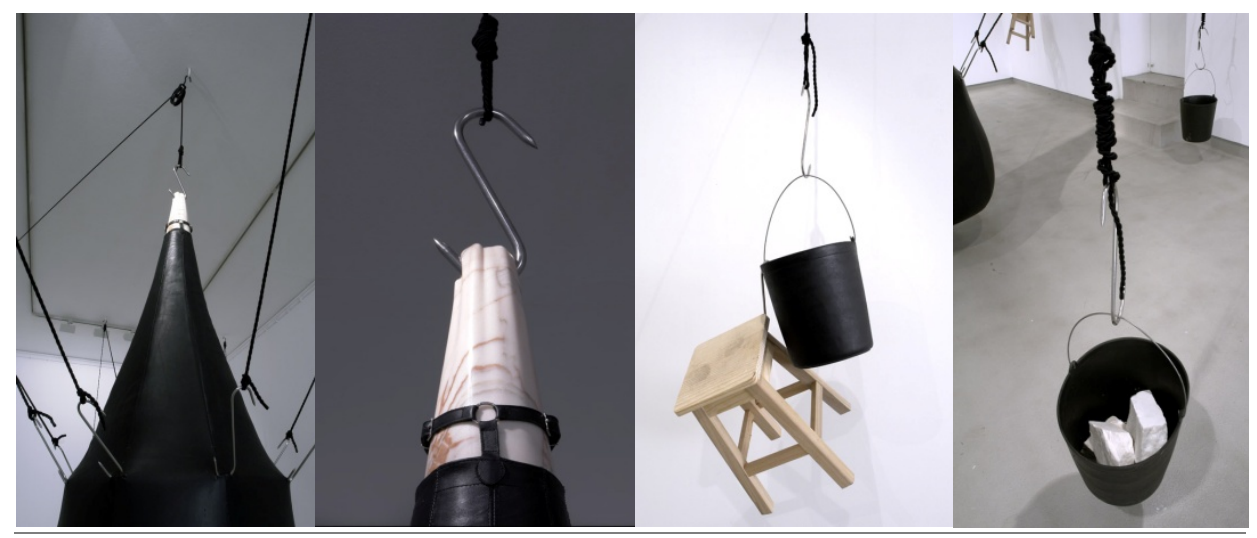

Figuras 4, 5, 6 y 7: Isaque Pinheiro, detalles de la instalación MAE. Cuero, mármol, cubos de PVC, metales diversos, cordones de seda.

Surgen los movimientos y estilos como momentos que definen la historia de las vanguardias artísticas modernas, donde en cada uno de ellos, el artista luchó junto a la mudanza, polémica y rebelión. La creación artística se desarrolló con base en dos tendencias: una tendencia lírica, desarrollada en las primeras décadas del siglo XX, donde se encuentran el Fausvimo, el Expresionismo, el Cubismo, el Futurismo, la Abstracción, el Suprematismo, el Neoplasticismo y el Construtivismo; y una segunda tendencia más onírica, donde se encuentran la Pintura Metafísica, el Dadá y el Surrealismo.

Se pierde el control de los instrumentos de la expresión artística, donde los nuevos productos industriales aportan gran potencial estético, además de la inclusión de elementos reales adheridos a los soportes, como forma de conceder más importancia al objeto, como se observa en los collage o en los trabajos cubistas. Si el materialismo fue la base de las ciencias del siglo XIX, la base de la ciencia moderna sería la filosofía del idealismo y del agnosticismo vista como medio para encontrar las certezas absolutas, y crucial en la trayectoria de Marcel Duchamp. Todas estas ideas y cuestiones llevadas al extremo, consolidan la actitud de que cualquier objeto de uso cotidiano o industrial, puede estar investido de un posible discurso artístico, como son 
ejemplos, a partir de 1913, los ready-made de Marcel Duchamp, constituidos por objetos ya fabricados y en su gran mayoría de uso doméstico. Él mismo asume que son objetos ya acabados donde ha incluido una firma, o en algunos de los casos inscripciones, y aconseja que para interpretarlos no es necesario un esfuerzo demasiado grande, ni tan poco tendrán que ser entendidos de forma romántica, impresionista o cubista; más bien que no tienen razón de ser. O sea, que las cosas 0 las formas son casuales, así como la mano que dibuja un conjunto de movimientos al azar.

Con otra intención, el Futurismo proclamó una agresividad formal, una lucha contra algunos de los conceptos establecidos en la filosofía y literatura del siglo XIX, una búsqueda entre la revolución industrial para saciar la necesidad de ser moderno. Por otra parte, el artista del Suprematismo presentó una pintura no-objetiva, en que su idea se afirmaba cuando expresaba la pureza analítica del material, rechazando totalmente el contexto donde había crecido y quedando atrás una pintura de caballete de formas típicas y temas antiguos. Mientras tanto el artista dadá luchó contra todo lo que estaba previamente establecido, en un acto extremado de antidogmatismo, con la necesidad de ser antiartístico, antiliterario y antipoético, proponiendo un profundo cambio, tanto en la concepción del objeto artístico como en su apariencia, el reflejo de la crisis en que se debatía el arte moderno en aquel momento. Ya en 1920 los construtivistas propusieron el diseño industrial frente a la creación artística, conectado al proceso revolucionario y fuertemente influenciado por el marxismo.

También la escultura, con alguna dificultad, rompió su compromiso con la tradición en relación a su propio espacio real, sin poseer autonomía formal como la pintura. A principios del siglo XX, a pesar de sus diferentes ritmos, ambas evolucionaron, pero la evolución de la escultura tuvo que pasar por la renovación de los materiales. La nueva concepción espacial y la utilización de nuevos medios, transformaron la propia materia en fuente de renovación técnica. Al contrario que en la pintura, la escultura no rechazó el espacio real, sino su materia tradicional, que en épocas pasadas era concebida apenas con la talla directa, la fundición, o por técnicas como: soldadura, pegado, encaje de las piezas, etc. La posguerra, no parece marcar en la escultura, una ruptura tan nítida como en la pintura, debido a su lenta evolución. Todavía, los 
escultores procuraron sacar lo máximo de los materiales que usaban y por eso, el trabajo con el metal fue cada vez más directo, empezando a utilizar diversos materiales, y no solamente los designados de nobles y tradicionales para la escultura, como es el hierro forjado, la chapa de metal recortada, el acero, al níquel, etc. En estas fechas, la técnica escultórica no tuvo un dominio obsesivo como en la pintura, pero desapareció el volumen, la superficie plana tuvo como contrapunto el vacío, surgieron esculturas trabajadas con materiales industriales, como caligrafías volumétricas en el espacio, con carácter lineal, abierto y abstracto.

Sin embargo, si por un lado, la oferta industrial abre nuevas puertas a la expresión y creaciones artísticas, por otro, condiciona la misma actividad a través de la afirmación de los nuevos materiales y los procedimientos implicados en la ejecución de la obra. Son varios los testimonios de artistas que afirman haber experimentado nuevos materiales por su incansable curiosidad y necesidad, y sin grandes preocupaciones hacia posibles problemas, transformación y degradación precoces que estos materiales podrían presentar. Un caso a subrayar, es del artista Mohol-Nagy, que dice:

Pinté sobre aluminio, aleaciones no-ferrosas altamente pulidas, y termoplásticos. Si no hubiera temido que estos últimos materiales fueran perecederos, jamás hubiera pintado nuevamente sobre lienzo. Al trabajar con estos materiales -plásticos de color uniforme, opacos y transparentes- hice descubrimientos que me llevaran a modificar mi técnica. ${ }^{19}$

Es cierto que las propiedades de los materiales quedan subordinadas a la poética de los artistas, pero también es interesante verificar que la inmediatez, la facilidad de utilización y de ejecución, y el rápido secado de los materiales industriales consecuentemente ha influenciado $y$, de cierta forma, condicionado y conducido a determinados comportamientos en el arte.

Se reafirma con fuerza esta idea, cuando la introducción de determinados productos comerciales comportó un cambio en la actitud de los artistas, en dirección al lado corpóreo de la obra resaltando en, paralelo con la técnica tradicional. Si el artista en sus creaciones jugó con acumular materiales heterogéneos, densos y no compatibles

${ }^{19}$ MOHOL-NAGY, László. La nueva visión y reseña de un artista, p.147. 
entre sí, es porque este uso desenvuelto ofreció nuevos efectos visibles. La permanencia del aspecto ideológico sobre el material, ha llevado a descuidar voluntariamente el uso de materiales elaborados expresamente para el arte, rescatando los materiales brutos, en una óptica casi de primitivismo, como materialización de la idea. El artista pasó del uso de materiales tradicionales a las más diversas tecnologías innovadoras, llegando a ser la materia de la obra el centro del proceso creativo.

Son experimentados pigmentos, resinas, esmaltes y acrílicos, que en acelerada evolución ofrecen efectos estéticos completamente diferentes de los conseguidos tradicionalmente. Los artistas no se limitan a adquirir los productos propuestos en los vendedores especializados, dirigiéndose directamente a la industria, al encuentro de nuevos materiales de bajo coste creados para la aplicación en otras áreas, como por ejemplo la pintura industrial usada en los coches.

No hay duda que entre los años 1930-40, el incremento mundial de la industria química, provocó una aceleración en la introducción de nuevos materiales plásticos, con gran diversificación de la estructura polimérica, y subrayando este desarrollo industrial, una vez más, el artista Moholy-Nagy consciente de la posible problemática que pueden conllevar los nuevos materiales, escribió en la década de los 30:

Conocer a fondo estos materiales, y desarrollar técnicas para manipularlos puede ser una cuestión de décadas. Tampoco se han resuelto los problemas técnicos de la pintura sobre estos nuevos materiales. ${ }^{20}$

¿Cómo no iba a influir todo este desarrollo industrial en la creación artística? Es evidente que los nuevos materiales siempre formaron parte de las experiencias de artistas interesados en la búsqueda de nuevos efectos expresivos. Fue difícil renunciar a una gama de colores nunca antes vista, donde se podían encontrar colores mate, satinados o brillantes, de acabados metálicos, además de proporcionar en el acto, espesores distintos de acuerdo con la intención y forma de aplicación.

${ }^{20}$ MOHOLY-NAGY. ob. cit. p.149. 
En los años de entreguerras, Francia vive una controversia, pues lo que había sido innovación y avance se veía agotado. Los síntomas de agotamiento en los estilos europeos de los años 30, parecían ganar nuevo aliento cuando en contacto con el nuevo territorio. Los Estados Unidos al poco dejaban atrás un cierto provincialismo y aislamiento estético, con la acogida de los intelectuales y líderes emigrantes. En la década de los 40 se asientan nuevas bases debido al reconocimiento de la pintura estadounidense y se desplaza el centro artístico de París a Nueva York. No hubo ninguna nueva influencia o tendencia hasta surgir el que fue el primer estilo artístico genuino de los Estados Unidos, el Expresionismo Abstracto. A partir de entonces, París sigue siendo un centro activo para varias prácticas artísticas, pero ya no posee la preeminencia que le caracterizó durante la mitad del siglo.

A partir de 1945, la expresión artística se torna más polémica, al mismo tiempo, que amplia, diversificada y compleja, debido a la metodología desarrollada y los medios utilizados por los artistas, ambos definidos por su gran heterogeneidad, individualidad y experimentación. Sin duda la II Guerra Mundial trazó una línea divisoria en la cultura y por supuesto en la historia del arte, conduciendo a una diversidad de movimientos artísticos que también resultaron de la emigración iniciada en los años 30 de numerosos intelectuales y artistas europeos. El arte de la posguerra se caracterizó por el deseo de exprimir toda la riqueza y espontaneidad de la vida interior, a través de la forma en la cual el artista se proyecta, en presencia de desilusiones y muchas veces escasez de ideas que nunca jamás volverían a surgir de un entusiasmo ingenuo. Entre los años 1940 y 1950 se encuentran las llamadas Segundas Vanguardias o Vanguardias de la posguerra, como reflejo de una sociedad inquieta y muchas veces caótica: un arte que caminó en el sentido de redescubrir las vanguardias históricas y propuso nuevas soluciones. Una primera tendencia, caracterizada por un lenguaje abstracto informalista con un programa propio que pone en cuestión los valores tradicionales de la forma y donde se encuadran el Expresionismo Abstracto, Art Brut, Action Painting, Pintura Espacialista y, el Op Art; en una segunda, la Nueva Figuración y el Pop Art de lenguaje más figurativo; y una tercera tendencia, basada en un tipo de lenguaje más intervencionista o de acción, en que se encuentra el Happening. 
Es necesario subrayar lo determinante que fueron las influencias de una sociedad consumista y comercial, tan bien reflejadas en las creaciones del Pop Art, puesto que esta corriente artística llevó al extremo las cuestiones mercantiles de las creaciones artísticas, como productos banales, populares pero ante todo, comerciales.

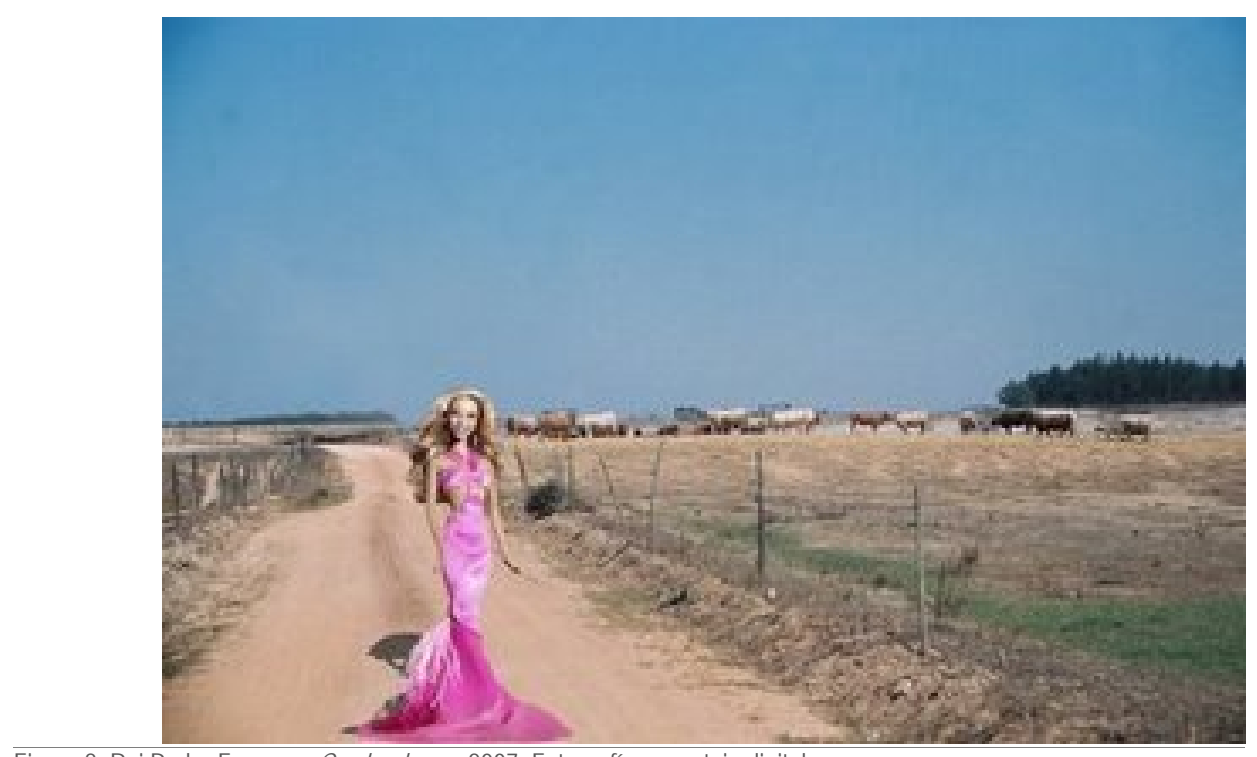

Figura 8: Rui Pedro Fonseca, Cowlandcape, 2007. Fotografía y montaje digital.

La abstracción conceptual es consecuencia de una maduración estética consumada, defendiendo su causa y poniendo al desnudo la materia prima. Obras de gran formato y de ejecución veloz y muy variada, surgen para satisfacer el mercado que empezaba a requerir precios favorables, llevando a la utilización rápida e indiscriminada de los nuevos materiales.

Essa nova pintura [americana] não constitui uma escola. Para formar uma escola nos tempos modernos são necessárias não só uma consciência de nova pintura, como uma consciência dessa consciência (...). Na vanguarda americana as palavras, como veremos, pertencem não à arte, mas aos artistas individuais. O que eles pensam em comum só é representado pelo que fazem separadamente. ${ }^{21}$

${ }^{21}$ Harold Rosenberg, Os pintores americanos de acção, 1952. en CHIPP, ob. cit. p.578.

T. A.: Esa nueva pintura [americana] no constituyó una escuela. Para formar una escuela en los tiempos modernos son necesarias no solo una conciencia de nueva pintura, como una conciencia de esa (...). En la vanguardia americana las palabras, como veremos, pertenecen no al arte, sino a los artistas individuales. Lo que ellos piensan en común solo es representado por lo que hacen separadamente. 
El paso de los años 50 a los 60 fue dominado por un clima de particular intolerancia: condujo el arte hacia una actitud de rechazo de las angustias vinculadas al existencialismo y al informalismo. Las experiencias artísticas de este periodo fueron provocadas por un incontable deseo de renovación y por una nítida oposición a cualquier dogmatismo o concepto de autoridad. Los artistas fueron animados a través de la libertad total y de mayor vivacidad de la actividad, a vivir con un espíritu de revuelta contra la ideología corriente y la profanación de los medios de expresión tradicionales. El arte había sido considerado como un proceso de conocimiento y "exprimirse" significaba alargar el campo de acción a operaciones de todo género. E arte encontraba su independencia como local central de experiencia, y además, de alterar la noción de artista, alteraba con determinación la noción del gesto y del espacio, de forma y de medio.

Es evidente que la producción artística de los años 50 y 60 fue consecuencia de la cultura vanguardista del inicio del siglo, cuando por primera vez fue asumida la imposibilidad de teorizar y trazar un límite preciso en la experimentación estética: surge la postmodernidad, un nuevo rótulo que engloba una diversidad de prácticas culturales y artísticas, una nueva búsqueda de lo nuevo, una forma de expresión mediática configurada con base en el consumo de masas, y, también ella, desea la ruptura con el pasado. Caracterizada por una producción industrial muy abundante, tentadora y anónima, los artistas utilizaron los materiales que salían al mercado, basando la selección de los mismos exclusivamente en sus criterios estéticos. El anonimato de los materiales producidos en aquellos años estuvo determinado por la calidad y el rápido cambio de marcas y productos, una vez que la química moderna determina infinitas variaciones sobre la misma materia.

Las llamadas Últimas Vanguardias, situadas entre las décadas 60 y 70, también siguen tres tendencias expresivas, en que la Abstracción Geométrica, se basa en un lenguaje abstracto; el Hiper-Realismo, el Body Art y el Nuevo Realismo Europeo se concretan en un lenguaje figurativo; y por ultimo un lenguaje intervencionista donde se coloca el Arte Mínimal, el Arte Póvera, el Land Art y el Arte Conceptual. 
Si pensamos en 1962 como marcando el final del expresionismo abstracto, tendríamos entonces una cantidad de estilos sucediéndose a una velocidad vertiginosa: el campo de color en pintura, abstracción geométrica, neorrealismo francés, pop, op, minimalismo, arte póvera, y luego lo que se llamó Nueva Escultura (...) y luego el arte conceptual. ${ }^{22}$
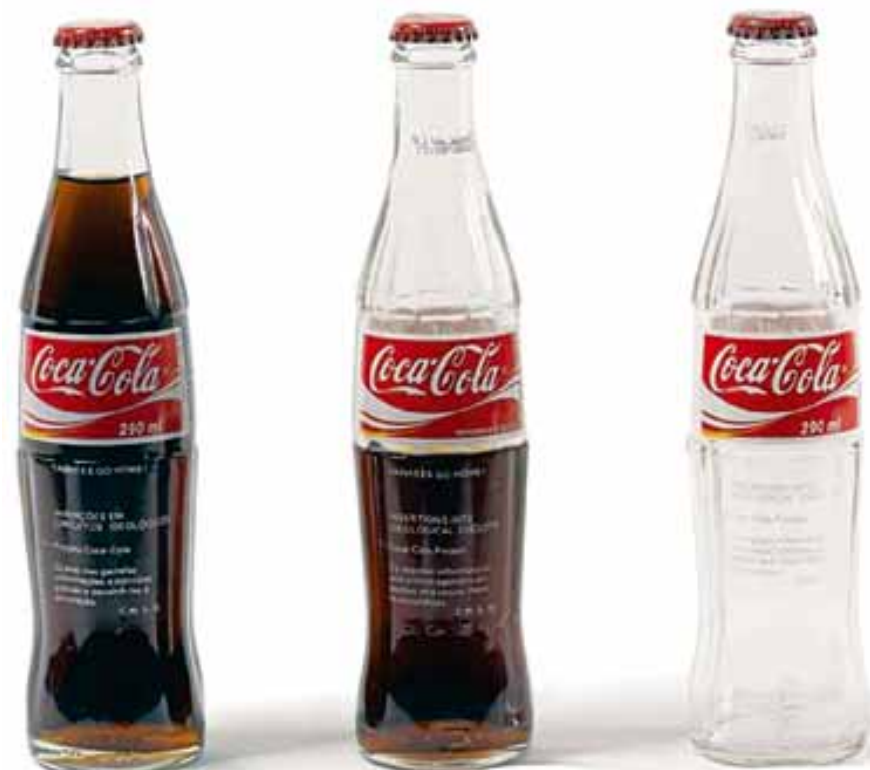

Figura 9: Cildo Meireles, Inserciones en circuitos ideológicos: Proyecto Coca-Cola, 1970, edición desconocida. Botellas de Coca-cola con transferencia de texto con serigrafía.

Un arte emergente que parece nacer para contrariar todos los valores artísticos, y parece negar la fuerte presencia de un mercado y sus valores comerciales. Un arte que vive sin objetos permanentes, que se constituye de ideas y conceptos, sin duda una nueva forma de expresión, o por otras palabras, la década de los setenta fue un período en el que se cuestionó la naturaleza del arte con tal radicalidad que se creó una situación de verdadero desconcierto. ${ }^{23}$

A partir de final de los años 70, se crean nombres como el Neoexpresionismo alemán, la Transvarguardía Italiana y la Figuración libre francesa como movimientos pictóricos que surgen en reacción al Minimalismo y al Arte Conceptual, y que no trayendo nada

22 DANTO, Arthur, C. Después del fin del arte. El arte contemporáneo y el linde de la historia, p. 35.

23 UBERQUOI, Marie-Claire, ¿El arte a la deriva?, p. 84. 
de nuevo han rehabilitado la pintura. Una pintura que se empezó a promover a fuerza de marketing a principios de los ochenta era una pintura expresionista, exacerbada, brutal y agresiva ${ }^{24}$. Es mantenida la necesidad de repudiar los aspectos burgueses que caracterizaron el arte durante años, viviendo el presente e indagando lo que es inmediato. Se desarrolla un arte sin límites técnicos, conceptuales y artísticos en que los New Media adquieren todo el protagonismo. En los años 80 así como en los 90, surge un arte extremadamente ecléctico, una búsqueda en las tendencias del pasado:

Si el retorno de la pintura con la sucesión de los estilos «neo» y el desarrollo espectacular de la escultura habían sido notas dominantes en la década de los ochenta, el auge de la fotografía y del video determinaría buena parte de la creación de los noventa. ${ }^{25}$

Los artistas en los años 90 utilizan la fotografía no únicamente como una forma de inmortalizar las acciones realizadas 0 un medio de documentar obras efímeras 0 conceptuales; la fotografía así como el video son el reflejo de un nuevo lenguaje dominante.

Para buscar nuevos horizontes muchos fotógrafos se dedican también a crear instalación, la fórmula mágica que impera en el arte de los años noventa y que permite al artista incorporar toda clase de elementos heterogéneos, entre ellos la fotografía y la parafernalia y la tecnología digital. ${ }^{26}$

Lo que era excepción se tornó regla ante el anticonformismo con las convenciones plásticas de un pasado, que abrió las puertas a las nuevas formas de comunicación y expresiones artísticas, un trayecto discontinuo y fragmentado, de tiempos y velocidades distintas. Es fundamental destacar las desenfrenadas manifestaciones que a partir de los años 60 se dieron a través de las mezclas de técnicas y la búsqueda de la interdisciplinariedad en el campo del arte. Los artistas ya no rechazan el público burgués y sus valores, pareciendo vivir bajo una utopía rebelde como base de su actitud creativa. Se observa un producto resultante de esta tendencia evolutiva, artística y humana, una conciencia estética que aumentó y difundió progresivamente su horizonte, su intensidad y su intencionalidad.

\footnotetext{
24 UBERQUOI. ob. cit. p. 87.

25 Ibídem. p. 133.

26 Ibídem. p. 138.
} 
Desde el ocaso de las vanguardias, el arte ha tenido que reinvendicarse a sí mismo sin tener que «atar al padre», porque el padre ya estaba muerto. No quedaban más academias que derrumbar ni tradiciones que combatir. El rey estaba desnudo y el postmodernismo no ha hecho otra cosa que evidenciarlo, porque los intentos por encontrarle nuevas vestimentas -incluso recosiendo las viejassólo han conseguido provocar mucho ruido mediático y pocas sorpresas.

A lo largo de los últimos cincuenta años se ha ido contra la belleza, contra el objeto artístico, contra el museo, contra la galería y contra el valor mercantil del arte.27

Toda una historia que se define a través de una evolución reiterante y cíclica, o sea, cuando una propuesta llega a su extremo, es el momento de iniciar nueva búsqueda en una dirección opuesta. Y es aquí donde el arte contemporáneo se encuentra y vive por sí solo, donde conquista y se hace imperial, donde su objetivo principal es establecer una relación cambiante con el individuo y la sociedad, mutante en el tiempo y en el espacio de acuerdo con sus espectadores y creadores. Vive y existe dominado por distintas entidades y alimentado de vicios mercantiles, con el triunfo del nihilismo, como la depreciación de la vida en su plenitud, con base en ficciones que no traen consigo la esencia de la propia vida.

27 UBERQUOI, ob. cit. p. 153. 
1.2. El artista como el agente de la ruptura con la tradición.

El público, en general, se ha aferrado a la teoría de que el artista es un semejante suyo que debe producir Arte del mismo modo que un zapatero zapatos. Con esto quiere dar a entender que debe producir la clase de pintura o escultura que ha visto y que fue antes señalada como Arte. Puede comprenderse esta extraña exigencia, pero no apoyarla, pues es la única cosa que el artista no puede hacer. ${ }^{28}$

Es evidente que son diversos los factores que han contribuido e influido en el desarrollo del papel del artista. Por un lado, el privilegio y reconocimiento social obtenido en el Renacimiento, y que a partir del siglo XVIII ha alcanzado una valoración excesiva; por otro lado, la difusión de una educación universal, así como la difusión de la cultura con la creación de los museos y las sucesivas organizaciones de los Salones; por otro, la aparición de la industria moderna y la gran importancia de los medios de masas; y, por último, la existencia de un mercado.

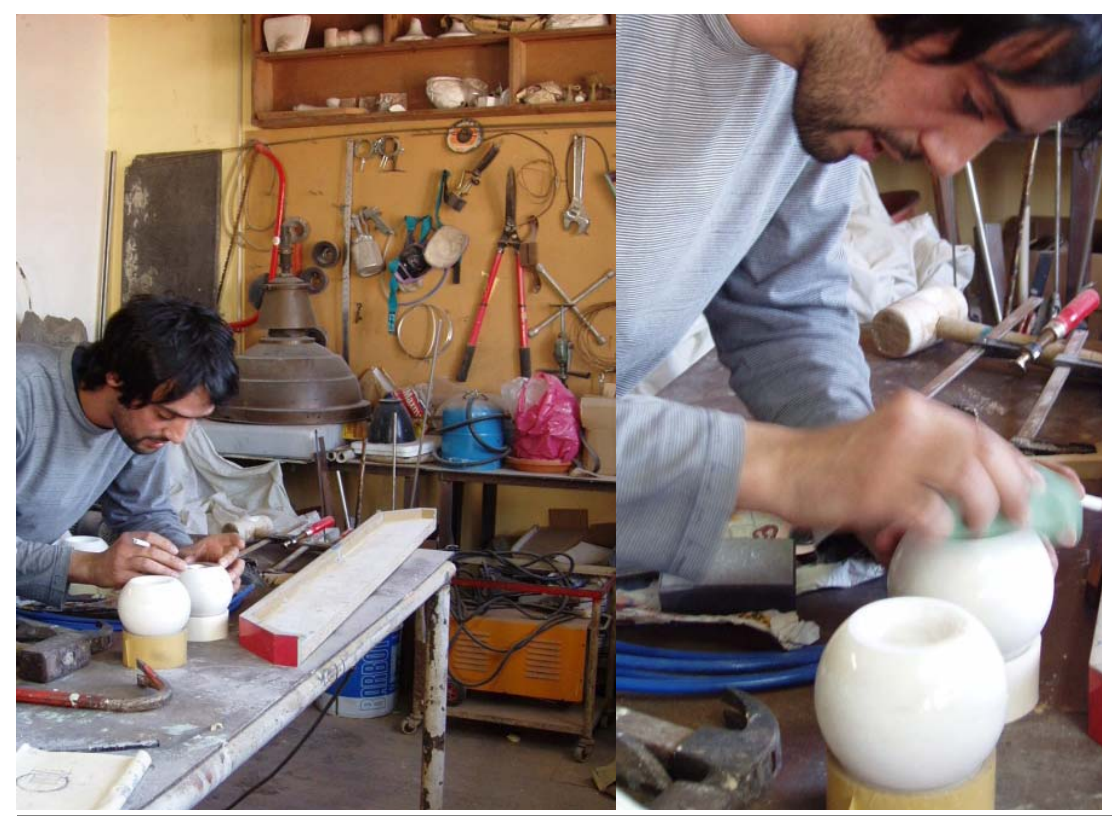

Figuras 10 y 11: El artista Isaque Pinheiro en su atelier, trabajando mármol.

${ }^{28}$ GOMBRICH, ob. cit. p.492. 
Hablar de la producción artística occidental, implica hablar de la individualización de la entidad del artista, algo que remonta al período áureo del Renacimiento. Hasta entonces, se presentaba como un oficio manual de referida perfección y el individuo que lo desempeñaba era un artesano altamente especializado. Es también, en los siglos XIV y XV, cuando se estructura la figura del artista como identidad independiente, que surgen las primeras biografías de artistas, como las escritas por Vasari publicadas en el siglo XVI. Ya en el Romanticismo no cabe duda de que el artista es ese ser creador, dotado casi divinamente. Lo cierto es, que esta denominación de artista se hace acompañada de una evolución, una reactualización como fruto cultural en que se trazan los primeros estereotipos en la relación de obra y artista.

Volviendo a finales del siglo XIV se encuentra el Libro del Arte de Cennino Cennini, considerado el último recetario antiguo, donde el autor deja sus recomendaciones y consejos, así como recetas reivindicando y dignificando el arte y a sus ejecutantes. Todo el tratado está compuesto de enseñanzas, un conjunto de consejos en los que Cennini no olvida ningún pormenor, como el presentado en el Capítulo LXIII, intitulado De cómo es de necesidad saberse hacer los pinceles y donde se podrá leer,

Ya te he dicho que todos los colores se emplean con pincel y cómo se muelen (...): ahora te hablaré de su uso con temple y sin él. Pero antes debes saber cómo te puedes valer de ellos; pues no es posible sin pinceles. Por lo cual, dejemos todo lo demás y, antes que nada, aprende a hacerte tus propios pinceles, lo cual conseguirás de la siguiente manera. ${ }^{29}$

A lo largo de la historia del arte se hicieron conocer innumerables tratados sobre la técnica artística a emplear y el comportamiento que el artista tenía que seguir a la hora de realizar una obra de arte. En tales tratados son expresados los más correctos procedimientos e indicados los mejores materiales para la obra, según la duración y la cualidad de los productos, teniendo como parámetros fundamentales la estabilidad e inalterabilidad.

El artista, considerado fundamentalmente el homo faber, con vasta experiencia, sabiduría en la producción artesanal y capacidad de elaboración intelectual y formal,

${ }^{29}$ CENNINI, Cennino. El libro del arte, p.109-110. 
une su conocimiento de la naturaleza al conocimiento de los procedimientos de la producción y construcción artística. Cabe referir, tratados como Sobre la Pintura de Leon Battista Alberti escrito en 1435, con la intención de formar al pintor, y que según sus consejos e indicaciones se convertiría en el pintor perfecto, el artista que al desempeñar tal actividad recibiese la colaboración o ayuda de una deidad, como en una comparación del artista con Dios. Alberti en su obra dejó demostrados todos sus conocimientos, transmitidos de un pintor que habla a los pintores, como él mismo expresa, animando a quien quiera ser un buen pintor que se entregue al intenso aprendizaje óptico de las superficies y entornos.

El oficio del pintor es circunscribir con líneas y pintar con colores en una superficie unos cuerpos dados, de tal modo que, con un cierto intervalo y a una cierta posición del rayo céntrico, cualesquiera cosas pintadas que veas, parezcan prominentes y semejantes a los cuerpos dados. [...] El modo en que pueden hacerlo, ya lo dijimos cuando tratamos más arriba de la composición y de la recepción de la luz. Pero quiero que el pintor, a fin de que pueda captar perfectamente todas estas cosas, sea ante todo un hombre bueno y docto en las buenas artes. ${ }^{30}$

Es a partir del Renacimiento cuando la producción artística vive un proceso de autonomía envolviendo a la actividad, que empezó a apartarse de la religión y su lenguaje, e inició una búsqueda hacia la forma pura. Tal como el artista se distingue del artesano, a su vez, la obra se diferencia largamente de los otros objetos. No hay duda, de que es en el Renacimiento donde se defiende, casi como una imposición, que la obra deberá ser única y creada por un solo individuo. Un hombre orgulloso por su capacidad de crear una imagen a través del dominio de la expresión artística dominante, como se refleja en toda la producción hasta finales del siglo XIX.

La observación directa sobre la naturaleza es el medio para alcanzar sus deseos y darles forma. Una unión entre arte y conocimiento deja que el artista se exprima en la medida que descubre, instaurando normas y métodos en un sistema tenido como infalible.

En primer lugar, has de considerar si las figuras tienen el relieve que exigen el lugar y la luz que las alumbra; que las sombras no sean las mismas en el centro de la historia que en los extremos, pues una cosa es que las figuras estén circundadas de sombras y otra que tan sólo tengan sombras en un lado. (...)

${ }^{30}$ ALBERTI, Leon Battista. Sobre la Pintura, pp. 143-144. 
En segundo lugar, considera la distribución o disposición de las figuras: que estén dispuestas conforme a las circunstancias de la historia. En tercer lugar, que las figuras estén diligentemente ocupadas en sus particulares intereses. ${ }^{31}$

Hay casi una metodología preconcebida e instituida para la buena pintura, algo que se acentuará con la creación de las academias también en el Renacimiento, cuando la concepción artística surge bajo criterios inamovibles y reglas indisolubles.

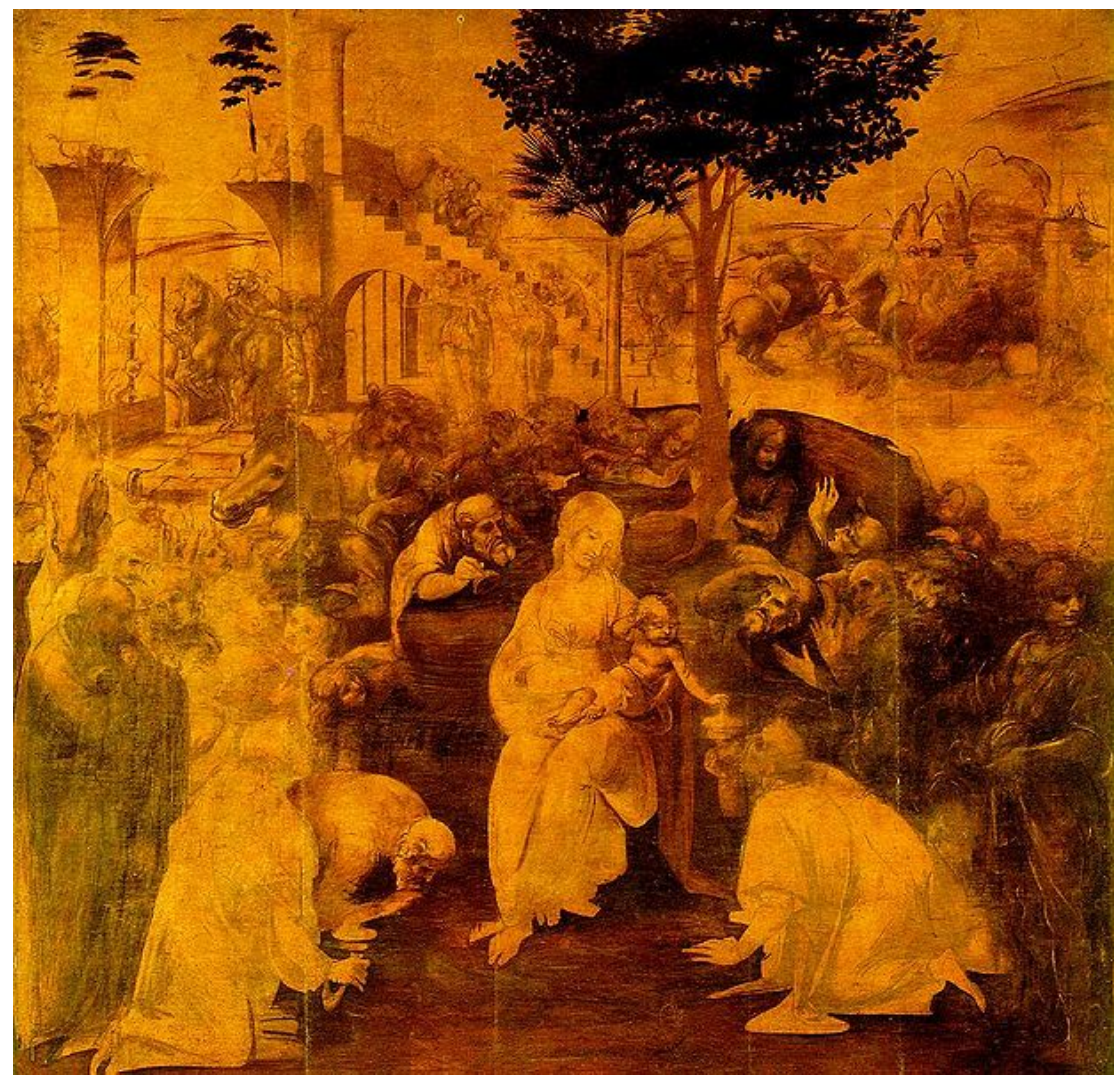

Figura 12: Leonardo da Vinci, La adoración de los magos, 1481-82. Oleo sobre tabla, 246x243cm, Galería de Uffizi.

El tratado Da Pintura Antiga, de Francisco de Holanda32, publicado en 1548 en Lisboa es otro testimonio de los consejos y creencias de épocas pasadas. El portugués Francisco de Holanda afirma que el artista puede inventar la imagen sin alcanzar la

31 VINCl, Leonardo da. Tratado de la pintura. pp. 390-391.

32 Francisco de Holanda (1517-1585, Lisboa) pintor y humanista, fue uno de los más relevantes exponentes de la reflexión estética en el renacimiento portugués. En 1537 parte para Roma donde convive con el maestre Miguel Ángelo. Como refleja en su tratado, la idea es responsable de la invención, concebida interiormente y fruto del ingenio, donde afirma que Dios es la fuente de toda la pintura, siendo también Él el primer pintor. 
idea, cuando la finalidad del verdadero artista es la de contemplar la "Belleza Absoluta", la esencia de las formas, indistintamente de la idea. El furor creativo es el proceso que permite al artista aspirar y ascender a la especulación y a la contemplación de la idea, siendo posible dibujar según el «don innato», la «reminiscencia» y la «aspiración divina».

Como neste ponto Ele [Deus] se tiver, porá velocíssima execução à sua ideia e conceito, antes que com alguma perturbação se lhe perca e diminua; e se ser pudesse pôr-se com 0 estilo na mão e fazê-la com os olhos tapados, melhor seria, para não perder, aquele divino furor e imagem que na fantasia leva. ${ }^{33}$

A mediados del siglo XVI, el arte se afirma, y define su autonomía ante la ciencia. A pesar de desarrollarse en diversos estilos en toda Europa las leyes establecidas en el Renacimiento perduran, pareciendo insolubles durante casi cuatro siglos.

También en el siglo XVII el tratado Arte de la Pintura de Francisco Pacheco presenta, como en los tratados anteriores de Battista y da Vinci, las recomendaciones que se pensaban necesarias para la formación de un buen pintor y lo indispensable para considerar la pintura una obra de arte.

Pero si la pintura es efectiva con verdadera razón -aunque de cosas que no son necesariasy las artes son infalibles, esto es, no yerran jamás y siempre consiguen su intento, todas las veces que el artífice aplicaré los medios convenientes y usará de los preceptos y reglas del arte, alcanzará gloriosamente lo que pretende, que es la perfección de su obra. ${ }^{34}$

Ya en el siglo XVIII las academias han estado sobre el patronazgo real y la Revolución Francesa ha dejado sus huellas en la enseñanza artística, por ello, cabe subrayar la importancia de los maestros del pasado, en que la pintura había dejado de ser una profesión cualquiera, (...). Ahora se convirtió, por el contrario, en algo así como la filosofía, que tenía que ser enseñada en academias. ${ }^{35}$ La proliferación de las academias ayudó al cambio de la condición social del artista y la expansión del mercado condujo a la mayor especialización, separando de forma radical y definitiva el artesano del artista, donde:

${ }^{33}$ HOLANDA, Francisco de. Da Pintura Antiga, p. 13.

T. A.: Como en este punto Él [Dios] se tuviera, pondrá velocísima ejecución a su idea y concepto, antes que alguna perturbación se le pierda y disminuya; y si pudiese ponerse con el estilo en mano y hacerla con los ojos cubiertos, mejor seria, para no perder, aquel divino furor e imagen que en la fantasía lleva.

${ }_{34}$ PACHECO, Francisco. Arte de la Pintura. p.88.

${ }^{35} \mathrm{GOMBRICH}$, ob. cit. p.396. 
las cualidades ideales que se requerían de un artesano/artista en el viejo sistema eran una combinación del genio y la regla, la inspiración y facilidad, la innovación y la imitación, la libertad y el servicio. Estas cualidades fueron finalmente descompuestas a lo largo del siglo $\mathrm{XVIII.}{ }^{36}$

De los varios cambios, se destaca la posibilidad del artista de poder pintar cualquier tema, mientras tuviese la capacidad de dar expresión al tema retratado. Diego Antonio Rejón de Silva ${ }^{37}$, en su tratado La pintura: poema didáctico en tres cantos, apunta,

Mal se podría llamar Pintor aquel que supiese hacer una figura con elegante contorno, y buen colorido, si de ningún modo pudiese darla la expresión que exigiese el asunto. De la misma manera, el que solo sepa copiar las obras de otro, y le falte la inteligencia necesaria para inventar una composición, y darle el decoro conveniente, según las circunstancias del asunto, será solo Copiante, no Pintor. ${ }^{38}$

A la par de los nuevos hechos del siglo XVIII, surge la gran transformación en el concepto de la expresión, y que tuvo un papel esencial en el siglo XIX, donde el artista era libre de representar lo que quería, en que la ruptura con la tradición había abierto un campo ilimitado para escoger. ${ }^{39}$

Reivindicando un sistema más libre las academias empiezan a perder su hegemonía y no es por casualidad que el arte moderno surja alrededor de 1860. Llegado el siglo XIX, se da continuidad a la evolución artística, principalmente en lo que dice respecto al método y técnicas de representación, es inevitable: el hombre en la sociedad industrial está a merced de múltiples estímulos y sensaciones ${ }^{40}$. Los temas no cambian, el artista continúa retratando paisajes y escenas de lo cotidiano, pero los cambios existen y alteran las reglas de estilo, de ejecución y del sujeto en la academia, quizás, su objetivo no es crear un objeto dirigido a su contemplación, sino intervenir en el mundo dirigiendo los esfuerzos a la transformación de las condiciones de habitabilidad. ${ }^{41}$

\footnotetext{
${ }^{36}$ SHINER, Larry. La invención del arte. Una historia cultural, p.164.

${ }^{37}$ Diego Antonio Rejón de Silva - 1754, Madrid/ 1796, Murcia - vivió la compleja etapa de conflictos entre los ámbitos gremiales y los académicos ocurridos en el último tercio del siglo XVIII. En su tratado relaciona el dibujo, composición y colorido como las tres partes de la pintura, insistiendo en la expresión como la representación visible y activa del movimiento. Por ello, el artista sería el resultado más allá de los aspectos manuales y mecánicos aprendidos en los talleres de sus maestros, reuniendo conocimientos en diversas áreas, como: perspectiva, geometría, historia, filosofía, etc. ${ }^{38}$ Diego Antonio Rejón de Silva, La pintura: poema didáctico en tres cantos. Segovia: Antonio Espinosa de los Monteros, 1786, pp. 134-135

${ }^{39} \mathrm{GOMBRICH}$, ob. cit. p. 413

${ }^{40}$ FISCHER, Ernest. El artista y su época, p.33.

${ }^{41}$ PUELLES Romero, Luis. Entre imágenes: experiencia estética y mundo versátil, p.138.
} 
El desarrollo autónomo de una metodología de investigación científica y el progreso de la ciencia en los ciclos productivos, dará a conocer materiales desconocidos al artista. Con el objetivo de sistematizar los nuevos conocimientos y eventos, se publicaron tratados como: De la loi du contraste simultané des couleurs et de l'assortiment des objets colorés, en 1839 de Chevreul, o Science de la peinture nel 1886 de Vibert, químico de la Lefranc, y The chemistry of prints and paintings, en 1890 de Church, químico de la Royal Academy of Arts de Londres. Con el impulso de la industria, hay una búsqueda en la física y química del color donde se alcanzan fundamentales progresos, además del interés en saciar el conocimiento hay un deseo de agrupar a las recetas y procedimientos tradicionales los secretos desvelados sobre los nuevos materiales. Todo ello es demostrado en la actividad de los fabricantes de materiales artísticos, entre los pioneros Winsor \& Newton en Inglaterra, Lefranc en Francia y Schöenfeld en Alemana.

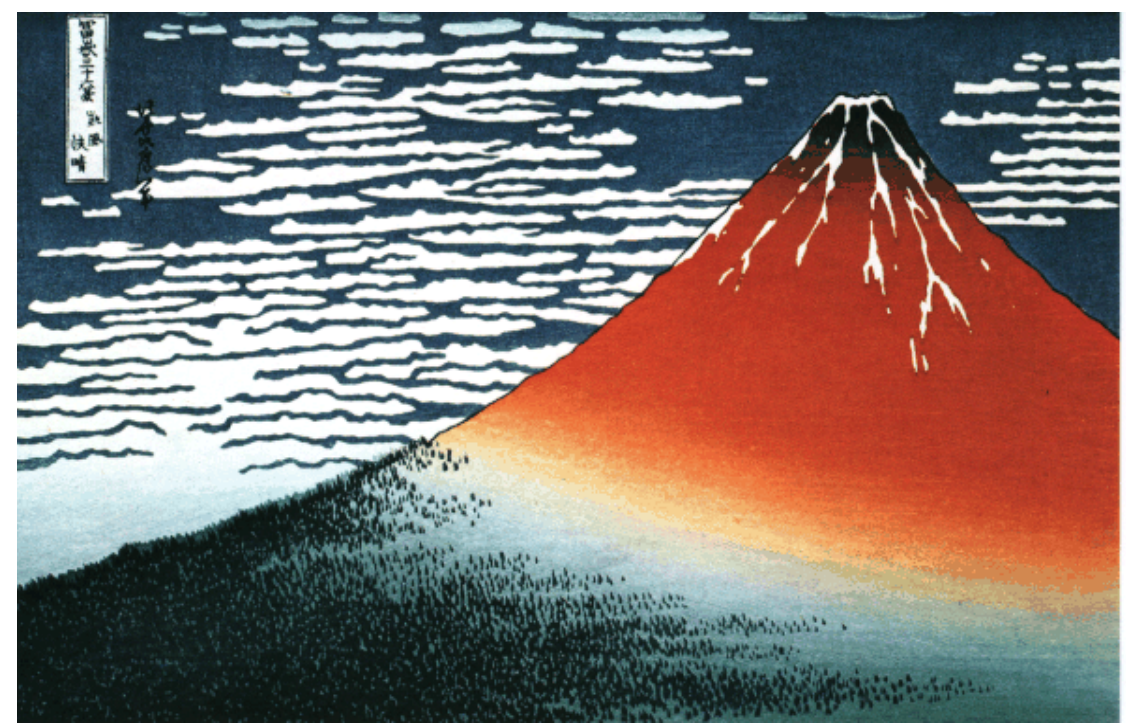

Figura 13: Katsushika Hokusai. South Wind at Clear Dawn (Gaifu kaisei), 1832, perteneciente a la serie 36 vistas del Monte Fuji.

París, centro artístico europeo durante el siglo XIX, fue el entorno ideal para una innovadora práctica artística, donde el artista era libre de pintar nuevos temas sin seguir normas académicas, pues el artista no tenía que responder ante nadie sino ante 
sus propias sensaciones de lo que pintaba y cómo pintaba. ${ }^{42}$ Aliada la aparición de la fotografía y la estampa japonesa, ambas contribuirán en gran manera a la innovación temática y técnica. La presencia de la fotografía llevó a los artistas a buscar algo que esta técnica de representación no tenía, y la verdad es que el arte moderno no habría llegado a lo que es sin el choque de la pintura con este invento. ${ }^{43}$

Es en 1848 con el grupo de artistas de Barbizón, donde se desarrolla la búsqueda de un realismo a través del contacto directo con la naturaleza, donde las pinceladas sueltas rompen el acuerdo entre la pintura, como los primeros pasos de un discurso social y en busca de la realidad. Surge una pintura de instantes, sin tiempo para mezclar y armonizar los colores, donde se fija rápidamente en la tela el paisaje, sin dar gran importancia a los pormenores. Libertad y ortodoxia, desenvoltura y rigor siguen un camino que perderá todos sus límites, dejando tras de sí las referencias alegóricas y literarias, y las reglas académicas como se puede ejemplificar a través del efecto mate de pinturas sin barniz protector. Hechos como éste han dejado atrás reglas básicas para la pintura como graso sobre magro y han tenido sus repercusiones hasta hoy en su particular valoración expresiva.

Otras son las alteraciones significativas en el proceso de creación, como el uso de preparaciones muy absorbentes obtenidas con yeso y cola, pintadas directamente sobre la tela, el uso del color directo del tubo, los empastes de espátula y pinceles, el abuso de diluyentes y la supresión de barnices finales, hace de la superficie pictórica una superficie opaca y frágil, y como expresa Gombrich en su Historia del arte,

La lucha de los impresionistas se convirtió en una especie de leyenda áurea de todos los innovadores en arte, quienes en lo sucesivo podrían acogerse siempre a aquella manifiesta incapacidad del público para admitir los nuevos métodos. ${ }^{44}$

La pérdida de conocimiento de la técnica tradicional determinó condiciones de extrema fragilidad en las pinturas de los siglos XIX y XX. Una vez incitados a utilizar nuevas técnicas, que no las enseñadas en las academias, los impresionistas pudieron ser considerados como los primeros artistas modernos. Sin embargo, sus propuestas

\footnotetext{
42 GOMBRICH, ob. cit. p.432.

43 Ibídem. p.434.

44 Ibídem. p.433.
} 
no fueron completamente revolucionarias ni sus fines distintos de las demás pinturas realizadas desde el siglo $\mathrm{XV}$, pero lo cierto es que el impresionismo dejó varias posibilidades abiertas, que posteriormente fueron desarrolladas en distintas direcciones. Entre ellas la seguida por Cézanne, y este sí, considerado el padre del arte moderno. Cézanne al contrario de los impresionistas fijaba en la tela la esencia de la luz en las cosas y no los momentos fugaces, le interesaba transmitir la permanencia a través de pinceladas articuladas y sin dispersión, una preocupación con los volúmenes, los contornos y las relaciones espaciales, donde había una cosa que sí estaba dispuesto a sacrificar si era necesario: la «corrección» convencional del contorno. 45

Otro camino en el que el impresionismo dio paso, fue el estudio de la teoría científica cromática desarrollado por George Seurat y sus compañeros del puntillismo y divisionismo. Si las pinturas impresionistas resultaban de experiencias visuales espontáneas, las pinturas de Seurat seguían con exactitud un método científico: superficies limpias, compuestas por pequeñas pinceladas uniformes y de color puro, jugando con la cuestión de división técnica de la luz y color, como si de una ecuación matemática se tratase.

Van Gogh, un segundo camino solitario derivado de la pesquisa impresionista, refugiándose de la vida moderna, hizo de la pintura, de líneas agresivas y contorsionadas, su medio de comunicación y la forma de encontrarse a sí mismo, dejando atrás todo lo que eran recetas, normas y reglas. Con una mayor preocupación en expresar a través de pinceladas ritmadas y colores vibrantes y una alienación respecto al mundo que lo rodeaba, su propia agitación y estado de espíritu.

Minha pincelada não tem qualquer sistema. Eu ataco a tela com toques irregulares do pincel, que deixo como saem. Empastes, pontos da tela que ficam descobertos, aqui e ali pedaços absolutamente inacabados, repetições, brutalidades; em suma, estou inclinado a pensar que o resultado é demasiado intranquilizante e irritante para que isso não faça a felicidade dessas pessoas que têm ideias preconcebidas fixas sobre a técnica. ${ }^{46}$

\footnotetext{
${ }^{45} \mathrm{GOMBRICH}$, ob. cit. p.449.

${ }^{46}$ Carta de Vicente Van Gogh a Émile Bernard, Arles, abril de 1888. en CHIPP, ob. cit. p.28.

T. A.: Mi pincelada no tiene cualquier sistema. Yo ataco la tela con toques irregulares del pincel, que dejo como salen. Empastes, puntos de la tela que quedan descubiertos, aquí y allá pedazos absolutamente inacabados, repeticiones, brutalidades; en suma, estoy inclinado a pensar que el resultado es demasiado inquietante e irritante para que eso no haga la felicidad de esas personas que tienen ideas preconcebidas fijas sobre la técnica.
} 
Por último Paul Gauguin, cansado de la civilización europea buscó en el sur del Pacífico ambientes exóticos y primitivos. Sus pinturas de líneas equilibradas y colores armoniosos buscaron penetrar en el espiritu de los nativos y observar las cosas tal y como son. 47

Los tres solitarios que se sintieron incomprendidos durante sus etapas de creación, han tenido repercusión en los jóvenes, que salidos de las escuelas de arte, se sentían insatisfechos con la técnica y metodología adquiridas. $Y$ nada mejor que un sentimiento de descontento para buscar nuevos caminos hacia el arte moderno, que en el fondo surgen de las propuestas e ideales de estos tres artistas, como tan bien exprime una vez más Gombrich:

La solución de Cézanne condujo, finalmente, al cubismo surgido en Francia; la de Van Gogh, al expresionismo, que halló sus principales representantes en Alemania; y La de Gauguin a las varias formas de primitivismo que han tenido lugar. ${ }^{48}$

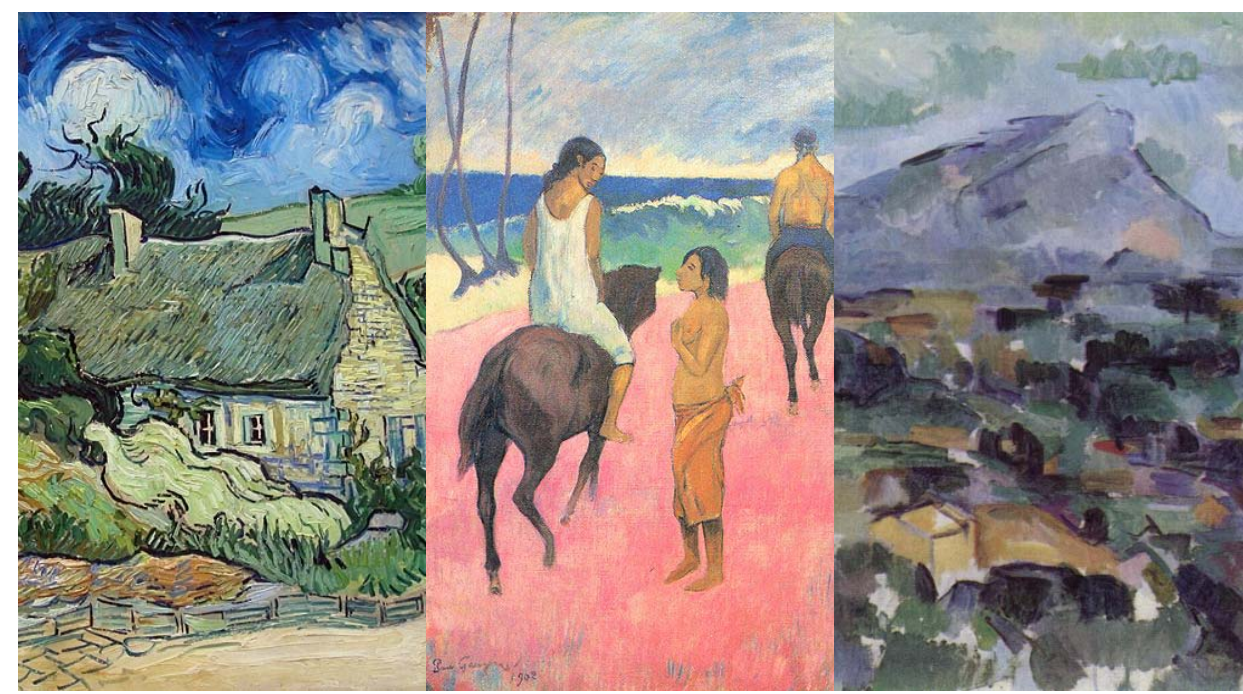

Figura 14: Van Gogh, detalle de Campos en Cordeville, en Auvers-sur-Oise, 1890, oleo sobre tela. Figura 15: Paul Gauguin, detalle de Jinete en la Playa, 1902, oleo sobre tela. Figura 16: Paul Cezanne, detalle de La montaña SainteVictoire, 1905, oleo sobre tela.

${ }^{47}$ GOMBRICH, ob. cit. p. 458.

48 Ibídem. p.459. 
Tres movimientos que nacen en busca de algo distinto, que dejan tras de sí explicaciones científicas sobre la sociedad y la naturaleza, que parten para y de un nihilismo general. El artista busca un camino marginal pero no necesariamente en solitario, porque pertenecer a un grupo le garantiza cierta seguridad. Estos grupos están determinados por su forma de trabajar o principalmente apoyados por los mismos críticos o comercializados por los mismos marchantes.

En los primeros años del siglo XX, se afirma un nuevo lenguaje, y simultáneamente la confirmación del artista como creador liberado de todas las normas. Al traspasar la frontera de la tradición, se asegura el desafío para la producción y para la metodología industrial, abandonando hasta los instrumentos y la materia habituales de la pintura, para crear objetos que participan del experimentalismo y de una nueva lógica, que siguen modas y ritmos de producción muy propios. Un cambio que se mantiene y que actualmente es la base de las experiencias artísticas, como un juego entre materias y nuevas técnicas.

O quadro tornou-se agora uma entidade que pertence à mesma ordem de espaços que os nossos corpos; já não é o veículo de um equivalente imaginário daquela ordem. O espaço pictórico perdeu o seu "dentro" e tornou-se todo um "fora". O espectador já não pode escapar para ele, fugindo do espaço no qual se encontra. ${ }^{49}$

En los años 30 los hechos y su significado se tornan menos claros y los artistas surgen como casos aislados, siendo imposible reducir su actividad a un denominador común. Los artistas son los primeros en asumir que no existe ningún nexo entre ellos y que sus trabajos tendrían que ser lo más diferentes posibles. La verdad, es que existía un denominador común, que era esa necesidad tan brutal de buscar lo nuevo, que por sí sólo transformaban el rechazo y esa incesante necesidad en la única "tradición"; además de la permanencia en el mismo mundo, rodeados de las mismas influencias y formando parte de un mercado común.

Todas las transformaciones del lenguaje pictórico, que se inician en el siglo XIX y se desarrollan en el siglo XX, actúan en el mismo sentido: liberan la pintura de todo lo

${ }^{49}$ Clement Greenberg, Abstracto, representacional e assim por diante, 1961. en CHIPP, ob. cit. p. 590.

T. A.: El cuadro se tornó ahora una entidad que pertenece al mismo orden de espacios que nuestros cuerpos, ya no es el vehículo de un equivalente imaginario de aquella orden. El espacio pictórico perdió su "dentro" y se tornó todo un "fuera". El espectador ya no puede escapar de ello, huyendo del espacio en el cual se encuentra. 
que hacía de ella un arte de imitación, queriendo negarse a ser un índice de lo real, como es subrayado por Dora Vallier en la siguiente cita:

Esta arte, de facto, não deve nada ao passado. É uma outra arte. Mas é-o por causa da sua posição extrema. Integra na arte valores até então excluídos. No entanto, este estado da pintura não representa uma liquidação da herança recebida, mas sim um salto para o lado e, ao mesmo tempo, uma alteração de valores, na medida em que, pela primeira vez, a forma é subordinada à matéria. Já não se trata de realizar na tela uma forma previamente concebida, mas sim de a deixar surgir a partir da matéria. ${ }^{50}$

En este sentido, el arte actuó de una forma tan profunda que acabó por afectar y transformar la figuración, como una acción que infringe la lógica. Son innumerables los testimonios de artistas, que presentan su firmeza ante la ruptura con la tradición. Según Hans Hofmann en sus clases ${ }^{51}$ define al artista como:

agente em cujo pensamento a natureza se transforma numa fonte de criação, em que aborda os seus problemas do ponto de vista metafísico. Sua faculdade de sentir as propriedades inerentes às coisas domina o seu instinto criativo. ${ }^{52}$

Los tratados son sustituidos por manifiestos y el arte es la representación de «mundos» distintos, en que cada «mundo» es la expresión interna e individualizada de cada artista. Los criterios y procesos de creación y ejecución de una obra son mutantes, no sólo de artista a artista, sino también en el trayecto del propio individuo. Hay artistas que siguen la tradicional forma de pintar, pero hay otros como Jackson Pollock que optó por realizar obras de grandes dimensiones donde las telas eran colocadas en el suelo y de forma libre y ritmada creaba una armonía pictórica y cromática, sin recurrir a los instrumentos tradicionales como el caballete, los pinceles, la espátula. A través de distintos estímulos el artista se entregaba totalmente al acto de pintar en un automatismo activo y vital, en una acción vertiginosa que aportaba a la expresión un papel revolucionario, y haciendo que Pollock se sintiera en el más alto

${ }^{50}$ VALLIER, Dora. $A$ arte abstracta, p.218

T. A.: Este arte, de hecho, no debe nada al pasado. Es otro arte. Pero lo es a causa de su posición extrema. Integra en el arte valores hasta entonces excluidos. No obstante, este estado de la pintura no representa una liquidación de la herencia recibida, sino un salto para un lado y, al mismo tiempo, una alteración de valores, en la medida en que, por primera vez, la forma es subordinada a la materia. Ya no se trata de realizar en la tela una forma previamente concebida, sino de dejarla surgir a partir de la materia.

${ }^{51}$ WEEKS S. T. y HAYES B. H. Search for the Real and Other Essay by Hans Hofmann, p.65. en CHIPP, ob. cit. p.544

52 T. A.: Agente en cuyo pensamiento la naturaleza se transforma en una fuente de creación; aborda sus problemas desde el punto de vista metafísico. Su facultad de sentir las propiedades inherentes a las cosas domina su instinto creativo. 
grado de la mística de la casualidad, como al encuentro de un estado de gracia en la elaboración de cada una de sus obras.

O que devia entrar na tela não era uma imagem, mas um acontecimento.

O pintor já não se aproxima de seu cavalete com uma imagem na mente; dirige-se a ele com o material na mão para fazer alguma coisa sobre aquele outro material que está à sua frente. A imagem seria o resultado desse encontro..$^{53}$

Además, no sólo los cambios se manifiestan en el momento de la creación, sino también en los nuevos conceptos de concepción y exposición, una vez que el artista deja de valorar los marcos de las pinturas y los pedestales de las esculturas. La pintura procura lo tridimensional, los collages rompen los límites del plano, la escultura se funde en el ambiente, el artista busca quebrar los límites entre el arte y la vida, siendo estas propuestas como un cuerpo unido e indisoluble. Todos los espacios son lugares posibles de creación y de exposición. El espectador gana un nuevo protagonismo en la relación entre el espacio y el arte, se establecen nuevas relaciones estéticas entre el objeto, el artista y el público: surge el arte de acción, con una relación directa entre artista y público. Los artistas intentan destruir los museos como lugares que crean obstáculos para el desarrollo del arte, haciendo ellos mismos la gestión del espacio expositivo. Hay una confrontación directa con la noción del museo y sus mecanismos de intimidación, hay una manifestación constante en la relación entre contexto, significado y aproximación a la obra de arte. El artista llama la atención. La obra surge como objetos que se transforman, hay un juego entre el artista y la obra. El artista conquista el espacio, un espacio donde se construye, se acciona, se reactiva, produciendo una conexión entre el espacio interno y externo del artista.

Hay distintas formas de abordar una tela o una hoja de papel en blanco, y en el deseado estado de inconsciencia ha sido uno de los medios utilizados por varios artistas, motivando movimientos y corrientes, siguiendo nuevos caminos, como en el caso del surrealismo o la pintura de acción.

53 Harold Rosenberg, Os pintores americanos de acção, 1952. en CHIPP, ob. cit. p.578

T. A.: Lo que debía entrar en la tela no era una imagen, sino un acontecimiento. El pintor ya no se aproxima a su caballete con una imagen en la mente; se dirige a él con el material en la mano para hacer alguna cosa sobre aquel otro material que está delante de sí. La imagen sería el resultado de ese encuentro. 
Para ser artista hay que captar y transformar la experiencia en recuerdo, el recuerdo en expresión, la materia en forma. Para el artista, la emoción no es todo; debe conocer su oficio y encontrar placer en él, comprender todas las reglas, procedimientos, formas y convenciones con que la naturaleza -la arpía- se puede domar y someter al contacto con el arte. ${ }^{54}$

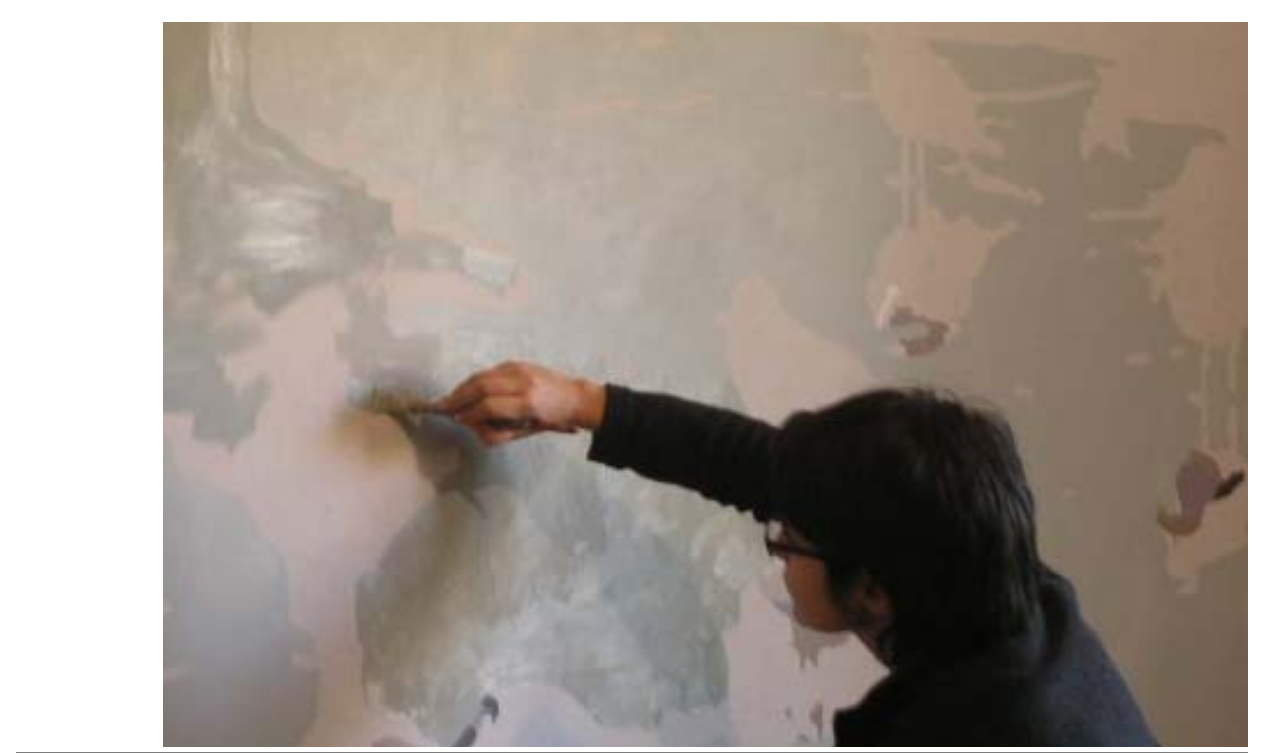

Figura 17: La artista Ana Cardoso en su atelier (2006).

Si hay movimientos y corrientes artísticas, como el Surrealismo y la Action Painting, que han justificado sus creaciones con base en el inconsciente, como la forma de búsqueda de sí mismos; a su vez, existen movimientos que encuentran su fuerza en la reducción de la materia, de la forma y de la idea, una búsqueda a través de la abstracción trazada por el Minimalismo. Todavía, serían muchos los ejemplos de ruptura a lo largo de la historia con la posibilidad de escribir páginas y más páginas sobre la necesidad que el artista sintió, y siente, en romper con el pasado en presencia de un deseo avasallador y sin límites de convergir con lo 'nuevo'. No hay una formula, hay un culminar de vivencias y pensamientos que agregados a varios aspectos sociales y históricos llevan a la concretización de acciones únicas con distintos valores, pero que sin duda dibujan y tienen su lugar de destaque en la historia del arte, como la decisiva y transformadora propuesta de Ducahmp, o la desmaterialización del arte transmitida por Yves Klein en sus Antropométries o las

${ }^{54}$ FISCHER, Ernst. La necesidad del arte, p.8. 
extremadas propuestas de Piero Manzoni con sus Esculturas Vivas. Así, se tendrá que comprender cada obra en sus distintas dimensiones, como: materia y contenido, como pensamiento y proceso, o como afirma Mark Rothko, un cuadro no es la imagen de una experiencia; es una experiencia. ${ }^{55}$

Es curioso plantear, que si por un lado se conoce a artistas que elaboran obras con materiales industriales según la filosofía de la construcción de una obra de arte tradicional -soporte y medio pictórico-, por otro, están presentes obras que son una mezcla de pintura y escultura, que nacen en el espacio, y son aún objetos que no están limitados a una composición que el artista determina, y esto ocurre porque hay un nuevo artista,

[...] un artista-alquimista, atraído por las posibilidades físicas, químicas y biológicas de los nuevos elementos que irrumpían en el terreno del arte: animales, vegetales y minerales; un artista que más que trabajar sobre principios necesitaba descubrir las raíces de las cosas, participar en los acontecimientos naturales -el crecimiento de las plantas, las reacciones químicas de un mineral- para acabar descubriéndose a sí mismo, su cuerpo, su memoria, sus gestos y todo lo que ello derivaba: lo sensorial, lo impresionable y lo sensual. ${ }^{56}$

Robert Smithson, artista que desarrolló su trabajo en la línea del Land Art habla de un artista que él creía cercano a la actividad del ingeniero y que tomaba el paisaje como material de unas nuevas obras. ${ }^{57}$ Son varias las definiciones que los propios artistas ofrecen sobre la "persona artista". Una es la definición dada por Joseph Beuys cuando defiende que el arte es vida y que cada hombre, un artista, subrayada también por Jonh Cage cuando dice que el arte debería ser la afirmación de la vida con el fin de acceder al milagroso dominio del nuevo despertar de la conciencia humana. ${ }^{58}$ De la misma forma, Sydney Geist subraya:

Submersa nos estilos públicos, escolas e teorias de arte, independente dos ismos e impermeável à crítica, é a mente do artista. Ela é o mundo da fantasia e do desejo, do sonho e da obsessão, da necessidade secreta e do programa formulado, da Ideia e da ideia fixa. É a parte da arte que dá ressonância à estrutura e significado às marcas e formas que 0 artista faz: é a parte "impura". No vasto campo de ídolos quebrados, lendas desgastadas e tabuletas apagadas, ela constrói seu próprio mito. ${ }^{59}$

\footnotetext{
${ }^{55}$ KAHLER, Erich. La desintegración de la forma en las artes, p.60-61.

56 GUASCH, Anna María. El arte del siglo XX en sus exposiciones. 1945-1995, p.182.

57 Ibídem. p.189.

58 Ibídem. p.55.

${ }^{59}$ Sidney Geist, O mito privado, 1961. en CHIPP, op. cit. pp.591-592.
} 


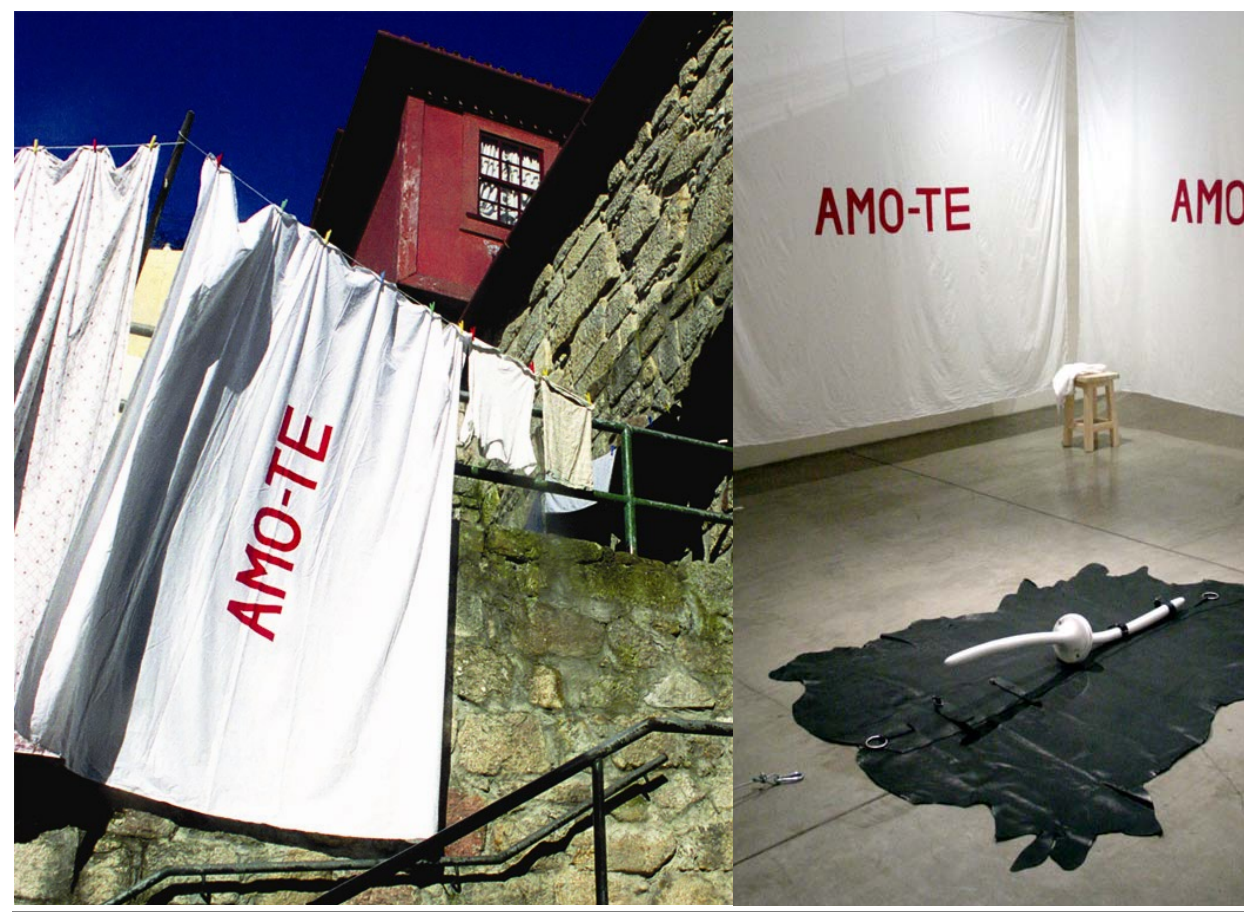

Figura 18: Isaque Pinheiro, Instalación Amo-te, 2003. Sabana pintada. Figura 19: Isaque Pinheiro, Instalación Hoje Amote, 2003. Cerámica, cuero, sabana pintada.

Para finalizar la cuestión del papel desarrollado por el artista como sujeto que define parte del recorrido de la historia del arte a través de su expresión y su idea, es necesario subrayar que, en pleno siglo XX, el artista deja de ser el simple creador, el ejecutor de la obra, para pasar a ser el ejecutor de un proyecto artístico, se da la valorización del proyecto o poética de la obra por encima de su formalización y, en definitiva, la reducción del arte al conceptual60. Son varios los ejemplos donde el artista simplemente hizo el proyecto de la obra, donde alguien, por su encargo, lo materializó. Este cambio conceptual se reflejará también en los montajes de las exposiciones y en las intervenciones de los conservadores/restauradores, sin ser posible decir rigurosamente que haya objeto artístico, al menos en el sentido tradicional. ${ }^{61}$ Los cambios son tan acentuados que se manifiestan en todos los rincones del mundo

T. A.: Sumergida en los estilos públicos, escuelas y teorías del arte, independiente de los ismos e impermeable a la crítica, es la mente del artista. Ella es el mundo de la fantasía y del deseo, del sueño y de la obsesión, de la necesidad secreta y del programa formulado, de la Idea y de la idea fija. Es la parte del arte que da resonancia a la estructura y significado a las marcas y formas que el artista hace: es la parte "impura". En el vasto campo de ídolos quebrados, leyendas desgastadas y tableros apagados, ella construye su propio mito.

60 GUASCH, ob. cit. p.203.

61 LARRAÑAGA, Josu. Instalaciones. p.51. 
del arte, sin olvidar los museos. Estos han tenido que adoptar su estructura y sus criterios expositivos a las nuevas propuestas artísticas pero también a las nuevas necesidades sociales del artista y del público, que ya no se dirigen únicamente a la tutela y valorización patrimonial sino que buscan la dinámica y el impulso de la cultura además de la memoria histórica.

Genéricamente y en forma de conclusión, el artista del siglo XX y XXI deberá, casi por obligatoriedad, ser original, innovador, con una actitud llevada al límite de la ruptura y de lo marginal, en un juego entre su vida y su creación. Y siguiendo las palabras de Régis Debray, en que la desacralización de la imagen y sacralización del fabricante de imágenes han avanzado al mismo paso, a lo largo de todo el siglo XX. Lo sagrado monstruoso, en ese sentido, es el monstruo sagrado. ${ }^{62}$

Si para algunos, el artista es ante todo un ser humano que con su arte nos permite penetrar en su experiencia personal más profunda, (...) cada una de sus obras es como una declaración de intenciones de su condición humana, de sus sentimientos, de sus pasiones, sus sueños 63 ; para otros, el artista será visto como un genio en el que su obra será única y permanente. O para algunos curators y comisarios que mandan en la escena internacional, el artista ya no es un visionario, sino fabricante de productos de consumo de lujo, destinados a un público más cercano al sensacionalismo que la reflexión intelectual64. Sin analizar categóricamente los términos -único y permanente- una vez que en la realidad del arte contemporáneo, tales conceptos abandonan su lugar de predominancia en presencia de la dinámica propuesta en algunas obras. Pero independientemente de estas cuestiones, el artista tendrá que encajar en los estereotipos de la estrategia social, así como vivir bajo el reconocimiento social de sus creaciones además de sí mismo, mientras vive y permanece, junto a su creación, como una imagen comercial y mediática, rotundamente como mercancía.

62 DEBRAY, Régis. Vida y muerta de la imagen. Historia de la mirada en Occidente, p.56.

${ }^{63}$ KUSPIT, Donald. en GUASCH, Anna Maria. La crítica dialogada. Entrevistas sobre arte y pensamiento actual (20002007), p.25.

64 UBERQUOI, Marie-Claire, ¿El arte a la deriva?, p.160. 


\subsection{El mercado del arte.}

El mercado surge como reemplazo de la hegemonía de la clientela aristocráticoeclesiástica, como manifestación del nuevo protagonismo burgués en la era de los Salones, iniciados en París en 1833 y continuados con cadencia anual y fue adquiriendo cada vez mayor peso en el curso de la segunda mitad del siglo XX.65

En los temas anteriormente tratados, no hay duda de que la creación artística y todo su medio, han caminado a un ritmo mutuo y constante en relación a la evolución socio-cultural. Un cambio fundamental y que no pasa desapercibido en medio de tantas mutaciones es la creación y crecimiento de un mercado del arte, en pleno París del siglo XIX, en la era de los Salones. Un régimen compuesto claramente por un consumidor de la pequeña y media burguesía y que se evidencia a partir de 1850 . Este hecho es sin duda un asunto que deja sus huellas en varias actividades y profesiones desarrolladas alrededor del arte. Un ejemplo, es la práctica persuasiva del mercado de querer conservar la obra de arte en estado de eterna juventud, que no es novedosa, ni es sólo, típica del arte moderno y contemporáneo. Ha estado presente en otras épocas de la historia, como se puede reconocer en los procedimientos de los coleccionistas a partir del período barroco. Sin embargo, este ítem surge de la necesidad de entender brevemente el papel que desempeña el mercado del arte en el contexto actual, en un triángulo bien definido entre arte, mercado y realidad social, y percibir cómo surgió el concepto de arte como mercancía, como bien de lujo o como inversión de bienes y lo que esto conlleva.

El hecho es que el arte siempre se ha desarrollado muy bien, gracias, donde existe la perspectiva del dinero. La idea de que el dinero, el mecenazgo y el comercio automáticamente corrompen las fuentes de la imaginación es una mentira piadosa, (...) pero contradicha rotundamente por la propia historia. (...) En su conjunto, el dinero hace a los artistas más bien que mal. ${ }^{66}$

${ }^{65}$ CRISPOLTI, Enrico. Cómo estudiar el arte contemporáneo, p.119-120.

${ }^{66}$ HUGHES, Robert. A toda a critica. Ensayos sobre arte y artistas, p.450. 
Si en tiempos pasados la actividad del artista, o del mismo modo del artesano, estaba sujeta a las órdenes de patrones y mecenas, actualmente los artistas, con los compradores y el público tienen la posibilidad de moverse en un mismo plano. Y esta realidad remite al siglo XVIII, en el que el arte y el dinero ya eran reflejo del éxito labrado por cada artista para conquistar su independencia.

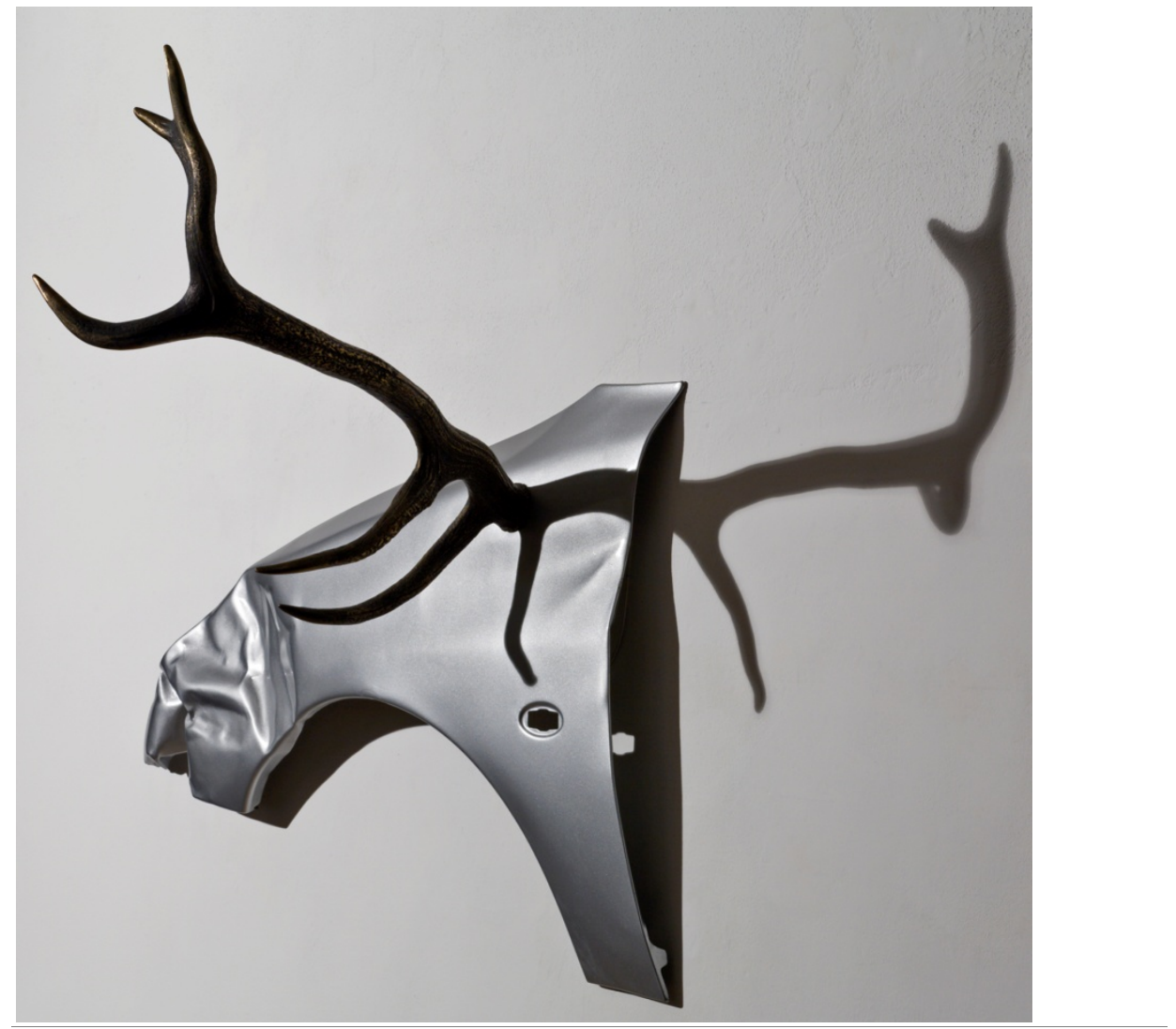

Figura 20: Isaque Pinheiro, escultura Só Ihe faltava falar, 2008. Bronce y acero pintado, 85x110x62cm.

La presencia de un mercado del arte ha acompañado el surgimiento de los artistas como entidades sociales debidamente reconocibles, así como del museo, de las ideas de bellas artes y de la estética. No es de hoy, la presencia social del empresario del arte y el artista de nombre sonante, pero el concepto de que el arte es un bien de inversión sí que es una noción, casi tan sólo, del siglo XX, puesto que hasta entonces, las creaciones artísticas se limitaban a desarrollar una determinada finalidad 0 
función, una compra hecha por placer, prestigio y muestra de poder. En tiempos de mutación, el artista desempeña un papel determinante en este contexto mercantil, puesto que sus exigencias son distintas al artista del Renacimiento. Como ya fue dicho en páginas anteriores, el artista del Romanticismo da un paso adelante trabajando bajo una intención y necesidad propia. El artista del siglo XX y XXI sigue este trayecto, pero en presencia de un sistema y estructura mercantiles, en el que artista y obra son al mismo tiempo elementos constitutivos y productos de una red de consumo y comunicación, cediendo a la presión de un mercado para volverse visibles.

Con el paso del tiempo y con el desarrollo y la importancia que ganó el coleccionismo en el siglo XIX, apareció el marchante, con un papel importante en el sentido de establecer contacto como intermediario entre el artista y el comprador. La misión del marchante pasaba por encontrar nuevos talentos, conocer las obras, los gustos de sus clientes y en especial, diferenciar las obras buenas de las malas. La conexión entre arte y dinero empezaba a establecerse, y el papel de este intermediario alcanzó un nuevo aliento en el siglo XX, cuando los artistas vendían sus obras si habían sido descubiertos por buenos marchantes. Su papel ha alcanzado gran dimensión y en la consecuencia de este estatus, algunos de ellos abrieron las primeras galerías en las ciudades más importantes.

París, como centro de la revolución cultural y artística, se había convertido en una realidad cultural y económica. Entendido como el impulsor de una nueva conciencia, donde el sistema académico dejaba de ser el único medio a valorar y asignar las obras de arte, en la medida que junto al desarrollo y formación de un mercado del arte surgió la profesión del crítico de arte. Sin duda los años 20 en Francia fueron años de éxito tanto para el marchante como para el artista, en que la valorización internacional era el resultado del fuerte aliento de compradores de colecciones públicas y privadas. Pero la década de 1930 contraría esta valorización en los precios y la descendencia de las compras por parte de museos y coleccionistas, llevando a miedos y recelos de los marchantes y a grandes dificultades económicas para los artistas.

Por otra parte en los Estados Unidos y en un panorama anticonformista, en que las exposiciones académicas no tenían ya sentido, parece ser fundamental hacer llegar al 
público el arte, y como consecuencia en 1905, en Nueva York, nacen las Little Galleries of the Photo-Secession o 291 Gallery de Alfred Stieglitz. Otro importante hecho en la historia del arte de los Estados Unidos fue la inauguración en 1913 de Armory Show, la International Exhibition of Modern Art, la exposición que despertó la conciencia y el interés por las nuevas tendencias artísticas. Lo cierto es que Nueva York pasó a ser el centro comercial más importante del mundo, como se torna evidente cuando entre 1940 y 1946, el número de galerías pasó de cuarenta a ciento cincuenta y las ventas de obras de arte contemporáneo se incrementaron en un 300 por ciento. ${ }^{67}$

La globalización y la facilidad de medios, hace del arte algo más que un sistema de comunicación, y el mercado actual, no es más que un sistema donde el arte funciona como cualquier otro tipo de bienes o productos, un consumo que se presenta como forma de privilegio social y cultural, una vez adquirido un objeto único. Y nada mejor que referir el testimonio de Andy Warhol, que de forma determinante ha hecho evolucionar todo el sistema del arte cuando trató su arte como un producto más de consumo, fruto de repeticiones y series. Como Duchamp, Warhol abandona la estética tradicional renunciando a la manualidad y la unicidad de la imagen, optando por lo que es banal, usual y comercial y se mueve en una red, un circuito que no está únicamente dentro de los límites trazados por el mundo del arte, sabiendo que el arte contemporáneo es sobre todo, arte de contemporización. $Y$ contemporización significa condescender, amoldarse, conformarse, transigir... Intentar sumarse no al tiempo, sino a la actualidad.68

Lo cierto es que el proceso de comercialización del mercado tiende a cambiar radicalmente las condiciones y finalidades socioculturales de la producción y del disfrute de las obras de arte69. Es la imagen la mercancía, donde el propio valor de las obras de arte viene dotado de un trayecto trazado entre galerías, museos, exposiciones, críticos, marchantes y coleccionistas, un ciclo de publicidad y popularidad, con sus adecuadas referencias económicas y expositivas.

\footnotetext{
67 UBERQUOI, op. cit. p.16.

${ }^{68}$ MORAZA, Juan Luis. Ornamento y Ley. Procesos de contemporización y normatividad en arte contemporáneo, p.83.

${ }^{69}$ POLI, Francesco. Producción artística y mercado, p.24.
} 
El mundo capitalista industrializado y comercializado se ha convertido en un mundo exterior de infinitas relaciones materiales. El hombre que habita en él es un ser alienado. A menudo este mundo acusa el arte y a la literatura moderna de atentar contra la realidad. Evidentemente existen estas tendencias; pero no han sido los artistas ni los poetas los que han acabado con ella. ${ }^{70}$

Pero entre este tejemaneje comercial, ¿cómo se valoran las obras de arte y cuál es su valor como documento histórico? El problema no está en valorar económicamente la obra de arte, puesto que eso podrá ser una cuestión sin fácil resolución (y la que menos preocupa en esta investigación). La cuestión está en percibir hasta qué punto las exigencias del mercado y de la sociedad, arrastrada por un consumismo veloz, encumbren la esencia y simbolización de la obra en sí misma, entendiendo que estos fenómenos pueden traer cambios en los bienes artísticos vistos como simple mercancía sin la asociación directa a su valor simbólico. Si hoy en día se vive a la sombra de un nihilismo de conocimiento técnico y de metodología, no se deberá aceptar por sí solo un mercado desligado de valor, cuando manipula y se mueve sobre cuestiones estéticas. El mercado asume un papel dominador, donde la obra de arte tendrá que sobrevivir impune, luchar aunque sólo sea para salvaguardar su materialidad original.

El arte parte de la objetividad de la materia, alcanzando la idea abstracta de valor; el dinero parte de una abstracción, que es el valor, alcanzando la objetividad material del mundo. Hay una irreductibilidad. No es posible reducir uno al otro. El dinero desea el arte, porque ve en él su origen. El arte anhela el dinero, porque ve en él su origen. ${ }^{71}$

En la realidad los valores parecen contradecirse. Lo cierto es que la obra de arte es manejada como un producto comercial, como una imagen de consumo en el seno de una sociedad donde impera el fetichismo y el placer de adquisición. Es verdad que la obra de arte no es un bien de consumo cualquiera, distinguiéndose entre todos los otros objetos por su valor estético y simbólico, pero si se destroza este valor no asegura su función, su autenticidad y originalidad. En el contexto de esta transacción se juega también con la reputación del artista y sus records de cotización, el deseo del comprador, la ideología del éxito, la proyección mediática y el marketing, puesto que en la actualidad la función de la obra de arte pasa por

${ }^{70}$ FISCHER, Ernest. El artista y su época, p.18.

${ }^{71}$ DOCTORS, Marcio. Teoría dos valores. en MONTEJO Navas, Adolfo. El arte frente al imperio del mercado, p.30. 
ser un objeto de transacción y de intercambio regido, como cualquier producto 0 servicio, por las leyes de la oferta y la demanda, por el valor de cambio, por los mecanismos de las plusvalías y por las estrategias que buscan ganancias, conformando un valor singular en la estructura económica y mercantil. ${ }^{72}$

Mientras se desarrolla esta escena mercantil, son otras las cuestiones presentes en el siglo XX que se traspasan al siglo XXI, y que no quedan privadas de una función, como las exposiciones temporales, su multiplicidad y espontaneidad en contraposición a las exposiciones permanentes y en una lucha con las eficaces y comerciales retrospectivas de artistas de renombre.

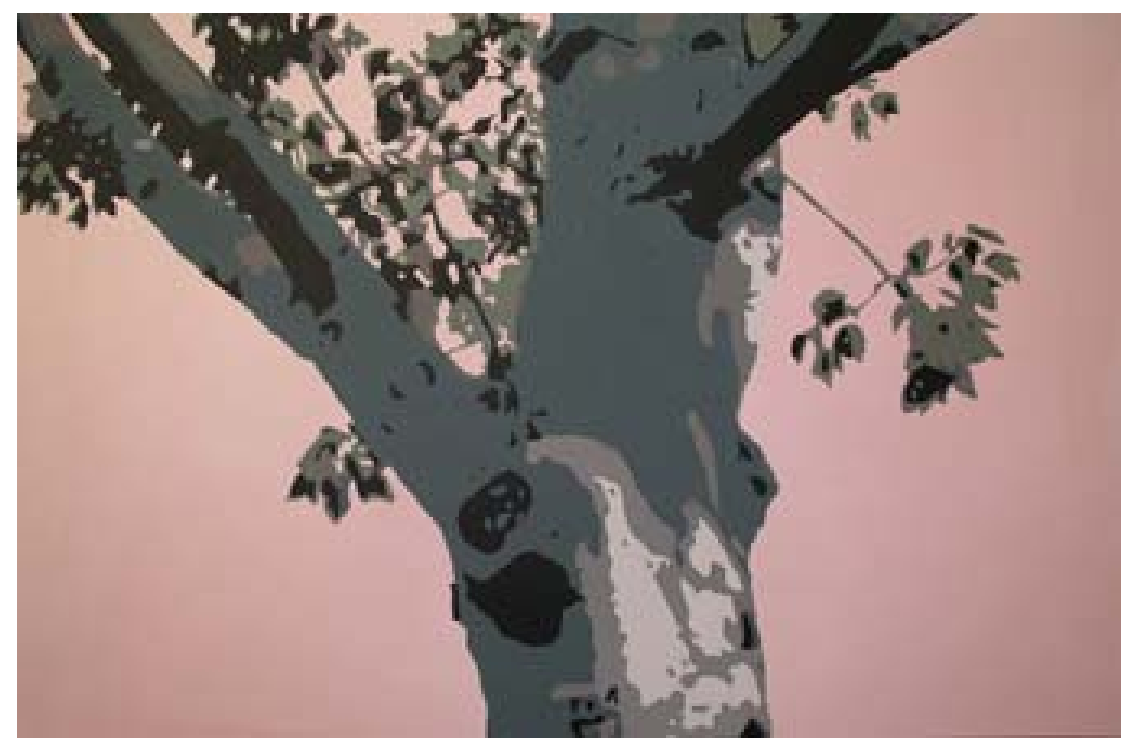

Figura 21: Ana Cardoso, Know everybody knows, 2005. Acrílico sobre tela, 80x120 cm.

No son en vano estas constantes manifestaciones, también ellas con un carácter efímero subyacente. Hay un intercambio de favores e intereses en el mercado del arte, donde el artista defiende una posición, el museo exhibe lo último para no perder su estatus y las exposiciones temporales son un buen medio para ese fin. ¿Qué hay mejor que una exposición temporal, cuando ésta alcanza los mismos objetivos que una exposición permanente pero de una forma más rápida? Decirlo de otra forma, es asumir el poder que tiene la ideología comercial introducida en la sociedad, puesto que,

72 SOLANS, Piedad. Las máscaras de la mercancía, p.44. 
En arte, nada tiene tanto gancho para el público como la exposición: efímera, caduca, acontecimiento único y cada vez más espectacular. Forma parte de los hábitos de ocio del hombre contemporáneo: ansiedad de novedades, sed de imágenes, urgencia, consumo; movimiento que justifica asistencias y viajes. ${ }^{73}$

En el seno de este panorama, no se puede olvidar que el artista es también un agente en el proceso mercantil, en el que en la mayoría de los casos, su papel está sometido a las demandas de los marchantes, de los críticos y de los inversores y en el que la valorización de un artista, depende de la cotización que alcanza con la comercialización de sus obras, ya que, en cierto modo, el artista no sólo explota patrimonialmente su obra, sino también a sí mismo; y su firma será un instrumento fundamental de esta explotación ${ }^{74}$. Ante todo, el mercado del arte no sería rentable si no funcionara con la magia ${ }^{75}$, una magia que engloba el arte y a los artistas, los coleccionistas y los marchantes, las ferias del arte, las casas de subasta, las galerías y los muesos, los múltiples profesionales que desempeñan funciones específicas en el mundo del arte y que muchas veces se sienten incapaces de enfrentarse a contracorriente. Pero a esta contracorriente se suman otras cuestiones, más graves, relacionado con la cuestión del valor estético y económico que alcanzan las obras de arte, está un interés privado que muchas veces va en contra del interés general y público, orientado para el robo, la estafa y falsificación de los bienes culturales.

Es cierto que el mercado se mueve por modas, y que el concepto que se puede tener del mercado del arte, depende del interés y punto de vista que es determinado en un momento preciso de la historia y de acuerdo con varios factores. Pero es inevitable negar el tercer puesto ocupado por el mercado ilegal en la escala mundial de comercios ilícitos, para el cual es necesario presentar sistemas preventivos de forma a evitar tales actividades. A pesar de que no son objeto de estudio los comportamientos ilícitos que comprometen la integridad del mercado del arte, como importaciones y exportaciones ilegales, bienes procedentes de excavaciones ilícitas y hallazgos no comunicados, robos y falsificaciones ${ }^{76}$ es interesante su enumeración.

\footnotetext{
73 VILLA, Rocío de la. Guía del usuario de arte actual. p.58.

${ }^{74}$ BERCOVITZ, Germán. Obra plástica y derechos patrimoniales de su autor, p.74.

75 DEBRAY, Régis. Vida y muerte de la imagen. Historia de la mirada en Occidente, p.57.

76 Llevará a duda cuando es afirmado que las falsificaciones no son objeto de estudio de esta investigación, pero tal afirmación surge en la medida de que la denominación de falso presente en la estadística del mercado ilícito del arte, no se refiere únicamente al concepto de falso que será abordado posteriormente; una vez que esta investigación hace
} 
Todavía, tienen su repercusión en el contexto del arte contemporáneo, ya que hoy en día es posible falsificar prácticamente todo, y engañar no solamente al turista 0 a personas poco informadas, sino también a coleccionistas y otros agentes interesados en ganar con un objeto que va a sustituir el original, puesto que conseguir una venta con estas características significa una transacción con enormes beneficios.

No es por casualidad esta reflexión sobre el mercado del arte, cuando es necesario tener consciencia que a pesar de que la evaluación de un bien cultural deba pasar por su creciente valor histórico, cultural y artístico, lo cierto es que las colecciones están constituidas de objetos, que resumidamente son bienes ante todo materiales.

hincapié a la introducción de un falso, histórico o artístico, como resultado de una alteración o manipulación material no identificada en pura relación con el proceso de restauración, inclusive realizado por el artista. 


\section{Lo aparente y lo oculto como contenidos de la creación artística.}

2.1. La idea y la materia de las obras del arte contemporáneo.

De todos modos, con la llegada de la filosofía al arte lo visual desapareció: era tan poco relevante para la esencia del arte como había probado ser lo bello. Para que exista el arte ni siquiera es necesaria la existencia de un objeto, y si bien hay objetos en las galerías, pueden parecerse a cualquier cosa. ${ }^{77}$

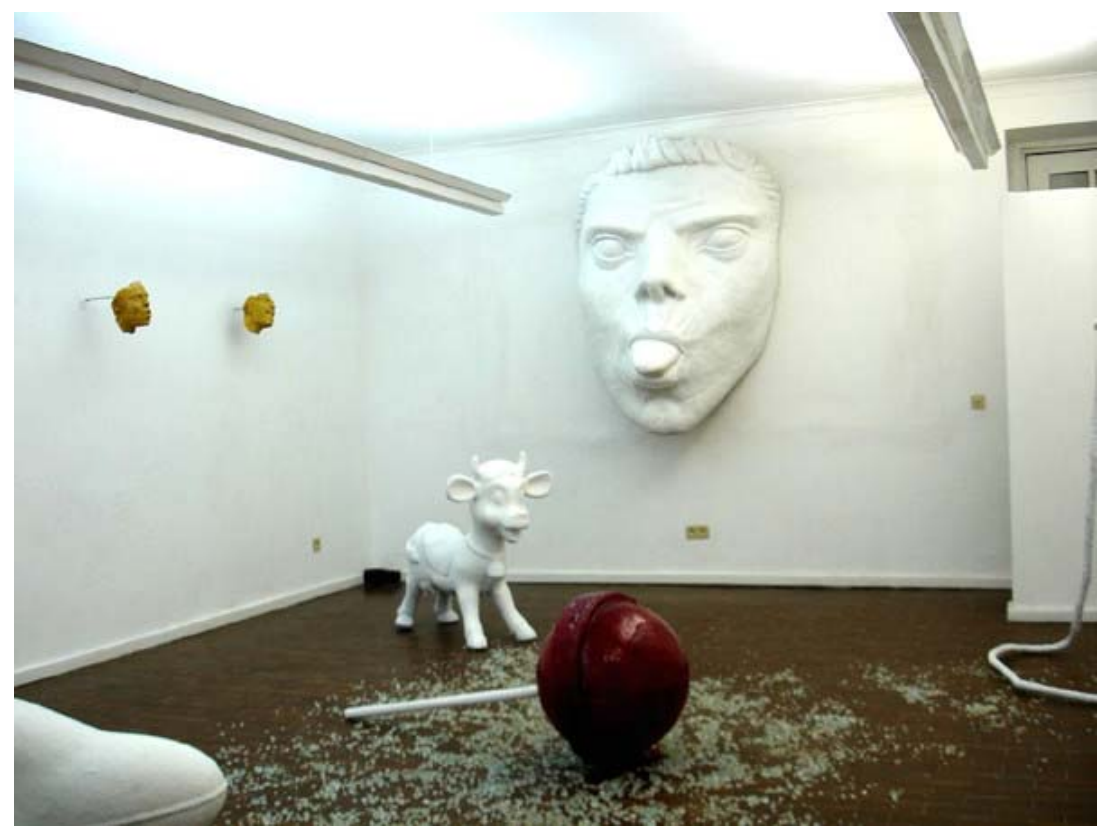

Figura 22: João Pedro Rodrigues, instalación Casulo II. Fibra de vidrio y vidrio pintado.

Partiendo del principio de que el arte es un lenguaje que se basa en un sistema estructurado de construcción y de comunicación constituido por un número variable

77 DANTO, Arthur, C. Después del fin del arte, p.38. 
de signos ordenados de forma particular, el objeto artístico es el resultado del proceso inventivo y original de comunicación visual que parte de diversas transformaciones de la materia como posibles signos, como el medio que el artista utiliza para construir y comunicar una realidad, en que el objetivo pasa por la producción de una experiencia perceptiva en el espectador. O dicho de otra forma: si la imagen fuera una lengua, sería traducible en palabras, y esas palabras a su vez en otras imágenes, pues lo propio de un lenguaje es ser susceptible de traducción. ${ }^{78}$

Siguiendo el pensamiento de Régis Debray, también en el arte, como en las otras formas de comunicación, hay un juego entre los diversos signos en una interrelación con individuos capaces de descodificar un mensaje, dentro de la propia subjetividad de la interpretación y sin dejar de lado que lo cierto es que existen tantas formas de arte como artistas, pero ni siquiera lo banal es inútil. ${ }^{79}$

Mientras tanto, cuando se hace un análisis de la evolución del arte es posible concluir que a lo largo de la historia éste ha tenido diferentes concepciones, siendo la historia del arte como la historia de un conjunto oleaje y cambio de tradiciones en el que cada obra mira al pasado y se dirige al futuro80.

En la prehistoria, lo que ahora se considera arte rupestre no era más que un medio de expresión, un lenguaje, un modo de comunicación entre los miembros de una comunidad y como afirma Benjamín, numa palavra: toda e qualquer comunicação de conteúdos é linguagem ${ }^{81}$. Pero, la evolución ha dotado a tal expresión de otras funciones, como la religiosa, la decorativa y la de representación; es el caso de la pintura realizada para el culto, las naturalezas muertas o los retratos y paisajes elaborados por aquellos que tenían el privilegio de ejercer tal actividad. Cada obra de arte desempeñaba una función de acuerdo con su contexto, además de poder ser considerada según los diferentes fenómenos:

${ }^{78}$ DEBRAY, Régis. Vida y muerte de la imagen. Historia de la mirada en Occidente, p.50.

79 MORAZA, Juan Luis. Ornamento y Ley. Procesos de contemporización y normatividad en arte contemporáneo, p.9.

80 GOMBRICH, ob. cit. p.491.

${ }^{81}$ BENJAMIM, Walter. Sobre arte, técnica, linguagem e política, p.177.

T. A.: ...en una palabra: toda y cualquiera comunicación de contenidos es lenguaje. 
estético, cultural, antropológico, académico, lúdico, económico, del conocimiento; que desempeñaría varios papeles: sociales (condicionados a las fluctuaciones de la sociedad y sometidos a su control), expresivos, profesionales, económicos (como elemento significativo de la calidad de vida); exponente de ciertas dimensiones humanas (poder, religión, imagen), educativas...82

La trayectoria es evolutiva y constante, y se hace acompañada de manifestaciones a todos los niveles, de manera que llegados al siglo XXI, una vez quebrados los límites vigentes a lo largo de los siglos y creados nuevos conceptos, no sólo sociales, culturales, políticos y económicos, sino consecuentemente artísticos, es aún más difícil encontrar una definición clara y unánime de tal actividad. Tal definición tendrá que incluir todas las formas de creación existentes, donde, como afirma Danto las obras de arte puedan parecer cualquier cosa en toda circunstancia, estar realizadas de cualquier materia ser presentadas de cualquier manera.83

La obra es, en sí misma, un sistema de dupla interpretación: donde la primera es la propia obra (la interpretación que el artista hizo de una determinada realidad materializándola y concretándola en un objeto dotado de valor especifico); y una segunda interpretación, la perteneciente a todos aquellos que observan el objeto, en la tentativa de interiorizar el proceso subjetivo de creación y comprender un mensaje, y es aquí donde reside su esencia ya que, como obra de arte se recrea cada vez que es experimentada estéticamente ${ }^{84}$. El espectador, delante de una obra de arte, se encuentra ante la necesidad de interpretar su mensaje, su contenido, pero no siempre esta labor es sencilla, directa y eficaz. Por ello, existe la necesidad de descodificar el código que se tiene ante los ojos, a través de la percepción y distinción de los diversos elementos que componen la obra. Si por un lado está el tema, que sólo no define una forma en particular; por otro, el contenido, donde está implicado el significado de la obra, y por último, la forma, que será la unificación del tema y del contenido. Para obtener la correcta percepción de la obra hay que destacar el contenido de la misma, y sumarla a toda aquella información asociada al artista, a los materiales que emplea, los temas que trabaja y la intención que pone a la hora de crear un objeto dotado de valor artístico según cánones estéticos.

82 MACARRÓN Miguel, Ana M. ${ }^{a}$ y MOZO González, Ana. La conservación y la restauración en el siglo XX, p.27.

83 DANTO, Arthur. en GUASCH, Anna María. La crítica dialogada. Entrevistas sobre arte y pensamiento actual (20002007), p.100.

${ }^{84}$ BRANDI, Cesari. Teoría de la restauración, p.14. 
La obra de arte, es por lo tanto, el resultado de la interacción entre concepto y lenguaje, que el artista pone en un plano concreto para suscitar la participación del espectador. A pesar de participar de una dimensión distinta, pertenece al mismo espacio que sus beneficiarios. Su contenido, es la esencia vital para que el espectador entre en su interior, es un conjunto de signos debidamente orientados para percibir evolutivamente lo que podrá comunicar la obra, asimilando las posibles relaciones entre forma y volumen, color y materia que fueron dejadas por el gesto descriptivo del artista. Un juego entre lo que figura en la obra y su significado, lo que es apariencia y lo que es esencia, y en su realidad y unión, se juega la conjunción de lo visible con lo invisible.

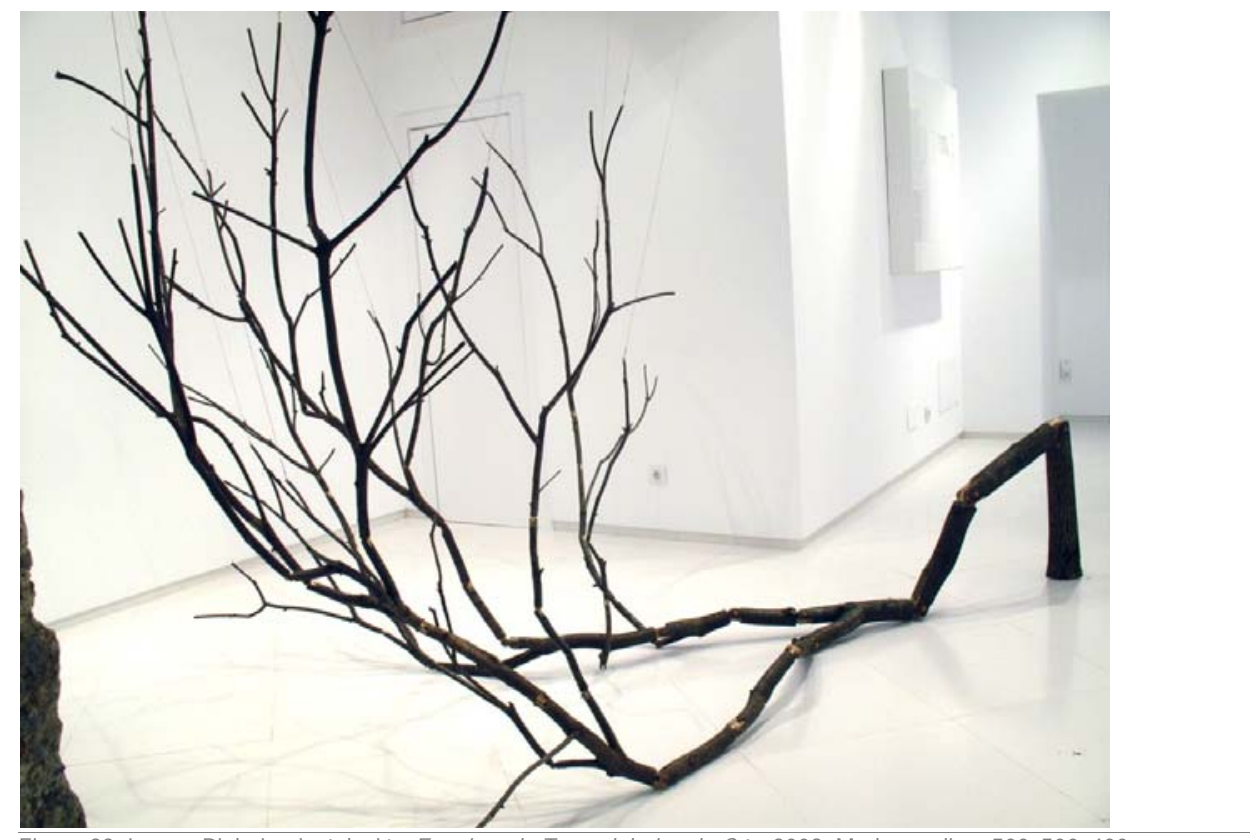

Figura 23: Isaque Pinheiro, instalación Em cima da Terra debaixo do Céu, 2008. Madera, y lino, 500×500×400cm.

Pero, hablar de arte contemporáneo no implica únicamente hacer una descripción de los materiales que dan forma y cuerpo a la obra, puesto que ya no es novedoso ni tan poco sorprendente, cuando en un museo se encuentran obras hechas de luz, de aire o de agua, de movimiento, de sonido, o simplemente de vacío. Un cambio profundo en la estética y concepción del arte y que es fundamental para percibir gran parte de las creaciones contemporáneas. 
En este sentido, será inevitable citar la definición que, en 1969 el artista Lawrence Weiner presenta sobre el arte, en la que resumió su idea del arte en un programa de tres puntos:

1. El artista puede construir la obra.

2. La obra puede ser fabricada.

3. La obra no necesita ser construida. ${ }^{85}$

En pocas palabras, el artista define la realidad creativa contemporánea, en la que se pueden distinguir esencialmente los tres momentos presentados. En el primer caso se encuentra el comportamiento clásico de la creación, el artista desarrolla un proceso expresivo y creativo hasta construir y concretar físicamente la obra; en el segundo punto, el artista no tiene necesariamente que crear todos los elementos que incluye en su obra, o sea, puede recurrir a objetos prefabricados, como son los ready-made de Marcel Duchamp, en los que se emplean objetos de uso cotidiano y de una naturaleza distinta a todos los productos denominados artísticos hasta la aparición de este tipo de obras de arte, o de la misma manera recurrir a la fabricación de nuevos elementos que constituirán la obra, o también, delegar parte del proceso creativo 0 constructivo de la obra. Por último, el tercer punto, el más novedoso e incluso que puede parecer polémico, es donde Weiner defiende que la obra de arte no tiene necesariamente que ser construida, sino simplemente formulada. En este caso, tendrían que ser analizados los diferentes estados de una obra de arte y percibir hasta qué punto es aceptable tal definición, o partir del principio, que el tercer punto se refiere con evidencia al Arte Conceptual, donde la constitución material de la obra está subordinada a la idea. O sea, que las palabras de Weiner se refieren a todas las obras que ocultan algo y que estar oculto es un hecho que se puede alcanzar a través del lenguaje, en otras palabras, una vertiente no visual en el arte. Las propias obras de Lawrence Weiner son el reflejo del deseo de desmaterialización del arte, considerando el lenguaje textual un medio para crear esculturas, siendo el tercer punto el reflejo de este deseo. Sin embargo, esta cuestión queda abierta debido a su ambigüedad, puesto que hablar de obra de arte implica referir su concepción, su formulación y su realización material, incluso, teniendo en cuenta que el arte

${ }^{85}$ REGUERA, Galder. La cara oculta de la luna. En torno a la «obra velada»: idea y ocultación en la práctica artística, p.17. 
conceptual demostró que no necesariamente debe haber un objeto visual palpable para que algo sea una obra de arte. Esto significa que ya no se podría enseñar el significado del arte a través de ejemplos. ${ }^{86}$

No obstante, es concluyente que el arte ha sido y siempre será expresión, por lo que el arte contemporáneo debe ser entendido como fenómeno y no meramente como una tendencia. Fenómenos que se tornan más ambiguos al paso de su evolución, evidenciados por el estilo y técnica empleados, como la manifestación de una idea, expresada y representada de forma compleja; y que Clemente Greenberg refiere: el arte es estrictamente una cuestión de experiencia, no de principios, y lo que cuenta en el arte, en primer y último lugar, es la calidad; todo lo demás es secundario. ${ }^{87}$

Además se caracteriza por una constante búsqueda, con el objetivo de concretar el proceso de ruptura con la tradición y que se puede hacer coincidir históricamente, con el momento en que muchos países europeos pasan de una sociedad de tipo tradicional a una sociedad moderna. Una sociedad fascinada con la libertad, con la idea artística de avant-garde, el sentimiento de no tener identidad fija, de ser libre para inventar; y la concepción del artista como subversivo88, dejando atrás una actitud de subordinación para alcanzar una total liberación artística.

Junto a este entramado de cuestiones, las dudas no están en querer determinar si los objetos creados por los artistas contemporáneos son o no obras de arte; las dudas surgen cuando en el mundo de la creación se encuentran obras que nacen de materiales duraderos, otras de materiales ya usados o con una duración cuestionable y, por último, obras que tienen como principal objetivo su crudo proceso de degradación, esto es, una existencia rotundamente efímera. Es evidente que hay una pérdida de la tradición en cuanto a la técnica y medios de expresión, lo que determina la singularidad de cada artista y la complejidad de la búsqueda de materiales y técnicas, de tal manera que resulta imposible encontrar definiciones de orden técnico y material sobre cada corriente artística. Al final, ¿Cuáles son las repercusiones que estos fenómenos han tenido en el entorno creativo?

\footnotetext{
86 DANTO, Arthur, C. Después del fin del arte, p.35.

${ }^{87}$ GREENBERG, Clemente. Arte y cultura. Ensayos críticos, p.126.

${ }^{88}$ HUGHES, Robert. A toda crítica. Ensayos sobre arte y artistas, p.39.
} 
La progresiva revelación y progresión de los artistas y movimientos ha provocado la adquisición de nuevos lenguajes, que en un primer momento tuvieron un impacto duro y repentino. El ambiente artístico se ha expresado en una creciente turbulencia, contaminando los campos operativos que siempre han tenido codificada la diferencia entre las disciplinas, principalmente los límites entre pintura y escultura. La eliminación de los territorios de las distintas disciplinas y la superación de la tradición, ha dado como resultado la introducción generalizada de actos efímeros como categorías aceptables. Esto se agrava en la confrontación con la propia pintura, ya que la pintura pierde su lugar central frente a la presencia de los nuevos medios visuales, y se establece una «experiencia» estética menos contemplativa y pasiva, más dinámica, ocupacional, escenográfica y lúcida. ${ }^{89}$

Para entender el desarrollo en el entorno artístico contemporáneo y actual, es necesario, una vez más volver al inicio del siglo XX, y destacar la determinante actitud de Marcel Duchamp, cuando busca la desmaterialización como expresión, y entender sus consecuencias en las creaciones del arte conceptual.

Uma passagem por Munique, na Alemanha, em 1912, e pelo movimento dada isolaram-no. Duchamp rompe com a prática estética da pintura: se declara 'antiartista'. E aí começa a aventura..$^{90}$

Su 'aventura' ganó vida cuando utilizó objetos prefabricados y de uso cotidiano haciéndose notar en el terreno de lo estético, pero también en los locales de exposición. Con el simple hecho de exponer la Fontaine transformó el vulgar objeto en una obra de arte, demostrando que al final cualquier cosa puede adquirir el status de obra de arte, dependiendo solamente del local y la hora en que fue expuesto. Y como tan bien explica Anne Cauquelin, o valor mudou de lugar: está agora relacionado ao lugar e ao tempo, desertou o próprio objeto. ${ }^{91}$ Además Duchamp se sirve del lenguaje para seguir desacralizando el arte y establecer una conexión directa al sistema artístico con el cotidiano, dando origen a un arte que pierde el aura de creación

${ }^{89}$ VILLA, Rocío de la. Guía del usuario de arte actual. p.24

${ }^{90}$ CAUQUELIN, Anne. Arte contemporânea, uma introdução, p.92.

T.A.: Una pasaje por Munich, en Alemania, en 1912, y por el movimiento dadá lo han aislado. Ducahmp rompe con la práctica estética de la pintura; se declara 'antiartista'. Y ahí empieza la aventura.

${ }_{91}$ CAUQUELIN, ob. cit. p.94.

T.A.: ... [la obra] puede entonces ser cualquier cosa, pero en una hora determinada. El valor cambió de lugar: está ahora relacionado al lugar y al tiempo, desertó el propio objeto. 
sublime y elitista, un deseo de desmaterialización que rompe los sistemas de comunicación.

Otras formas de expresión son dadas a través de la distinción entre contenido y forma, otro camino que gana cuerpo cuando el artista se proyecta enteramente en la obra, en la que vence el deseo de exprimir toda la riqueza y espontaneidad de la vida interior, a través de un lenguaje de características abstractas. Se aprecia en el camino hacia la abstracción, un primer momento, entre 1910 y 1920, que es el periodo de su origen, caracterizado por una extraordinaria vitalidad creadora y por una primera expresión abstractizante. Un segundo periodo, entre 1920 a 1930, en el que se asiste a la aplicación práctica de las formas abstractas. Y un tercero, a partir de 1930, en el que empieza la expansión del arte abstracto en toda Europa, a través de innumerables artistas, donde, el arte abstracto era imaginado como el estilo definitivo, el fin de la historia, en el que todas las tensiones y contradicciones quedarían resueltas ${ }^{92}$, y desde sus orígenes, la abstracción osciló entre la razón y lo intuitivo, entre la construcción y el lirismo.

En 1939, cuando empieza la Segunda Guerra Mundial, el arte parece perder toda su fuerza creadora, y después de 1945, su crecimiento es mutante pero traza un paralelismo casi incoherente: al mismo tiempo que gana nuevo aliento, pierde toda su nitidez y claridad. El modo de entender la creación artística cambió y los propios artistas la sintieron como una continua metamorfosis, lo que generó un ansia de productividad, una búsqueda más inédita. Se impusieron formas de aspecto abstracto, formas que ya no contenían la imagen directa del mundo exterior. El artista en lugar de nombrar exprime, cabiendo al espectador reaccionar y aprehender la significación de lo que es expresado. La realidad deja de estar indisolublemente ligada a la forma y el arte deja de pertenecer a un ámbito reducido y aislado.

Enfrentávamos a tela com o Eu, fosse ele o que fosse, e pintávamos. Enfrentávamo-la desarmados, por assim dizer. [...] Nesse período, um quadro que se parecesse com um quadro, isto é, com alguma coisa que já se conhecia, não era bom. Tentávamos fazer uma tábua rasa, começar a pintura de novo. Alguns de nós descobriram monstros. Outros encontraram uma pintura. Outros, ainda, encontraram a pintura.

${ }^{92}$ HUGHES, Robert. A toda crítica. Ensayos sobre arte y artistas, p.40. 
Os pintores desse período partilhavam de certas ideias sobre a pintura e sobre o processo de pintura. Não partilhavam - e ainda não partilham - de um estilo de pintura. Cada um deles tem um estilo próprio, cada vez mais individual e pessoal. ${ }^{93}$

Otros podrán ser los ejemplos de una búsqueda muy personal e independiente, reflejada en experiencias y pensamientos en constante maduración. Lucio Fontana considerado uno de los protagonistas de uno de los episodios más complejos y fascinantes del siglo $X X$, en que sus obras resultan de la pasión por el experimento empírico. Su investigación preparó el terreno para la emancipación del artista frente a la esclavitud del objeto, permitiendo alargar el campo de acción y quebrando las fronteras que fueron abiertas por la acción indeterminada y la actividad mental. No cabe duda que el pensamiento del artista nace como producto exclusivo. Si inicialmente Fontana desarrollaba sus obras a la par de las utopías modernistas y del abandono de la melancolía en una pesquisa pictórica abstracta, ya en 1949 traza la gran ruptura a través de una serie de trabajos perforados en los que introduce la idea de que no todo tiene que ser pintura. Es evidente la naturaleza conceptual y gestual de sus obras y su sentido estético: al rasgar, cortar o perforar las telas o la materia, es quebrada la continuidad material, creando una superficie ilusoria capaz de albergar la representación ficticia, en la que recupera la verdad de esa tela en beneficio de una nueva (forma de) creación. El trazo o los agujeros que hacen comunicar el anverso con el reverso de los soportes, abren una vía de comunicación con el infinito como nuevo elemento, aboliendo la necesidad (tradicional) de pintar. Para Fontana, este proceso no fue un acto de destrucción sino de liberación, una ironía ante las disciplinas institucionalizadas, en las que el material tiene una función mediadora. Para el artista, el color de la tela y la disposición de las incisiones o de los agujeros son la explicación estética de sus ideas al público. La materia de sus obras es al mismo tiempo el material (tela, bronce, etc.) o el vacío, el espacio determinado y manipulado por sus gestos.

${ }^{93}$ FERREN, John, Epitáfio para uma vanguarda, 1958. en CHIPP, ob. cit. p.582-583.

T. A.: Enfrentábamos la tela con el Yo, fuera ello lo que fuera, y pintábamos. La enfrentábamos desarmados, por así decir. (...) En ese período, un cuadro que se pareciera a un cuadro, es decir, con alguna cosa que ya se conocía, no era bueno. Tratábamos de hacer una tabla rasa, empezar la pintura de nuevo. Algunos de nosotros descubrirán monstruos. Otros encontraran una pintura. Otros, aún, encontrarán la pintura. Los pintores de ese período repartían ciertas ideas sobre la pintura y sobre el proceso de pintura. No compartían - y aún no comparten- un estilo de pintura. Cada uno de ellos tiene un estilo propio, cada vez más individual y personal. 


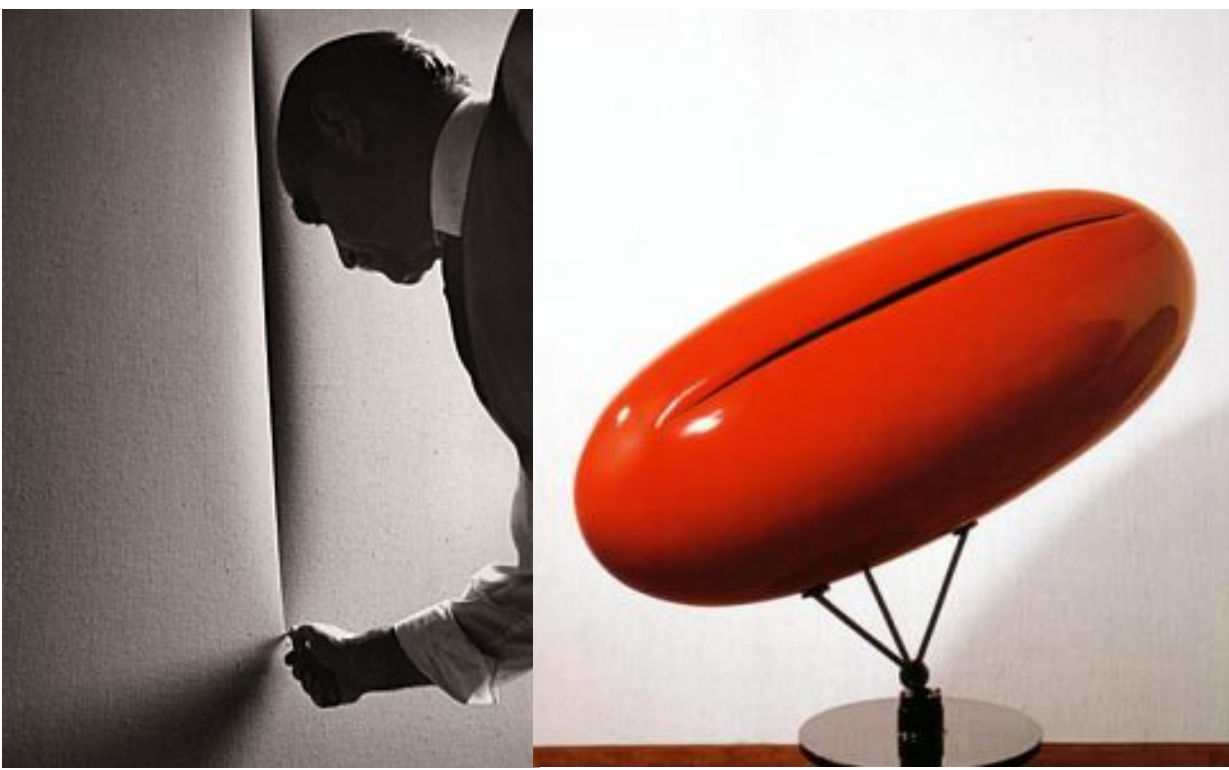

Figura 24: Fotografia de Lucio Fontana por Ugo Mulas. Figura 25: Concepto Espacial, 1967. Metal lacado y perfurado con soporte incorporado.

La valorización de la idea ante la materia gana verdadero aliento con el Arte Conceptual, una reacción al Pop Art, que surge a finales de los años 70. A pesar de que la mayoría de sus artistas iniciaron su labor a partir del arte minimalista: el arte aquí se problematiza en su propia función al poner en duda el principio ideológico como factor determinante esencial para el arte..$^{94}$

También al final de los años setenta, surge la palabra instalación para definir una tendencia del arte de la última mitad del siglo XX, y que a pesar de su difusión ha sido utilizada de forma superficial, dando la impresión que todo el arte se había convertido en instalación. Se ha caracterizado por su falta de definición, por tratarse de un medio de expresión que apareció en un momento en el cual emergieron propuestas artísticas muy diversas.

Pues el arte hoy básicamente se instala; y no meramente se exhibe. La instalación es la ocupación activa de un lugar. El arte se instala principalmente en los espacios a él dedicados, museos, centros, fundaciones o galerías, a través de cualquier clase de artefacto producido o recogido, y de actuación; pero también se instala en espacios naturales, mediante las intervenciones del land-art, y en las ciudades, con objetos, imágenes 0 proclamas verbales. ${ }^{95}$

94 THOMAS, Karin. Hasta hoy. Estilos de las artes plásticas en el siglo XX, p.302.

${ }^{95}$ VILLA, Rocío de la. Guía del usuario de arte actual. pp.24-25. 
La dificultad de establecer límites, en los que ya no se sabe dónde termina y empieza la pintura o la escultura, hace que la palabra instalación se difunda en el mundo artístico y sea recurrente su utilización para nombrar algunas expresiones artísticas que no se limitan únicamente a pintura o escultura. Está presente en este concepto toda la heterogeneidad del arte contemporáneo, lo que hace que sea tan difícil encontrar una definición rigurosa.

Aún hoy, cuando hablamos de instalar, lo hacemos refiriéndonos a actuaciones de diverso signo. Podemos entenderlo como el trabajo de engarzar, ensamblar o montar una construcción de carácter productivo y cierta proyección social [....]. O también, como una acción de establecer criterios de orden y de distribución en un espacio determinado [...]. En tercer lugar, podemos interpretarlo como el trabajo de adecuar un lugar con los accesorios que precisa para su correcto funcionamiento [...], y, en cuarto lugar, con el sentido de apropiarse o tomar posesión, tanto de un espacio [...] como también de un puesto de trabajo o de una responsabilidad. ${ }^{96}$

Aún, en todos los casos presentados por José Larrañaga, la cuestión esencial en la presentación de una instalación pasa por la preparación de un determinado espacio para ser posteriormente utilizado por su usuario. Se puede decir que es, por tanto, una forma de expresión con la intención de superar los límites tradicionales de la práctica contemplativa, resultado de una serie de confluencias, propósitos y realizaciones concretas y características espaciales, que confieren al espacio una dignidad espacial, dotando al espectador en el fundamento de la experiencia artística, no sólo al incluirlo en el espacio sino también al incorporarlo en el proceso de construcción representativa. Es desde luego, importante señalar, que el concepto de instalación está ligado a una forma de construir en el espacio, una expresión, que juega con la complejidad funcional y técnica. La instalación es, como tal, una obra abierta que se presenta al espectador para ser consumida, con el objetivo de poner en funcionamiento todos sus mecanismos, los conceptuales y los de producción de significado y experiencia en el arte, con el pretexto de estimular varios o todos los sentidos y envolver sus sentimientos y emociones. Es sin duda, fundamental esta relación del espectador con su espacio y ambiente de exposición, para que en la función estética de la creación coexista su motivación teórica y simbólica.

${ }^{96}$ LARRAÑAGA, Josu. Instalaciones. p.31. 
Si existen obras en que la materia es al mismo tiempo forma y contenido, por otro hay obras en que la materia es simplemente forma. El hecho de pertenecer al mundo de lo contemporáneo implica partir de un principio en el que es válida la utilización de cualquier material, tanto como soporte o como vehículo.

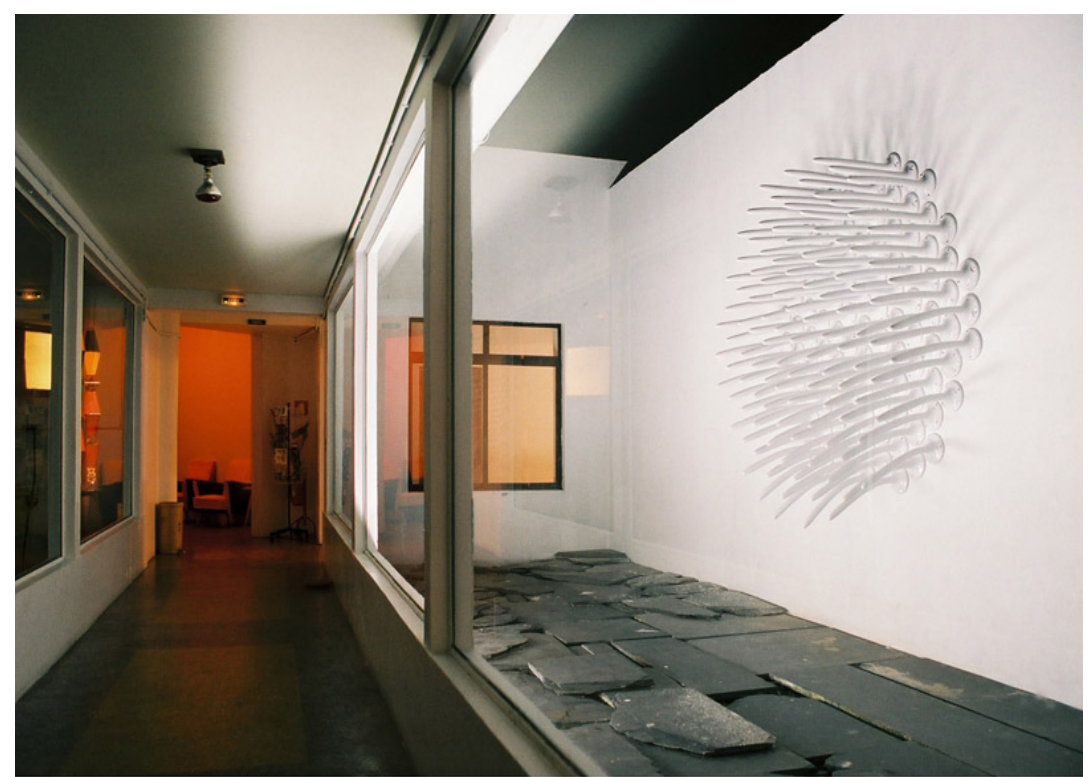

Figura 26: Isaque Pinheiro, São Rosas Senhor... São Rosas!, 2002. Cerámica, 210x 200 cm.

Como es posible observar, para conocer a fondo el arte contemporáneo no sólo se debe atender a su división cronológica o su denominación, e incluso hacer un análisis fundamentalmente conceptual, sino también desde el punto de vista material. O sea, en esta evolución artística y de expresión, los materiales pueden genéricamente estar divididos en tres tendencias según su empleo. La primera, que se manifiesta, aparentemente, en el ámbito tradicional, según sus características estratigráficas: un soporte natural o industrial, una preparación y una capa pictórica constituida de sustancias pigmentarias mezcladas en un aglutinante, sea de tipo tradicional o de síntesis química. La segunda, que propone el uso de materiales muy heterogéneos, como objetos de lo cotidiano, presentados individualmente 0 asociados a los materiales tenidos como tradicionales de la técnica artística, como es ejemplo el 
collage o la assemblage, un medio mezclado que no era ni pintura ni escultura y que tanto podía colgarse en la pared o del techo, como ser desparramado por el suelo. ${ }^{97}$

Otra serie de obras, como tercera tendencia, es aquella que se vale de particulares mecanismos, como algunas obras accionadas a motor del arte cinético, así como las experiencias que utilizan tecnología más avanzada, como la experimentación del Video Art, un juego entre los elementos mecánicos del video en afinidad con el espectador; o el Computer Art, que consiste en la utilización del ordenador, por parte de los artistas plásticos, para la creación de distintas imágenes de acuerdo con la programación utilizada.

En la mayoría de estos casos hay una condición común: se trata en parte de materiales y productos industrialmente preparados, algunos, poco conocidos en cuanto a su composición y funcionamiento, y no siempre elegidos para la obra de acuerdo con los requisitos de calidad y duración. En consecuencia, existe la necesidad de profundizar el conocimiento sobre tales productos y su comportamiento, porque, si por un lado, surgen las telas y colores tradicionales manipulados industrialmente, con ingredientes y procedimientos de fabricación mantenidos en secreto, por otro, están los productos nuevos, como los colores acrílicos o los numerosos tipos de materiales plásticos y de síntesis industrial, e incluso, mecanismos que pueden ser sencillos motores eléctricos 0 particularmente sofisticados como aquellos utilizados en la elaboración informática de las imágenes.

No obstante, el arte contemporáneo no participa únicamente de la utilización de materiales tradicionales e industriales. Los artistas alargan su campo de trabajo, utilizando cualquier medio para materializar su obra, para que su idea sea más fuerte, más directa. Para ello, recurren a todo tipo de materiales, como por ejemplo en la estética del Arte Póvera, constituida por diversos materiales naturales y corrientes, como la tierra, el carbón, palos, plantas, arena. Todo ello como forma de desmoronar la jerarquía de los materiales, todavía sin negar la presencia de los materiales industriales, pero recurriendo a la naturaleza como una negación al consumismo o simplemente evocando otras dimensiones materiales en el arte, o como reacción a las

${ }_{97}$ GUASCH, Anna María. El arte del siglo XX en sus exposiciones. 1945-1995. p.55. 
formas geométricas explorando las más diversas posibilidades presentes en las características físicas de los materiales.

La presencia de los elementos de la naturaleza fue llevada al extremo con las expresiones artísticas del Heart Art 0 Land Art, cuando el taller o la galería son sustituidos por los paisajes y los espacios expositivos dejan de ser interiores para pertenecer a ambientes exteriores lejanos. El clima, el paisaje, el suelo terrestre son, por excelencia, los medios de expresión, los materiales reales de estos artistas. Un ejemplo de obras efímeras que son inmortalizadas a través de reportajes fotografías y de videos, en los que a través de la dependencia de la naturaleza tienen el objetivo de crear procesos de transformación climática. Una propuesta llevada más adelante con el Ecological Art en que está la ecología relacionada con los procesos vitales, las transformaciones de energía, las relaciones entre las comunidades de plantas, animales y naturaleza inanimada. ${ }^{98}$

Otra tendencia, el Arte de Acción surge cuando la expresión artística tiene una necesidad inmediata de representación entre escenas de la vida cotidiana y elementos teatrales, una acción que juega con la sorpresa y la reacción de lo que envuelve la obra, creado un juego e interés mutuos entre la acción y el público, entre la propia experimentación y la reacción directa y momentánea. 0 aún, el Body Art como la total falta de materialización de la obra de arte, donde el cuerpo se convierte, al mismo tiempo, en soporte y materia de la obra, como transmite la artista Gina Pane hablando de su trabajo,

El cuerpo, materia bruta de transformación, ha planteado el problema de reciprocidad 0 , inversamente, el de la comunidad cuyo objetivo es la reciprocidad. (...) Es decir, mi cuerpo en acción no sólo está en Relación, sino en Relación en sí mismo. No es una superficie que englobe un centro (cuadro plano) ni un pedestal (portador de otra cosa), sino el entorno, lo externo, lo interno: Cuerpo incluso del discurso. ${ }^{99}$

Una vez más, el momento en que se realiza la obra de arte, queda fijado en fotografías y videos como la congelación de la acción.

${ }_{98}$ GUASCH, ob. cit. p.190.

99 PANE, Gina. Trabajo de la acción. en AA.VV. El instante eterno, p.197. 
Esta evolución, demasiado rápida, ha sido protagonista de profundas transformaciones, considerando que para los artistas contemporáneos, cuyo mayor capital no es la técnica (...), sino la fe en sus propuestas ${ }^{100}$, se transforma la relación de los materiales y técnica de ejecución, hasta el punto de imponer un replanteamiento sobre la duración de las creaciones, acto de creación y concretización, como aspectos intrínsecos a la existencia física de la obra.

Como fue expuesto anteriormente, se puede garantizar que varias fueron las formas encontradas por los artistas para resolver ciertas contradicciones en el arte y a lo largo del tiempo, sin dejar atrás el ejemplo de artistas como Marcel Duchamp, o más tarde Andy Warhol, que optaron por mostrar de formas distintas la esencia del arte a través de su concepto y no meramente a través de alguna de las facultades dispuestas en el objeto artístico. Tan radicales y controvertidas han sido estas actitudes, hasta el punto de hablar de muerte del arte, lo cierto es que el arte histórico, como había existido hasta entonces no iba a sobrevivir ante la supervaloración de lo conceptual en la obra de arte.

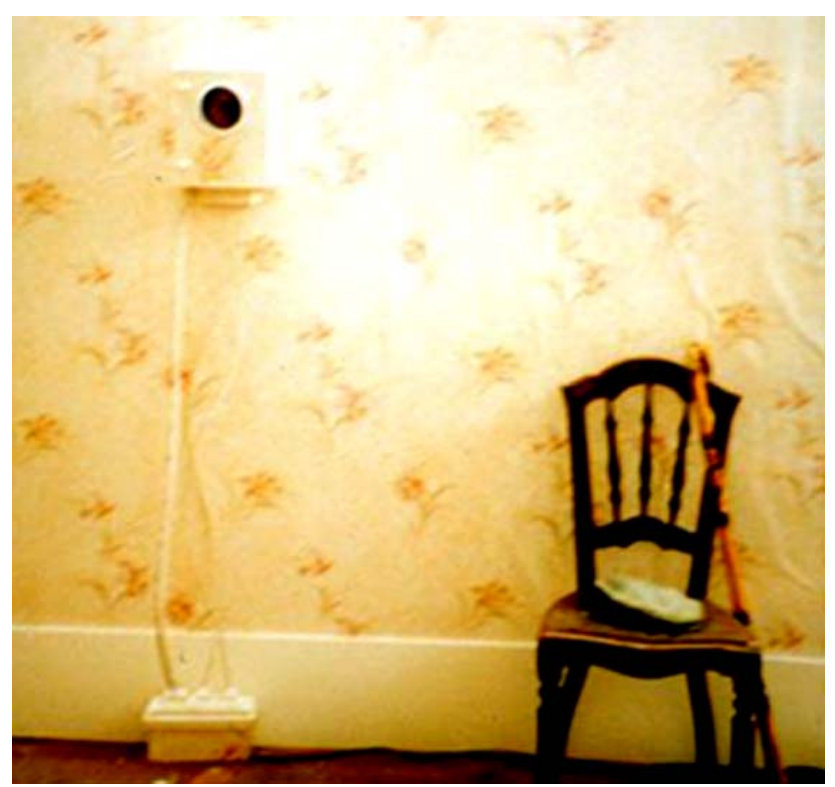

Figura 27: Rui Pedro Fonseca, instalación Adoro-te Avó... que Vivas Para Sempre!, 2002. Caja de alta tensión, batería, varios objetos personales (silla, sombrero, bastón), muro falso, 198×200x80cm.

100 VILLA, Rocío de la. Guía del usuario de arte actual. p.52. 
En conclusión, son muchos los cambios presentes en el desarrollo y lucha implicados en las varias rupturas socioculturales y artísticas. No obstante, aunque algunos de los comportamientos y expresiones artísticas parezcan contradecir la evolución de una historia rectilínea, lo cierto es que el arte contemporáneo es un sin número de formas, técnicas y expresiones, donde hay que tener conciencia de la intencionalidad de cada obra. Cada obra tuvo su proceso de crecimiento, sus influencias del pasado y del presente, y cada obra exhibe la intención del artista, en un juego complejo entre lo aparente y lo oculto, de los cuales, se desprende que, sin intención del artista no hay concepto; sin concepto no hay experiencia estética y sin experiencia estética no hay obra de arte. Por tanto, sin intención del artista no existe obra de arte. ${ }^{101}$ Si por un lado se pueden agrupar las obras de arte contemporáneo por la similitud de los materiales empleados, por otro, es muy limitado e imposible pensar en el arte solamente a través de sus características materiales y técnicas. Mientras tanto y por su importancia, se puede orientar la división y clasificación de las obras según el binomio materia/significado, sabiendo que es posible deparar con obras en que la materia es el hilo que conduce el concepto a un fin concreto y muchas veces consecuentemente efímero.

101 SORALUZE Herrera, Ioseba Imanol. La conservación de los objetos artísticos contemporáneos: degradaciones, criterios de actuación y tratamientos de restauración, p.172. 
2.2. Lo efímero y la temporalidad en el arte contemporáneo.

Pero lo efímero es algo muy triste, objetaréis. No, os diría yo, es el alma del ser, es lo que confiere a toda vida un valor, una dignidad, un interés, porque es lo efímero lo que crea el tiempo, y el tiempo es, al menos en la potencia, el don supremo, el más útil, emparentado por esencia e incluso idéntico a todo elemento creador y activo, a toda movilidad, a todo querer, a todo esfuerzo, a todo perfeccionamiento, a toda progresión hacia un plano más elevado y mejor. ${ }^{102}$

Está en cierto modo consensuado en la sociedad Occidental que toda creación deberá ser, conscientemente, transmitida para el futuro, o sea, que todo lo que es creado deberá llegar a un espacio temporal futuro, pero no se podrá detener el paso del tiempo natural y sus consecuencias sobre las obras de arte.

El tiempo nos hace lo que le hacemos a él. Ni al pensamiento ni al arte le ha gustado que el tiempo pase, y frente a él, ha inventado argucias, tretas de permanencia y perduración. (...) Y frente al conflicto de la muerte, ha resultado más difícil convivir con lo que es una condición de vida, que eludir el problema proyectándose a ficciones de eternidad.... El tiempo resume ese conflicto de identidad. Contra el tiempo, la carrera contra reloj ha consistido en una afirmación del espacio, del territorio que, legitimado, se ha convertido en el modelo para figurarse lo eterno. ${ }^{103}$

Palabras como forma y vida, parecen plantear cuestiones ligadas a las creaciones artísticas y conocimientos estéticos presentes en el arte contemporáneo. Si por un lado, hablar de forma implica pensar en algo estable y concreto, por otro, hablar de forma en arte contemporáneo, no siempre refleja esta definición, viviendo bajo una contradicción para muchos inaceptable y con distintas interpretaciones.

Si se plantea la cuestión de la forma, como imagen de la creación contemporánea, tendrá que hablarse incluso de temporalidad. Lo cierto es que el tiempo podrá

102 MANN, Thomas. El artista y la sociedad, p.317.

${ }_{103}$ MORAZA, Juan Luis. Ornamento y Ley. Procesos de contemporización y normatividad en arte contemporáneo, p.7. 
manifestarse acelerada e incontrolablemente sobre la forma, porque ésta no tiene la consistencia suficiente para superar el paso del mismo, o incluso podrá ser una manifestación propia de la creación, subrayando que no todo lo que es creado está bajo la noción de estabilidad o permanencia. O sea, es cierto que la obra necesita materia para ser visualizada, pero no siempre es su inalterabilidad y permanencia inmutable lo más relevante para su coherente transmisión para el futuro.

Existe una fuerza universal que se manifiesta fundamentalmente de cuatro maneras -en el hombre, las cosas, el espacio y el tiempo- y tiene tres "modalidades": la imagen, la forma y el ritmo. 104
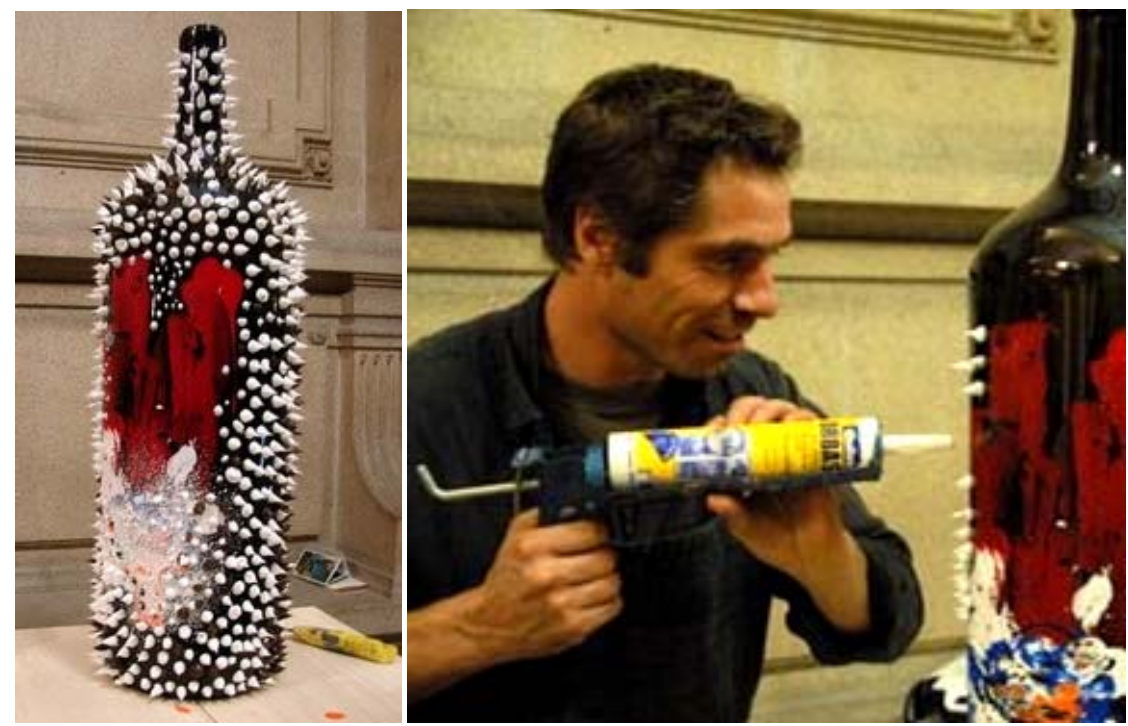

Figuras 28 y 29: João Pedro Rodrigues en la ejecución del trabajo, Toca-me105, 2007. Botella de vidrio, silicona y tinta acrílica.

Que la transitoriedad es una presencia constante en varias corrientes y creaciones artísticas no es sorprendente, pero, ¿qué hay más transitorio que el acto de creación contemporáneo? La facilidad en la búsqueda tecnológica e industrial y la estructura social consumista y veloz ofrecen al artista, en bandeja, los medios y la información para que éste encuentre la imagen, el icono, como representación de lo real, en lo que a cada creación se refiere o posee un tiempo distinto. Y ambos, los conceptos de

${ }^{104}$ READ, Herbert. Arte y alienación, p.49.

105 Trabajo realizado para un concurso promovido por la Red de capitales de Grandes Viñedos, en Oporto. 
efímero y temporalidad, pueden estar entrelazados en los diferentes tiempos: el tiempo de creación, el tiempo de acción y el tiempo de exposición.

Para hacer un análisis en función del tiempo, hay que pensar en el arte como objeto final, el arte como proyecto, o el arte como proceso. A la primera forma de expresión se pueden asociar todas las obras de arte que necesitan integridad física y material para que posteriormente puedan ser disfrutadas, como la pintura, la escultura, etc.; la segunda, engloba todas aquellas obras que siguen un parámetro de exposición sin que necesariamente se visualice el material original, o sea, muchas instalaciones que son varias veces montadas sin que eso interfiera en la correcta lectura de las mismas; y las ultimas, serán aquellas en las que el concepto de la obra pertenece al desarrollo de la acción, como podrán ser las performances, los happening, etc..

Por otra parte, pensar en temporalidad, conduce al pensamiento hacia lo efímero y esto implica asociar la obra a tres ideas. La primera resulta del tiempo de ejecución de la obra de arte, caracterizado por los rápidos instantes dejados sobre la superficie, en que la mancha é a forma como elemento pictórico existente para além do momento em que se concretiza na tela. Desta forma, acentua-se um factor [...] o tempo. O tempo limitado da execução de uma forma, considerado como um valor estético106. Una segunda idea se refiere al tiempo de vida de la obra de arte. Hablando de efímero en términos artísticos, simplemente hay que señalar las creaciones que nacen para morir, dejando aparte aquellas en las que el artista no tiene conciencia del deterioro de la materia empleada en la obra (y que por consecuencia serán obras efímeras pero sin que el artista las defina como tal), y una tercera que corresponde al tiempo de exposición de una obra de arte. Comúnmente se piensa en tiempo de exposición como la permanencia física y matérica de una obra a lo largo de años o incluso siglos, pero algunas creaciones presentan nuevos valores de exposición temporal y son catalogadas como efímeras, sin hacer de ese factor una minusvalía en términos artísticos.

106 VALLIER, Dora, $A$ arte abstracta, p 202.

T. A.: ... es la forma como elemento pictórico existente para allá del momento en que se concretiza en la tela. De esta forma, se acentúa un factor [...] el tiempo. El tiempo limitado de la ejecución de una forma, considerado como un valor estético. 
Es difícil, muchas veces, reconocer los diferentes tiempos en el arte contemporáneo, pero es nítida la dificultad de aceptar el paso del tiempo, tan acelerado y acentuado. De acuerdo con la tradición y cultura occidentales, es difícil asumir lo efímero como característica que repercute físicamente sobre la obra, pero todas las bellezas contienen, como todos los fenómenos posibles, algo de eterno y algo de transitorio, de absoluto y de particular. ${ }^{107}$ Los conceptos vida/muerte tienen una concepción bastante específica. Subrayando estos conceptos y su papel, es difícil aceptar el rápido envejecimiento de las obras de arte, donde se puede sentir una fuerte intención por varios organismos y personas especializadas en querer mantenerlas vivas.

Uma boa pintura com dez buracos é melhor que dez pinturas ruins sem nenhum buraco. Uma marca de carvão na parede pode ter mais arte do que dez quadros sobre um fundo sólido e cercados por ricas molduras de ouro.

Os melhores quadros de Leonardo da Vinci estão destruídos. Mas eles não morrem. Um pensamento engenhoso vive para sempre. ${ }^{108}$

Las palabras de Edvard Munch tocan aspectos como la interpretación o el gusto, pero es evidente que permanecerá en la 'memoria' de la humanidad lo que por determinadas características se destaca entre miles de objetos y creaciones. Forman parte de esta estructura elementos esenciales como la relatividad y la transitoriedad, aunque la obra de arte surja como un flujo de eventos abiertos, constituyendo una red sin fin de causas y efectos. Estos elementos de no permanencia, contrarían lo paradójico del tiempo y de la eternidad, donde se juega con la suerte de un vacío temporal y la eficacia estructural, como forma más pura en la estética de la obra. Hablar de temporalidad engloba muchas otras cuestiones, además de las planteadas e inherentes a las creaciones, como el mercado del arte 0 las fugaces exposiciones temporales. Ambos juegan sus mejores cartas y además dejan sus huellas en el transcurso de la creación contemporánea, a través de las muestras de corta duración y de la rápida adquisición y de la necesidad de consumo, características de la sociedad actual.

107 BAUDELAIRE, Charles. El Salón de 1846, p.197.

108 MUNCH, Edvard, Ekely, 1928. en CHIPP, ob. cit. p.113.

T.A: Una buena pintura con diez agujeros es mejor que diez pinturas malas sin ningún agujero. Una marca de carbón en el muro puede tener más arte que diez cuadros sobre un fondo sólido y cercados por ricas molduras de oro. Los mejores cuadros de Leonardo da Vinci están destruidos. Pero ellos no mueren. Un pensamiento ingenioso vive para siempre. 


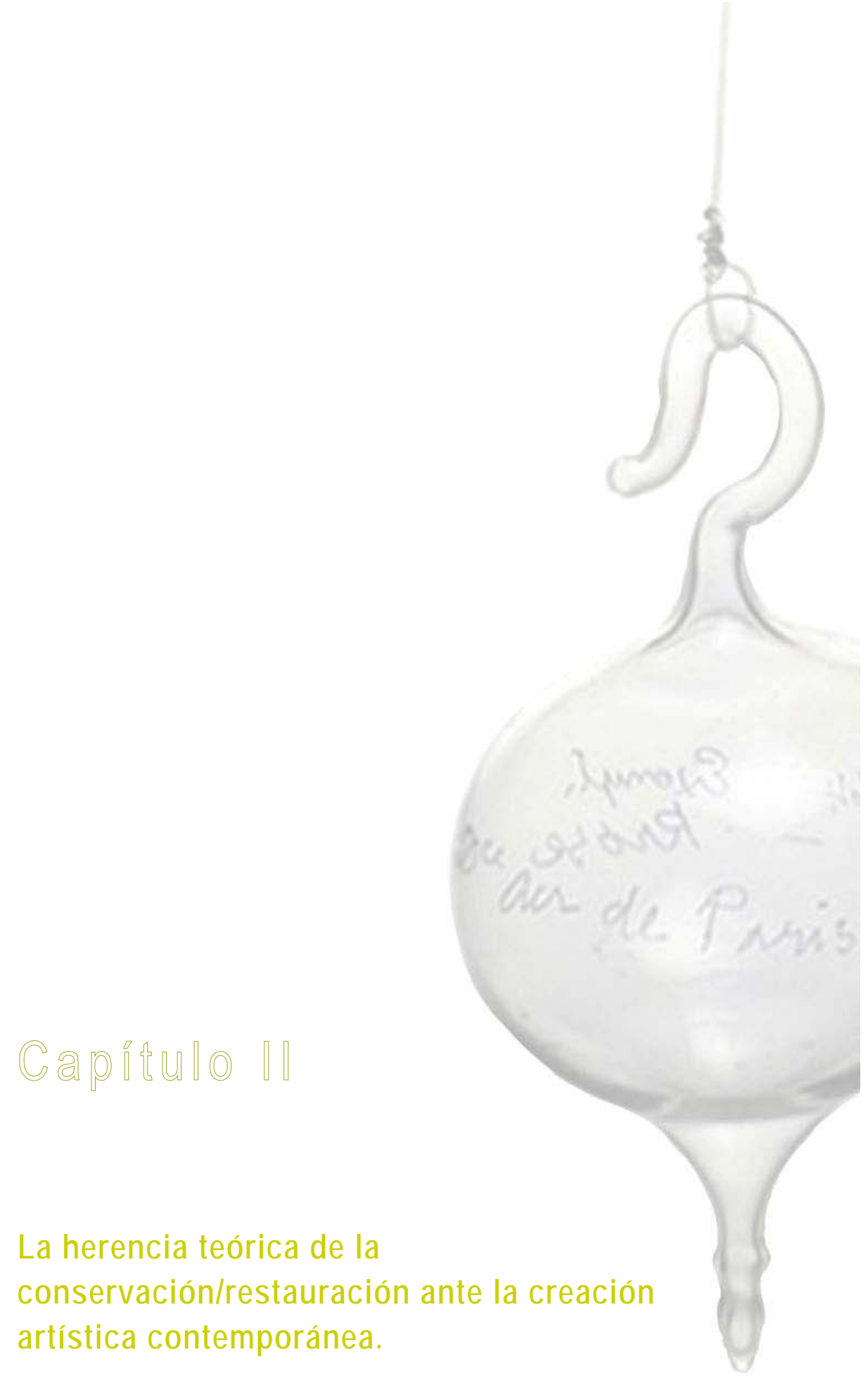



¿Hasta qué punto se aceptan las modificaciones, envejecimiento, desgaste y decaimiento de las obras de arte contemporáneas?

¿El arte contemporáneo compromete la cuestión técnica y teórica de la conservación/restauración?

¿La teoría de conservación/restauración ofrece las respuestas necesarias para la manutención y restauración del arte contemporáneo?

¿Hasta qué punto se fundamenta, teóricamente, un trabajo práctico de conservación/restauración?

¿La práctica de conservación/restauración del arte contemporáneo encontrará su fundamento y justificación en la Teoría de la Restauración?

¿Será el arte contemporáneo un problema a nivel de conservación/restauración de su materialidad? 



\section{La teoría como base fundamental para la práctica y desarrollo de la conservación/restauración.}

1.1. La creación y evolución de la disciplina de conservación/restauración.

Y un cuadro es, no ya un organismo vivo, sino algo más: una persona moral representada, con sus ámbitos sensibles, sus zonas de inteligencia valedera y sus precipicios insalvables. No cuenta más esto que aquello, el color que el relieve, la línea que el tono, lo que cuenta es la unidad: una persona moral sin integridad, sin unidad es algo monstruoso, aparte del objeto del arte, porque lo que no tiene unidad carece fatalmente de belleza, está huérfano de poesía. El milagro de una obra de arte bella es su unidad. 109

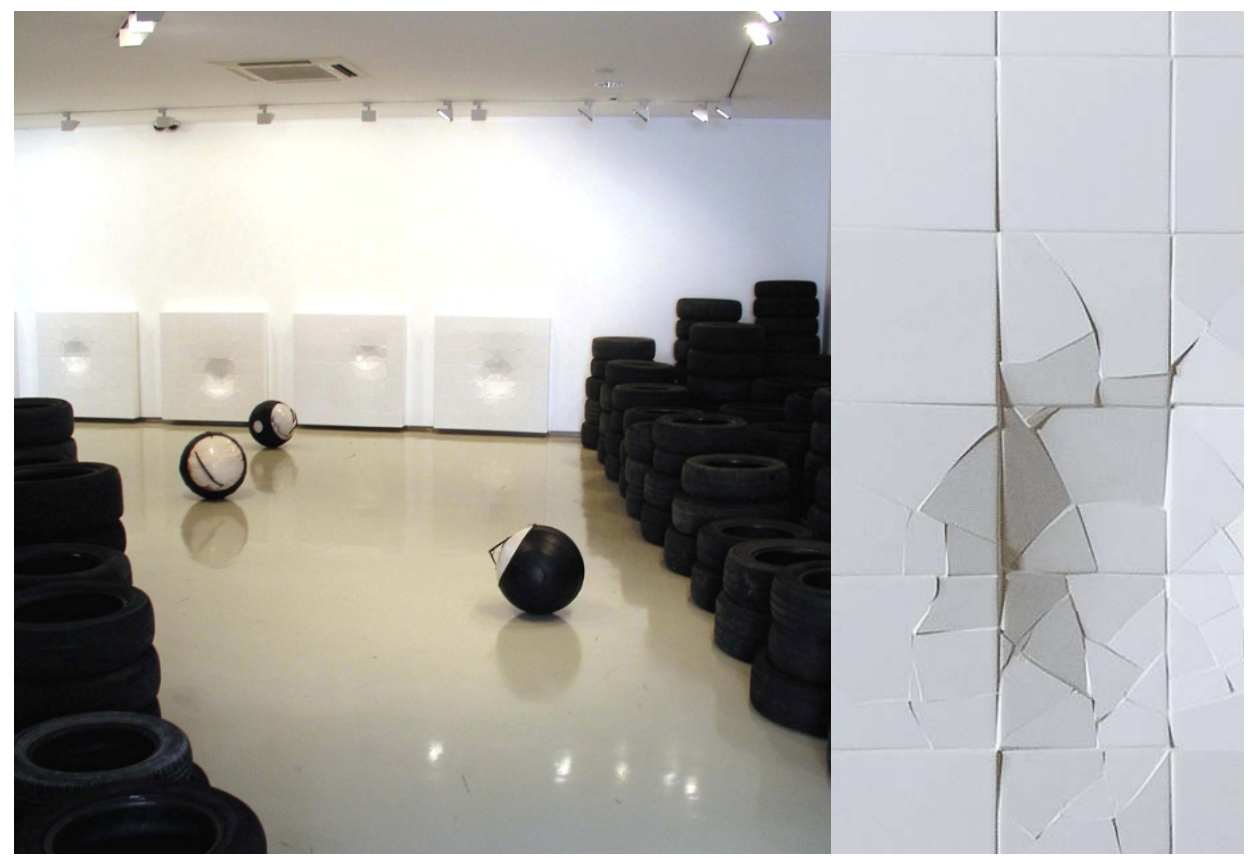

Figura 30: Isaque Pinheiro, instalación MAE (Más altas esferas), 2004.Neumaticos, esperas de mármol, paneles de azulejos. Figura 31: Isaque Pinheiro, detalle de Contacto, 2004. Panel de azulejos.

109 Introducción de Lorenzo Varela. en BAUDELAIRE, Charles. Curiosidades estética, p.19 
Hablar de los conceptos de conservación y restauración nos remite a la necesidad que todo el ser humano tiene, y que siempre ha existido, de proteger y preservar los bienes y valores materiales e inmateriales que le pertenecen. Este comportamiento a lo largo de la historia sufrió grandes cambios, según la evolución del concepto de propiedad, debido a sus diversas concepciones y significados, sean mágicos, religiosos, culturales o políticos. No obstante, son evidentes las influencias de las ideas religiosas, filosóficas, estéticas y políticas en la evolución de la conservación y restauración, como actividad intelectual y no meramente manual, determinando diferentes momentos, tanto ideológicos y culturales como técnicos. Primordialmente, la conservación/restauración acompañada de una actitud histórico-crítica tiene como objetivo conservar, preservar, mantener y transmitir todos los objetos, con determinadas características físicas, técnicas y formales, considerados bienes culturales, de reconocido valor artístico y estético, garantizando todos los valores intrínsecos a las obras a través de su consistencia física. Una necesidad de conocer estética y históricamente la obra de arte, a través de un conjunto de señales que se interpretan y reconocen, y luchando contra elevados niveles de arbitrariedad. Basando la actividad en lo que se entiende por un acto crítico, o sea, todo lo que no modificara la situación encontrada tras el acto filológico de identificación, sino que la conservara en toda su autenticidad. ${ }^{110}$

La evolución histórica de la conservación y restauración va acompañada de la evolución de varios aspectos que se relacionan entre sí. Los técnicos resultan de materiales y productos, técnicas y procedimientos, que algunas veces son difíciles de precisar por la escasez de datos de referencia; los aspectos ideológicos están caracterizados por los hechos sociopolíticos y las estructuras sociales; los económicos van asociados a los ideológicos y cobran especial importancia en el siglo XIX con la noción de propiedad privada y el coleccionismo, factores que motivarán la conservación y el mantenimiento del estado y autenticidad de las obras; y, por último, encontramos los aspectos jurídicos influidos por los aspectos económicos, una vez que la obra también es objeto de regulación jurídica.

110 BALDINI, Umberto. Teoría de la restauración y unidad de metodología. Vol.1, p.17. 
Según González-Varas se torna difícil definir cuál es el primer comportamiento que surgió con la intención de prolongar la existencia física de un objeto, puesto que los repintes aplicados por los hombres del Paleolítico superior a las pinturas parietales ${ }^{111}$, pueden ser entendidos como tal. Ya en la Edad Media pocas son las preocupaciones y el respeto por la obra, donde las intervenciones pasaban por el repinte, la reelaboración y corrección sin seguir ningún tipo de preocupación teórica. Con el Renacimiento se restablece el respeto por la Antigüedad manifestado en una intención conservadora de los hallazgos y monumentos romanos, pero la intervención sobre las obras de arte tampoco varía mucho comparativamente a las épocas anteriores, puesto que también en el Renacimiento la imagen es transformada, reconstruida en un proceso de incautación de valores mercantiles o eclesiásticos. Una vez más el campo artístico se ve invadido por valores menos respetuosos, y con el desarrollo del coleccionismo, de un mercado artístico y de las implicaciones de la Contrarreforma católica, menos aún se podrá esperar la mejor actitud hacia las obras de arte. El Barroco tampoco fue un período apreciado por sus buenas actitudes, puesto que los cambios de gusto, el desarrollo acelerado del coleccionismo y el oscilar de nuevas estéticas no frenó las transformaciones en las obras originales, antes por el contrario, llevó a que sufriesen alteraciones de formato o cambios estéticos de la imagen con la intención de adaptar las obras a nuevos espacios y de modernizar las iconografías, como consecuencia, una vez más, de la Contrarreforma y del Concilio de Trento. Tales comportamientos y actitudes no son más que el resultado de mudanzas de mentalidades y pensamientos, el surgir de nuevos valores y nuevas concepciones estéticas, así como cuestiones económicas y comerciales, llevando a lo largo de la historia a comportamientos poco razonables por parte no sólo de artistas, sino también de restauradores.

Si por un lado, en el Barroco se asiste a un crecimiento del espíritu coleccionista y la valoración de los objetos del pasado, con particular interés por la escultura, siendo las estatuas antiguas restauradas y completadas; por otra parte y en consecuencia, hay nuevos requerimientos del mercado, donde se estimula la diferenciación entre artista y restaurador. Esta distinción favorece a la especialización del restaurador, resultando

111 GONZÁLEZ-VARAS, Ignacio. Conservación de bienes culturales. Teoría, historia, principios y normas, p.132. 
en la experimentación y la discusión técnica y teórica sobre las posibilidades, congruencia y límites de la restauración, ya sea de la materia como del valor histórico-cultural de las obras de arte. ${ }^{112}$

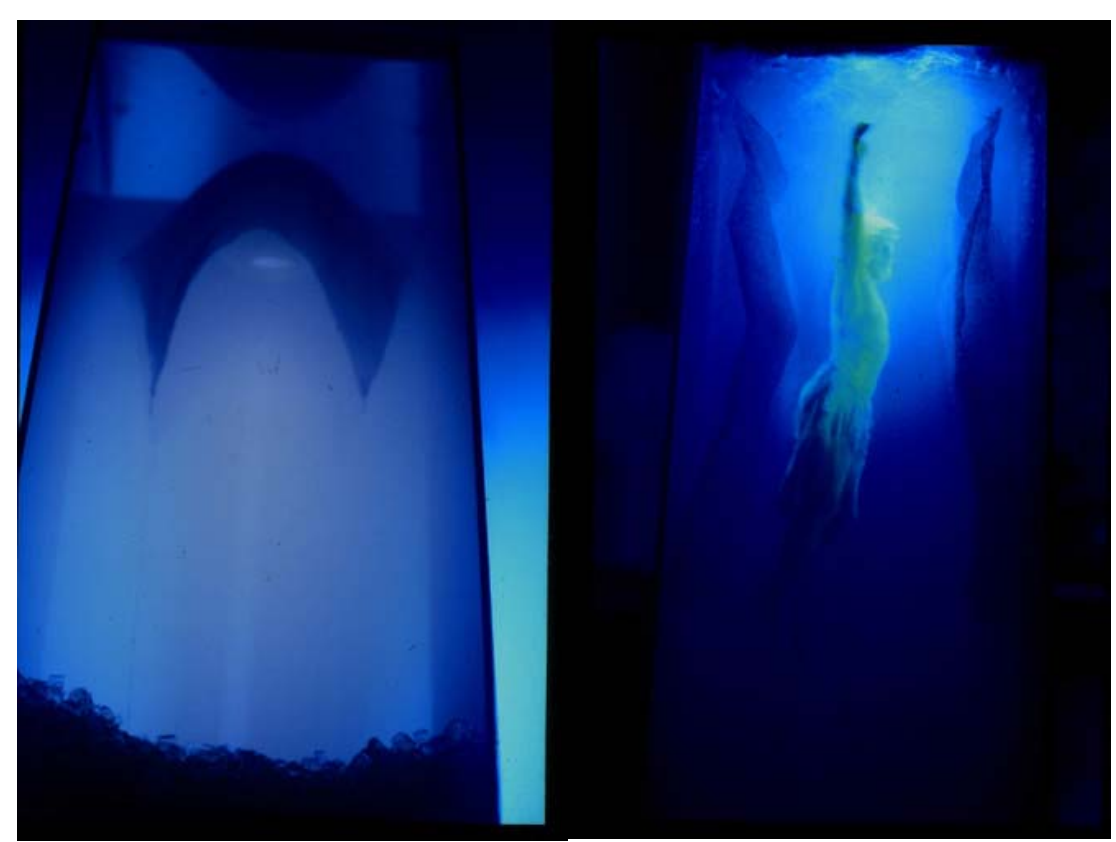

Figura 32: João Pedro Rodrigues, instalación Anemona. Vidrio, Agua, rede de acero y tinta fluorescente, $177 \times 30 \mathrm{~cm}$. Figura 33: João Pedro Rodrigues, instalación Ele.... Vidrio, agua, rede de acero, yeso y tinta fluorescente, $177 \times 30 \mathrm{~cm}$.

En el siglo XVIII, como resultado de la Revolución Francesa y del Neoclasicismo, a través del espíritu racional y científico surge la noción de propiedad privada, además del nacimiento de la burguesía y del sentimiento de patrimonio colectivo, que se refleja en la creación de academias y museos. Como una nueva tendencia que junta la promoción hecha por las academias a través de grandes exposiciones, y del estado como poseedor del patrimonio artístico que funda los nuevos espacios expositivos, una forma de materialización institucional. Todos estos cambios unidos al desarrollo industrial han generado un mercado de arte, nuevos especialistas y nuevos agentes sociales -los críticos de arte y los historiadores, los marchantes y los coleccionistas.

112 MACARRÓN Miguel, Ana M. ${ }^{a}$. Historia de la conservación y la restauración p.77 
Todavía, es a finales del siglo XVIII cuando se afirma la actitud crítica y técnica hacia la actividad de la restauración, en que la restauración artística tiene sus bases en la llustración. Es importante subrayar el poder que han tenido el espíritu científico y racional en el siglo XVIII, con el desarrollo de varios experimentos, entre ellos el análisis de los materiales y técnicas artísticas. El restaurador en el siglo XVIII trabajaba esencialmente para tres tipos de clientes: el Estado, la Iglesia y los coleccionistas privados. Con necesidades distintas entre sí y donde el resultado de la restauración era determinado por la calidad y la procedencia de la obra. Como consecuencia los repintes, reintegraciones, limpiezas, entre otros procedimientos realizados con base en los conocimientos científico-técnicos que dependían, principalmente, del sujeto al que pertenecía la obra y sus deseos ante la misma. A pesar de posibles críticas y desconfianza hacia el trabajo desempeñado por el artistarestaurador a lo largo del siglo XVIII, sus funciones hicieron de él una de las figuras más destacadas en el mundo del arte. De tal forma que el restaurador adquirió cierta autoridad, pasando a determinar las responsabilidades y tareas destinadas a su actividad, hasta entonces el que era restaurador era previamente artista.

Es el momento en el que las colecciones se empiezan a abrir al público y se crean centros de depósito. A finales del siglo XVIII y a lo largo del siglo XIX, estos espacios, además de la función pedagógica, asumen una función de investigación, que consiste en el estudio de los materiales constituyentes de las obras y en los diagnósticos previos a las intervenciones. Con todo surgen nuevas necesidades en los museos, como el inventario y la catalogación, o la selección de las obras y el montaje de exposiciones, que lleva a la especialización profesional y a la división de las tareas en los museos.

Mientras las Academias se equipan con colecciones de yesos, reproducciones de obras e incluso de originales, empiezan a abrirse al público (y sobre todo a los artistas) los primeros museos modernos [...]. Así emerge un fenómeno nuevo destinado a crecer en el siglo XIX; las obras de arte son analizadas no sólo en términos históricos [...], sino también en función del conocimiento, del redescubrimiento y, por último, de la recuperación de sus técnicas, en el ámbito de una racionalización de un nuevo tipo entre «teoría» y «práctica» del arte. ${ }^{113}$

113 BORDINI, Silvia. Materia e imagen. Fuentes sobre las técnicas de la pintura. p.108. 
A la par de los cambios que han afectado a la producción artística, como los socioeconómicos y las transformaciones ideológicas en la forma de materializar la propia creación, llega la revolución industrial, y el trabajo manual es sustituido por la producción mecánica. La aparición de las fábricas tiene consecuencias sobre el arte a varios niveles: el auge de las artes aplicadas; la expansión y transformación de las ciudades; y el coleccionismo financiado por la burguesía, como hace referencia la siguiente citación.

La industrialización y el consiguiente aumento de la población urbana dan lugar al ensanche de las ciudades y a la pérdida de función de las anteriores construcciones, conservando sólo el valor artístico y cultural. Esto tiene dos vertientes: el patrocinio de determinados «estilos» por parte de los mecenas del momento, hombres de negocios y grupos u organismos municipales y estatales, que derivará a nivel artístico en la proliferación de producciones sincréticas. Basadas en los «neos», y que por su gran importancia en la Historia de la restauración en el XIX merece un apartado propio.114

Con el siglo XIX, la tendencia científica se impone, a través de la creación de laboratorios y talleres especializados en restauración en los museos; la consecuencia de ello será la recopilación de un vasto conjunto de datos más objetivos y científicos, que hasta entonces no habían sido base de estudio. La obra es objeto de contemplación histórica según criterios, técnicas y metodologías más respetuosos, en los que la cultura occidental deja claro que lo importante es la obra y para tal, hay que conservar y proteger sus calidades intrínsecas además de su contexto de producción.

Es en pleno siglo XIX, al paso que se reconoce críticamente el patrimonio cultural y se establece el concepto de monumento histórico, cuando surge la restauración como actividad profesional capaz de asegurar la veracidad de una obra de arte. La restauración como fue referido, ya existía en el pasado, pero sólo en el siglo XIX gana el estatus de disciplina científica, de práctica consolidada y de fundamentos teóricos intencionalmente establecidos, pues la restauración sólo se transforma en ciencia cuando empieza a desarrollar documentación escrita.

El siglo XIX fue prodigioso en términos de investigación para la restauración pictórica, todavía, bajo una visión de la restauración romántica, con intención de proteger la

114 MACARRÓN Miguel, op. cit. pp. 145-146 
pátina y mantener la subjetividad de la obra, y acompañada de la creación de tratados de restauración subordinados a recetas y consejos, como es ejemplo el de Ulisse Forni. Su Manuale del pittore restauradore, reflete la preocupación con la orientación práctica de la actividad refiriendo que el artista dedicado a restaurar debería hacerlo de forma respetuosa y con gran conocimiento de las técnicas y materiales.

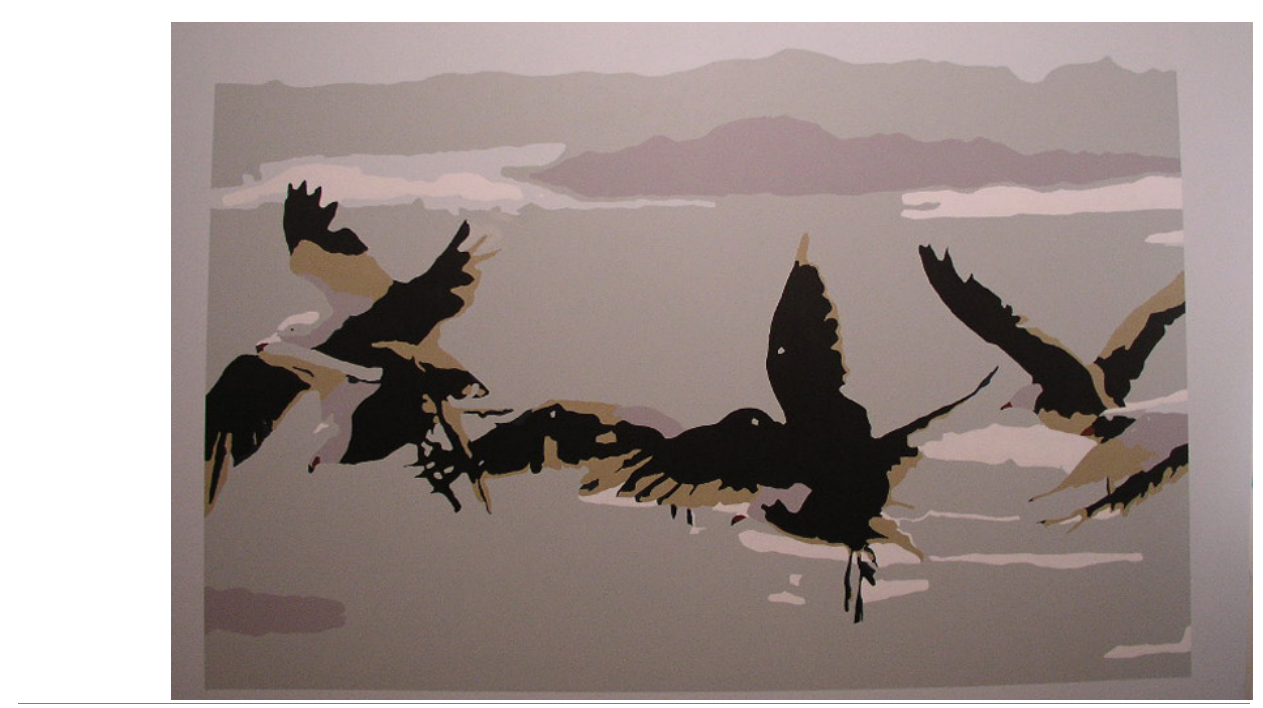

Figura 34: Ana Cardoso, Back Away, 2004. Acrílico sobre tela, 130x200cm.

La actividad dotada de principios y criterios teóricos y científicos deja atrás una práctica artesanal que tuvo su lugar en los siglos anteriores, en los que permanecía sobre la misma persona, la identidad del creador de las obras y del restaurador como el ser habilitado y capaz de intervenir en las mismas.

Se verifica el desarrollo del coleccionismo y la realización de las catalogaciones, y se convive con la experimentación de nuevos materiales, fruto de investigaciones en física y química aplicadas a las artes plásticas y a la restauración, así como con el nuevo ideal y concepción del arte, que condicionará los criterios y técnicas de intervención. Se empiezan a comprender los cambios cromáticos provocados por el paso del tiempo, los cambios químicos de las estructuras moleculares de los materiales, los problemas de reentelar e impregnar pinturas, etc. Las intervenciones de restauración fueron adquiriendo un carácter cada vez más científico. Se 
establecieron criterios y conceptos para las intervenciones, tratando de seguir una especie de reglamento creado para la actividad, con la intención de mantener la virginidad de las obras.

Viollet-le-Duc, John Ruskin junto con William Morris y Camillo Boito han dejado sus huelas en la evolución y historia de la restauración y conservación. Por un lado Violletde-Duc, con una visión más radical, defendía que era necesario sacrificar el monumento y su presencia temporal con sustituciones macizas, de forma a fingir un estado idealizado del edificio. Mientras tanto Jonh Ruskin junto a William Morris presentan su enorme respeto hacia la materia original y las huellas dejadas por el tiempo, optando por una manutención periódica, pero sin dejar de lado la posibilidad de que un edificio pueda morir, perspectiva deliberadamente radical donde la ruina asumía un papel primordial ante la reconstrucción.

Camillo Boito, arquitecto, restaurador, historiador, escritor y profesor, traza su perspectiva en la obra I restauradori, en una conferencia hecha en la Exposición de Turim en 1884. En la conferencia expone sus nociones de conservación/restauración en función de la arquitectura, pintura y escultura, un texto con su debida importancia en la medida que Boito a finales del siglo XIX establece y reforma los principios para la teoría contemporánea, defendiendo la mínima intervención y la intervención distinguible, citando:

Ora, nas restaurações da pintura eis aquí o ponto chave: PARAR A TEMPO; e aquí está a sabedoria: CONTENTAR-SE COM O MENOS POSSIVEL.115

A pesar de Boito inicia su investigación teniendo como base los principios de Violletle-Duc, a finales del siglo XIX se aleja de tales principios y desarrolla una posición renovada e independiente. A partir de este momento, defiende una restauración científica alcanzando la metodología para la restauración histórica en una rectificación de la restauración estilística que tenía como principal objetivo la reconstrucción hipotética e idealista. Boito establece su método llegando a criticar tanto el punto de

115 BOITO, Camillo. Os restauradores, p.53.

T.A.: Pues, en las restauraciones de pintura es aquí el punto clave: FRENAR A TIEMPO; y aquí está el saber: CONTENTARSE CON LO MENOS POSIBLE. 
vista de Viollet-de-Duc como el de Ruskin, puesto que sus perspectivas divergentes eran muchas veces contradictorias e incoherentes en sí mismas.

En 1927, Giovanni Secco-Suardo publica su tratado II restauratore dei dipinte, donde se propone definir la figura del restaurador, citando genéricamente cómo él definía el restaurador perfecto:

1. Anzitutto egli debe essere dotato di un numero non comune di cognizioni e possedere particulari disposizioni per tutti i rami dell'arte. (...)

2. Debe avere attitudine alla maecanica.

3. Debe avere conoscenza dei principi della chimica (...).

4. Debe conoscere non soltanto le sostanze occorrenti nei vari caso ma il modo come devono essere adoperate (...).

5. Debe, e con molti sacrifici, rinunciare alla propria personalità di artista o meglio dimenticare del tutto le proprie tendenze ed uniformarsi invece strettamente agli svariatissimi stili degli infiniti autori dei quali è chiamato a ripararne le opere (...).

6. Non debe alterare il carattere o meglio l'originalità del dipinto (...).

7. Debe essere pittore in tutta l'estensione del termine e versato (...) in tutte le pratiche dell'arte. (...).

8. Debe essere animato da un caldo amore per la sua arte. (...).

9. Oltre tutte e fra tutte le qualità di cui debe essere dotato un restauratore sono da ricordare e sottolineare in modo tutto particolare l'onestà, la discrezione e la diligenza che egli debe sempre dimonstrare nello svolgimento del proprio lavoro e nei suoi rapporti con l'ambiente della sua attività. ${ }^{116}$

Un manual con la intención de evitar los secretos y las acciones empíricas de restauración, y el cual el autor describe:

L'arte del restauro è fra le più ingrate che far si possano. Per riuscirvi è mestieri fare per essa i più grandi sacrifici: quando il restauratore a forza di acume e di pratiche giunge a toccar lo scopo producendo un'opera assolutamente perfetta, non solamente non gli è permesso vantarsene, ma gli è tolto persino il conforto di vedere l'opera sua coronata dal plauso universale. Chè la discrezione gli vieta di vantarsi delle proprie operazioni per non

116 PIVA, Gino (a cura di). L'arte del restauro. II restauro dei dipinti nel sistema antico e moderno. Secondo le opere di Secco.Suardo e del Prof. R Mancia, p.7-10.

T.A.: 1. Primero debe estar equipado con una serie de conocimientos y poseer particulares disposiciones para todos los ramos del arte. (...) 2. Debe tener capacidad para la mecánica. 3. Debe tener conocimiento de los principios de la química (...). 4. Debe conocer no sólo las sustancias necesarias en los varios casos, y la manera cómo deben utilizarse (...). 5. Debe, y con mucho sacrificio, renunciar a la propia personalidad como artista, o mejor olvidar todas sus tendencias y en lugar de ajustarse estrictamente a los estilos de la infinita variedad de autores de los cuales es llamado a reparar las obras (...). 6. No debe alterar el carácter o más bien la originalidad de la pintura (...). 7. Debe ser pintor en toda la extensión del plazo y versátil (...) en toda la práctica del arte. (....). 8. Debe ser animado por un cálido amor por su arte. (...). 9. Durante todos y entre todas las cualidades de que debe estar provistos un restaurador son de recordar y destacar de forma particular la honestidad, la discreción y la diligencia que debe siempre demostrar de su trabajo y en su relación con el ambiente de su actividad. 
discreditare i quadri per le quali esse furono fatte, mentre l'eccellenza stessa del suo lavoro impedisce che sia compreso e degnamente apprezzato dalla massima parte dei riguardanti stante quell'assioma che IL MIGLIOR RESTAURO È QUELLO CHE MENO SI SCORGE.117

Son sin duda curiosas las precisiones de Secco-Suardo, en que de sus palabras se puede deducir que la intervención de restauración era valorizada por su capacidad de confundirse con el original, nociones que a lo largo de la historia de la restauración fueron, y hasta hoy son, cuestionadas. Además de las aportaciones presentadas, Gaetano Previati118 es el responsable por Introduzione allo studio del restauro, texto introductorio presente en el tratado de Secco-Suardo, en el cual Previati insiste en las cualidades necesarias de un buen restaurador. Además de la referencia a los conocimientos profundos sobre la técnica pictórica, entre el reconocer con exactitud un tono, un retoque, un quehacer esencialmente basado en el arte de pintar, etc. es del todo interesante, por su contemporaneidad, el tercer punto presentado:

3.Che non sia un vero e proprio pittore creatore perchè, anche se abilissimo, sarebbe sempre dominato dalla sua originalità e dalla sua arte, mentre il restauratore, essendo impersonale, è spesso più scienziato che artista. ${ }^{119}$

Siguiendo la evolución histórica, también en el siglo $\mathrm{XX}$, y con preocupaciones similares a Camillo Boito se destaca Gustavo Giovannoni, por querer asegurar el concepto documental de la obra, definiendo de esta forma, las bases actuales de la conservación/restauración.

Gustavo Giovannoni tiene un papel importante en la primera mitad del siglo XX y dando continuidad al pensamiento de la restauración científica de Boito, participa en la redacción de la Carta de Atenas de 1931 y de la Carta Italiana del Restauro de 1932.

117 PIVA, op. cit. p.10.

T.A.: El arte de la restauración es el más ingrato que se puede hacer. Para tener éxito es necesario hacer los mayores sacrificios: cuando un restaurador a fuerza de agudeza y práctica llega a tocar su fin produciendo una obra absolutamente perfecta, no sólo no tiene permiso para alardearse, se elimina incluso el gusto de ver la obra coronada de un aplauso universal. Que la discreción prohíbe alardearse de sus propias operaciones para no desacreditar los cuadros para lo cual fueron hechos, mientras la excelencia de su trabajo impide que sea comprendido y debidamente apreciado por la mayor parte de los cuidados aparte del axioma que LA MEJOR RESTAURACIÓN ES AQUELLA QUE MENOS SE VE.

118 Gaetano Previati, pintor italiano que desarrolla su obra con base en la técnica del Divisionismo. Nasció en Ferrara, 1852 y murió en Lavagna, Génova, en 1920. Estudió en Florencia, Milano y en la Academia de Bellas Artes de Brera. 119 Ibídem, p.17.

T.A.: 3. Que no sea un verdadero y típico pintor creador, aunque hábil, siempre sería dominado por su originalidad y su arte, mientras el restaurador, al ser impersonal, es más científico que artista. 
Ya en 1939, Giulio Carlo Argan define la restauración como:

actividad rigurosamente científica e investigación filológica dirigida a recuperar y volver a poner en evidencia el texto original de la obra, eliminando alteraciones y superposiciones de todo género hasta conseguir de aquel texto una lectura clara e históricamente exacta (...) coherentemente con este principio, la restauración, que en un tiempo venía ejercida predominantemente por artistas que a menudo sobreponían una interpretación personal a la visión del artista antiguo, es hoy ejercida por técnicos especializados, continuamente guiados y controlados por estudiosos: a una competencia genéricamente artística ha sustituido de este modo una competencia rigurosamente historicista y técnica. ${ }^{120}$

Pero es a mediados del siglo XX cuando se define la restauración crítica, sin anular la fuerza de los principios que defendían la obra de arte como historia y documento, donde Cesari Brandi ha tenido un papel destacado con la elaboración de su Teoría del Restauro en complemento a la restauración científica, consciente de que la restauración constituye un acto crítico hacía la obra de arte.

En seguimiento de los criterios y valores presentados por Brandi, en 1978, Umberto Baldini redacta el primer volumen de su Teoría del restauro e unità di metodología, y en 1981 el segundo volumen. Con la preocupación de esclarecer varios conceptos con repercusión en la práctica de conservación/restauración, Baldini defiende la operación filológica ${ }^{121}$ como el mejor medio para conocer el estado genuino de una obra, en que a cada obra pertenecen, por lo menos, tres actos: el primero es el de la creación por parte del "artista"; el segundo es la acción del "tiempo" sobre la obra; y el tercero es la acción del hombre122, y subraya la imposibilidad de devolver la obra al primer acto y tiempo de vida, cuando por algún motivo ha sufrido alguno cambio 0 daño.

Entonces, el único método válido en todos los sentidos es un acto crítico (...), ya que puede recuperar en su justo equilibrio los valores que aún existen en la obra. Para encontrarlos sólo hay que saber buscar (ahí está el acto de filología); no es necesario inventarlos, recrearlos o modificarlos (y ahí está el 'tercer acto'). ${ }^{123}$

120 GONZÁLEZ-VARAS, Ignacio. Conservación de bines culturales. Teoría, historia, principios y normas, p.271.

121 Es fundamental percibir verdaderamente lo que comprende la operación filológica, y tras consultar el Diccionario de la Real Academia Española, surgen distintos puntos de vista. Por un lado, es la ciencia la que estudia una cultura tal como se manifiesta en su lenguaje y en su literatura, principalmente a través de los textos escritos; y, por otro lado, es la técnica la que se aplica a los textos para reconstruirlos, fijarlos e interpretarlos.

122 BALDINI, Umberto. Teoría de la restauración y unidad de metodología. Vol. 1, p.7.

${ }^{123}$ BALDINI, Umberto. Teoría de la restauración y unidad de metodología. Vol. 2, p.13. 


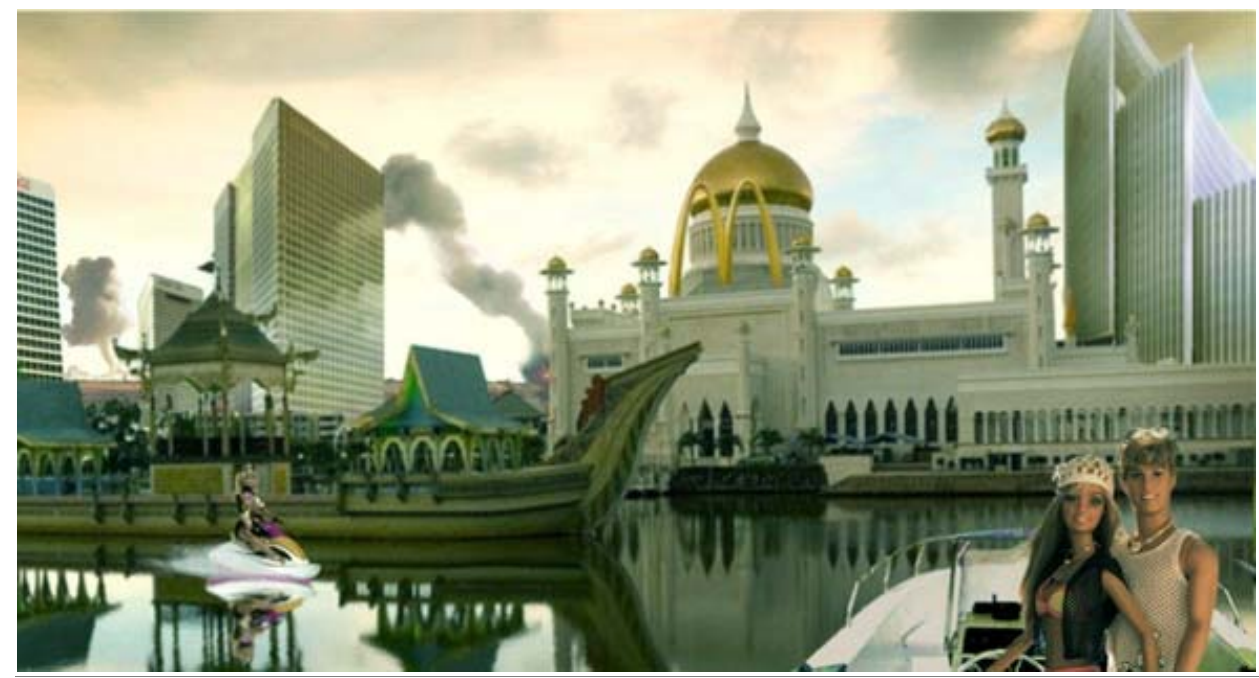

Figura 35: Rui Pedro Fonseca, Summer Delight, 2007 (del proyecto Barbarybarbyzation). Caja de luz, 84x50x17cm.

Uno de los conceptos fundamentales de la Teoría de Baldini es el de mantenimiento, que define como indispensable, inaplazable, inevitable y necesario. ${ }^{124} \mathrm{Y}$ lo es, porque es la forma que permite transmitir la obra al futuro evitando (...) su evolución, por rápida o lenta que sea, hacia 'thánatos'; conservando lo más posible su 'bíos' y no modificando arbitrariamente su 'heros'.125 Todavía, es necesario referir, que el mantenimiento no es sinónimo de restaurar, y lo que diferencia cada acción es el tiempo en que se insieren: el mantenimiento existe durante el segundo acto con la intención de conservar lo existente, y por otra parte, restaurar participa del tercer acto, un acto crítico. No deja de lado la importancia de la actividad de restauración bajo una actitud crítica, que respete con rigor el texto que constituye cada obra.

Pero nunca podrá ser un acto mecánico, dado que es, sobre todo y en todos los sentidos, sólo un 'acto crítico' capaz de establecer la relación entre los valores que aún ofrece la obra. Y para encontrar estos valores hay que saber buscarlos (y ahí está el acto de filología); no es necesario inventarlos, recrearlos o modificarlos (y ahí está nuestra intervención, nuestro 'mantenimiento'). ${ }^{126}$

Todos estos cambios y nuevos criterios han venido acompañados de una importante discusión a lo largo del siglo XX, según la base del valor estético e histórico de la obra

\footnotetext{
124 Ibídem. p.49.

125 lbídem.

Thánatos, bíos y heros, términos definidos en la pagina 106.

126 BALDINI, ob. cit. p.56.
} 
en su conjunto, ya que los criterios fundamentales se sustentan en devolver a la obra su legitimidad e integridad. Por ello, las intervenciones tienen que seguir principios y criterios éticos fundamentales, que de forma breve se podrían resumir: respeto por todos los valores documentales, lucha contra reintegraciones hipotéticas, impedimento de intervenciones que rompan la unidad de la obra, realización de un buen diagnostico previo y de un informe completo, y garantía de que el conservador/ restaurador es responsable y conocedor de sus capacidades y limitaciones.

Habiendo sido referida la evolución en la disciplina de conservación/restauración y presentadas las definiciones más importantes, es del todo interesante cerrar este tema con la exposición de las definiciones presentadas en la $\mathrm{XV}^{\mathrm{a}}$ Conferencia Trianual, realizada en Nueva Delhi durante el mes de setiembre de 2008, con el titulo Terminología para definir la conservación del patrimonio cultural tangible, donde se define la conservación como un conjunto de medidas (que comprenden la conservación preventiva, la conservación curativa y la restauración) que tienen el objetivo de asegurar la accesibilidad del patrimonio tangible a generaciones, no sólo del presente, sino también del futuro, en que todas estas medidas y acciones deberán respetar el significado y las propiedades físicas del bien cultural en cuestión ${ }^{127}$. Por otra parte, por restauración se comprenden todas las medidas aplicadas directamente con el objetivo de facilitar la apreciación del bien, así como mejorar su comprensión y su uso. A lo cual es añadido, estas acciones sólo se realizan cuando el bien ha perdido una parte de su significado o función a través de una alteración o un deterioro pasados. Se basan en el respeto del material original. En la mayoría de los casos, estas acciones modifican el aspecto del bien. ${ }^{128}$

Si el arte tradicional de cierta forma creaba diversos puntos de vista según el restaurador que interviniese en ella, el arte contemporáneo es el seno de la controversia, y en este sentido es necesaria la búsqueda de unos principios generales para garantizar la homogeneidad de las intervenciones de restauración. Antes de

127 Documento del ICOM-CC, disponible en la página oficial de E.C.C.O., en http://www.ecco-eu.org/documents/eccodocumentation/index.php

${ }_{128}$ Documento del ICOM-CC, disponible en la página oficial de E.C.C.O., en http://www.ecco-eu.org/documents/eccodocumentation/index.php. 
llevar a cabo una intervención es necesario comprender la intención del artista y hacer un análisis cuidadoso e interdisciplinario entre conservadores/restauradores, críticos, historiadores, artistas, químicos, etc., y encontrar en el seno del debate la mejor forma de intervenir la obra. Hoy el conservador/restaurador alarga su campo de acción con el fin de acompañar las exigencias y características de las obras, y para ello tendrá que contactar directamente con el mundo de la creación.

Es cierto que desde el punto de vista científico y tecnológico, la conservación del arte contemporáneo exige conocimiento y calidad de la intervención, que no puede consistir únicamente en la experiencia acumulada con la conservación/restauración del arte antiguo. Son varios los medios para alcanzar las informaciones suficientes sobre cada obra, sabiendo desde luego que la química puede traer grandes contribuciones a la conservación/restauración, pero conscientes que,

Para ejercitar el buen juicio, el restaurador tiene que ser capaz de pensar como un maestro de otro tiempo; aquí la ciencia no sirve de nada, pues no puede identificar y mucho menos analizar valores estéticos. ${ }^{129}$

Se ha presentado en esta breve reseña sobre la evolución de la disciplina de la conservación y restauración, que antes de que el conservador/restaurador fuera considerado un profesional de calidad, era el artista quien desarrollaba tal actividad. Hoy existe la consciencia que tendrá de ser una actividad desarrollada únicamente por personal especializado, pero el hecho de que sea una ciencia, no implica la transformación de la figura del conservador/restaurador en un científico. La conservación/restauración es mucho más amplia que el área que queda contenida entre las cuatro paredes de un laboratorio. No se pide la formación artística del conservador/restaurador con el miedo de que este caiga en la duda de los límites de actuación, pero es fundamental que domine el leguaje empleado en las obras en el cual pretende intervenir, pues no será necesario enfrentarse a algunos aspectos como directamente arguyen James Beck y Michael Daley.

A buen seguro como reacción a los excesos de épocas pasadas, ahora la ciencia, más que la estética, fija la tarea de los restauradores, al menos en museos y galerías, así como entre

${ }^{129}$ BECK, James y DALEY, Michael: La restauración de obras de arte: Negocio, cultura, controversia y escándalo, p.142. 
los profesionales que trabajan para ellos. El guardapolvo blanco ha sustituido al blusón del artista, y hoy en día los conocimientos de química son más importantes que la formación artística. El hecho de que los restauradores estén supeditados a los análisis del material reduce su capacidad de abordar las pinturas como obras de arte. La restauración se ha convertido en una investigación casi científica cuyo resultado final no puede predecir. Lo que aflore a la postre tendrá que ser aceptado como un descubrimiento, aunque sea ilógico desde el punto de vista artístico y a los ojos del artista e incluso de personas con sentido común pueda parecer que la pintura ha resultado dañada. ${ }^{130}$

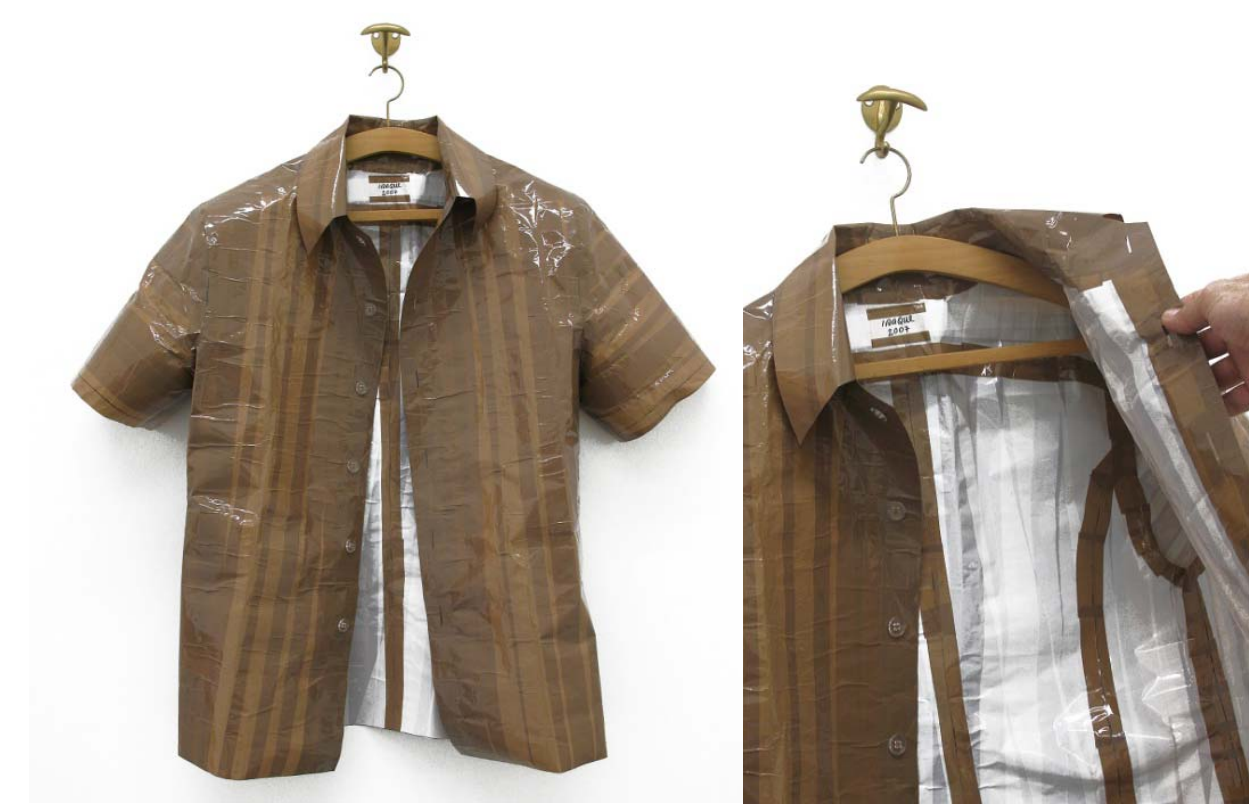

Figura 36: Isaque Pinheiro, instalación S/Titulo, 2007. Fita adesiva, 60x70×20cm. Figura 37: Isaque Pinheiro, detalle de S/Titulo.

Es necesario crear una nueva metodología para esta práctica, tanto histórica como críticamente controlada. Materiales con defectos intrínsecos, condiciones ambientales no adaptables, manipulación no atenta o no controlada, producción de alteraciones 0 daños en las obras, son aspectos constantes para la operatividad de la conservación/restauración del arte contemporáneo.

En este sentido y en respuesta a las necesidades de la conservación/restauración frente al arte contemporáneo, varios son los organismos y entidades que desarrollan

130 BECK, James y DALEY, Michael. La restauración de obras de arte: Negocio, cultura, controversia y escándalo, p.143144. 
una densa investigación con el objetivo de establecer criterios de actuación. Así actúa el INCCA, The Internacional Network for the Conservation of Contemporary Art, una red de profesionales relacionados con la conservación del arte moderno y contemporáneo, que nace en 1999 con el objetivo de crear una base de datos sobre los artistas y las obras. Ante estos objetivos, durante tres años (2004-07), fue desarrollado el proyecto Inside Installation. Preservation and Presentation of Installation Art, en el cual participaron un diversificado conjunto de organismos e instituciones de varios países. Con base en las complejas cuestiones de mantenimiento de las instalaciones, fue realizada la investigación y el estudio de varias instalaciones, con la intención a agrupar la información necesaria para posteriores intervenciones y de aportar datos fundamentales para la toma de decisiones en una práctica poco estudiada, además de la realización de conferencias, seminarios y workshops sobre el tema. Una investigación dividida en diversas secciones y recursos, ofreciendo un abanico de información, como: 1) participación del artista, con principal objetivo de recompilar información sobre el trabajo, los métodos, los materiales, etc., a través de la realización de entrevistas; 2) teoría y ética, donde están incluidos una serie de artículos, directrices, cuestiones teóricas y modelos de actuación, y al cual está asociado el proceso de toma de decisiones (a través del Modelo de toma de decisiones, es creada una base de datos sobre distintas fases: registro de los datos; condición; significado; discrepancia; opciones de conservación; consideración; propuesta de tratamiento, de forma a desarrollar el intercambio de información y planteando soluciones para posibles problemas de conservación); 3) preservación, una sección que incluye artículos sobre la problemática de conservación, y donde se presentan algunas directrices prácticas para la concretización de planos de conservación; 4) documentación, la sección que incluye una serie de información y directrices para la realización de una documentación eficaz y los conocimientos y métodos necesarios y útiles para la creación del archivo; 5) materiales, que es una sección dedicada a artículos sobre materiales empleados en el arte moderno y contemporáneo, además de aportar información sobre su conservación y tratamiento; 6) cuestión jurídica, al cual están asociados artículos sobre derecho de autor y derechos morales implicados en la conservación del arte. Además de toda esta información disponible en internet, 
INCCA pone a la disposición un glosario y vasta literatura, que acompañan la complejidad de la actividad.

Está demostrado que el camino del arte contemporáneo es ambiguo, y la necesidad de agrupar lo máximo de información sobre obras y artistas contemporáneos, a través de investigaciones, entrevistas, etc., es uno de los objetivos principales en todas las instituciones y organismo poseedores de obras de arte contemporáneo. Como tal, la necesidad de concretizar criterios de intervención justifica la organización de eventos, congresos, jornadas etc., que no se reduzcan a la simple presentación de ejemplos de intervención y prácticas conservativas. Los congresos de conservación/restauración tendrán que ser el medio más eficaz y dominante para profundizar los estudios teóricos. Es desde luego importante la divulgación del trabajo desarrollado en las distintas áreas de investigación, pero es imprescindible una base teórica consolidada y que justifica por sí misma la buena intervención.

Pero, ¿Cómo se defienden tales criterios de conservación/restauración del arte contemporáneo?, o planteando el tema de otra forma, ¿el arte contemporáneo compromete la cuestión técnica y teórica de la conservación/restauración? 


\title{
1.2. La Teoría del restauro en el contexto del arte contemporáneo. ${ }^{131}$
}

\begin{abstract}
Si discute sull'opportunitá e sulla legittimità de un intervento che modifichi la catterizzazione materiche o sostituica parti degradate di un'opera contemporanea, anche se il fine è quello nobile della conservazione e del mantenimento del suo significato. Si teorizza l'ineluttabilità del degrado dei materiali costitutivi, tanto più per l'arte contemporaneo, che spesso nei suoi protagonisti non considera la durata come una qualificazione essenziale dell'opera, imponendo dunque la necessità esclusiva di una conservazione preventiva, quando e fino a quando possa essere efficace. Nel caso di opere di artisti vivanti, la discussione se debba l'autore essere o no il legittimo restauratore della sua stessa opera è ancora aperta e ecssa su posizzione contrastanti e irreducibili. Si insiste sulla specificità del restauro del contemporaneo al punto di sostense la necessità di una preparazione diversa per la qualificazione professionale del restauratore più adatto. ${ }^{132}$
\end{abstract}

Se parte del principio que son bien conocidas las características generales de las obras de arte contemporáneo, sin embargo, aún suscitan varios puntos de discusión, levantando cuestiones y dudas en la práctica de la conservación/restauración. E hecho de que la forma de intervenir de los pintores antiguos fuera completamente distinta de la actividad artística contemporánea no es por sí sólo el motivo de replantear la actividad del conservador/restaurador, pero es la primera señal de mutación, lo que no implica la eliminación o la exclusión de todos los valores teóricos

131 Parte del presente capítulo fue publicado anteriormente en el artículo La teoría en la práctica de la conservación/restauración el arte contemporáneo. en Conservación de Arte Contemporáneo, ga Jornada. Madrid: Museo Nacional Centro de Arte Reina Sofía/Grupo Español IIC, 2008, pp.209-218.

132 CORDARO, Michele. L'eterogeneità dell'arte contemporanea. en AA. VV. Arte contemporanea. Conservazione e restuaro. p.63.

T.A.: Se discute sobre la oportunidad y sobre la legitimidad de una intervención que modifique la caracterización matérica o sustituya partes degradadas de una obra contemporánea, aunque el noble fin sea el de la conservación y del mantenimiento de su significado. Se teoriza sobre la inevitable degradación de los materiales constitutivos, tanto más para el arte contemporáneo, cuyos protagonistas no consideran la duración como una calificación esencial de la obra, imponiendo por lo tanto la necesidad exclusiva de una conservación preventiva, cuando y hasta cuando pueda ser eficaz. En el caso de obras de artistas vivos, la discusión sobre si debe ser o no el autor el restaurador de su propia obra aún está abierta y encendida sobre posiciones contratantes e irreducibles. Se insiste sobre la especialidad del restaurador del arte contemporáneo hasta el punto de sostenerse la necesidad de una preparación diversa para la calificación profesional del restaurador más apto. 
en los que la conservación/restauración se mueve y desarrolla. El conservador/restaurador puede verse confrontado con distintas dificultades ante texturas irregulares, falta de protección, pulverulencia de la materia, superficies monocromáticas, opacas, de color plano, composiciones compuestas de materiales heterogéneos entre sí, o incluso la presencia de materiales degradados y cambios constantes. No es sorprendente decir que materiales nuevos traen consigo problemas nuevos, reconociendo que la evolución histórico-social ha comportado grandes influencias en el mundo artístico. Los nuevos materiales presentan diferentes parámetros de estabilidad y durabilidad en el tiempo y dominar y comprender el comportamiento de los distintos materiales industriales, de estructuras complejas y diversos componentes, implica reconocer características como elasticidad, envejecimiento, durabilidad, resistencia, etc. Que los materiales cambien con el tiempo, no es un concepto introducido en el siglo XX, pero que los materiales se deterioren en cortos periodos de tiempo hasta perder su función, es una realidad introducida por el arte moderno y contemporáneo.

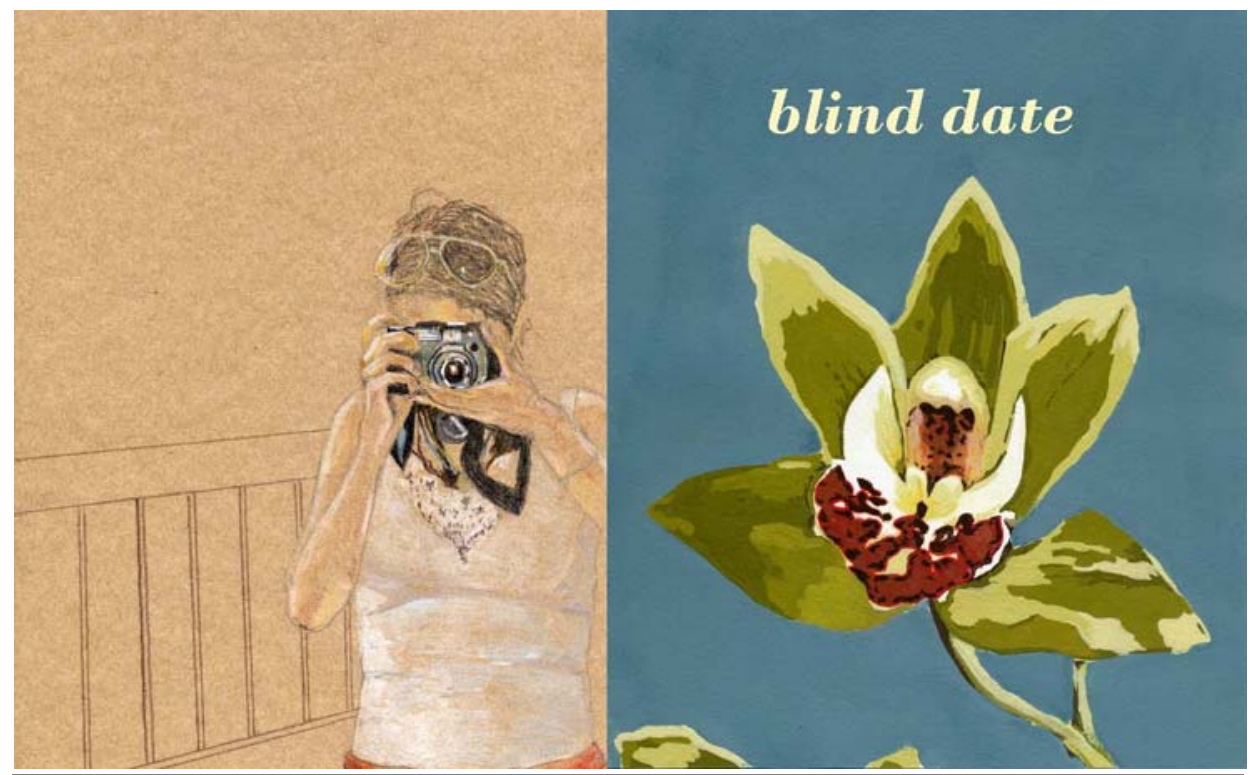

Figura 38: Ana Cardoso, Blind date, 2008. Lápiz y guache sobre cartón, 29,7x 42cm. 
Es, por tanto, desde luego aceptable hablar de craquelados, agujeros, cambios de color, quemaduras, manchas, etc., como elementos constitutivos de las obras contemporáneas y no considerar que esas características son inmediatamente señales específicas de alteración de la materia, u obligatoriamente fenómenos resultantes del deterioro no deseado. En la práctica, ¿cuáles son las consecuencias presentadas por estos elementos? La respuesta es muchas veces ambigua, pero no debe quedar sin tratarse. Concretamente son elementos constitutivos de la obra, por lo cual no tendrá sentido eliminarlos, puesto que pretenden y componen el lenguaje artístico dentro de una dimensión abstracta. Con el arte tradicional el deterioro implicaba desde luego una pérdida de calidad estética para la obra, pero en las obras en que uno de los elementos estéticos es la propia alteración de los materiales y las características que resultan de su transformación, tal elemento no puede ser eliminado, es irreversible y nunca podrá ser considerado como pérdida de calidad estética. Por ello, está desde luego condicionada la intervención de conservación/restauración, al estar en presencia de obras en que uno de los elementos estéticos es la propia alteración de los materiales y las características que resultan de su transformación. Operaciones habituales como la limpieza o la reintegración pueden ser más complejas de lo imaginado, o incluso se vuelven cuestiones problemáticas, teniendo en cuenta la legitimidad de tales intervenciones en determinadas obras, en las que el único impulso legítimo será conservar la estructura de la obra sin que llegue a un límite indeseado de descomposición o deterioro. La verdad, es que hablar de restauración del arte contemporáneo remite inmediatamente a la colaboración de la disciplina de conservación, en el sentido de prevenir y evitar que la presencia de problemas técnicos frene el disfrute y la correcta lectura de la obra.

De forma contradictoria el arte contemporáneo no vive bajo el ideal de eterna juventud, y conservar y restaurar una obra de esta índole implica penetrar en las cuestiones subordinadas a la materia no olvidando la verdadera importancia de su poética. Tal como las obras del pasado, también las creaciones contemporáneas son creadas para cumplir una función, con la intención de ser 'utilizadas'. No sería lógico, que con una primera mirada fuera hecha una evaluación del estado de conservación 
de la obra, pues la degradación física y química en determinadas obras no es sinónimo de detención obligatoria de tal mutación formal.

La rebelión contra la decadencia es la razón de ser de la restauración. La no-adaptación a esta realidad podría significar seguir trabajando con las viejas normas y violar la propia época con esquemas del pasado. Cada nuevo esfuerzo de adaptación es un reconocimiento de esta realidad. Repitámoslo de nuevo: la obra de arte determina los métodos de conservación, y esto también es válido para la restauración de aquel que rehúsa la conservación ${ }^{133}$

Ante todos estos cambios, ¿Qué papel desempeña la Teoría de la Restauración? No cabe duda de que los principios actuales de la actividad de conservación/restauración de los bienes culturales coinciden con los establecidos por Cesari Brandi, como será demostrado con un breve análisis teórico, citando:

[...] cualquier intervención al respecto será en cada caso la única legítima e imperativa; la que ha de explicarse sólo con la más amplia gama de ayudas científicas; y la principal, si no la única, que verdaderamente la obra de arte consienta y requiere en orden a su subsistencia como imagen fija e irrepetible. ${ }^{134}$

Cesari Brandi además de su distinguida trayectoria desarrollada sobre la Historia del Arte italiana, es el autor de la más elaborada teoría para la restauración, destacando su actividad en este ámbito con la creación y dirección del Istituto Centrale del Restauro. Una de las innovaciones y también polémicas, que propuso con su teoría fue acrecentar al valor histórico y documental el valor artístico. Con la intención de crear una actividad homogeneizada, estructura su teoría entre la restauración y la crítica del arte, reconociendo el significado y la función de la crítica del arte como juicio que explicita la calificación formal de la obra de arte ${ }^{135}$, y define la actividad como restauración crítica. Su fundamento teórico de la restauración busca dejar de lado el empirismo y su debate se basa en la polaridad de la restauración artística: si por un lado, está la restauración resultado del deseo de mantener la obra tal como está; por otro, se encuentra la restauración como forma de reintegrar la imagen damnificada.

En la Teoría de la Restauración, Brandi busca solucionar varias cuestiones y problemas y para ello presenta su definición y comprensión de la instancia estética y

\footnotetext{
${ }^{133}$ ALTHÖFER, Heinz. Restauración de pintura contemporánea. Tendencias, materiales, técnicas, p.11.

134 BRANDI, Cesari. Teoría de la Restauración. p.16.

135 GONZÁLES- VARAS, Ignacio. Conservación de bienes culturales. Teoría, historia, principios y normas, p.271.
} 
de la instancia histórica como dos conceptos subordinados al producto artístico y que por sí definen la acción de restauración. De esta forma la instancia estética será lo que constituye la esencia de la obra, la calidad específica que le corresponde por el hecho de ser la base de la «artisticidad»136, al cual Brandi asocia en concreto lo que define como momento metodológico de reconocimiento ${ }^{137}$, y que a su vez, está determinado por un tiempo y un lugar de realización, además del tiempo y espacio de lo que es su conciencia en el presente, o sea, la obra de arte posee una doble historicidad, constituyendo lo que se entiende por instancia histórica.

Brandi clarifica el papel desarrollado por la temporalidad, acreditando que la restauración sólo tiene sentido cuando encuentra su punto en el transcurso del tiempo, dado que en la vida de una obra existen distintos momentos: el primero, que pertenece al tiempo de realización de la obra, al cual la restauración no podrá pertenecer, con la intención de evitar que se confunda con la recreación de la obra, dejando atrás transformaciones parciales e injustificadas; el segundo tiempo, consiste en el puente temporal que va desde la conclusión de la obra hasta la visión 'actualizada' de la misma, o sea, es en este tiempo que se da el reconocimiento de la obra, en que durante un determinado espacio temporal se reconoce la obra y se adquiere una visión concreta de la misma, en su bipolaridad y artisticidad, en el presente. Tampoco es a este tiempo que pertenece la restauración, dado que eso implicaría una intervención estilística ocultando el paso del tiempo con el objetivo de alcanzar el supuesto estado original. Un tercer tiempo, que corresponde al momento en que la obra de arte está en la conciencia humana, y que será el tiempo en el que la restauración se inserta correctamente, coincidiendo con el presente tanto para el observador como para la historia.

\footnotetext{
136 GONZÁLES- VARAS, ob. cit. p.273.

137 Al alrededor de los conceptos: momento metodológico de reconocimiento, existe una discusión permanente. Entenderlos pasa por la comprensión y reconocimiento de la obra en si misma, además de la distinción de los tres tiempos en la vida de una obra de arte. Originalmente Brandi define restauración como: il restauro costituisce il momento metodologico del riconoscimento dell'opera d'arte, nella sua consistenza fisica e nella sua duplice polarità estetica e storica, in vista della sua trasmissione al futuro* o sea, restauración solo tiene sentido como desarrollo de una metodología critica, después del momento de reconocimiento de la obra de arte como tal, y que ese momento está determinado por factores intrínsecos, que la caracterizan según las instancias estética y histórica, determinado por el momento exacto de consciencialización social, al cual quedará asociado con exactitud el momento para la restauración.

*BRANDI, Cesari. Teoria del restauro, p.34.
} 
Con el mismo sentido, Umberto Baldini habla de thánatos, bios y heros como los tres estados de las obras de arte, citando:

Durante su vida la obra de arte puede encontrarse en tres estados: el de la "destrucción" (thánatos), que puede producirse por una falta de acción por parte nuestra (descuido y abandono que llevan a la degradación), o por un acontecimiento externo violento y traumático (terremoto, guerra, caída, incendio, etc.); el de la prolongación de su "vida" (bios), que resulta del acto físico del cuidado material de la obra para protegerla de los daños y las pérdidas (mantenimiento y conservación); y el de la "restitución" de su realidad como obra de arte (heros) que se manifiesta en el acto final de filología crítica (acto de restauración). ${ }^{138}$

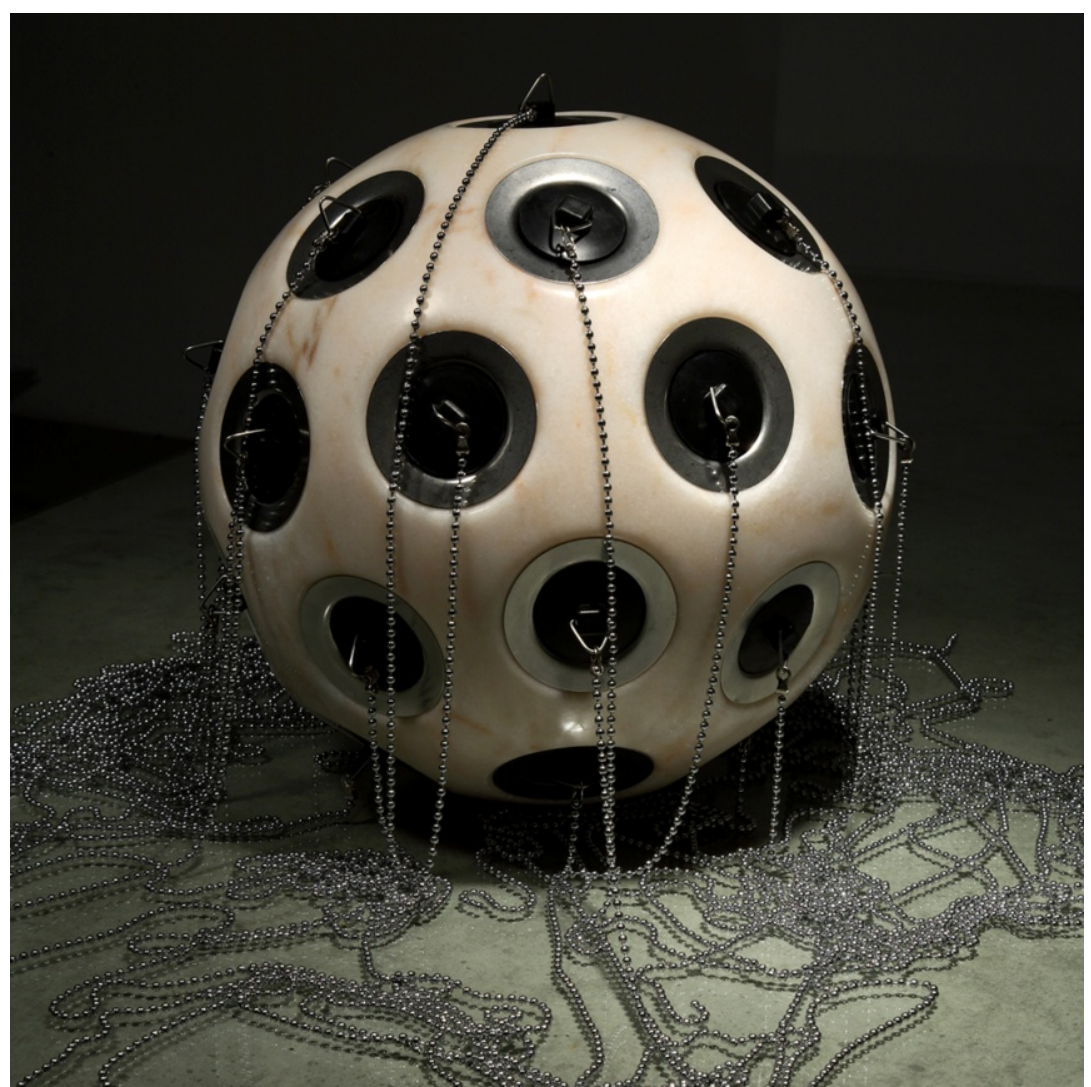

Figura 39: Isaque Pinheiro, escultura Planeta Piercing \#2, 2006. Mármol, inox y goma, 32×32×32cm.

Todavía en el transcurso del tiempo y con base en la instancia histórica, Brandi habla de elementos añadidos que son todos aquellos elementos que surgen desde la conclusión de la obra hasta el estado actual de la misma, resultantes de alteraciones

${ }^{138}$ BALDINI, Umberto. Teoría de la restauración y unidad de metodología. Vol.1, p.7. 
naturales o de intervenciones del hombre y que la restauración no deberá anular obligatoriamente u ocultar. Si por un lado los elementos añadidos son de igual modo testimonios del quehacer humano, con su importancia histórica y con el mismo derecho a ser conservados; por otro lado, están las reconstrucciones que intentan pertenecer al proceso creativo de forma que no exista distinción entre ellas y el original, ocultando el intervalo de tiempo que va de la conclusión de la obra hasta el presente. En todo caso, todos estos conceptos tienen que encajar con la instancia estética en la que los elementos añadidos considerados testimonios históricos no siempre serán mantenidos, si no respetaren la unidad de la obra y su instancia estética, así como las reconstrucciones, que siguen las mismas exigencias de eliminación, siempre y cuando hayan tenido el objetivo de crear una nueva unidad artística.

Hasta aquí ninguno de los conceptos de Brandi entra en conflicto con la ideología y propuestas del arte contemporáneo, por el contrario, ayudan a establecer criterios y límites si es necesaria una intervención.

Continuando con la definición que Brandi presenta de la restauración como el momento metodológico del reconocimiento de la obra de arte, en su consistencia física y en su doble polaridad estética e histórica, en orden a su transmisión al futuro ${ }^{139}$, es también del todo pertinente para la restauración del arte contemporáneo, si se admite que, el arte contemporáneo está pensado y estructurado para ser transmitido al futuro, en determinada concretización física. Brandi termina de hablar del concepto de restauración, presentando lo que considera el segundo principio de la restauración:

La restauración debe dirigirse al restablecimiento de la unidad potencial de la obra de arte, siempre que esto sea posible sin cometer una falsificación artística 0 una falsificación histórica y sin borrar huella alguna del transcurso de la obra de arte a través del tiempo. ${ }^{140}$

Si no son éstas las condiciones, entonces ni siquiera se podrá hablar de restauración, sino de aproximación para el recuerdo, a través de una documentación del evento, puesto que

139 BRANDI, ob. cit. p.15.

140 Ibídem. p.17. 
La documentación adquiere un significado nuevo en la conservación; de hecho, sólo la programación hace posible la conservación de la obra de arte para la posteridad. Lo último que pervive es el «mensaje» del artista. El arte contemporáneo evidencia el fenómeno del arte como nunca hasta ahora; muestra lo que el arte es. Ya no hay referencia a la materia. No hay reglas fijas, sólo puntos de vista y líneas de orientación a la hora de afrontar cada caso específico. ${ }^{141}$

Restauración es primeramente la reconstrucción del texto autentico de la obra, la idea, y en segundo lugar la intervención sobre lo que compone la obra, la materia. Para ello, a la conocida definición, Brandi asocia dos cuestiones metodológicas importantes: por un lado, lo que constituye la materia de la obra de arte, el aspecto y la estructura; y por otro lado, el restablecimiento de la unidad potencial de la obra de arte. La restauración, como acto crítico, está destinada a la materia de la obra, que a su vez es imagen, y a sus materiales constitutivos, en los que Brandi resume que se restaura sólo la materia de la obra de arte. Concretamente, este axioma supone que no se debe intervenir sobre el significado de la obra, en el que la materia está subordinada a una imagen, y el elevado valor de la imagen no supone el mismo grado de valoración de la materia. Y para clarificar esta idea, Brandi divide la materia artística en aspecto y estructura, justificando que la materia podrá ser substituible cuando es estructura, siempre y cuando ésta no interfiera con el aspecto. Pero la substitución nunca podrá ser llevada a cabo cuando sea aspecto en la medida que interferirá directamente con la imagen.

Con el segundo axioma que corresponde a la unidad potencial de la obra, Brandi defiende que el restablecimiento de la unidad de la obra debe ser ponderado segundo las instancias histórica y estética, en el que los fragmentos juegan un papel en el todo, trazando los límites de intervención de manera a no crear un falso histórico y/o artístico. Y será posteriormente preocupación de la conservación/restauración, siempre que sea necesario, interpretar la obra sin distorsionar su mensaje, que por sí sólo es indivisible, y que a través de su total percepción sea posible salvaguardar la potencialidad material de la obra. Si hay casos en los que las obras exigen una manutención constante porque el objetivo es que coexistan los objetos tal como han sido creados (y aquí no hay diferencia con las obras de arte tradicional, teniendo en cuenta la intención del artista), ante esta información, el conservador/restaurador

${ }^{141}$ ALTHÖFER, Heinz. Restauración de pintura contemporánea. Tendencias, materiales, técnicas, p.12. 
podrá seguir una metodología idéntica a la que desarrolla para la conservación/restauración del arte tradicional, donde por lo menos sabe que a través de la mínima intervención actuará para que el objeto perdure el mayor tiempo posible. Cabe considerar que existen obras en un punto opuesto de la intencionalidad artística, como aquellas en las que hay trazado un ciclo mutante de deterioro material; en estos casos el conservador/restaurador podrá tomar dos caminos de acuerdo con lo definido por la obra y la intención del artista en ella presente. El primero, que parece radical pero que es coherente con la intención artística y la instancia estética de la obra, consiste en dejar "morir" la materia, llegando la obra a su auge conceptual; y el segundo camino, en el cual el conservador/restaurador podrá realizar pequeñas intervenciones, como la sustitución de piezas, con previo aviso y autorización del artista, donde la obra está en constante mutación pero permanecerá a través de la manutención de su materia. En concreto y de forma genérica, el primer caso agrupa las obras que encajan en las características de las obras tradicionales; en el segundo y tercer casos, se encuentran las obras que viven bajo la presencia de lo efímero y de la mutación, jugando intencionalidades distintas: a) lo efímero premeditado; b) lo efímero que surge del deterioro no deseado de los materiales. En los tres casos la conservación/restauración hará un análisis profundo de la idea que en cada obra figure, sin que entre en la arbitrariedad y ambigüedad. Con todo, existe la posibilidad de que en algunas obras no sea rehabilitada al cien por cien su idea, por falta de información y datos que no han sido conseguidos a través del artista o su entorno, y en estos casos la obra permanecerá válida por su valor como documento histórico.

Para la práctica de la restauración, se tendrá que hablar brevemente de algunos conceptos como la reintegración o la sustitución de piezas. No cabe duda que el arte contemporáneo es un conjunto de manifestaciones tan heterogéneas y diversas que lleva directamente a una variedad infinita de intervenciones. De tal forma, la reintegración puede ser también una cuestión problemática a la hora de solucionar cuestiones técnicas que influyen en la lectura de la obra. Por sí solo, es un tema que conlleva un largo abanico de hipótesis, no siendo posible definirlo en pocas páginas, puesto que podrían ser muchos los casos prácticos que pongan en juego la cuestión de reintegración, como las conocidas pinturas monocromáticas, los materiales 
extremadamente deteriorados, las mezclas de materiales, etc. Todavía, también con el arte contemporáneo se puede desarrollar distintos procesos de reintegración y los métodos pueden seguir los mismos parámetros defendidos para el arte tradicional siempre que sea posible su utilización, demostrando que también este concepto podrá ser válido en la práctica artística contemporánea en la media que se respeta la obra en sus instancias. Como tal su utilización se basa en tres principios básicos: el primero, consiste en que la reintegración sea invisible a la distancia adecuada para la correcta observación de la obra, pero que sea inmediatamente reconocible a una distancia menor; el segundo, que dice respecto a la materia que sólo es insustituible si ésta interfiere directamente en la imagen; y el tercer principio dice respecto al futuro de la obra que supone que cualquier intervención no torne imposible futuras intervención. Si la disciplina de la conservación/restauración en el arte tradicional insistió con determinación en las cuestiones de reintegración de las lagunas de forma a tener una identificación de fácil diferenciación y reconocimiento, con algunas obras del arte contemporáneo este requisito puede proporcionar determinadas oposiciones, como en presencia de obras monocromáticas, entre otras. En general, la cuestión de la reintegración está subordinada a la autenticidad de la obra, y se defiende que ésta está protegida siempre que se realiza una reintegración diferenciada, pero lo cierto es que en muchos casos de obras de arte contemporáneo, esto sería una crueldad para la realidad formal de la creación además de destrozar parte o la totalidad del concepto de la obra. Y no será necesario hacer un esfuerzo demasiado grande para imaginar una pintura monocromática con una reintegración diferenciada. Si por un lado, se está en presencia de la autenticidad material; por otro, se olvida la instancia estética, que es lo que caracteriza y determina un objeto de bien artístico. En este caso, hay que buscar en la teoría una respuesta práctica, en la cual se podrá encontrar para algunas situaciones una eficaz solución con la reintegración mimética, pero siendo conscientes que no será siempre un recurso plausible de acuerdo con las características formales, matéricas y estéticas de la creación puesto que también la reintegración mimética podrá tornarse en ciertas circunstancias visualmente inaceptable, por lo que habría que buscar otro tipo de solución. En este sentido, la expresión: cada caso es un caso, es la evidencia de una manifestación llevada al límite. En el caso de las pinturas antiguas, es sabido que en presencia de faltantes en 
zonas importantes en términos de iconografía (como rostros, manos, etc.) que la reintegración mimética no se debe llevar a cabo, por falta de información y resultando únicamente en la creación de un falso, la obra monocromática no presenta tal cuestionamiento. Subordinada a estas cuestiones, no es fácil encontrar una solución, mucho menos general, puesto que se pueden seguir distintos caminos: a) mantener la obra con la laguna si ésta no interfiere en demasía en la lectura de la obra; b) reintegrar la laguna si hay posibilidad; c) crear una copia de la obra (una vez que la obra original ya no desempeña su función y no presenta la posibilidad de intervención); d) repintar la obra.

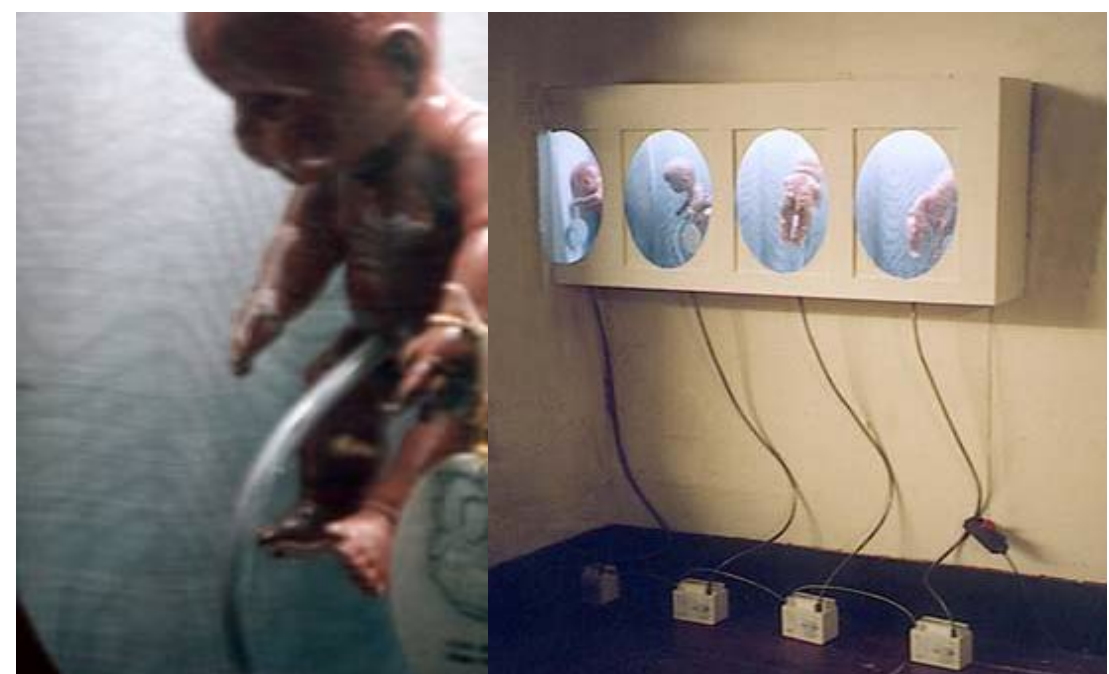

Figuras 40 y 41: Rui Pedro Fonseca, detalle e instalación Serie X, 2002. Caja de luz con varios materiales, $82 \times 140 \times 30 \mathrm{~cm}$.

Otro aspecto que se resalta en la conservación y mantenimiento del arte contemporáneo es la reparación y sustitución de parte o la totalidad de la obra, como puede acontecer en varias obras compuestas por mecanismos, componentes electrónicos, materiales perecederos en los que el material simplemente es el medio para llegar a la concretización de la obra. Este hecho ha llevado a los conservadores/restauradores a concretar algunos aspectos éticos de su profesión, como el total respeto al material original, haciendo prevalecer el criterio del respeto sustancial de la intención del autor y del significado de la obra. También en la Teoría 
de la Restauración, se pueden encontrar los fundamentos que justifican estos procedimientos como legítimos:

[...] la materia de que resulta la imagen, la cual es insustituible únicamente donde colabore directamente a la figuración de la imagen, es decir, en cuanto es aspecto, pero no en tanto es estructura. ${ }^{142}$

Si en realidad la imagen importa por la forma que ha recibido la materia, y si ésta no es más que el vehículo de la imagen, es claro que lo que será indispensable conservar de la materia que se ha convertido en imagen consistirá en aquello que directamente determina el aspecto, mientras todo lo que constituye la estructura interna o el soporte podrá ser sustituido. ${ }^{143}$

Es cierto que este fundamento presentado por Brandi -que justifica ciertas actitudes hacia la obra- es válido siempre y cuando la obra así lo determine, pero con algunas obras de arte contemporáneo no es legítimo tal comportamiento, si ésta tiene como finalidad todo un proceso de deterioro o si no es la intención del autor. Pero, tal como acontece en otras obras y también en algunas de las obras del arte tradicional, lo que tiene que prevalecer es la idea que supuestamente envuelve una obra. Es tan válida la sustitución de piezas, cuando la materia está subordinada al contenido, como el reconocimiento de obras pre-fabricadas o totalmente elaboradas por terceros, como obras de arte. La cuestión fundamental está en la comprensión de los conceptos estructura y aspecto, que Brandi define tan claramente, y que según tal base teórica no hay por qué ir más allá de la intencionalidad de la obra.

Para finalizar cabrá preguntarse, ¿cuál es el papel que juega la Teoría de la Restauración en la conservación/restauración del arte contemporáneo?, ¿después de este análisis, hay algo de erróneo, en la aplicación de la Teoría de Brandi en las creaciones contemporáneas?

La Teoría habla por sí misma, e injusto sería afirmar que la Teoría de la Restauración ya no da las respuestas necesarias para la conservación/restauración de las creaciones contemporáneas, cuando desde luego es asumida como un acto crítico, esencial para el reconocimiento e interpretación de las creaciones heterogéneas. En la Teoría, sobresale la instancia estética, hecho imprescindible para una correcta

142 BRANDI, ob. cit.p. 26 .

143 Ibídem. p.84. 
aproximación e interpretación del arte contemporáneo, donde sus creaciones resultan de una valorización conceptual y en las que la imagen tiene un valor ilimitado; 0 cuando se defiende la importancia de la obra en sus diferentes tiempos de existencia. Cuestiones fundamentales a tener en cuenta, cuando en la actualidad se vive a la sombra de lo fácil que es recrear, completar y reinterpretar una obra y además conscientes de que en una última hipótesis se trata de un arte que mayoritariamente sobrevive bajo la fría denominación de mercancía. Ante la contradictoria producción contemporánea, que supuestamente debería mantener su aspecto de lo acabado de hacer, existe la necesidad de subrayar que también en estas creaciones es fundamental el paso de tiempo, y si este paso deja huellas más profundas e indestructibles en la obra, éste es un hecho que pertenece a la instancia histórica de la misma, y utilizando una vez más las palabras de Brandi,

Ni un conservador, ni un restaurador puede pretender tanto, precisamente porque es una pretensión, y una pretensión indemostrable, la de poder volver a un supuesto aspecto originario cuyo único testimonio válido sería la obra en un momento en que fue acabada, 0 sea, sin el paso del tiempo; es decir, un absurdo histórico. ${ }^{144}$

Para el arte contemporáneo, el análisis de la estructura/aspecto de la obra se hace necesariamente más exigente y fundamental, en comparación con las obras de otras épocas. No sólo se lleva a cabo para guiar las intervenciones de conservación y restauración, sino también para facilitar la lectura de la obra, aspecto éste esencial para su buena interpretación; y como tal, el resultado será una buena intervención ${ }^{145}$. El reconocimiento de los componentes y de la técnica, puede clarificar y ayudar a entender las intenciones de los artistas y la infinita variedad de lenguajes, mutantes y personales, en tiempos de anarquía técnica.

En resumen, lo que Brandi defiende íntegramente es la obra. Y, así, es evidente que la intención se sujetará a las exigencias por ella presentadas, tal como expone igualmente Heinz Althöfer:

\footnotetext{
144 BRANDI, ob. cit. p.101.

Citación en que Brandi hace referencia a las limpiezas integrales.

${ }^{145}$ ALTHÖFER, ob. cit. p.12.
} 
El original es el documento más importante, no la interpretación, ni la documentación secundaria. La misma obra de arte determina cómo debe ser observada y cuál debe ser el tratamiento. $Y$ otra cosa: el arte mismo crea problemas y define la correspondiente restauración. Pero nada se resuelve para siempre. ${ }^{146}$

Seguramente, desde el punto de vista científico y tecnológico, la conservación/restauración del arte contemporáneo exige conocimiento y calidad de intervención, que no puede consistir únicamente en la experiencia tenida con la conservación/restauración del arte antiguo. Son varias las cuestiones que resultaron de las creaciones que surgen a partir de los años 60, cuando los artistas se liberan de todas las reglas implantadas en las artes plásticas. Nacen obras que no respetan normas de creación, ejecución, exposición y esencialmente de duración. Sin ironía, el simple concepto de 'duración' de las obras, implica y refleja varios cambios en términos de postura del conservador/restaurador. Desde luego, éste delante de la obra de arte contemporáneo tendrá, antes de cualquier procedimiento de intervención, cuestionar si la obra sufrirá o no cambios, no sólo estructurales sino también conceptuales. La prioridad de la actividad es el respeto por el material, porque cualquier cambio puede implicar la alteración total o parcial del significado de la obra, pero si se parte del principio que todas las obras necesitan intervención tampoco se ha comprendido la estrecha relación entre la materia y el significado. Seguramente varían las técnicas y materiales en la intervención, pero el fundamento de la restauración como acto crítico se sustenta en la indagación y valoración de la estructura formal, es decir, el estudio de cómo ha sido realizada y su intencionalidad en la estrechísima relación con los materiales. No cabe duda que a la obra de arte son atribuidos a distintas escalas valores históricos, culturales y artísticos, testimonios de determinada época y sociedad, atendiendo a las diferentes concepciones y exigencias, de acuerdo con los momentos y los sujetos que actúan en torno a los bienes culturales.

Por ello, el conservador/restaurador tiene que ser analítico y tener la capacidad de distinguir cuáles son las obras que pasarán por un proceso de conservación, y en último caso las que piden un proceso de restauración, puesto que lo que resulta intolerable es el absoluto sacrilegio que supone la intervención restauradora que momifica

\footnotetext{
${ }^{146}$ ALTHÖFER, ob. cit. p.11.
} 
irreversiblemente el arte como un hallazgo arqueológico.147. Cuando se llega a este punto, además de destruir la instancia estética de la obra, se ha creado un objeto con determinado valor histórico que es transmitido al futuro sin sentido, pues solo tiene sentido hablar del restablecimiento de la unidad potencial de la obra siempre y cuando la intervención no sobrepasa sus instancias, histórica y estética, y cuando se transmite la obra en sus trazos temporales. Parece evidente, pero en la práctica no siempre se hace hincapié en la importancia de teorizar la actividad y para cerrar este análisis nada mejor que la premisa: es la propia obra de arte la que condiciona la actividad de la restauración y nunca al revés.

${ }^{147}$ ALTHÖFER, ob. cit. p.12. 


\section{La nueva visión y noción de las creaciones contemporáneas.}

2.1. Lo efímero y la temporalidad de la idea versus materia: sus repercusiones en la conservación/restauración.

Conocedores y artistas recusan como zotes e ignorantes a los que reconducen la obra de arte a sus condiciones exteriores, en nombre de una experiencia intuitiva, incomunicable e intimista, que, según aseguran, constituye la verdad del arte. Cada obra, dicen, es única. Reino de lo particular, el arte excluye toda generalización, sólo admite la monografía, y el juicio caso por caso. Nada se puede explicar, todo se debe interpretar. (...) La obra de arte, dicen, es un artefacto social, y la denegación estetizante de ese condicionamiento social es también un hecho social. ${ }^{148}$

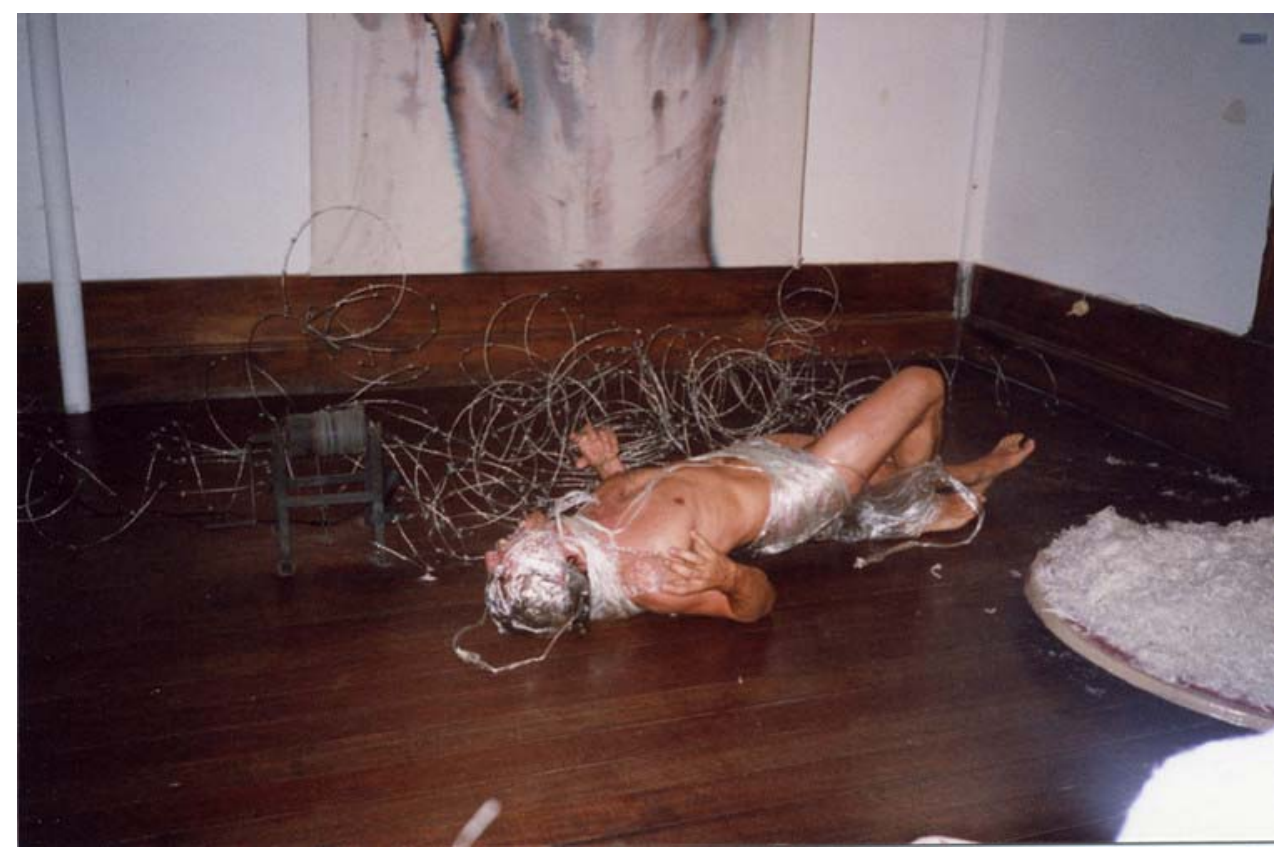

Figura 42: João Pedro Rodrigues, Performace perteneciente al Proyecto Casulo II, realizada en la Galeria Craesbeeck Porto 2003

148 DEBRAY, Régis. Vida y muerte de la imagen. Historia de la mirada en Occidente, pp.108-109. 
La cuestión de la conservación/restauración del arte contemporáneo no puede ser analizada bajo una vieja mentalidad, una conciencia tradicionalista de las formas y técnicas, una postura del pasado. Ante todo, la conservación/restauración tendrá que estar guiada por el acto crítico, debidamente teorizado y justificado y si las creaciones contemporáneas implican el repensar de la teoría hay que ajustar sus conceptos a las nuevas expresiones.

Muchas obras, como algunas instalaciones o las conocidas manifestaciones insertadas en el Land Art, por dar algún ejemplo, se imponen como eventos ligados a un sitio, en que en un futuro solo existirán como registros, y no volverán a ser el mismo evento en la misma situación, por la cual ha sido creado y propuesto. En oposición a esta realidad se plantean distintas cuestiones a las cuales hay necesidad de responder. ¿Cuál es el comportamiento más correcto, tanto del conservador/restaurador, como del curador de los museos e instituciones? ¿Hay coherencia ante la base conceptual de la obra de arte y su motivo de creación, cuando es nuevamente exhibida con base en los escritos del artista, cuando esto es sencillamente fruto de repetición? ¿Y ante las obras constituidas de productos comestibles como aquellas de la corriente Eat Art y otras manifestaciones completamente efímeras, cómo reaccionar?

En muchos casos, tal vez más importante que hablar de restauración de las obras, es pensar en cómo podrán ser transmitidas, en su coherencia material y conceptual, al futuro. Ante estos cambios conceptuales en el panorama artístico, es evidente la necesidad de redefinir los conceptos de conservación y restauración, o mejor, es exigido volver a pensar cómo teóricamente la disciplina de conservación/restauración puede cubrir todas las necesidades que el arte contemporáneo presenta. Algo que surge definitivamente, a partir de los años 60, como consecuencia del cambio en el propio concepto de arte, de su desarrollo, creación y proyección, como repercusión de una evolución industrial, social y cultural como se ha descrito anteriormente. No es preocupación de la conservación/restauración definir lo que es o no es arte, por lo cual esta cuestión no está insertada en el campo de investigación y labor de la actividad del conservador/restaurador; éste únicamente tiene que solucionar las 
cuestiones presentadas por los objetos con determinadas características, que llegan a sus manos, y no cuestionar su validez artística.

La realidad contemporánea transmite sus valores estéticos y artísticos de distintas formas, además de valorar, difundir y dar a conocer las creaciones y acciones, muchas veces sin gran preocupación por la conservación física de las obras; subrayando que el hecho de conservar materialmente tales expresiones puede ir en contra de la propia creación y la intención por la cual existe y fue creada. Sería un error permanecer en una definición generalizada, o en la tentativa de incluir todas las formas y categorías artísticas en uno sólo modo o género de arte. No es redundante decir que la historia del arte contemporáneo no está reducida a las cuestiones técnicas y materiales, sabiendo que algunas obras, como las creadas sobre las distintas ideologías del Arte Minimalista o del Arte Conceptual o del Land Art, etc., no se justifican por la permanencia de la materia por la cual están constituidas, más bien son obras eternamente durables porque es la idea su fundamento. Como tal, es suficiente para su coherente permanencia ideológica o material, la existencia de una completa documentación del evento, del acto, de la acción o de la creación 0 simplemente la salvaguardia del proyecto, puesto que la obra es únicamente el medio para transmitir una idea. Una cuestión presente siempre que el artista no se preocupa en demasía por los materiales que utiliza, su estado y durabilidad, sino por lo que estos materiales transmiten. La intención de seleccionar determinados materiales en la concretización de la idea no reside en la necesidad de hacerlos permanecer inmutables, ya que son fundamentalmente estructura y no meramente aspecto.

Volviendo al siglo $X X$, a un texto fundamental sobre un análisis teórico para la conservación del patrimonio, referente a los monumentos, son del todo interesantes las palabras de Aloïs Riegl, en que habla del concepto de antigüedad, pero con una perspectiva totalmente contemporánea:

Las manifestaciones de destrucción (deterioro prematuro) en la obra humana reciente nos desagradan tanto como las manifestaciones de creación reciente (restauraciones exageradas) en la obra humana antigua. Lo que complace al hombre contemporáneo de comienzos del siglo XX es más bien el ciclo natural de creación y destrucción en toda su pureza, así como el percibirlo con toda claridad. Toda obra humana es 
concebida así como un organismo natural en cuya evolución nadie debe intervenir; este organismo ha de gozar libremente de su vida y el hombre puede, como mucho, preservarle de una muerte prematura. ${ }^{149}$

De forma sencilla o pragmática, la base de la restauración siempre ha sido y será el respeto por la obra, y respetar la obra no significa obligatoriamente mantener su materia, ni tampoco la reconstrucción o reinvención de ésta, ya que hablar de restauración de arte contemporáneo puede ser sencillamente hablar de conservar y preservar la idea. O tal vez, lo más indicado será considerar la reforma del concepto de restauración, que no consistirá en una actividad de decisiones eternamente unánimes, sino una actividad preocupada por el sentido, un sentido que envuelve tanto la obra y su valor simbólico y conceptual, como todo a su alrededor: esencialmente una conciencia temporal y social. Hablar de restauración será entonces referirse a un largo proceso de pesquisa, estudio y archivo de vasta documentación visual (tanto fotográfica como audio-visual) y teórica (entrevistas, siempre que sea posible el contacto con el artista y su medio, catálogos, además de toda la documentación existente). Resulta evidente que en relación a semejantes expresiones artísticas, la única actitud correcta es aquella que predispone una atenta y precisa documentación agregada, de la descripción de todos los materiales empleados por el artista, desde la fase preparatoria a la reproducción del evento, además de una descripción lo más desarrollada posible teniendo en cuenta la intencionalidad de la misma. No obstante, es una ciencia que vive bajo la conciencia de que el arte contemporáneo tiene características particulares y problemas técnicos resultantes, principalmente, del empleo de determinados materiales. Es determinante el hecho de que el lenguaje artístico no está limitado más al uso de los materiales tradicionales del arte, de los cuales son bien conocidos las naturalezas, las propiedades y los comportamientos, pero se ha alargado a productos industriales, a los bienes de consumo, a los materiales degradados o traídos directamente de la naturaleza y hasta los materiales comestibles.

No cabe duda de que la contemporaneidad de los materiales es una de las dificultades más comunes en la actividad de los conservadores/restauradores. Su

${ }^{149}$ RIEGL, Alöis. El culto moderno a los monumentos, p.51. 
identificación es difícil, por diversos motivos, entre ellos falta de información del fabricante, nombres comerciales distintos y ausencia de la descripción de las propiedades, composición y posibles alteraciones en el tiempo. A esto se une el deber de preservar la identidad estética e histórica, que implica la necesidad de interrogarse sobre la finalidad de cada creación y sin olvidar que nace una nueva visión cuando la intención del artista no pasa por la permanencia material, en la que no se podrá dar una excesiva importancia a la materia si realmente ésta es la intención del artista. La obra de arte además de sus valores estético, formal y técnico, tiene intrínseco el papel de transmitir al futuro ese conjunto de valores y creencias de generación en generación. La conservación/restauración tendrá que respetar y cuestionar la legitimidad de algunos de los tratamientos e intervenciones para no distorsionar un mensaje.

No obstante, la naturaleza de los materiales, los procedimientos técnicos y el rápido envejecimiento que presentan gran parte de las obras han producido una alarma en el campo de la conservación/restauración, por eso, toda la atención está centrada mayoritariamente hacia las causas de deterioro de las obras. Con todo, nunca deberá quedar al azar lo que justifica la presencia de esos materiales y lo que constituye la obra, que es sin duda la idea.

Una obra de arte constituye, es cierto, una unidad cerrada donde todos los elementos se vinculan entre sí y tienen sus raíces en la misma creación individual. Si uno o más de ellos se aíslan, pierden el carácter artístico que les confiere totalidad. ${ }^{150}$

En muchas de las obras no se puede olvidar que la mutación de los materiales y consecuentemente de la obra, forma parte de su autenticidad y sólo así, se justifica su existencia y permanencia física.

Para entender una imagen es necesario recurrir a los distintos niveles que la constituyen: el técnico, el temático y el informativo o significativo. Es en el nivel técnico donde la conservación/restauración encontrará la información que necesita sobre la materialidad de la obra, una vez que dicho nivel esté determinado por los elementos físicos que constituyen la imagen y subordinado a un sistema, donde cada

150 VENTURI, Lionello. Cuatro pasos hacia el arte moderno, p.15. 
elemento comporta información precisa de características dominantes con relación entre sí. Por supuesto es en el soporte 0 en las formas, en las que se señalan los problemas, creando vacíos para la conservación/restauración en la información del sistema, que se tiene como imagen. A esta información directa ofrecida por la obra está asociada un conjunto de información indirecta, existente en los apuntes del artista, como pueden ser sus textos, sus dibujos, sus proyectos, sus catálogos, u otro tipo de información obtenida a través de terceros. Además, es necesario referir la importancia que ganan los catálogos, como refiere Rocío de la Villa; lo cierto es que la historia del arte actual se escribe a través de los catálogos de las exposiciones ${ }^{151}$, como tales son definidores de un extenso abanico de informaciones a varios niveles, y muchas veces se convierten en el único documento resultante de una muestra expositiva, a los cuales queda asociado un valor de prestigio a quien lo posee.

Para el público que efectivamente ha asistido, la posesión del catálogo supone desde la posibilidad de profundizar sus conocimientos sobre lo visto, a revivir posteriormente la fruición estética ante las imágenes auténticas ahora reproducidas, o simplemente conservar un souvenir de una de las páginas honrosas, respetables y prestigiosas, de su biografía. ${ }^{152}$

Dejando de lado estas cuestiones, muchas veces la información disponible es insuficiente en determinadas obras, y no hay duda que el conservador/restaurador vive bajo un complejo desafío entre la diversidad, lo novedoso, lo experimental y lo perecedero, característico de muchos de los bienes artísticos, pero esto no implica obligatoriamente un problema. Habrá quien diga que no se puede conservar todo porque no habría espacio para almacenar todos los objetos. Otra versión más coherente con la intencionalidad en el ámbito del contexto artístico contemporáneo es que no hay que conservar todo, porque existen obras que tienen que morir para concluir el ciclo al que fueran propuestas, o por otra parte, obras que se materializan y luego desaparecen quedando registradas o proyectadas para una próxima aparición cultural.

Si por conciencia el ser humano es susceptible a la degradación y a lo efímero, por otro lado el arte contemporáneo no tiene que ser sinónimo de nuevo. Aquí nace el

151 VILLA, Rocío de la. Guía del usuario de arte actual. pp. 71.

152 Ibídem. pp. 70-71. 
ineludible paradigma y que es visto como uno de los problemas del arte contemporáneo: ¿cómo puede un arte de ayer presentar problemas de conservación? La propia sociedad establece que, es lo material lo que tiene valor y se vive bajo una excesiva valorización de la materialidad. En consecuencia, el arte contemporáneo parece existir bajo un paradigma ante lo que es el propio acto de creación (efímero, veloz y perecedero), y en lo que socialmente está implicado: una obligación de sobrevivir a todos los fenómenos exteriores a sí misma. Creer que todo tiene que poseer un aspecto exterior como acabado de pintar, de montar, como recientemente creado, no es el camino directo para encontrar el punto de equilibrio, puesto que muchas veces la propuesta artística es otra. Además, hacerlo podrá dar origen a lo que en conservación/restauración se considera crear un falso, que tanto podrá ser histórico 0 artístico de acuerdo con las transformaciones efectuadas. Restaurar no es únicamente conocer los materiales y dominar las técnicas de restauración; restaurar y conservar implica dominar los conceptos estéticos y filosóficos de la creación. Una ciencia y actividad que posee un papel determinante en el mundo artístico, y cualquiera que sea su desarrollo, su acción tendrá que ser lo más coherente posible sin equivocarse. Si con el arte tradicional, la conservación/restauración vivía bajo la frase hecha cada obra es única, cada caso un caso único, con el arte contemporáneo es posible alcanzar el auge de tal afirmación, en que los caminos a seguir pueden ser tan dispares y numerosos, tantos como las intenciones artísticas, planteando respuestas teniendo como base lo que teóricamente se entiende por restauración crítica.

Si en el arte tradicional es muchas veces difícil establecer criterios genéricos para lo que se entiende por intervención, una acción respetuosa, rigurosa y justificada ante la obra, ¿cómo se pueden establecer criterios que también sean respetuosos, conscientes y correctos ante la diversificada gama de géneros y categorías artísticas?, ¿En qué límites es aceptado lo efímero en las creaciones contemporáneas?

En el capitulo anterior se hace una posible división general en términos de materiales en función de su durabilidad, y se concluyó que en el arte contemporáneo no es suficiente tal división, siendo necesario paralelamente, hacer en concordancia, una 
segunda división o clasificación en función a su concepto. Lo que lleva, genéricamente, a un primer grupo de obras hechas para durar, a un segundo grupo constituido por aquellas obras que son hechas para durar pero que sus materiales no lo permiten, tal como están agrupados o son utilizados, y por último, las obras que nacen bajo el deseo de un fin material.

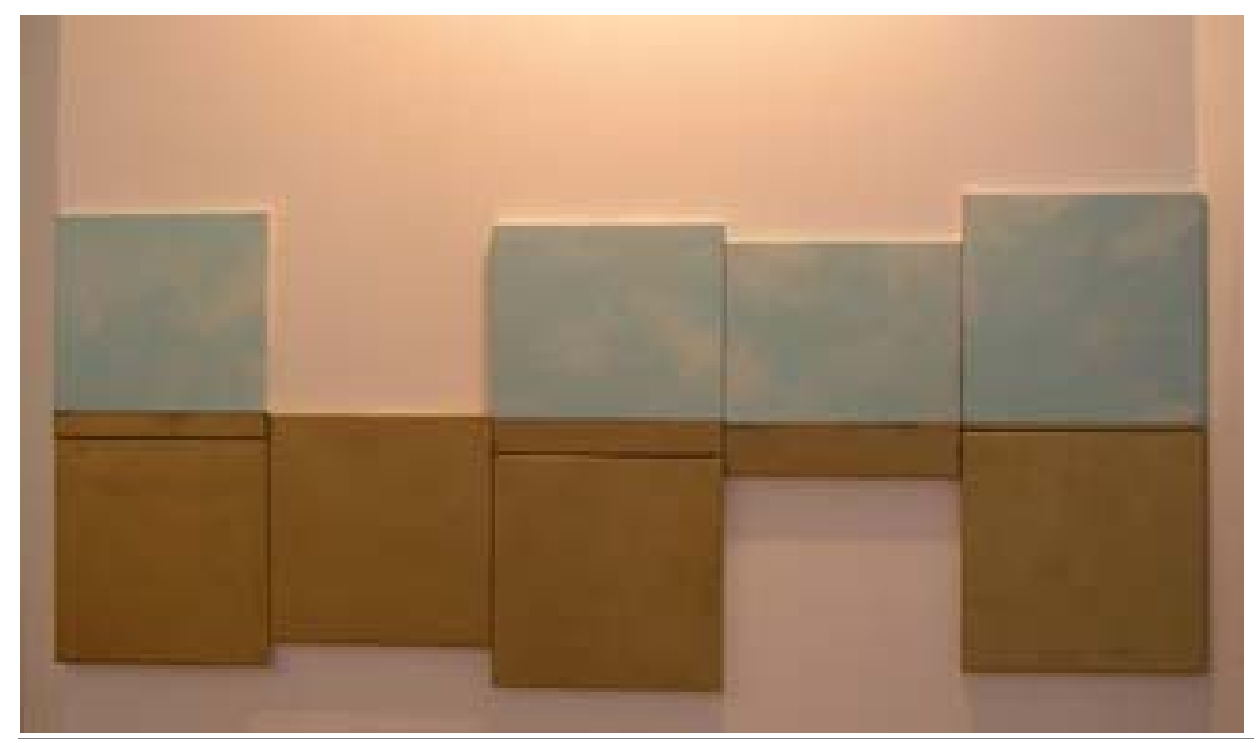

Figura 43: Ana Cardoso, S/ título, 2006. Acrílico sobre tela, 8 piezas de 30x30cm [4 dípticos].

Las obras del primer grupo no interfieren en lo que es la práctica tradicional de conservación/restauración. Su materialidad funciona como estructura y aspecto de lo que es imagen y este hecho no sobrepasa las bases tradicionales de la disciplina de conservación/restauración. El segundo grupo de obras, a su vez, no tiene en sí la tan deseada respuesta directa para un posible tratamiento de conservación/restauración, siendo éstas las que platean mayores dificultades, una lucha entre el paso del tiempo y el deterioro y mutación material. O sea, es cierto que la obra fue creada bajo el objetivo de perdurar en el tiempo, pero llegó a un punto en que su estructura ya no sustenta la imagen y es necesario intervenir para que la obra llegue a un futuro, tal y como fue el deseo de su creador. Lo ideal es definir un tratamiento que frene las degradaciones del material, pero en la práctica muchas veces no es posible, llevando a resultados que pueden diferenciarse según las instancias estética e histórica de cada obra. Obviamente hacer un análisis del objeto en función de su artisticidad es 
fundamental, puesto que es en la instancia estética donde habita el sentido para el cual el objeto ha sido creado y la primera que tiene que ser valorada, pero no siempre la intervención hace posible la integridad de ambas instancias. Todavía, es sobre la materia donde se realiza la intervención y en este sentido, pueden ser adaptados varios caminos, en los que lo más adecuado siempre sería la mínima intervención o en un lado completamente opuesto, cuando hay que realizar una intervención drástica, si así se puede llamar a la sustitución, parcial o en general, de la materia constituyente. O tal vez será una reposición de la obra, o una segunda materialización, o en último caso, en el futuro, será vista principalmente como documento histórico de una determinada manifestación artística.

El último grupo incluye todas las obras que están pensadas para que su materia siga un ciclo evolutivo hasta llegar a un fin. Bajo este objetivo hay dos posibles vertientes a seguir: la primera, que la obra es un proyecto y éste valorado por su carácter inédito como el certificado de originalidad de la obra, esto porque, es una idea que se materializará siempre y cuando sea deseo de su creador 0 de quien la posee, respetando la forma que ha sido planteada por el artista. En respuesta a este deseo, la conservación/restauración nada más tiene que hacer, a no ser crear una documentación exhaustiva de la creación y su presentación, y tratar lo que es el proyecto como la "reliquia" a conservar. La segunda vertiente, más drástica, incluye todas las formas de expresión que consisten en un único acto creativo, lo más puro de la creación, sin que exista la posibilidad de volver a repetirse, reproducirse o montar lo que es la propia obra de arte en sí misma. Por ejemplo, la Performace, o el Body Art, donde a través del cuerpo se transmite un concepto, una idea sin implicar una elaboración sucesiva, como un evento que se produce en un momento concreto. Según Rocío de la Villa, tales expresiones artísticas quedan agrupadas en el concepto de exposición congelada, o sea que tales expresiones hacen del catálogo el único medio de registro de la exposición o acción.

Aun cuando instalaciones, acciones, happenings y performances, puedan repetirse, necesariamente cambiará la inserción en los espacios, la gestualidad del artista o la participación del público. Lo que dota de un valor esencial al catálogo, que deja de ser complemento para pasar a ser documento imprescindible. Y culmina, también, la importancia siempre creciente del catálogo en la tradición moderna. ${ }^{153}$

153 VILLA, Rocío de la. Guía del usuario de arte actual. p.70. 
La situación producida y su intencionalidad quedarán sobre el rodaje fotográfico 0 cinematográfico, como el momento fijado y registrado del mismo evento. En este sentido, el único planteamiento es respetar lo trazado por el artista, en el que el procedimiento posible a seguir es la presentación de lo que es una aproximación a la obra (fotografías, videos u otro tipo de documentación), que en muchos casos, posteriormente son considerados como "nuevas" obras. Por una parte, estos nuevos objetos llegarán al futuro como representación de la obra, entendidas como una 0 varias representaciones de lo que ha sido el acto creativo pero no la obra. Por otra parte, no se puede eliminar la posibilidad que algunas veces estas representaciones se asumen como una nueva obra, una vez que puedan surgir diversas formas de representación, resultando en nuevas obras de acuerdo con la intención que propone el artista y su creación.

Conservare un evento figurativo effimero come ad esempio un happening con mezzi quali registrazioni, cinema, foto sembra sia un andare contro la loro peculiarità, (...). Potrebbe essere una nuova opera, di altri o dello stesso artista(...). L'evento originario perduto si mescola allora con il nuovo, ma non è più quello, diventa l'esperienza di un sogno non dell'opera. 154

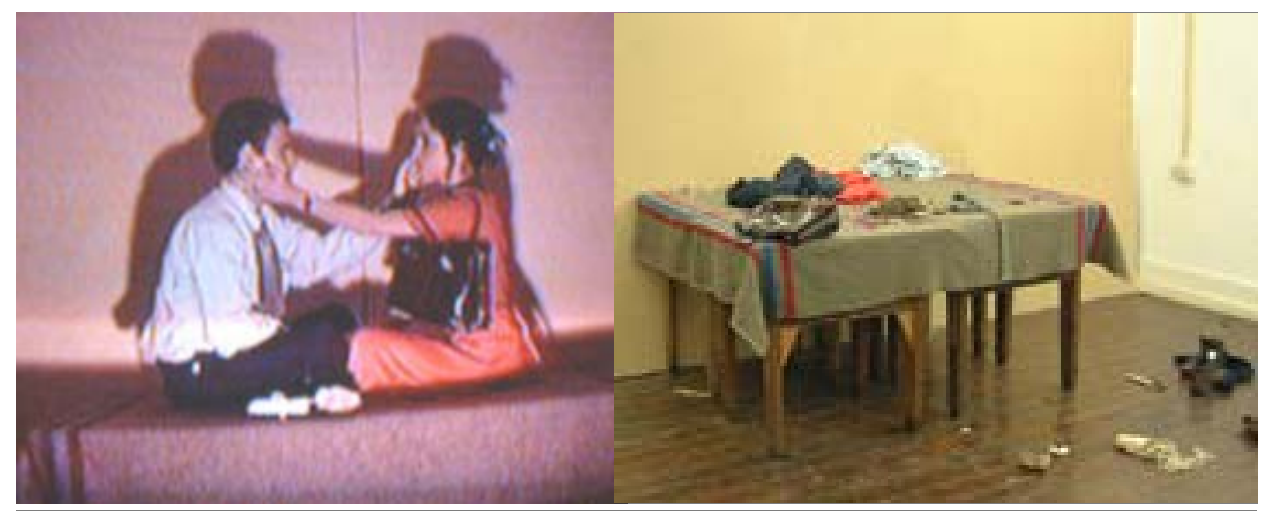

Figuras 44: Rui Pedro Fonseca, Performance 1Move. Figura 45: Fotografía del final de la performance.

Con todo, estos registros pueden ser valorados únicamente por su valor documental, o además podrán alcanzar elevada distinción de acuerdo con su historicidad y

${ }^{154} \mathrm{LEVI}$, Corrado. Paradossi sulla conservazione dell'arte effimera. en AA. VV. Arte contemporanea. Conservazione e restauro. p.179.

T.A.: Conservar un evento figurativo efímero como por ejemplo un happening con medios de registro, cine, foto parece ser un andar contra sus peculiaridades, (...). Podrá ser una nueva obra, de otro o del mismo artista (...). El evento original perdido se mezcla ahora con el nuevo, pero no es más aquello, llega a ser la experiencia de un sueño no de la obra. 
artisticidad. En ellos se centrará la conservación preventiva y la conservación/restauración, porque incluso siendo únicamente registros, el valor alcanzado por tales documentos es equivalente al que podría alcanzar el propio objeto artístico. Serán el video y la fotografía entendidos como documentos, pero también y esencialmente, como los nuevos objetos a ser protegidos y conservados, dando origen a un nuevo campo de acción y preservación.

El debate no queda encerrado en las cuestiones de adquisición y de representación, pero hay que abordar también las cuestiones de exposición, cuando la obra no está únicamente reducida a su consistencia estructural, y surge la necesidad de presentarla públicamente. Se da una situación compleja, cuando en presencia de obras que un día cumplieron su ciclo de vida o que tienen una presencia física delimitada, sin ofrecer la posibilidad de volver a montar o reponer la obra. En este sentido y sobre la necesidad de su presentación pública, son varias las soluciones con base en un valor documental. O sea, la presentación de lo que puede ser la representación de la obra al público: por un lado, cabe la posibilidad de una presentación aparentemente neutra, a través de la fotografía; por otro, la presentación que resulta de la manipulación de un determinado medio o del propio medio, como la selección de distintas imágenes; 0 incluso se puede manipular la propia realidad, a través de la alteración de los entornos.

Dimensiones del espacio en relación a la magnitud de la imagen, colocación, luz y color. Todo ello puede modificar la percepción del espectador, hasta distorsionar por completo su aprehensión de la obra.

Otras cuestiones más pragmáticas, pero dependientes también del montaje en el espacio, pueden favorecer o molestar la disposición del espectador. ${ }^{155}$

Todavía, en todos los casos, será necesario subrayar que, incluso respetando el binomio idea/materia hay que tener conciencia de que el espectador interiorizará la obra y su mensaje de acuerdo con la forma específica de presentación. A la hora de exponer la obra, hay por tanto, que respetar el contexto de la misma, una vez que los cambios pueden interceptar el concepto de la obra y la forma como ésta es interpretada. Y este concepto llevado al extremo podrá ser consecuentemente la

155 VILLA, Rocío de la. Guía del usuario de arte actual. p.65. 
creación de falsos artísticos, siempre y cuando no hay un respeto integral en la exposición de los objetos.

No hay duda de que el arte contemporáneo lleva al límite varias cuestiones, incluso que una obra es un organismo vivo en que la integridad es el resultado de su unidad, y el mantenimiento de este organismo presenta diferencias relevantes cuando es comparado al mantenimiento y conservación de la obra tradicional. Todavía, la obra de arte siempre será un todo consistente y coherente, incluso con la dificultad de establecer lo que es estructura y aspecto en una creación contemporánea. Es una unidad, como algo viviente, tanto en la presencia de una nueva representación o de una buena documentación, en la que independientemente de esta necesidad hay que defender su totalidad e integridad en consonancia de sus instancias.

Intendere el restauro solo come il bloccare questo processo di degrado fisico che pure è in qualche modo vitale, vuol dire creare delle mummie, delle cose morte che non c'entrano più molto con ciò che era l'originario prodotto dell'artista. ${ }^{156}$

Vittorio Urbani es exacto cuando afirma que la restauración no debe ser entendida como la detención de un proceso físico siempre que el frenar los cambios producidos en la obra no elimine su intención original. Los conceptos de forma y contenido forman parte de un mismo objeto en una comunicación mutua, constante y dependiente, donde uno es el qué determina el cómo, y a la inversa, el cómo no existe sin el qué que trata de comunicar ${ }^{157}$, o sea, en la práctica es imposible respetar la materia si, principalmente, no se respeta el significado. La creación artística es por tanto el juego entre forma y contenido sin que la forma se sobreponga al contenido, como elemento indivisible que queda junto a su fundamento. ${ }^{158}$

Una realidad que supone dos posibles actitudes contrarias entre sí y que son definidas única y simplemente por la propia obra y sus intenciones. Si por un lado existen obras que tienen que morir, y lo que llega al futuro son representaciones de de lo que fue la obra; por otro, existen obras en que la materia está subordinada a la

156 URBANI, Vittorio.Il «rigoglio degli ibridi». en AA. VV. Arte contemporanea. Conservazione e restauro, p.122-123. T.A.: Entender la restauración sólo como el detener de este proceso físico que sin embargo es en cualquier modo vital, quiero decir crear una momia, de la cosa muerta que no entran más en aquello que era el producto original del artista.

157 KAHLER, Erich. La desintegración de la forma en las artes, p.14.

158 Ibídem. p.15. 
idea. Y en este último caso, no hay motivo para decir no a la reconstrucción de esa propia materia, una vez que este procedimiento mantiene el respeto por la instancia histórica y estética de la misma. En estas circunstancias no es creado un falso artístico porque el fundamento de la obra es su concepto, ni tampoco es creado un falso histórico porque, incluso si la reconstrucción de la obra implica nuevos materiales o la intervención de alguien que no sea el artista, este comportamiento no oculta su valor documental y una coherencia histórica frente a la intención del artista. Situaciones como esta, están vigentes en el Arte Conceptual, instalaciones, obras ambientales, etc. $Y$ como ejemplo, se puede recurrir a las obras minimalistas entre otras, en las que el artista, proyectaba la obra y encargaba su materialización. Y lo hacía de la forma más distante creyendo enteramente en la cuestión de que el material se limitaba a una búsqueda del purismo de la forma, un simple producto industrializado. O el arte conceptual que llevaba más adelante la ideología del concepto en que cuestionaba la realidad artística a través de la distinción entre imagen, objeto o definición.

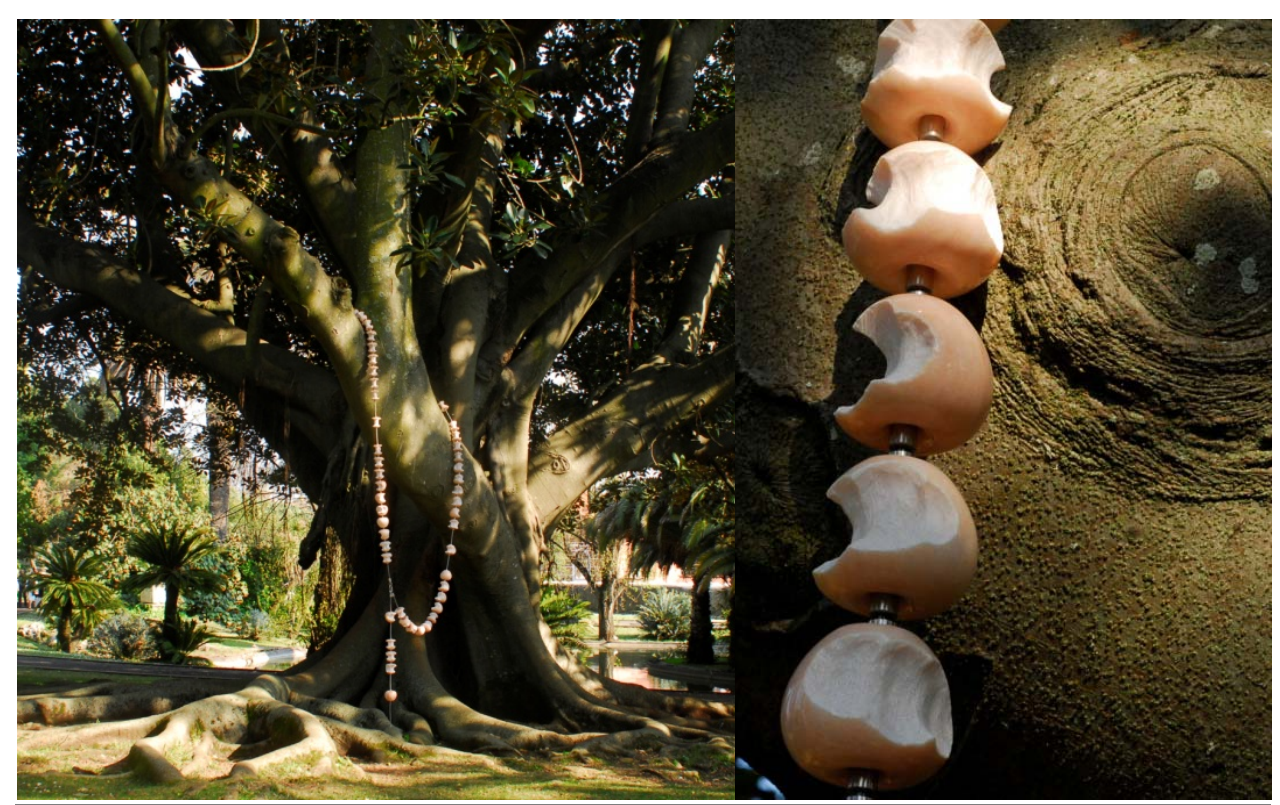

Figura 46: Isaque Pinheiro, instalación 1/3, 2007. Mármol y acero inox, medida variables. Figura 47: Isaque Pinheiro, detalle de $1 / 3$. 
En tiempos pasados, pudo haber sido complicado aceptar estas nuevas nociones, además de la dificultad de aceptar estos objetos como obras de arte, pero actualmente ya no tiene sentido hacer estos cuestionamientos, puesto que el hecho de que el objeto haya sido ejecutado por alguien que no el artista no es el impedimento para que tal objeto no sea considerado obra de arte. La cuestión de la artisticidad es bastante ambigua, y son varios los ejemplos en el trayecto trazado por los movimientos y tendencias del arte contemporáneo, llegando al límite de la cuestión, cuando los propios artistas decían cosas como «si yo digo que esto es arte, es que es arte», como lo hizo Donald Judd.

Las instalaciones son, sin lugar a dudas, uno de los medios de expresión que levantan más cuestionamientos, no sólo por su heterogeneidad matérica y expresiva, pero esencialmente por su particular carácter efímero y su lenguaje conceptual. Son creaciones normalmente pensadas para un determinado espacio, en que su ubicación tiene un papel fundamental en la transmisión de su mensaje. En la mayoría de los casos es de fácil adaptación, pero es un factor a tener en cuenta a la hora del montaje. Si por un lado deja abiertas varias hipótesis de exposición, por otro es un riesgo que sean tan versátiles, o que sean vistas como volubles e inconstantes. El hecho de que muchas veces estén constituidas por elementos efímeros, puede llevar a la confusión y a la seducción por lo nuevo, en que la cuestión de la sustitución de piezas o de partes, gana terreno. Cuestión ésta que debe ser analizada según la intención por la cual ha sido creada cada obra. Según el mensaje de la obra de arte, como está reflejado en páginas anteriores, lo que tendrá de prevalecer no es obligatoriamente el objeto como tal, sino su idea reflejada en el proyecto adquiriendo el estatus de obra de arte. Aunque pueda parecer contradictorio, el objeto no es más que la representación física de la idea, y más que nada, esta es una obra eternamente durable, puesto que la idea por si misma nunca dejará de existir. Si el artista así lo determinada, la obra podrá ser presentada infinitas veces, como una constante reproducción del original, cuando por original se entiende la idea proyectada. Un cambio en la historia material de la representación, o sea, la obra es siempre la misma, incluso con diferentes materializaciones físicas, sin que se pueda considerar la primera manifestación como única y la original, puesto que la idea se 
mantiene. Un hecho que puede interferir de cierta forma en la noción de autenticidad, cuando simplemente tal terminología tiene una estrecha conexión con la materialidad del objeto. En estos hechos se encuentran varias respuestas para la actividad de la conservación/restauración y hay que seguir interpretando la intencionalidad evolutiva de las obras. Una evolución radical, cuando algunas ofrecen la posibilidad de coexistir después de un fin, material o de la intención, en la primera representación, cuando el material es únicamente el medio para concretar una intención, el medio utilizado para dar cuerpo a un concepto. Las posibles intervenciones de conservación/restauración son, sin duda, dictadas por las particularidades de cada obra, pero conscientes de que no siempre la clarividencia y la facilidad están evidentemente presentes en la obra como claves para la buena interpretación. Es fundamental definir anticipadamente los procedimientos a seguir, pues tal como expresan Althöfer y Rava o como en la cita de Vittorio Urbani en páginas anteriores, es posible transmitir una momificación de la obra y no la obra, resultando contradictorio con la obra y su significado, atribuidos por el artista según determinada intención. Y momificar una obra de arte no es más que eliminar o frenar su funcionalidad, tal como acontece con cualquier objeto cuando la función por la cual ha sido creado y producido deja de ser efectiva, perpetuando la presencia física de un objeto inútil. También el arte, creado bajo valores estéticos, tendrá que mantenerse fiel a sí mismo para que no se torne en un objeto sin función.

En el capitulo anterior se hizo una introducción a lo efímero como presencia incontrolable en el arte contemporáneo, así como también, a lo efímero de la materia como intención previamente proyectada. Dos situaciones distintas pero con finales muy similares entre sí, pues ambas son determinadas por las cuestiones materiales de la obra, una vez que la degradación física y química de un objeto es inevitable y más aún cuando es el resultado de materiales heterogéneos e inestables. Todavía, es responsabilidad de la conservación/restauración presentar respuestas para las obras en que lo efímero es una presencia incontrolable e indeseada para el artista.

Le cose si complicano poiché hanno in sé caratteristiche conflittuali, transeunti e sacre assieme.(...) 
Tentare di conservare e tramandare opere effimere con mezzi riproduttivi o con ripetizioni, sembrerebbe cosa facile oggi, ma c'è da domandarsi se non sia un tradimento teorico, e quindi un falso. ${ }^{159}$

Corrado Levi presenta una nueva cuestión, ya que no sólo existe la posibilidad de crear una momia sino también dar origen a un falso artístico y/o histórico.

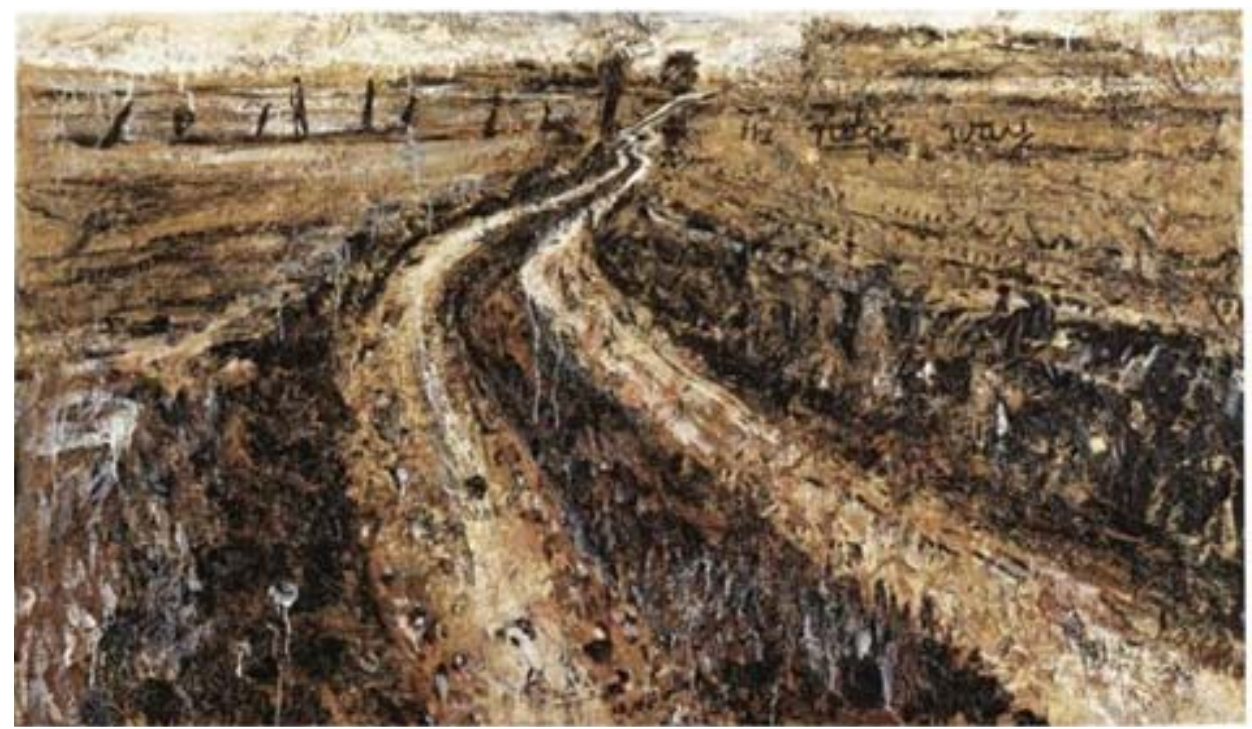

Figura 48: Anselm Kiefer, The ridge way, 1983. Oleo, emulsión, laca, paja y paño de saco.

Hay que percibir la unicidad del mensaje de cada obra, y opiniones como las del artista Kiefer tendrán que estar presentes en la toma de decisiones por parte del conservador/restaurador. La obra de Anselm Kiefer compuesta de elementos como paja, ceniza, plomo, hierro, carbón, tejidos, hilos, papeles, pegamento, con objetos 0 fragmentos, barro y madera, distintos elementos de la naturaleza, mezclados con óleo 0 acrílico de forma coherente pero no homogénea, tiene que ser entendida bajo el concepto de mutación, en un constante proceso de cambios físicos y químicos a los que los materiales empleados están sujetos. El propio artista afirma no comprender por qué terceros se preocupan tanto con las alteraciones de sus cuadros, una vez que

159 LEVI, Corrado. Paradossi sulla conservazione dell'arte effimera. en AA. VV. Arte contemporanea. Conservazione e restauro, p.179.

T.A.: Las cosas se complican puesto que tienen en sí características conflictivas, transeúntes y sagradas juntas. (...) Intentar conservar y transmitir obras efímeras con medios reproductivos o con repeticiones, parece cosa fácil hoy, pero hay que preguntarse si no es una traición teórica, y por lo tanto un falso. 
se alguma coisa for retirada ou cair, pode-se simplesmente colá-la de volta ${ }^{160}$. Estas cuestiones también pueden tener ciertas implicaciones prácticas, a la hora de la intervención que muchas veces no es únicamente conservativa, pues existen distintos intereses a la hora de la comercialización de los bienes, en los que invertir supone hacerlo sobre un bien durable. Crudamente y con otras palabras, o motivo subjacente é que sua obra é um mau investimento económico para os coleccionadores e museus que querem comprá-la para sempre. ${ }^{161}$ Está claro que la mutación es un elemento constante en las obras de Kiefer, y según su punto de vista, si alguien se preocupa con el deterioro de las mismas es porque no ha entendido el significado de sus trabajos. Noción ésta que tendrá sus repercusiones a la hora de analizar y percibir características intencionadas, naturales e inevitables, como el deterioro y la mutación y con la misma validez que otras características expresivas.

Son varias las distinciones entre el arte del pasado y el arte contemporáneo, y su complejidad aumenta en presencia del binomio forma/contenido y en consonancia con la cuestión del tiempo y de la temporalidad, que aportan al arte una peculiaridad subyacente. Siempre se vivió bajo el conocimiento de que el arte ha sido hecho y producido para perdurar, pero la introducción de un fin físico presente en algunas obras de arte contemporáneo olvidan y suprimen este canon, extendiendo las posibilidades de creación a un mundo sin límites de aceptación, en que los extremos ganan un aliento casi descontrolado. Características como degradación y efímero no son obligatoriamente cuestiones perennes de negación. $Y$ ante el aumento de las manifestaciones efímeras es evidente la necesidad de instituir una nueva escala de valores en la que sin duda hay que interpretar el mensaje y saber cuáles son las cuestiones implicadas en ese trámite, ya que el propio acto de interpretación es por sí solo ambiguo y también resultado de un determinado momento histórico, cultural y social.

${ }^{160}$ ALBANO, Albert. Arte em transição. en BOMFORD, David. Workshop, Critérios éticos e estéticos na restauração de pinturas, sin paginación.

T.A.: ... si alguna cosa es retirada o se cae, se puede simplemente pegar de nuevo.

161 Ibídem. sin paginación.

T.A.: ...el motivo subyacente es que su obra es una mala inversión económica para los coleccionistas y museos que quieren comprarla para siempre. 
Credo che se si vuole conservare anche «l'effimero più effimero» il mezzo c'è: se vogliamo conservare, dobbiamo innanzitutto individuare il testo e poi un metodo per la conservazione, abbandonando per un po'l'abitudine che abbiamo all'opera d'arte compiuta in ogni suo dettaglio che ci viene proposta come un'apparizione: in certe manifestazioni artistiche bisogna entrare e, come sucede per la musica, anche interpretare. ${ }^{162}$

La conservación/restauración puede encontrar respuestas ante estos hechos a través de una posible división en función del valor del "tiempo". Como ya fue expuesto anteriormente, se pueden genéricamente agrupar las creaciones en dos grupos. Un primer grupo que incluye todas aquellas obra que fueran creadas con el objetivo de perduran en el tiempo, y un segundo grupo que son las consideradas obras efímeras. Todavía hay un conjunto de obras, que se podrían agrupar en ambos grupos puesto que son creadas con la intención de perdurar en el tiempo, pero son consideradas efímeras por cuestiones materiales, donde lo efímero se manifiesta a través de materiales que no podrán resistir al tiempo pero sin que esa fuera la intención del artista. $Y$ de este modo, Toniato apunta que,

Esiste:

1. un'opera costruita perché vuole durare

2. un'opera che vuoloe essere soltando un documento del proprio tempo

3. un'opera che, benché dotata d'innegabile qualità, non vuole e non può durare

4. un'opera che è ideata per autodistruggiersi, ossia che si dà anche al prorio evento di distruzione. ${ }^{163}$

Esta división podrá ser el punto de partida para concretar un plano de actuación 0 un complemento sumado a los análisis del punto de vista técnico y del punto de vista del concepto. De esta forma, con el cruce de la información entre los tres campos de análisis se podrá encontrar la ayuda suficiente para establecer límites rigurosos y definir criterios de intervención.

162 ANGELUCCI, Sergio. «Dinamismo di un cavallo in corsa+case» di Umberto Boccioni. en AA. VV. Arte contemporanea. Conservazione e restauro. p.251-252.

T. A.: Creo que se si quiere conservar también «el efímero más efímero» el medio es: si queremos conservar, debemos antes de nada individuar el texto y después un método para la conservación, abandonando por un poco el hábito que tenemos de hacer que cada detalle de la obra de arte venga propuesto como una aparición: en ciertas manifestaciones artísticas es necesario entrar y, como sucede para la música, también interpretar.

${ }_{163}$ TONIATO, Toni. Tematiche del restauro contemporaneo. en AA. VV. Arte contemporanea. Conservazione e restauro. p.37.

T. A.: Existe: 1. una obra construida para durar; 2 . una obra que quiere ser solamente un documento del propio tiempo; 3. una obra, que si bien fue dotada de inigualable calidad, no quiere y no puede durar; 4. una obra que es idealizada para autodestruirse, o sea, que se da al propio evento de destrucción. 
Cuando se analiza una obra de arte contemporánea, además de tener en cuenta los materiales y la materia y técnica constituyentes, es necesario hacer prevalecer el concepto a ellas vinculado, sin olvidar que se debe cuestionar hasta qué punto, se restaura sólo la materia de la obra de arte. ${ }^{164}$ Hay un juego paralelo en el mantenimiento físico de la obra, ante materiales perecederos y caducos. Por un lado, no existe obra sin una materialización constante e idealmente perpetua; por otro, algunas creaciones se identifican y caracterizan por la importancia atribuida a la idea por la cual se hace materia, y por último las creaciones que presentan los valores tenidos como tradicionales y socialmente aceptadas. Así, cuando se interviene la obra, es necesario considerar atentamente hasta qué punto el axioma que cree en restaurar apenas la materia es verdaderamente aplicable, de forma que no interfiera en su instancia estética, una vez que materia implica el ya hablado binomio forma/contenido.

Con todo, se debe resaltar un aspecto que puede llevar a errores prácticos. Lo primero a señalar es que, si por un lado se considera el arte contemporáneo una confrontación de experiencias de un arte de ayer, esto no significa que este arte sea un arte nuevo y sin daños, y transmitirlo al futuro implica protegerlo bajo su doble historicidad además de su artisticidad. Por otro, hay necesidad de ser consciente que si hay obras que implican un montaje, hasta el punto de adquirir nuevos materiales para este efecto, esto no implica categóricamente una renovación general de todo lo que encaja en la vasta designación de arte contemporáneo, pues además de ser una generalización errónea, llevaría a una falsa facilidad en su reconstrucción, reposición, recreación. La diversidad expresiva del arte contemporáneo propone de un modo generalizado, cuestiones en los varios campos de acción, que directa 0 indirectamente, juegan su papel en el vasto mundo del arte. El montaje, también se ve afectado llevando a replantear la propia acción, una vez que consiste en la inserción y reinserción de la obra con la intención de mantener una harmonía de acuerdo con su significación, sin caer en el error de desvirtuarla.

Las dudas que surgen a la hora de montar una exposición o en la reposición de una obra, por ejemplo, pueden ser varias y se plantean porque pueden llevar a resultados

${ }^{164}$ BRANDI, ob. cit. p.16. 
artísticos comprendidos como falsos, cuando en el tiempo de vida de la obra es inevitable la presencia de incertidumbres, desorientaciones y perturbaciones. El arte contemporáneo es un medio fácil y una esfera que invita a la creación de falsos artísticos, por diversos factores, entre ellos, el hecho de surgir obras que se materialicen a través de cualquier objeto 0 tipo de material, lo que inevitablemente facilita o invita a la imitación, o falsificación.

La diversa gradazione della rilevanza del falso è legata al fatto che nell'arte contemporanee, come tutti sappiamo, è lidea, il concetto, che ha un valore primaziale; la qualità a volte non sussiste affatto, o comunque, è un elemento secondario ed imitabile. ${ }^{165}$

No es intención aportar recetas sobre cómo hacer una buena intervención, pero una buena aproximación al arte contemporáneo, implica saber leer críticamente cada obra y percibir cuál es su papel en la historia a través del discurso creativo del artista. Con el arte contemporáneo no es posible definir una actividad y establecer criterios de intervención dejando de lado las contradicciones y paradojas características del propio arte. Y para ello, tener presente "el sentimento del tiempo" es fundamental, questo opere accettano una sfida: per tentare di essere vive hanno accettato el rischio di morire. Niente che voglia essere vivo più rinunciare al rischio di morire.166 No se pueden eliminar, ni tampoco circunscribir estas cuestiones, como elementos superficiales 0 secundarios, cuando, muchas veces, en realidad son la base de un lenguaje expresivo. Si la autenticidad de la obra está determinada por la decadencia material, no más determinante podrá ser su significado y simbología: la simbología de un medio material como elemento de transmisión, una transformación única (sin descartar la posibilidad de repetición) en que se concibe y construye conceptual y simbólicamente la obra. Con base en esta estructura teórica, la conservación/restauración no podrá definir su actividad partiendo del principio que el arte contemporáneo es un problema, sino intentar definir estrategias conservativas, y trazar principios claros y concretos,

165 LEMME, Fabrizio. I fondi d'investimento in opere d'arte: presupposti economici, tipologia, prospettiva. en RICOSSA, Sergio (a cura di). I mercati dell'arte. Aspetti pubblici e privati, p.70-71.

T.A.: La diversa gradación de la relevancia del falso está relacionada con el hecho de que el arte contemporáneo, como todos sabemos, es la idea, el concepto, en que tiene un valor principal; la calidad a veces no subsiste en absoluto, 0 en todos los casos, es elemento secundario e imitable.

166 URBANI, Vittorio.Il «rigoglio degli ibridi». en AA. VV. Arte contemporanea. Conservazione e restauro. p.122 y 123.

T.A.: ...estas obras aceptan un desafío: para estar vivas han aceptado el riesgo de morir. Nada que quiso estar vivo puede renunciar al riesgo de morir. 
puesto que la teoría tiene la capacidad de abarcar todos los conceptos a los cuales el arte está asociado.

Es cierto que parece existir una acentuada sombra de caducidad en los bienes artísticos y culturales contemporáneos, también esto es reflejo de una sociedad de consumo y de un mercado sin frenos, pero para la conservación/restauración la cuestión es otra: ¿Hasta qué punto se acepta la modificación y transformación de las obras recientes? Sin duda es un hecho que afecta los valores más evidentes e interiorizados de una actividad preocupada en mantener, salvaguardar lo máximo posible todos los objetos y manifestaciones dotados de un valor propio, en que la unicidad y la originalidad juegan papeles destacados. Es también cierto, que la introducción de estos nuevos valores y formas de ver el "mundo", tiene sus repercusiones en todas aquellas actividades, disciplinas y ciencias que se desarrollan en el seno del arte. Y aún más, en la conservación/restauración hay obligatoriamente la introducción de una nueva forma de pensar las obras hacia un futuro, la nueva aproximación al arte que resulta de una actitud estética distinta de la entendida como tradicional. Surge una nueva responsabilidad y necesidad de pesquisa tecnológica y científica para las instituciones culturales, para todos los conservadores/restauradores, así como para los artistas, y todos los involucrados con el arte.

El verdadero desafío del mantenimiento de la memoria de algunas de las tendencias, sobre todo de los últimos 50 años, es manifestado en una extremada individualización, con una precisa objetividad, proponiendo en el acto, acción y ambiente momentáneos, un por supuesto explícito de la no duración y en el irrepetible, pues nell'arte contemporanea le opere possono essere immateriali, basate su suoni, ombre, o luci.167

Según las necesidades humanas y en el deseo por la permanencia del material hay una lucha por lo único y por el original de forma a marcar una diferencia en el mundo material y del poder. La conservación/restauración como disciplina que trabaja sobre

${ }_{167}$ CHIANTORE, Óscar y RAVA, António . Conservare l'arte contemporânea. Problemi, metodi, materiali, ricerche, p.20.

T.A.: ...en el arte contemporánea las obras pueden ser intangibles, sobre la base de sonidos, sombras o luces. 
los bienes culturales, tiene un papel determinante, jugando sus cartas delante de estos conceptos sociales. Con todo, no se puede dejar llevar por las exigencias sociales porque no puede ser el deseo y gusto de la sociedad los que determinen qué y cómo hacer una intervención, la cual es dictada por la propia obra. No es fácil aceptar ciertas ideas: existen obras que se montan y se vuelven a montar siempre, cuando y donde sea necesario; que los materiales utilizados pueden ser nuevos y recién adquiridos; que lo material no tiene cualquier valor; que la misma pieza puede tener diversas formas de exposición o que el artista no está preocupado en recuperar una obra. Como tan bien refiere Althöfer, la realidad está en percibir

nell'intencinalità artistica per salvaguardare l'essenziale dell'opera, che è in definitiva il suo messagio recondito. L'opera d'arte deve invecchiare e modificarsi in modo naturale, armonico, e non per mancanza di attenzioni dovute a carenze interpretative. II restauratore percepisce le caracteristiche espressive affidate ai materiali e ne garantisce la continuità di funzione nel tempo. ${ }^{168}$

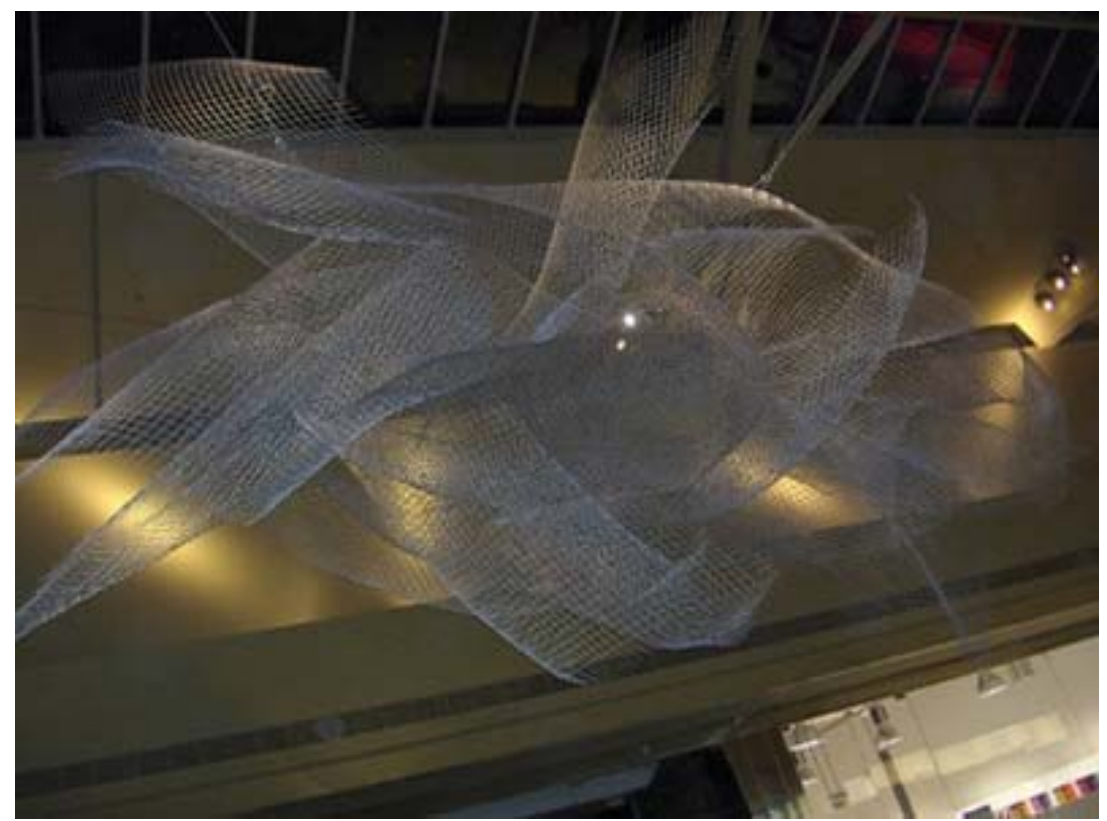

Figura 49: João Pedro Rodrigues, instalación S/Título. Red metálica, esmalte de aluminio, 800×500cm.

${ }^{168}$ CHIANTORE, Óscar y RAVA, António. Conservare l'arte contemporanea. Problemi, metodi, materiali, ricerche. Nota degli autori, sin página.

T.A.: (...) en la intencionalidad artística para salvaguardar la esencia de la obra, que es en última instancia su mensaje oculto. La obra de arte debe crecer y cambiar de modo natural, armónico, y no por falta de atención debido a las deficiencias en la interpretación. El restaurador percibe las características expresivas confiadas a los materiales y de ellas garantiza la continuidad de la función en el tiempo. 
La conservación/restauración incluso ante los diversos extremos presentados por el arte contemporáneo, tendrá que ceñirse a sus criterios teóricos puesto que los valores como la autenticidad y la integridad de una obra no pueden ser cuestionados en presencia de las creaciones heterogéneas y perecederas. Si hay casos donde es posible aplicar los criterios tradicionales de la intervención, otros son extremados, hasta el punto de eternizar la obra con documentación específica, o incluso una substitución total del material constituyente.

Todavía, el hecho de que las obras contemporáneas sean más heterogéneas que las obras antiguas, no significa que la variedad expresiva justifique el desuso teórico y la arbitrariedad práctica en la conservación/restauración. Por contra, cuanto más diversificados sean los resultados creativos, más específicos y concretados tendrán que ser, la investigación y la práctica. Si la especialidad del arte contemporáneo es dada por una extrema individualidad del hacer artístico y del uso de indistintos tipos de materiales e incluso con deterioros patentes, esto comporta cuestiones posteriores. Tales características traen para el conservador/restaurador, habituado a trabajar sobre el arte antiguo, un esfuerzo añadido de reflexión y análisis con la intención de trazar soluciones que no se dan automáticamente, sino que nacen de la compleja comprensión del significado y simbología de la obra artística. Por ello, las intervenciones de conservación y restauración deben conformarse con el respeto de la originalidad y autenticidad de la materia, pero principalmente de la idea a ella vinculada. Solo existirá la verdadera autenticidad si el resultado final de la intervención agrupa idea y materia en un todo coherente. A estos hechos quedan pendientes otras nociones a las que hay que referirse. Cuando se habla de autenticidad de la obra contemporánea esto no implica la originalidad de la materia, como ya ha sido referido en páginas anteriores, una vez que el objetivo del artista es única y simplemente desarrollar un proceso de creación y de evolución creativa sin que el material tenga que sobrevivir; o sea, determinadas obras podrán ser montadas distintas veces sin que eso implique el material original o más correctamente el material usado en la primera presentación pública. Procedimientos como estos, u otros como el rehacer o volver a montar las obras indeterminadamente sin la presencia del artista por ejemplo, son hechos cada vez más frecuentes y muchas 
veces inconcebibles a ojos de terceros que no están suficientemente informados sobre el mundo creativo contemporáneo.

La conservación/restauración en presencia de las manifestaciones y creaciones de un arte sin límites, totalmente liberal, autónomo incluso 'autodestructivo', tendrá que procurar apoyo de los artistas, instituciones, historiadores, críticos, mercado y especialistas jurídicos, ya que se está en presencia de un arte, también él, interdisciplinario. Y como tal, la conservación/restauración tiene que jugar entre las cuestiones estéticas, formales, técnicas, patrimoniales, jurídicas y comerciales, además de la necesidad de plantear la incoherencia entre la realidad y las normas de protección de las obras. Añadidas, a esta realidad, habitan una serie de cuestiones que hacen mover el propio arte contemporáneo, y que desde luego no pueden ser puestas de lado. El sin número de exposiciones temporales tiene su repercusión directa en el objeto artístico, por sus inevitables problemas de transporte, manipulación y movilidad. El material, la búsqueda de lo nuevo y de los nuevos medios no sólo están asociados a una idea por la cual existe el deseo de materializar, es en definitiva una materia susceptible de comercialización. Desde luego se plantea la cuestión: ¿Qué implicaciones pueden surgir para la obra a la hora de su comercialización o manipulación económica? 


\title{
3. El poder persuasivo del mercado del arte y las exposiciones temporales.
}

\author{
Las soluciones sencillas, que no requieren intervenciones «científicas» y transformaciones \\ milagrosas, son poco atractivas para los restauradores, los patrocinadores y demás personas y \\ entidades pertenecientes al establishment de la restauración. 169
}

La observación de Beck es sin duda un punto de partida para una discusión que siempre estará abierta, y una perspectiva entre muchas otras donde se puede o no estar de acuerdo. En el capítulo anterior fue brevemente descrito y analizado el nacimiento y desarrollo del mercado del arte y el papel de las exposiciones temporales. El punto anterior de ese mismo capítulo dejó abiertas cuestiones referentes al mercado, y en el presente punto, está patente el entusiasmo y el deseo de responder a ciertas cuestiones, o por lo memos hacer una aproximación a la realidad.

El ser humano es libre de encuadrar su pensamiento en lo que parece más justo y coherente, pero lo cierto es que afirmaciones como la de Beck, que parecen rebosar de fundamentalismo, tienen algo de verdad. El mercado vive de sus maniobras con inversiones para largos plazos, en las que el arte, como auténtica mercancía, forma parte de una lista de importantes beneficios, en que pueden estar presentes ocultamente diversos comportamientos de poca claridad. Son distintas las posibilidades de inversión a través de la compraventa del arte, y distintos los objetivos de tales comercializaciones, una vez que existen agentes de mercado interesados en comprar las obras por sus utilidades y calidades intrínsecas, y aquellos con la única perspectiva de realizar una buena inversión del capital. Pero una cosa es cierta,

${ }^{169}$ BECK, James y DALEY, Michael. La restauración de obras de arte: Negocio, cultura, controversia y escándalo, p.45. 
mientras existe demanda y posibilidades de cambio, el arte es, como tal, un bien económico, y supuestamente un bien de consumo durable. Es el medio que rige un mercado difícil y sinuoso, en que si en un principio los agentes del mercado eran los artistas, los coleccionistas y los marchantes, actualmente el abanico se expande a distintas instituciones (museos, centros de arte, ferias, galerías, casas de subasta) y variados agentes como artistas, coleccionistas, críticos, comisarios, asesores, inversores, etc.

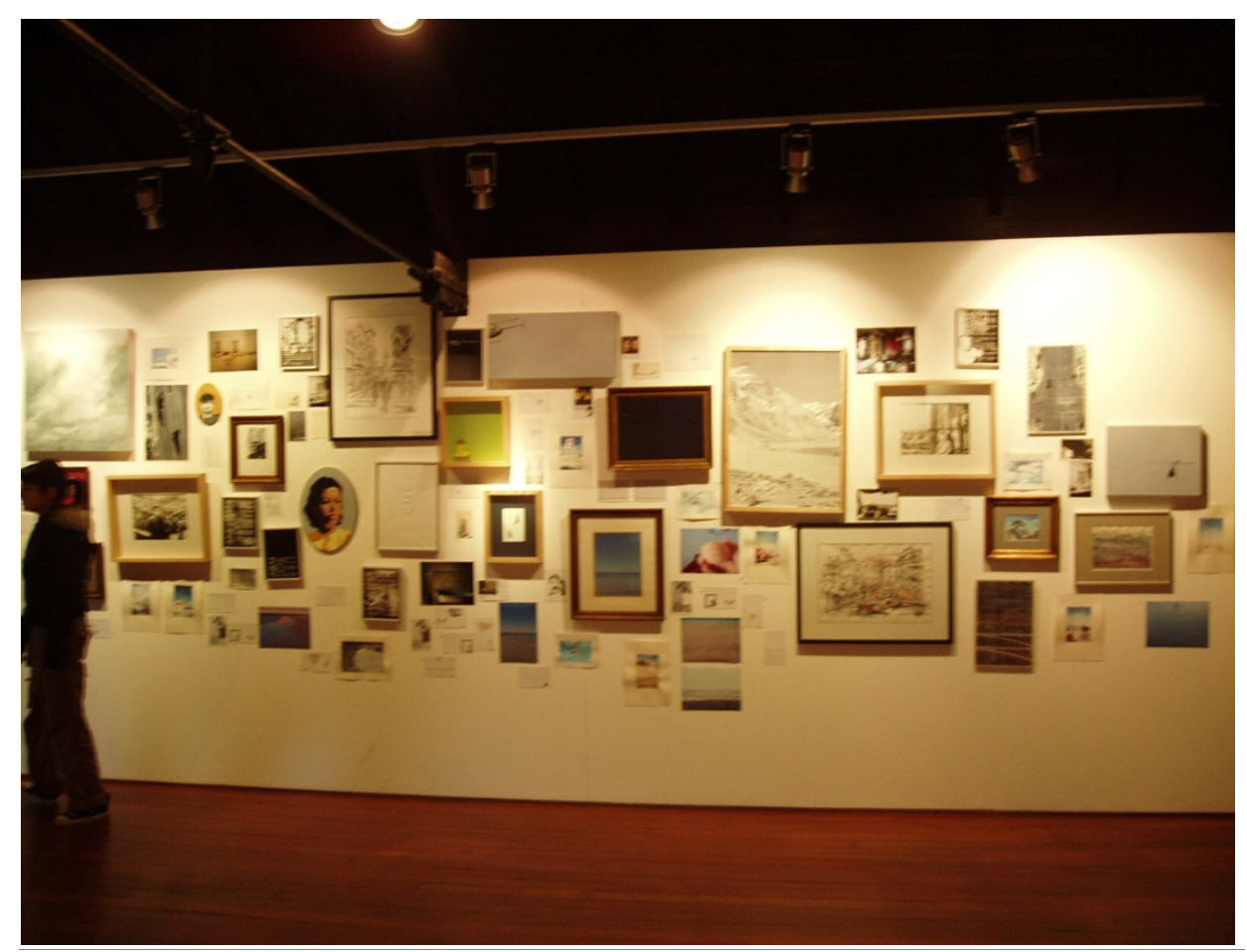

Figura 50: Exposición_de Ana Cardoso y co-autoria con Kasia Gubernat, My Life on sale, Caves Calém, Oporto. 2005.

En esta investigación no se pretende alimentar las polémicas comerciales existentes alrededor de las obras de arte, pero sí, ser consciente de los factores externos que pueden interferir en estas. Es cierto que hablar de mercado de arte implicaría, por supuesto, hablar de un mundo que tiene muy poco que ver con el arte, sus propuestas y objetivos son bien distintos de los fundamentos artísticos. Además la presencia de un mercado secundario tampoco facilita las cuestiones de autenticidad y 
protección de los bienes, por eso se necesita un sentimiento de autorresponsabilidad en el mundo del mercado del arte.

El mercado sufre cambios estructurales, fruto de la globalización y del incremento de notables recursos financieros, estando basado en un modelo tradicional de oferta y demanda en una relación de interés y rendimientos. Si hasta este punto de la investigación ha estado en el centro del estudio el bien cultural y artístico, como la manifestación contenedora de un valor incontrolable, en este punto de análisis continuará a tener ese papel destacado sin detener la reflexión en los valores económicos de las obras de arte y sus cotizaciones, que pueden variar grandemente de acuerdo con su base de valor y los valores intrínsecos, dictados por distintos factores como la importancia y papel del artista en la sociedad y la historia, así como, anche altri elementi obiettivamente riscontrabili nell'opera d'arte considerata come rarità dell'opera, presenza di firme, marchi, presenza di difetti, restauri ecc. ${ }^{170}$

Actualmente, se tiene la conciencia de que la obra de arte se hace valer por el nombre del artista, siendo imposible circular fluidamente en el mercado sin tener en cuenta, primordialmente, su paternidad, a la cual la valorización económica se establece como un misterio, dependiendo de la variabilidad del gusto y de la variabilidad histórica. Como tal, serán puestas de lado, las cuestiones económicas y de valorización monetaria, porque del mismo modo que no pertenece a la conservación/restauración definir lo que es o no arte, tampoco pertenece a su práctica establecer criterios de valorización mercantil. Las cuestiones principales pasarán por la necesidad de intentar establecer criterios de actuación coherentes sin que existan las malas interpretaciones no inocentes.

No hay duda que el acentuado desarrollo del coleccionismo y el progreso del mercado de arte internacional, han incrementado las intervenciones sobre las obras de arte. El coleccionismo intensificó los criterios esteticistas y combinados con los criterios históricos y de gusto, recogió actitudes poco correctas como las falsificaciones 0

170 SOBRERO, Maria Rosa. Aspetti econmici del collezionismo d'arte. en RICOSSA, Sergio (a cura di). I mercati dell'arte. Aspetti pubblici e privati, p.140.

T. A.: ...también otros elementos obviamente hallados en la obra de arte considerada como rareza de la obra, la presencia de firmas, marcas, la presencia de defectos, restauraciones, etc. 
restauraciones poco respetuosas, como por ejemplo en el coleccionismo anticuario. Pero la obra de arte vista como documento histórico y de valor artístico incalculable, frena o debería frenar los procesos de intervención y restauración. Lo cierto es que en el siglo XIX el mercado del arte tiene su papel bien definido a través del elevado tráfico de obras, donde el restaurador gana nuevo aliento, dado que es aquel individuo al cual se le atribuye la capacidad de recomponer la obra con facilidad y sin grandes recelos, para que ésta responda a las demandas del mercado y su posterior circulación.

Inoltre, solitamente, il collezionista non avendo un immediato interesse mercantile sull'oggetto che acqusisce, ha in alta considerazione il concetto di purezza dell'oggetto, e se il restauro è necessario lo esige assolutamente conservativo: questi criterri del collezionista influenziano anche il mercato ad alto livello, poiché gli oggetti non rispondenti ai canoni di integrità originaria saranno inesorabilmente refiutati anche dagli investitori puri.171

En la actividad de conservación/restauración siempre existió la necesidad de crear reglas y seguir normas, y no debería ser en presencia de los factores comerciales y económicos donde se quiebren tales intenciones. Es largo el camino del restaurador, cuando en pleno siglo XIX el mercado del arte ya había asumido su auténtico desarrollo, y en el cual el restaurador desempeñaba un papel fundamental delante de las obras que necesitaban sus tratamientos sin escrúpulos, pues

se restauran los soportes, se eliminan los barnices alterados y, en ocasiones, se eliminan los retoques, se camuflan las partes dañadas de la superficie pictórica e, incluso, a veces, se extraen varios cuadros de pequeño tamaño al desmembrar uno más grande y así poder venderlos con mayor comodidad y provecho. ${ }^{172}$

Los valores, económicos y comerciales, de una obra muchas veces superan la capacidad de valorarla como expresión y como bien cultural, puesto que actualmente la obra y el artista están dominados por otra valorización que no la meramente estética, apartando muchas veces el motivo principal de la existencia física del bien, el motivo por el cual ha sido creado. Los intereses de un marchante, de un coleccionista

171 SOBRERO, ob. cit. p.127-128.

T. A.: Además, por lo general, el coleccionista no tiene un inmediato interés mercantil sobre el objeto que adquiere, tiene en alta consideración el concepto de pureza del objeto, y si la restauración es necesaria la exige absolutamente conservativa: estos criterios del coleccionista influyen también en el mercado a alto nivel, porque los objetos que no se ajustan a los cánones de integridad original serán inexorablemente repudiados también por los inversores puros.

172 GONZÁLEZ-VARAS, ob. cit. p.251. 
0 de una casa de subasta no siempre miran hacia la autenticidad e integridad del bien cultural. Tal como existe una constante evolución en el arte, de las técnicas y los contenidos, también las necesidades sociales sufren cambios y éstos se reflejan en los gustos y nuevas exigencias, lo que consecuentemente puede conducir a comportamientos erróneos, donde hay que tener en cuenta que, la obra de arte es una e inalterable, y no puede vestirse con 'ropa' distinta según los dictados de la moda o de nuestros gustos. ${ }^{173}$ No siempre tales comportamientos son mal intencionados, pues las cuestiones de cambio de gusto forman parte de la propia estructura social, y las transformaciones que estos cambios sociales y culturales provocan en las obras de arte, también pasarán a formar parte de la instancia histórica de la misma. Son varios los ejemplos en la propia historia del arte que reflejan transformaciones muchas veces radicales por las cuestiones del gusto, y en estos casos la conservación/restauración no consigue frenar gran parte de estas manifestaciones sociales, puesto que también pertenece a ese medio y hay una imposibilidad de distanciamiento de la realidad. La cuestión no es querer justificar la presencia o no de los cambios de gusto y su reflejo en las obras de arte, la cuestión fundamental es saber hasta qué punto el mercado puede interferir en la autenticidad de los bienes culturales, cuando sus intenciones no son inocentes. En la actualidad se vive bajo otros criterios y exigencias, una madurez social y cultural resultante de todos estos años de historia, pero también hay más interferencias en la vida de las obras de arte.

A su debido momento, ya no quedaron escuelas 0 artistas que rescatar del olvido. En la actualidad, no hay olvido. Prácticamente todo lo que fue hecho en el pasado ha sido resucitado; (...).

De esta manera, los motivos desinteresados del estudioso van a la par que las intenciones del mercado de arte. Resucitar algo, estudiarlo e investirlo de pedigrí es convertirlo en vendible. ${ }^{174}$

¿Qué pasa hoy en día con las creaciones contemporáneas?, ¿Cuáles son las motivaciones actuales en presencia de tales transformaciones?, ¿Cuál es el papel del conservador/restaurador en este mundo comercial?

173 BALDINI, Umberto. Teoría de la restauración y unidad de metodología. Vol. 2, p.43.

174 HUGHES, Robert. A toda crítica. Ensayos sobre arte y artistas, p.463. 
Es necesario tener conciencia que son muchos los factores que juegan un determinado papel en el vasto círculo artístico, en que algunos elementos tienen más influencia sobre determinados aspectos que otros, como pueden ser las instituciones artísticas, y destacando las exposiciones temporales. Los museos también sufrieron cambios como consecuencia de la evolución social, cultural y artística, y en pleno siglo XXI son o intentan ser un acentuado centro de dinámica cultural, capacitado para acoger las más innovadoras y distinguidas creaciones, en una búsqueda incesante por la diferencia, lo nuevo y la mejor iniciativa.

Esta evolución espectacular a favor del arte contemporáneo ha resultado muy beneficiosa para mucha gente: primero para los marchantes, segundo para numerosos artistas que han podido alcanzar una rápida promoción, y tercero para el público que, quiérase o no, ha tenido mayor oportunidad de acercarse a la creación de su tiempo. ${ }^{175}$

Cambios que son y tienen muchos reflejos en varias áreas de acción, y que sin duda también tendrán su impacto en las cuestiones de conservación/restauración a través de una de las iniciativas más desarrolladas actualmente como son las conocidas y desenfrenadas exposiciones temporales, un fenómeno contemporáneo con consecuencias determinadas. Como resultado de una sociedad de ritmo frenético, hay que crear vínculos comerciales y experiencias rápidas y eficaces para que no deje de existir parte de las transacciones que son muchas veces las bases de un arte. Casi como iniciativa mercantil, surgen las exposiciones también ellas efímeras y caducas, pero con grandes consecuencias físicas para los bienes culturales y artísticos. Hechos a evitar como serán los daños causados por el transporte, traslado, constantes movimientos y dislocaciones de las obras requeridas para exposiciones espectaculares, llamativas y efímeras en diversos puntos del mundo. No obstante restaurar implica tener en cuenta las características de la obra y ante todo el concepto que a ella se vincula, dependiendo de su contemplación y valoración, además de las características intrínsecas, están las características del espacio y su entorno. Estos aspectos no podrán quedar de lado, cuando las dimensiones físicas del objeto determinan las condiciones mínimas para su adecuada exhibición, siendo este uno de los grandes motivos que justifica la elaboración de entrevistas a los artistas, pues

175 UBERQUOI, Marie-Claire. ¿El arte a la deriva?, p.111. 
ellos, más que nadie, tienen una idea clara de cómo relacionar su obra con el espacio expositivo y con el espectador.

Es cierto que con el arte siempre ha estado asociado un valor económico, pero ni siempre la obra de arte fue vista bajo un proceso de comercialización o como pura mercancía, ni siempre la obra ha sido motivo de interés por su posible valoración económica en un futuro, ni tampoco ha formado parte de un panorama de inversión para sumar provechos. Pero el hecho de que se trata de un objeto único, venerado y que funciona como un icono social y cultural, original y auténtico, hace de esta transacción una inversión asegurada. Hasta aquí todo parece normal, independientemente de si uno está de acuerdo o no con este panorama, pero así se asume el arte y también es este el medio en el que subsiste. El problema se plantea cuando este negocio interfiere en las instancias de la obra, en las cuales el restaurador/conservador tiene un papel fundamental bajo su ética de trabajo.

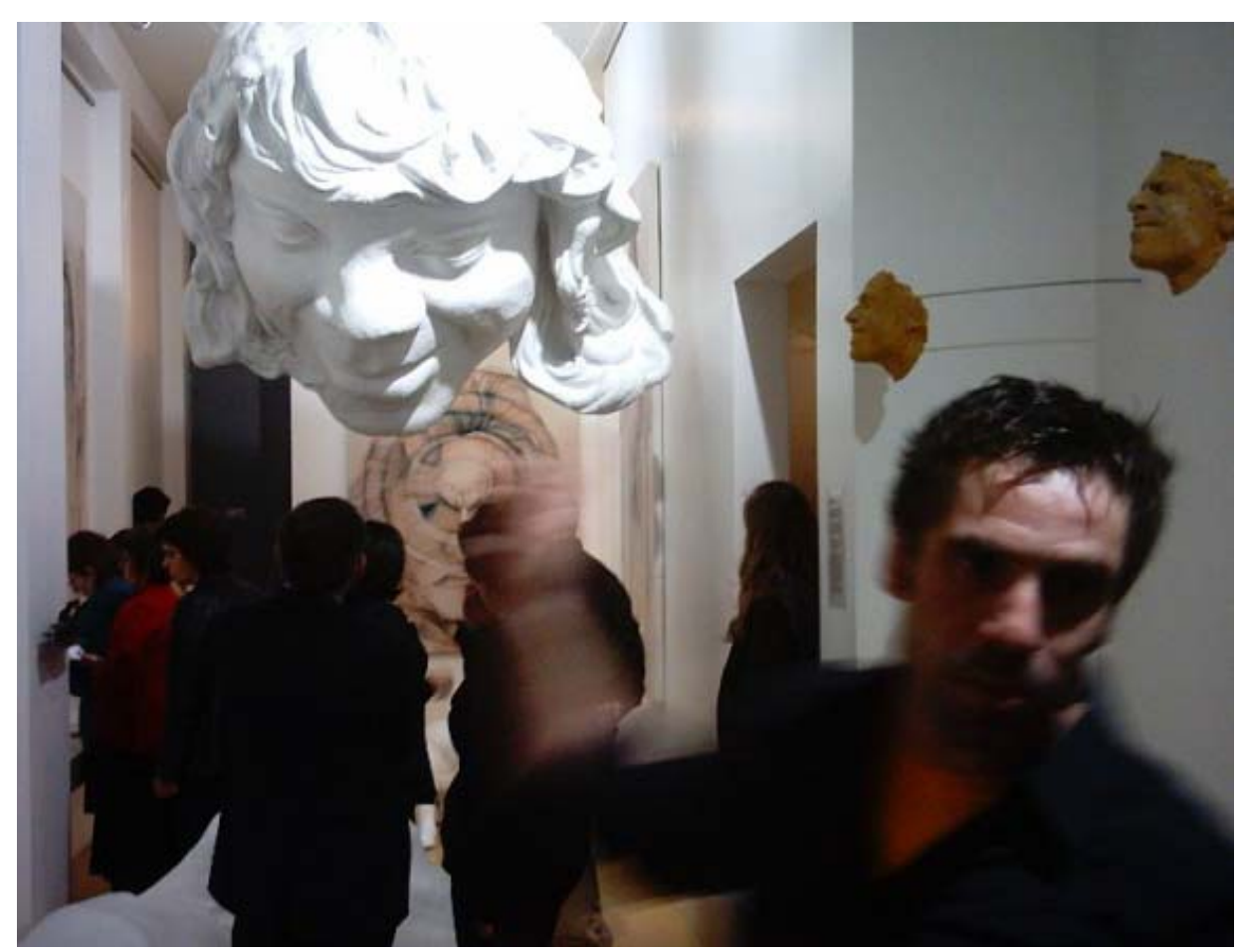

Figura 51: João Pedro Rodrigues en la inauguración de la exposición conmemorativa del $1^{0}$ cumpleaños de su galería, 2008. 
Son muchas las cuestiones que se pueden plantear alrededor del extenso mundo del mercado del arte, pero quizás, será clave la siguiente cuestión: ¿Al final, en qué influye el mercado del arte en la actividad de conservación/restauración?

La respuesta ideal sería, que el mercado del arte no influye de ninguna forma sobre la conservación/restauración. Una postura con gran carga de inocencia, puesto que es imposible vivir al margen de tan fuerte mecanismo, y desde la creación del mercado, siempre en la historia de los bienes culturales y artísticos han estado presentes tales influencias. Son varios los hechos que van contra lo que sería el ideal, el respeto máximo por la obra, cuando realmente la actividad de conservación/restauración también se inserta en el propio medio mercantil. Si en tiempos pasados el arte podría vivir al margen de las exigencias mercantiles y de un marketing realmente controlado y estudiado, hoy el propio artista y su obra son piezas fundamentales para su desarrollo, o visto de una forma más drástica, pero no muy lejos de la realidad, el mercado es un elemento indispensable para el constante crecimiento y novedad en el campo artístico y estético. Si es la palanca para accionar parte del sistema creativo, también se podrá ver como una influencia negativa, siempre y cuando se ponga por encima de los valores artísticos y estéticos, en los cuales el coleccionismo adquiere un papel fundamental.

La spiegazione è tutta interna al fenomeno del collezionismo, da alcuni ritenuto una manifestazione di cultura, da altri un fenomeno di paranoia, mentre nella sostanza è soprattutto un investimento sul valore artistico di particolari opere, sul loro valore ideologico, sull'aumento nel tempo del loro valore venale.

In parole crude: è un fenomeno con consistenti aspetti speculativi. Ed è per questo, secondo me, che il collezionista diventa anche il conservatore, cioè colui che in tutti modi, anche con il restauro, si oppone al consumo e al disfacimento degli oggetto da lui raccolti, cerca cioè di allungarne la resistenza il più a lungo possibile. ${ }^{176}$

Las palabras de Alberto Biasi, presentan parte de lo que engloba el mercado de arte asociado al coleccionismo. Pero también, es necesario ser consciente de que el

176 BIASI, Alberto. Si restaura l'arte d'oggi. Che bello! en AA. VV. Arte contemporanea. Conservazione e restauro, p.157. T.A.: La explicación es toda interna al fenómeno del coleccionismo, algunos consideran una manifestación de cultura, otros un fenómeno de paranoia, mientras en la sustancia es sobre todo una inversión sobre el valor artístico de particulares obras, sobre su valor ideológico, sobre el aumento en el tiempo de su valor venal. En palabras crudas: es un fenómeno con consistentes aspectos especulativos. Y es por esto, según yo, que el coleccionista llega a ser también el conservador, es él quien de todos modos, también con la restauración, se opone al consumo y a la degradación del objeto de su colección, que busca alarga la resistencia lo máximo posible. 
coleccionista preocupado por conservar su colección puede promover un proceso erróneo en el propio ciclo evolutivo de las obras que posee, o de otra forma, puede exigir ciertos procedimientos en un objeto que le pertenece, por lo cual lleva a pensar que no es consciente de que la obra posee protección bajo los derechos morales y del autor.

La indeterminación de algunas de las creaciones contemporáneas podrá llevar a segundas interpretaciones. Como fue visto anteriormente, si por un lado existen obras en que el material es únicamente un medio físico, esto no implica la generalización de comportamientos e intervenciones. Más bien, ayuda a comprender la diferencia de cada propuesta artística y percibir la inmensa importancia del mensaje intrínseco de cada obra. Como es ejemplo el arte conceptual, donde prevalece la actitud mental en un proceso evolutivo, una ambigüedad creativa que entra en el mercado del arte, y vive en él. A pesar de parecer contradictorio, este tipo de creaciones saben sobrevivir en él, se ajustan para alcanzar, también ellas, una elevada cotización y lo pueden hacer de distintas formas. El objetivo artístico de destrucción matérica y su auge evolutivo con el fin de la obra, no es por sí sólo la negación a la comercialización. Lo cierto, es que la presencia ambigua de muchas de las creaciones, y las constantes mutaciones y despreocupaciones por parte de artistas o propietarios a favor de lo mercantil, genera una falsa facilidad en el control de la actividad de la conservación/restauración ante determinados factores materiales. Y aquí, cuando se refiere a la actividad de la conservación/restauración, esto no implica que las personas que desarrollan tal actividad sean única y simplemente los conservadores/restauradores, hay que añadir la presencia del artista, no sólo como creador sino como un agente envuelto en diversas cuestiones como el mantenimiento, la conservación e incluso misma la restauración de su obra; cuestión fundamental en esta investigación, la cual se desarrollará con más consistencia.

Hay necesidad de concretar ideas y buscar las influencias que posiblemente pueden desarrollar un papel en la actividad del conservador/restaurador, lo que implicará hablar y esclarecer algunos conceptos que unen ambos campos, puesto que los fenómenos anteriormente citados y las características de determinadas obras, pueden llevar a la creación indeterminada de falsos históricos y/o artísticos. En busca de 
respuestas, palabras como copia, imitación, réplica, facsímiles, múltiples, falsificación, reproducción, reconstrucción, restablecimiento y restitución, deberán ocupar un lugar destacado en un estudio teórico sobre conservación/restauración, y con mayor evidencia percibir lo que significa cada una de estas acciones frente al arte contemporáneo. En los capítulos anteriores la intención de la investigación está centrada en resolver cuestiones teóricas y conceptuales de forma a no crear errores de interpretación, pero en esta fase la preocupación es otra: la cuestión ya no queda cerrada en las posibles malas interpretaciones de un mensaje artístico, sino a la consecuencia de esa mala lectura de la obra que desarrollará posiblemente una mala intervención.

Pero está claro que para llevar a cabo una actuación correcta es necesario primero leer críticamente la obra tal y como queda después del acto filológico. (...) Pero entre realizar una reconversión que sería inaceptable y condenar a muerte algo que aún vive y que puede seguir viviendo hay un abismo. ${ }^{177}$

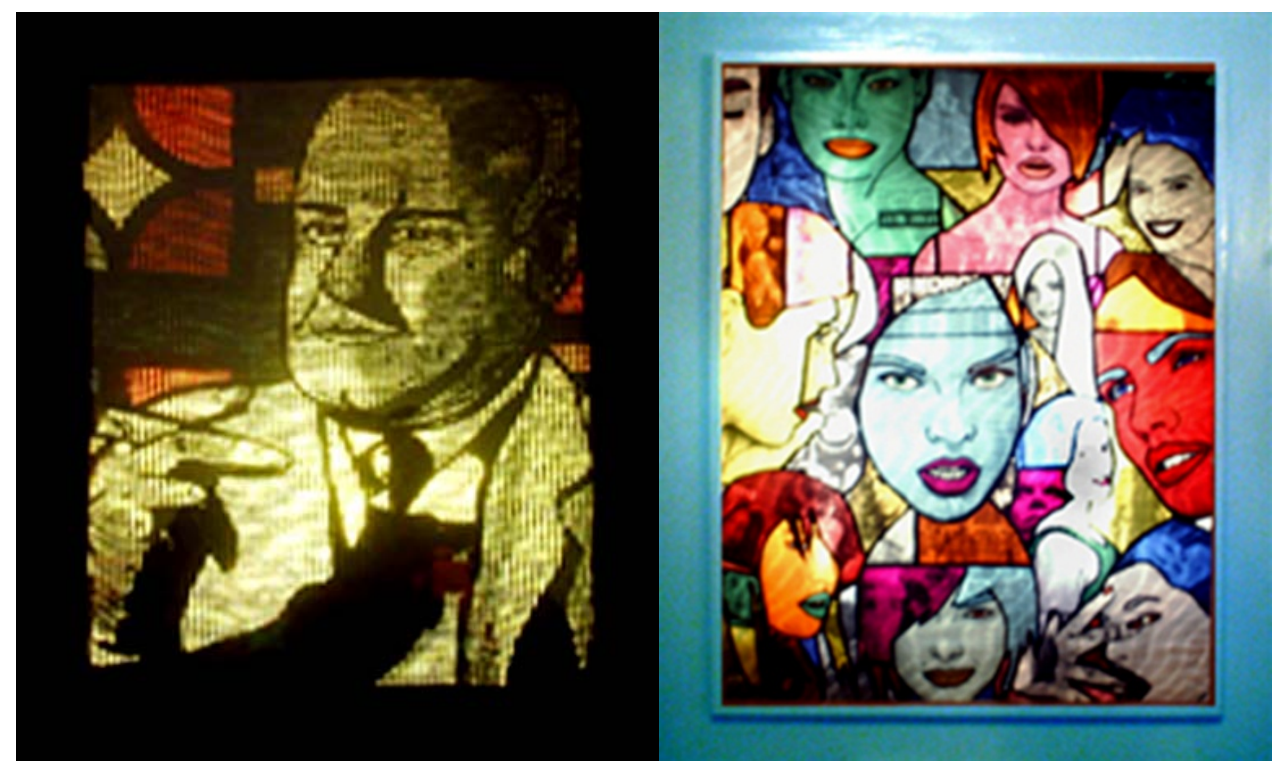

Figura 52: Rui Pedro Fonseca, instalación Mr Pat, 2005. Caja de luz con imágenes, 44,5×32x17cm. Figura 53: Rui Pedro Fonseca, instalación Composition X, 2005. Caja de luz con imágenes.

177 BALDINI, Umberto. Teoría de la restauración y unidad de metodología. Vol. 1, p.60-61. 
En general, una mala intervención puede ser resultado de dos factores: uno, la mala interpretación de la obra que proviene de la falta de información y de documentación; y segundo, la formación insuficiente por parte de quien realiza la intervención. Todavía, existe la necesidad de plantear la hipótesis y considerar que se halla un tercer factor que puede derivar en una mala intervención, y que no es desde luego inocente: aquella intervención que intenta ocultar el paso del tiempo y al cual están asociados muchos procedimientos, y que posteriormente se intentará ejemplificar. A pesar de la posibilidad de que todo es una cuestión de concepto, hay que saber distinguir cada acción, pues con el arte contemporáneo es muy sencillo seguir un camino equivocado.

Siempre existieron, y estarán presentes, las malas interpretaciones o la tentativa de ocultar daños, prejuicios y determinados momentos en el tiempo de vida de la obra, pudiendo este hecho consistir en la creación de una falsificación. Con el arte contemporáneo pueden surgir varias cuestiones asociadas a éste y otros conceptos que parecen quedar olvidados, o en pensamientos que vacilan entre dudas. Como en páginas anteriores, también en este punto hay la necesidad de esclarecer conceptos para que las dudas queden lo más lejanas posible. Lo cierto es que creaciones tan heterogéneas y muchas veces ambiguas pueden ofrecer un camino poco claro ante ciertas intervenciones. Y hablar de intervención en arte contemporáneo, implica referir que ésta también puede ser desempeñada por el propio artista, factor determinante en este estudio y para el cual existe la necesidad de encontrar límites de actuación en el contexto de conservación/restauración.

El hecho de que las obras se degraden rápidamente y a un ritmo muchas veces indeseado, conciliado con la cuestión de que en gran parte de los casos el artista está vivo y puede llegar a intervenir sobre su obra como forma de resolver una situación de deterioro, puede acabar siendo algo que no va al encuentro de lo que posiblemente está acreditado, según las bases teóricas de conservación/restauración. Si en tiempos pasados se hablaba de las cuestiones de copias, imitaciones, falsificaciones 0 réplicas, hechas por terceros, con interés únicamente mercantil, hoy el interés se ha acentuado muchísimo más, pero puede que parte de esos términos sean utilizados no 
en función de una actividad realizada únicamente por terceros sino también por el propio artista.

En este sentido, se inicia el estudio y análisis genérico de algunos conceptos esenciales para la comprensión y esclarecimiento de dudas. Cuando se habla de obra de arte se parte del principio de que es un objeto resultante de la invención de un artista, luego un objeto original.

Mesmo na reprodução mais perfeita, um elemento está ausente: 0 aqui e agora da obra de arte, sua existência única, no lugar em que ela se encontra. (...)

O aqui e agora do original constitui o conteúdo da sua autenticidade e nela se enraíza uma tradição que identifica esse objecto, até aos nossos dias, sendo aquele objeto, sempre igual e idêntico a si mesmo. ${ }^{178}$

Comúnmente se dice que un original es un objeto singular de un autor, e intrínsecamente esta definición cohabitan las denominaciones de reproducción y copia. Considerar algo original, hace referencia al origen de algo 0 su comienzo 0, por otra parte, refiere algo de lo cual fue realizada una copia o reproducción. El hecho de que sea un objeto original lo hace auténtico, o sea, la autenticidad es un valor intrínseco a un objeto, una cualidad que resulta del respeto de la instancia histórica a través de la autenticidad material, y el respeto por la instancia estética que se ciñe a la autenticidad conceptual.

A autenticidade de uma coisa é a quintessência de tudo o que foi transmitido pela tradicção, a partir de sua origem, desde sua duração material até o seu testemunho histórico. ${ }^{179}$

De otra parte, si se habla de original hay necesidad de referir, que no está implicada la idea de que este objeto sea ejecutado por el propio artista, pues tal como figuran varios ejemplos en la historia del arte contemporáneo, las obras ejecutadas por terceros, son de la misma forma objetos originales y auténticos.

${ }_{178}$ BENJAMIN, Walter. A obra de arte na era de sua reprodutibilidade técnica. en Magia e técnica, arte e política, p.167. T.A.: Incluso en la reproducción más perfecta, un elemento está ausente: el aquí y ahora de la obra de arte, su existencia única, en el lugar en que ella se encuentra. (...) El aquí y ahora del original constituye el contenido de su autenticidad y en ella se enraíza una tradición que identifica ese objeto, hasta nuestros días, siendo aquello objeto siempre igual e idéntico a sí mismo.

179 Ibídem. p.168.

T.A.: La autenticidad de una cosa es la quinta esencia de todo lo que fue transmitido por la tradición, a partir de su origen, desde su duración material hasta su testimonio histórico. 
Existen, por tanto, tres posibles hipótesis en la relación entre el creador de la concepción plástica y el ejecutor: 1) que el creador de la concepción no haya sido relevante para la originalidad de la obra: el autor será el ejecutor que aporta la originalidad y concreta una concepción plástica que no lo era suficientemente como para considerarse individual; 2) que sea el ejecutor el que es irrelevante para el resultado final: en este caso, la ejecución es meramente material, y el autor es el creador de la concepción plástica; 3) un tercer caso, en el que la ejecución personal toma como punto de partida una concepción suficientemente concretada para ser protegida. ${ }^{180}$

O sea, independientemente de cómo ha sido concretado y de lo que puede en un futuro consistir, es este objeto, considerado el objeto original, el cual podrá dar origen a posibles o posteriores réplicas, copias, imitaciones o falsificaciones.

Desde el punto de vista jurídico, tienen la calidad de originales todas las obras de un escultor que sean consecuencia de un proceso de reproducción y edición, incluido el modelo original que sirvió para la ejecución en materia definitiva de estos nuevos ejemplares, aunque para confirmar dicha condición deberán estar firmados y acompañados del quebrado que acredite las condiciones de la edición de cada pieza. ${ }^{181}$

Por otra parte, por reproducción se puede entender cualquier objeto que resulta del acto 0 efecto de producir. En contrapunto al original, lo que se entiende por reproducción o repetición industrial de una obra de arte, normalmente con fines sociales, de forma a volverse accesible a la sociedad un bien considerado de lujo, además de asociado a los fines comerciales, como es descrito por Walter Benjamin en la siguiente cita:

Em sua essência, a obra de arte sempre foi reprodutível. O que os homens faziam sempre podia ser imitado por outros homens. Essa imitação era praticada por discípulos, em seus exercícios, pelos mestres, para difusão das obras, e finalmente por terceiros, meramente interessados no lucro. ${ }^{182}$

De forma sencilla, reproducir es volver a producir o producir de nuevo, siendo una copia de la obra, independientemente del tamaño, material, y procedimientos de producción. Como también figura en el Diccionario del arte y de los artistas,

180 BERCOVITZ, Germán. Obra plástica y derechos patrimoniales de su autor, p.140.

${ }^{181}$ SAURAS, Javier. La escultura y el oficio del escultor, p.315

182 BENJAMIN, ob. cit. p.166.

T.A.: En su esencia, La obra de arte siempre fue reproductible. Lo que los hombres hacían siempre podría ser imitado por otros hombres. Esa imitación era practicada por discípulos, en sus ejercicios, por los maestros, para la difusión de las obras, y finalmente por terceros, meramente interesados en el lucro. 
reproducción es la copia de una pintura o un dibujo, realizada por algún procedimiento que haga posible su impresión en un gran número con el fin de popularizarla183. Según la actividad de conservación/restauración, se puede hablar de la realización de reproducciones para colocar en su ubicación original (...) y mantener los originales en condiciones de conservación adecuadas de protección y climatización ${ }^{184}$, o por otra parte, considerada como una réplica de una obra con el objeto de poder trasladar el original a un lugar más idóneo para su conservación ${ }^{185}$, definiciones éstas también asociadas al concepto de copia.

Es evidente que se está en presencia de diferentes definiciones de reproducción, teniendo en cuenta el área de actuación. La presentada por Javier Sauras se refiere a los bienes escultóricos, que por sí sólo tiene características precisas, además de las otras dos definiciones que abordan el concepto sobre la base de conservación/restauración. Es necesario percibir que el propio uso de determinadas palabras puede traicionar las definiciones, como la presentada en el Diccionario de restauración y diagnostico. Una vez que por réplica se entiende la copia realizada por el propio artista, o bajo su supervisión o dirección, lo que podrá conducir a una idea errónea del acto de reproducir, una vez que no es la réplica la única forma de reproducción. Con otras palabras y referente a objetos escultóricos, Javier Saura define la réplica como un traslado en el que los resultados no suelen ser idénticos, pues lo usual es que se haga de un material a otro diferente, e incluso que se varíen algo las dimensiones de la copia respecto al original, mediante ampliación o reducción. ${ }^{186} \mathrm{El}$ diccionario de la Real Academia Española, define sucintamente la réplica como la copia de una obra artística que reproduce con igualdad la original, y en Conservación y restauración. Materiales, técnicas y procedimientos. De la $A$ a la $Z$, réplica es la copia exacta de una pintura o escultura, hecha por el propio artista ${ }^{187}$, definición idéntica a la presentada en el Diccionario de términos de arte, pero el cual añade que esa copia exacta deberá ser realizada por el propio artista o bien bajo su inmediata supervisión, con frecuencia tan semejante a su modelo que es imposible decir cuál de las dos ha sido

\footnotetext{
${ }^{183}$ READ, Herbert (editor asesor). Diccionario del arte y de los artistas, p.305.

${ }_{184}$ CALVO, Ana. Conservación y restauración. Materiales, técnicas y procedimientos. De la A a la Z, p.191.

185 Diccionario de restauración y diagnostico, p.176

${ }^{186}$ SAURAS, Javier. La escultura y el oficio del escultor, p.338.

${ }^{187}$ CALVO, ob. cit. p.190.
} 
realizada primero. ${ }^{188}$. O sea, en conclusión con base en las cuatro definiciones, réplica es sin duda una reproducción, que deberá ser hecha por el propio autor del original 0 bajo su supervisión, pero desde luego implicando la existencia de un objeto previo considerado como la primera realización.

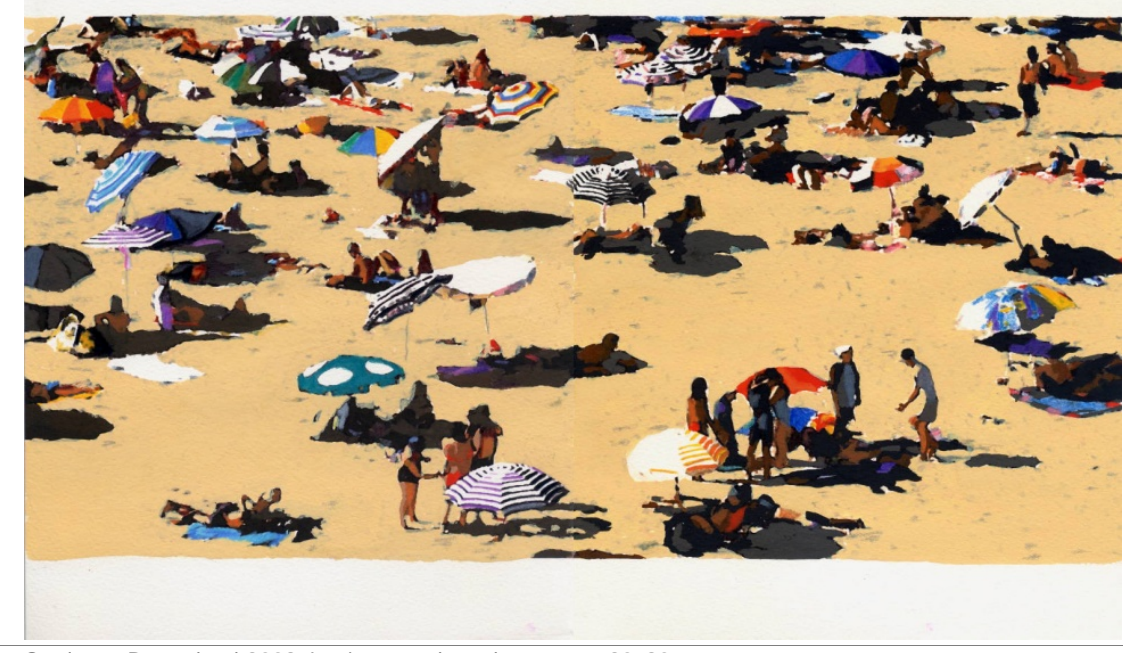

Figura 54: Ana Cardoso, Dreamland, 2008. Lápiz y guache sobre cartón, 20x30cm.

Y en este sentido, es necesario hablar del concepto de copia, entendido, en general, como la reproducción fidedigna de una obra, con objetivos didácticos, o como substitución de piezas que pueden resultar dañadas con su exposición, que coincide con la primera definición de reproducción presentada anteriormente, o sea, la copia es siempre una reproducción, realizada por otra mano que no la del artista. De forma clara en el diccionario de la Real Academia Española, se define copia como la imitación de una obra ajena, con la pretensión de que parezca original. Más que imitación, la copia es una reproducción, y en ese sentido, Ana Calvo en su libro presenta la copia como la reproducción de una obra de arte, realizada por otra mano diferente a la del autor ${ }^{189}$. O sea, supuestamente se podrá entender por copia y por réplica reproducciones fidedignas, en que únicamente existe la diferencia entre la réplica y la copia por la presencia, ejecución o autorización del autor. La réplica tampoco tendrá

188 MONREAL y Tejada, Luis y HAGGAR, R.G. Diccionario de términos de arte, p.349.

189 CALVO, ob. cit. p. 66. 
de distinguirse del original como una reproducción de determinado objeto, y la copia es la reproducción fiel de una obra pero hecha por otro autor que no el propio artista. Lo que también difiere de la versión, cuando por ésta se entiende, el objeto realizado por el propio artista como una variante de la obra original.

Abriendo un paréntesis en este tema, ya la curiosidad de hablar de los términos de reproducción y copia bajo las nociones jurídicas, íntimamente conectadas a los Derecho de autor (que posteriormente serán presentados y analizados). Por ello, es el autor que posee la exclusiva sobre la reproducción de su obra, en que hay que citar que normalmente los términos reproducción y copia son usados como sinónimos ${ }^{190}$, consistiendo en la fijación, independientemente de forma, medio, intención, etc., para la percepción de la obra, y en este sentido, habría dos tipos de reproducción: la reproducción de la obra como tal bien inmaterial, y la reproducción del objeto plástico mismo, que conllevaría la reproducción de una ejecución artística concreta ${ }^{191}$. Jurídicamente se analiza esta cuestión de la siguiente forma:

La obra inicial o bien se reproduce, o bien se transforma; 0 es la misma o es otra distinta. (...) en una ejecución plástica concreta concurren frecuentemente tres elementos: concepción, ejecución, y «aura». Si se exigiese la permanencia de los tres, nunca habría reproducción, y habría que dar la razón aquellos que sostienen que la obra plástica no es reproducible (...), porque las copias no serían equivalentes al original; normalmente se perderá el elemento de «aura». Si exigimos que permanezcan al menos concepción y ejecución, entonces solamente podremos calificar de auténticas reproducciones las que sean mecánicas (fotográficas por ejemplo). ${ }^{192}$

Y se añade:

(...) la transformación asume distintos niveles, es gradual. Si se mantiene la concepción plástica, pero se transforma, sustituyendo la ejecución (por ejemplo, en el caso de copia de un cuadro por otro pintor), entonces, como hemos expuesto anteriormente, la situación es similar a la de una nueva ejecución musical de la misma obra. En realidad se produce una

190 Si clarifica esta idea con la siguiente cita: el mismo original plástico sería una copia: la copia original. en BERCOVITZ, Germán. Obra plástica y derechos patrimoniales de su autor, p.222.

191 BERCOVITZ, ob. cit. p.222.

192 Ibídem. p.257-258. 
curiosa dicotomía: una obra será al mismo tiempo reproducción (de la concepción plástica) y nueva creación (de la ejecución). ${ }^{193}$

La doctrina, también abarca el tema de las réplicas como un tipo de reproducciones particulares, creadas por el propio autor a través de una nueva ejecución, citando:

Ciertamente las réplicas tienen en común con la obra original una afinidad en cuanto al «aura», al corresponder al mismo artista; sin embrago, no consideramos que exista diferencia sustancial del régimen jurídico de estas obras que justifique la distinción. Se trata de ejecuciones distintas de la propia obra, aunque el ejecutor sea el mismo. ${ }^{194}$

Desarrollando un poco más este tema, hay que hablar de otros dos conceptos. Por un lado el facsímil, que es la reproducción lo más fiel posible de un libro o documento, hecha para divulgar y facilitar el estudio del original, o en otro sentido, un objeto será considerado facsímil cuando consiste en una perfecta imitación o reproducción de una firma o dibujo para su difusión ${ }^{195}$, por otras palabras, es una obra de arte que no es ejemplar único, sino que de ella se ha hecho una edición limitada y casi siempre numerada: grabados, serigrafías, esculturas fundidas, cerámicas, etc. ${ }^{196}$, los cuales se diferencian de la repetición que, por ejemplo, es una pintura que un artista realiza reproduciendo otra de su misma mano, sin introducir variaciones de importancia. ${ }^{197}$ Por otro lado, los múltiples, que son los objetos multiplicados por el propio autor, resultado de la posibilidad que algunas obras de arte ofrecen de ser multiplicadas, como son ejemplo los grabados y las esculturas, sin que este hecho ponga en cuestión el valor creativo del múltiple, y que influyen únicamente en su valor comercial. Se trata de obras a las que no se les puede negar el mismo valor expresivo del original. Basta pensar en los múltiples bronces realizados por un artista utilizando el mismo molde, o en las "tiradas" de un mismo grabado. 198

Por último, y sin quedar muy claro está la imitación, que consiste en la creación de una obra según un principio de semejanza a un determinado objeto original, difiriendo de la falsificación y de la copia, a la vez que la falsificación puede ser una imitación

\footnotetext{
193 BERCOVITZ, ob. cit. p. 258.

194 Ibídem. p.223-224.

195 CALVO, ob. cit. p.99.

${ }^{196}$ MONREAL y Tejada, Luis y HAGGAR, R.G. Diccionario de términos de arte, p.272.

197 Ibídem. p.348.

198 BALDINI, Umberto. Teoría de la restauración y unidad de metodología. Vol. 1, p.53.
} 
cuando se hace pasar por original, al cual el Diccionario de términos de arte define trabajo que procura reproducir con mayor exactitud posible las formas y maneras de una obra de autor o estilos ajenos. Si la imitación se hace con propósito de engaño, es una falsificación. ${ }^{199}$

La falsificación tiene un proceso idéntico a la reproducción, a la copia o a la imitación, pero la intención con la cual es realizada es lo que la distingue de las otras acciones, esto ocurre porque no se limita a copiar sino a simular todas las características del objeto original. No hay duda que lo que define el acto de falsificación es el modo fraudulento con que se ejecuta un objeto, lo que normalmente sucede con fines comerciales, y según la intención de hacerlo pasar por auténtico, teniendo en cuenta el autor, época y periodo, así como también no suscita cualquier duda, de que lo que la hace diferente de la imitación es la predisposición para asumir determinada intención. Pero tampoco cabe duda, que tal como pasó con el arte antiguo y moderno, lo mismo pasa con el arte contemporáneo, y lo que hace proliferar las falsificaciones es sobre todo la importancia que los objetos adquieren con su comercialización, debido a los valores económicos incrementados por el sistema capitalista, el coleccionismo y la especulación, puesto que falso es la obra de arte que con engaño y ánimo de lucro se atribuye a una época o autor que no le corresponde, pues su apariencia ha sido lograda mediante manipulaciones maliciosas. ${ }^{200}$

En el Apéndice 1 de la Teoría de la Restauración, dedicado en exclusivo al tema de la falsificación, Brandi intenta aclarar esta cuestión, partiendo de la premisa que el concepto de falsedad habita en un juicio y no en el objeto por sí sólo, pues como objeto (incluso una imitación o una falsificación) posee las mismas calidades que el objeto original, o sea, es una falsificación o imitación de acuerdo con la intencionalidad que justificó su producción y posterior comercialización. También en la Teoría se explica que la diferencia entre copia, imitación y falsificación no pasa por los modos de producción sino en la intención de la misma. Las tres acciones, independientemente de la intencionalidad (con que se caracteriza la falsedad de un objeto), son resultado de una acción humana con características precisas de acuerdo

199 MONREAL y Tejada, Luis y HAGGAR, ob. cit. p.207.

200 Ibídem. p.165. 
con la sociedad y época en que está inmersa, presentando también estos objetos una historicidad y informaciones importantes sobre la historia y la sociedad.

Por lo tanto, la copia, la imitación la falsificación reflejan la facies cultural del momento en que se realizaron, y en este sentido gozarán de una historicidad que se podrá considerar doble, por el hecho de haber sido ejecutadas en un determinado tiempo y por el hecho de contener inconscientemente en sí mismas el testimonio de las predilecciones del gusto, de la moda de esa época. ${ }^{201}$

Y para complementar esta cuestión, Brandi presenta los siguientes ejemplos, en que el primero se refiere a la copia e imitación, y el segundo y tercero se refieren a la falsificación, demostrando que en cada caso concreto hay la posibilidad de distinguir entre el falso histórico del artístico, pero que este último (falso artístico) siempre será un falso histórico porque toda la obra de arte representa un momento determinado en la historia.

1. realización de un objeto a semejanza o como reproducción de otro objeto, a la manera o en el estilo de un determinado período histórico o de determinada personalidad artística, sin otro fin que una documentación del objeto o el placer que se supone obtener de ello;

2. producción de un objeto como el anterior, pero con la intención especifica de llevar a alguien a engaño acerca de la época, la consistencia material o el autor;

3. introducción en el comercio, o también difusión de un objeto, aun que no haya sido realizado con intención de llevar a engaño, como una obra autentica, de época, de materia, de fabricación, o de autor diferentes a los que realmente son propios del objeto en sí. 202

Las definiciones están dadas genéricamente, para que sea hecha una reflexión más práctica, con base en los criterios de conservación/restauración en reflejo de las creaciones contemporáneas y de las cuestiones que se pueden plantear alrededor de estos conceptos. Un caso que parece necesario plantear en este estudio es el hecho de la reproducción hecha por el propio artista. Partiendo de estos datos y según las definiciones anteriores, esta reproducción puede ser entendida como una réplica, un múltiple o posiblemente una versión, dependiendo del proceso que ha seguido el trabajo. Para que sea réplica tendría que ser una reproducción exacta hecha por el propio artista. Para que sea considerado múltiple, éste tiene que diferenciarse del original por la posibilidad de la presencia de un número de serie (en que ambos serán copia), y para que sea una versión tendría que ser una derivación de la obra original.

201 BRANDI, ob. cit. p.66-67.

202 Ibídem. p.66. 
Tal vez la forma más sencilla de encontrar una respuesta sea a través del planteamiento de ejemplos.

El concepto de copia (que deja de lado una intención fraudulenta) no parece presentar grandes dudas, cuando es conocido su papel en diversas situaciones. Si por un lado es una práctica académica como ejercicio de la enseñanza, por otro, puede estar representada por el objeto en una colección o exposición, que sustituye el original por motivos de conservación preventiva del mismo, de valor indiscutiblemente superior que el presente en la exposición. Si por casualidad este proceso llega a ser desarrollado por el propio artista, el resultado será una réplica la cual igualmente están asociados los valores de ambas las instancias, o si por señal el artista no lo asume como réplica o simple copia, será seguramente un falso.

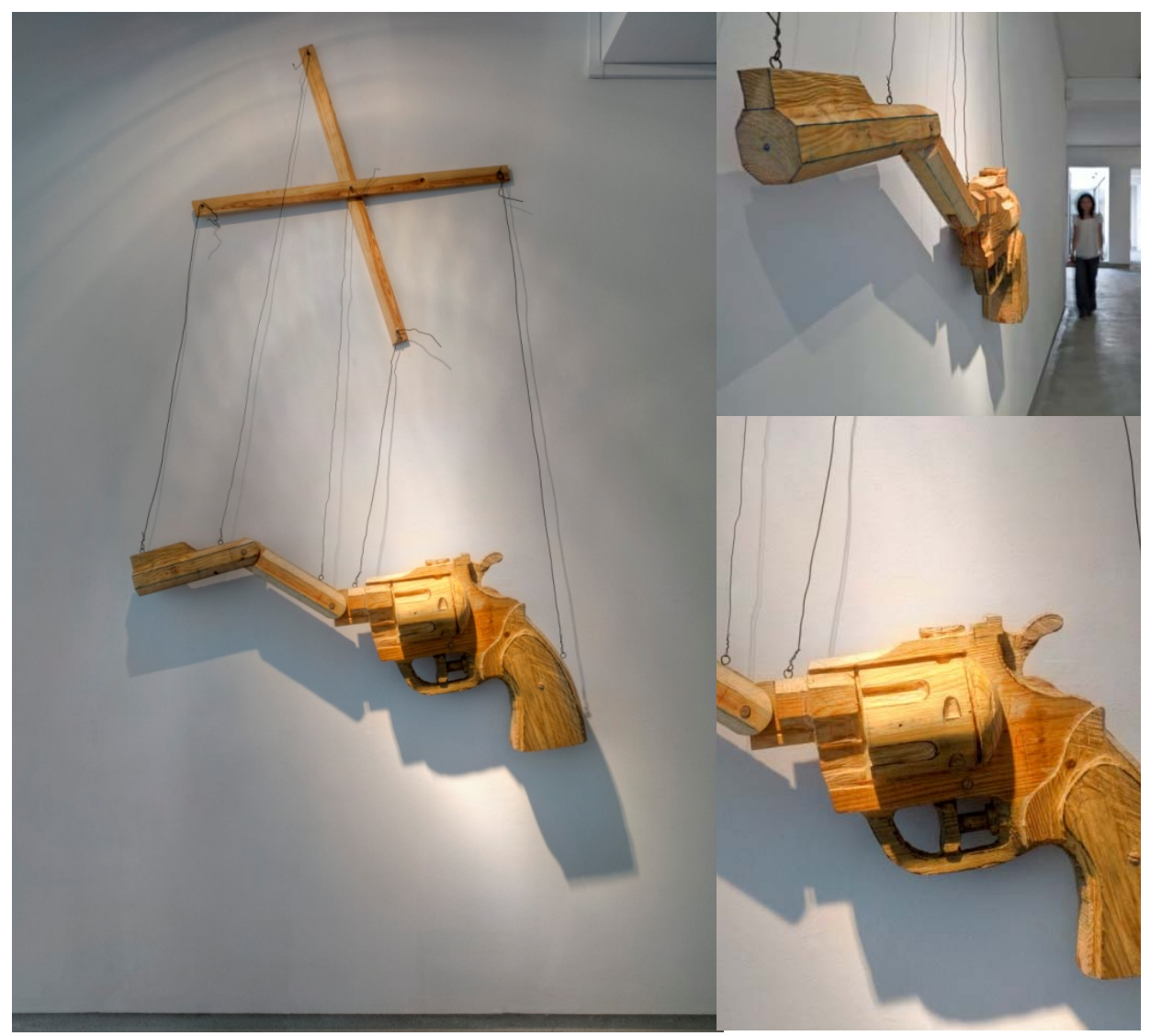

Figura 55: Isaque Pinheiro, escultura Em cima da Terra debaixo do Céu, 2008. Madera y acero, 200x125x18cm. Figuras 56 y 57: Detalles de Em cima da Terra debaixo do Céu. 
En presencia de un caso hipotético pero sencillo, se propone una pintura monocroma. Esta obra, pintada en los años 80 será solicitada para una retrospectiva del artista. Pero la obra tiene un problema: con el paso del tiempo y el mal acondicionamiento, la obra presenta varias abrasiones, lo que distorsiona su mensaje, una vez que su concepto inicial se concreta en una obra de color plano, de capa pictórica lisa y regular, de superficie completamente limpia y sin cualquier tipo de suciedad visual. La obra perdió su función, su correcta lectura es interceptada por elementos externos a la misma, no vive sólo en el momento de su construcción, sino también mientras cumple su función, puesto que fue construida para ser utilizada, y esa función se modifica y se ajusta en el tiempo. ${ }^{203}$

¿Cómo reaccionar ante esta situación? Según los valores teóricos y los criterios de conservación/restauración, la intervención seguiría un tratamiento lo más respetuoso posible en cuanto a la superficie cromática original, llevando a cabo una intervención minina y sabiendo desde luego que sería imposible sobre esta superficie intervenir con base en la abstracción cromática, como puede ser el trateggio.

Pero la realidad podría ser otra, en la cual se parte del principio que este análisis de las condiciones y estado de la obra fue llevado a cabo por el artista, con la intención de buscar una solución correctiva para la capa pictórica. El artista, ante la problemática presentada por la obra no tendrá problema alguno en realizar un repinte sobre la pintura dañada. Pero como se verá, que no es considerado repinte se la intervención es llevada a cabo por el artista, una vez que por repinte se entiende

como toque de color que se da a una pintura tiempo después de su ejecución y por una mano ajena a la de su autor. Los repintes suelen ser hechos por los restauradores, ya sea para tapar desconchados o bien para alterar algún aspecto de la composición, para ocultar algún detalle que se considera impúdico o simplemente desagradable204.

Una intervención completamente diferenciable del retoque una vez que este es visto,

${ }^{203}$ BALDINI, Umberto. Teoría de la restauración y unidad de metodología. Vol. 2, p.47.

${ }^{204}$ MONREAL y Tejada, Luis y HAGGAR, ob. cit. p.348. 
como método de dudoso valor para restaurar un cuadro trabajando sobre las porciones dañadas con nueva pintura. El retoque ha de limitarse a cubrir pequeñas zonas en que falte la pintura original, sin cubrir grandes superficies ni rehacer lo que falte de composición. Además debe realizarse con pigmentos que puedan ser eliminados fácilmente si algún día se quiere comprobar lo que de auténtico queda en la obra, y con disolventes que no alteren su color con el paso del tiempo, pues de lo contrario pronto delatarían la restauración efectuada 205 .

Pero no cabe duda, que con el arte contemporáneo y particularmente con las obras monocromáticas que introdujeron nuevas situaciones, se tornó una técnica muy usada tanto por artistas y como también restaurados.

Los artistas asumen y aceptan la necesidad del repintado si desean mantener incólume el estado original de la superficie, es decir, el significado. Los restauradores, sin embargo, entienden la necesidad del repintado como un sistema de recuperar el discurso de la obra, ya que en las pinturas monocromas el significado prevalece sobre la autenticidad de la materia. 206

Al cual loseba Soraluze añade, por tanto, el repintado en un objeto monocromo supone una intervención responsable y crítica que tiene como deber el mantenimiento del universo intelectual de la obra, así como recuperar la capacidad comunicativa y la experiencia estética ${ }^{207}$.

Todavía, antes de encontrar una solución para este caso hipotético pero no irreal, se harán referencia a varios conceptos como repinte, restitución y repristinación como posibles denominaciones de esta acción. Es considerado repinte, siempre que se haya realizado tal acción en tiempo posterior a la obra original y por otra persona que no sea el propio artista, con la intención de reparar u ocultar daños existentes en la superficie original, hasta pudiendo camuflar y modificar su aspecto. Considerado un método corriente de restauración de pinturas a partir del siglo XII, sustituido posteriormente por intervenciones de menor extensión (...). Lo utilizaban en el mercado de antigüedades para «mejorar» la calidad de las pinturas. ${ }^{208}$ Por lo tanto, el repinte es considerado un

205 MONREAL y Tejada, Luis y HAGGAR, ob. cit. p.351.

${ }^{206}$ SORALUZE Herrera, ob. cit. p.225.

207 Ibídem. p.168.

${ }^{208}$ GIANNINI, Cristina (dirección) y ROANI, Roberta. Diccionario de restauración y diagnostico, p.175. 
añadido hecho por terceros, cuando por añadido se comprende una acción realizada en el exterior de la obra y su eliminación tendrá que basarse en un juicio de valor de las instancias, tanto histórica como estética. Sin embargo, repintar es

Pintar sobre lo ya pintado, con objeto de ocultar deterioros, de igualar reintegraciones, o de modificar una obra realizada anteriormente. La acción de repintar es llevada a cabo por otra persona distinta al autor de la obra. Con este sistema erróneo se intentaron restaurar muchas pinturas, modificando su colorido e incluso su composición original. ${ }^{209}$

Tal vez pudiera ser una tentativa de restitución, cuando restituir es intentar devolver al objeto su estado completo, restableciendo lo que se ha perdido por accidente o con el paso del tiempo, considerada la acción por la que una obra artística que había sido alterada o desmembrada es devuelta a su forma primitiva ${ }^{210}$. Todavía esta acción, sinónimo de reintegración, no implica una intervención en la totalidad de la obra, pero sí de las partes perdidas o desmembradas; o por otra parte, será el acto de devolver un objeto a su sitio de origen, como puede acontecer con las obras robadas y recuperadas.

¿Al final lo que pasa en este caso, será un proceso de repristinación? En su libro, Ana Calvo, cuando se refiere a las obras monocromáticas o con acabados especiales, 0 a las obras realizadas para espacios públicos y urbanos, expone: el tratamiento de muchas de estas obras pasa por su repristinación, con el repintado general de las superficies si se han degradado.211 Entonces, ¿Qué es repristinación? La repristinación era una acción llevada a cabo en restauración llegando a ser el término usado en lugar de restauración, que hoy es considerada inadmisible, puesto que tiene por objeto devolver a una obra artística su aspecto original, rehaciendo cuanto le falte $y$ arreglando todo lo deteriorado hasta dejarla como nueva ${ }^{212}$, o como es expuesto en el Diccionario de términos de arte, repristinación es considerada una acción que tiene por objeto devolver a una obra artística su aspecto original, rehaciendo cuanto le falte $y$ arreglando todo lo deteriorado hasta dejarla como nueva. Es un criterio de restauración

${ }^{209}$ CALVO, ob. cit. p.189.

210 MONREAL y Tejada, Luis y HAGGAR, ob. cit. p.350.

211 CALVO, Ana Manuel. Conservación y restauración de pintura sobre lienzo, p.317.

${ }^{212}$ CALVO, Ana. Conservación y restauración. Materiales, técnicas y procedimientos. De la A a la Z, p.190. 
que hoy se considera inadmisible, por lo que también la palabra ha caído en desuso ${ }^{213}$, en un mismo sentido pero con otras palabras, consistía en una intervención completa con la intención de «volver a forrar y limpiar, revisar y refrescar las pinturas».214 Lo único que niega el hecho de considerar esta acción, una repristinación, es el campo de acción, pero teniendo en cuenta que el proprio artista pueda ser el restaurador de su obra, entonces será en todo caso una repristinación. ¿Es por lo tanto una acción correcta y aceptable en la actualidad? La respuesta es negativa, puesto que la repristinación es una intervención basada en la reconstrucción interpretativa, por lo cual la torna una solución impracticable según los criterios de conservación/restauración.

El artista, posiblemente recurrirá a los mismos materiales y técnicas para realizar la intervención, obteniendo con éxito una pintura tal y cual fue creada en los años 80. ¿El espectador que observa, en la retrospectiva del artista: la obra original, una réplica o una versión? Ciertamente no se puede considerar el resultado final como la obra original sin más: puede que sea la obra original con un repinte, o una restitución hecha por el propio artista pasados años de la creación de la misma; puede que sea una reproducción exacta de la obra original sobre la obra original, pero nunca será una versión, siempre y cuando el artista reproduzca con fidelidad la obra. El hecho de que sea realizado un repinte total es el resultado de ocultar un determinado espacio de tiempo, e inevitablemente la creación de un falso histórico, temporal, siempre que esta intervención no sea señalada.

Por otra parte existe la reconstrucción, a diferencia del añadido, ésta no amplía 0 completa, pero sí, intenta conformar nuevamente la obra, intervenir en el proceso creativo de manera análoga a como se produjo el original.215 Según esta definición, el repinte total realizado por el artista sobre la obra original, podría ser considerado una reconstrucción o reelaboración (al cual corresponde el termino rifacimento), puesto que intenta reducir o eliminar un periodo de tiempo, uniendo o ocultando el viejo con el nuevo.

${ }^{213}$ MONREAL y Tejada, Luis y HAGGAR, ob. cit. p.349.

${ }^{214}$ GIANNINI, Cristina (dirección) y ROANI, Roberta. Diccionario de restauración y diagnostico, p.176.

${ }^{215}$ BRANDI, ob. cit. p.40. 
El objetivo explícito o implícito de la reconstrucción es siempre hacer desaparecer un lapso de tiempo, bien sea porque la última intervención en fecha, en la que consiste la reconstrucción, quiera asimilarse al tiempo mismo en que nació la obra, o bien porque pretenda refundir completamente en la actualidad de la reconstrucción ese tiempo anterior. ${ }^{216}$

La reconstrucción o la reelaboración, puede seguir dos caminos: el primero, que es el de la repristinación, cuando se intenta de forma mimética recuperar el supuesto aspecto original de la obra; y un segundo camino, que consiste en rehacer la totalidad de la obra, hecho que se basa en la creación de una nueva obra y que ni siquiera puede entrar en el campo de análisis de la disciplina de conservación/restauración. Pero dentro de estas cuestiones, Brandi añade que, la recomposición debe conservarse, aunque resulte prejudicial para la obra, en caso de haber causado la destrucción de una o más partes de ella. ${ }^{217}$ Y se acrecienta que por otra parte, la eliminación de un añadido también puede ser entendida como una falsificación, pues está ocultando un dato en la historia de la obra.

Parece, que se está ante una imitación, realizada por el propio artista. Las dudas no se quedan aquí, pues al final, ¿qué tiene de legítimo esta intervención?, ¿Está garantizada esta intervención por el hecho de haber sido el artista quien la realiza? Pues la respuesta es negativa y veamos:

Es decir, si se puede consentir al artista, creador de una determinada obra, reproducirla después de un tiempo fechándola o haciéndola pasar por anterior a la época precisa en que se realiza la reproducción. Si esta última condición es excluida de modo explícito por la inserción de la fecha real, no puede emitirse juicio de falsedad, pero cuando la fecha sea voluntariamente alterada u omitida, el animus de llevar a engaño difícilmente podría ser puesto en duda, y el artista, falsario en sí mismo, no asumirá ni moral ni jurídicamente figura diferente de la de cualquier otro falsificador. ${ }^{218}$

Brandi lo deja claro. La nueva obra respeta la instancia estética, que por señal ya no desempeñaba su función y por eso la necesidad de la intervención. Pero la cuestión fundamental, es cuando se está en la presencia de una alteración y no es referida la fecha de esa intervención. ¿Hay integridad en la intervención sólo por el hecho de que ha sido realizada por el propio artista? No, esto no tiene valor por sí solo una vez que

\footnotetext{
${ }^{216}$ BRANDI, ob. cit. p.40-41.

${ }^{217}$ BASILE, Guiseppe. Teoría e practica del restauro in Cesari Brandi, p.81.

${ }^{218}$ BRANDI, ob. cit. p. 69.
} 
la obra es una obra de arte no por deseo del artista, sino por un reconocimiento social, y a partir de este reconocimiento la obra vive bajo protección legal, y el propio artista también está sujeto a sus normas. Las palabras de Brandi son concretas, e independientemente de esta intervención sea o no realizada por el artista, tendrá que ser una intervención fechada, si no lo es será considerado un falso de la misma forma, pues es un acto realizado en el tercer tiempo de vida de la obra, el tiempo del reconocimiento social en el presente del observador. A lo mejor, sería más coherente considerar esta obra una ruina, o sea, incapaz de transmitir su mensaje con claridad a través de la unidad potencial de la obra. Irónicamente, el estado de ruina, en este caso no implica el desecho total de la materia, todavía es evidente que restaurarlo podrá llevar a la falsificación o convertirlo en copia o imitación, y lo indicado será únicamente conservar el bien en su estado actual:

Es suficiente recordar que ni siquiera en la fase de 'primer acto' la idea es igual a la imagen para llegar a la conclusión de que es absolutamente imposible repetir un acto de la obra. Cualquier acto de réplica, sea cual sea, será siempre y necesariamente diferenciado. Entonces, puesto que la igualación no es posible, la diferenciación es absolutamente necesaria, para no caer en el error y en el efecto negativo de introducir en la obra una igualdad falsa haciéndola pasar por auténtica. Cometiendo así una doble falsedad ideológica y definible con términos prohibidos, como imitación, competición* y falsificación. ${ }^{219}$

Todavía, tras este reconocimiento de posible valor, Brandi cuestiona, si se puede reconocer a un falso el valor de obra de arte, no a través de la copia del original, sino de una interpretación autónoma que no la de su autor. A lo cual, Brandi responde:

\begin{abstract}
Para que la obra imitada asumiera un valor autónomo, será necesario que lo pudiese ser confundida respecto a su fecha de nacimiento real, y que la forma de la que se parte se hubiese mantenido verdaderamente como punto de partida para una nueva subjetividad. Esto es posible, pero al ofrecer una datación inequívoca, excluye la sospecha de falsificación y hace entrar a la obra en la categoría de las obras de arte auténticas, a las que corresponde un juicio aseverativo en cuanto a su declaración de tales, mientras el de falso es un juicio problemático, con lo que la diferencia entre arte y falsificación se demuestra también en la forma lógica del juicio que la califica. 220
\end{abstract}

\footnotetext{
** Umberto Baldini diferencia las tres acciones, consistiendo la imitación en la utilización de la misma materia; y competición la materia utilizada es distinta.

${ }^{219}$ BALDINI, Umberto. Teoría de la restauración y unidad de metodología. Vol. 2, p.23.

220 BRANDI, ob. cit. p.68-69.
} 
No hay duda que la fecha en una obra de arte, juega un papel fundamental, además de la información a ella asociada, está en sí misma intrínseco un valor subyacente, constituyendo el otro lado de la moneda, o sea, si por un lado está el indiscutible valor artístico de una obra, que incluso siendo un falso puede estar presente, por otro, está el valor adquirido por la instancia histórica el cual puede depreciarse si se trata de un falso.

También Enrico Crispolti, habla de la falsificación, y explica que no se puede llamar falsificación a los cuadros realizados por el propio artista, pero sí reelaboraciones antedatadas, reelaboraciones a las cuales se asocia una nueva elaboración con la fecha de la primera finalización del trabajo, una repetición tal como indica el prefijo re-. Ya antedatación refiere una datación que denota anterioridad en el tiempo o en el espacio. Y Crispolti, añade que hay que distinguir las reelaboraciones de las antedataciones, subrayando que ni todas las reelaboraciones son antedatadas, ni todas las ante-dataciones resultan reelaboraciones. Una idea que puede parecer compleja, principalmente por la novedad de los términos empleados, pero que se encuadra en esta discusión. El autor hace referencia a distintas nociones de antedatación, entre ellas la antedatación relativa donde considera que la antedatación puede llevarse a cabo también por el deslizamiento del tiempo sobre una obra autentica, simplemente anticipando, por ejemplo, en un par de años la fecha que resulta modificada o agregada. $^{221}$

También para las reelaboraciones el autor intenta establecer una especie de clasificación, distinguiendo en primer lugar las que son consideradas correctas, o sea: aquellas que son reelaboradas y identificadas como tal222; y en segundo lugar, hay que distinguir aquellas que se consideran las reelaboraciones incorrectas, las que el autor denomina como engañosas imitaciones, o sea: aquellas obras que son reelaboradas sin que la data sea a de la altura de reelaboración, pero que corresponde a una primera existencia de las obras 223 ; y por último, en un extremo, las que se consideran reelaboraciones incorrectas, denominadas como propias reinvenciones, siempre y cuando

\footnotetext{
${ }^{221}$ CRISPOLTI, Enrico. Como estudiar el arte contemporâneo, p.151

222 Ibídem. p.151

223 Ibídem. p.151
} 
el artista crea nuevas obras pero coloca una data anterior a su creación, como pertenecientes a un determinado periodo. ${ }^{224}$

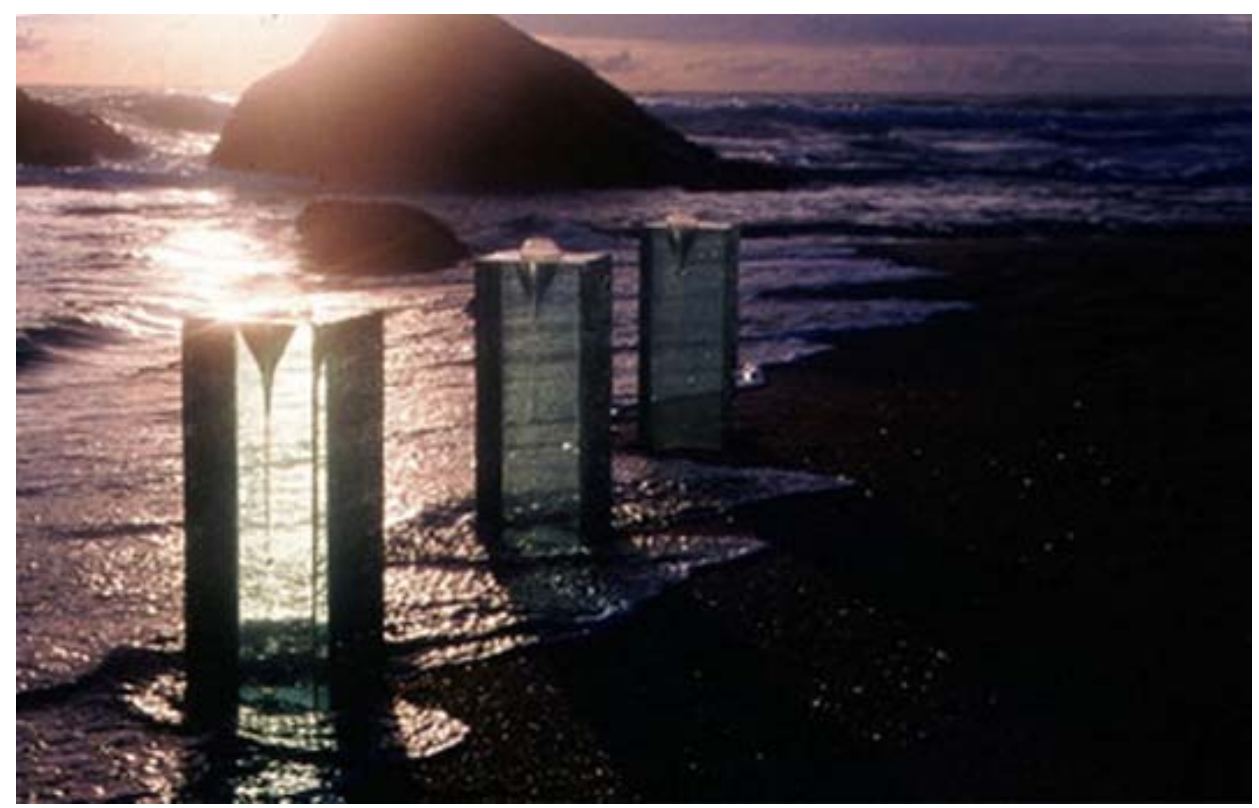

Figura 58: João Pedro Rodrigues, instalación en la playa de S/Titulo. Receptáculos de vidrio, agua salada y preservativos.

Crispolti incrementa otros conceptos, y refiere que entre las realizaciones existen las realizadas ex nuevo $-y$ por tanto sobre otra tela o soporte diferente 225 , o por otra parte, las simples transformaciones autógrafas de obras propias, llevadas a cabo incluso a distancia de años 226 . El autor considera las transformaciones autógrafas una especie de arrepentimiento posterior a la realización, una acción que pertenece a la fenomenología de la propia evolución del proceso creativo227.

Es importante subrayar que las reproducciones de las obras e incluso la actitud de querer tener lo original son desde luego aceptables, pero siempre teniendo en cuenta que cuando se hace algo como pedir al artista que pinte de nuevo su obra, se está pidiendo para que él haga una intervención, que, por más que se niegue, es una

\footnotetext{
${ }^{224}$ CRISPOLTI, ob. cit. p.152.

225 Ibidem. p.155.

226 Ibídem. p.155.

227 Ibídem. p.156.
} 
intervención drástica, dejando atrás lo que se entiende por original y cuestionando conceptos como autenticidad. Incluso teniendo en cuenta la intención, los métodos y los materiales como los idénticos a los originales, la intervención deberá ser identificada como tal, fechada de forma a respetar la instancia histórica de la obra. $Y$ cuando se exponga esa obra debe ser hecha la referencia de que es fruto de una intervención y referida la fecha de esta última, por ejemplo 1980/2000. Teóricamente, si la intervención es hecha por el propio artista, desde el punto de vista de la instancia estética no se duda en cuanto a su validez, siempre y cuando la intervención respete exactamente el original. Pero, ya no se podrá decir lo mismo en cuanto a la instancia histórica, en la medida que oculta un determinado espacio temporal. Cuestión que sería sobrepasada, si se indicar la fecha de la intervención. Todavía, es necesario preguntar, pues será un gran error alimentar y creer que por ser el artista el que hace la reproducción del objeto es desde luego aceptable como original o como la obra de arte primitiva.

Pero debemos plantearnos también el caso de la obra de arte en la que el artista no haya previsto necesariamente el envejecimiento como un modo de completar su obra en el tiempo, como un acabado a distancia. El problema queda planteado en este punto, pero no puede resolverse íntegramente en función del criterio histórico, dado que aquí prevalece la exigencia estética. Sin embargo, desde el punto de vista histórico debemos reconocer que es un modo de falsificar la historia si los testimonios históricos son privados, por decirlos así, de su antigüedad, es decir, si se obliga a la materia a adquirir una frescura, un perfil nítido, una evidencia tal que contradiga la antigüedad que testimonia. ${ }^{228}$

De este punto de análisis se pasa a otro. Se puede hablar de las esculturas de Calder por ejemplo, y de conocimiento público, que siempre que es necesario, por motivos de corrosión, desgaste o pérdidas significativas en el valor cromático de la obra, se elimina la pintura para volver a pintar con los colores indicados para esa acción y respetando las definiciones del propio artista. Ante esto, surge la curiosidad y se plantea la siguiente cuestión: ¿cuál es la diferencia entre el repinte total de una pintura o de una escultura? La respuesta se puede simplificar haciendo otra pregunta: ¿se puede repintar el Cuadrado Negro de Kazimir Malevich? o ¿y por qué no repintar un Piet Mondrian siempre y cuando los colores cambien su luminosidad o se observe

${ }^{228}$ BRANDI, ob. cit. p.40. 
suciedad patente en los blancos o daños irreversibles? ¿Sería legítimo que los propios artistas, si estuvieran vivos, lo hiciesen?

Se pueden plantear decenas de preguntas alrededor del mismo tema, pues tanto el arte moderno como el contemporáneo suscitan una diversidad de dudas cuando se tiene por delante la necesidad de realizar alguna intervención, lo que puede llevar a cierta confusión. Una vez más, se buscarán las repuestas en los valores teóricos de la disciplina de conservación/restauración. Se considera válida la eliminación y la reintegración cromática íntegra de la obra de Calder, porque el color no es más que estructura en sus creaciones. En este punto se abre un pequeño paréntesis en la relación entre autenticidad e intención del artista pues esta relación en algunos casos del arte contemporáneo vive bajo puras contradicciones, puesto que la intención del artista y autenticidad, luchan por prevalecer hegemónicamente en el tratamiento a realizar. Sin embargo, la obediencia a uno de los factores solicita un acercamiento a priori de los valores de antigüedad, histórico y novedad, (...).229 Existen obras en que prevalece la autenticidad matérica de la obra, en tales casos se juega con la parte conceptual y estética de la misma y su historicidad, presente en la materialidad de la obra; por otro, la intención del artista prevalece ante todos los otros valores. Pero aquí se hace hincapié en la cuestión de la intención del artista puesto que es algo variable, o si, hay la intención patente en la obra cuando el arista no está presente, y la intención del artista vivo que ve su obra a deteriorar y que analiza la cuestión de otra forma: que pretende rehacer la obra porque ésta perdió su función. En ambas las soluciones, si depende que la actuación crítica además de iniciarse con la comprensión material e inmaterial de la obra, requiere una evaluación precisa de las contraindicaciones que se originan en la toma de decisiones. ${ }^{230}$

Como ya fue hablado anteriormente, estructura y aspecto son los conceptos con los que se define una materia, en que el aspecto representa directamente la imagen de la obra de arte, y cuando haya que sacrificar alguno de los elementos de la obra se optará por sacrificar la estructura de la misma. En el caso del Calder, el color es fundamental para la lectura de la obra, pero no es la base de la imagen. Lo que ya no

${ }^{229}$ SORALUZE Herrera, ob. cit. p.168.

230 Ibídem, p.168. 
se puede decir sobre Cuadrado negro, donde el color además de su valor estético representa la materia, lo que es imagen de la obra con sus características estéticas, visuales y perceptivas, de textura y color. Siguiendo este pensamiento, ¿qué es lo que teóricamente protege las pinturas neoplasticistas de Piet Mondrian? Las conocidas obras están constituidas por colores planos, ¿qué papel juegan los colores en estas obras? Baldini ayuda a responder a estas cuestiones en la siguiente cita:

(...) es sin embargo necesario distinguir entre un ladrillo, aunque lo haya mandado colocar Leon Battista Alberti, y una pincelada dada directamente por Rafael. Si entendemos este concepto, será más fácil comprender aún más profundamente cómo hay que llevar a cabo un acto de "restauración". ${ }^{231}$

No es fácil encontrar una respuesta clara para todos estos planteamientos, cuando parece más correcta la eliminación de la capa de color en una escultura, y el procedimiento idéntico no parece válido para una pintura con las mismas características cromáticas, donde simplemente cambian las características dimensionales. Lo cierto es que no es lo mismo, hacer la lectura de una escultura y de una pintura, en la cual el color en cada manifestación artística juega papeles distintos. Puede que sea una cuestión historicista, socialmente aceptada, pero es verdad que el color supone menos "peso" en la escultura que en la pintura, y esto porque el propio color es al mismo tiempo la imagen en la pintura. Es evidente que no son casos similares, pues un lienzo o una tabla sin color no son una pintura, y una superficie tridimensional sin color continua siendo una escultura. Con todo, este hecho no justifica por sí mismo la eliminación de la capa pictórica de todas las esculturas, siendo una cuestión variable de acuerdo con el papel que desempeña el color en cada obra. En cuanto a las pinturas de Mondrian, no sería legitimo la realización de repintes pues el color es aspecto, lo que sustenta la instancia estética de la obra, además la realización de un repinte no iba a ser más que una competición con el original, entre viejo y nuevo. ¿Pero sería legítimo que fuera el artista quien hiciera los repintes?

Otras son las cuestiones planteadas por el arte contemporáneo a la vez que su campo de acción es más vasto y las posibilidades y cambios en el medio expositivo

${ }^{231}$ BALDINI, Umberto. Teoría de la restauración y unidad de metodología. Vol.1, p.15. 
son inevitables, en presencia de las denominadas instalaciones. En páginas anteriores ya fueron demostradas las posibilidades que estas expresiones artísticas ofrecen, y la forma como se manosea el binomio forma/concepto, presentando distintas posibilidades a la hora de exponer. Es conocida la maleabilidad de este tipo de creación, y la facilidad de adaptación al espacio expositivo y sus características, y en consecuencia existe la necesidad de pensar un poco sobre las cuestiones anteriores. ¿Al final cuáles son los conceptos más coherentes: crear, recrear 0 restituir?

En la obra creada, recreada o restituida, lo que es reproducción de un original es de igual forma documento histórico, incluso si se convierte en una falsificación, está en sí mismo reconocido su valor como documento, o cuanto menos, un valor adquirido por las cuestiones técnicas de reproducción, puesto que desde el punto de vista de la ejecución técnica, es decir, de la artesanía, puede serle reconocido sin duda un valor de documento histórico. ${ }^{232}$

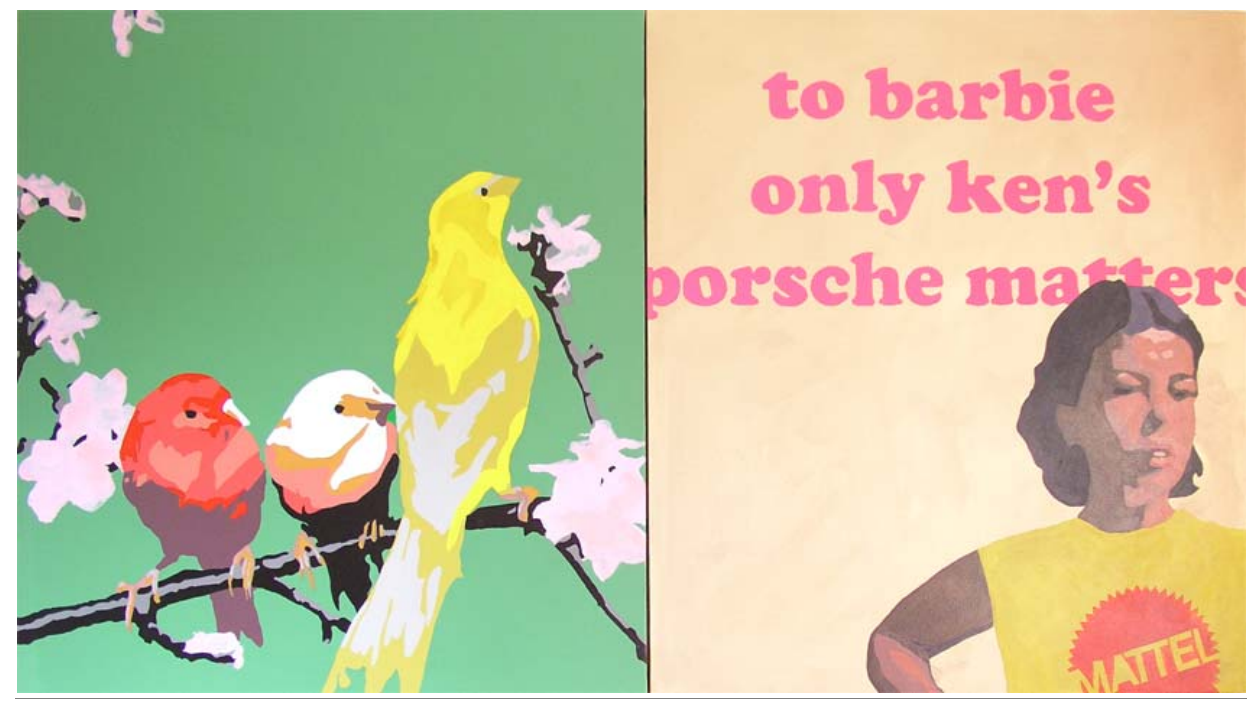

Figura 59: Ana Cardoso, Think Pink, 2007. Acrílico y purpurina sobre tela, 160x180cm.

${ }^{232}$ BRANDI, op. cit. p.68. 
En este sentido y teniendo en cuenta que la obra de arte es el documento directo de información y en sí están patentes distintas nociones de valor, se plantean constantemente cuestiones sobre la autenticidad de las obras, su originalidad y su transmisión hacia el futuro, pero conscientes de que no siempre estos planteamientos constituyen las preocupaciones en una transacción o momento de negociación. Al final ¿hasta qué punto este hecho influye en la transmisión hacia el futuro de las obras de arte?, ¿se va creando una historia distinta de aquella que supuestamente corresponde verdaderamente a cada obra? No es novedoso encontrar en una exposición, una obra de los años 60080 impecable. ¿Qué ha sucedido en este caso? La obra ha sido repintada porque posiblemente estaba dañada, y ya no desempeñaba su función como objeto artístico. ¿Qué cambia saber por quién ha sido hecho ese repinte? Por conciencia, tendemos a pensar que cambia radicalmente decir que un repinte ha sido hecho por el artista, o por un tercero, como un conservador/restaurador. Según Crispolti, esto sería considerado una reelaboración, pero sin datos para decir si es correcto o incorrecto este hecho, ya que no se tiene información de las fechas, tanto de finalización de la obra como de exposición. Pero hipotéticamente, sería verdadera siempre y cuando esa reelaboración presentase una re-datación, o sea una segunda fecha de intervención; o sería falsa si ocultase la reelaboración y mantuviese únicamente la fecha de término de la obra. Pero otras son las cuestiones heredadas: ¿Cual es la legitimidad de una reelaboración hecha por el propio artista?, ¿Cuál es el papel del conservador/restaurador en estos momentos?, ¿Hay realmente alguna distinción en términos de acto y de principios teóricos? Decididamente no. El acto de repinte o de reelaboración tendrá siempre el mismo valor independientemente de quien lo haga, puesto que está realizado en un tiempo histórico distinto del tiempo de la creación. O sea, incluso hecho por el artista, es una intervención fuera del primer tiempo de la obra (un tiempo que se inicia con la materialización de la idea hasta la conclusión de la obra), ya bien realizado en el segundo tiempo de vida de la obra (tiempo que va desde la finalización de la obra hasta llegar a la conciencia del espectador), y que desde luego no se podrán poner trabas una vez que en este tiempo aún se está dando la consciencia de la obra, sin que exista el reconocimiento de obra como obra de arte. Brandi refiere las varias tentativas erróneas, como el hecho de incluir la restauración en el propio proceso de 
creación, como el acto más grave en la restauración y al cual denomina restauración de fantasía. Otra tentativa es encajar la restauración en el espacio de tiempo que va desde la conclusión de la obra y el presente, o sea la tentativa de ocultar un determinado espacio de tiempo y al cual se encuentra lo que se llama restitución. Queda claro, que el momento de realizar una intervención de restauración es en el presente.

La restauración, para representar una operación legítima, no deberá concebir el tiempo como algo reversible, ni la abolición de la historia. La acción de la restauración, además, y por la misma exigencia que impone el respeto a la historicidad compleja que compete a la obra de arte, no deberá plantearse como secreta y casi fuera del tiempo, sino ofrecer los medios para ser delimitada como evento histórico que es, por el hecho de ser una acción humana e insertarse en el proceso de transmisión de la obra hacia el futuro. ${ }^{233}$

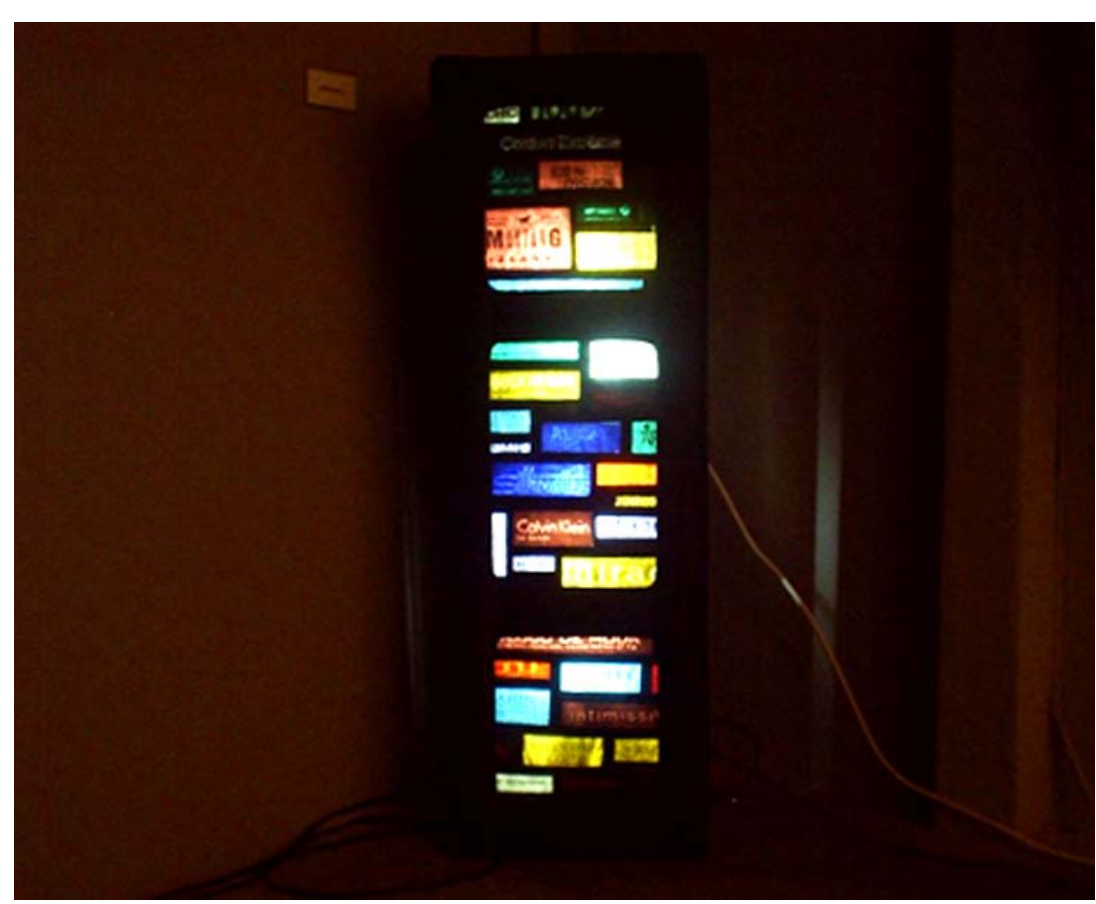

Figura 60: Rui Pedro Fonseca, instalación Confort, 2004. Caja de luz con imágenes impresas, varios materiales.

Tal como fue demostrado anteriormente, el añadido o la reelaboración, incluso hechos por el artista, siempre serán considerados un añadido, realizado en fecha posterior a la conclusión de la obra, en un período de la historia de la obra al cual ya no

${ }^{233}$ BRANDI, ob. cit. p.33. 
pertenece la creación. Y si son desarrollados con las mismas técnicas, sobre el mismo proceso de creación siempre será un añadido. ¿Y podrá éste ser considerado falso?

Es indispensable volver a la Teoría, cuando Brandi expone la historicidad de la obra planteando la cuestión de la eliminación o no de los añadidos de acuerdo con la instancia histórica, defiendo que desde el punto de vista histórico, las adiciones sufridas por una obra de arte no son más que nuevos testimonios del quehacer humano234, por lo cual subraya que en este sentido lo añadido no se diferencia del núcleo originario y tiene idéntico derecho a ser conservado ${ }^{235}$. Con la intención de subrayar la diferencia entre añadido y reconstrucción, Brandi habla de reconstrucción como una de las formas de ocultar el paso del tiempo, dado que reconstruir implica querer hacer de lo nuevo idéntico a viejo, una forma de traspasar un tiempo pasado al presente, un refundir por completo una obra que nació en el pasado pero que se intenta obtener en un presente; al revés, el añadido no se recalca, sino más bien se desarrolla o se injerta236. Nociones que resultan en dos casos distintos en función de la instancia histórica de la obra. Un primer caso que se presenta cuando la intervención de la obra desea pertenecer a una fecha anterior, retrotraída, a la cual Cristolpi llama de antedatación; y un segundo caso, en que la reconstrucción quiere disolver y trasformar la obra existente sin dejar vestigios. En cuanto al primer caso, no cabe duda de que no es aceptable puesto que crea un falso histórico al tener la intención de abolir un determinado espacio temporal; el segundo, no teniendo marco en el campo de la restauración puede ser legítimo, a la vez que constituye un testimonio de la actividad humana, con sus valores y datos históricamente representacionales, al los cuales se pueden hacer corresponder las reelaboraciones correctas citadas por Crispolti.

En el caso de que se trate de una intervención pictórica o de la introducción de un elemento cromático en un tejido cromático ya existente, la restauración podrá adquirir la connotación de una autentica restitución (formal o cromática, o ambas cosas a la vez). Ello ocurrirá cuando la intervención no se lleve a cabo recurriendo a reconstrucciones arbitrarias o incluso múltiples, sino limitándose a una acto crítico de mantenimiento (mantenimiento=mantener)

${ }^{234}$ BRANDI, op. cit. p.39.

235|bídem. p.39

236 Ibídem. p.40. 
sin alteración alguna de la forma, del color o de ambos, dado que la imagen está ya plenamente expresada y definida, es decir, que 'existe'. ${ }^{237}$

Por otra parte, Brandi habla de reconstrucción, de restitución del aspecto original de la obra, o de la copia, cuando se refiere a la ruina. Según la instancia histórica la ruina se define como todo el vestigio o testimonio de la actividad humana y punto de partida de la acción de la conservación. Según la instancia estética de la obra, citando: la cuestión de la ruina no podrá ser planteada sin una íntima contradicción ${ }^{238}$, en que anteriormente Brandi explica que no se puede denominar ruina a los vestigios que aún poseen valor artístico, o si por acaso estos vestigios ya no poseyeran tal valor entonces tampoco se puede hablar de artisticidad, sino únicamente de historicidad. Entre estos parámetros, se considera ruina cualquier resto de una obra de arte que no pueda ser devuelto a su unidad potencial sin que la obra se convierta en una copia o una falsificación de sí misma ${ }^{239}$, a lo que Guiseppe Basile añade:

Se refiere al caso extremo de una manufactura, reducida a testimonio apenas reconocible de una obra (o de un evento humano) pero ya incapaz - en el caso de una obra de arte- de ser reconducido a la unidad potencial sin convertirse en una copia o una falsificación de sí mismo y que, por lo tanto, puede ser sólo conservado, no restaurado. 240

Al final¿Qué involucra la palabra falsificación?

En conclusión, la historia de la falsificación deberá hacerse teniendo en cuenta las copias y las imitaciones, y no únicamente las falsificaciones ciertas.(...) Precisamente por la dificultad de probar el dolo, es decir, el animus que preside la producción del objeto o su comercialización, se deberá presumir -como en derecho- la buena fe hasta que se pruebe lo contrario, y por lo tanto, con doble razón no se podría excluir de la historia de la falsificación el uso y la producción de copias, réplicas e imitaciones. ${ }^{241}$

Según los valores teóricos vigentes en la disciplina de conservación/restauración, acciones como reconstrucción y repristinación/restablecimiento ni siquiera pueden insertarse en el grupo de términos utilizados en la restauración.

\footnotetext{
${ }^{237}$ BALDINI, Umberto. Teoría de la restauración y unidad de metodología. Vol. 2, p.31.

238 BRANDI, ob. cit. p.43.

239 Ibídem. p.43.

240 BASILE, Guiseppe. Teoria e practica del restauro in Cesari Brandi, p.82.

${ }^{241}$ BRANDI, ob. cit. p.67.
} 
Como refiere la Teoría, la restauración no puede pertenecer al periodo que va desde la constitución del objeto hasta la conclusión de su formación. Una vez que la imagen ya fue concluida, tal actividad, puede llevar al error de ser entendida como una intervención de restauración, pero tal intervención no pasa de una fusión de una imagen en otra imagen, de un acto sintético y creativo que desautoriza la primera imagen y la encierra en una nueva. ${ }^{242}$ Baldini también aproxima su teoría a esta idea, cuando apunta,

Servirá para mantener viva en el tiempo aquella cadena de unión que evita la renovación arbitraria de la obra, que mantiene el vínculo entre lo antiguo y lo nuevo, que no cierra una vida sino que la conserva hasta que la obra sea 'digna de ser disfrutada', no relegándola a la idolatría de la momificación. 243

¿No será el mercado el principal motivo de momificación de las obras?, ¿Cuál es el verdadero papel del mercado del arte? Las respuestas, están patentes en la siguiente cita:

Una pintura color burdeos de gran tamaño realizada por Mark Rothko fue vendida en Sotheby's, hace unos meses, a un coleccionista japonés en un precio récord para los Rothko: un millón seiscientos mil dólares. No había sido simplemente resguarda, sino según manifestó un anterior propietario, William Rubin, del Museo de Arte Modernorepintada del todo, a consecuencia de los daños que habían ocasionado los transportistas franceses en una gira europea. Había desaparecido casi un metro cuadrado de la pintura original, y había pasado muchos meses de reelaboración en un costoso hospital para expresionistas abstractos, viejos y maltratados, dirigido por un restaurador de Long Island. En el momento de la venta había otros cuantos Rothko de una calidad e interés históricos similares en el mercado de Nueva York, ninguno de ellos dañado, y valorados todos en unos cuatrocientos mil dólares. Si alguna vez se consiguió un precio récord por ignorancia, fue ésa. Sin embargo, a nadie le importó; la pintura está ahora bien instalada en algún tokonoma distante, y la venta, en lugar de ser considerada como un hecho anormal que comprometía una pintura, dobló los precios de Rothko de un día para otro. ${ }^{244}$

Podrá existir una tendencia genérica a someter una obra a determinadas intervenciones y medidas preventivas que, si no son muy miradas, pueden revelarse más dañosas que la pasiva aceptación de las alteraciones que el tiempo produce sobre las mismas. Esta actitud proviene de una historia compleja que se puede

\footnotetext{
242 BRANDI, op. cit. p.32.

${ }^{243}$ BALDINI, Umberto. Teoría de la restauración y unidad de metodología. Vol. 2, p.60.

${ }^{244}$ HUGHES, Robert. A toda crítica. Ensayos sobre arte y artistas, p.461
} 
sintetizar en los mecenas, amantes del arte, que coleccionaban obras y que deseaban conservarlas con un gran tratamiento y meticulosidad.

Spesso ripeto ai miei collezionisti: «ricordatevi che non existe la proprietà dell'opera d'arte, questa è un valore universale, e chi lo acquisto ne diventa custode e ha il privilegio di goderne, ma anche la responsabilità di conservarlo come bene dell'umanità.. 245

Es importante subrayar que el mercado tiene un fuerte poder sobre el mantenimiento de las obras, y que de cierta forma éste obliga a mantener la obra sin alteraciones. Pero también es cierto que el estado de conservación de la obra y su supuesto valor artístico tienen influencia en el valor económico. Un ciclo permanente que se puede manifestar de distintas formas como fue analizado anteriormente.

Todos los objetos están dotados de valor económico, pero lo que diferencia el objeto común de las obras de arte es su valor artístico y cultural que adquiere, e independientemente de ser un bien comercial, debe ser respetado y conservado según su autenticidad, tanto material, técnica como estética.

No sólo el restaurador, sino también el público y el mercado tendrán que ser conscientes de la nueva realidad del arte, a pesar de que socialmente se contradigan algunas de las nociones hasta ahora presentadas, puesto que la obra artística no se concibe como fenómeno efímero, sino como acto de gran alcance. ${ }^{246}$

Es esencial partir de la premisa que no todas las obras ofrecen la posibilidad de una intervención de restauración y que hay obras que sólo tienen sentido cuando llegan al final su "vida", y no sufren el intento de la conservación, porque si así sucede el espectador estará delante de un falso artístico, una obra de arte que ha perdido su autenticidad y no es más que un documento histórico. Son muchos los factores que pesan en la actividad del conservador/restaurador, pero este hecho no indica que haya que cambiar radicalmente las bases profesionales, eso sí, es necesario elaborar, ante todo, una nueva mentalidad ante el objeto, confrontando los nuevos valores que

245 FERRARI, Claudia Gian. Una cultura della conservazione e del restauro contemporaneo. en AA. VV. Arte contemporanea. Conservazione e restauro. p.117.

T. A.: Frecuentemente repito a mis coleccionistas: «acordaos que no existe la propiedad de la obra de arte, ésta es un valor universal, y que la adquisición no pone guardián y posee el privilegio de disfrutar, pero también la responsabilidad de conservarlo como bien de la humanidad.

${ }^{246}$ FISCHER, Ernest. El artista y su época, p.30. 
se imponen con el arte moderno y contemporáneo, enfrentar su naturaleza mutante para encontrar la mejor solución ante los problemas de su conservación.

No obstante, la clave viene dada siempre por la sensibilidad, la destreza, los conocimientos, la intuición y la orientación del ejecutor del trabajo, junto con su visión de lo que se puede y debe esperar de una intervención y de lo que no se puede ni debe esperar de ella.247

En la actualidad, es avasalladora la presencia de un espíritu consumista, proyectado en la compraventa de los objetos artísticos, pues el arte ha perdido entretanto toda función útil: no es -o no lo es en primer lugar- un objeto de culto, ni tiene una función práctica ${ }^{248}$, es redundantemente una mercancía, al cual se asocian varios engranajes y agentes que controlan su destino, sin olvidar el mercado ilícito resultado no sólo del tráfico permanente de las obras para las exposiciones temporales, también por la densidad de exportaciones e importaciones que cada país realiza.

247 BECK, James y DALEY, Michael. La restauración de obras de arte: Negocio, cultura, controversia y escándalo, p.61. 248 CORREDOR-MATHEUS, Jose. en AGUILERA, Vicente Cerni (dirigido por). Diccionario del arte moderno. Conceptos, ideas, tendencias, p.328. 



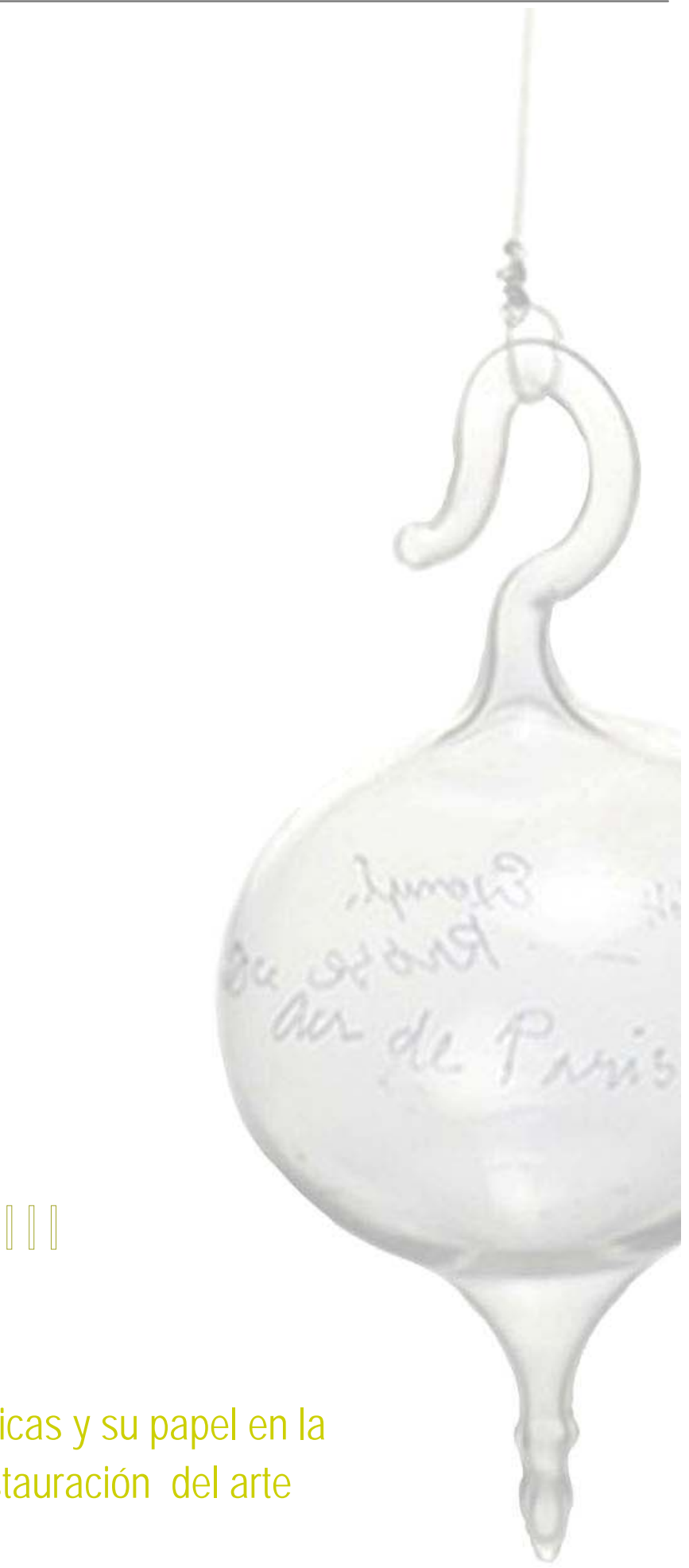

Las normas jurídicas y su papel en la conservación/restauración del arte contemporáneo. 

¿Qué puede encontrar el conservador/restaurador en la legislación vigente?

¿Hasta qué punto la Ley de Propiedad Intelectual responde a los planteamientos que surgen con el arte contemporáneo?

¿Cuáles son los límites trazados por las leyes para la profesión del conservador/restaurador?

¿Cuál es el papel del artista en la conservación/restauración de sus obras? Y ¿Realmente existen límites en su actuación?

¿Es coherente que sea el artista quien restaure su propia obra? 



\section{El artista además de la creación.}

La conciencia de que las obras de arte (...) deben ser tuteladas de forma orgánica e igualitaria, lleva necesariamente a la elaboración de normas técnico-jurídicas que sancionen los límites dentro de los cuales debe entenderse la conservación, ya sea como salvaguardia y prevención, ya como intervención de restauración propiamente dicha....) Tales normas, que se podrían definir sin duda como áureas, permanecieron también sin fuerza de ley, como instrucciones internas de la Administración, y ni la teoría ni la praxis que a continuación fueron elaboradas por el Instituto Central de Restauración se extendieron a todas las restauraciones de obras de arte de la Nación. ${ }^{249}$

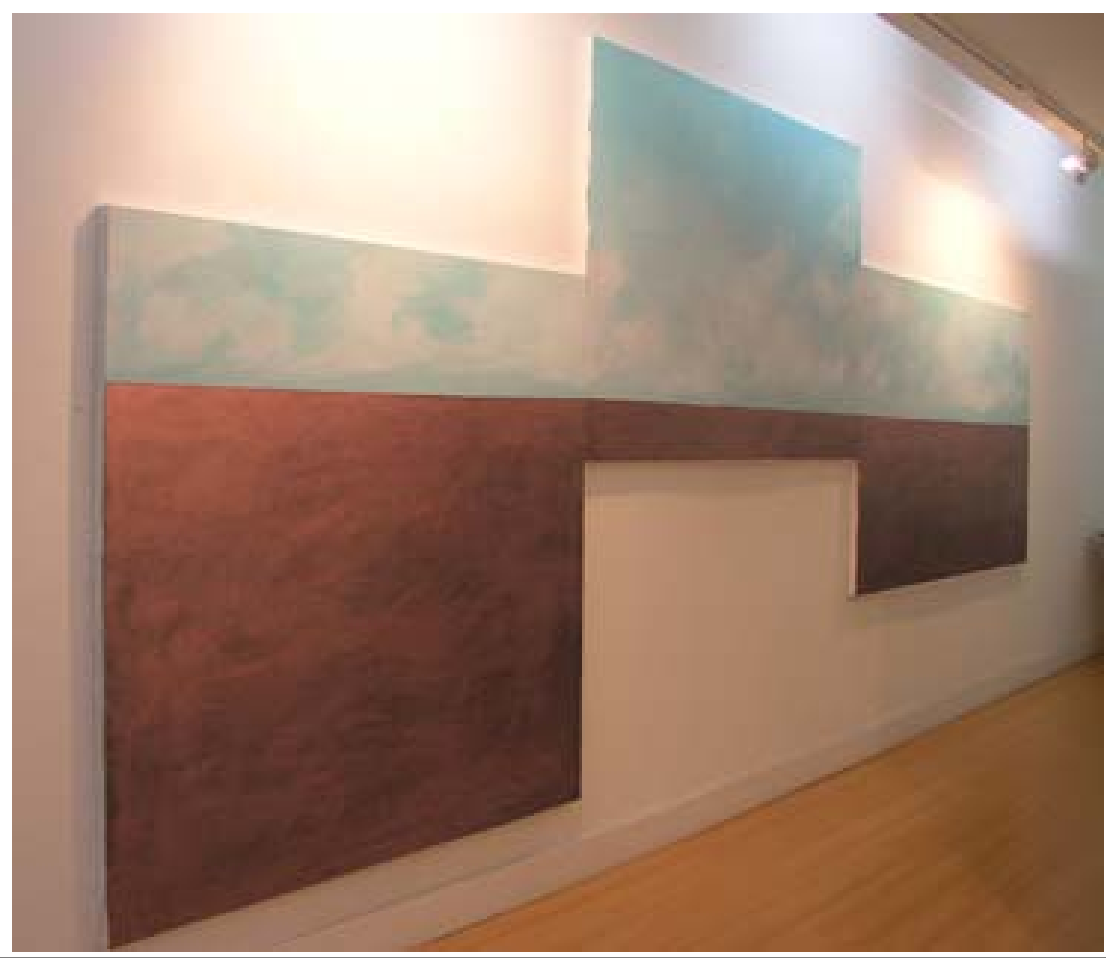

Figura 61: Exposición individual de Ana Cardoso, Muito Pouco ou Nada. Galeria João Lagoa, Porto, 2006.

${ }^{249}$ Carta del Restauro 1972. en MARTíNEZ Justicia, María José. Antología de textos sobre restauración, p.170-171. 
El planteamiento que dio inicio a esta investigación, con el paso del tiempo se tornó más denso y complejo, sumergiéndose en caminos completamente desconocidos. Es el caso del presente capítulo, que surge como la última esperanza para encontrar las respuestas que aclaren las ideas expuestas en páginas anteriores. Si es cierto que la legislación es una posible solución para trazar caminos concretos, en el área de la conservación/restauración esos caminos aún están poco pulidos, sin olvidar que esta búsqueda se tornará más compleja cuando se une a la conservación/restauración la heterogeneidad y dinamismo del arte contemporáneo. Mientras tanto, existen distintos medios por los cuales se puede obtener información, intentando descartar dudas. Teniendo en cuenta el planteamiento propuesto, un acercamiento teórico con el objetivo de encontrar respuestas lo más claras posibles en cuanto al papel del artista respecto a la conservación/restauración de su obra, es del todo fundamental y relevante subrayar y pensar que en la conservación y restauración del arte contemporáneo gran parte de las veces está implicada la presencia del artista. Sin duda, una realidad con varios puntos de análisis: si por un lado, el trabajo de pesquisa está facilitado en la medida de que se puede recoger información sobre las obras junto a los propios autores; por otro, el artista entusiasmado interviene en su obra, y a veces este hecho levanta diversos cuestionamientos teniendo en cuenta los criterios y normas de la disciplina de conservación/restauración. En este sentido, hay que proponer el marco de tales intervenciones entre conceptos como derecho moral, patrimonial y de propiedad de forma a encontrar los límites de actuación. Para ello, es fundamental transponer tales intenciones a las leyes que protegen al artista plástico como autor, el Derecho de autor con base en el Texto Refundido de la Ley de Propiedad Intelectual, así como el análisis de las leyes que protegen, además del artista a los bienes culturales, como la Constitución Española y la Ley del Patrimonio Histórico Español. Como complemento de las normas jurídicas que están en vigor en España, se concede la aproximación a los conceptos y normas legales en el panorama internacional, con la presentación genérica de documentos y convenios que son fundamentales para la unificación de las normativas entre la Comunidad Europea y demás países del mundo. $\mathrm{Y}$ haciendo el puente con la conservación/restauración se analizan las Cartas de Restauro y las normativas teóricas que protegen el patrimonio para establecer límites de actuación en lo que 
dice respecto a los bienes culturales. Concretando, se buscan las respuestas a la cuestión: ¿Hasta qué punto la Ley de Propiedad Intelectual, y en específico las facultades presentes en el Derecho de autor, permiten al artista alterar su obra ya reconocida cultural y socialmente?, para que posteriormente se comprenda y se expongan las limitaciones, si existen, en las leyes vigentes, tanto para los artistas plásticos como para los conservadores/restauradores.

El deseo de encontrar estos límites está únicamente justificado por la necesidad de respetar y proteger los bienes culturales y artísticos, pero es patente que las leyes europeas, y específicamente las vigentes en España, están formuladas sobre la base de la relación autor-obra, lo que justifica con mayor evidencia la protección hacia el creador, desviando del centro de actuación e interés la protección de la obra de arte. Será, para ello, fundamental establecer puntos concretos de defensa y protección en ambos los sentidos, ya que se está en presencia de valores únicos e insustituibles caracterizadores de los bienes culturales y artísticos, y que deberán sobrevivir para que generaciones futuras disfruten de sus valores históricos y artísticos con los que han sido creados y por los cuales deben ser preservados.

Por la complejidad que las leyes y normativas imponen, este capítulo será iniciado con una pequeña contextualización sobre la creación y evolución de los Derechos de autor y de la Propiedad Intelectual, en que posteriormente se analizarán los puntos fundamentales y artículos seleccionados aplicables a la obra y su creador. Lo cierto, es que sería gratificante percibir y exponer los límites presentes en la Ley de Propiedad Intelectual y definir cuáles son los derechos que se oponen a los derechos del creador, pero conscientes de que tanto las normativas estatales como las internacionales pueden no establecer los límites necesarios para el control de la actividad de conservación/restauración y de las intervenciones realizadas por el autor. 


\subsection{Derecho de autor y la Ley de Propiedad Intelectual.}

\subsubsection{Reseña histórica, convenciones y tratados internacionales.}

No será sorprendente referir que con la intención y deseo de propagar las creaciones originales, hace siglos existió la necesidad e intención de proteger, tanto a sus autores y creadores como a las creaciones, de la difusión pública y desmedida de las mismas. Además de la relación directa que se establece con la evolución histórica y vacilante de la humanidad, una relación entre individuo y sociedad, es inevitable la conexión del Derecho de autor con el progreso tecnológico y las técnicas de reproducción, que obligaron a la modificación y revisión de las leyes sobre derecho de autor, tornándose algo complejo en el mundo actual.

La fecha de origen y establecimiento del Derecho de autor es incierta, pero está fuertemente conectada y asociada su creación con la invención de la imprenta en la Europa del siglo XV, puesto que antes de la creación de la imprenta las obras tenidas como creaciones intelectuales estaban regidas por el derecho de propiedad, o sea que el sujeto poseedor de la obra, su propietario, poseía todos los derechos sobre la misma. Lo cierto es que la imprenta incrementó grandes cambios, por los cuales, entre finales del siglo XV y comienzos del siglo XVIII, se han creado diversos decretos y leyes para la concesión de derechos exclusivos, porque hasta la Revolución Francesa los impresores y los libreros tenían el derecho de impresión y de venta ejerciendo un poder de monopolio a través del privilegio obtenido con la propiedad intelectual, y después de la Revolución se da el cambio y se establece una nueva realidad jurídica, en que el derecho de autor se consideró un derecho natural a la propiedad del producto de determinada ejecución.

La primera ley de Derecho de autor fue concedida en 1710, en Inglaterra, conocida por la ley de la Reina Ana, en que reconoció por primera vez la existencia de un derecho 
individual de protección sobre una obra impresa ${ }^{250}$. Siendo esta ley únicamente aplicable para los libros, dejando de lado todos los otros objetos impresos, en corto espacio de tiempo la ley fue considerada limitada de acuerdo con las prerrogativas a los autores de libros. En 1735, se hizo la promulgación de la ley de los grabadores, reclamando la protección para los artistas, dibujantes y pintores.

En Francia, en 1777, Luis XVI concibió seis decretos que establecen las bases para la impresión, edición y reconociendo el derecho de autor para publicar y vender sus obras. Varios fueron los cambios hechos en estos decretos, en que un derecho sobre derecho de autor de 1791 sancionó el derecho de ejecución y representación y otro de 1793 confirió al autor el derecho exclusivo de reproducción 251 .

En España se reconoció por primera vez el derecho de autor en 1762, en el reinado de Carlos III en que la ley prescribía que la facultad de imprimir un libro sólo esta concedida al autor.

Es en el siglo XVIII cuando surge la noción de Propiedad Intelectual por la influencia del naturalismo y de la llustración, cuando fue pretendida la máxima protección del autor, instaurando por fin el más poderoso derecho sobre las cosas invocado a través del derecho de propiedad.

El término "propiedad" se va superando puesto que con el paso del tiempo sufre cambios constantes por influencia de fenómenos económicos, teniendo presente los intereses extramatrimoniales o morales del autor, como la concepción más adecuada que atribuye al autor un derecho, al cual están asociadas las facultades, moral (inédito, paternidad, integridad, arrepentimiento) y patrimonial (reproducción, distribución, comercialización pública y trasformación). El término supone la protección sobre el soporte material en el que está incorporada la obra, o sea, la ley ciñe su protección a la obra escrita sobre forma de libro, al derecho de reproducción en relación a la obra plástica, pero retribuida al adquiriente del soporte original y no a su autor. Por ejemplo, en España, la Ley de 10 de junio de 1847 (propiedad literaria)

250 UNESCO, El abc del derecho de autor, p.14.

251 Ibídem. p.15. 
mantiene ciertas cuestiones de la legislación de la imprenta, con la preocupación de proteger al autor al reconocer un derecho sobre los frutos de su trabajo. Ya, la Ley de enero de 1879 incluso utilizando la denominación de "propiedad" propone algunos avances, pretendiendo que la expresión 'propiedad intelectual' no sea una fórmula pero que tenga consecuencias jurídicas y fundamentalmente que se confronte al derecho de propiedad sobre los bienes materiales por su garantía y perpetuidad.

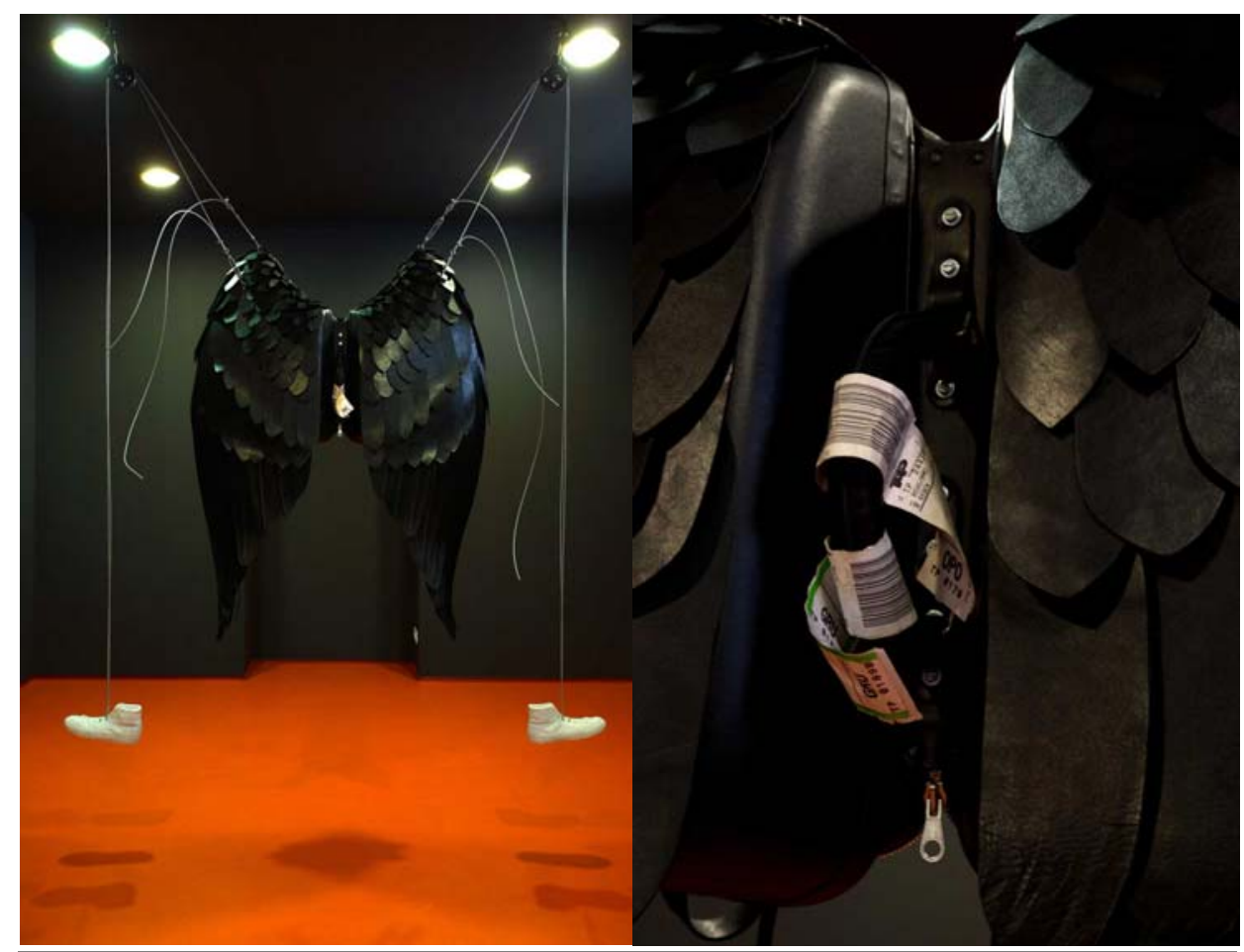

Figura 62: Isaque Pinheiro, instalación Sapatos de pedra e um horizonte que está sempre mais além, 2006. Cuero, mármol y metal, altura variable $\times 200 \times 50 \mathrm{~cm}$. Figura 63 : Detalle de las alas.

Es en el Código Civil de 1889 donde se produce la convención de la propiedad intelectual, como una de las propiedades especiales reglamentadas. La Ley de Propiedad Intelectual de 11 de noviembre de 1987, concibe el derecho de autor integrando una doble e indivisible orden de facultades. Si por un lado están las facultades de carácter personal que corresponden a los derechos morales; por otro lado, están las facultades de carácter patrimonial, a las que corresponden los derechos de explotación, atribuidos al autor según un carácter exclusivo y excluyente como derechos 
de monopolio. Por último, es necesario referir el Texto Refundido de la Ley de Propiedad Intelectual, de 12 de abril de 1996, cuyo núcleo está constituido por la anterior Ley de 1987, a la cual se incorporaron todas las disposiciones legales vigentes para la materia. El Texto Refundido es la ley en vigor, al cual se añadirán diversas modificaciones posteriormente.

En la legislación española, la definición de propiedad intelectual consiste en:

1. una propiedad inmaterial (por su objeto) de carácter especial, que la Ley atribuye a los autores de las obras literarias, artísticas y científicas por el solo hecho de su creación, y que está integrada por un conjunto de derechos de carácter patrimonial y personal. Sería, por tanto, un derecho subjetivo formado por un conjunto de facultades que se atribuyen a los titulares originales de ese derecho; esto es, a los autores. ${ }^{252}$

La justificación para mantener la denominación de propiedad intelectual consiste, no sólo en la presencia de la misma en las anteriores leyes, sino también en referirse a otros sujetos de derechos que participan en la creación, existiendo otros derechos de propiedad intelectual distintos de los del autor, como los derechos afines o conexos a los autores. O sea, un derecho subjetivo atribuido no sólo a los autores, sino también a varios sujetos que participan en la creación, y por ello entendidos como los titulares de los derechos afines o conexos. Con todo, las esferas de protección entre los varios derechos quedan perfectamente separadas, y a pesar de existieren como derechos en la Ley, en esta investigación no será incluido su estudio.

El derecho de autor equivale a afirmar, en el plano jurídico, que los escritores y autores tienen derecho a la propiedad sobre sus obras. Los escritores y autores tienen derecho a estar protegidos contra el uso no autorizado de sus obras y a recibir una parte de los beneficios obtenidos gracias a su utilización pública. El derecho de autor -y en algunos países (...)- también protege un conjunto de interés que se han dado en llamar «derechos morales» de los autores. Se trata primordialmente de que se le reconozca al autor la paternidad de la obra y se respeta lo esencial del carácter de la misma, así como su integridad. 253

Es cierto que gran parte de los estados y países establecieron sus leyes sobre derecho de autor y que con el paso de la evolución tecnológica fueron sufriendo

${ }^{252}$ ROIG Serrano, Miguel. El futuro de la creación. Los derechos de autor de los creadores visuales. p.32.

253 UNESCO, ob. cit. p.18. 
modificaciones, en las que tampoco tuvieron eficacia fuera de los respectivos territorios nacionales. Mientras tanto y en respuesta a la necesidad de proteger las obras más allá del territorio nacional, en 1886 fue firmado por varios países el primer acuerdo multilateral: el Convenio de Berna para la Protección de las obras Literarias y Artísticas, y en 1952 se aprobó la Convención Universal sobre Derecho de Autor.

Este tratado internacional establece la máxima protección posible de los derechos de autor, sobre la denominación de Convenio de Berna para la Protección de las Obras Literarias y Artísticas 0, más conocido como, la Convención de Berna. En 1886 se firma el primer texto, que más tarde ha sido completado y revisado en distintas ocasiones, pero las últimas modificaciones se establecen en 1979, en que todos los países participantes, un total de 149 estados, se comprometen a adoptar, con conformidad a la Convención, las medidas necesarias para cumplir los objetivos propuestos. A través de los 38 artículos está demostrado el deseo de máxima protección de todas las obras literarias y artísticas independientemente del modo y de la forma de expresión que se dan a conocer, además de los 6 artículos presentados en anexo como disposiciones especiales relativas a los países en desarrollo, que constituyen la unión entre los países que accedieron a esta convención. Uno de sus objetivos establece que los autores de obras literarias y artísticas gozan del derecho exclusivo de autorizar la reproducción de sus obras. Cabe decir que esta protección no se sobrepone a la legislación sobre los Derechos de autor vigente en cada país la cual deberá regular y definir cuáles son las obras protegidas, pero sí, es más una protección de los autores y sus derecho habientes, concediendo digna protección y uso honrado fuera del país de origen de la creación, como figura en los tres principios básicos que la componen. El primer principio, define que las obras originarias de alguno de los estados contratantes deben recibir la misma protección exigida a las obras de sus propios ciudadanos; el segundo principio, dicta que esa misma protección no deberá estar condicionada al cumplimento de formalidad alguna; y por último, el tercer principio, determina que tal protección es independiente de la existencia de una protección correspondiente en el país de origen, como son ejemplo las excepciones de los plazos de protección, variables en cada Estado. Además de los principios básicos presentados, hay que referir los artículos 9 y 16, que exponen 
los derechos de reproducción (Art. 9.1. Los autores de obras literarias y artísticas protegidas por el presente Convenio gozarán del derecho exclusivo de autorizar la reproducción de sus obras por cualquier procedimiento y bajo cualquier forma254) y la normativa para los ejemplares falsificados (art.16), aplicable siempre que la obra tenga protección legal en su país de origen.

Por otro lado, dentro del mismo tema, está la Convención de Ginebra de 1952, más conocida como la Convención Universal sobre Derecho de Autor del cual resulta el Texto Oficial en 1952, y que posteriormente en 1971 en París se redacta el Texto Oficial revisado. Con el deseo de asegurar en todos los países la protección del Derecho de autor sobre las obras literarias, científicas y artísticas, es formulada esta convención universal para proteger a sus autores y las obras en difusión, además de asegurar la protección de los intereses patrimoniales del autor, describiendo en cada artículo las protecciones que los Estados contratantes pueden y deben presentar, teniendo siempre en cuenta la legislación interna de cada Estado.

En el mismo sentido, es necesario citar los Tratados de la OMP1255, concluidos en 1996 pero solamente en 2002 entran en vigor, consistiendo en dos tratados que prosiguen la actualización de los tratados sobre derecho de autor y derechos conexos ya existentes, en relación al Convenio de Berna. El primer Tratado de la OMPI, centrado en la protección de obras literarias y artísticas, incluyendo además de las tipologías clásicas, los programas de ordenador, las bases de datos o las obras audiovisuales. Ya el segundo tratado, se centra en los productores de fonogramas $u$ otras grabaciones sonoras y de los derechos de los artistas intérpretes o ejecutantes. Ambos con la intención de asegurar el control sobre la explotación de las obras y garantizar una remuneración por los usos de las mismas en especial cuando éste es realizado a través de Internet, y de acuerdo con los derechos de distribución, alquiler y comunicación pública.

${ }^{254}$ Convenio de Berna para la Protección de las obras Literarias y Artísticas. en < http://www.bibliotecasvirtuales.com/ biblioteca/derechosdeautor/conveniodeberna.asp>

255 OMPI, es la Organización Mundial de la Propiedad Intelectual, creada en 1967 y dedicada al fomento del uso y de la protección de las obras del intelecto humano. 
Por último, se cierra esta contextualización general sobre los derechos de autor, haciendo referencia a la VEGAP, Visual Entidad de Gestión de Artistas Plásticos y a la UAAV, Unión de Asociaciones de Artistas Visuales. La VEGAP, es una entidad formada por los autores y sus herederos, fundada en 1990, que protege a los artistas plásticos y que reconoce, respeta y gestiona de forma colectiva en España los derechos de autor establecidos en la Ley de Propiedad Intelectual, como derechos de carácter personal y de carácter patrimonial, si es deseo de los autores. Por otra parte, la UAAV, se formó en 1996 como la unión de siete asociaciones de artistas visuales con el objetivo de articular al colectivo de artistas en el ámbito estatal y ante la necesidad de interlocución entre la comunidad artística y las instituciones españolas, europeas y los agentes intermediarios256, a lo cual es importante hacer referencia a la Propuesta de decálogo de buenas prácticas profesionales en las artes visuales 257 , aprobado por la Unión de Asociaciones durante la asamblea general de 13 de julio de 2006, en Madrid. En forma de cierre, si cita el artículo 1 de tal documento, donde está evidente el respeto a la libertad de creación y expresión, con base en el artículo 20 de la Constitución Española, en que en ningún caso y bajo ningún pretexto un mediador o institución podrá censurar ni modificar la obra del artista.

256 En <http://www.uaav.org/>.

257 Documento consultado en <http://www.avam.net/docs/down/descarga_5.pdf>. Acceso en: 5.mayo.2008. 


\title{
1.2. Los creadores visuales como autores
}

\author{
A questo punto è evidente che il rapporto tra autore e proprietario diventa essenziale perché \\ sono diritti che possono non coincidere. E il diritto d'autore è un diritto prima di tutto morale \\ perché attiene direttamente alla persona, ma è oggetto di un rapporto economico che \\ riguarda l'utilizzazione dell'opera, i suoi limiti: problemi vastissimi che si pongono, nonostante \\ l'assenza di una legislazione specifica, anche all'attenzione della comunità in generale.258
}

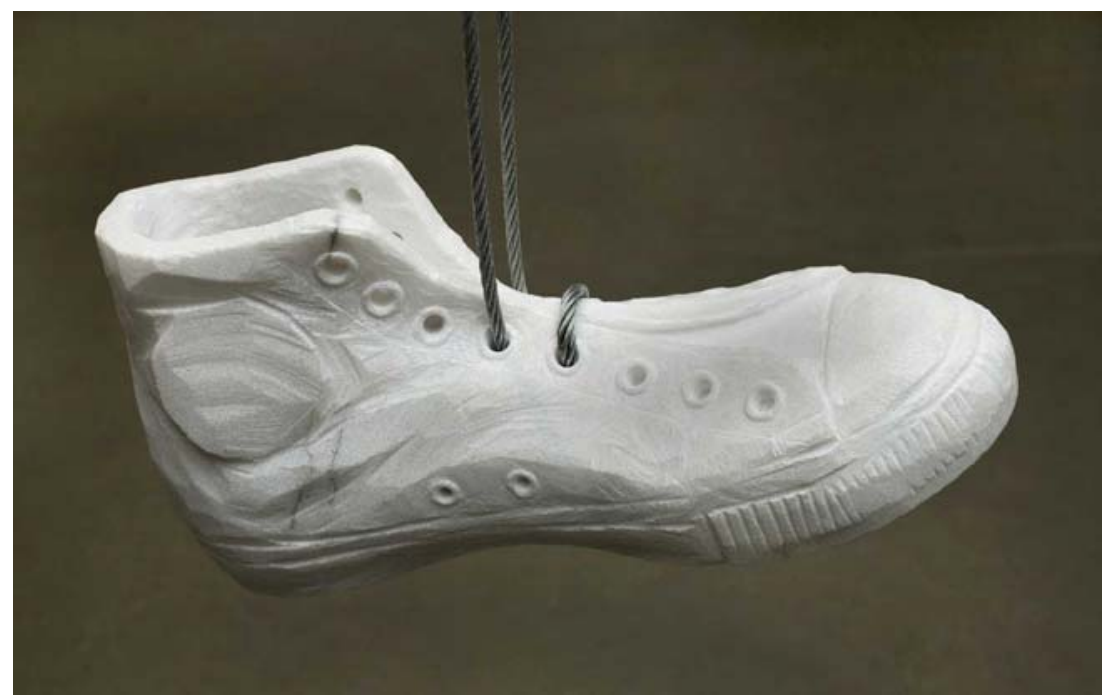

Figura 64: Isaque Pinheiro, detalle de la instalación Sapatos de pedra e um horizonte que está sempre mais além, 2006. Zapatilla esculpida en mármol.

El Art.6 de la Declaración Universal de los Derechos Humanos, expone que todo el ser humano tiene derecho, en todas las partes, al reconocimiento de su personalidad jurídica, al cual se añade con el Art.27.2, de la misma Declaración, toda persona tiene derecho a la protección de los intereses morales y materiales que le correspondan por

258 SACCHETTO, Plinio. La legge e il restauro dell'arte. en AA. VV. Arte contemporanea. Conservazione e restauro. p.130.

T. A.: En este punto es evidente que la relación entre autor y propietario llega a ser esencial porque son derechos que pueden no coincidir. $Y$ el derecho de autor es un derecho antes de todo moral porque trata directamente a la persona, pero es objeto de una relación económica que respete la utilización de la obra, sus límites: problemas vastísimos que se ponen, a pesar de la ausencia de una legislación específica, también a la atención de la comunidad en general. 
razón de las producciones científicas, literarias o artísticas de que sea autora. La declaración adoptada en 1948 por la Asamblea General de las Naciones Unidas determina de forma sucinta los derechos e intereses pertenecientes a cualquier individuo, incluso particulariza tal protección universal a los creadores, es como tal una señal de la protección universal del autor. Sin duda, el vínculo entre individuo y la vida en sociedad supone una relación sujeta a reglamentación en sus distintos campos de acción. Si por un lado, están las normas morales, acciones libres, establecidas por la ética presente en la sociedad en que su violación se da con evidente reprobación social; por otro lado, surgen las normas jurídicas, caracterizadas por su complejidad y comprendidas con una superestructura del fenómeno social, y que imponen un comportamiento como regla. En esta medida, el Derecho presupone derecho como norma y derecho como facultad; derecho objetivo y derecho subjetivo; en que el concepto derecho expone algo que viene dirigido, regido, o sea disciplinado con fuerza inflexible. ${ }^{259}$

Si en paginas anteriores la relación entre artista y la creación se detuvo en la contextualización histórica, cultural y artística de carácter social, en las páginas siguientes se asomará a la persona jurídica y las protecciones a sí atribuidas por el hecho de estar asociado a una creación original fruto de su capacidad intelectual. Sabiendo que los orígenes de los Derechos de autor surgen con la imprenta, hay una dificultad intrínseca en la aplicación de los mismos derechos en el campo de las artes plásticas, pero que con el tiempo se fueron amoldando y en los cuales se pueden encontrar ejemplos claros de privilegios concedidos a los artistas plásticos, como es el caso de Alberto Dürer. A lo largo de la primera mitad del siglo XVIII surgen los primeros esbozos para la protección respecto a la realización y venta de grabados, pero, sólo en 1744 se establecieron reglas que afectaban a los diseñadores (una situación que resulta de la creación de la industria de seda de Lyon, que afecta a los creadores de patrones para tejidos). Es en la Revolución Francesa cuando surge la Ley de 19 de julio de 1793 (ámbito nacional francés), en la que se consagra el derecho de reproducción, dotando al Derecho de autor de un sentido moderno.

${ }^{259}$ BADENES Gasset, Ramón. Conceptos fundamentales del derecho. Las relaciones jurídicas patrimoniales, p.5. 
En España la protección a los autores plásticos nace con la Ley de Propiedad Literaria de 10 de junio de 1847, pero su base únicamente se refiere a la reproducción de las obras, distinta de la Ley de Propiedad Intelectual de 10 de enero de 1879 que alberga protección para los autores de mapas, planos o diseño científico, además de la protección para los autores de obras de arte y su reproducción. Sin embargo, solamente 12 de abril de 1996 se define el Texto Refundido de la Ley de Propiedad Intelectual, ley en vigor.

Concretamente, desde finales del siglo XVIII, es concebida la existencia de un derecho de autor a los artistas plásticos, pero uno de los problemas existentes en la legislación para los derechos de los creadores visuales fue la necesidad de invocar y extender las leyes de protección de las obras literarias a las obras plásticas, puesto que existe una diferencia inmensa entre una obra literaria y un lienzo o escultura que son obras únicas, y es a través de la evolución histórica y el desarrollo de los medios de multiplicación, de copia y reproducción, lo que dará un verdadero sentido y significación propia a las normas del derecho de autor aplicadas a los creadores visuales 260

De este modo, en la legislación vigente y como refiere el art.5.1 de la Ley de Propiedad Intelectual (a partir de ahora L.P.I.), es reconocido a los creadores visuales su condición de autores, titulares de los derechos de autor, reconocimiento que les corresponde en cuanto personas naturales que crean alguna obra artística, y que el art.1 refiere que es concedido tal derecho al artista, por el solo hecho y desde el momento mismo de su creación ${ }^{261}$, de lo que se concluye que son objeto de propiedad intelectual todas las creaciones originales artísticas expresas en cualquier soporte y por cualquier medio, conocido en la actualidad o que se venga a conocerse en un futuro (art.10).

La Ley parece establecer y regular con facilidad los Derechos de autor a los creadores visuales, dejando la atribución de la paternidad o de la integridad y respeto por la obra y su utilización bien definidos, pero con una consciencia palpable de que el mercado del arte desarrolla fuerzas contrarias a estas

260 ROIG Serrano, ob. cit. p.40.

261 Ibídem. p.39. 
protecciones, porque el derecho de reproducción, ha perdido ya su significado tradicional de multiplicación o producción de ejemplares para pasar a ser definido como la fijación o incorporación de la obra a un soporte físico, con independencia de que esa fijación se utilice luego o no para la obtención de ejemplares. 262

Pero el tema central no está en las cuestiones de paternidad ni de reproducción 0 distribución, por ejemplo, cuestiones éstas que la ley define con claridad. Las cuestiones principales tocan otros limites de actuación, ¿al final, cuales son los límites del papel del artista en la conservación y restauración de su propia obra?, ¿será que la respuesta está en la Ley de Propiedad Intelectual y en los Derechos de autor redactados?

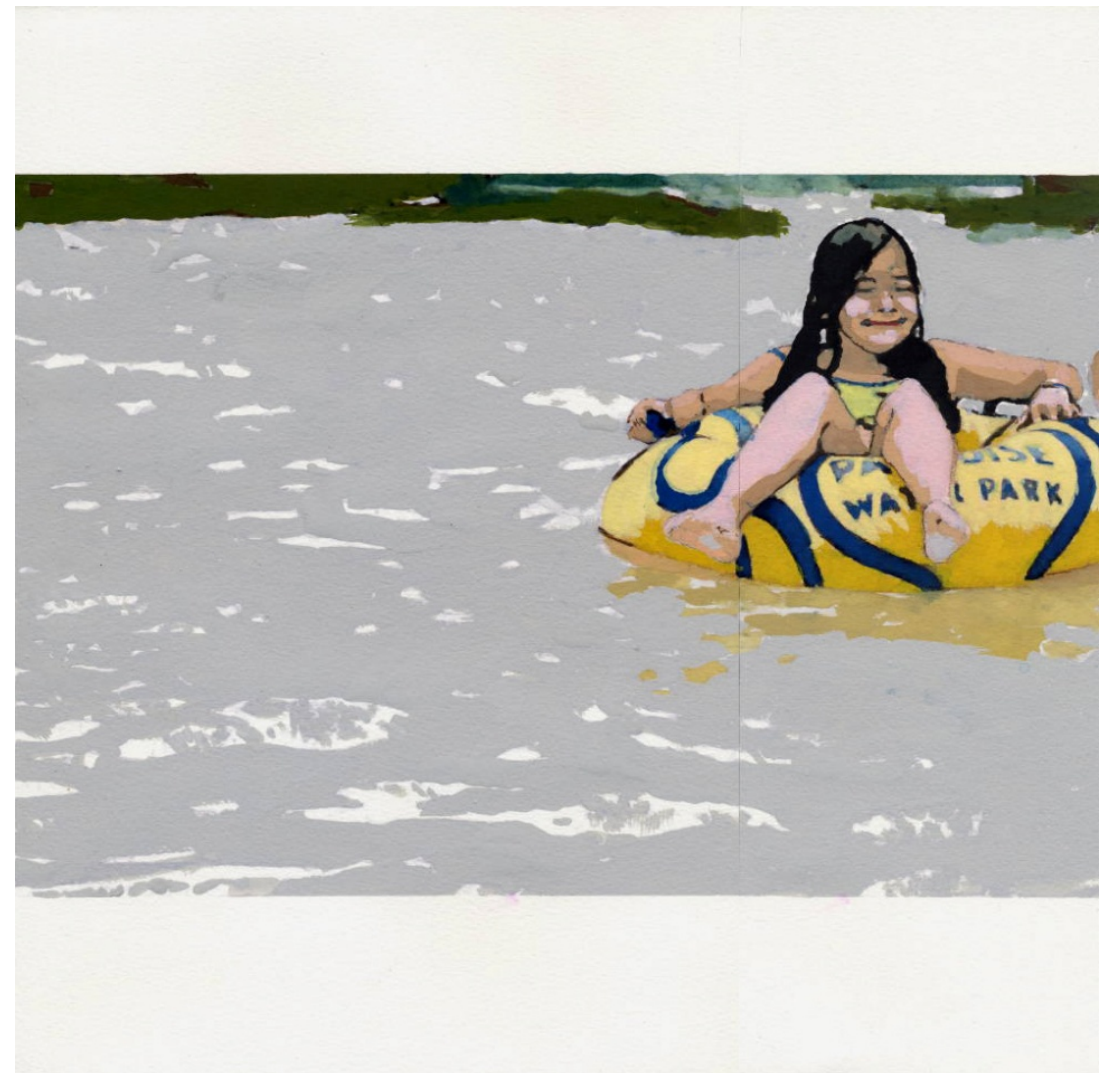

Figura 65: Ana Cardoso, Splash, 2008. Grafiti y guache sobre cartón, 30×27cm.

${ }^{262}$ ROIG Serrano, ob. cit. p.41. 
1.2.1.Selección de artículos del Texto Refundido de la Ley de Propiedad Intelectual. ${ }^{263}$

En este apartado, serán presentados únicamente los artículos referentes al autor y sus derechos en relación con la obra, que de cierta forma o medio, irán al encuentro de la concretización de las ideas y planteamiento clave, sabiendo que el Derecho de autor engloba muchas otras nociones que no son exclusivas de los deberes y derechos de su autor.

Artículo $1 .^{\circ}$ Hecho generador.-La propiedad intelectual de una obra literaria, artística 0 científica corresponde al autor por el sólo hecho de su creación.

Art. $2 .^{\circ}$ Contenido.-La propiedad intelectual está integrada por derechos de carácter personal y patrimonial, que atribuyen al autor la plena disposición y el derecho exclusivo a la explotación de la obra, sin más limitaciones que las establecidas en la Ley.

Art. 3. ${ }^{\circ}$ Características.-Los derechos de autor son independientes, compatibles y acumulables con:

1. ${ }^{\circ}$ La propiedad y otros derechos que tengan por objeto la cosa material a la que está incorporada la creación intelectual.

$2{ }^{\circ}$ Los derechos de propiedad industrial que pueden existir sobre la obra.

Art. $5{ }^{\circ}$ Autores y otros beneficiarios. -1 . Se considera autor la persona natural que crea alguna obra literaria, artística y científica.

Art. 6. ${ }^{\circ}$ Presunción de autoría, obras anónimas o seudónimas.-1. Se presumirá autor, salvo prueba en contrario, a quien aparezca como tal en la obra, mediante su nombre, firma o signo que lo identifique.

Art.10. Obras y títulos originales.-1. Son objeto de propiedad intelectual todas las creaciones originales literarias, artísticas 0 científicas expresadas por cualquier medio 0 soporte, tangible 0 intangible, actualmente conocido 0 que se invente en el futuro, comprendiéndose entre ellas:

e) Las esculturas y las obras de pintura, dibujo, grabado, litografía y las historietas gráficas, tebeos o comics, así como sus ensayos o bocetos y las demás obras plásticas, sean o no aplicadas.

Art.14. Contenido y características del derecho moral.- Corresponden al autor los siguientes derechos irrenunciables e inalienables:

1. ${ }^{\circ}$ Decidir si su obra ha de ser divulgada y en qué forma.

2. ${ }^{0}$ Determinar si tal divulgación ha de hacerse con su nombre, bajo seudónimo o signo, 0 anónimamente.

3. ${ }^{\circ}$ Exigir el reconocimiento de su condición de autor de la obra.

${ }_{263}$ Todos los artículos citados, constan del Real Decreto Legislativo 1/1996, de 12 de Abril, por el que se aprueba el Texto Refundido de la Ley de Propiedad Intelectual, regularizando, aclarando y armonizando las disposiciones legales vigentes sobra la materia. en BERCOVITZ Rodríguez-Cano, Rodrigo (Dirección) Legislación sobre Propiedad Intelectual, 765p. 
4. ${ }^{\circ}$ Exigir el respeto a la integridad de la obra e impedir cualquier deformación, modificación, alteración 0 atentado contra ella que suponga perjuicio a sus legítimos intereses o menoscabo a su reputación.

5. ${ }^{\circ}$ Modificar la obra respetando los derechos adquiridos por terceros y las exigencias de protección de bienes de interés culturales.

6. ${ }^{\circ}$ Retirar la obra del comercio, por cambios de sus convicciones intelectuales 0 morales, previa indemnización de daños y prejuicios a los titulares de derechos de explotación.

$\mathrm{Si}$, posteriormente, el autor decide reemprender la explotación de su obra deberá ofrecer preferentemente los correspondientes derechos al anterior titular de los mismos y en condiciones razonablemente similares a las originarias.

7. ${ }^{\circ}$ Acceder al ejemplar único o raro de la obra, cuando se halle en poder de otro, a fin de ejercitar el derecho de divulgación o cualquier otro que le corresponda.

Este derecho no permitirá exigir el desplazamiento de la obra y el acceso a la misma se llevará a efecto en el lugar y forma que ocasionen menos incomodidades al poseedor, al que se indemnizará, en su caso, por los daños y prejuicios que se le irroguen.

Art. 17. Derecho exclusivo de explotación y sus modalidades.- Corresponde al autor el ejercicio exclusivo de los derechos de explotación de su obra en cualquier forma y, en especial, los derechos de reproducción, distribución, comunicación pública y transformación, que no podrán ser realizadas sin su autorización, salvo en los casos previstos en la presente Ley.

Art.21. Transformación.- 1. La transformación de una obra comprende su traducción, adaptación y cualquier otra modificación en su forma de la que se derive una obra diferente.

Art.56. Transmisión de derechos a los propietarios de ciertos soportes materiales.-1.El adquiriente de la propiedad del soporte a que se haya incorporado la obra tendrá, por este solo título, ningún derecho de explotación sobre esta última.

2. No obstante el propietario del original de una obra de artes plásticas o de una obra fotográfica tendrá el derecho de exposición pública de la obra, aunque ésta no haya sido divulgada, salvo que el autor hubiera excluido expresamente este derecho en el acto de enajenación del original. En este caso, el autor podrá oponerse al ejercicio de este derecho, mediante la aplicación, en su caso, de las medidas cautelares previstas en esta Ley, cuando la exposición se realice en condiciones que perjudiquen su honor 0 reputación.

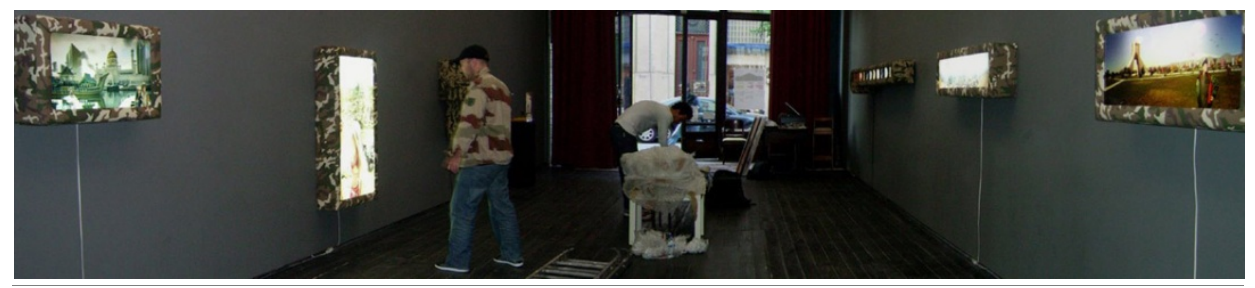

Figura 66: Montaje de la exposición del proyecto Barbarybabyzation de Rui Pedro Fonseca. Oporto, 2007. 


\subsubsection{Comentarios a los artículos seleccionados}

No cabe duda que al Derecho de autor está asociado a un conjunto de normas y principios jurídicos presentes, como ya fue referido, en el Texto Refundido de la Ley de Propiedad Intelectual, y que se regulan a través de los derechos morales y de los derechos patrimoniales, concedidos a los autores, como creadores de obras literarias, artísticas 0 científicas presentadas como inéditas, como lo establecido en los arts. $2 .^{\circ}$ y 5. ${ }^{\circ}$. A los derechos morales está asociada la protección moral del creador, así como la garantía del reconcomiendo entre el creador y su obra, y por ello, es considerado autor la persona que crea la obra. Los derechos patrimoniales están estrictamente establecidos para la protección de la obra, o sea que se reconoce la paternidad de la obra, por lo cual tiene derecho a definir las utilizaciones de la misma, pero sin considerar los atributos morales del autor. El art.5. ${ }^{\circ}$, no es una norma atributiva de derechos, sino predicativa de la condición de autor, por lo que las personas jurídicas podrán ser titulares originales de derechos afines, cesionarios presuntos de derechos de autor por el simple hecho de la creación, pero nunca autores.

En la L.P.I., no sólo son consideradas como objeto de protección las creaciones originales, sino también cualquier otra obra que reúna los requisitos exigidos de forma a gozar de tal protección, siempre y cuando el primer requisito sea la originalidad. Para comprender la noción de originalidad, es necesario hacer la distinción entre ésta y novedad como criterio diferenciador entre propiedad intelectual -que exige originalidad- y propiedad industrial -que exige novedad; o sea, una pintura no tiene que probar su novedad, pues podrá existir un sinnúmero de autores que pinten el mismo tema, sin embargo, para que la obra goce de protección tiene que ser reflejo de la personalidad del autor, como manifiesto único de esa personalidad. Son objeto de protección las obras de creación por su expresión formal, porque la creación original implica una forma expresiva, en que no es la idea lo considerado patrimonio de la humanidad, porque la idea es algo abstracto de libre circulación, puesto que es necesario una manifestación formal de dicha protección. Esta y otras cuestiones 
hacen de la Ley algo amplio, puesto que cualquier creación original de las artes visuales es hoy objeto de propiedad intelectual, independientemente de su medio de expresión, y estar protegida significa proteger el título, el nombre y la imagen del autor. Con todo, hasta este punto no se presentan problemas mayores: si ante de una pintura o una escultura, o cualquier otra expresión artística contemporánea, ésta respeta el concepto de originalidad como demostrado anteriormente, es por sí misma objeto de protección. Además, una protección también asegurada siempre que una idea original sea expresada a través de cualquier medio para su materialización física y posteriormente la atribución de paternidad.

Otra cuestión que está asociada al tema de las creaciones es el de las denominaciones de obras en colaboración, obra compuesta y obra derivada, todas como resultado de la presencia o colaboración de varios autores. Con todo, en este estudio no se realizará ningún análisis de tales denominaciones, por su distinto enfoque y un resultado dispar en términos de la información deseada.

Uno de los puntos que fueron introducidos en la Ley de Propiedad Intelectual de 1987, se refiere a las facultades que sustentan el creador frente a su obra y que derivan del derecho moral. Tales facultades, entendidas como un escudo de protección ante terceros que tienen la intención de invadir y vulnerar la titularidad y los intereses legítimos que el autor tiene sobre su obra, son inalienables e irrenunciables, puesto que son intransferibles, a excepción de los supuestos de legislación mortis causa. De este modo, el derecho moral corresponde al autor, sólo por el hecho de haber creado una obra original, tornando tales derechos irrenunciables, en que los autores no pueden renunciar a sus prerrogativas morales, o sea, no pueden dejar de poseer de forma voluntaria las facultades morales; e inalienables, pues no son susceptibles de estimación económica, luego están fuera del comercio, por lo cual es imposible la transmisión de tal derecho a terceros (art.14), concluyendo que las facultades morales quedarán siempre inherentes a la esfera del autor en relación a su creación. ${ }^{264}$. Una protección que se sustenta sobre dos puntos: que el autor es la única persona que tiene el poder y el deber para decidir en qué momento la obra se encuentra terminada

264 SARDÀ, Mariona y GUITIÉRREZ Vicén, Javier. El futuro de la creación. Los derechos de autor de los creadores visuales. p.78. 
y susceptible de manifestación pública; así como, al autor pertenece el deber de salvaguarda de los intereses económicos y personales en todos los procesos de explotación.

Para ello, se clasifican los derechos de autor en dos grandes grupos:

a) los derechos morales, que conciben mayoritariamente como derechos de la personalidad, inherentes al autor, irrenunciables e intransmisibles.

b) los derechos patrimoniales, que se confieren al autor con carácter exclusivo, y estos se pueden dividir en: los derechos de explotación, que consisten en los derechos que se atribuyen al autor en régimen de monopolio, con carácter exclusivo y excluyente, de modo que nadie puede utilizarlos sin el consentimiento del autor; y los derechos de simple remuneración, que conceden al autor la facultad de prohibir la explotación de su obra.

En resumen, la denominación de "derecho de autor" pone en relieve el lado personal, una vinculación íntima entre sujeto y obra, sin que haya vinculaciones directas con la esfera patrimonial o moral, siendo un derecho subjetivo e integrado por facultades de orden moral y patrimonial. Y en que la L.P.I. tiene la finalidad de proteger al autor como creador intelectual de una obra original, y por ese hecho merece disfrutar del resultado obtenido y con el cual enrique el patrimonio cultural y artístico.

Pero, ¿hasta qué punto el Derecho de autor, y en específico las facultades presentes en el derecho moral, darán al autor el derecho de alterar la obra ya reconocida cultural y socialmente? La respuesta está asociada al art.14.3, que proclama la paternidad como consecuencia del acto de creación intelectual, y a ésta vinculado el respeto a la integridad de la obra, que supone una conexión con el derecho de divulgación, en que su autor deberá vigilar, de forma que la obra sea conocida tal como fue creada, además de ser mantenida en ese estado hasta que su autor decida introducir alguna modificación o alteración, o sea, que le pertenece el poder exigir el respeto a la integridad de la obra e impedir cualquier deformación, modificación, alteración 0 atentado contra ella que suponga prejuicio a sus legítimos intereses o menoscabo a su reputación (art.14.4). Y esta posibilidad sucede porque el autor también posee el 
derecho de modificación, como una manifestación del derecho fundamental a la libre creación artística, como expone el art.14.5, o sea, que el autor puede modificar la obra respetando los derechos adquiridos por terceros y las exigencias de protección de bienes culturales. En este sentido, existe un límite que la L.P.I. define en dos puntos y que impide modificar la obra arbitrariamente. El primer punto estipula que deben ser respetados los derechos adquiridos, y el segundo punto está definido por las exigencias de los bienes de interés cultural. De acuerdo con el primer punto, el autor puede realizar variaciones en la obra si estas modificaciones no se dan sobre la integridad de la misma, y siempre con el consenso del titular de los derechos de explotación, por lo cual estos derechos corresponden exclusivamente al autor de las creaciones visuales, o caso contrario, para ser ejecutados por terceros es necesaria la autorización del autor. Así pues, el autor podrá siempre incorporar a la obra creada su evolución artística, dentro de los límites que el propio artículo ya señala. ${ }^{265}$
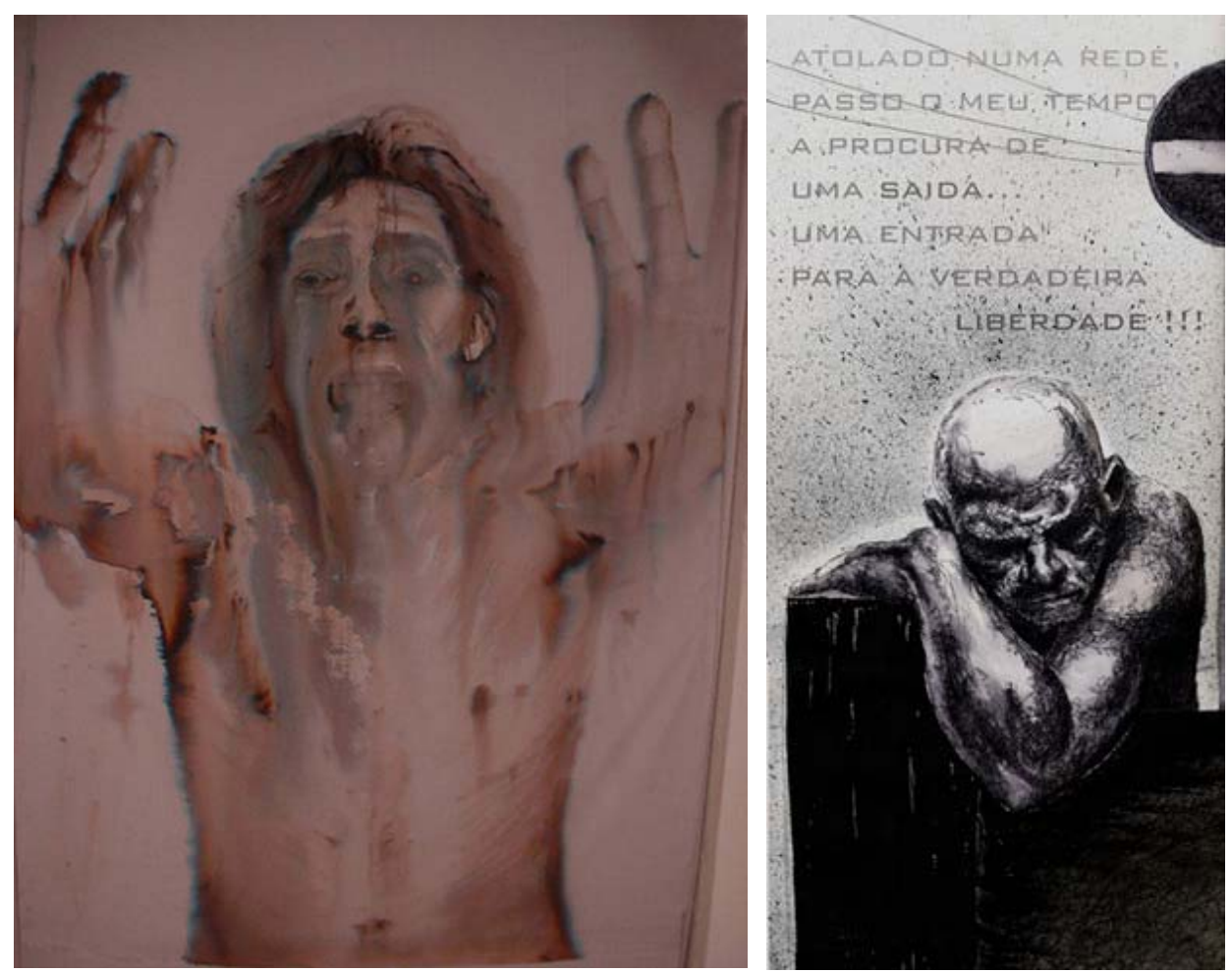

Figura 67: João Pedro Rodrigues, !!??!!!. Cromatografía sobre tejido, 200x150cm. Figura 68: João Pedro Rodrigues, Atolado. Dibujo de tinta de china sobre papel.

265 SARDÀ, ob. cit. p.86. 
En el art.14.7 se refiere que se puede acceder a la obra por distintos motivos, como la divulgación, exposición 0, por ejemplo, para consignar en la misma el nombre o firma del autor. Con todo, no se puede acceder a la obra para ejercitar el derecho de modificación frente al propietario material de la obra. Así, como no hay derecho de acceso para restaurar o para ejercitar los derechos de alquiler y préstamo si el autor no se reservó el derecho de exposición. Esta cuestión remite al art.17, que habla de los derechos de explotación de una obra que sólo se concretizan si ésta no está exteriorizada o fijada en un soporte material de cualquier clase.

Todavía hay necesidad de explicar el término «modificación», cuando por el mismo se comprenden correcciones y mejoras sustanciales, así como modificaciones accesorias de la obra, pero siempre que sean imprescindibles y que respeten la esencia de la obra; o sea, el carácter originario por el cual la obra ha sido divulgada deberá ser mantenido. $Y$ en este punto es necesario hacer la distinción entre «obra modificada» (derecho moral, art.14.5) y «obra transformada» (derecho patrimonial, art.17), pues el término «modificación» también se emplea en el art.21 para definir el derecho de transformación. Modificar supone por lo tanto, un cambio de contenido y de los rasgos esenciales de la obra, mientras que transformación se refiere a una alteración accidental de la forma, sin variaciones de los elementos sustanciales y definiciones de la obra. En el art.21 se habla de transformación para referir una acción, generalmente proveniente de una persona que no el autor (y aquí entraría la figura del conservador/restaurador) y que da origen a una obra nueva, derivada de la anterior (cuestión que ya no puede pertenecer a los criterios de conservación y restauración), pero con una tutela autónoma en la L.P.I. que le permite coexistir con ella. El derecho de transformación, comprende la facultad de traducción, la adaptación y cualquier otra modificación de la obra que deriva en una obra diferente, es decir, creando una obra nueva derivada. La obra derivada es una transformación de la obra preexistente, o sea, una obra que es parecida pero distinta de la precedente. El art. 21 es por lo tanto, una de las cuestiones más difíciles y complejas del derecho de autor, puesto que existen dos lados por la cual puede ser vista: el lado, objetivo de la protección de la obra, del cual surgen las llamadas obras derivadas, sea, por el lado subjetivo del derecho de transformación que corresponde al autor; además, de una 
última posibilidad, la que corresponde a la transgresión de las reglas que la reconocen y protegen a través de la transformación ilícita. Lo cierto es que nadie puede modificar una obra sino su propio autor, y eso es posible hacerlo legalmente si da origen únicamente a una obra derivada.

En otro punto, lo cierto es que son varios los posibles ejemplos en los cuales los artistas muchas veces no tienen consciencia de cómo pueden envejecer sus trabajos, y cuando deparan con el deterioro pueden reaccionar de distintas formas con el objetivo de llevar a cabo una intervención, fundamental o no para la vitalidad de la obra, a través de varios medios. Cuando esta tarea es llevada a cabo por terceros, como los conservadores/restauradores surge una nueva cuestión: ¿es necesario contactar con al artista o sus herederos para encontrar una solución? En el estudio estadístico que se presenta en el capítulo IV de esta investigación, se puede comprobar que más de la mitad de los artistas entrevistados afirman que es fundamental la realización de una consulta previa. Además existe otra justificación, de orden moral, sin negar el papel de los derechos de autor, que comporta la relación del artista con su creación. No se ponen en duda los derechos que al artista plástico tiene sobre su creación, considerada original y personal, o sea, todos los trabajos originales están bajo protección legal, protegiendo el artista y su obra, del uso no autorizado durante todo el tiempo previsto por el derecho de explotación. Un derecho, que en los varios países de la Comunidad Europea puede variar su duración entre 50 y 70 años después de la muerte del artista. Todavía, en estos puntos no está involucrada de ninguna forma la actividad de conservación/restauración, lo que cambia cuando se habla de los derechos morales, siempre y cuando el artista esté preocupado con la preservación de su obra. Un derecho no comerciable, al cual están asociadas distintas cláusulas como: el derecho de paternidad o el derecho de integridad, y que son fundamentales para la obra siempre que se establece el vínculo entre creador y obra. Es necesario referir que el artista como tal, puede ejercer sobre terceros el derecho de integridad, cuando la obra no ha sido respetada de acuerdo con su intención creativa. O sea, el derecho moral establece que independientemente de que la obra sea de su pertenencia o haya sido vendida, al autor siempre le será atribuida la autoría que le otorgan determinados derechos, como exigir integral respeto hacia el 
objeto, sin sufrir ninguna modificación, mutilación o deformación, en que la presunción no cuestiona el carácter de obra protegida. Tanto los derechos morales, como los derechos de integridad, están indisolublemente conectados al artista, el creador vivo, y sólo el artista puede involucrarlos. Después de su muerte estos derechos son transferidos a sus herederos. De un modo general, los derechos morales no engloban todas las necesidades que en realidad pueden suceder con las obras de arte. Además, el grado de protección varía de acuerdo con la reputación del artista, pero es cierto que todo lo que es creado, e identificado como original de un individuo, tendrá automáticamente la mínima protección a través de lo establecido jurídicamente con los derechos morales.

De acuerdo con la L.P.I. y las disposiciones que la complementan, los derechos de autor son independientes y compatibles con la propiedad y otros derechos sobre el soporte material al que se incorpora la creación, con los derechos de propiedad industrial que puedan existir sobre la obra, y con los derechos afines o conexos a los del autor, que la Ley atribuye a otros partícipe de la actividad creadora.266

${ }^{266}$ ROIG Serrano, ob. cit. p.33. 


\subsection{Aspectos jurídicos de la relación autor y propietario.}

El hecho de que los bienes culturales y artísticos sean fruto de un doble interés: el interés privado (propietario del bien) y el interés público (estado o comunidad), hace necesario determinar un tratamiento legal especial, por lo cual, el derecho de propiedad es una facultad en la que están implicados un conjunto de derechos y obligaciones, además de conectado a cuestiones de interés general y con una función social.

Al contrario que en el Derecho Romano, el propietario ya no posee todos los derechos sobre la obra, sin limitaciones y de forma absoluta, puesto que el derecho de propiedad tiene límites, y éstos son trazados por la función social del bien, así como por la propia naturaleza del objeto. Por ejemplo, el artista puede tener asociada la titularidad de propietario y los derechos de autor. Pero en realidad, muchas obras están en manos de particulares, creando una nueva área de acción que queda entre la propiedad privada y el dominio público, donde es evidente, la necesidad de hablar de derecho de propiedad.

La ley de la Constitución de 1931 refiere por primera vez que la propiedad privada debe estar conectada a los intereses de la economía nacional y la Ley de Principios del Movimiento Nacional, y expone que los intereses individuales y colectivos han de estar subordinados siempre al bien común de la Nación (principio V)267, reconociendo a la propiedad privada en todas sus formas como derecho condicionado a su función social (principio $X)^{268}$, función que continua evidente en el párrafo 2 del art.33 de la actual Constitución. Con otras palabras, la propiedad no es el derecho subjetivo del propietario, es la función social del tenedor de la riqueza. ${ }^{269}$ Dentro de este panorama, es necesaria una regulación jurídica, ya que los bienes culturales lo son en sentido patrimonial, o sea, poseen un valor económico que los hace susceptibles de

267 LUGO Y GUILLÉN, Felix Benítez de. La situación general de la protección del Patrimonio en España. en La lucha contra el tráfico ilícito de Bienes Culturales, p.21. 
comercialización, y a este valor económico se asoma el concepto de apropiación, como se evidencia a través de la existencia de un propietario, público o privado, para la mayoría de los bienes. Sin embargo, sabiendo que los bienes culturales pertenecen a un propietario privado, también sirven fines de interés social por lo cual estarán sujetos a un régimen particular que armonice los intereses privados y la tutela pública, que por naturaleza son muy distintos entre sí.

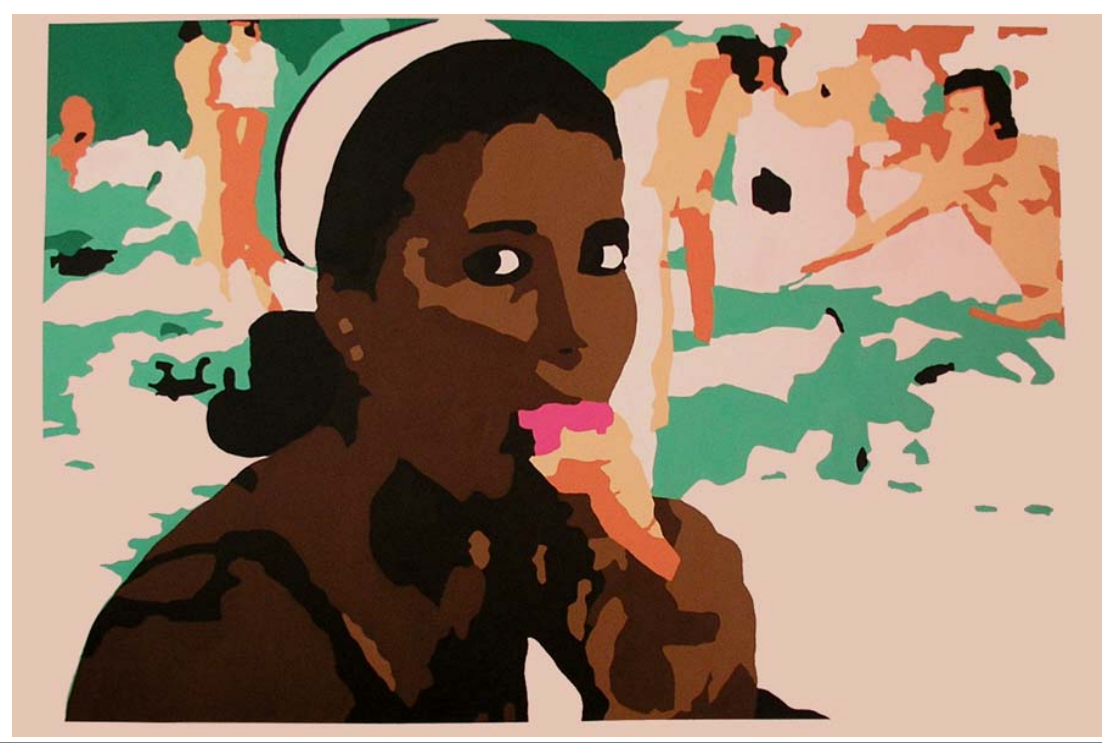

Figura 69: Ana Cardoso, Time over nothing, 2004. Acrílico sobre tela, 130×200cm.

No cabe duda de que el hecho de ser creador garantiza determinados derechos a los autores, como los derechos morales y de integridad, pero estos también pueden ser el comienzo de un conflicto entre artista y propietario, puesto que el autor puede negar cualquier tipo de intervención por parte del propietario, o tercera persona como podrá ser el restaurador, con recelo de deformación en la obra, y defendiendo su honra y reputación como se define en la L.P.I. Conflicto entre autor y propietario surge por la separación de los derechos morales de los derechos de explotación, en que el autor mantiene los derechos morales sobre la creación, incluso después de vendida. Por lo cual, el propietario, el conservador/restaurador o cualquier persona, no pueden ejercer ningún tipo de alteración física, modificación, mutilación o distorsión de la obra, sobre riesgo de ser punido jurídicamente. Mientras tanto, como regla general, el propietario 
obtendrá el total control de la obra, después de la muerte del artista y durante el tiempo previsto por la ley (50 o 70 años dependiendo del país en cuestión), puesto que el autor no abdica, y tampoco puede renunciar, a sus derechos morales. Como tal, la problemática patente en esta relación pasa por la falta de consideración por los derechos de cada parte, o sea, el artista posee libertad para modificar la obra, pero también él tendrá que tener en cuenta los derechos del propietario.

Es bastante común que la obra sufra daños de cualquier tipo y que el propietario desee su obra íntegra y sin manifestaciones exteriores que interrumpan la correcta lectura de la misma, y en esta situación pueden suceder distintas soluciones: que el artista en conformidad con el propietario interviene en la obra, eliminando los daños; que el propietario decida, él mismo, solucionar el problema; o que el propietario se dirija a un especialista y éste restaure la obra. Tres situaciones completamente distintas para las cuales se buscarán las respuestas en la normativa legal. El hecho de que en conformidad del propietario, sea el artista quien intervenga en la obra, no hay porque frenarse tal acción, volviendo a citar el art.14.5: Corresponden al autor los siguientes derechos irrenunciables e inalienables: Modificar la obra respetando los derechos adquiridos por terceros y las exigencias de protección de bienes de interés culturales. De acuerdo con la segunda situación, la cuestión es más compleja pues la ley no engloba conceptos de intervención ni conservación o restauración, remitiendo a lo que está más próximo de tal planteamiento, las nociones de modificación y transformación, por las cuales tampoco se encontrará una respuesta concreta, puesto que también ellas se refieren a otro tipo de manifestaciones sobre los bienes. Hecho directamente relacionado con la cuestión de la L.P.I. al tener su base legal en la evolución y necesidad de trazar una protección legal para los autores y los libros. Todavía, con lo establecido por la ley no hay gran diferencia entre una intervención hecha por el propietario o por un restaurador siempre que la misma no modifique la integridad del mensaje general de la obra, y que no interfiera en la reputación del autor, como expone el art.14.4, caso contrario el artista está en su derecho de reclamar y recibir una indemnización. Todavía, después de la muerte del artista es el propietario quien ejerce el derecho de exploración, por la posibilidad de poder desarrollar el pleno control sobre la obra, no obstante, también este control está sujeto a un tiempo 
determinado instituido por la ley y que en general en la mayoría de los países europeos corresponde a los 50 años. Situación que puede cambiar si la obra está protegida por otra ley para los bienes culturales, o si el artista transfiere los derechos morales al propietario, pero conscientes de que los artistas no pueden renunciar por completo de los derechos morales. Si da por tanto, una situación de respeto mutuo donde se busca el equilibrio: el propietario tiene que respetar los derechos morales y de integridad pertenecientes al artista, y el artista respetar el derecho de propiedad del adquirente de su obra.

Otra cuestión que podrá surgir implicada en la relación entre artista y propietario y conectada al panorama de la conservación/restauración, está patente en la degradación de una obra, degradación ésta intencionada o deseada por el creador. En este caso, el hecho de que el propietario haya invertido económicamente en un bien, puede manifestarse en una problemática cuando, en último caso, se da el deseo de prolongar la vida de la obra. A lo cual se añade la cuestión: ¿pesarán más los derechos morales del autor o el deseo de preservación? Antes de cualquier cosa, es fundamental referir que el artista a la hora de vender la obra debe transmitir al comprador su intención y la negación a la preservación de la misma, lo que determina su significado. $Y$ son posibles dos caminos, uno, el que respeta a la intención del artista sin más; y el segundo, que cuando no es clara la intención del artista, se debe preservar al máximo la obra y su auténtico aspecto físico, como testimonio del patrimonio cultural.

En la relación autor-propietario el derecho que tendrá que prevalecer es él del autor, lo cual lleva conceptualmente a la reducción análoga del derecho de propiedad a través de la formulación de una propiedad condicionada y limitada, y por lo tanto, consintiendo un limitado uso del bien, como la toma de decisión para la restauración, cuando ésta no puede concretarse sin el consenso del autor.

El artista además de los derechos morales que establecen el respeto por la obra, también se puede sentir perjudicado con alteraciones en la obra realizadas por sus propietarios o terceros, llevando al perjuicio su reputación. En el análisis de la alteración de la obra y el perjuicio que podrá resultar, es necesario tener en cuenta el 
porqué y el propósito de la intervención, a qué nivel y con qué intención es hecha la misma, cuales son las condiciones y la importancia de la obra en cuestión. Un ejemplo será, que el propietario y el conservador/restaurador tienen la intención de intervenir sobre la obra por su deterioro material, a lo cual se negará el artista ya que es intención que la obra que permanezca bajo el concepto de destrucción física. En este caso, los derechos morales protegen los intereses y derechos individuales del autor, por los cuales la obra no deberá ser intervenida, y además el conservador/restaurador estará sujeto a la obediencia y respeto por los códigos éticos que caracterizan la profesión. $Y$ si algo contrario se realiza, el conservador/restaurador irá contra el derecho de integridad del artista. Pero, el artista también está subordinado a los derechos del propietario, por lo cual, si su intención es el deterioro físico de la obra tendrá que notificarlo con evidencia en el momento de la venta, pues en caso contrario, el propietario podrá llevar a cabo una intervención de mantenimiento, sin que legalmente se puna tal procedimiento. Todavía, de un modo general, la protección establecida con los derechos morales no parece abarcar todas las circunstancias para la preservación de la obra, hecho que se reafirma puesto que los derechos de autor no establecen todas las medidas referentes a la obligación que el propietario tiene de mantener la obra, dejando dudas en cuanto al deber del propietario, puesto que él, dependiendo de la obra, podrá seguir distintas acciones, entre abdicar, conservar, mantener o restaurar la obra, y todo ello en contra del deseo del artista. Otra forma de ver la cuestión, es percibir que el artista, también tendrá que ser consciente de que si utiliza materiales degradados 0 hace combinaciones inestables y desconocidas, de las cuales resultarán seguramente daños materiales irreversibles, y puesto que ha optado por tal metodología, deberá asumir su degradación incluso si es indeseada, sin que el propietario esté obligado a la conservación exhaustiva o a la restauración de la obra, implicando elevados gastos. En estos casos, el artista tiene que aceptar el deterioro como tal. El artista, deberá transmitir al comprador sus intenciones para que se establezca un acuerdo entre las partes y en el futuro sea respetada la obra como tal; así como si el artista recusa la preservación de la obra, deberán ser justificadas las motivaciones de dicha intención. Por eso, es fundamental que el artista demuestre con claridad cuál es su intención en la creación de determinada obra de arte, porque incluso dejando de ser el propietario 
de la obra cuando ésta es vendida, es su autor, derecho que está regulado con directrices nacionales e internacionales como se ha visto anteriormente, de forma a sancionar violaciones contra la integridad de la obra cuando es deformada, mutilada 0 modificada.

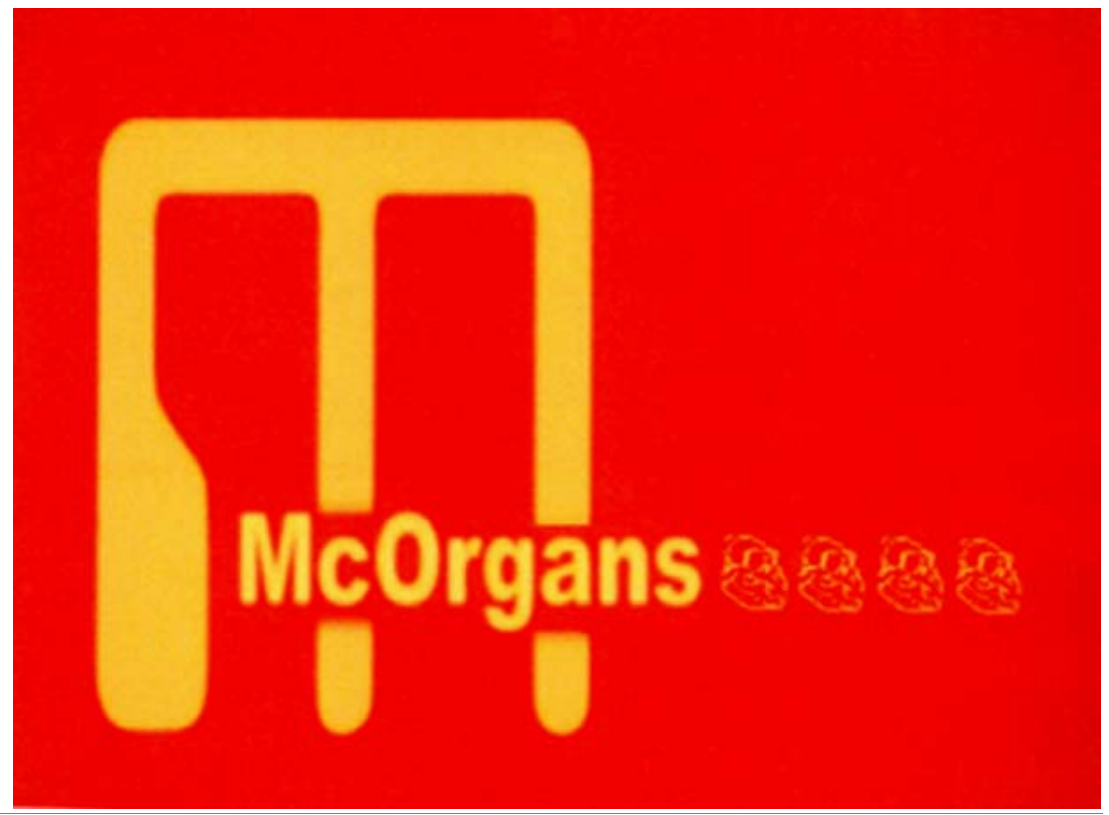

Figura 70: Rui Pedro Fonseca, cartel Mc Organs. 


\title{
2. La obra como Patrimonio cultural y artístico.
}

\author{
2.1. La protección legal para los bienes muebles.
}

Se podría decir que el «capital» de la obra plástica está compuesto por estos elementos: concepción plástica ejecución técnica personal, y «aura». Y, para pretender ser tutelada, la creación, la creación plástica debería tener por lo menos uno de estos valores. ${ }^{270}$

El hecho de que determinados bienes poseen una naturaleza diferente a los demás objetos 0 actividades, hace de ellos centro de reflexión, en que se torna necesario establecer criterios de actuación, deduciendo de esto la necesidad de un régimen jurídico, económico y fiscal especial como la más pura forma de protección y respeto, por su múltiple carácter, se destacan y son poseedores de un eminente interés estético, además de los intereses histórico y cultural.

Un ejemplo de este interés, está patente en la consciencialización mundial para la protección de los bienes culturales, con la Conferencia General de la Organización de las Naciones Unidas para la Educación, la Ciencia y la Cultura, celebrada en París, del 24 de octubre al 28 de noviembre de 1978 de la que nace la Recomendación sobre la Protección de los Bienes Culturales Muebles ${ }^{271}$. Subrayando el interés por los bienes culturales, demostrado a través del aumento de exposiciones, los intensos intercambio cultural y un crecimiento mundial de instituciones dotadas de enormes riquezas culturales, con serias consecuencias como la acentuación de riesgos a varios niveles, es fundamental que los Estados intensifiquen y generalicen medidas de prevención de forma a garantizar la protección eficaz para todos los bienes culturales muebles, pertenecientes a cada Estado, a organismos de derecho públicos 0 a personas jurídicas 0 físicas de derecho privado. Sobre estas intenciones, se

270 BERCOVITZ, Germán. Obra plástica y derechos patrimoniales de su autor, p.74.

271 Documento consultado en la página web oficial de la UNESCO, Organización de las Naciones Unidas para la Educación, la Ciencia y la Cultura, <http://portal.unesco.org/es/ev.php-URL_ID=13137\&URL_DO=DO_TOPIC\& URL_SECTION=201.html>, todos los artículos citados fueron extraídos de esta misma dirección. 
pretendió extender los principios y normas definidas en convenciones anteriores, y dictadas en este documento las recomendaciones que todos los Estados Miembros tengan en cuenta la protección de los bienes culturales muebles, por su importancia y valor como testimonios de generaciones pasadas (art.1). En su segundo artículo se expone que cada Estado Miembro debería adoptar los criterios que considere más oportunos para determinar qué bienes culturales muebles dentro de su territorio deberían ser objeto de la protección prevista en esta Recomendación. A lo cual se añade la importancia y papel del público hacia una mejor protección, junto a los organismos tanto privados como públicos, encargados de disponer información y la más adecuada educación para incrementar la protección de los bienes (art.4), ya que los bienes culturales están expuestos a una inmensidad de riesgos y malas condiciones (art.6), a lo cual cabe referir la importancia del art.10, la protección y la prevención de los riesgos son mucho más importantes que la indemnización en el caso de deterioro o de pérdida, ya que la finalidad esencial consiste en preservar el patrimonio cultural y no en sustituir unos objetos irreemplazables por sumas de dinero.

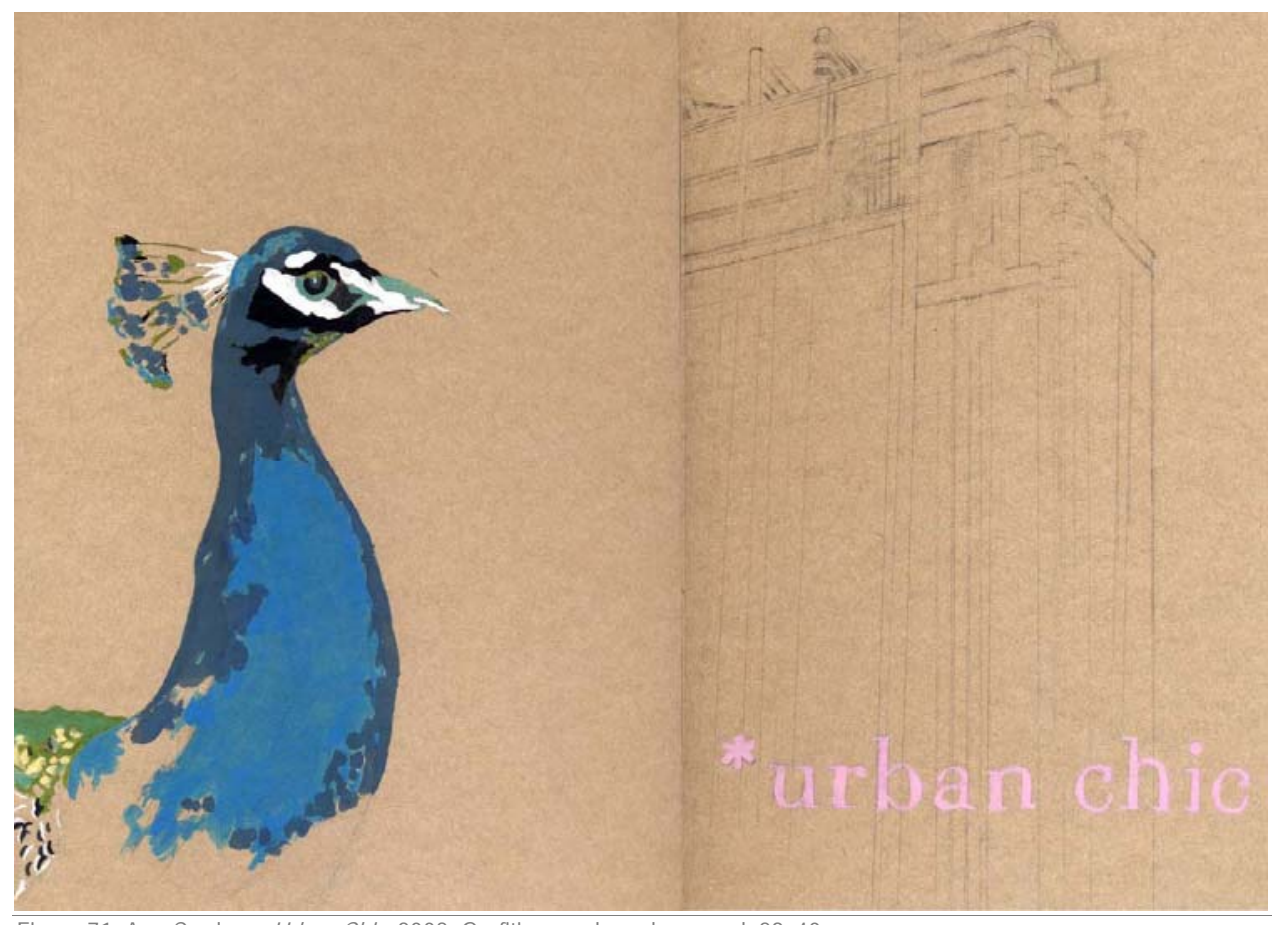

Figura 71: Ana Cardoso, Urban Chic, 2008. Grafiti y guache sobre papel, 29x40cm. 
El documento desarrolla varios aspectos sobre la cuestión de las medidas recomendadas: la especificación de criterios para los bienes culturales muebles pertenecientes a las colecciones de museos o instituciones similares, situados en edificios religiosos o lugares arqueológicos, además de las recomendaciones para el transporte y para las exposiciones temporales con fácil consecuencia de daños, así como alertas a los Estados Miembros para la colaboración y comprensión por parte de la sociedad, de la importancia de tales bienes. Pero es sobre las medidas recomendadas a las instituciones privadas donde se centrará este estudio. En cuanto a las colecciones privadas este documento establece varias recomendaciones, asumiendo la necesidad de que cada Estado Miembro deberá crear un sistema legislativo y constitucional de forma a abarcar la protección, tanto de los bienes culturales como de los derechos pertenecientes a las personas físicas.

Se cierra el documento con la recomendación de otras medidas, como garantías estatales, de forma a mejorar la financiación de la cobertura de riesgos y por último la necesidad de establecer una cooperación internacional para establecer normas éticas y técnicas de colaboración con las organizaciones internacionales y promover los intercambios de información científica y técnica, en especial sobre las innovaciones en materia de protección y conservación de los bienes culturales muebles.

No cabe duda de que el artista, como creador y autor de ese objeto original posee determinados poderes regidos legal y jurídicamente, que le confieren cierta protección, a sí mismo y a la obra, pero, también es cierto que no le es conferido el poder de otorgar una obra con la denominación de obra de arte, ni tampoco de bien cultural. Como tal, toda la creación intelectual será una exteriorización del creador, con un fin material, puesto que no requiere tutela aquello que permanece exclusivamente en la mente del individuo ${ }^{272}$, del cual si puede deducir que algo que no es perceptible 0 fijado materialmente no implica protección alguna. En este sentido se tendrá que abrir una paréntesis, pues decir que la idea no es tutelada, no quiere decir que las obras de Arte Conceptual o las obras efímeras, por ejemplo, no merezcan protección legal, esto porque, su fundamento es la idea pero su contenido no es abstracto sino una

272 BERCOVITZ, ob. cit. p.93. 
concepción formal concreta a través de una fijación material, una ejecución plástica concreta y única, o sea, son las llamadas «ideas elaboradas», pero llevadas a un punto tal de concreción formal, que no puede decirse ya que no sean expresión particular, concreta, aunque todavía meramente conceptual, de un tema plástico273.

La argumentación, pensamos que no llega a ser del todo convincente. Estimamos que la idea en sí misma, precisamente lo que los artistas conceptuales consideran la parte más importante de sus obras, no es tutelable por el Derecho de autor. El Derecho de autor no puede proteger ideas abstractas y métodos. Pero no podemos olvidar que estos artistas venden a precios bastante altos sus objetos, frecuentemente acompañados de certificados de autenticidad y unicidad. Aquí la protección deberá alcanzar solamente al objeto en sí mismo, como ejecución o representación concreta de una idea no tutelable. El valor que es vendido realmente es el del «aura» del objeto, la autenticidad de la obra. ${ }^{274}$

Incluso en el mundo jurídico se torna complejo el tema de la tutela, porque no sí puede agrupar todos los objetos en una misma denominación de arte solo porque posee determinadas características, ya que también para el Derecho es totalmente subjetivo el concepto de arte, él cual necesita de reglas objetivas. Las obras de artes se manifiestan como realidades físicas, visibles y a veces palpables ${ }^{275}$, manifestación humana intencionada y que obligatoriamente está conectada a la actividad psíquica del autor 276 .

Como ya fue dicho, la clasificación de obra de arte, es determinada socialmente en un determinado momento de la vida de la misma, y en un consenso social y cultural cuando una o varias personas la distinguen del resto de objetos, a través de la exhibición o presentación pública. Por otra parte, a pesar de la amplitud que puede poseer el término, bien cultural es todo objeto 0 actividad social que caracteriza un determinado momento histórico según denominadores estéticos, científicos, históricos y económicos, con la intención de ser disfrutados por la sociedad y formando un patrimonio histórico. Su significado e importancia social en la historia de una civilización y país, justifica una protección específica y, de hecho, lo que conduce a la necesidad de preservar tales objetos 0 actividades es la implicación que tienen con la

273 BERCOVITZ, ob. cit. p.98.

274 Ibídem, p.116.

275 Ibídem. p.102.

276 Ibídem. p.103. 
sociedad, y para eso es necesario recurrir al Derecho para crear normas y reglas para la difusión y respeto de los mismos. Pero, ¿será que este hecho tiene consecuencias a la hora de limitar el papel del propio creador en relación con la conservación/restauración de su obra?, ¿Cuál es la protección que existe para los objetos denominados obras de arte o bienes culturales?, y por último, ¿cuáles son los poderes del valor histórico y artístico de un objeto?

\subsubsection{Constitución Española}

La Constitución Española fue aprobada por las Cortes en sesiones plenarias del Congreso de los diputados y del senado celebradas a 31 de octubre de 1978, ratificada por el pueblo español en referéndum a 6 de diciembre de 1978 y sancionada por S.M. el Rey ante las Cortes el 27 de diciembre de 1978 (B.O.E., núm.311-1, de 29 de diciembre de 1978).

De la Constitución Española fueron seleccionados únicamente cinco artículos 277 referentes a la cultura y al patrimonio español, puesto que los preceptos constitucionales son una primera aproximación legal a los bienes culturales y artísticos, es importante este acercamiento para agrupar la máxima información. De forma general, la Constitución es una fuente de promoción y tutela, reconociendo la libertad de expresión (art. 20), y donde se especifica que acceder a la cultura implica posee capacidad de apreciar los productos culturales además de estudiarlos y participar en ellos (art.44), artículo que también refiere que la cultura es un derecho público, ya que el patrimonio cultural se impregna de un matiz público y social que transciende de la mera titularidad privada ${ }^{278}$. Ya el art. 46 es más específico haciendo referencia al patrimonio histórico, artístico y cultural y su soporte de protección llevado a cabo por los organismos públicos con la intención de garantizar la conservación, promover el enriquecimiento del patrimonio y sancionar los atentados contra él. Dicho

\footnotetext{
277 MINISTERIO de la Presidencia, Boletín Oficial del Estado. Constitución España., 234p.

278 LUGO Y GUILLÉN, Felix Benítez de. La situación general de la protección del Patrimonio en España. en La lucha contra el tráfico ilícito de Bienes Culturales, p.26.
} 
artículo comenta el carácter social del patrimonio, y el deber de conservar y proteger la herencia cultural, donde la Ley Penal sancionará cualquier atentado contra este patrimonio.

\section{Articulo 20}

Se reconocen y protegen los derechos:

A expresar y difundir libremente los pensamientos, ideas y opiniones mediante la palabra, el escrito o cualquier otro medio de reproducción.

A la producción y creación literaria, artística, científica y técnica.

Artículo 44

1.Los poderes públicos promoverán y tutelarán el acceso a la cultura, a la que todos tienen derecho.

2.Los poderes públicos promoverán la ciencia y la investigación científica y técnica en beneficio del interés general.

\section{Articulo 46}

Los poderes públicos garantizarán la conservación y promoverán el enriquecimiento del patrimonio histórico, cultural y artístico de los pueblos de España y de los bines que lo integran, cualquiera que sea su régimen jurídico y su titularidad. La Ley penal sancionará los atentados contra este patrimonio.

\section{Articulo 132}

3. Por ley se regularán el Patrimonio del Estado y el Patrimonio Nacional, su administración, defensa y conservación.

Articulo 149

El Estado tiene competencia exclusiva sobre las siguientes materias:

28. ${ }^{a}$ Defensa del patrimonio cultural, artístico y monumental español contra la exportación y la expoliación; museos, bibliotecas y archivos de titularidad estatal, sin prejuicio de su gestión por parte de las Comunidades Autónomas.

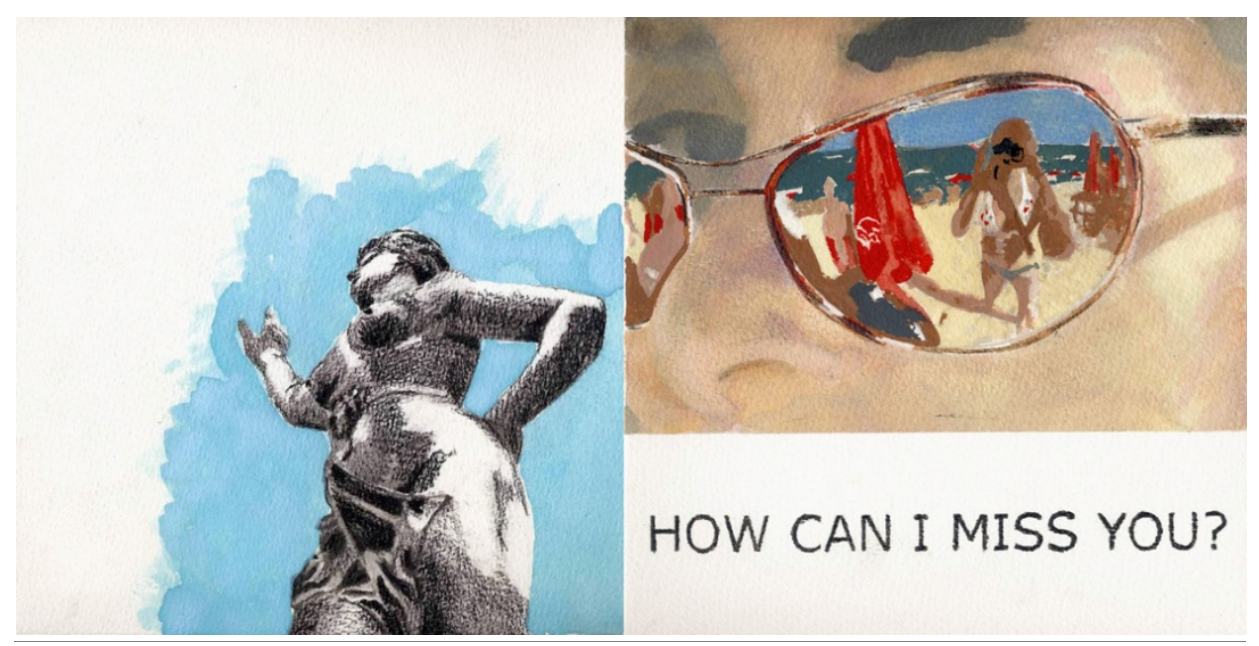

Figura 72: Ana Cardoso, How can I miss you, 2007. Acrílico, guache, acuarela, lápiz de color y grafiti sobre cartón, $200 \times 40 \mathrm{~cm}$. 


\subsubsection{Ley del Patrimonio Histórico Español}

Los bienes artísticos, antes de estar asociados a un interés individual, son de interés universal, de carácter colectivo y público, con repercusiones sociales, estableciendo en la sociedad un interés y deber de proteger su patrimonio cultural, por ser un hecho que pertenece a su historia y cultura, además del valor económico inseparable de la materialidad del bien, así como por la importancia y estímulo que aportará a las generaciones futuras, donde verán figurado su espíritu de emulación en beneficio del desarrollo de la cultura nacional y universal. Por otra parte, existe la obligación de proteger el patrimonio cultural, por su incorporación a la humanidad; el hombre, para su plena concretización, tendrá que instituir señales de identidad en que se destaquen los testimonios artísticos e históricos como reflejo de sus raíces comunitarias. En este sentido de protección, se establecen normas destinadas a incorporar criterios e instrumentos de actuación, en las que se destaca el código establecido por la Ley del Patrimonio Histórico Español, que es la disposición legal general del Estado y que sirve de referencia a las Comunidades Autónomas, que tendrán también sus propias normas, estableciendo diversos niveles de protección y sanciones administrativas para la salvaguardia de los bienes culturales. O sea, la Ley del Patrimonio, materializó a nivel estatal lo que la Constitución presenta en su art.46, y es clara en cuanto a sus propósitos: proteger, acercarse y trasmitir a las generaciones futuras (art.1.1) lo que constituye el Patrimonio Histórico Español, todos los bienes que posteriormente son enumerados y especificados en el seguimiento del artículo en su segundo apartado, subrayando en tercer apartado como deben ser designados los más relevantes.

En la defensa de los valores culturales españoles, la Ley del Patrimonio Histórico Español 16/1985 de 25 de junio y el Real Decreto 111/1986 de 10 de enero, no establece un concepto concreto de patrimonio histórico, sino que determinan los valores que son dignos de protección, citando el art. 1.2, donde se enumeran los bienes que integran el Patrimonio Histórico Español, resumidamente: son aquellos que tienen valor cultural. La L.P.H.E. unifica en un solo texto legislativo toda la 
normativa para la protección del patrimonio histórico, pero, ¿Cuáles son las obras que están protegidas?

La L.P.H.E., establece tres clasificaciones o categorías legales de los bienes integrantes del patrimonio histórico a los cuales corresponden distintos niveles de protección, es decir la inclusión de un bien en el régimen especial por ser bien integrante del patrimonio histórico es automática sin prejuicio de la declaración de Bien de Interés Cultural o inclusión en el Inventario lo que supondrá otro nivel de protección en cada caso. Estos niveles se presentan: un primer nivel de mínima protección que protege todos los bienes de valor histórico y artístico o cultural con determinado interés pero no están incluidos en otras categorías de protección; un segundo nivel, intermedio, reservado sólo para bienes muebles inscritos en el Inventario General de Bienes Muebles; y por último, el nivel máximo de protección o tutela, que integra a bienes muebles e inmuebles que gozan de régimen especial de protección, conservación, exportación, enajenación, denominados por Bienes declarados de Interés Cultural (B.I.C.). A diferencia de los bienes inmuebles, los bienes muebles pueden ser declarados B.I.C. (Art.13/L.P.H.E.), tener acceso al Inventario o pertenecer a una categoría en que gozará de mínima protección (Art. 26.4/L.P.H.E.).

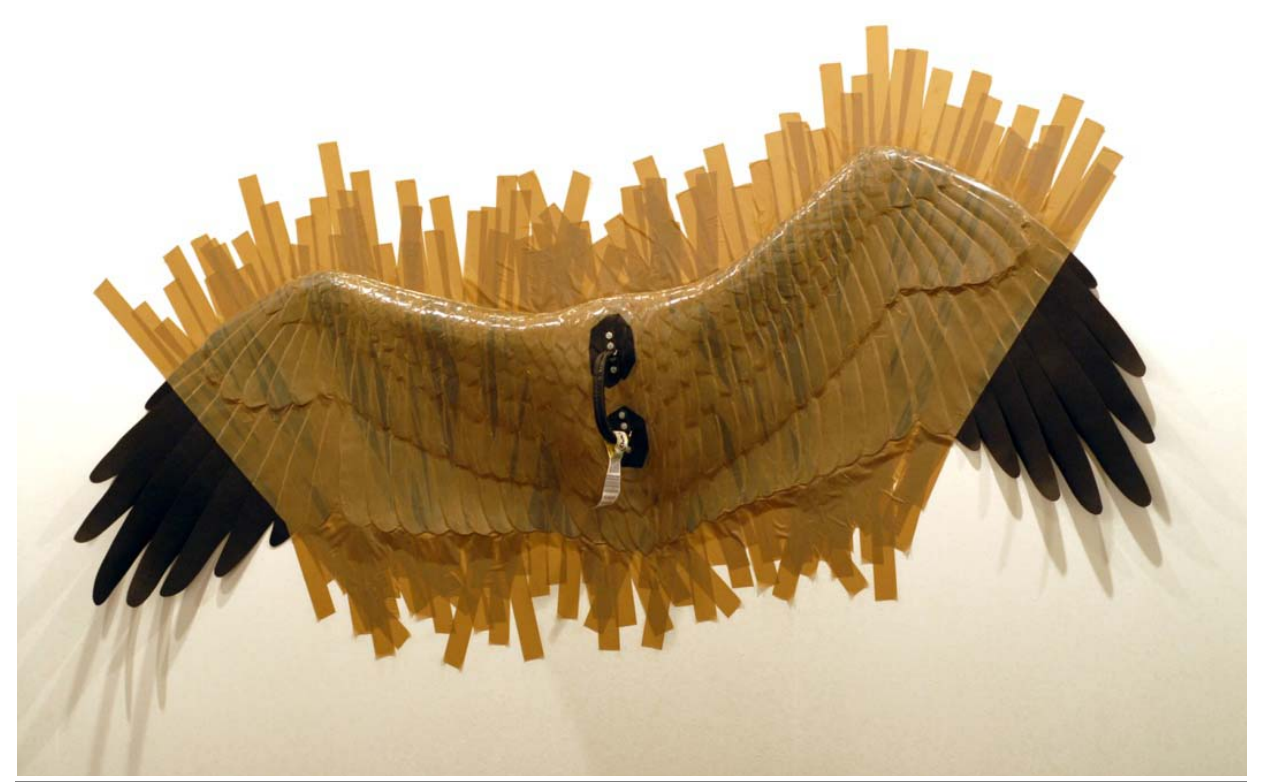

Figura 73: Isaque Pinheiro, instalación Apego a um lugar, 2007. Cuero, fita adhesiva, papel y poliéster, 130x270cm. 
A parte de estas tres protecciones establecidas por la Ley, existen bienes culturales que no están formalmente protegidos por falta de registro, pero que por su valor y significado atribuidos socialmente forman parte del Patrimonio Histórico. O mejor, la atribución social es tan determinante que el conocimiento público determina su incorporación y protección. Éste es un punto importante para esta investigación, ya que legalmente la tutela y clasificación a que corresponden los bienes será determinante en su protección. Como tal, la L.P.H.E. determina que los bienes podrán poseer tres condiciones: a) Bienes de Interés Cultural (BIC), los más representativos de la Historia, Cultura y Arte de España, a lo cual es necesario añadir que una obra de un artista vivo no puede ser clasificada BIC, a pesar de las excepciones, como se refiere en el art.9.4; b) bienes incluidos en el Inventario, deben ser protegidos por su especial conocimiento e interés en cuanto a la significación histórica, artística y cultural; c) bienes que forman parte del Patrimonio Histórico y Artístico pero que no están comprendidos en las anteriores categorías.

En el art. 36 se presenta la obligación más general ante los bienes muebles e inmuebles y sus titulares, puesto que hace únicamente referencia a la conservación, mantenimiento y custodia sin profundizar más en los términos usados, pero es importante al evidenciar la cuestión de la conservación sobre el uso.

\subsubsection{Artículos seleccionados. ${ }^{279}$}

\section{\$1 LEY16/1985, DE 25 DE JUNIO, DEL PATRIMONIO HISTÓRICO ESPAÑOL}

\section{Artículo 1}

1. Son objetos de la presente Ley de protección, acrecentamiento y transmisión a las generaciones futuras del Patrimonio Histórico Español.

2. Integran el Patrimonio Histórico Español los inmuebles y objetos muebles de interés artístico, histórico, paleontológico, arqueológico, etnográfico, científico 0 técnico. También forman parte del mismo el patrimonio documental y bibliográfico, los yacimientos y zonas arqueológicas, así como los sitios naturales, jardines y parques, que tengan valor artístico, histórico y arqueológico.

3. Los bienes más relevantes del Patrimonio Histórico Español deberán ser inventariados o declarados de interés cultural en los términos previstos en esta Ley.

279 Patrimonio Histórico Español. (4. ${ }^{\text {EEd }) ~ M a d r i d: ~ E d i t o r i a l ~ C i v i t a s, ~ 1996, ~ 114 p . ~}$ 


\section{Art.8}

1. Las personas que observen peligro de destruición o deterioro en un bien integrante del Patrimonio Histórico Español deberán, en el menor tiempo posible, ponerlo en conocimiento de la Administración competente, quien comprobará el objeto de la denuncia y actuará con arreglo a lo que en esta Ley se dispone.

2. Será pública la acción para exigir ante los órganos administrativos y los Tribunales Contencioso-Administrativos el cumplimento de lo previsto en esta Ley para la defensa de los benes integrantes del Patrimonio Histórico Español.

\section{Art.9}

1. Gozarán de singular protección y tutela los bienes integrantes del Patrimonio Histórico Español declarados de interés cultural por ministerios de esta Ley 0 mediante Real Decreto de forma individualizadas.

2. La declaración mediante Real Decreto requerirá la previa incoación y tramitación de expediente administrativo por el Organismo competente, según lo dispuesto en el artículo 6 de esta Ley. En el expediente deberá constar informe favorable de alguna de las Instituciones consultivas señaladas en el artículo 3, párrafo 2. ${ }^{\circ}$, o que tengan reconocido idéntico carácter en el ámbito de una Comunidad Autónoma. Transcurridos tres meses desde la solicitud del informe sin que éste hubiera sido emitido, se entenderá que el dictamen requerido es favorable a la declaración de interés cultural. (...)

4. No podrá ser declarada Bien de Interés Cultural la obra de un autor vivo, salvo si existe autorización expresa de su propietario o media su adquisición por la Administración.

\section{Art.26}

1. La Administración del Estado, en colaboración con los demás Administraciones competentes, confeccionará el Inventario General de aquellos bienes muebles del Patrimonio Histórico Español no declarados de interés cultural que tengan singular relevancia.

6. A los bienes muebles integrantes del Patrimonio Histórico Español incluidos en el Inventario General, se les aplicarán las siguientes normas:

a) La Administración competente podrá en todo momento inspeccionar su conservación.

\section{Art.27}

Los bienes muebles integrados del Patrimonio Histórico Español podrán ser declarados de interés cultural. Tendrán tal consideración, en todo caso, los bines muebles contenidos en un inmueble que haya sido objeto de dicha declaración y que ésta los reconozca como parte esencial de su historia.

\section{Art. 36}

1. Los bienes integrantes del Patrimonio Histórico Español deberán ser conservados, mantenidos y custodiados por sus propietarios o, en su caso, por los titulares de derechos reales o por los poseedores de tales bienes.

2. La utilización de los bienes muebles incluidos en el Inventario General, quedará subordinada a que no se pongan en peligro los valores que aconsejan su conservación. Cualquier cambio de uso deberá ser autorizado por los Organismos competentes para la ejecución de esta Ley.

3. Cuando los propietarios o los titulares de derechos reales sobre bienes declarados de interés cultural o bienes incluidos en el Inventario General no ejecuten las actuaciones exigidas en el cumplimiento de la obligación prevista en el apartado $1^{\circ}$ de este artículo, la Administración competente, previo requerimiento a los interesados, podrá conceder una ayuda con carácter de anticipo reintegrable que, en caso de bienes inmuebles, será inscrita en el Registro de la Propiedad (...). 
4. El incumplimiento de las obligaciones establecidas en el presente artículo será causa de interés social para la expropiación forzosa de los bienes declarados de interés cultural por la Administración competente.

\section{Art. 37}

1. La Administración competente podrá impedir un derribo y suspender cualquier clase de obra o intervención en un bien declarado de interés cultural.

2. Igualmente podrá actuar de ese modo, aunque no se haya producido dicha declaración, siempre que aprecie la concurrencia de alguno de los valores a que hace mención el artículo 1 de esta Ley. En tal supuesto, la Administración resolverá en el plazo máximo de treinta días hábiles a favor de la continuación de la obra 0 intervención iniciada o procederá a incoar la declaración de Bien de Interés Cultural.

3. Será causa justificada de interés social para la expropiación por la Administración competente de los bienes afectados por la declaración de interés cultural el peligro de destrucción o deterioro, 0 un uso incompatible con sus valores (...)

\section{Art.39}

1. Los poderes públicos procurarán por todos los medios de la técnica la conservación, consolidación y mejora de los bienes declarados de interés cultural, así como de los bienes muebles declarados en el Inventario General a que alude el artículo 26 de esta Ley. Los bienes declarados de interés cultural no podrán ser sometidos a tratamiento algún sin autorización expresa de los Organismos competentes para la ejecución de la Ley.

2. En el caso de bienes inmuebles, las actuaciones a que se refiere el apartado anterior irán encaminadas a su conservación, consolidación y rehabilitación y evitarán los intentos de reconstrucción, salvo cuando se utilicen partes originales de los mismos y pueda probarse su autenticidad. Si se añadiesen materiales 0 partes indispensables para su estabilidad o mantenimiento las adiciones deberán ser reconocibles y evitar confusiones miméticas.

3. Las restauraciones de los bienes a que se refiere el presente artículo respectarán las aportaciones de todas las épocas existentes. La eliminación de alguna de ellas sólo se autorizará con carácter excepcional y siempre que los elementos que traten de suprimirse supongan una evidente degradación del bien y su eliminación fuere necesaria para permitir una mejor interpretación histórica del mismo. Las partes suprimidas quedarán debidamente documentadas.

\section{Art. 67}

El Gobierno dispondrá las medidas necesarias para que la financiación de las obras de conservación, mantenimiento y rehabilitación, así como de las prospecciones y excavaciones arqueológicas realizadas en bienes declarados de interés cultural tenga preferente acceso al crédito oficial en la forma y con los requisitos que establezcan sus normas reguladoras. A tal fin, la Administración del Estado podrá establecer, mediante acuerdos con personas y Entidades públicas y privadas, las condiciones para disfrutar de los bienes crediticios.

\section{Disposiciones Adicionales}

Primera Los bienes que con anterioridad hayan sido declarados histórico-artísticos 0 incluidos en el Inventario del Patrimonio Histórico Artístico y Arqueológico de España pasan a tener la consideración y a denominarse Bienes de Interés Cultural; los muebles que hayan sido declarados integrantes del Tesoro o incluidos en el Inventario del Patrimonio Histórico-Artístico tienen la condición de bienes inventariados conforme al artículo 26 de esta Ley, sin prejuicio de su posible declaración expresa como Bienes de Interés Cultural. Todos ellos quedan sometidos al régimen jurídico que para esos bienes la presente Ley establece. 
\$2 REAL DECRETO 111/1986, DE 10 DE ENERO, DE DESARROLLLO PARCIAL

DE LA LEY 16/1985, DE 25 DE JUNIO, DEL PATRIMONIO HISTORICO ESPAÑOL

\section{Art.11}

De acuerdo con lo previsto en el artículo 6.b) de la Ley 16/1985, corresponde al Ministerio de Cultura tramitar los expedientes para declarar de interés cultural los bienes integrantes del Patrimonio Histórico Español adscritos a servicios públicos gestionados por la Administración General del Estado o que formen parte del Patrimonio Nacional. Su tramitación por dicho Ministerio se efectuará de acuerda con las normas establecidas en este capítulo.

2.Corresponde a las Comunidades Autónomas la declaración de interés cultural de los restantes bienes del Patrimonio Histórico Español, cuya tramitación se regirá por su propia normativa.

\section{Art.17}

La incoación del expediente para dejar sin efecto la declaración de interés cultural de un determinado bien se efectuará de oficio o a solicitud del titular de un interés legítimo y directo, y se notificará y publicará en los términos previstos en el artículo 12.2 de este Real Decreto.

\section{Art.21}

El Registro General de Bienes de Interés Cultural tiene por objeto la anotación e inscripción de los actos que afecten a la identificación y localización de los bienes integrantes del Patrimonio Histórico Español declarados de interés cultural. Estará adscrito a la Dirección General de Bellas Artes y Archivos del Ministerio de Cultura que, a través de la Subdirección General de Patrimonio Histórico, desarrollará las funciones relativas a la formación y actualización del citado Registro. (...)

\section{Art.24}

1. El Inventario General comprenderá los bienes muebles integrantes del Patrimonio Histórico Español, no declarados de interés cultural, que tengan singular relevancia por su notable valor histórico, arqueológico, artístico, científico, técnico o cultural. Estará adscrito a la Dirección General de Bellas Artes y Archivos del Ministerio de Cultura que, a través de la Subdirección General de Protección del Patrimonio Histórico, desarrollará las funciones relativas a la formación y actualización del citado Inventario General. 


\section{La conservación/restauración}

C'è poi la limitazione oggettiva che riguarda specialmente l'arte moderna: quando si constata che nella maggior parte degli artistas contempoarenei la stessa opera d'arte è reputata una scelta provvisoria, destinata ad essere enunciata e documentata, ma non conservata nel tempo, il concetto di restauro si estrania completamente dal significato e dalle intenzioni di quest'opera. Forse bisognerebbe ritenere, sotto un profilo giuridico, che in tal caso un restauro condotto contro le intezioni dell'artista (che sono quelle di dare solo provvisorietà alla sua opera) possa addirittura essere qualificato come attività illecita, se costituisce lesione del diritto morale d'autore che include anche questo intento, questa proiezione limitata nel tempo dell'opera d'arte. ${ }^{280}$

Los planteamientos alrededor de la práctica de conservación/restauración del arte contemporáneo son con determinación numerosos y distintos entre sí. Junto a la cuestión principal de esta investigación, otras dudas están presentes, entre ellas la referida en la cita anterior. Es cierto que la conservación/restauración no debe ir en contra de la intención del artista ni de su ideología, y que no siempre rige entre los deseos sociales y comerciales también característicos de la producción contemporánea, pero ¿hasta qué punto la legislación refiere límites de actuación? Para empezar, cuando es necesario realizar una intervención de conservación/restauración, no existe una obligación legal que exija al conservador/restaurador el contacto con el artista, hecho que puede tener reflejo en la intervención cuando no hay un denominador común en términos de creaciones, pero lo cierto es que incluso no siendo obligatoria esta consulta, se torna esencial para

280 VALENTINI, Stelio. Diritio d'autore, dititti del poprietario: gli aspetti giuridici del restauro. en AA. VV. Arte contemporanea. Conservazione e restauro. p.145.

T. A.: Existe la limitación objetiva que se refiere especialmente al arte moderno: cuando se constata que en la mayor parte de los artistas contemporáneos la misma obra de arte es reportada a una elección provisional, destinada a ser enunciada y documentada, pero no conservada en el tiempo, el concepto de restauración se aleja completamente del significado y de la intención de esa obra. Tal vez necesitará retener, bajo un perfil jurídico, que en tal caso una restauración que se conduzca contra la intención del artista (que es aquella de dar sólo provisionabilidad a la su obra) pueda incluso ser cualificada como actividad ilícita, se constituye lesión de derecho moral del autor que incluye también este intento, esta proyección limitada en el tiempo de la obra de arte. 
definir con claridad la intención del artista además de evitar conflictos, teniendo en cuanta el derecho a la integridad que aportan los derechos morales del artista. Un procedimiento que muchas veces está asociado a varias cuestiones, entre ellas la falta de consenso entre la intención del artista y el deseo de la intervención, deseo definido por el propietario o administrador, o por otro lado, la falta de consenso sobre los métodos y la forma como se realizará la intervención. Asociada a este último planteamiento se da origen gran parte de las veces la posibilidad de que sea el artista quien realice la propia intervención, la cual no irá contra los derechos morales del mismo, como ha sido visto anteriormente, ya que tampoco existen códigos éticos limitativos.

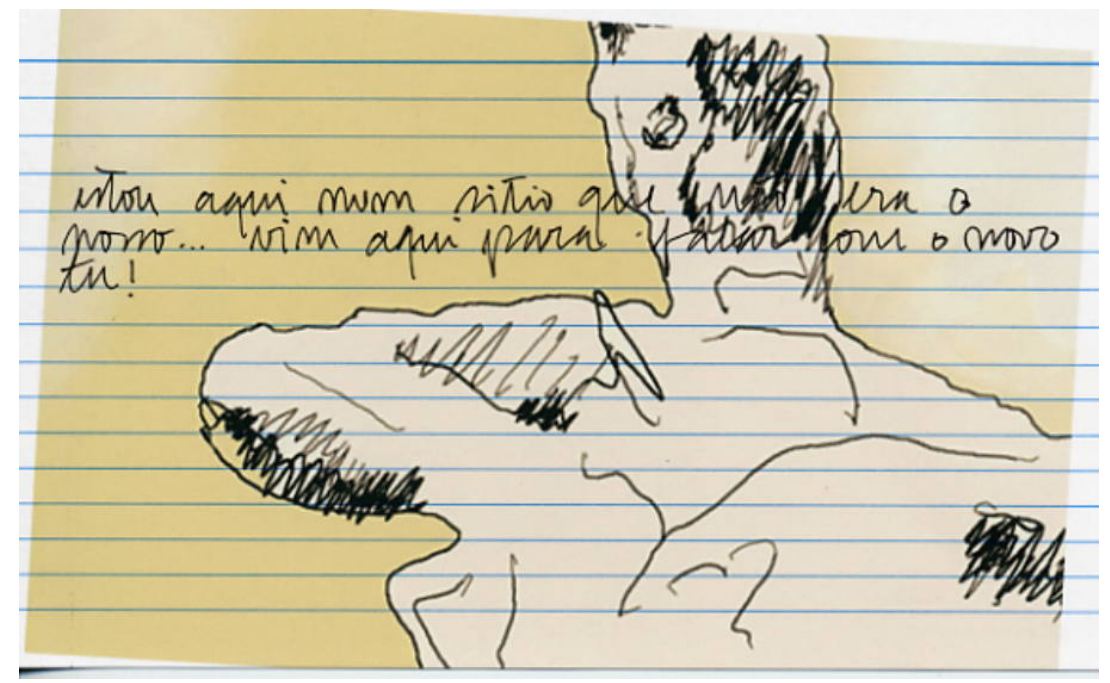

Figura 74: Ana Cardoso, S/Titulo, Serie diarios, 2005. Dibujo e impresión digital y dibujo con bolígrafo, sobre cartón de líneas, $15,5 \times 9,5 \mathrm{~cm}$.

Desde el punto de vista de la conservación/restauración se da la necesidad de frenar, y preguntar: sin ser el artista conservador/restaurador, ¿por qué es él mismo quien realiza la intervención? Lo cierto es que no estando limitada la acción del artista sobre su propia obra, esto lo invitará a la facilidad de intervención, y posibles alteraciones sin respetar la obra en su momento de creación y su periodo de vida, por lo cual, inevitablemente se perderá parte de la obra, parte del periodo perteneciente al segundo momento de vida de la obra. Se está en presencia de una encrucijada. Si por un lado, la ley protege el procedimiento del artista a través de los derechos 
establecidos en la L.P.I., por otro, el artista realiza una acción punida éticamente por las normas y criterios vigentes en la conservación/restauración, ¿pero será que este código ético tiene poder sobre la legislación estatal? La respuesta no es evidente cuando para ello se tiene que incorporar otra pregunta, ¿al final, dónde está materializado este código de ética profesional?

Esta última cuestión remite al año 1932, momento en que es elaborada la Carta del Restauro, siendo la primera vez que se separan los términos conservar y restaurar y, en la que se evidencian dos puntos fundamentales de la actividad. Por un lado está la intervención fisiológica sobre el objeto destruido, y por otro está la conservación que consistirá en un mantenimiento fisiológico continuo y equilibrado para que no llegue a ser necesaria la restauración. Lo cierto es que la restauración se mueve sobre la materialidad del bien cultural, y por lo tanto, es fundamental desde el momento en que la obra se separa del autor, establecer cuál es su intención y cuál debe ser su evolución física, puesto que frenar la vida de la obra puede ser lo contrario al sentido que compone la integridad de la misma. En la actividad de la conservación/restauración el siglo XX fue fundamental, una vez que se tornó una época de dudas, pero también de definiciones, llevando a los órganos responsables de cada Estado a desarrollar programas de protección, rehabilitación y recuperación del patrimonio cultural, además de una corporación internacional que luchara en el sentido de unificar normativas y recomendaciones, como se puede observar a partir de 1931. 


\subsection{Las Cartas de Restauro, convenciones y directrices internacionales.}

Hasta ahora fueron abordadas diversas cuestiones teóricas con un esfuerzo constante, y el más puro deseo de consolidar y encontrar respuestas para lo que es considerado problemático en la conservación/restauración del arte contemporáneo. Todavía, es cierto que la teorización siempre deja abierta una diversidad de planteamientos de causa/efecto, que desde luego son difíciles de limitar. Por ello, en esta investigación una de las propuestas clave es encontrar en las normas jurídicas y en las leyes del patrimonio y del derecho de autor lo que queda por definir, partiendo del principio que tal vez sea casi imposible encontrar una respuesta nítida en ausencia de ideas precisas.

Las primeras normativas internacionales, fruto de tratados y convenios, nacen con el objetivo de trazar líneas de actuación y concretar teóricamente criterios éticos para la actividad de conservación/restauración de los bienes culturales, y están presentes en las Cartas del Restauro, como marcos orientativos con la intención de fijar límites y principios generales para intervenir sobre los bienes culturales. Se subraya por su importancia, la Carta de Atenas de 1931, como el primer documento internacional enfocado hacia los monumentos artísticos e históricos. La Carta Italiana del Restauro 1932, fue redactada por el Consiglio Superiore delle Antichità e Belle Arti, donde Gustavo Giovannoni ha establecido una continuidad con el pensamiento de Camillo Boito. Una Carta con once capítulos donde:

la mayor parte de sus principios permanecen actualmente vigentes, como el respeto por el valor histórico y documental de los monumentos y la necesidad de conservarlos en toda su «autenticidad», prohibiéndose falsificaciones y «reconstrucciones en estilo». ${ }^{281}$

En 1964 nasce la Carta de Venecia, un documento redactado en el Congreso Internacional de Arquitectos y Técnicos de los Monumentos Históricos, totalmente dedicado a los monumentos de la humanidad, como en el mismo se expone. Es en 1972 que fue redactada la Carta Italiana del Restauro, en que claramente su objetivo

${ }^{281}$ GONZÁLEZ-VARAS, Ignacio. Conservación de bines culturales. Teoría, historia, principios y normas, p.442. 
era la elaboración de normas técnico-jurídicas para determinar los límites de las intervenciones sobre las obras de arte. Pero, lo cierto es que tal intención no ha alcanzado su objetivo por falta de perfeccionamiento jurídico. Es de subrayar en esta Carta la distinción entre «salvaguardia» y «restauración». Además se denota la influencia de la teoría brandiana con la restauración crítica en la elaboración de tal carta, una vez que son puntos fundamentales del documento la defensa de la instancia histórica y de la instancia estética, llegando a numerosos centros de restauración de todo el mundo. El prestigio de la Carta de 1972 resulta de la traducción al conciso lenguaje normativo de la rica elaboración teórica del pensamiento de Cesari Brandi. ${ }^{282}$

El texto introductorio a la Carta de 1972, indica:

En relación con el campo más controlable de las obras pictóricas y escultóricas, aunque una mayor cautela en la restauración -a pesar de la falta de normas jurídicas- haya evitado daños graves, como las consecuencias de las funestas limpiezas integrales -como lamentablemente ha sucedido en el extranjero-, sin embargo, la exigencia de la unificación de los métodos ha resultado imprescindible para intervenir con eficacia sobre obras de propiedad privada, obviamente no menos importantes para el patrimonio artístico nacional que las de propiedad estatal o en cualquier caso pública. ${ }^{283}$

En tal documento, se presentan diversos anexos, en que se destaca el Anexo $C$ que presenta las instrucciones para la ejecución de una restauración sobre pinturas y esculturas, presentando las prohibiciones y los comportamientos tolerables ante de una obra de arte, y refiriendo que tanto en las pinturas como en las esculturas el examen del estado de conservación de la obra debe ser pormenorizado; además del deber de redactar un informe de lo que constituye el proyecto de restauración; y que éste se haga acompañado de la debida documentación fotográfica. En este mismo anexo, se refieren las precauciones que se deben tomar a la hora de restaurar, como: exámenes preliminares, señalando las posibilidades de limpieza, la substitución del soporte o la realización del reentelado. En el final del Anexo, está presente la siguiente advertencia para las obras ya restauradas, sugiriendo como conducta

282GONZÁLEZ-VARAS, ob. cit. p.444.

${ }^{283}$ Carta del Restauro 1972. en MARTÍNEZ Justicia, María José. Antología de textos sobre restauración, p.171. 
general que la obra de arte no debe volver a su lugar original si la restauración fue resultado de la inestabilidad térmica e higrométrica del local.

Más tarde, surge la Carta de 1987 de la Conservación y Restauración de los objetos de arte y cultura, en su Artículo 1 se presenta con la intención de renovar, integrar y sustancialmente sustituir la «Carta Italiana del Restauro» de 1972.284 Todavía, este último texto italiano de restauración surge como modificación de algunos puntos expresados en la Carta Italiana del Restauro de 1972, con mayor incidencia en el contexto arquitectónico. Además se hace una ampliación, donde el respeto y salvaguardia no se limita a los objetos artísticos pero sí a los bienes culturales, así como una ampliación en los conceptos y operaciones de intervención, como son el uso y definición de los términos: conservación, prevención, salvaguardia, restauración y mantenimiento, y el novedoso interés por la conservación preventiva, así como la redefinición de lo que se entiende por instancia histórica e instancia estética.

En suma, las aseveraciones fundamentales de Cesari Brandi resultan matizadas en su resolución normativa, pero su sistemática teorización, sus adquisiciones teóricas y sus axiomas fundamentales, como el equilibrio entre la «instancia histórica» y la «instancia estética» en el momento de la restauración, no se resienten en modo alguno de estas objeciones o matizaciones que la evolución del pensamiento y la práctica de la restauración ha adquirido en los últimos decenios. ${ }^{285}$

Con otra propuesta, y tal como fue presentado en el capítulo anterior, el conservador/restaurador siempre se puede regir por los criterios presentados en la Teoría de la Restauración o la Teoría de restauración y unidad de metodología, que desde luego son válidos de la misma forma para el arte contemporáneo, pero a través de los cuales tampoco se instituyó una norma jurídica y es casi imposible sacar conclusiones para algunas de las cuestiones que corresponden a los límites de actuación legales, tanto del conservador/restaurador como de su creador. Por ello, se iniciará una investigación sobre los códigos y leyes que engloben tales temas.

Es importante referir que a lo largo de los años se crearon distintas recomendaciones y convenciones establecidas internacionalmente para protección del patrimonio

${ }^{284}$ Carta de 1987 de la Conservación y Restauración de los objetos de arte y cultura. en MARTínEZ Justicia, María José. Antología de textos sobre restauración, p.195.

285 GONZÁLEZ-VARAS, ob. cit. p.450. 
cultural en distintas áreas y manifestaciones históricas, culturales y artísticas, pero no se les hace referencia porque no abordan en exclusivo la protección, salvaguardia, conservación y restauración de los bienes muebles, objetos de este estudio.

Junto a la necesidad de proteger, salvaguardar y conservar los bienes culturales en pleno siglo XX se busca una definición clara de la profesión, como se puede demostrar en el documento, El Conservador-Restaurador: una definición de la profesión ${ }^{286}$, emitido por el ICOM, Consejo Internacional de Museos, en 1984, por la evidente falta de formación, principios, criterios y definiciones de las actividades que indiscriminadamente usaban la denominación de conservación/restauración. Es fundamental señalar puntos caracterizadores de la profesión respecto a los bienes culturales como en su artículo 2.2., cuando se expone que la misión del conservador/restaurador es comprender el aspecto material de los objetos que gozan de una significación histórica y artística a fin de prevenir su degradación, favoreciendo su identificación, de modo que sea posible establecer una distinción entre lo que es original y lo falso, a lo cual se añade en el artículo 3.4, que debe ser consciente de la naturaleza documental de un objeto. Dado que cada pieza contiene -sola o en el conjunto- una serie de datos y mensajes históricos, estilísticos, iconográficos, tecnológicos, intelectuales, estéticos y/o espirituales. Este documento es claro en cuanto a la formación y trayectoria que debe seguir un conservador/restaurador, hasta llegar a una madurez profesional responsable, crítica y rigurosa.

Una intención seguida por numerosas instituciones, que a través del E.C.C.O, la Confederación Europea de las Organizaciones Profesionales de Conservadores/Restauradores, redactan un documento para definir la Profesión y el Código de Ética para la misma, desarrollando y preparando las directrices profesionales con base en el estudio de varios documentos del patrimonio y de la conservación/restauración, nacionales e internacionales. Son trazadas las primeras Directrices Profesionales, en que se define la profesión del conservador/restaurador, en un texto aprobado por la Asamblea General, en Bruselas a 1 de marzo de 2002, dividido en tres puntos de análisis (I. definición del conservador/restaurador; II.

${ }^{286}$ Documento publicado en la página web del Grupo Español del IIC y del cual se extraen todos los artículos citados, en $<$ <ttp://ge-iic.com/files/Cartasydocumentos/1984_El_conservador-restaurador_una_definicion_de_la_profesion.pdf>. 
educación y formación; III. distinción de otras áreas relacionadas). A 7 de marzo de 2003 es aprobado por la misma Asamblea General un segundo texto con Directrices Profesionales para trazar el Código de Ética. Un documento compuesto por cuatro puntos (I. principios generales para la aplicación del código; II. obligaciones para con el patrimonio cultural; III. obligaciones para el propietario o responsable legal; IV. obligaciones para con los colegas y la profesión), que se desdoblan en un total de 28 artículos. Además, hay un tercer texto aprobado por la misma Asamblea a 2 de abril de 2004, que corresponde a las Directrices para la profesión, desarrollado en cuatro puntos (I. objetivos básicos para la educación de la conservación/restauración; II. nivel de educación; III. formación práctica; IV. instrucción teórica).

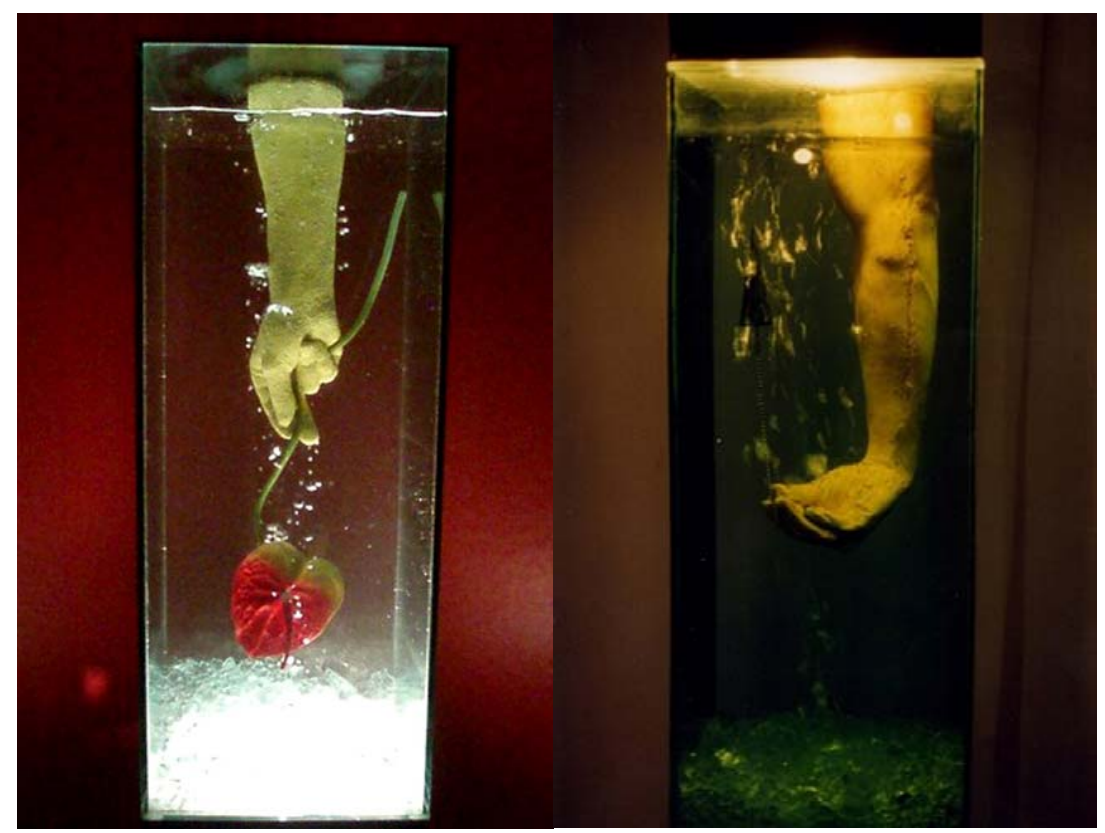

Figura 75: João Pedro Rodrigues, Banho no lago. Técnica mixta: vidrio, agua, pasta de cerámica, flor en silicona, 177×30×30cm. Figura 76: João Pedro Rodrigues, Bipolar. Técnica mixta, Vidrio, agua, pasta de cerámica, metal. $177 \times 30 \times 30 \mathrm{~cm}$.

En las Directrices Profesionales I, se demuestra la importancia que la figura del conservador/restaurador tiene en la sociedad, y su papel fundamental para la preservación y transmisión, a las generaciones futuras, de los bienes que constituyen el patrimonio material: cultural y artístico de cada Estado. E.C.C.O. define al conservador/restaurador en varios puntos que caracterizan su actividad, además de la 
formación y educación que son fundamentales para defender su principal objetivo: proteger y preservar el patrimonio cultural y artístico, en oposición a la creación de objetos.

En las Directrices Profesionales II, se profundiza en los conceptos establecidos en el primer texto a través del Código de Ética, y éste se engloban los principios, las obligaciones y los comportamientos que el conservador/restaurador miembro de la organización E.C.C.O. deberá tener en cuenta, que junto al propietario y la sociedad será responsable de los bienes que cuida, en caso contrario será responsable de una práctica anti-profesional cuando no respete las obligaciones, prohibiciones y principios presentes en tal código. De forma muy general, el conservador/restaurador debe respetar el significado estético, histórico, espiritual y la integridad física de la obra, además de recurrir a la ayuda de otros profesionales y ser consciente de todos los aspectos que conlleva la conservación preventiva. En cuanto al tercer punto, en que son indicadas las obligaciones que el conservador/restaurador tiene para con el propietario o el responsable legal, se imponen, el esclarecimiento del propietario, la confidencialidad profesional y la posición negativa al apoyo del comercio ilícito de bienes. Por último, se refiere el espíritu y respeto por la integridad y dignidad de los colegas, la apertura de forma a contribuir para el desarrollo de la profesión con aclaraciones, experiencias y publicación adecuada de los trabajos desarrollados, entre otras objeciones expuestas en el último punto del Código de Ética.

En las Directrices Profesionales III, se subraya la necesidad de profundizar e invertir en la educación y formación profesional, a través de una práctica consolidada con la experiencia, además de la instrucción teórica fundamental para el equilibrio de la profesión.

En forma de conclusión, se retoma el documento del ICOM, El ConservadorRestaurador: una definición de la profesión, pues está concebida de forma clara la distinción de la profesión en relación a cualquier otra actividad que tendenciosamente tiene el objetivo de aproximarse por lo que se subentiende y es denominado de conservación/restauración, y sin dejar lugar a dudas, aquí están presentes y definidos los limites de actuación: 
4.1. Las actividades profesionales del conservador-restaurador son diferentes de las profesiones artísticas 0 artesanales. Uno de los criterios fundamentales de esta diferencia es que por sus actividades, el conservador-restaurador no crea objetos culturales nuevos. Reconstruir físicamente lo que ya no existe o no puede ser preservado es del campo del artesano 0 de las profesiones artísticas tales como la forja artística, doradores, ebanistas, decoradores y otros. Sin embargo, éstos pueden también beneficiarse considerablemente de los descubrimientos y conocimientos de los conservadores-restauradores.

4.2. Sólo un conservador-restaurador bien formado y cultivado, experimentado y muy sensible puede aconsejar la intervención sobre un objeto dotado de una significación histórica y 10 artística por parte de un artista, un artesano 0 un conservador-restaurador. Sólo esta persona, de acuerdo con el conservador u otro especialista, tiene todos los medios para examinar el objeto, determinar su condición y evaluar su significación documental material.

A través de las normativas citadas si comprende la falta de especificación y límites que rigen la actividad, pero de forma a cerrar el tema se presenta la siguiente cita, donde se hace referencia a la conservación/restauración bajo término y el registro del Derecho de autor y algunas consideraciones jurídicas para la restauración/conservación de las obras de arte.

Por último, hay que recordar el problema de la consideración jurídica de las restauraciones de obras de arte. Normalmente tendremos que considerar no tutelables por el Derecho de autor la aportación del restaurador. Su trabajo es técnico y no debería crear nada nuevo (como mucho habrá errónea lectura, pero no la intención de crear). A este respecto es paradójico el hecho de que, desde el punto de vista del Derecho de autor, en principio sería más fácilmente tutelable la «restauración» que modifica, se aleja de la obra «restaurada». Además, no podemos olvidar que también el derecho a la integridad podría verse lesionado en algún caso.

Podría también argumentarse que la obra original sigue siendo la parte principal del objeto; como en la accesión, el trabajo del restaurador se incorpora a la cosa principal: la obra preexistente, que no debería verse trasformada sustancialmente, y que sería la realmente explotada y buscada por el público. ${ }^{287}$

No cabe duda que la actividad del conservador/restaurador no tiene como objetivo destacarse sobre lo que es la materia de la obra, y por ello no tiene sentido pensar en tutelar lo que es la intervención del conservador/restaurador, ni siquiera poner en hipótesis que la restauración puede alterar la obra, porque si sucede tal hecho algo de erróneo fue materializado en esa intervención. Si incluye esta reflexión no al hilo de los criterios para la actividad de conservación/restauración, sino por analizar la conservación/restauración bajo la perspectiva de los derechos de autor. De cualquiera

${ }^{287}$ BERCOVITZ, ob. cit. p.139. 
de las formas, la ley no se plantea la intervención del artista como una intervención de conservación/restauración ni tampoco limita su actuación, dejando en abierto todas esas cuestiones. Como forma de ejemplificar las distintas perspectivas en el seno de la actividad de la conservación/restauración, y con la intención de cerrar este capítulo, se presentan dos opiniones, donde cada autor aporta su singular perspectiva sobre el tema de la conservación/restauración con especial participación del artista en el momento de la restauración. Sin duda, un tema susceptible y con un sinfín de pequeños matices y dudas, para los cuales existe el deseo de encontrar un punto de unanimidad.

Con una afirmación rotunda, Giulio Paolini, expone sin cualquier tipo de restricción su intención de definir los límites de la actuación del artista, cuando define que l'artista è il peggior restauratore della sua opere perchè si esperientisce a ritornare su qualcosa che ha già fatto in precedenza. È però certo il miglior suggeritore a chi interviene per indirizzare conrrettamente l'intervento. ${ }^{288}$

Otra perspectiva ante el mismo planteamiento y dispar de la anterior es la presentada por Albert Albano en la siguiente cita: isso foi levado até ao extremo de o artista ser proibido de tocar novamente na sua obra, visto que se considera que essas intervenções são melhor realizadas pelo conservador239.

288 PAOLINI, Giulio. en ANGELUCCI, Sergio (a cura di). Arte Contemporanea. Conservazione e restauro. Contributi al «Colloquio sul restauro dell'arte moderna e contemporanea», p.249.

T.A.: ...el artista es el peor restaurador de su obra porque experimenta volver a algo que hizo anteriormente. Pero es sin duda el mejor sugeridor que interviene para dirigir concretamente la intervención.

${ }_{289}$ ALBANO, Albert. Arte em transição. en BOMFORD, David. Workshop, Critérios éticos e estéticos na restauração de pinturas, sin paginación.

T.A.: ...eso fue llevado hasta el extremo de prohibir al artista tocar nuevamente su obra, visto que se considera que esas intervenciones son mejor realizadas por el conservador. 


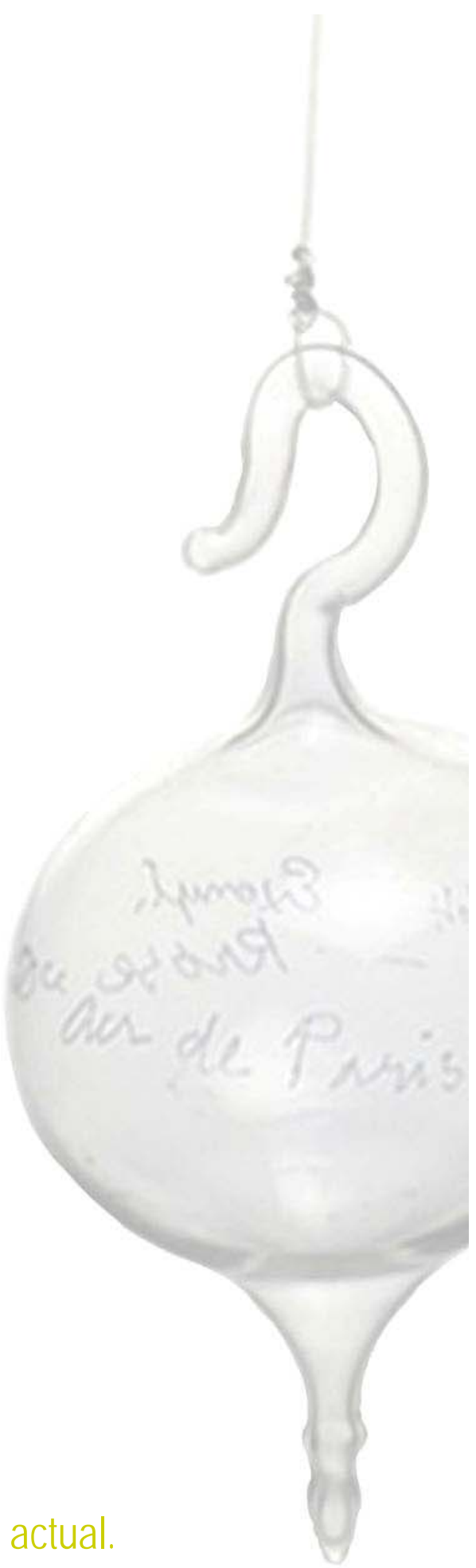

La realidad artística y la práctica actual. 

¿Qué aporta la realidad artística actual?

¿Qué se puede trabajar en la aproximación de los dos mundos?

¿Cómo entiende el artista los límites de actuación delante su obra?

¿Cómo asume el artista la conservación/restauración? y ¿Cuál considera que es el papel del conservador/restaurado? 



\section{Trabajo de campo y estudio estadístico. ${ }^{290}$}

\section{En el arte contemporáneo la gama fenomenológica de la topología de la obra es enormemente extensa, hasta alcanzar la dimensión de ambiente y lo cotidiano.291}

\subsection{Nota introductoria}

Al visitar un museo de arte contemporáneo, no cabe duda de que se está delante de una colección compleja, donde no sólo están presentes los géneros tradicionales de expresión plástica como son la pintura, escultura, dibujo, grabado, etc., sino también varios ejemplares de obras creadas a través de lenguajes más recientes, algunas completamente innovadoras y de gran diversidad como son la fotografía, los audiovisuales, la instalación, etc. Esta realidad, dada por la libertad de expresión del arte contemporáneo, algunas veces suscita una infinidad de nuevos cuestionamientos y problemas en los criterios de intervención sobre los objetos y conceptos. Es esencial y fundamental una reflexión sobre la adaptación de la política y postura del conservador/restaurador ante las expresiones artísticas producidas desde finales del siglo XIX hasta nuestros días. Por ello, es importante el conocimiento y entendimiento de las creaciones artísticas y, si es posible, el contacto con los autores, para la comprensión en profundidad de su obra, y principalmente de los conceptos implícitos en ellas, para que una futura intervención de conservación y restauración no resulte dañina o cambie su idea, que es, la representación de un concepto hecho materia.

\footnotetext{
290 Fue anteriormente presentado y publicado un estudio estadístico idéntico, pero con una población menor puesto que se basó exclusivamente en 77 entrevistas a artistas plásticos, de título: Un acercamiento a la creación artística actual: la investigación como base de actuación para la conservación, y figura en, La conservación Infalible, de la teoría a la realidad, pp.79-87.

291 CRISPOLTI, Enrico. Cómo estudiar el arte contemporáneo, p.165.
} 
A pesar de los problemas que la práctica artística moderna y contemporánea puede presentar, por el hecho de la heterogeneidad de los materiales y su carácter efímero, es posible establecer procedimientos que ayudarán al conservador/restaurador a llegar a conclusiones sobre las obras, su diversidad y las metodologías de intervención a seguir. Así, es fundamental que un conservador/restaurador sea crítico y activo, que además de basar su práctica en las teorías de restauración, encuentre apoyo en las entrevistas realizadas a los artistas plásticos, como las realizadas para concretar este estudio. Y como ejemplo de la metodología seguida se presentan en anexo, cinco de las entrevistas realizadas a los artistas plásticos portugueses.

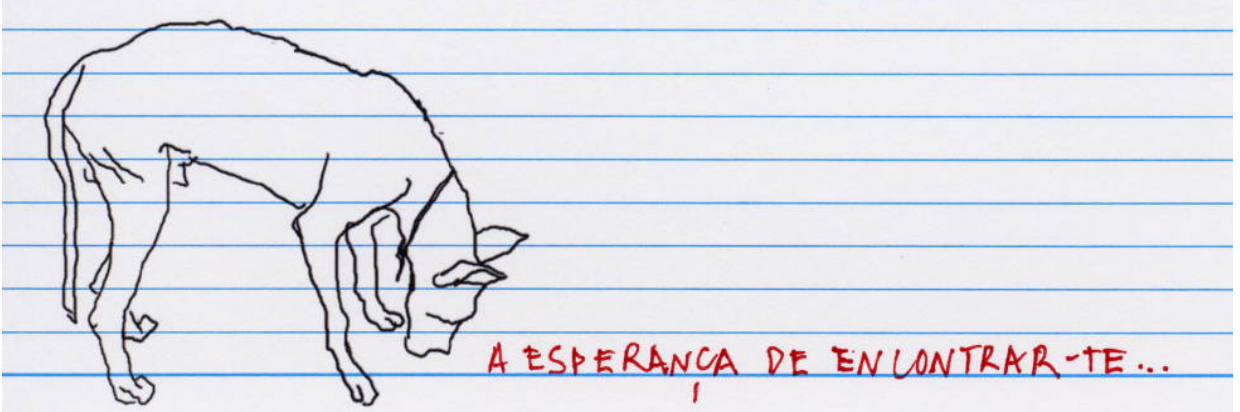




\subsection{Objetivos y metodología.}

El presente estudio estadístico tiene como objetivo el estudio sistemático del comportamiento del artista vivo, ante la conservación de su obra. Para alcanzar con claridad el objetivo propuesto, fue necesario recurrir tanto a métodos cualitativos como a métodos cuantitativos de análisis, dado que se utilizó la observación por medio de preguntas directas (encuestas), con el fin de obtener respuestas susceptibles de ser manejadas mediante un análisis cuantitativo. Por otro lado, fue también necesario recurrir a un examen intensivo, tanto en amplitud como en profundidad, de una muestra representativa. Con este motivo, se ha realizado un estudio estadístico basado en entrevistas, para aportar datos fundamentales para la correcta comprensión de su creación. Esencialmente, con el análisis de las teorías de restauración, la evolución conceptual del arte, normativas legales y el contacto directo con la actividad artística, es posible establecer criterios de actuación, que respeten el concepto de las obras, así como el 'ideológico' que caracteriza el arte moderno y contemporáneo.

Con la presentación de este estudio estadístico y la planificación de los objetivos del mismo, se presentan las conclusiones debidamente fundamentadas sobre cómo el conservador/restaurador y el artista deberán actuar ante la conservación y restauración de las obras contemporáneas y actuales, queriendo establecer los límites que determinan dónde termina la responsabilidad de uno y empieza la del otro.

El presente estudio es el resultado de la aplicación de la técnica de la observación no participativa. Así, se realizaron y consultaron 100 entrevistas para el sondeo de opinión, puesto que la principal intención era la de conocer la opinión y las actitudes de los artistas entrevistados ante las cuestiones de conservación/restauración. E procedimiento se limitó a la recogida de datos utilizando la comunicación verbal y las llamadas entrevistas abiertas, porque la conducción por parte del entrevistador ha sido flexible y las cuestiones fueron presentadas de forma que el entrevistado tuviera la posibilidad de exponer y justificar libremente su opinión, no siendo limitada su 
respuesta a "sí" o "no". En este sentido, se inició el estudio con la elaboración de una entrevista sencilla con un total de 35 cuestiones, dirigida a la población de estudio: los artistas plásticos. La determinación de la muestra ha tenido como intención constituir un modelo reducido de la población a estudiar, siendo realizada una estructura idéntica a la del conjunto afín, siempre teniendo como principales criterios: la edad, la actividad desarrollada, la ubicación de las obras, y la selección aleatoria. Todo ello con el propósito de crear una muestra representativa del grupo y teniendo en cuenta el sondeo estratificado (división del grupo por estratos, y en este estudio, por décadas/edades). De esta forma quedaron representados todos los grupos y aunque exista una diferencia entre el número de artistas entrevistados entre décadas, ese hecho no altera los datos ni proporciona datos que conduzcan a información adulterada, siendo importante referir que la fuente fue imparcial y las entrevistas fueron realizadas con la mayor objetividad posible. De forma que no alterasen los datos, con una lenguaje claro y preciso, con el fin de no propiciar interpretaciones indeseadas en el entrevistado. Es importante subrayar que la realización de la entrevista puede estar condicionada por la relación entre entrevistador/entrevistado, y que la variable (lo que define la muestra en función de las características aportadas) fundamental en este estudio, es la referente a la primera cuestión de las encuestas (vertiente práctico/técnica) sobre las actividades desarrolladas por los artistas, pudiendo presentarse un $10 \%$ de margen de error teniendo en cuenta que algunos de los artistas no realiza un solo género de obra.

En función de la temática, las encuestas están divididas en dos partes: una primera, basada en la vertiente práctico/técnica que abarca concretamente todas las cuestiones sobre lo que realiza el artista, los métodos que usa, las fases de su trabajo y los procesos por donde pasa la obra hasta su conclusión; y una segunda parte, basada en la vertiente teórica/conceptual, que consiste en una serie de cuestiones sobre la preocupación y manutención de la obra, así como la conservación y restauración, siempre teniendo en cuenta la opinión y actitud del artista ante estos conceptos.

El presente estudio estadístico se centrará únicamente en el análisis y presentación de los resultados de 5 cuestiones de la primera vertiente y otras 5 de la vertiente 
teórico/conceptual, puesto que son las cuestiones que ofrecen datos concluyentes sobre la actividad artística y su relación con la disciplina de conservación/restauración.

El campo de estudio está compuesto por un 90\% de artistas españoles, en su mayoría de la comunidad valenciana, y un 10\% de artistas portugueses; esta diferencia porcentual no altera los resultados cuando la práctica artística es idéntica en ambos países. 


\subsection{Los resultados estadísticos.}

Los primeros resultados obtenidos en el estudio presentan la población de estudio y la división de la muestra, optando por una división por décadas (año de nacimiento), comenzando por el año 1931 hasta 1990, como se puede analizar en la gráfica 1. Así, fueron entrevistados 11 artistas de la década de los años 31-40, 17 artistas de los años 41-50, 23 artistas de los años 51-60, 16 artistas de los años 61-70, 17 artistas de los años 71-80 y 16 artistas de los años 81-90.

Gráfica $1: \mathrm{N}^{0}$ artistas

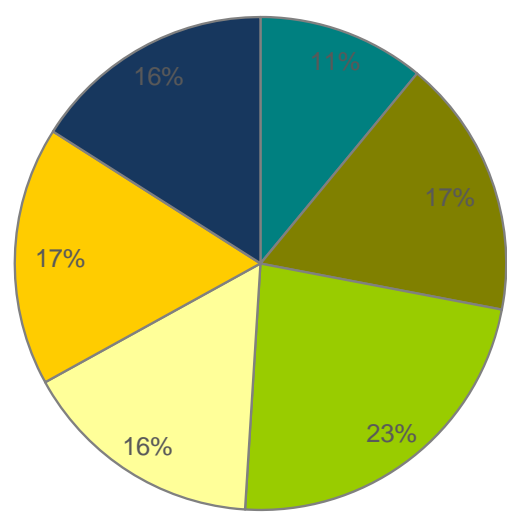

- $1931-40$

Es fundamental conocer las actividades desarrolladas por los artistas entrevistados, por ello, en este sentido, las áreas más relevantes son la pintura, seleccionada por el 92\% de artistas, la escultura, 21\% de artistas, el dibujo, 21\% de artistas, seguidos del $9 \%$ que realiza instalación, el gravado es desarrollado por un 5\% de los artistas, y la acuarela por el 3\%. Para completar, la encáustica, la fotografía, la pintura mural, el grafiti, la performace y la cerámica son utilizados por un número de artistas que oscila entre el $1 \%$, dato que figura en la siguiente gráfica. Cruzando la información de la 
gráfica con todas las entrevistas, se puede afirmar que un $85 \%$ de los artistas basa su actividad sobre varias categorías y géneros de obras.

\section{Gráfica 2 : Categorias}

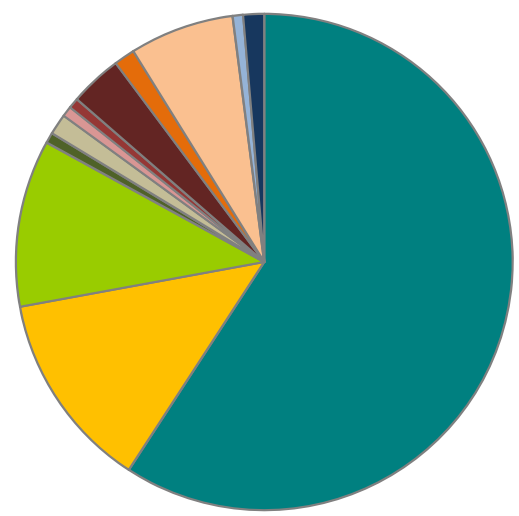
- Pintura - 92\%
DEscultura - $21 \%$
Dibujo $-21 \%$
Encaustica - $1 \%$
$\square$ Acuarela - $3 \%$
$\square$ Grafitti - 1\%
Mural-1\%
- Grabado $-5 \%$
Fotografia - $1 \%$
口Instalación - 9\%
口Performace - $1 \%$
- Ceramica - $1 \%$

Figura 79: Gráfica 2, Categorias.

La segunda cuestión, consistió en profundizar en el tema de la identificación de la obra, sobre si la obra iba o no firmada. En la gráfica 3 (página siguiente) se presentan los dados obtenidos en esta cuestión, el 67\% de los artistas contestaron afirmativamente, el 20\% negativamente, y el 13\% restante contestaron que firman en algunos casos. En cuanto al lugar de la identificación, la mayoría ha referido que lo hacía en el reverso de la obra, para que ésta no interfiriese en la lectura de la totalidad de la misma, y el $25 \%$ de los artistas informaron que también colocaban la fecha junto a la firma.

La tercera cuestión analizada y representada en la gráfica 4 (página siguiente), se refiere a la catalogación (y aquí se hace entender por catalogación, el registro tanto fotográfico como descriptivo de la obra). Del total de los artistas, el $41 \%$ ha dicho que catalogan algunas de las obras, el $38 \%$ de los artistas han contestado que todas sus obras están catalogadas y el 2\% han asumido que no hacen catalogación. 


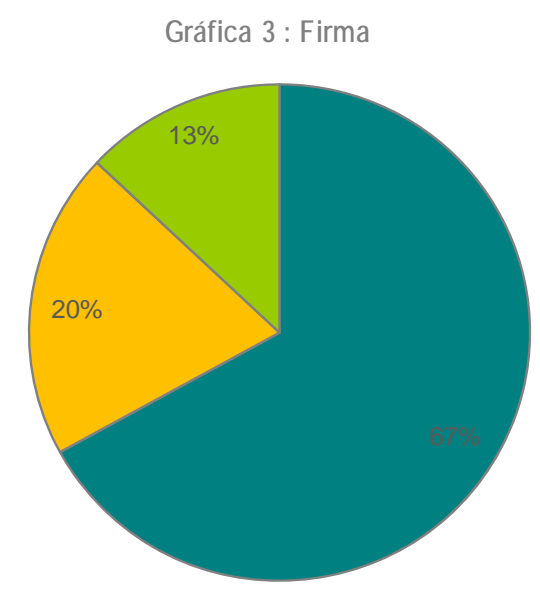

घ Si $\square$ No $\quad \square$ Algunas

Figura 80: Gráfica 3, Firma.

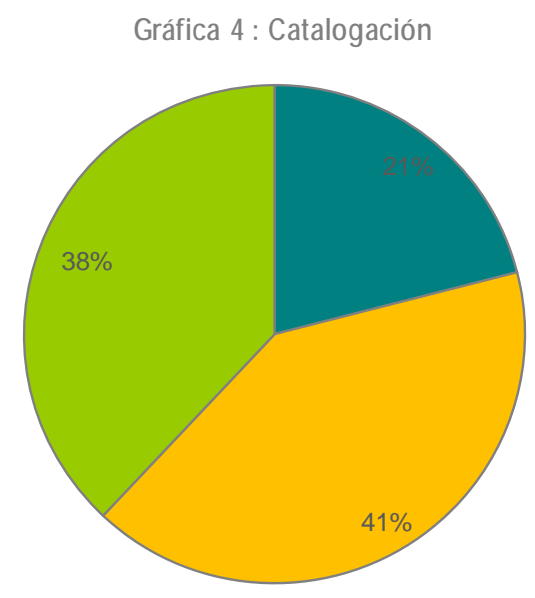

no No $\quad$ Algunas $\square$ Todas

Figura 81: Gráfica 4, Catalogación. 
En cuanto a la ubicación de las obras, que corresponde a la cuarta cuestión analizada y presentada en la siguiente gráfica, demuestra que el 92 de los artistas dicen que sus obras pertenecen a colecciones nacionales (incluyendo privadas y colectivas), donde de ese $70 \%$, el $3 \%$ también pertenecen a colecciones internacionales (privadas y colectivas); el restante $4 \%$ pertenece a los artistas que tienen sus obras únicamente en su fondo.

\section{Gráfica 5 : Ubicación}

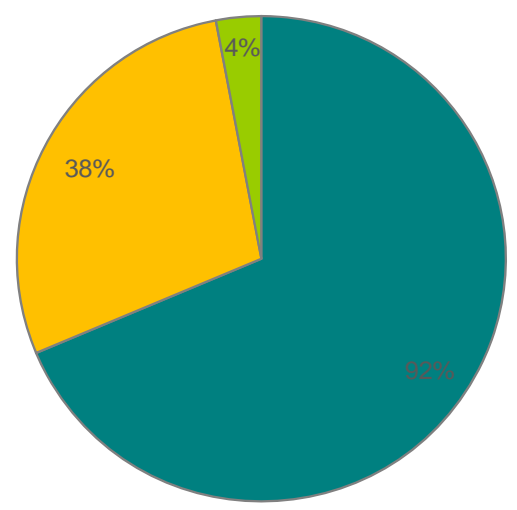

La última y quinta cuestión relativa a la vertiente práctico/técnica y representada en la gráfica 6 (página siguiente), tiene como objetivo saber si los artistas consideran o no su obra efímera. El $74 \%$ de los artistas ha contestado rotundamente que no, el 10\% ha dicho que algunas de sus obras y un $11 \%$ ha dicho que sí. 
Gráfica 6 : Obra efímera

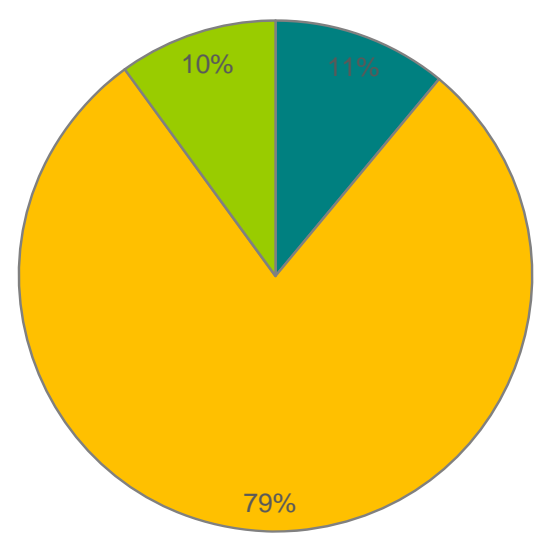

- Si $\quad \square$ No $\quad \square$ Algunas

Figura 83: Gráfica 6, Obra efímera.

Se inicia el estudio sobre la vertiente teórico/conceptual, siendo la primera cuestión: ¿Conoce el estado de conservación en que se encuentran sus obras? ¿Le preocupa? ¿Es bueno su estado de conservación? Del total de artistas entrevistados, el 73\% dijeron que lo conocían, el 19\% que no lo conocían y el $8 \%$ no han contestado a la cuestión, como figura en la gráfica 7 (página siguiente).

En cuanto a la preocupación por la obra, resultados presentados en la gráfica 7a (página siguiente), el 67\% dice que se preocupan, el 15\% que no se preocupan y el 18\% no han contestado. En cuanto al estado de conservación de las obras y que los artistas tienen conocimiento, el $54 \%$ dice que es bueno y el $46 \%$ no ha contestado, como figura en la gráfica $7 b$ (página siguiente). 


\section{Gráfica 7 : Estado de Conservación}

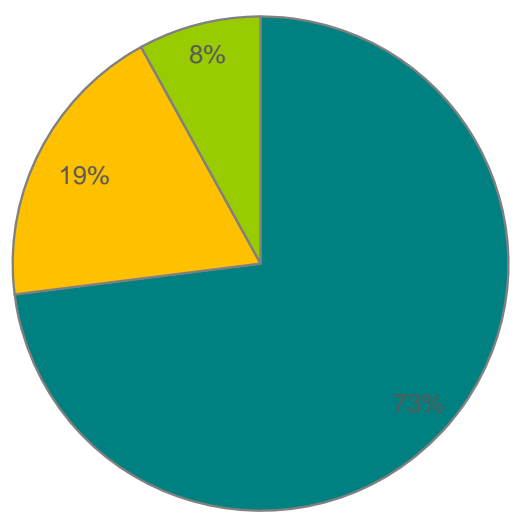

- Conoce $\square$ No Conoce $\square$ Abstención

Figura 84: Gráfica 7, Estado de conservación.

Gráfica 7a : Estado de Conservación

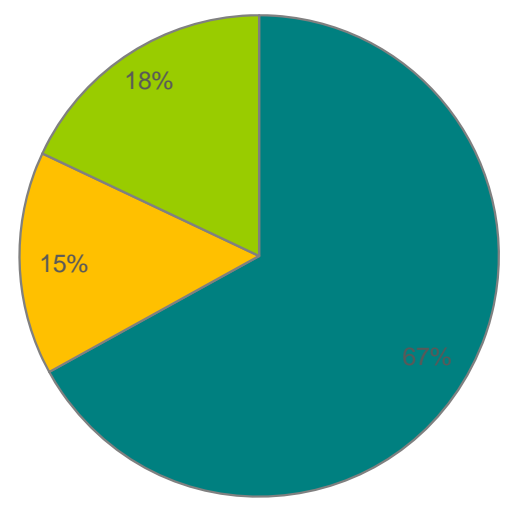

- Preocupa $\square$ Nopreocupa $\square$ Abstención
Gráfica 7b : Estado de Conservación

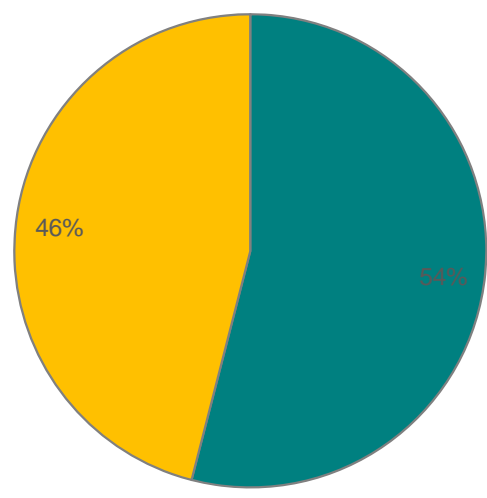

$\square$ Abstención 
La segunda cuestión, ¿Qué actitud tomaría ante una intervención de conservación/restauración? ¿Estaría de acuerdo, en desacuerdo, es necesaria la consulta previa?, ha sido respondida de acuerdo con lo que figura en la gráfica 8. Un $77 \%$ ha contestado que estaría de acuerdo, un 6\% que no estaría de acuerdo y un $17 \%$ no ha contestado; y paralelamente, en la gráfica $8 a$, el $16 \%$ de los artistas ha dicho que es indispensable la consulta antes de la intervención y el 57\% que era importante este aspecto, y por último, un $27 \%$ de los artistas no ha contestado a la cuestión.

Gráfica 8 : Intervención Conservación/Restauración Gráfica 8a : Intervención Conservación/Restauración

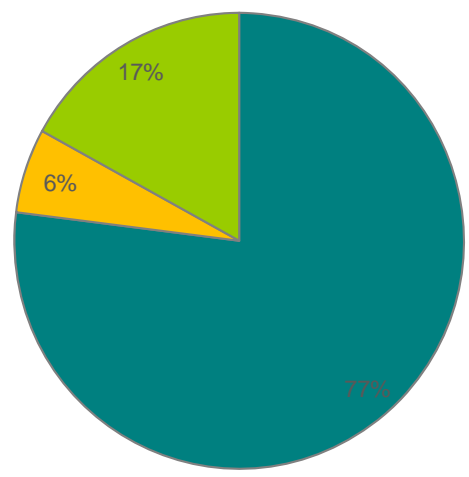

- Concuerda $\square$ Noconcuerda $\square$ Abstención

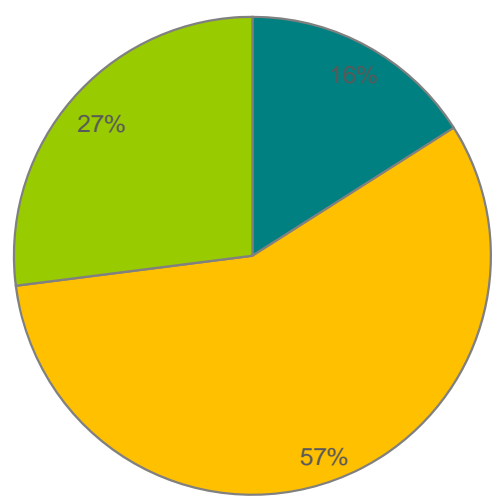

- Indispensable consulta

口Importante consulta $\square$ Abstención

Figura 87 : Gráfica 8, Intervención conservación/restauración. Figura 88: Gráfica 8a, Intervención conservación/restauración.

En relación a la tercera cuestión, ¿Quién cree que debe intervenir sobre su obra en caso de ser necesario?, representada en la gráfica 9 (página siguiente), se han obtenido los siguientes resultados: del total de artistas, el 52\% ha contestado que el trabajo es responsabilidad del restaurador, el 17\% dice que debe ser el artista quien la realice, el $25 \%$ ha dicho que ambos (restaurador y artista), y el $6 \%$ no ha contestado a la cuestión. 
Gráfica 9 : Por quien

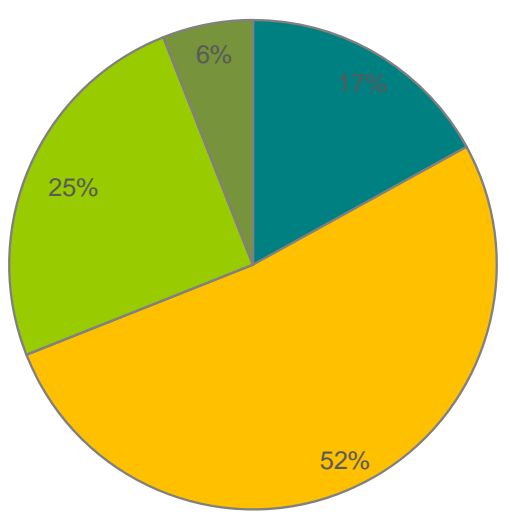

- Artista $\square$ Restaurador $\square$ Ambos $\square$ Abstención

Figura 89: Gráfica 9, Por quien.

La cuarta cuestión, consistió en saber si alguna de sus obras ya había sido restaurada. El 52\% de los artistas ha contestado que no, el 36\% ha dicho que sí y de este $36 \%$, un $20 \%$ ha dicho que la restauración había sido realizada por él mismo. Por último, un $12 \%$ no ha contestado a la pregunta, como demuestra la siguiente gráfica.

Gráfica 10 : Obra restaurada

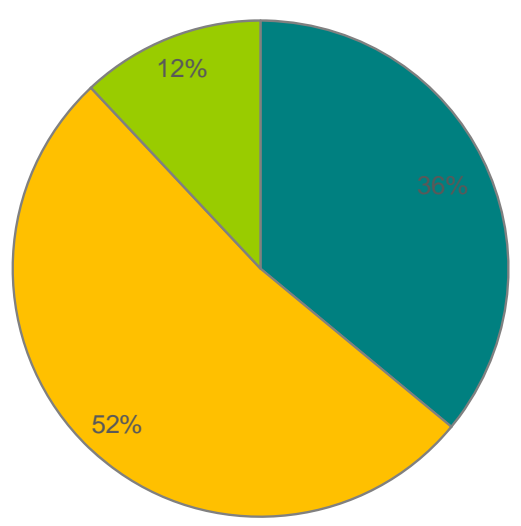

口Si $\square$ No $\square$ Abstención 
La última cuestión analizada en este estudio y representada en la gráfica 11, fue, ¿Cómo ve y comprende la conservación/restauración?, el 25\% de los artistas ha dicho que la conservación/restauración es importante, el 10\% dice que es esencial, el 29\% que debe consistir en lo que sea necesario para la obra, el 28\% que la intervención debe ser mínima, y el 8\% no han contestado a la cuestión.

\section{Gráfica 11 : Conservación/Restauración}

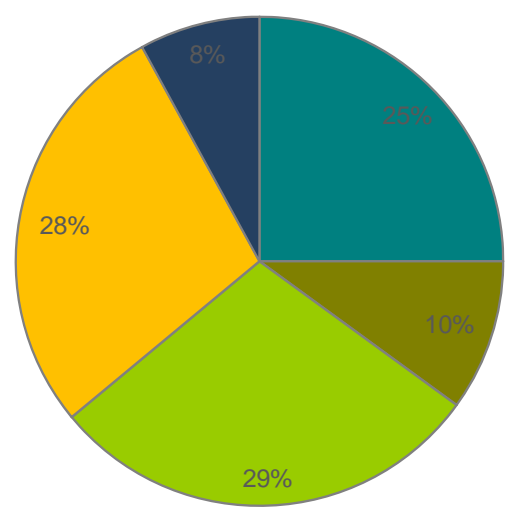

- Importante

Esencial

- Lo que pida la obra

口Minima intervención

- Abstención

Figura 91: Gráfica 11, Conservación/restauración. 


\subsection{Conclusiones del estudio.}

Antes de ser realizado y concretado el presente estudio estadístico, ya estaba formada una idea general de lo que se vive en la realidad de la conservación/restauración del arte contemporáneo, pero se torna más fácil analizar y llegar a conclusiones más concretas, cuando se pone en marcha un estudio que tampoco es de grandes dimensiones, pero que reafirma con las 100 encuestas realizadas y consultadas la idea preestablecida.

Después de analizados y organizados los datos es posible afirmar que éstos comprueban las evidencias que se suponían antes del estudio, llegando a conclusiones lógicas de acuerdo con la población en cuestión, dado que antes de realizado el estudio estadístico, ha sido realizada una investigación exhaustiva, resultante de la manipulación y tratamiento de información obtenida a través de documentos, revistas e Internet. Por otro lado, es fundamental referir la información agrupada con técnicas no documentales, a través de la observación, participación y experimentación de campo (puesto que la formación es en Artes Plásticas y en que se desarrollaron actividades en el área, con un contacto directo con el grupo de estudio, pero sin caer en el peligro de la interiorización total de los intereses e ideas del grupo).

De las 10 cuestiones fundamentales de las entrevistas, se puede concluir que más de cuatro quintos de los artistas no encuadran sus obras en el arte efímero, pues crean las obras con la intención de hacerlas perdurar en el tiempo, pero son conscientes que un día pueden desaparecer. Lo cierto es que muchos tienen conocimiento de la posible degradación de los materiales, y siendo el valor porcentual de los artistas que se preocupa por la obra superior a los que no se preocupa, se puede afirmar que, en muchos de los casos, no conocen suficientemente la constitución material de la obra para dominar su conservación plena. En general, tienen una clara preocupación por la adquisición de los materiales, sabiendo que en este aspecto hay un factor determinante que es el económico, llevando algunas veces a recurrir a materiales que no son de la mejor calidad. 
Gran parte de los artistas hacen registro o catalogación de sus obras, lo que es un aspecto fundamental para el caso de ser necesario hacer alguna consulta sobre la trayectoria de los mismos.

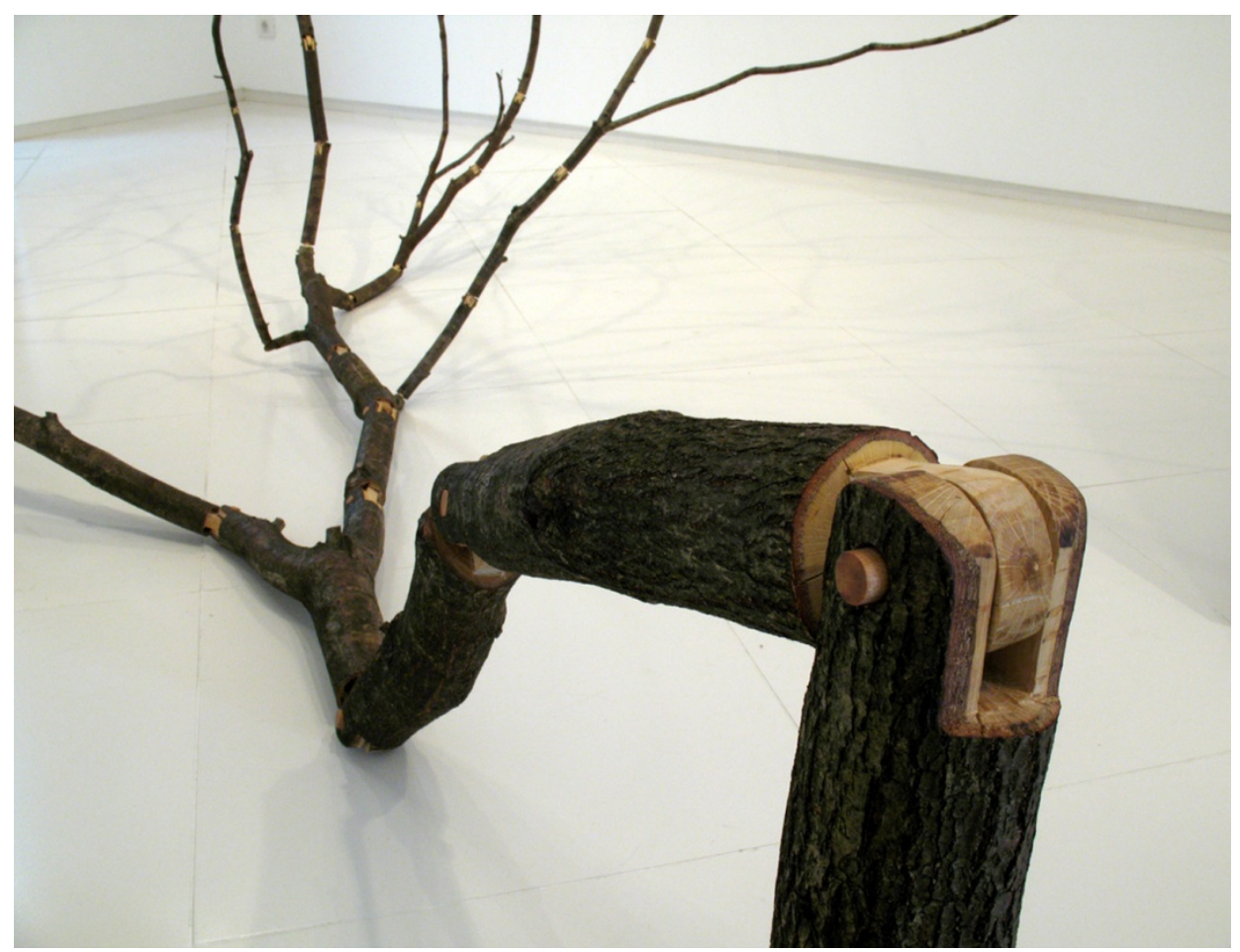

Figura 92: Isaque Pinheiro, detalle de la instalación Em cima da terra debaixo do céu, 2008. Madera, 500x500x400cm.

En cuanto al campo de la conservación/restauración, son curiosos, y en algunos de los casos, poco atractivos para el conservador/restaurador, los resultados estadísticos obtenidos. Empezando por la actitud frente a la conservación/restauración, el 77\% de los artistas afirman estar de acuerdo con que se haga una intervención en la obra, y curiosamente el 16\% dice que la intervención no debe ser llevada a cabo antes de hacer la consulta previa al artista. Pero lo más curioso es que un $17 \%$ afirma que debe ser el artista quien realice la intervención y un 25\% que dice que ambos, quedando sin percibirse muy bien cuál es el papel de cada uno -conservador y artistaen una intervención conjunta, y esto porque los artistas consideran verdaderamente importante el concepto de la obra donde los materiales surgen únicamente vinculados a la idea. Pero lo cierto, es que muchos de los artistas han apuntado que se sienten 
capaces de hacer la restauración de la obra, y que si lo hicieran no alterarían el concepto de la misma, más bien al contrario según ellos, harían la intervención de forma general y no puntual para que el aspecto final quedase más coherente con el concepto inicial de su creación. Un punto de vista que solamente puede tener un artista, puesto que los valores y normas vigentes en la actividad de conservación/restauración son completamente contrarios a esta postura. Y al cruzar estos datos con los obtenidos en la cuestión de cómo ve y comprende la conservación/restauración, se llega a una incoherencia enorme, cuando, los mismos artistas en las mismas entrevistas, en un casi 30\% dicen que solo se debe hacer lo que es verdaderamente necesario, donde un $28 \%$ considera que la intervención debe ser mínima. Con todo, es positivo que un 52\% afirme que debe ser el conservador/restaurador quien realice la intervención, debido a su formación específica en el área. Pero, en contrapunto, de los artistas que tienen conocimiento de que alguna de sus obras ha sido restaurada (que es un 36\%), más de la mitad ha dicho que había sido él mismo quien había realizado la intervención, sin olvidar que, en general, gran parte de los artistas no tienen conocimiento de los criterios vigentes en la disciplina de la conservación/restauración.

En función de las entrevistas realizadas y analizadas, y de la constante investigación en ambos campos (el artístico y el de conservación/restauración), es posible concluir que la conservación/restauración del arte contemporáneo, tiene que establecer nuevos criterios de intervención y una nueva metodología, pero además, parece esencial establecer una conexión con el arte, una conexión directa para la transmisión de su actividad y sus criterios de intervención, y viceversa. En el campo artístico, también, es necesario hacer un esfuerzo para comprender el papel esencial que desempeña el conservador/restaurador, con la intención de reconocer que es el conservador/restaurador, quien tiene los conocimientos para intervenir en las obras, respetando los procedimientos por él desarrollados. Así, el artista tendrá que dar un paso al frente y comprender que difícilmente tendrá capacidad para abordar su obra con el distanciamiento necesario para la correcta intervención, según el código de la conservación/restauración. 
En la práctica, es necesario una profunda aproximación a la obra, de forma que se perciban cuáles son sus elementos constitutivos, su naturaleza y los significados que le pertenecen, siendo la obra de arte contemporáneo, en su gran mayoría, un 'objeto' en constante mutación, donde individualizar la cuestión interna de la misma es, sin duda, una ayuda preciada para seleccionar la correcta metodología de intervención.

Tampoco son muy novedosos los resultados presentados, pero no es la novedad lo que se busca. Lo que decididamente hay necesidad de encontrar son datos concretos de los cuales se podrá partir para nuevas aportaciones a la práctica de la conservación/restauración, y en tal práctica se evidencia el arte contemporáneo por su heterogeneidad. Si la creación artística contemporánea está caracterizada por la espontaneidad y experimentación, la conservación/restauración no deberá dejarse llevar por tales valores, ni tan poco asumir un lado favorable en su papel delante de tan poderoso mercado del arte. En este panorama cabe preguntar, ¿cuál es el verdadero papel del conservador/restaurador versus el poder persuasivo del mercado y el poder de los artistas? 


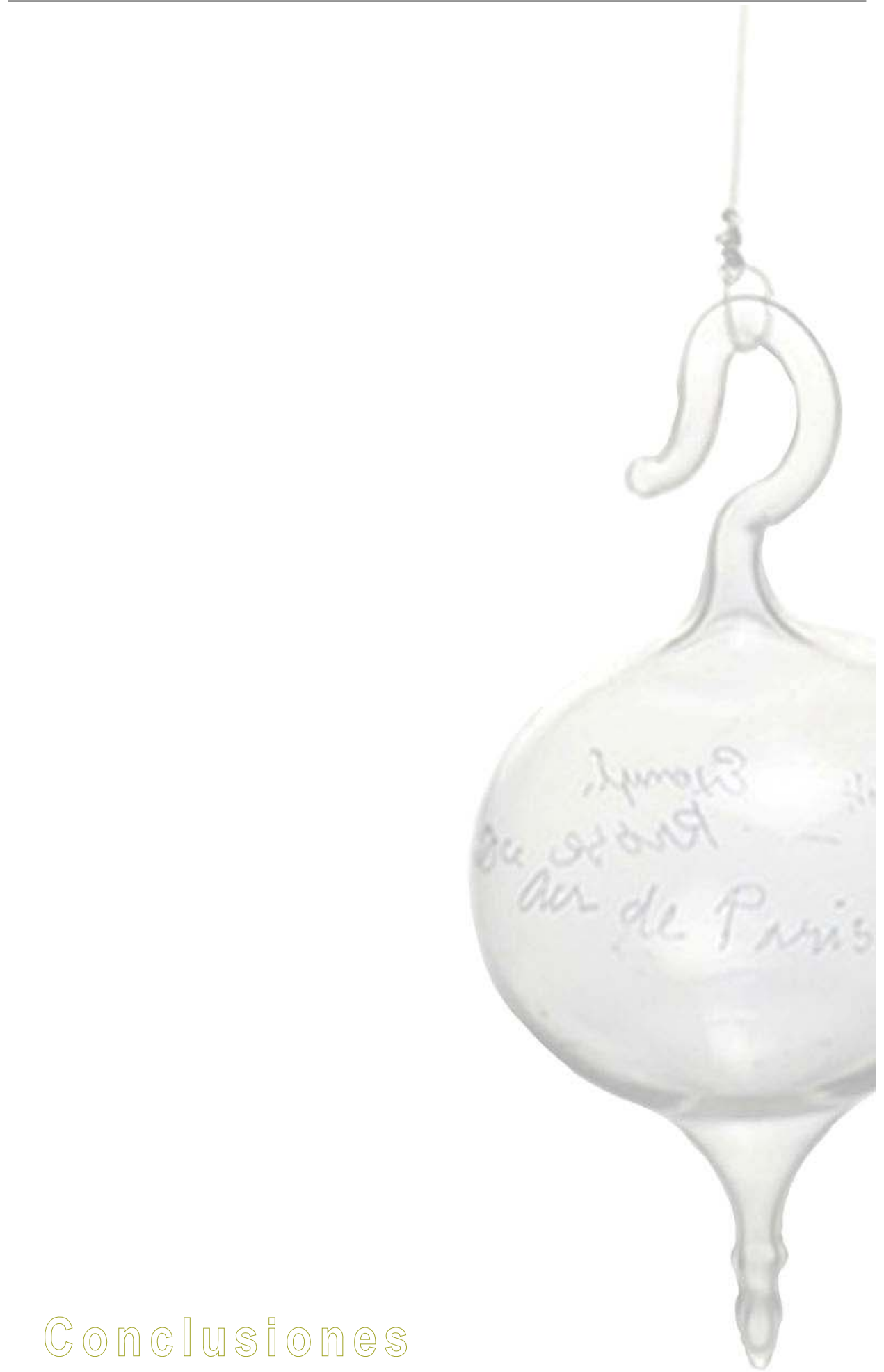



- ¡Yo no teorizo! No invento nada. Constato lo que todo el mundo puede constatar. Que una idea fija no puede ser fija. Quizás fija (si algo puede serlo) lo que no es idea. Una idea es un cambio -0, mejor dicho, un modo de cambio... Lo ve. ¡Nada de teoría! Trate de fijar una idea... Voy a comentarlo. ¡Es inútil! Una idea es un medio, o un señal de... transformación, que actúa en mayor o menor medida sobre el conjunto del ser. Pero nada dura en la mente. Le desafío a detener lo que quiera. Todo es transitivo... Pero casi todo es renovable. ${ }^{292}$

Llegados a este punto y a pesar de que Paul Valéry afirme redondamente que las ideas no se fijan, es deseo que después de estos años de investigación y ardua entrega, algunas de las ideas si hayan quedado fijadas de algún modo: o sea, a través de las dudas, a través de la sed en encontrar las respuestas. No fue desde luego objetivo último inventar nada, y tal como la cita lo describe, las ideas existen y ya existían. Simplemente hube la necesidad de agruparlas en un mismo volumen, en las mismas páginas, y si existe algo de nuevo, esa novedad está única y simplemente en el hecho de la interpretación, esa sí, con la intención de fijarse. Fijar será por lo tanto, creer y defender esa idea que puede que sea un medio o la señal de la transformación. Sin embargo, si se produjo algún cambio éste está sobre la idea de que todo es transitivo... pero casi todo es renovable, así la renovación hace del transitivo un tanto menos imperecedero, en que la idea por más abstracta que sea pueda llegar a ser fijada.

292 VALÉRY, Paul. La idea fija. Madrid: La balsa de la Medusa, 1988, p.26. 
No cabe duda que hablar del arte contemporáneo es por sí sólo un tema denso, apasionante, pero complejo, que conlleva una estructura ambigua, muchas veces cerrada en un código expresivo poco común, poco tradicional y con una búsqueda infinita de transformaciones, mutaciones e innovaciones. Pero, pensarlo en términos de conservación/restauración, aún hace de este tema más hilarante y merecedor de reflexión constante. Pensar en la conservación/restauración implica tener una visión diversificada y capaz de retener un abanico de información que muchas veces parece dispar. Puede observarse como el medio para transmitir la obra a las generaciones futuras a través de intervenciones mínimas y constantes controles preventivos y manutención cautelosa, o como la disciplina capaz de conocer los materiales constitutivos de la obra y su reacción con el paso del tiempo, así como la actividad que preservará y documentará la intención del artista, y esta suma hace inevitablemente de la conservación/restauración una ciencia compleja y entregada al deseo de garantizar que las obras además de vivir en el presente, vivan en tiempos futuros. La obra de arte, ante todo, es un fenómeno histórico y su historia se compone de objetos en constante mutación, en una evolución y rupturas casi abruptas y desiguales. En esta realidad, transformada y transformadora, es fundamental individualizar la cuestión interna de la obra en un mensaje que indisolublemente vive sobre un doble existencialismo: la materia como apariencia y la idea como oculto. Luego hay que hacer prosperar, si ésa es la intención del artista, la creación en su dualidad expresiva, de forma que permanezcan la materialidad y la intencionalidad de la obra, con el objetivo de que ésta sea disfrutada por las generaciones futuras en su coherencia física e ideológica. Es indiscutible la necesidad e importancia que caracteriza tal aproximación, de carácter fundamental en una actitud perenne de significación, en que además de seccionarse los materiales constitutivos, se debe penetrar en la contemplación de los elementos no táctiles, de naturaleza primordial para una existencia justificada, conexa y congruente.

Se hacen, y se hicieron desde el inicio de los años 80, grandes esfuerzos para profundizar conocimientos sobre los nuevos materiales artísticos, con la finalidad de obtener gran cuantidad de datos a fin de conocer con profundidad la operatividad artística contemporánea. Resulta claro que para operar sobre la obra de arte es 
necesario conocer la infinidad de materiales que constituyen las obras, así como los materiales que se van aplicar sobre la materia plástica, de los cuales existe una documentación puntual y escasa. Nombres comerciales y casas productoras son elementos indispensables para reconstruir la tipología de los compuestos químicos, pero es también necesario conocer el año, o la época de producción, una vez que su formulación viene variada en el tiempo, aunque mantengan igual denominación y las siglas de los productos. Nunca se facilitará una documentación completa sobre los materiales polímeros empleados en la obra de arte, lo que dificulta evaluar de forma objetiva las problemáticas presentes. A esta necesidad se añade la importancia de tener a disposición las fichas de restauración, correspondientes a la información relativa a los materiales utilizados en las anteriores intervenciones conservativas. E tiempo y los resultados de tantos trabajos sobre las obras modernas y contemporáneas han demostrado, también, que la evolución de los procedimientos técnicos no es el único parámetro que puede direccionar al conservador/restaurador, además es indispensable una base bien demarcada y asumida actitud teórica, que permita un correcto marco de las operaciones desarrolladas.

Se recorre un trayecto fascinante, en que parte del terreno ya está desbravado y con ello un denso conjunto de información que no debe crear un alejamiento, antes por el contrario, debe encaminar a la comprensión de lo que es representación, intención y expresión en la más pura forma de comunicar, no dejando aparte que muchas veces el sentido de la obra coexiste en una transformación física y evolutiva de su componente material, y que la experiencia adquirida subraya que sólo tiene sentido plantear una intervención o una actuación de conservación/restauración si ésta es esencial para mantener vivo su carácter evolutivo y cíclico. La obra deberá existir hasta que pueda funcionar como realidad y no como ficción, mientras se vive en la paradoja de aceptar la degradación como elemento constitutivo de la creación. Es fundamental comprender que el frenar de esta evolución autodestructiva resultaría en la perdida de la función de algunas obras y en la momificación de tales creaciones. Sin embrago, la conservación/restauración deberá evaluar el juego entre materia e idea, e incluso, a pesar de la necesidad de permanencia física de la obra, es ante todo fundamental, que la materialidad tenga una significación plausible y coherente, 
porque jamás tendrá sentido hacer prevalecer la materia sin concepto, cuando éste es la esencia de la obra, la justificación de su función comunicativa, expresiva y existencial. Que no se vea la degradación únicamente como un problema sobre la materialidad de las obras, sino, como una característica, también ella deseada, por su eficaz y rápida actuación temporal y materica. La presencia de características como la temporalidad y el efímero, son como tal, unas veces intencionadas, otras, determinadas por varios factores como los económicos o por la simples falta de información sobre las características físicas, mecánicas y químicas de los materiales empleados, y hacen de la degradación material una presencia constante en el mundo creativo contemporáneo. Si realmente la obra no es creada bajo el concepto de efímero es cierto que el artista se preocupa con la preservación de la misma a varios niveles, como preocupaciones con el transporte, el almacenamiento y exhibición de las mismas, por lo que desea hacer perenne la relación materia e intención, y si hay cambios acentuados sobre la materia, seguro que el artista también manifestará el deseo de intervenir en la obra de forma a frenar tales manifestaciones sin aprecio. Si el deterioro a lo largo de los siglos fue visto como el primer enemigo para la conservación/restauración, actualmente deberá ser observado como uno más de los elementos constitutivos de la obra, y saber reaccionar ante este hecho tan determinante, no siempre se demuestra a través de criterios claros y evidentes. Por ello, es necesario acercarse con firmeza a los orígenes del arte contemporáneo, con sus manifestaciones singulares y exclusivas de carácter, estructura, materia y concepto.

En resultado de una mutua y paralela evolución, la conservación/restauración se encaminó a seguir el impulso de un mundo envuelto en la búsqueda incesante, todavía una búsqueda distinta a la implantada en el mundo de la creación, ya que los artistas buscan con sed la novedad, y los conservadores/restauradores buscan con ansia las respuestas para una intervención que actúe ante el suceso creativo instaurado. Varias son las decisiones que hay que tener en cuenta a la hora de intervenir en una obra de arte, que por sí misma se presenta degradada, que a menudo puede vivir entre lo efímero y la contradicción, y donde la diversidad y las dificultades no deben dejar a parte las funciones del arte: el arte existe para ser 
consumido según una intención predeterminada por el artista, para un público, un medio y una realidad. El conservador/restaurador deberá ser consciente de esta realidad, además de pensar que un simple retoque en una obra con determinadas características puede desvirtuar su mensaje. Por ello, su actuación podrá seguir una simple división: si por un lado es posible considerar las obras y tratarlas como las tradicionales; por otro, las creaciones contemporáneas pueden presentar características técnicas inéditas; o por último, son obras que requieren un análisis estrictamente ideológico. En este sentido, el abanico de posibilidades parece dar origen a una encrucijada, para la cual la experiencia, la reflexión, la información y los ensayos ganan aliento en la orientación y planificación de cualquier intervención. Elevar la teoría a una práctica consolidada es dar sentido a la actividad y sus formas de materialización, además son fundamentales los exámenes previos al momento metodológico de reconocimiento para justificar el sentido de cualquier intervención.

La conservación/restauración no debe ir al encuentro de lo nuevo por sí misma, sino a la búsqueda de soluciones que operen eficazmente sobre las expresiones artísticas que desde los años 60 hasta hoy, implantan una investigación caracterizada por la incertidumbre y por un bacilar entre lo que es materialidad e intención. Todavía, también en este contexto cohabitan los dos lados de la moneda: si por un lado, el arte contemporáneo trae a la conservación/restauración un asombroso abanico de dudas y cuestionamientos, por otro, muchas veces se da la oportunidad de hablar con el propio artista, facilitando y reuniendo información primordial, en el sentido de trazar la mejor solución en la correcta prevención o adecuada restauración de la obra. Siendo también ésta, la gran y plausible justificación para una de las tareas más desarrolladas por el conservador/restaurador del arte contemporáneo: el contacto directo con el artista o su medio a través de la realización de entrevistas, puesto que es determinante el acercamiento al mundo creativo.

Es cierto que la conservación/restauración tiene que establecer nuevos criterios de intervención y una nueva metodología, pero antes parece esencial establecer una conexión con el arte, una conexión directa para la transmisión de su actividad y sus criterios de intervención. No deja de ser evidente, que aún en el siglo XXI, se cree en la idea que cualquier intervención de conservación/restauración alterará, estética y 
conceptualmente, la obra, y en este sentido, será importante la contribución del restaurador/conservador como el conocedor de las características de los materiales, su constitución y mantenimiento. Además, parece esencial el deseo de luchar contra este pensamiento erróneo, pues ya hace tiempo de que la conservación/restauración vivía de la actividad meramente reparativa. Se vive en una verdadera encrucijada donde la crítica acaba por ser una señal inevitable en las tareas de conservación/restauración, además de las opiniones antagónicas que se pueden hallar en la actividad. Algo casi evidente, cuando se desarrollan acciones sobre un objeto con distintos componentes y distintas intencionalidades, en que la forma, el espacio, la armonía visual o el valor cromático, entre otras calidades estéticas, son parámetros que interaccionan, y donde cualquier actuación sobre el aspecto de la obra deberá respetar todos esos elementos. En este sentido, la intervención no podrá dar preferencia a ninguno de esos valores formales y simbólicos, cayendo en el peligro de modificar la intencionalidad y la lectura de la obra. Es evidente la subjetividad que la actividad podrá sufrir si no es debidamente consolidada teóricamente, y en la cual, se torna obvio que cada línea de pensamiento, por sí misma, dará respuestas distintas, pero igualmente correctas, de acuerdo con fenómenos externos a la obra.

Si por un lado, conservadores/restauradores critican a sus compañeros de profesión porque la ambigüedad es uno de los elementos caracterizadores en las decisiones de la actividad, por otro, los artistas critican a los conservadores/restauradores porque se enteraron de malas intervenciones o por no tener el conocimiento suficiente de la profesión, sus criterios y normas de actuación, y aún se puede hablar de las críticas que terceros, como historiadores del arte, críticos, directores de museos, etc., hacen a los conservadores/restauradores que aunque en algunas ocasiones tengan razón, en otras sus manifestaciones son poco fundamentadas. La propia historia del arte está repleta de ejemplos, e incluso antes de que se definiera la profesión de conservación/restauración, ya los artistas que desenrollaban tales tareas criticaban a otros artistas y sus intervenciones. Con el arte contemporáneo surgen distintas cuestiones que no tienen que ser vistas bajo el tema de la crítica, como la falta de conocimiento de los artistas de muchos de los materiales que utilizan y emplean en 
sus obras, las cuestiones de temporalidad y efímero que la obras presentan 0 la facilidad de crear, exponer y vender lo que es material bajo una denominación de obra de arte. Estos fenómenos no deberán ser hechos criticables en cuanto a la conservación/restauración sino entendibles como elementos posiblemente caracterizadores de las creaciones. Además, la mirada técnica y perspicaz, del conservador/restaurador educada y entrenada para un desempeño clínico de la profesión, podrá llevar a cuestionar cual es el papel del artista en cuanto a la conservación/restauración, puesto que el artista no duda en realizar una intervención general sobre la obra, no creyendo coherente realizarla de forma puntual mientras no altere el concepto de la creación y porque, en su mayoría, tampoco son conscientes de los criterios éticos y normas vigentes en la disciplina de la conservación/restauración. Cuando es necesaria una intervención en una obra de un artista vivo, lo correcto es recurrir al mismo con la intención de obtener la máxima información posible, pues el artista es sin duda el mayor interesado en el mantenimiento y respeto hacía su obra, y de esta forma el conservador/restaurador encontrará en él su mejor asesor y su cliente más exigente. Sin embargo, la realidad en la cual vive la disciplina de la conservación/restauración es más compleja, puesto que otros pueden ser los antagonismos presentes en la actividad, a referir los que se encuentran en la base de las intervenciones llevadas a cabo por el propio artista. Si por un lado, se defiende que el artista es la mejor fuente de información, por otro, ese hecho no conlleva, por sí mismo, la mejor actitud de restauración cuando hay la posibilidad de que sea el artista quien intervenga en la obra.

El resultado de toda la evolución social, cultural y artística que se hice incontenible a lo largo del siglo XX, fue lo que dio origen al planteamiento general de la presente investigación, resumido en la cuestión, ¿al final, cual es el papel del artista y cuáles son sus límites en términos de conservación y restauración de su obra?

La respuesta a esta cuestión no está determinada en una única área de actuación, una vez que el arte contemporáneo tampoco vive aislado de influencias, además de las internas coexiste bajo las fuertes influencias externas a su contexto directo. Si por un lado, la historia del arte demuestra a través de la evolución social y cultural los cambios y rupturas que afectaron para siempre el propio concepto de arte, por otro, 
se presenta la disciplina de la conservación/restauración también con sus evoluciones, su madurez como ciencia y sus pilastras como profesión. Es cierto que la evolución es intrínseca a la historia del mundo y de las sociedades, siendo varios los fenómenos que la acompañan y que interactúan con lo que denominan bienes culturales, y a los cuales inevitablemente existe el deseo de proteger, salvaguardar y mantener siempre que sus valores sean coherentes y de riqueza social, cultural y artística indiscutible. $Y$ es porque realmente existen estas riquezas, que se implan reglas, normas y cánones divergentes y algunas veces paradójicos entre las distintas áreas de acción, como es el caso de la conservación/restauración en contrapunto a las artes plásticas, en que si puede dar el ejemplo de la falta de claridad en los límites para la conservación/restauración en cuanto al papel del artista además de creador.

En una misma situación, la reconstrucción de una obra será vista de forma distinta si es analizada por un artista 0 si lo es bajo el punto de vista de un conservador/restaurador, porque no se puede excluir que el primero se distingue por un conjunto de cualidades, como pueden ser la intención, la expresión o la habilidad y destreza técnica, al cual se une la imposibilidad de un distanciamiento natural ante su creación. Otras son las cuestiones que eso implica a nivel de terminología, ya que queda la duda de reconocer en el objeto reconstruido por su propio autor la obra original, cuando a lo mejor lo que resulta de esa acción no es la restauración del original ni la copia exacta del mismo, sino tal vez una nueva obra. En cuanto al análisis y desarrollo de tal acción, desde el punto de vista de la conservación/restauración se siguen caminos bastante distintos. Hablar de reconstrucción implica la consciencia plena de la destrucción material de la obra, con el objetivo de recuperar la legibilidad de la misma pero con consciencia de que no puede ser una reconstrucción arbitraria, sin fundamento e injustificada, porque al contrario del artista el conservador/restaurador no tiene libertad de crear una nueva obra como sustitución del original. Y si la situación llega a este punto, la intervención debe ser distinguible a fin de no crear ningún tipo de falsificación, puesto que es objetivo último mantener la unidad potencial de la obra, por su valor histórico y estético. Recuperar una obra deberá significar recuperar su mensaje artístico original, independientemente de si eso implica estar delante, por ejemplo, de la reconstrucción bidimensional (fotografía) de una obra tridimensional 
(instalación). La reconstrucción puede ser un procedimiento eficaz en algunas situaciones, pero no deja de ser agresivo, puesto que en una obra de arte cuando pierde su función, deja de tener sentido la existencia material, valiendo como testimonio histórico, cultural y artístico.

Si con los criterios y normas de actuación, el conservador/restaurador sigue una pauta de actuación, no es tan seguro que la intervención del artista no levante dudas, sabiendo que siempre existe la posibilidad de que éste traspase los fundamentos y criterios de una intervención, dando origen a la posibilidad de crear un falso histórico. Y se está en presencia de un falso cuando hay la tentativa de ocultar valores documentales y estéticos en el original, independientemente de quién ejecuta tal acción. O sea, un artista que repinta la totalidad de una superficie monocromática respeta la instancia artística de la pintura, pero no respecta la instancia histórica si no hace referencia a la intervención. Desde el punto de vista teórico, no se garantiza la autenticidad de la obra si la tarea de restauración es desempeñada por el artista ya que tiene que ser identificado y documentado tal procedimiento y dejar constancia para una verdadera y correcta transmisión para el futuro.

En este sentido, hay que analizar dos puntos: si por un lado, el artista es el mayor conocedor de su obra, de los materiales y técnica, por otro, el conservador/restaurador es alguien que estudió y profundizó en un área de conocimiento específico de forma a desempeñar no solamente un papel social sino una profesión reconocida. Y por aquí, hay que subrayar, que siendo el artista el mayor conocedor de la obra deberá ser también la fuente donde el conservador/restaurador recorrerá la información más fiable para realizar la intervención, pero que este hecho no garantiza la distancia necesaria que es esencial para intervenir en la obra. El conservador/restaurador no tendrá ningún problema en crear tal distancia para que la obra sea respetada, siguiendo su intención y concepción, las cuales implican varias perspectivas. No cabe duda, que el artista como creador de la obra tendrá mayor dificultad en aceptar su trabajo según la valorización de la instancia histórica, además de la facilidad que se le presentará para la creación de algo nuevo por el simple hecho de su evolución ideológica, técnica y metodológica del que su propio recorrido artístico es fruto. La solución de que sea el artista quien intervenga en la obra no debe 
ser adoptada arriesgando la hipótesis, de que ésta sufra modificaciones sustanciales con respecto a la configuración originaria, donde la intervención del artista afirmará una nueva actitud creativa. Tal postura, aunque legítima desde el punto de vista del autor, está bastante lejos de la exigencia respetuosa por la obra, en el ámbito de la conservación/restauración. La restauración del autor es, en gran parte de los casos, una contradicción de acuerdo con los términos y conceptos teóricos defendidos y presentados para una buena intervención, en que es esencial el papel del conservador/restaurador para demostrar la importancia de mantener la obra tal como fue creada, incluso si el artista la considera ultrapasada y tiene el deseo de alterar cualquier pormenor. Con base en este planteamiento, parece imposible inserir la actividad de la conservación/restauración en la actividad artística, siendo el acto de creación un momento concreto, único y verosímil en que el objeto o acción que resultan de ese momento, posteriormente, en algún tiempo de su vida serán reconocidos y denominados obras de arte. Es comprensible la dificultad que ésta teorización supone en el campo de la creación, pero lo cierto es que no se debe correr el riesgo de la modificación de la obra, cuando la restauración no puede dar lugar a dudas en cuanto a la datación de la obra y su originalidad. Pero jurídicamente, si la ley establece que ni siquiera el autor de una obra puede copiar su propia obra si ha cedido los derechos sobre la misma, ¿será que la puede modificar? Lo cierto, es que el artista puede crear una copia pero no exacta, sino una nueva interpretación de la misma concepción plástica, por la cual da origen a una novedad creativa distinguiéndola de la reproducción.

La protección legal aborda varios puntos, donde la protección a los artistas está bastante definida, estableciendo límites rígidos en cuanto a los procedimientos erróneos de terceros, un Derecho que tutela un interés individual, en que éste prevalece sobre el interés general. Es necesario ser consciente que la Ley de Propiedad Intelectual tiene como base la protección de las obras literarias dejando de parte algunos puntos importantes en el análisis y protección de las obras artísticas, una vez que la Ley presenta problemas generales que no son específicos del artista plástico, además está íntimamente creada para la protección de los autores poniendo en un lado menos estructurado las obras de arte, una vez que solo remite su 
protección para las cuestiones de reproducción, exposición y explotación. Además alude directamente a un factor fundamental que es el mercado del arte, en que obviamente no responde a todos los planteamiento que surgen con las creaciones contemporáneas, mucho menos los que entran en contacto con la conservación/restauración. El derecho de autor no protege la información transmitida, sino la expresión y el modo de transmitirla.

En definitiva es una cuestión antagónica y con posibilidad de crear algunas susceptibilidades, además cuando jurídicamente pocos son los límites para la actuación del artista. Supuestamente debería ser posible, a través de la conservación/restauración, como disciplina autónoma y capacitada, y del papel que desarrolla el conservador/restaurador en el panorama del patrimonio cultural, justificar la existencia y necesidad de límites, puesto que sus criterios y normas de intervención son fruto de años de trabajo, lucha teórica y aprendizaje constante. Pero también ante esta realidad, no hay que olvidar que aún puede existir cierta descreencia en relación a la intervención por parte de terceros, con todo, tampoco deberá ser ésta la escusa para permitir que la intervención sea realizada por el artista. Sin embargo, es inevitable preguntar, ¿Cuándo termina el poder del artista en la alteración 0 intervención de su propia obra? Desde luego no es sencillo definir tales límites una vez que el artista considerado autor posee derechos sobre la obra que le dan el poder de realizar modificaciones en la misma, con respecto a los derechos de propiedad o si se trata de un bien de interés cultural. Del otro lado de la moneda, es también importante referir que hay artistas interesados en recurrir a los conservadores/restauradores, de forma a enriquecer su trabajo en lo que dice respecto a las cuestiones técnicas, pero también están aquellos que no tienen interés en adquirir información porque creen que no es fundamental para expresar sus objetivos. Es cierto e inexcusable, que la forma como un artista y un conservador/restaurador observan la obra es distinta, pero esta distinción se queda en el ojo más detallista del conservador/restaurador y que no debe tener reflejo en la decisión de lo que debe ser preservado o no de una obra, ya que la intervención deberá ser definida con claridad a través de la intención y significado de la obra, por lo 
cual, una vez más se subraya que debe ser siempre la obra quien determine la restauración y no al contrario.

Y en un breve paréntesis, se habla de los museos, a pesar de que muchos de los planteamientos expuestos no se encuadran en las problemáticas presentadas en las instituciones públicas, con el fácil ejemplo dado por la legislación que protege y cataloga todos los objetos pertenecientes a una colección museística de Bien de Interés Cultural. Pero, a modo de conclusión, se cree necesario volver a repetir que con relación a los criterios de intervención y actuación no todos los caminos son caracterizadores del buen hacer, pues deberá existir la consciencia que también las instituciones viven maniobras mercantiles, y el turismo es sin duda una fuente de rendimiento, por el cual las obras deben poseer el aura del bien conservado y del bien restaurado. No se niega el hecho de que el museo es el 'dueño' de una obra única, de valor incontrolable y reconocido, no únicamente en su medio existencial, sino en los varios rincones de los cinco continentes, y que cuando se observa se debe aprehender materialmente intacta.

No hay que dejar a parte, la importancia que cobra un objeto cuando es denominado obra de arte. Y es tan determinante tal importancia, que esta denominación jamás es atribuida a los objetos por su propio autor, siendo este sentido, quizás, lo que puede crear determinados límites de actuación, ya que si existe una denominación que no es de su autoría, es porque parte de este objeto ya pertenece a alguien más que al propio creador, hecho que éste último deberá respetar. Es cierto que el reconocimiento social hace del objeto algo más, y si el artista dispone su creación a la aceptación pública y social, deberá también aceptar que la obra tendrá de sobrevivir tal como fue reconocida socialmente, o sea, que de cierta forma, el poder que posee el artista de alterar y modificar su propia creación se ve reducido al respeto por la obra y por la aceptación social, puesto que pasa a ser un objeto que gozará de un estatuto especial, un estatuto proprio en cuanto patrimonio de la humanidad y por el cual se le otorgará un sistema de protección. Es fundamental que el artista comprenda la importancia que juega la instancia histórica en la vida de una obra de arte, y no es querer negar que también la modificación de una determinada obra, se tornaría parte de esa misma instancia. Lo cierto, es que la intención y objetivos de la 
conservación/restauración son los mejores tanto para la obra como para el artista, una vez que estará garantizado el mantenimiento y la salvaguardia del bien cultural como tal, y el artista jamás deberá dudar del respecto hacia la integridad de la obra así como de su reputación. La intención de proteger valores como la originalidad y la autenticidad, a los cuales se contraponen la copia, la imitación y la falsificación, serán la forma de exaltar y valorar a lo largo de los siglos, el mérito ya patente en la obra y su creador, pero con posibilidad de adquirir un vigor incalculable.

Si existen varios agentes en acción, es porque cada uno tiene una función específica en el desarrollo de este sistema de la creación. El artista, el creador, el que hace de la idea una concepción física; la obra, el bien cultural que deberá permanecer en esa su concepción física si su función es llegar al público; y el público, que se deleita por excelencia con la creación según su función y él que dará a la obra sentido para que se transmita al futuro. El conservador/restaurador, en un trabajo de cooperación interdisciplinar, consciente de que la obra es un bien cultural, por su consistencia física y conceptual, por su instancia histórica y estética, por su autenticidad, originalidad y unicidad, por lo cual posee el deber de proteger, salvaguardar y transmitir a generaciones futuras lo que es creación.

De la misma forma que se establecen los derechos de autor para que el artista se sienta protegido y respetado, también es esencial crear normativas legales que establezcan el respeto por las creaciones, ya que malas prácticas pueden existir continuamente, y en cualquier área de acción humana. Tal como el artista tiene poder para exigir el cumplimento de lo que está legalmente establecido, lo mismo tendrá de acontecer en las áreas que asegura el patrimonio y que en la presente investigación pasan por la conservación/restauración del arte contemporáneo, ciencia que se destaca de las demás ciencias proteccionistas. Como es referido en paginas anteriores, así como en casi todos los congresos y encuentros sobre arte contemporáneo y conservación y restauración, es fundamental establecer una buena relación profesional entre los varios intervinientes, de forma a facilitar todos los trámites que sean necesarios, además de la obtención segura y fundamental de información imprescindible para la buena aproximación a las creaciones contemporáneas. 
La cuestión no pasa por el deseo de crear limites en la libertad creativa del autor, pero si hay necesidad de establecer límites, éstos se sitúan en la relación entre autor y la obra. No hay que descartar la importancia de concentrar en un sólo documento la protección necesaria para lo que es hoy patrimonio y que mañana puede ser recuerdo, sin olvidar que la obra es imagen donde figura un hecho histórico, y es materia donde éste se incorpora, pero siempre conscientes de que todo lo que envuelve la obra y a su creador está inserido en una red de consumo que se impone con presiones a varios niveles, como mercancías con pesos diferenciados en el seno de la mercantilización inevitablemente vinculada a los tiempos que corren.

Y porque siempre se camina hacía un fin concreto, aunque esto signifique iniciar un nuevo recorrido, se pretende en el futuro contraponer estos mismos conceptos estudiados bajo la legislación y ámbito portugués. La presente tesis como un acercamiento teórico buscó respuestas concretas sobre algo que muchas veces es abstracto y sin duda indeterminado. Por ello, se asume la ambigüedad que la teoría puede presentar hasta el día en que todos los agentes e individuos que se mueven en el campo de la conservación/restauración sigan las mismas normativas y se establezcan criterios y normas unánimes.

Que las creaciones contemporáneas no supongan un problema para la restauración sino si un medio de ver la vida en sociedad, un testimonio de esas vivencias y una forma pura de reflexión y disfrute.

Hemos dicho que los problemas son formas positivas y que en su positividad misma está la solución. La respuesta a los problemas está en el modo como cada época o cada pensamiento (cada perspectiva, en definitiva) los determina, articula sus elementos y les impone una disposición específica. O dicho de otro modo: las soluciones empíricas a un problema determinado están dadas en el modo como se determina este problema.

293 Introducción de Miguel Morey, en DELEUZE, Gilles. Diferencia y repetición, p.21. 


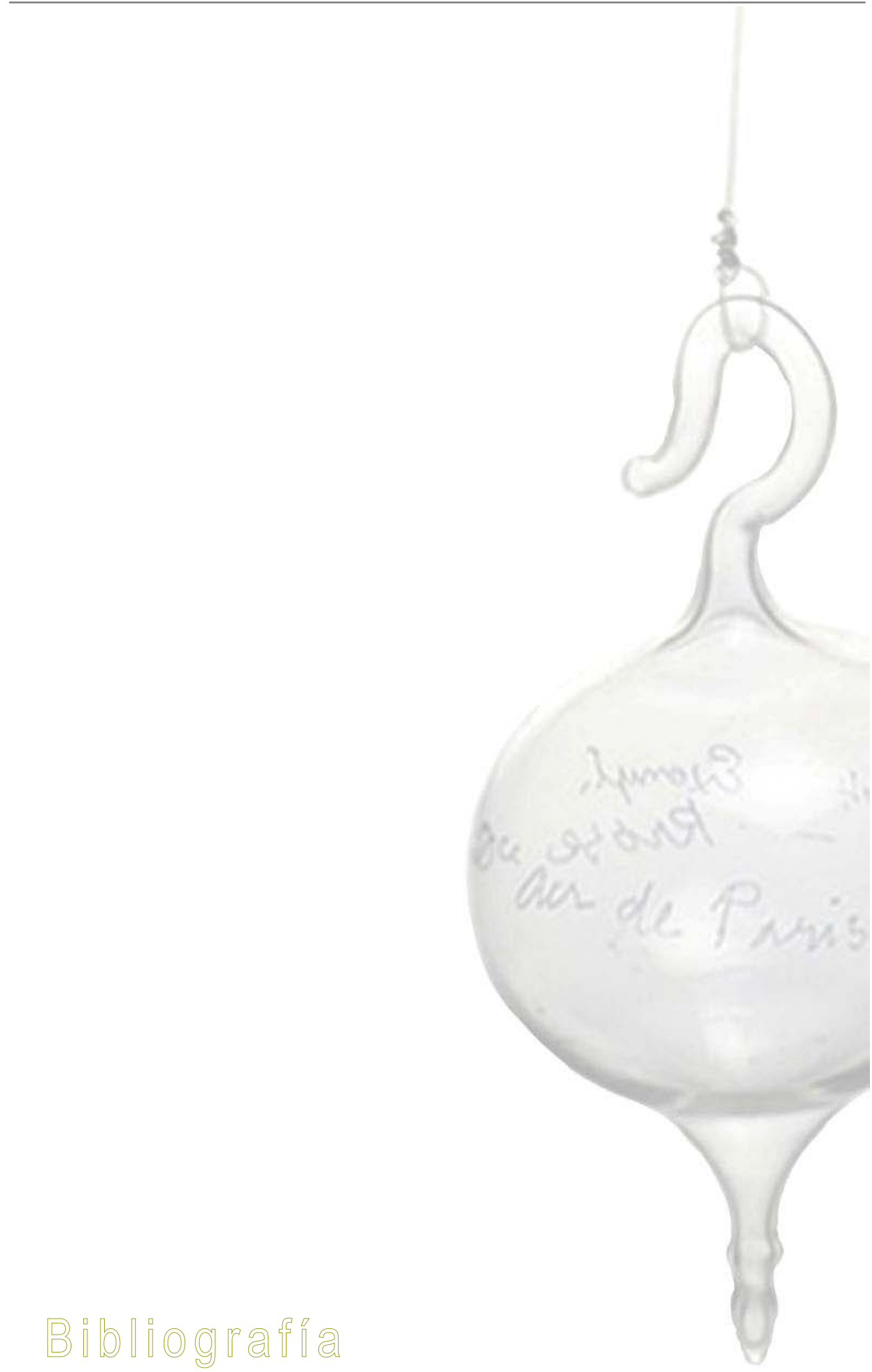





\section{Arte: historia, artistas y mercado}

ADORNO, Theodor W. Experiência e criação artística. Lisboa: Edições 70, 2003, p.159.

AGUILERA Cerni, Vicente (dirigido por). Diccionario del arte moderno. Conceptos, ideas, tendencias. Valencia: Biblioteca Valenciana, 1986, 569p.

ALBERTI, Leon Battista. Sobre la Pintura. Valencia: Fernandos Torres Editor, 1976, p.221.

ALIAGA, Juan Vicente. La elocuencia política del cuerpo. en Exit Book, anuario de libros de arte y cultura visual, $n^{0} 5$. Salamanca: 2006, pp.61-75.

ALMEIDA, J. Ferreira de y PINTO, J. Madureira. A investigação nas ciências sociais, Lisboa: Edições Presença, 1982.

AA.VV. Libro de Actas del I Congreso Internacional: Nuevos materiales y tecnologías para el arte. Madrid: Facultad de Bellas Artes U.C.M., Noviembre de 2005, p.554.

AA.VV. El instante eterno. Valencia: La Imprenta, Comunicación Gráfita y Castelló Consorci de Museos de la Comunitat Valenciana, 2001, p.292.

ARENAS Fernández, José (Coordinación). Arte efímero y espacio estético. Barcelona: Editorial Anthropos, 1988, p.554.

ARGAN, Giulio Carlo. El pasado en el presente. El revival en las artes plásticas, la arquitectura, el cine y el teatro. Barcelona: Editorial Gustavo Gili, 1977, p.312.

ARNHEIM, Rudolf. Ensayos para rescatar el arte. Madrid: Catedra, 1992, p.242.

AUMONT, Jacques. La estética hoy. Madrid: Cátedra - Signo e imagen, 1998, p.335.

BADOSA Conill, Luis. Arte e industria. Influencias industriales en el arte del siglo XX. 1990-1945. País Vasco: Servicio editorial Universidad del País Vasco, tesis doctoral, p.533.

BARRAGÁN Martínez, Carlos. El índice. La huella de la manualidad y la mecánica en fotografía y pintura. Valencia: Diputación de Valencia, Institució Alfons el Magnànim, Collección Formes Plástiques, 2004, p.207.

BARRO, David. Imagens para uma representação contemporânea. Porto: Mimesis, 2003. 
BARTHES, Roland. Lo obvio y lo obtuso. Imágenes, gestos, voces. Barcelona: Paidós, 1986, 380p.

BATCHELOR, David. Minimalismo. Lisboa: Editorial Presença, 2000, 80p.

BATTACOCK, Gregory (editor). La idea como arte. Documentos sobre leerte conceptual. Barcelona: Editorial Gustavo Gili, 1977, 156p.

BAUDELAIRE, Charles. El Salón de 1846. Valencia: Fernando Torres Editor, 1976, 202p.

BAUDELAIRE, Charles. Curiosidades estéticas. Barcelona: Ediciones Júcar, 1988, p. 232.

BEARDSLEY, Monroe C. y HOSPERS, John. Estética: Historia y fundamentos. (8a ed.) Madrid: Cátedra, Colección Teorema, 1988, 175p.

BENJAMIN, Walter. Sobre Arte, Técnica, Linguagem e Política. Lisboa: Relógio d' Água Editores, 1992, 235p.

BERGER, René. El conocimiento de la pintura. El arte de apreciarla. ( $2^{\mathrm{a}}$.ed.) Barcelona: Editorial Moguer 1976, 261p.

BORDINI, Silvia. Materia e imagen. Fuentes sobre las técnicas de la pintura. Barcelona: Ediciones de Serbal, 1995, 249p.

BOURDIER, Pierre. Génese histórica de uma estética pura, en 0 poder simbólico. Lisboa: Livros Horizonte, 1982, pp.281-298.

BÜRGER, Peter. Teoria da Vanguarda. Águeda: Colecção Veja Universidade, 1993, 180p.

BOZAL, Valeriano (dirección). Historia de las ideas estéticas y de las teorías artísticas contemporáneas. Volumen I, (2ª . Ed.). Madrid: Edición Visor Dis., 2000, 473p.

BOZAL Fernández, Valeriano. El lenguaje artístico. Barcelona: Ediciones Península, 1970, 307p.

CALLE de la, Román. En torno al hecho artístico. Valencia: Fernando TorresEditos, 1981, 226p.

CAUQUELIN, Anne. Arte contemporânea, uma introdução. São Paulo: Martins Fontes, 2005. 168p.

CENNINI, Cennino. El libro del arte. Madrid: Ediciones Akal, 2002, 264p.

CHIPP, Herschel B. Teoria da Arte Moderna. (2aed.) São Paul: Martins Fontes: 1998, 675p. 
CHUCHURRA López, Osvaldo. Estética de los elementos plásticos. (2ª ed.) Barcelona: Editorial Labor, 1975, 154p.

CIRLOT, Lourdes. Las claves de las vanguardias artísticas en el siglo XX. Cómo identificarlas. (2ª ed.) Barcelona: Editorial Planeta, 1991, 78p.

CLAIR, Jean. La responsabilidad del artista. Las vanguardias, entre el terror y la razón. Madrid: Visor, La balsa de la Medusa, 1998, 126p.

COMBALÍA Dexeus, Victoria. La poética de lo neutro. Análisis y crítica del arte conceptual. Barcelona: Editorial Anagrama, 1975, 135p.

CONNOR, Steven. Cultura Postmoderna. Introducción a las teorías de la contemporaneidad. Madrid: Ediciones Akal, 1996, 200p.

COOPER, James F. The Problem with Modern Art: Or, Why Beautiful Art Matters First Principles, < http://www.firstprinciplesjournal.com/articles.aspx?article $=607$ \&theme=home\&page $=1 \&$ loc $=b \& t y p e=c t t f>$. Acceso en: 9.mar.2009.

- $\quad$ CRISPOLTI, Enrico. Cómo estudiar el arte contemporáneo. Madrid: Celeste Ediciones, 2001, 265p.

- DANTO, Arthur C. Después del fin del arte. El arte contemporáneo y el linde de la historia. Barcelona: Paidós, 1999, 252p.

- DEBRAY, Régis. Vida y muerte de la imagen. Historia de la mirada en Occidente. Barcelona: Paidós, 1994, 317p.

- DELEUZE, Gilles. Diferencia y repetición. Barcelona: Ediciones Júcar, 1988, 489p.

- DELGADO-GAL, Álvaro. La esencia del arte. Madrid: Ediciones Taurus, 1996, 205p.

DIDEROT, Denis. Escritos sobre arte. Madrid: Ediciones Siruela, 1994, 200p.

DONDIS, D. A. La sintaxis de la imagen. Introducción al alfabeto visual. (6a. ed.) Barcelona: Editorial Gustavo Gil, 1985, 211p.

- D'OREY, Carmo. O que é a arte? A perspectiva analítica. Lisboa: Dinalivro, 2007, 138p.

- $\quad$ DORFLES, Gillo. Elogio da desarmonia. Lisboa: Edições 70, 1986, p.191.

- DUVERGER, Maurice. Ciencia Politica, Teoria e Método, Rio de Janeiro: Zahar Ed., 1962, 437p.

ECO, Umberto. Obra aberta, (2a ed.) Barcelona: Editorial Ariel, 1984, 355p. 
FISCHER, Ernst. El artista y su época. Madrid: Editorial Fundamentos, 1972. 170p.

FISCHER, Ernst. La necesidad del arte, (2ª.ed.). Barcelona: Nexos, 1967, p.270.

FIZ, Simón Marchán. Del arte objetual al arte de concepto (1960-1974). Epilogo sobre la sensibilidad "posmoderna". Antología de escritos y manifiestos. (7a ed.) Madrid: Ediciones Akal, 1997, 222p.

FLORES, Laura. Fotografía y Pintura: dos médios diferentes? Barcelona: GG, 2005, 319p.

FRIED, Michael. El lugar del espectador. Estética y orígenes de la pintura. Madrid: La balsa de la Medusa, 2000, 276p.

GABLIK, Suzi. ¿Ha muerto el arte moderno? Madrid: Ediciones Hermann Blume, 1987, 126p.

GIMPEL, Jean. Contra el arte y los artistas. Argentina: Granica editor, 1972, 172p.

GIORDANO, Alessandro dal Lago Serena. Mercati d'aura. Logiche dell'arte contemporanea. Bologna: Editrice il Mulino, 2006, 285p.

GOMBRICH, E. H. Historia del arte. (4ª ed.) Barcelona: Ediciones Garriga, S. A., 1967, 535p.

GOMBRICH, E. H. La imagen y el ojo. Nuevos estudios sobre la psicología de la representación pictórica. Madrid: Alianza Editorial, 1987, 302p.

GOMBRICH, E. H. Temas de nuestro tiempo: propuestas del siglo XX. Acerca del saber y del arte. (2a ed.) Madrid: Editorial Debate, 2002, 223p.

GREENBERG, Clemente. Arte y cultura. Ensayos críticos. Barcelona: Editorial Gustavo Gili, 1979, 217p.

GUASCH, Anna María. La crítica dialogada. Entrevistas sobre arte y pensamiento actual (2000-2007). Murcia: CENDEAC, 2007, 181p.

GUASCH, Anna María. El arte del siglo XX en sus exposiciones. 1945-1995. Barcelona: Ediciones del Serbal, 1997, 422p.

GUERREIRO, Luis Juan. Promoción y requerimiento de la obra de arte. Estética de las tareas artísticas. Buenos Aires: Editorial Losada, 1967. 280p.

HEARTNEY, Eleanor. Pós-Modernismo. Lisboa: Editorial Presença, 2002, $80 p$.

HOLANDA, Francisco de. Da Pintura Antiga (1548). Lisboa: Horizonte, 1984. 
HONNEF, Klaus. Andy Warhol, 1928-1987. Germany: Taschen, 2000, 95p.

HUGHES, Robert. A toda crítica. Ensayos sobre arte y artistas. (2a .ed.)

Barcelona: Editorial Anagrama, Colección argumentos, 1997, 497p.

- HOSPERS, John. Significado y verdad en el Arte. Valencia: Fernando Torres Editor, 1980, 330p.

- JIMÉNEZ, JOSÉ. Teoría del arte. Madrid: Editorial Tecnos, 2003, 281p.

KAHLER, Erich. La desintegración de la forma en las artes. México: Siglo XXI Editores, 1969, 139p.

- KAPROW, Allan. La educación del des-artista. Madrid: Ediciones Árdora, 2007, 125p.

- $\quad$ KAVOLIS, Vytautas. La expresión artística: un estudio sociológico. Buenos Aires: Amorrortu Editores, 1968, 203p.

- $\quad$ KEPES, Gyorgy (editor). La situación actual de las artes visuales. Buenos Aires: Editorial Paidos, 1963, 124p.

- $\quad$ KRAUBE, Anna Carola. Historia da pintura, do renascimento aos nossos dias. Colónia: Könemann, 1995, 128p.

- $\quad$ KRIS, Ernest y KURZ, Otto. La leyenda del artista. (4⿳a ed.) Madrid: Ediciones Catedra, Ensayos arte, 2002, 133p.

LARRAÑAGA, José. Instalaciones. Hondarribia: Editorial Nerea, Arte Hoy, 2001, 103p.

LOTMAN, Yuri M. Estructura del texto artístico. (2a ed.) Madrid: Ediciones ISMO: Colección Fundamentos 58, 1982, 364p.

LUCIE-SMITH, Eduard. Movimientos artísticos desde 1945. (5ª Ed.) Singapore: Ediciones Destino, Thames and Hudson, 1998, 303p.

LYOTARD, Jean-François. La condición postmoderna. (9aEd.) Madrid: Catedra, 2006, 119p.

- MANN, Thomas. El artista y la sociedad. Madrid: Ediciones Guadarrama, 1975, 327p.

- MARTíN Martin, Jesús Ángel. Arte y mercado. en www.gestioncultural.org, mayo de 2008.

- MÉNDEZ, Lourdes. Antropología de la producción artística. Madrid: Editorial Síntesis, 1995, 288p.

- $\quad$ MICHELI, Mario de. Las vanguardias artísticas del siglo XX. (2a ed.) Madrid: Alianza editorial, 1981, 447p. 
MINK, Janes. Marcel Duchamp 1887-1968. Germany: Taschen, 2000, 95p.

MOHOLY-NAGY, László. La nueva visión y reseña de un artista. Buenos Aires: Torfano, 1963, 190p.

MOLTEJO Navas, Adolfo. El arte frente al imperio del mercado. en Revista Lápiz 221, Revista Internacional de Arte, Año XXV, pp.26-41.

MOLYNEUX, John. The legitimacy of modern art. en Socialist Workers Party. Britain: September 1998. http://pubs.socialistreviewindex.org.uk/isj80/art.htm>. Acceso en: 4.ene.2004.

- MORAZA, Juan Luis. Ornamento y Ley. Procesos de contemporización y normatividad en arte contemporáneo. Murcia: CENDEAC, 2007, 127p.

- MORGAN, Robert C. Del arte a la idea. Ensayos sobre arte conceptual. Madrid: Ediciones Akal, 2003, 156p.

- MORRIS, WILLIAM. Arte y sociedad industrial. Valencia: Fernando Torres Editor, 1975, 216p.

NARANJO, Eduardo. Arte y pintura: dilemas de hoy. en Libro de actas del $16^{\circ}$ Internacional Meeting on Heritage Conservation, volumen 1. Valencia: Universidad Politécnica de Valencia Editorial, 2006, pp.131-139.

- $\quad$ NAKOV, Andrei B. (editor) y TARABUKIN, Nikolai. El último cuadro. Del caballete a la máquina. Por una teoría de la pintura. Barcelona: Ediciones Gustavo Gili, 1977, 168p.

- NIETZSCHE, Friedrich. A origem da tragédia. Lisboa: Guimarães Editores, 1994, 192p..

- PACHECO, Francisco. Arte de la Pintura. Barcelona: Las Ediciones de arte, 1982, 142p.

- OREY, Carmo d'. "o que é arte" ou "quando há arte?". en Revista Análise, n8, 1990, pp.67-88.

PEDROLA, Antoni. Materiales, procedimientos y técnicas pictóricas. (2a ed.) Barcelona: Editorial Ariel, 2002, 222p.

- $\quad$ PERNIOLA, Mario. La estética del siglo veinte. Madrid: Edición La Balsa de la Medusa, A. Machado Libros, 2001, 254p.

- POLI, Francesco. Producción artística y mercado. Barcelona: Editorial Gustavo Gil, 1976, 141p.

- PONENTE, Nello. Estructuras del mundo moderno 1850-1900. Barcelona: Ediciones de Arte Albert Skira, 1965, 208p. 
POPPEP, Frank. Arte, acción y participación. El artista y la creatividad de hoy. Madrid: Ediciones Akal, 1989, 314p.

PUELLES Romero, Luis. Entre imágenes: experiencia estética y mundo versátil. en Revista Estudios Visuales, Estética, Historia del arte, Estudios Visuales, n³, enero 2006, pp. 128-151.

- $\quad$ RAMIREZ, Juan Antonio. El valor de la imagen. en Revista Lápiz 217, Revista Internacional de Arte, Año XXIV, pp. 26-41.

- READ, Herbert (editor asesor). Diccionario del arte y de los artistas. Barcelona: Edicones Destino/ Thames and Hudson, 1995, 384p.

- READ, Herbert. Arte y alienación. (2ªEd.) Buenos Aires: Editorial Proyección, 1976,193p.

- $\quad$ READ, Herbert. Imagen e idea. La función del arte en el desarrollo de la conciencia humana. México: Fondo de cultura económica, 1957, 245p.

REGUERA, Galder. La cara oculta de la luna. En torno a la «obra velada»: idea y ocultación en la práctica artística. Murcia: Cendeac, 2008,136p.

REGUERA, Galder. La cara oculta de la luna. en Revista Lápiz 218, Revista Internacional de Arte, Año XXIV, pp.34-53.

RICOSSA, Sergio (a cura di). I mercati dell'arte. Aspetti pubblici e privati. Torino: Umberto Allemadi \& C., 1991, 143p.

SALABERT, Pere. (D)efecto de la pintura. Barcelona: Anthropos Editorial del Hombre, 1985, 490p.

- $\quad$ SAURA, Antonio. Escritura como pintura. Sobre la experiencia pictórica 19501994. Barcelona: Círculo de lectores - Galaxia Gutenberg, 2004, 206p.

- SCHAPIRO, Meyer. Estilo, artista y sociedad. Teoría y filosofía del arte. Editorial Tecnos, 1999, 255p.

- $\quad$ SEDLMAYR, Hans. El arte descentrado. Las artes plásticas de los siglos XIX y XX como síntoma y símbolo de la época. Barcelona: Editorial Labor, 1958, 240p.

SHINER, Larry. La invención del arte. Una historia cultural. Barcelona: Edicones Paidós, 2004, 476p.

SOLANS, Piedad. Las máscaras de la mercancía. en Revista Lápiz 221, Revista Internacional de Arte, Año XXV, pp.42-57.

STURGIS, Alexander. Entender la pintura. Análisis y explicación de los temas de las obras. Barcelona: Blume, 2002, 272p. 
THOMAS, Karin. Estilos de las artes plásticas en el siglo XX. Barcelona: Ediciones del Serbal, 1988, p.333.

TRIMARCO, Angelo. Confluencias, arte y crítica en la postmodernidad. Madrid: Julio Ollero Editor, Instituto de Estética y Teoría de las Artes, 1991, $114 p$.

- UBERQUOI, Marie-Claire. ¿El arte a la deriva?. Barcelona: De bolsillo, 2004, $171 p$.

- $\quad$ ULLRICH, Wolfgang. Consumo en lugar de recepción. en Revista Lápiz 220, Revista Internacional de Arte, Año XXV, pp.42-55.

- $\quad$ VALÉRY, Paul. La idea fija. Madrid: La balsa de la Medusa, 1988, 123p.

- $\quad$ VALLIER, Dora. A Arte Abstracta. Lisboa: Edições 70, 1980, 295p.

- VENTURI, Lionello. Cuatro pasos hacia el arte moderno. Buenos Aires: Ediciones Nueva Visión, 1960, 84p.

- $\quad$ VETTESE, Angela. Invertir en arte. Producción, promoción y mercado del arte contemporáneo. Madrid: Ediciones Pirámide, 2002, 292p.

- VILLA, Rocío de la. Guía del usuario de arte actual. Madrid: Editorial Tecnos, 1998, 324p.

- VILLAFAÑE, Justo. Introducción a la teoría de la imagen. (5aaed.) Madrid: Ediciones Pirámide, 1996, pg.230.

- $\quad$ VINCI, Leonardo da. Tratado da Pintura. (5ªed.) Madrid: Akal, 2004, p.508.

- WEITEMEIER, Hannah. Yves Klein 1928-1962. Germany: Thaschen, 2001, p.95.

- $\quad$ WOOD, Paul. Arte Conceptual. Lisboa: Editorial Presença: 2002, p.80.

- YNGVASON, Hafthor (edited by). Conservation and maintenance of contemporary public art. Cambridge: Archetype Publications Ltd, 2002, 154p.

- $\quad$ ZUBIAGA Horta, Arturo, RENAMAYOR Sánchez, Carmen, DORADO Pérez, Ángel y PÉROLA Fernández, Inés de. Los plásticos más usados. Madrid: Ediciones UNED, Universidad Nacional de Educación a Distancia, 2000, p.356.

Otras referencias electrónicos:

Instituto de Camões, <http://www.instituto-camoes.pt/cvc/filosofia/ren5.html>. Acceso en: 15.mar.2006. 
Sobre sites, <http://www.sobresites.com/pintura/critica.htm>. Acceso en: 15.mar.2006.

- $\quad$ Isaque Pinheiro, < http://www.isaquepinheiro.com/>. Acceso en: 9.abril.2008.

- Portal Iboamericano de gestión cultural, <http://www.gestioncultural.org>. Acceso en: 4.mayo.2008.

- $\quad$ Arte y mercado, <http://www.arteymercado.com/intromercarte.html>. Acceso en: 4.mayo.2008.

- Idea sapiens.com, <http://www.ideasapiens.com/arte/estetica/arte\%20contempo raneo\%20percepcion_publico.htm>. Acceso en: 5.mayo.2008.

- Onto Art: Reflexiones sobre Ontologia del Arte, <http://ontoart.wordpress.com /2008/05/23/razones-en-el-arte-contemporaneo-por-gerard-vilar/>. Acceso en: 23.may.2008.

- $\quad$ Agenda Crítica, < http://agenciacritica.net/>. Acceso en: 6.set.2008.

- João Pedro Rodrigues, < http://www.joaopedrorodrigues.com/oficina/>. Acceso en: 10.jun.2008.

- Rui Pedro Fonseca, < http://www.geocities.com/ruipedro_fonseca/>. Acceso en: 10.jun.2008.

\section{Conservación, restauración y patrimonio}

AA.VV. Libro de actas del Seminario internacional de conservación de pintura. El soporte textil: comportamiento, deterioro y criterios de intervención. Valencia: Editorial Universidad Politécnica de Valencia, Marzo de 2005, 436p.

- $\quad$ AA. VV. Arte contemporanea. Conservazione e restuaro. Torino: Umberto Allemandi \& c., Fundazione di Venezia, 2005, 317p.

- $\quad$ ABADA Martínez, María Jesús. La conservación de una colección privada de arte contemporáneo. en Arte: materiales y conservación. Madrid: Fundación Argentaria, 1998, pp. 137-150.

- $\quad$ ALCALÁ Ramón, José. Conservación de lo intangible o abandono de la idea de conservación. en Revista de Museología, publicación científica al servicio de la comunidad museológica n³0-31. Madrid, 2004, pp.11-20.

- AlCÁNTARA, Rebeca Hewitt. Un análisis crítico de la teoría de la restauración de Cesari Brandi. México: Colección Científica/ Instituto Nacional de Antropología e Historia, 2000, 148p. 
ALISAL, Eloisa del. Espacios para el arte: lugares en continua redefinición. en Em Questão, Vol. 13, No 2, 2007, <http://www.seer.ufrgs.br/index.php/Em Questao/article/view/2981/2034\&mkt=pt-PT\&FORM=MIC9E5>. Acceso en: 5.ene.2008.

ALONSO Hierro, Juan. La preservación del patrimonio histórico en perspectiva europea (los casos de España, Francia, Italia y Portugal). en Revista Restauro- La restauración en España en los últimos 23 años: pasado, presente y futuro del sector, №.1, 2008, pp.18-20, $<$ http://www.revistarestauro.com/CONTENIDOS/ restaur01\%20pdfbaja/050057_EUROPAb.pdf>. Acceso en: 12.may.2009.

ANGELUCCI, Sergio (a cura di). Arte Contemporanea. Conservazione e restauro. Contributi al "Colloquio sul restauro dell'arte moderna e contemporanea». Fiesole: Nardini Editore, 1994, 336p.

ALTHÖFER, Heinz. Il restauro delle opera d'arte moderne e contemporanee. Firenze: Nardini Editore, 1991, 197p.

ALTHÖFER, Heinz. La questione del ritocco nell restauro pittorico. Padova: Edizione El Prato, 2002, 63p.

ALTHÖFER, Heinz. Restauración de pintura contemporánea. Tendencias, materiales, técnicas. Madrid: Ediciones Akal, Ismos, 2003, 167p.

- $\quad$ ARENAS Fernández, José. Introducción a la conservación del patrimonio y técnicas artísticas. Barcelona: Editorial Ariel, Historia de Arte, 1996, 197p.

ARQUILLO Torres, Francisco. El conocimiento de las posibilidades de recuperación de una obra de arte no debería ser exclusivo del especialista. en $17^{0}$ International Meeting on Heritage Conservation. Valencia, 2008, pp. 373377.

AUSEJO López-Cano, Jacob. Encuentro entre estética y restauración. en Libro de actas del $16^{\circ}$ Internacional Meeting on Heritage Conservation, volumen 2. Valencia: Universidad Politécnica de Valencia Editorial, 2006, pp.809-820.

BALDINI, Umberto. Teoría de restauración y unidad de metodología. Volumen I, (Edición cast.). Guipúzcoa: Editorial Nerea, 2002, 189p.

BALDINI, Umberto. Teoría de restauración y unidad de metodología. Volumen II, (Edición cast.). Florencia: Nardini Editore/ Editorial Nerea, 1998, 132p.

BARBERO Encinas, Juan Carlos. Fondo y figura. El sentido de la restauración en el arte contemporáneo. Madrid: Ediciones Polifemo, 2008, 320p. 
BARBERO Encinas, Juan Carlos (coord.). Aportaciones teóricas y experimentales en problemas de conservación. en Actas del II Seminario sobre restauración de bienes culturales. Aguilar de Campo: Speed Publicaciones, 2007, 205p.

BARBERO Encinas, Juan Carlos. La memoria de las imágenes. Notas para una Teoría de la Restauración. Madrid: Ediciones Polifemo, 2003, 261p.

BARRETO, Margarita. Os museus e a autencidade no turismo. en Revista Itinerarium, v.1, 2008, <http://www.seer.unirio.br/index.php/itinerarium>. Acceso en: 10.fev.2009.

- $\quad$ BARROS García, José Manuel. Imágenes y sedimentos: la limpieza en la conservación del patrimonio pictórico. Valencia: Institució Alfons el MagnànimDiputació de València, 2005, 186p.

BASILE, Guiseppe. Progetto Burri: caratteri, finalità, risultati, in La Collezione Burri a Città di Castello: dalla conoscenza alla prevenzione. Padova: Edizione II Prato, Gli Ori, 2009, pp.13-28.

- BASILE, Guiseppe. L'ICR e il restauro del contemporaneo: continuità di un metodo. Padova: Edizione, II Prato: Gli Ori, 2008, pp.1-7.

BASILE, Guiseppe. Teoria e practica del restauro in Cesari Brandi. Padova: Edizione II Prato, 2007, 152p.

BASILE, Giuseppe. Cesari Brandi. en R\&R, Restauración y Rehabilitación, Revista Internacional del Patrimonio Histórico. Valencia: Universidad Politécnica de Valencia, noviembre 2006, nº 101, pp.66-69

- BECK, James y DALEY, Michael: La restauración de obras de arte: Negocio, cultura, controversia y escándalo. Barcelona: Ediciones del Serbal, 1997, 276p.

BOITO, Camillo. Os Restauradores. Brasil: Ateliê Editorial, 2003, 63p.

BOMFORD, David y LEONARD, Mark. Issues in the conservation of paintings. Readings in conservation. Los Angeles: J. Paul Getty Museum, 2004, 581p.

- BOMFORD, David. Workshop, Critérios éticos e estéticos na restauração de pinturas. São Paulo: Fundação VITAE y The British Council, 1999, sin paginación.

- $\quad$ BOMFORD, David. Conservation of paintings. London: National Gallery, 1997, 80p.

- BONSANTI, Giorgio y CIATTI, Marco (a cura). Ulisse Forni, Manuale del pittore restauratore. Studi per la nueva edizione. Firenze: Edifir-Edizioni Firenze, 2004, 292p. 
BRANDI, Cesari. Teoria do restauro. Lisboa: Orion, 2006, 238p.

BRANDI, Cesare. Teoría de la restauración. (2a ed.) Madrid: Alianza Forma, 2002, 149p.

- $\quad$ CABRERA Orti, Ma Angustias. Los métodos de análisis físico-químicos y la historia del arte. Granada: Universidad de Granada, 1994, 144p.

CALVO, Ana Manuel. Conservación y restauración. Materiales, técnicas y procedimientos. De A a la Z. (3ª ed.) Barcelona: Ediciones del Serbal, 2003, 256p.

- $\quad$ CALVO, Ana Manuel. Conservación y restauración de pintura sobre lienzo. Barcelona: Ediciones del Serbal, 2002, 383p.

- CASAZZA, Ornella. II restauro pittorico : nell'unità metodologia. ( $3^{a}$.ed.) Firenze : Nardini, 1989, 157p.

- $\quad$ CASIELLO, Stella (a cura di). La cultura del restauro. Teorie e fondatori. ( $3^{\mathrm{a}}$ ed.) Venezia: Marsilio Editori, 2005, 405p.

- CHIANTORE, Oscar y RAVA, Antonio. Conservare l'arte contemporanea. Problemi, metodi, materiali, ricerche. Martellago: Electa, 2005, 329p.

COLALUCCI, Gianluigi. Validità della Teoria di Cesari Brandi. en, Jornada Internacional A 100 Anni della Nascita di Cesari Brandi. Valencia: Universidad Politécnica de Valencia, 2007, pp.13-17.

- CONSTANTINE, Mildred. Preserving the legacy of $20^{\text {th }}$. Conservation, The Getty Conservation Institute Newsletter vol.13, n², 1998, pp.4-15.

- CONTI, Alessandro. Storia del restauro e della conservazione delle oepre d'arte. Milán: Electa Editrice, 1975, 286p.

- CONTI, Alessandro (a cura). Sul restauro. Torino: Guilio Einaudi Editore, 1988, 197p.

- $\quad$ CORZO, Miguel Angel (edited by). Mortality Immortality? The legacy of 20thcentury art. Getty Conservation Institute: Los Angeles, 1999, 192p.

- $\quad$ CRUCES, Francisco. Problemas en torno a la restitución del patrimonio. Una visión desde la antropología. en, Políica y Sociedad, n²7. Madrid, 1998, pp.77-87.

- $\quad$ ELLIS, Margaret Holben. The day before yesterday: materials and methods of twentieth century Works of art on paper. Lisboa: Fundação Caloustre Gulbenkian, 2003, 44p. 
ESCOHOTADO Ibor, María Teresa, et al. La limpieza de obras de arte ¿hasta dónde se puede llegar?. en Revista de Museología, Publicación científica al servicio de la comunidad museológica, n. 18, Madrid, 1999. p. 6-9.

ESCOHOTADO Ibor, María Teresa. La problemática de la obra de arte contemporáneo. en MACARRÓN Miguel, Ana M. a y MOZO, Ana González. La conservación y la restauración en el siglo XX. Madrid: Editorial Tecnos, 1998, pp.199-208.

- ESCOHOTADO Ibor, María Teresa. Los soportes de la obra de arte contemporánea. en Revista de Museología: Publicación científica al servicio de la comunidad museológica, nº.4, Madrid, 1995, p.55-57.

ESCOHOTADO Ibor, María Teresa. Aspectos generales de la restauración del arte actual. en Actas del XVIII Congrés de Conservación de Béns Culturales. Valencia: Generalitat Valenciana, 1990.

- GARCÍA Fernández, Isabel María. La conservación preventiva y la exposición de objetos y obras de arte. Murcia: Editorial KR, 1999, 459p.

- GARCÍA Fortes, Salvador. Introducció a la conservació-restauració del patrimoni. Barcelona: Universitat de Barcelona, 1998, 164p.

GIANNINI, Cristina (dirección) y ROANI, Roberta. Diccionario de restauración y diagnóstico. San Sebastián: Editorial Nerea, 2008, 224p.

GIANNINI, Cristina. Lessico del restauro. Storia, tecniche, strumenti. Fiesole: Nardini Editore, 1992, 195p.

GÓMEZ Pintado, Alinhoa. El oro en el arte: materia y espíritu contribución a la restauración en el arte contemporáneo (tesis doctoral). Bilbao: Universidad del Pais Vasco, Departamento Pintura, 2008, 501p.

- GONZÁLEZ, Antoni Moreno-Navarro. ¿Y si no fuera siempre pecado reconstruir? en Revista Restauro- La restauración en España en los últimos 23 años: pasado, presente y futuro del sector, №.1, 2008, pp.18-20, $<$ http://www.revistarestauro.com/CONTENIDOS/restauro1\%20pdfbaja/018021_AGONZALEZb.pdf>. Acceso en: 12.may.2009.

HERRÁEZ, Juan A., LORITE, Miguel A. Rguez. La conservación preventiva de las obras de arte. en Revista Arbor (CLXIV, 645): Ciencia, pensamiento y cultura, septiembre de 1999, pp.141-156. <http://geiic.com/files/grupoconservacionpre/ CONSERVACIONPREVENTIVA.pdf>. Acceso en: 3.out.2007.

HEUMAN, Jackie (edited by). Material matters the conservation of modern sculpture. London: Tate Gallery Publishing, 1999, 128p. 
INSAURRALLDE Caballero, Mirta Asunción y JIMÉNEZ Ramírez, Mauricio Benjamín. La teoría como matriz de desarrollo de la restauración. en Libro de actas del $16^{\circ}$ Internacional Meeting on Heritage Conservation, volumen 2. Valencia: Universidad Politécnica de Valencia Editorial, 2006, pp.837-845.

INEVA Tamarat, Pilar. La restauración artística a través del tiempo. Consecuencias prácticas. Especial estudio del caso valenciano. Valencia: Universidad Politécnica de Valencia, Departamento de Conservación y Restauración de los bienes Culturales, 1995, tesis doctoral.

LANZONOVA, Elena. II restauro dell'arte contemporanea in Italia: problema e limiti. <http://artmagazine.arcadja.it/2007/10/15/il-restauro-dellarte-contemporanea -in-italia-problemi-e-limiti>. Acceso en: 15.oct.2007.

- $\quad$ LLAMAS Pacheco, Rosario. Conservar y restaurar el arte contemporáneo. Un campo abierto a la investigación. Valencia: Editorial Universidad Politécnica de Valencia, 2009, 219p.

LLAMAS Pacheco, Rosario. Nuevos criterios de intervención en el arte contemporáneo. Obras con fecha de caducidad. en Conservación y restauración de nuevos materiales empleados en el arte contemporáneo. Valladolid: Fundación Cristóbal Gabarrón, 2009, pp.27-43.

LLAMAS Pacheco, Rosario. Investigar para enseñar o cómo profundizar en el conocimiento de la disciplina de la conservación del arte no convencional. en XVI Congreso Internacional de Conservación y Restauración de Bienes Culturales. Valencia, 2006, pp.821-836.

- LLAMAS Pacheco, R. Documentación previa a la restauración del arte contemporáneo. En Actas del 11 Seminario Internacional Forum UNESCO/University and Heritage, Florencia, 2006.

- LÓPEZ-CANO Ausejo, Jacob y ROIG Picazo, Pilar. El concepto de la restauración a través de la estética. en Arché. Publicación del Instituto Universitario de Restauración del Patrimonio de la UPV. N01. Valencia: Universidad Politécnica de Valencia, 2006, pp.33-38.

- MACARRÓN Miguel, Ana M. a . Historia de la conservación y la restauración. Madrid: Editorial Tecnos, 1995, 189p.

- $\quad$ MACARRÓN Miguel, Ana M. a y MOZO, Ana González. La conservación y la restauración en el siglo XX. Madrid: Editorial Tecnos, 1998, 216p.

- MARTÍNEZ Justicia, Maria José. Antología de textos sobre restauración. Jaén: Universidad de Jaén, 1996, 279p.

- MARTINS, Ana y SARAIVA, Sandra. Tintas sintéticas em obras contemporâneas da colecção do Museu da FBAUP: uma análise química. en 
@pha.Boletim, n05, Prevenção da arte contemporânea, 2007. $<$ http://www.apha.pt /boletim/boletim5/pdf/2-AnaMartins.pdf>. Acceso en: 8.may.2008.

- MEHRA, Vishwa Raj. Foderatura a freddo. I testi fondamentali per la metodología e la practica. Frenze: Nardini Editore, 1995, 200p.

- $\quad$ MIRALLES Pérez, Juan. Restauración de obras de gran formato sobre soporte textil. Experimentación y metodología. Valencia: Universidad Politécnica de Valencia, Departamento de Conservación y Restauración de los Bienes culturales, 2003, tesis doctoral, 276p.

- MONREAL y Tejada, Luis y HAGGAR, R.G. Diccionario de términos de arte. Barcelona: Editorial Juventud, 2007, 426p.

- MONTANER, Joseph María. Museos para el siglo XXI. Barcelona: Editorial Gustavo Gili, 2003, 157p.

- $\quad$ PASTOR Homs, M. ${ }^{\text {a }}$ Inmaculada. Pedagogía museística. Nuevas perspectivas y tendencias actuales. (2a ${ }^{\mathrm{a}}$. ed.) Barcelona: Ariel Patrimonio, 2007, 187p.

PENDÁS, Benigno. Conservación restauración de bienes culturales: nuevas perspectivas sobre gestión y legislación. en, $17^{\circ}$ International Meeting on Heritage Conservation. Valencia, 2008, pp. 3-7.

PINO del Díaz, Cesar. Conclusiones de la I jornada de conservación y restauración de la Fundación Cristóbal Gabarrón: El arte contemporáneo. La asignatura pendiente de la restauración y conservación del patrimonio artístico. Diciembre de 2003, pp.1-5.

- $\quad$ PINO del Díaz, César. ¡Dios mío! ¿Qué hago con esto? ¿Cómo se conserva esto?. Magos, técnicos o restauradores. <www.restauracion.com.es/Portal/ 96/Magos\%20tecicos\%200\%20restauradores.pdf> . Acceso en: 3.out.2007.

PIVA, Gino (a cura di). L'arte del restauro. Il restauro dei dipinto nel sistema antico e moderno. Secondo le opere di Secco-Suardo e del Prof. $R$ Mancia. (3a.ed.) Milana: Ulrico Hoepli Editore, 1988, 435p.

- RALLO Gruss, Carmen. Medios preventivos y planes de emergencia en museos. en La lucha contra el tráfico ilícito de Bienes Culturales. Madrid: Ministerios de cultura, 2006, pp.169-172.

RAMÍREZ Carrera, Fernando. Afanes de una ciencia enmudecida: la conservación. en El País, setiembre 2005.

RICO Martinez, Lourdes y MARÍNEZ Cabetas, Celia. (Coords.). Conservación y restauración de bienes culturales. Madrid: Akal, 2003. 
RICO, Juan Carlos. La difícil supervivencia de los museos. Gijón: Ediciones Trea, 2003, 382p.

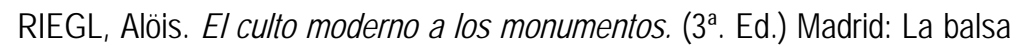
de la Medusa, 2008, 99p.

RIGHI, Lidia (a cura di). Conservare l'arte contemporanea. Firenze: Nardini Editore, 1992, 222p.

- $\quad$ ROIG Picazo, Pilar y GONZÁLEZ Tornel, Pablo (editores). La restauración. Teoría y aplicación práctica. Cesari Brandi. Valencia: Editorial Universidad Politécnica de Valencia, 2008, 239p.

- RUIZ DE LACANAL, Ma Dolores. El conservador-restaurador de bienes culturales. Historia de la profesión. Madrid: Editorial Síntesis, 1999, 302p.

- $\quad$ SANTOS, Figueiredo. A cultura como objecto de controlo turístico. en Working Papers, Edição n014, 1.Abril.08, 10p., <http://www.cecl.com.pt/workingpapers/ content/view/31/61/1/7/>. Acceso en: 14.may.2009.

- $\quad$ SANTOS Rusillo, Mateos. La difusión preventiva: una estrategia comunicativa para asegurar el futuro de los recursos patrimoniales .en $17^{\circ}$ International Meeting on Heritage Conservation. Valencia, 2008, pp.209-213.

SCHILLING, Michael, LAKE, Susan, STEELE, Elizabeth y LOMAX, Suzanne Quillen. Modern science and contemporary paintings. en Conservation, The Getty Conservation Institute Newsletter vol.17, n³, 2002, pp.5-20.

- $\quad$ SCIOLONE, Giovanna. II restauro dei dipinte contemporanee: dalla tecniche di intervento tradicionali alle metodología innovative. Firenze: Nardini Editore, 1993, 254p.

- $\quad$ SEDANO Espín, Pilar. Evolución en la conservación y restauración de las obras de arte. en Revista Restauro- La restauración en España en los últimos 23 años: pasado, presente y futuro del sector, №.1, 2008, pp.46-49, $<$ http://www.revistarestauro.com/CONTENIDOS/restauro1\%20pdfbaja/050057_EUROPAb.pdf>. Acceso en: 12.may.2009.

- $\quad$ SEDANO Espín, Pilar. La conservación del arte contemporáneo. en Revista PH: Boletín del Instituto Andaluz Patrimonio Histórico, 2001, pp.128-133.

- $\quad$ SEDANO Espín, Pilar. La conservación de la obra de arte en los muesos. Funciones del departamento de restauración. en Arte: materiales y conservación. Madrid: Fundación Argentaria, 1998, pp. 107-119.

- $\quad$ SILVA, Armando Coelho Ferreira da. A(s) Ciência(s) do Património: Notas para a fundamentação e enquadramento da conservação e restauro. en 
Ciências e Técnicas do Património, Revista da Faculdade de Letras, I Série, Vol.1. Porto, 2002, pp.211-220.

SORALUZE Herrera, Ioseba Imanol. La conservación de los objetos artísticos contemporáneos: degradaciones, criterios de actuación y tratamientos de restauración. Valencia: Universidad Politécnica de Valencia, 2006, tesis doctoral, 509p.

SZMELTER, Iwona. The Strategy of Conservation Treatment: Considering General Conservation Theories and Tenets. en BIKOS, Conservation Restorers Bulletin, vol. 11 no. 2, (41) 2000, pp. 168-170. $<$ http://www.incca.org/Dir003/INCCA/CMT/text.nsf/0/76A86ECC5585CCEEC1256 B0200384B58?opendocument>. Acceso en:06.may.2008.

TÂPOL, Benoít de. Nuevo proyecto museográfico: una nueva manera de evaluar las condiciones de conservación de una colección. en Revista de Museología, publicación científica al servicio de la comunidad museológica $n^{0}$ 29. Madrid, 2004, pp.99-106.

- TEIXEIRA, Joana C. M. La teoría en la práctica de la conservación/restauración el arte contemporáneo. en Conservación de Arte Contemporáneo, ga Jornada. Madrid: Museo Nacional Centro de Arte Reina Sofía/Grupo Español IIC, 2008, pp.209-218.

- TEIXEIRA, Joana C. M. y LLAMAS Pacheco, Rosario. Un acercamiento a la creación artística actual: la investigación como base de actuación para la conservación. en La conservación Infalible, de la teoría a la realidad. Madrid: libro de actas do III Congresso do Grupo Español do IIC, 2007, pp.79-87.

- TEIXEIRA, Joana C. M. y LLAMAS Pacheco, Rosario. El artista y su papel en la conservación del arte no convencional. en Conservación de Arte Contemporáneo, $8^{a}$ Jornada. Madrid: Museo Nacional Centro de Arte Reina Sofía, 2007, pp. 65-73.

TEJEDOR Barrios, Carlos. La restauración como medio de "redefinición" histórico-artística. en Aportaciones teóricas y experimentales en problemas de conservación. en Actas del II Seminario sobre restauración de bienes culturales. Aguilar de Campo: Speed Publicaciones, 2007, pp.187-205.

TIOZZO, Vanni. Riflessioni sul restauro dell'Arte Contemporánea. en Progetto Restauro, $n^{0}$ 20. Padova: Ediciones II Prato, noviembre 2001, pp.40-45.

URBANI, Giovanni. Intorno al restauro. (a cura di Bruno Zanardi). Milano: Skira Editore, 2000, 174p. 
VAILLANT, Milagros C., DOMÉNECH, M. T., RODRIGO, N. V. Una mirada hacia la conservación preventiva del patrimonio cultural. Valencia: Editorial Universidad Politécnica de Valencia, 2003, 322p.

- $\quad$ VANRELL, Arianne y ROTAECHE, Mikel. Preservación y reinstalación de instalaciones de arte. en VI Reunión del Grupo de Arte Contemporáneo del GEIIC. Museo Nacional Centro de Arte Reina Sofía: Madrid, 2005, pp.107116.

- VARAS González, Ignacio. Conservación de bienes culturales. Teoría, historia, principios y normas. (3ª ed.) Madrid: Ediciones Cátedra, 2003, 628p.

- VIÑAS Muñoz, Salvador. Teoría contemporánea de la Restauración. Madrid: Síntesis, 2003, 205p.

Otras referencias electrónicas:

ARP: Associação Profissional de Conservadores-Restauradores de Portugal, <http://arp.org.pt/profissao/codigo-de-etica.html>. Acceso en: 10.may.2009.

- $\quad$ AXA, <http://www.axa-art.com>. Acceso en: 5.may.2008.

- El mundo, <http://www.elmundo.es/especiales/2007/cultura/estudio_abierto/ index.html>. Acceso en: 5.may.2008.

- Grupo Español IIC, <http://geiic.com/files/grupoconservacionpre/RESOLUCION DEVANTA.pdf>. Acceso en: 3.out.2007.

- INCCA, <http://www.incca.org/Dir003/INCCA/CMT/text.nsf/0/76A86ECC5585C CEEC1256B0200384B58?opendocument>. Acceso en: 10.fev.2006.

- Tate Modern, <http://www.tate.org.uk/learning/learnonline/modernpaints/>. Acceso en: 5.abr.2008.

- Virtruvius: Resenhas online, <http://www.virtruvius.com.br>. Acceso en: 5.abr. 2008.

\section{Leyes y normas jurídicas}

AA.VV. Algunas precisiones contra la demagogia. en Revista Lápiz 218, Revista Internacional de Arte, Año XXIV, pp. 26-53. 
AA. VV. Protección y límites del derecho de autor de los creadores visuales. Seminario Diego Rivera, Ignacio Zuloaga. Madrid: Trama Editorial, Fundación arte y derecho, 2006, 270p.

ABAD Liceras, José María. Breves reflexiones sobre la Ley 16/1985 desde una visión jurídica. en Revista Restauro- La restauración en España en los últimos 23 años: pasado, presente y futuro del sector, №.1, 2008, pp.38-42, <http://www.revistarestauro.com/CONTENIDOS/restauro1\%20pdfbaja/050057_EUROPAb.pdf>. Acceso en: 12.may.2009.

ACCOYER. Pascale. The legal relationship between the owner, the artist and the conservator. en INCCA, 2004. < http://www.incca.org/legal-issues/318accoyer-thesis-2004>. Acceso en: 15.fev.2006.

- $\quad$ ALVAREZ Álvarez, José Luis. Estudios sobre el Patrimonio Histórico Español y la Ley e 25 de junio de 1985. Madrid: Editorial Civitas, 1989, 897p.

- BADENES Gasset, Ramón. Conceptos fundamentales del derecho. Las relaciones jurídicas patrimoniales. $\left(11^{\mathrm{a}}\right.$. Ed.) Barcelona: Marcombo, Boixareu Editores, 1997, 357p.

- BARRACA Ramos, Pilar de. La situación general de la protección del patrimonio cultural en España. en La lucha contra el tráfico ilícito de Bienes Culturales. Madrid: Ministerios de cultura, 2006, pp.39-50.

- BERCOVITZ, Germán. Obra plástica y derechos patrimoniales de su autor. Madrid: Editorial Tecnos, 1997, 449p.

- $\quad$ BERCOVITZ Rodríguez-Cano, Rodrigo (Dirección) (8a .Ed.). Legislación sobre Propiedad Intelectual. Madrid: Editorial Tecnos, 2008, 765p.

- $\quad$ BERCOVITZ Rodríguez-Cano, Rodrigo (Coordinador) (3a .Ed.). Comentarios a La Ley de Propiedad Intelectual. Madrid: Editorial Tecnos, 2007, 2322p.

BEUNEN, Annemarie. Moral rights in modern art: an international survey. en Modern Art: Who Cares? (1999), p. 222-232. <http://www.incca.org/files/pdf/ resources/beunen_a._moral_rights_in_modern_art.pdf> Acceso en: 15.fev.2005.

CASAMAR Pérez, Manuel. Los códigos deontológicos. en La lucha contra el tráfico ilícito de Bienes Culturales. Madrid: Ministerios de cultura, 2006, pp.205-208.

COUTO Gálvez, Rosa María de. La contratación en la creación visual. Contrato de encargos de obras, transmisión de derechos para la edición y concurso de obras de arte. Madrid: Trama Editorial, 2008, 150p. 
DOMÉNECH Ortega, Jorge. Aspectos Jurídicos en la conservación y restauración del arte contemporáneo. en Revista General de Legislación y Jurisprudencia, número 10. Editorial Reus, Diciembre de 2000.

- FERNÁNDEZ Gallego., Ramón Falsificación y robo de obras de arte. en La lucha contra el tráfico ilícito de Bienes Culturales. Madrid: Ministerios de cultura, 2006, pp.87-90.

FIDALGO Martín, Consuelo. El sistema judicial y protección del patrimonio histórico-artístico. en La lucha contra el tráfico ilííito de Bienes Culturales. Madrid: Ministerios de cultura, 2006, pp.53-64.

- GARCÍA Fernández, Javier. La función de la legislación en la protección y en la defensa del patrimonio cultural iberoamericano. en Patrimonio Cultural e Identidad. Madrid: Ministerio de cultura, 2007, pp.25-34.

GARCÍA Calderón, Jesús María. La relación del patrimonio histórico con el derecho penal. en La lucha contra el tráfico ilícito de Bienes Culturales. Madrid: Ministerios de cultura, 2006, pp.67-84.

LUGO Y GUILLÉN, Felix Benítez de. La situación general de la protección del Patrimonio en España. en La lucha contra el tráfico ilícito de Bienes Culturales. Madrid: Ministerio de la Cultura, 2006, pp.19-37.

- MINISTERIO de la Presidencia, Boletín Oficial del Estado (11. ${ }^{a}$ Ed.). Constitución España. Madrid: Imprenta Nacional del Boletín Oficial del Estado, 1997, 234p.

PASTOR Valls, Ma Teresa y PÉREZ García, Carmen. Legislación española e intervención de obras contemporáneas. en Libro de actas del $16^{\circ}$ Internacional Meeting on Heritage Conservation. Valencia: Universidad Politécnica de Valencia Editorial, 2006, pp. 947-958.

Patrimonio Histórico Español. (4. $\left.{ }^{a} E d\right)$ Madrid: Editorial Civitas, 1996, 114p.

PELEGRINI, Sandra. Educación patrimonial e identidad en América Latina. en Patrimonio Cultural e Identidad. Madrid: Ministerio de cultura, 2007, pp.75-82.

PÉREZ DE CASTRO, Nazareth (edición preparada por), RODRÍGUEZ-CANO, Rodrigo Bercovitz (dirección). Texto refundido de la Ley de Propiedad Intelectual. Madrid: Editorial Tecnos, 1998, p.147.

- $\quad$ PIGNATELLI y Meca, Fernando. La protección de los bienes culturales en los conflictos armados. en La lucha contra el tráfico ilícito de Bienes Culturales. Madrid: Ministerios de cultura, 2006, pp.131-150.

ROGER Vide, Carlos y SERRANO Gómez, Eduardo. Manual de Derechos de Autor. Madrid: Editorial Reus, 2008, 207p. 
- SÁDABA, Igor. Propiedad intelectual. ¿Bienes públicos o mercancías privadas?. Madrid: Los libros de la Catarata, 2008, 273p.

- SEPULCRE Aguilar, Alberto. El proyecto de restauración: marco legal, estructura y documentos. en Aportaciones teóricas y experimentales en problemas de conservación. en Actas del II Seminario sobre restauración de bienes culturales. Aguilar de Campo: Speed Publicaciones, 2007, pp.65-100.

- $\quad$ UNESCO, El abc del derecho de autor. Paris: Organización de las Naciones Unidas para la Educación, la Ciencia y la Cultura, 1981, 82p.

Otras referencias electrónicas:

- $\quad$ Artistas Visuales Asociados en Madrid - AVAM, <http://www.avam.net/>. Acceso en 5.may.2008.

- $\quad$ European Confederantion of Conservator-Restorers' Organisations - E.C.C.O., $<$ <ttp://www.ecco-eu.org/>. Acceso en: 10.may.2009.

Bibliotecas virtuales: Convención de Berna, <http://www.bibliotecasvirtuales. com/biblioteca/derechosdeautor/conveniodeberna.asp>. Acceso en: 8.may.2009.

- ICOM: El Conservador-Restaurador, definición de una profesión, <http://geiic.com/files/Cartasydocumentos/1984_El_conservador-restaurador_una _definicion_de_la_profesion.pdf>. Acceso en: 10.may.2009.

Unesco: Convención Universal sobre Derecho de Autor, <http://portal.unesco. org/es/ev.phpURL_ID=15381\&URL_DO=DO_TOPIC\&URL_SECTION=201.html >. Acceso en: 8.may.2009.

- $\quad$ Unión de Asociaciones de Artistas Visuales - UAAV, < http://www.uaav.org/>. Acceso en: 10.may.2008.

Visual Entidad de Gestión de Artistas Plásticos- VEGAP, $<$ <ttp://www.vegap.es/ES>. Acceso en: 5.may.2008. 



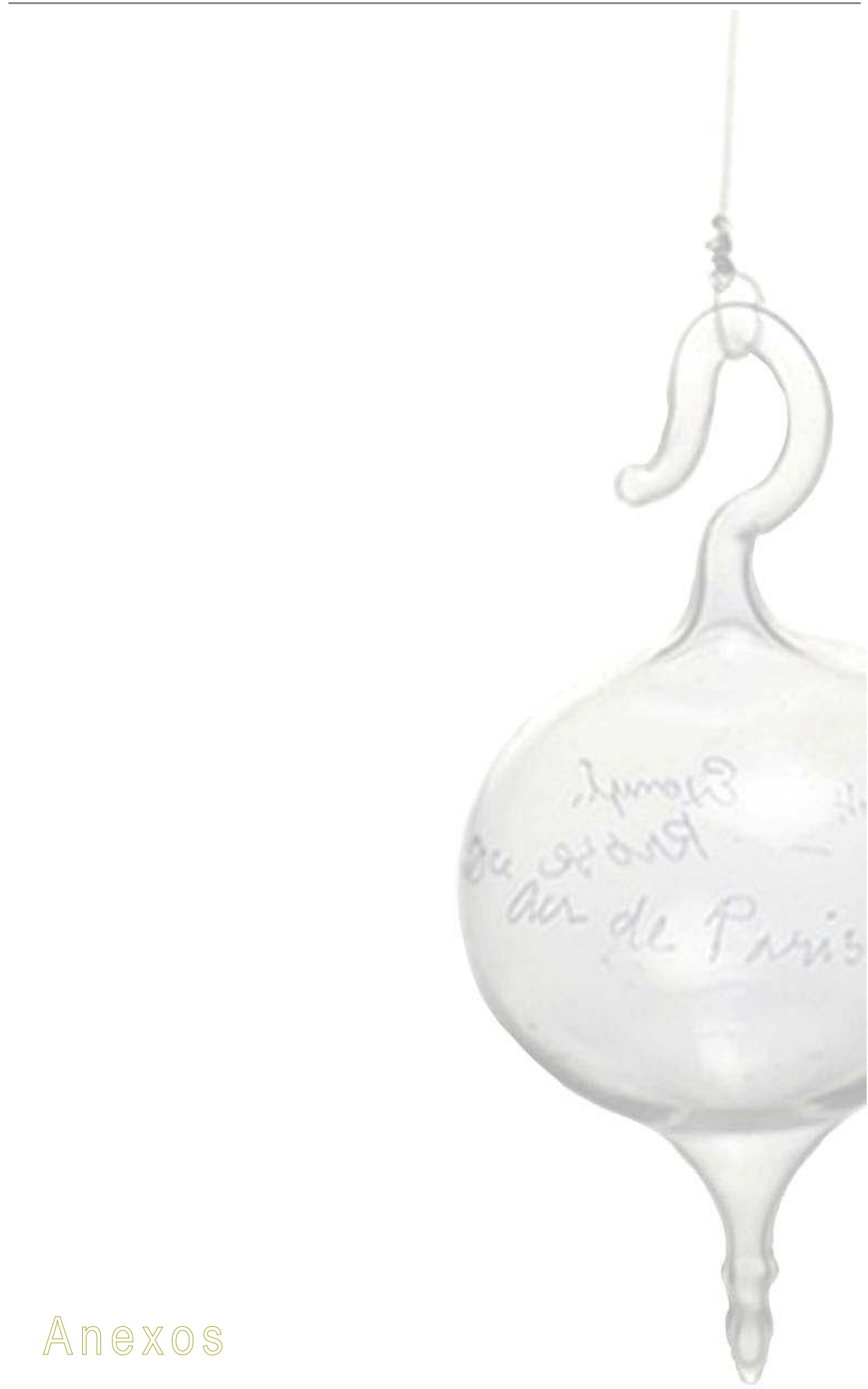





\section{Entrevista a cinco artistas plásticos portugueses}

En la práctica de la conservación/restauración siempre ha sido importante agrupar toda la información posible sobre la obra de arte, pero esta actitud es cada vez más imperante ante las obras de la arte contemporáneo.

Uno de los medios más eficaces y rápidos para obtener la información correcta sobre las obras respetando el valor conceptual, su idea y significado, materia y constitución, es el contacto directo con el artista, siempre que es posible y si no contactar con su medio y entorno, y percibir cual es su intención en la creación. Es sin duda una práctica internacional llevada a cabo por varios grupos de trabajo empeñados en interpretar y diseminar los varios componentes de una creación contemporánea, y para ello se apoyan en las declaraciones de los artistas, aproximación establecida normalmente por medio de entrevistas.

También, en este trabajo de investigación, se realizaron varias entrevistas, de las que se destacan, cinco, realizadas a los artistas portugueses Ana Cardoso, Carlos Mesquita, Isaque Pinheiro, João Pedro Rodrigues y Rui Pedro Fonseca, no con intención de interpretar una obra específica de cada artista sino con el deseo de aproximar los dos campos de acción y reflexionar sobre de qué forma habita la conservación/restauración en la dinámica e ínfima variedad creativa contemporánea. En estas entrevistas se sigue un modelo sencillo, que aborda las cuestiones técnicas, materiales y conceptuales, en que simplemente se agregan cinco ejemplos de entre las cien encuestas estudiadas para la concretización del estudio estadístico anteriormente presentado. 


\section{Ana Cardoso \\ Porto, $1980^{294}$}

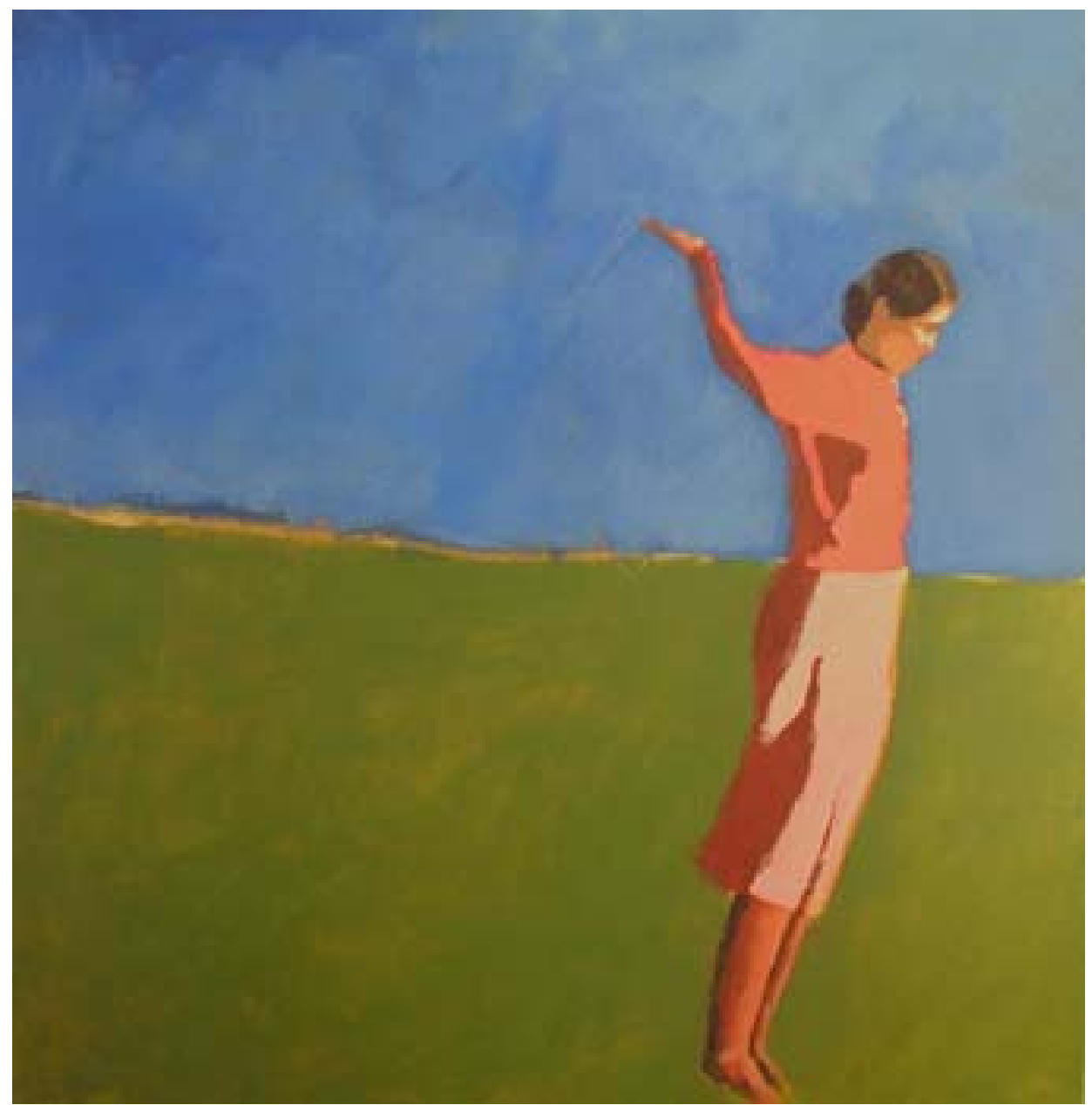

Figura 93: Somam-se-me dias, 2006. Acrílico sobre tela, 150x150 cm.

294 Licenciada, en 2004, en Artes Plásticas/Pintura en la Escola Superior Artística do Porto, y con una pos-graduación en Prácticas y teorías del Dibujo, por la Facultad de Bellas Artes de la Universidad de Oporto, en 2005. Su primer exposición individual ha sido en 2004: Saturday Morning, Galeria João Lagoa, Trofa, seguida de My Life on sale, Caves Calém, Porto, un proyecto co-autoria con Kasia Gubernat, en 2005; y en 2006 realizó su segunda exposición incdiviaula, Muito Pouco ou Nada, Galeria João Lagoa, Porto. Realizó un total de 12 exposiciones colectivas entre los años 1997 hasta 2006. 
¿En qué consiste su trabajo actual?

Mi trabajo es básicamente pintura, acrílico sobre tela. Trabajo sobre tela industrial, utilizo varios tipos de tejido de acuerdo con sus características y diversos tamaños. Siempre utilizo tela industrial, pero algunas veces aplico una preparación de yeso. Me acuerdo que en esos trabajos en que colocaba las preparaciones de yeso muchas veces tenía problemas como craquelados y fisuras en las pinturas, por la falta de elasticidad del yeso. Con la elaboración de varios trabajos con preparaciones en yeso y la experiencia adquirida, empecé a percibir que sería mejor hacer preparaciones en acrílico para no tener problemas de compatibilidad de materiales. Por eso, actualmente utilizo directamente el acrílico.

¿Qué materiales emplea en sus pinturas?

Utilizo esencialmente acrílicos y no tengo costumbre de trabajar con empastes. Intento siempre comprar los materiales en tiendas especializadas. En tiempos anteriores compraba los materiales donde fuera, pero actualmente recurro a tiendas especializadas para que no surjan problemas inesperados en las obras y para que tenga la información necesaria de los materiales. La verdad es que no tengo conciencia de su constitución y cuando trabajo con acrílicos no me preocupo mucho con esa cuestión una vez que trabajo con acrílico sobre acrílico. Pero, anteriormente hice varios trabajos en resina y dejé de utilizar ese material, porque no lo dominaba lo suficiente para controlar su durabilidad, resistencia y consistencia.

¿Las pinturas tienen algún tratamiento final?

$\mathrm{Si}$, aplico un barniz. Inicialmente usaba el barniz, no sólo por proteger la pintura, sino también por su función estética y conceptual en la obra. Actualmente, aplico el barniz a spray simplemente por su función protectora.

¿Cuánto tiempo invierte en la elaboración de una obra?

Eso es difícil de decir. Por ejemplo, en la última exposición que realicé, los trabajos empezaron por ser una cosa, trabajé en ellos tres meses y de repente a las dos semanas de la exposición cambié los trabajos, por eso, en términos prácticos los trabajos fueron hechos en una semana y media sobre un proyecto de tres o cuatro meses.

¿Firma las obras?

Sí las firmo por detrás, excepto los dibujos que firmo por el anverso.

¿Sabe en qué punto considera terminadas las obras?

Yo pienso que eso se sabe con el tiempo. Además, lo principal es saber donde se quiere llegar con el trabajo, y en ese sentido lo que se tiene que hacer es parar y pensar si ya se alcanzó la idea. Por ejemplo, siempre que puedo trabajo varias telas al mismo tiempo, y puedo decir que en tiempos cortos. 
¿Hace la catalogación de sus obras?

Sí, siempre hago un registro de las obras, pero es posible que me falte el registro de una obra u otra. Además sólo sé el destino de las obras hasta la galería, pues gran parte de mis trabajos son vendidos a través de una galería.

¿Cuál es el estado de conservación de las obras?

Pienso que el estado actual es bueno, a excepción de una pintura en que surgieron unas fisuras sin percibir porqué. Actualmente, tengo más cuidado con los materiales que compro, pues sé que hay unos mejores que otros. Intento que los acrílicos que uso sean más resistentes.

¿Cómo encara el concepto de degradación en una obra?

Pienso que la degradación es inevitable. Lo que yo puedo hacer es utilizar los materiales que sé que son mejores para que la obra tenga mayor resistencia, pero hay cosas que no dependen de mi y que no puedo evitar, como el factor tiempo. Así como creo que el tiempo ya modifica la obra antes incluso de estar acabada.

Una cosa es cierta: yo no sé cómo envejecerá mi obra, por eso no tengo la noción de cómo el paso del tiempo influenciará en su lectura, si es que influencia.

\section{¿Considera sus obras efímeras?}

Yo considero que todas las obras tienen un límite, pero no considero mis obras efímeras, y las hago para que perduren lo más posible en el tiempo. En este sentido, por ejemplo, ya aconteció que al vender un trabajo aconsejase al comprador las condiciones necesarias para el buen mantenimiento de la obra, procurando que la obra fuera colocada en un local donde no recibiese luz directa.

¿Cómo funciona el almacenamiento, transporte y exhibición de sus obras?

Normalmente soy yo quien hago la protección de las obras para el transporte, y como son telas no es muy complicado transportarlas. El almacenamiento, por ejemplo, he tenido un problema hace unos meses, pues no he colocado correctamente las telas deformando el bastidor. En cuanto a la exhibición de las obras siempre expongo las telas según el concepto de la obra, pero lo hago con la preocupación de controlar la luz sobre las obras durante su exposición.

\section{¿Enmarca sus pinturas?}

En gran parte de mis trabajos no existe moldura, esperando que cuando sean adquiridos los compradores tampoco les coloquen molduras, pero pienso que no puedo controlar la exhibición de los trabajos en este punto. Este aspecto de no poner marcos, no es una cuestión económica pero sí estética y principalmente conceptual, pues pienso que la presencia de la moldura en mi pintura disolvería su sentido.

Una vez vendí un trabajo sin marco y que tenía los lados pintados de otro color porque la pintura continuaba en las laterales. El comprador me ha cuestionado si la 
obra debería o no quedar sin moldura. Yo he dicho que no era para tener moldura y que jamás hubiera pasado por la cabeza poner un marco en aquella pintura, y me ha dicho que iría respectar eso, pero no sé hasta qué punto la obra se mantiene hasta hoy de acuerdo con mi intención.

¿Ya alguna obra tuve que ser restaurada?

$\mathrm{Si}$, esa pintura con fisuras que he referido anteriormente. Hasta hoy no sé lo que pasó, sólo sé que el barniz empezó a craquelar. He quitado el barniz y lo apliqué nuevamente, y volvió a craquelar. Como no resolvía la situación he recurrido a la ayuda de alguien con formación en conservación/restauración.

¿Concuerda que las intervenciones en las obras sean hechas por el propio autor?

Pienso que cuando una obra tiene un problema, por ejemplo, con el barniz, lo mejor será dirigirse a una persona especializada. De cualquier forma, si el artista está vivo pienso que su papel es importante en las tareas de restauración, y me parece esencial pedir información a los artistas. Además, pienso que cualquiera que sea la intervención sólo es válida si respetar la voluntad del artista.

¿Cómo ve a los conservadores/restauradores?

Yo no tengo mucho contacto con ese área, pero pienso que tienen un papel importante en la conservación y mantenimiento del arte, todavía creo que lo del conservar no debería ser solo del conservador/restaurador.

¿Cómo ve la hipótesis de que el artista haga una ficha técnica para cada obra? ¿Lo ve irrealizable?

Pienso que es posible, y tal vez debería ser una cosa a llevar en serio a partir de hoy. Nunca lo había pensado, pero tal vez sería una forma eficaz de prevenir muchos problemas.

Entrevista realizada en marzo de 2006. 


\section{Carlos Mesquita \\ Porto, 1961295}

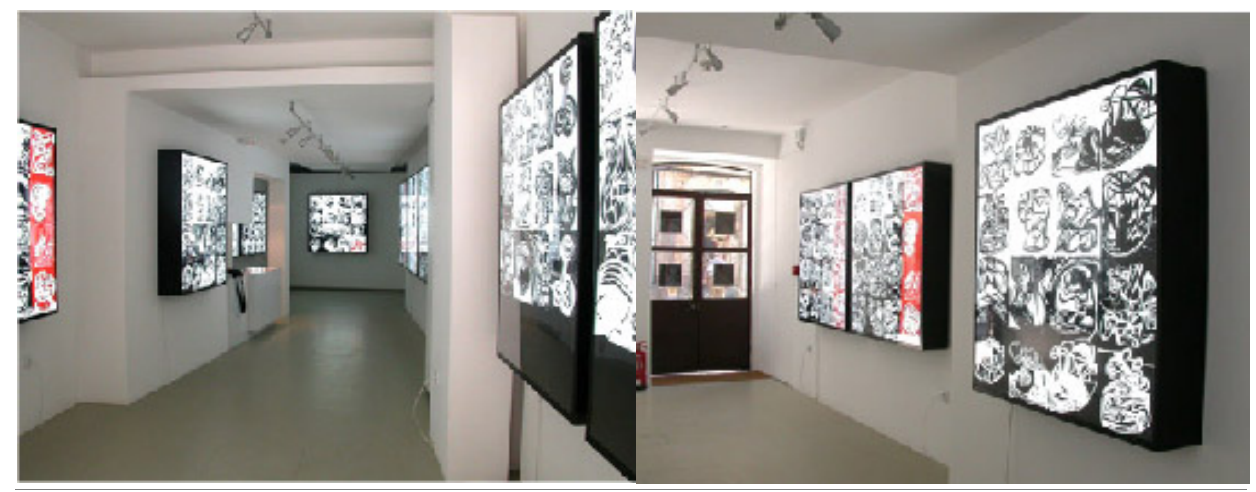

Figura 94 y 95: Vistas de la exposición individual 'Paying my rent everyday in the tower of light', 2003. Galeria Fuga Pela Escada, Guimarães.

\section{¿En qué consiste su obra?}

Cuando era estudiante opté por trabajar con la técnica de acrílico, una vez que con óleo sólo he trabajado durante un año, durante mi carrera, por razones que tienen que ver con el ritmo de vida de las personas y también por razones de salud (alergias). El acrílico en función de mi proceso de trabajo me parece más coherente y adaptable, y en mi tiempo de estudiante quería obtener resultados de acuerdo con mis referencias teóricas. En esa altura trabajaba bajo la influencia de la obra de Jean Dubuffet y del concepto de Arte Bruto, luego la técnica de óleo no era adecuada al ritmo de mi vida.

Ya mi última exposición, en 2003, consistió en la presentación de cajas de luz. El proceso de trabajo pasó por la elaboración de dibujos sobre papel a tinta de china,

295 En 1984, se licencia en Artes Plásticas/ Pintura, en la Escola Superior de Belas Artes, Oporto, en 1988 termina una pos-graduación en Printmaking, en la Slade School of Fine Art, University Collage London, en 1998 termina el mestrado en Arte multimedia en la Faculdade de Belas Artes de Oporto, en 2004 inicia el doctorado "Modos de Conhecimento na Prática Artística Contemporânea", en la Universidad de Vigo. Su primera exposición individual fue en 1985, en la Galeria Espaço Lusitano, Pintura, Porto; en 1986, en la Galeria Nasoni expone Pintura, Porto; 1987, en la Galeria da Cooperativa Árvore, Médio de In-Vocação, Pintura, Porto; en 1995, en la Galeria Módulo, Câmara Obscura, Encáusticas, Porto; y en 2003, realiza la exposición: 'Paying my rent everyday in the tower of light' Galeria Fuga Pela Escada, Guimarães. Ha realizado 20 exposiciones colectivas entre los años 1985 y 2005, tanto nacionales como internacionales. En 1985, ha ganado el Prémio Revelación en la $1^{a}$ Exposición de Arte Contemporánea A. Fernando de Oliveira, Museu Nacional Soares dos Reis; en 1986 ha obtenido la Mención Honrosa en la Exposición de Dibujo organizada por la Cooperativa Árvore, en el Mercado Ferreira Borges, y en 1988, ganó el Premio de la Fundação Engenheiro António Almeida. Su obra además de estar presente en varias colecciones privadas nacionales e internacionales, se encuentra en colecciones como: Fundação de Serralves, Oporto, Banco Português do Atlântico (painel de dibujos a tinta da china de grandes dimensiones), Coleccionador Americano, Los Angeles, Colección Particular de Jaime Isidoro y Casa de Serralves. 
dibujos de pequeño formato, que posteriormente fueron pasados a soporte digital. He trabajado con una diseñadora grafica durante unas dos semanas, para digitalizar los dibujos a negro y blanco, y en el ordenador fue introducido el color según mi indicación. Las imágenes quedaron todas gravadas con una definición muy elevada y a través de una empresa de artes graficas fue hecha la impresión sobre una película apropiada para suportar la temperatura provocada por la luz. La construcción de las cajas de luz fue hecha por una empresa especializada, con la profundidad adecuada, y todos los cuidados que ha que tener para un buen deleite de la obra, una vez que por detrás de los dibujos estarían las bombillas de luz fluorescente.

Como quedó un registro digital es posible reeditar aquellas series de imágenes.

¿Qué materiales utiliza normalmente en sus trabajos?

Hablaré de la encáustica por sus características y porque me he interesado durante un largo periodo por esta técnica. Estudié el proceso técnico con bastante rigor, he hecho algunos ensayos técnicos con varias recetas de encáusticas, y después he escogido uno de los procesos técnicos y durante dos años, o tal vez un poco más, he elaborado diversos trabajos, según ese proceso. Hacía una mezcla de cera de abeja poco refina, con mucho ocre, con grandes cuantidades de parafina y posteriormente mezclaba los pigmentos, que compraba en una droguería o en una tienda que vendía pigmentos con bastante cualidad. Era una mezcla hecha de forma intuitiva, a pesar de tener alguna información de otros artistas que trabajaban con la misma técnica. La información sobre la técnica resultó de una investigación bibliográfica, en que no encontré mucha información, pero los libros que he comprado fueron suficientes para profundizar las cuestiones ligadas a la técnica, además de un libro regalado por el pintor Ângelo de Sousa que reunía una serie de artistas internacionales del siglo XX y que desenrollaban sus pinturas con la aplicación de la encáustica.

Como resultado, he expuesto en la Galería Modulo un conjunto de pinturas elaboradas a encáustica. Con los años he tenido conciencia que es un material frágil, pues con el paso del tiempo, algunos de los pigmentos amarillean; proceso que he podido observar por poseer algunos trabajos, y por ahí sé que en algunos casos envejecen bien.

La parafina usada en la mezcla con que realizaba las encáusticas, amarillea con más facilidad de lo que pensaba, pues creo que sufrirá un proceso de oxidación bastante acelerado. Es evidente que todo depende del porcentaje de parafina, del porcentaje de la cera de abeja y de los pigmentos. En esta mezcla hay ciertos colores en que se denota más la transformación cromática, como los colores claros.

Este proceso técnico me permitió pasar de las dos dimensiones para construir una especie de proyectos escultóricos, pues por un lado son pinturas en encáustica, pero por otro existe una especie de molde donde era depositada la encáustica, trabajos con dimensiones entre $150 \times 120 \mathrm{~cm}$ y que pesaban unos 20 a 40 kilos funcionando casi como esculturas. 
Actualmente no tengo hechos trabajos en encáustica, pero pienso en volver pues es una técnica que me interesa muchísimo. He explorado bastante la técnica, por ejemplo he hecho trabajos en que mezclaba la encáustica con bastones de óleo, con papeles vegetales, con lápiz de cera, en que recubría los dibujos con camadas de encáusticas.

\section{¿Recurre a tiendas especializadas para comprar los materiales?}

En los primeros años tenía esa preocupación de comprar los materiales de marcas especializadas, después con el paso del tiempo empecé a colocar cuestiones de carácter conceptual de la obra y he empezado a mirar con alguna desconfianza para esos productos, pues la relación precio y cualidad en el contexto de nuestro mercado y de nuestro poder económico es una cosa completamente desproporcionada, por eso he tentado otras vías para conseguir buenos materiales. En cierta altura encontré una persona formada por la Facultad de Ciencias, que trabajaba con empresas que producían diversos tintes, y durante algún tiempo compraba los acrílicos y los medios, en grandes cuantidades y a un precio razonable. Por otro lado, también he experimentado comprar los pigmentos, el acetato ponivinil y hacer la mezcla, para pintar. Hoy estoy muy reticente en cuanto a los materiales de marcas reconocidas, pues su costo es tan elevado que se torna casi imposible desarrollar proyectos de grandes dimensiones con ese tipo de productos.

¿Qué soporte utiliza en la realización de sus obras?

Como estudiante he utilizado diversos procesos técnicos, como la tela industrial, en que por encima de la preparación que ya posee la tela, aplicaba un primario para acrílico o para óleo, dependiendo de la técnica que fuera a utilizar, creando una preparación más consistente. En una fase especifica, por motivos económicos, he comprado piezas del designado lino industrial, un paño crudo con trama un poco gruesa. Empezaba por lavar el paño pues traía una goma y algún pelo; cuando seca la colocaba en la horizontal, quemaba el pelo y después con varios tipos de lijas, desde las más gruesas a las finas, empezaba a trabajar la superficie hasta obtener una superficie blanda; después aplicaba una capa de cola de huesos y por último preparaba adecuadamente la superficie de acuerdo con la técnica. Usaba este proceso para la pintura acrílica porque me parecía obtener un soporte bastante estable y hasta hoy las pinturas están en perfectas condiciones.

\section{¿Aplica alguna capa de protección en sus pinturas?}

Siempre aplicaba barniz por la cuestión estética pero evidentemente por su función protectora. Por cuestiones de estética, utilicé barniz mate y sobre la pintura acrílica aplicadas varias capas, pues el color adquiría vibración, intensidad y hasta profundidad.

Primero utilizaba varios barnices de acabado, pero para mi primera exposición en el 87, como algunos de los trabajos tenían dimensiones razonables, hablé con el pintor 
Ângelo de Sousa que me indicó una receta de un buen barniz de acabado, que hasta hoy continuo utilizando. Consistía en comprar barniz de acabado para óleo (Tallens), que se mezclaba con un 20\% de White Spirite, y así resultaba más cuantidad de barniz. Teóricamente es correcto utilizar graso sobre magro y tal procedimiento no ha traído ningún problema a la pintura.

\section{¿Enmarca las obras?}

Raramente, pero puede suceder puntualmente. Me acuerdo de una pintura que he realizado, y en determinada altura en el proceso de trabajo verifiqué que asociándolas, se producía un concepto que me interesaba. En ese caso recurrí a un marco, pero muy sobrio.

\section{¿Firma sus obras? ¿Dónde las firma?}

Firmo. Hay situaciones en que las firmo en el plano de la pintura, pero muchas veces las firmo en el reverso de la obra. En relación a la serie de las encáusticas, de un modo general, lo hacía siempre en el reverso, unas veces por una cuestión conceptual, otras por razones de carácter estético y del tamaño de las obras, pues escribir con el pincel caliente, no permite gran rigor.

\section{¿Tiene su obra catalogada?}

Tengo un archivo fotográfico, tanto en papel como en slide y una parte de los trabajos en soporte digital, en que están prácticamente todas las cosas que he producido, excepto un número muy pequeño de obras que no tengo registro. Por ejemplo no tengo registro de algunas exposiciones que he realizado, no tengo el registro de las encáusticas expuestas en la Galería Modulo, o de la participación en la Bienal da Maia. De esta última, sólo tengo pormenores y las fotografías utilizadas en la instalación, pero no tengo ningún registro general del espacio, y por algún motivo no he hecho ningún registro del conjunto.

Otro caso fue la elaboración de un painel de dibujos adquirido por un banco del cual no tengo ningún registro general, siendo un trabajo significativo en mi trayectoria.

Todavía, tengo un archivo, pero está todo un poco en bruto, pues no está organizado de una forma sistemática.

Además, tengo un archivo con centenas de trabajos de pequeños formatos y eso sí, está todo por tratar, y lo quiero registrar todo fotográficamente.

¿Cuál la localización de sus obras?

En este momento tengo pocas obras en galerías. Aconteció que las pinturas de acrílico cuando fueron expuestas fueron vendidas para colecciones particulares, hay obras, por ejemplo, que se encuentran en la colección de un coleccionador americano. Después, por ejemplo, tengo ese panel de dibujos que está en un banco, tengo una pintura de acrílico en la Fundación de Serralves, y otras obras he guardado para mí y no pienso vender. 
¿Y cómo almacena y transporta sus obras?

Pues eso es un capitulo complicado. La verdad, con las telas nunca fue muy complicado, pues se trata de tener aquellos procedimientos habituales de proteger la obra con plásticos, tejidos, cartones, por lo tanto nunca he tenido problema a ese nivel.

Cuanto a las encáusticas se han presentado cuestiones de almacenamiento y transporte y por razones económicas no he resuelto esas cuestiones al cien por cien. He tenido algunos problemas con las encáusticas sobre madera, sin cualquier protección, por accidentes, esto porque en esa altura no he tenido conciencia de los problemas de conservación que eso conlleva.

Para el buen mantenimiento y transporte debería haber mandado construir para cada trabajo cajas con las dimensiones y revestimiento adecuado, después de haberlas concluido pues tenían aristas vivas sin protecciones laterales y al contacto con algo se deforman.

¿En general, cuál piensa que es el estado de conservación de sus obras?

Las pinturas a acrílico puedo decir que están en óptimo estado. Las encáusticas que he visto envejecer, pienso que han envejecido bien, pero es claro que con el tiempo se fueron tornando más amarillas. Todavía, como ese amarillamiento se da en la totalidad de la obra, del punto de vista conceptual, estético y visual no molesta nada. Pero hay algunas que sufrirán diversos accidentes de transporte y almacenamiento, pues no he conseguido crear las condiciones más adecuadas, también por motivos económicos.

¿Considera sus obras efímeras?

En relación a los acrílicos tuve interés en utilizar procesos para garantizar al máximo el buen estado de las piezas, a través de telas bien preparadas y materiales de buena calidad, una influencia de mi formación académica.

Después, más tarde, cuando empecé a trabajar con las encáusticas, de cierta forma al realizarlas asumí que esa cuestión del efímero me interesaba. En las encáusticas me interesé mucho más por el proyecto, el concepto donde definí dos líneas: una línea más intuitiva, que parte del arte bruto, del automatismo psíquico; y después otra línea con carácter conceptual más riguroso, que colocaba otros problemas en el sentido de lectura, en que me interesaba sin duda el concepto.

¿Cuánto tiempo normalmente invierte en la elaboración de una obra?

Cuando estudiante invertía mucho tiempo en el proceso de trabajo, en esas primeras series de pinturas muy inspiradas en la obra de Jean Dubuffet. Siempre gusté de trabajar sin tener una idea predefinida sobre aquello que pasaría, y por eso, me envolvía en un proceso de trabajo en que investía mucho tiempo. 
Por ello, el tiempo concreto de conclusión de cada obra, en términos pragmáticos era muy variable. Lo cierto es que, trabajaba varias obras al mismo tiempo y es verdad que un trabajo podría concretizarse en tiempos relativamente cortos.

¿Cómo funciona el tiempo en su trabajo?

En el caso de las pinturas, la propia idea de trabajar a partir del desconocimiento presupone la cuestión del tiempo, el tiempo traducido en accidentes, acasos, variaciones de estados de espíritu, siempre visibles en la naturaleza y que van a ser incorporadas de varias formas en el trabajo.

En el caso de las encáusticas, aparte de tener esas dos líneas de trabajo, el tiempo de ejecución siempre fue más corto, por naturaleza técnica. Al dibujar con encáustica es sabido que el tiempo de secado es casi automático, y la cuestión de rehacer, de volver a dibujar o de encontrar otras soluciones se coloca de una manera muy distinta, además de ser uno de los motivos que me ha encantado de esa técnica. El objetivo era encontrar otros tiempos de ejecución y enfrentarme con determinadas especificidades técnicas que la encáustica traía y que después tenía consecuencias a nivel estético y a nivel del tiempo de ejecución.

¿Ya alguna obra suya fue restaurada?

Es una buena pregunta, pero no tengo conocimiento de ninguna restauración.

¿Quien cree que debe hacer la restauración de sus obras?

Puedo hablar de un trabajo de encáustica que ha sufrido un accidente porque alguien decidió limpiar la obra y ha roto una de las aristas. He tenido conocimiento de lo sucedido y como tenía que ser restaurada me auto propuse para hacer la reparación. Concuerdo con que en ciertas situaciones sea el artista quien haga la restauración de la obra, si está vivo y con disponibilidad para eso. En ciertos contextos, o porque el artista no está disponible o porque la naturaleza de la intervención puede ser más exigente, tiene más sentido que sea una persona con formación en conservación/restauración.

¿A usted le parece viable que el artista elabore una ficha técnica sobre la obra? ¿O le parece una cuestión irrealizable?

Pienso que es posible, quien tiene formación académica tiene capacidad para hacerlo. Lo que pasa es que mentalmente el artista no está disponible para hacer esa ficha. Podría tener sentido proponer eso o convidar al artista a colaborar en un proyecto así.

¿Le parece esencial, que cuando una obra tiene que ser intervenida, que el conservador/restaurador entre en contacto con el artista?

Sin duda que es importante, a no ser que esté demostrado, lo que para mí no es claro, que por procesos estrechamente realizados en laboratorio alguien 
científicamente haga una intervención ejemplar, del punto de vista técnico. Después hay otra dimensión, que es cuando el artista se propone intervenir sobre cualquier obra suya, lo hará según dos perspectivas: probablemente no hará una restauración técnica, en un sentido restrictivo, quirúrgico, que sería el abordaje del restaurador, y en otros casos el artista puede repensar la restauración con alguna libertad estética, en que sólo él lo puede hacer.

¿Pero en ese caso no le parece que puede cambiar el concepto de la obra?

Sí o no. Puede ser una superficie que tiene un conjunto de manchas de carácter expresivo y que interfieren en la lectura de la obra. Yo puedo intervenir sobre ellas, manteniendo la unidad del cuadro sin intervenir únicamente en lo poco que se degradó, pero haciendo una intervención sobre una superficie mucho mayor respetando la composición de todo el cuadro. Simplemente lo puedo asumir con mayor libertad, y hasta llego a pensar que no tiene sentido hacer la restauración a penas en aquella escasa parte del cuadro.

¿Le parece que en su ejemplo también es necesaria una intervención?

Sí, porque el estado en que se encuentra la obra sin duda que influencia visualmente la lectura. Una cuestión que llevará su tiempo, pero pienso resolver ese problema.

¿Cuál piensa quien es la mejor actitud ante una obra efímera?

Si hay referencias e información del artista a través de un texto o a través de una entrevista que explique conceptualmente en qué consiste su obra, hay que tener en cuenta toda la información para que otra obra tenga sentido. Puede haber situaciones en que el artista deja referencias claras sobre lo que entiende por el concepto de efímero. Todavía, pueden también existir situaciones en que esa información no está presente y entonces ahí las personas pueden hacer la restauración y tomar decisiones que ya son de su esfera.

¿Cómo ve los conservadores/restauradores?

Pienso que es una actividad que tiene sentido, no sólo en las cuestiones de preservación sino también con una buena contribución en profundizar y preservar los conocimientos técnicos. Podría desarrollarse en el sentido de divulgar, a partir de la práctica y lo científico, lo que es sabido sobre las técnicas y sobre los materiales. Además dar a conocer esos conocimientos técnicos, y sobre todo en el caso del arte contemporáneo, podrá interesar al gran público y al público especializado. Pienso que es esencial tener una buena formación cultural y hasta tener experiencia como pintor 0 artista, en el sentido de percibir las cuestiones que están envueltas en el proceso de trabajo del arte contemporánea, como una valía más, para percibir cuándo se debe intervenir, cuáles son los límites, las metodologías y las prioridades.

Entrevista realizada en marzo de 2006. 


\section{Isaque Pinheiro}

Lisboa, 1972296

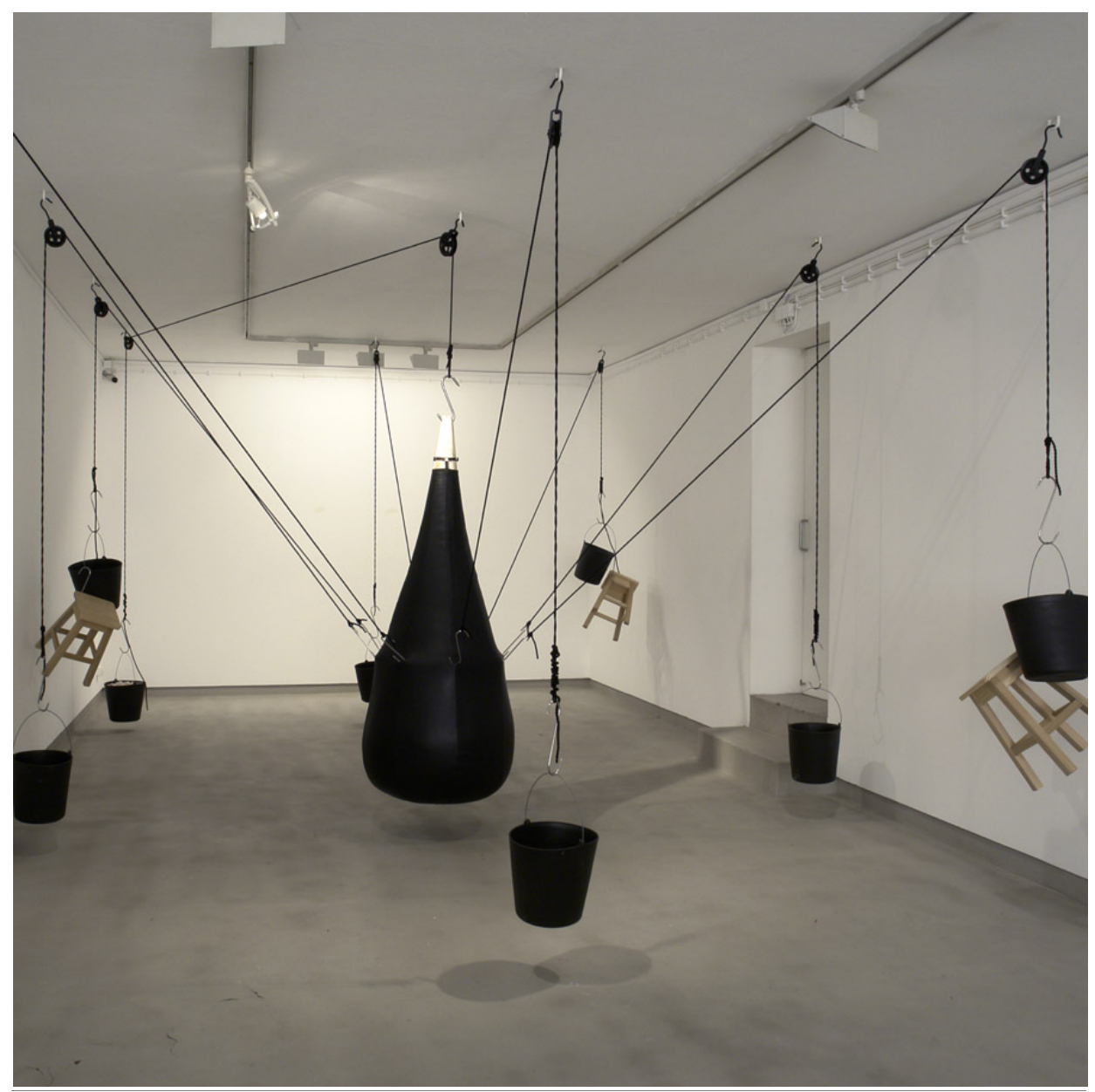

Figura 96: Instalación MAE (Mais Altas Esferas) o tempo não para, 2006. Dimensiones variables.

296 Desde 2001 ha realizado varias exposiciones, siendo las individuales: 2001, "Handle with Care", Espaço Maus Hábitos, Oporto; 2002, "Amor de...", Galeria Municipal de Montemor-o-Novo, Montemor-o-Novo, y la exposición, "São extéreis, Senhor... são extéreis!" Galeria Extéril, Oporto; en 2003, "Hoje amo-te", Galeria Animal, Santiago, Chile, y "Hoje amo-te", Espaço Consigo, Coimbra; en 2004, "Oppening" Internationale Kunsthalle Porto 1, Oporto; la exposición, "MAE, projecto das Mais Altas Esferas", Galeria Cubic, Lisboa, y la exposición, "MAE, projecto das Mais Altas Esferas", Galeria Ao Quadrado, en S. M. da Feira; en 2005, "Universos Paralelos", Galería Esther Montoriol , en Barcelona; y en 2006, "Sombras da ribalta", Galeria Presença, en Oporto. Desde 2001 hasta 2006 ha realizado 23 exposiciones colectivas, tanto nacionales como internacionales. Tiene su obra representada en varias colecciones privadas nacionales e internacionales, así como en la Fundación PLMJ y en el Centro Gallego de Arte Contemporáneo. 
¿En qué consisten sus trabajos?

Mis trabajos son esculturas, pero hay casos en que realizo instalaciones con los objetos. Además de hacer obras que funcionan únicamente como instalaciones. Cuando estoy desarrollando un proyecto pienso en cómo voy disponer los objetos en la galería y en ese sentido las obras, muchas veces funcionan como instalaciones. Las piezas que hago viven bien solas, viven por sí mismas, aunque estando en una exposición como instalación, son autónomas y la instalación desmembrada. Según su concepto, no tengo ningún problema, cuando son adquiridas individualmente.

¿Cuál es el peso de la vertiente conceptual en su obra?

Es una obra bastante conceptual, pero también la vertiente plástica está bien presente. En verdad, tiene tanto de plástico como de conceptual.

Normalmente explico los conceptos de los trabajos a la galería, a través de una buena conversación y siempre fue respetado el trabajo y su significado.

\section{¿Proyecta y ejecuta sus obras?}

Normalmente soy yo quien ejecuto las obras: las proyecto y las ejecuto. Es muy complicado para mí mandar hacer cosas, pues nunca salen como quiero; con algunas excepciones en que las piezas tienen que ser producidas industrialmente y en esos casos hago los prototipos, los moldes y en la fábrica son producidos los elementos propiamente dichos. Pero normalmente soy yo quien hago todo.

\section{¿Firma las obras?}

Normalmente firmo las obras, pero intento hacerlo en lugares discretos, esto cuando la firma no es parte de la estética de la obra. Hay piezas que no puedo firmar, por su forma, y cuando eso acontece hago un certificado de autenticidad. Por casualidad no doy mucha importancia a la firma, y por eso prefiero pasar los certificados de autenticidad, que son certificados dados por la galería con quien trabajo y que hacen referencia a todos los datos de la obra, presentan una fotografía, describen la obra y garantizan la autoría del trabajo.

\section{¿Cataloga todas sus obras?}

Pienso que la obra tiene que quedar muy bien registrada. Mi registro es fotográfico e intento registrar bien, todo lo que hago, inclusive hay obras que ya no existen y todo lo que tengo es su registro. No hay porqué no conservar el registro.

¿De qué materiales está constituida su obra?

Yo trabajo mucho con piedra, mármol. Trabajo también bastante con cuero, con cerámica, con vidrio. Depende de lo que imagino. Primero pienso en el trabajo y después a voy buscar el material que se adapta mejor a la idea.

También tengo realizado algunas cosas con resinas, compro los componentes directamente en fábrica, la misma que abastece la Facultad de las Bellas Artes 
(Oporto), pero es una fábrica de materiales industriales. Siempre que compro material recibo toda la información y si es necesario es puesta a mi disposición un ingeniero que explica las propiedades de los materiales y toda la información necesaria.

¿Conoce bien los materiales con que trabaja?

Por ejemplo en relación a los poliésteres no tengo mucha información, ni en relación a su conservación. La información que tengo, no solo en relación a los poliésteres sino en relación a casi todos los materiales, son las informaciones triviales o básicas como intentar que las piezas no se expongan a la luz, humedades, no pasen por diferencias de temperatura, etc.

Ya participé en algunos Workshop que me han dado ciertos conocimientos, pero esencialmente fue con la práctica que los adquirí. Además, como todas las técnicas que uso, que resultan del conocimiento empírico, o sea, estropeé mucho material y trabajé con artistas que tenían formación. No tengo cursos de esas áreas técnicas, pero muchas horas de trabajo. La única técnica en la que me he formado, fue a fundición.

\section{¿Busca nuevos materiales para sus trabajos?}

Me gusta mucho experimentar materiales. Es un mundo demasiado vasto y no estoy, de forma alguna, limitado. Ya me aconteció experimentar con un material o una técnica donde nacen piezas solo del hecho de experimentarlo, de quedar encantado con un material o técnica, con lo cual empiezan a surgir ideas, o sea, el proceso inverso del imaginar una cosa y buscar un material para su concretización.

¿Usted se preocupa con el deterioro de los materiales y de sus obras?

Yo tengo la costumbre de pensar siempre en eso. Me preocupo con la resistencia de mi trabajo, y como no me han surgido ideas para trabajos efímeros, siempre quiero que el trabajo sea resistente. Por ejemplo, en relación al mármol, si sé que el trabajo se quedará en el exterior no le doy pulimento, pues el mármol en el exterior perderá el pulimento.

¿Aceptaría sugerencias para cambiar un material por otro que garantizase mejor resistencia?

Si con el material sugerido tuviese estéticamente los mismos resultados, claro que si. ¡Además lo agradecía! Yo pienso que eso es parte del aprendizaje, pues en toda mi vida he aprendido con las opiniones de los otros.

¿Cómo almacena sus obras?

Tengo obras en las más variadas condiciones, de las más precarias a las más cuidadosas. Es muy complicado pues hago trabajos muy voluminosos y no tengo espacio para guardarlos de la mejor manera, pero tengo conciencia que guardarlas así tal vez no sea la mejor forma de mantenimiento. 
¿Y en cuanto a su exhibición?

Siempre acompaño los montajes de las exposiciones, tengo siempre la preocupación que las obras no sean dañadas. Por eso hago todo para estar presente en el montaje de la exposición.

¿Y el transporte de las obras como se realiza?

También soy muy cuidadoso. Normalmente hago cajas apropiadas para el transporte de las piezas. Si soy yo quien las transporta y coloco en el espacio de exposición no hago cajas, pero sé como acomodarlas en el transporte. En caso contrario, tengo la preocupación de hacer embalajes para que las piezas sean transportadas cuidadosamente. Por suerte, en este momento, empiezo a no tener que preocuparme con eso, pues como trabajo con una galería que tiene exclusividad sobre mi trabajo en Portugal (Galería Presencia), y como ya tengo muchos gastos, pienso que la galería debe asumir esos gastos, y dejo a su responsabilidad el transporte de las obras, una vez que tienen personas especializadas para hacerlo.

¿Ya alguna obra ha tenido que ser restaurada?

Sí, ya he tenido que restaurar piezas mías y fui yo quien hizo la restauración. Pero, en esta última exposición en el Centro de Arte Contemporáneo, una de las piezas de cerámica estaba rota, debido al transporte, y fue el equipo de restauración de la institución quien realizó la restauración. Pero normalmente soy yo quien hago las restauraciones.

¿Entonces está de acuerdo con que sea el propio artista quien haga las restauraciones de sus obras?

Yo pienso que siendo el propio artista tendrá responsabilidad para dejar la obra como fue y sabrá con certeza encontrar una solución para la obra. Si fue él quien la hizo, conoce la técnica; si mandó hacerla conoce los técnicos, luego sabe dar la vuelta a la situación. Pero también pienso que tiene todo el sentido que la intervención sea hecha por personas especializadas, para dejar las obras como eran exactamente. Pero muchas veces los restauradores no tendrán la información suficiente para que la operación resulte en una buena intervención, y entonces en esas situaciones deberán hablar con el artista para saber si el artista tiene alguna solución, poniendo la hipótesis de que el trabajo estuviese dañado. Pienso que cada caso es un caso.

¿Dejaría sus obras para que fuesen restauradas?

Depende del restaurador, pero en principio si. Es claro que quiero siempre ver lo que pasa, lo que aconteció y hablar con la persona que hará la restauración, para ver lo que me dice, lo que hará y juntos encontrar una solución. Pero de entrada si, confiaría, no tiene porqué no.

Entrevista realizada en marzo de 2006. 


\section{João Pedro Rodrigues}

Rambouillet, Francia, 1967297

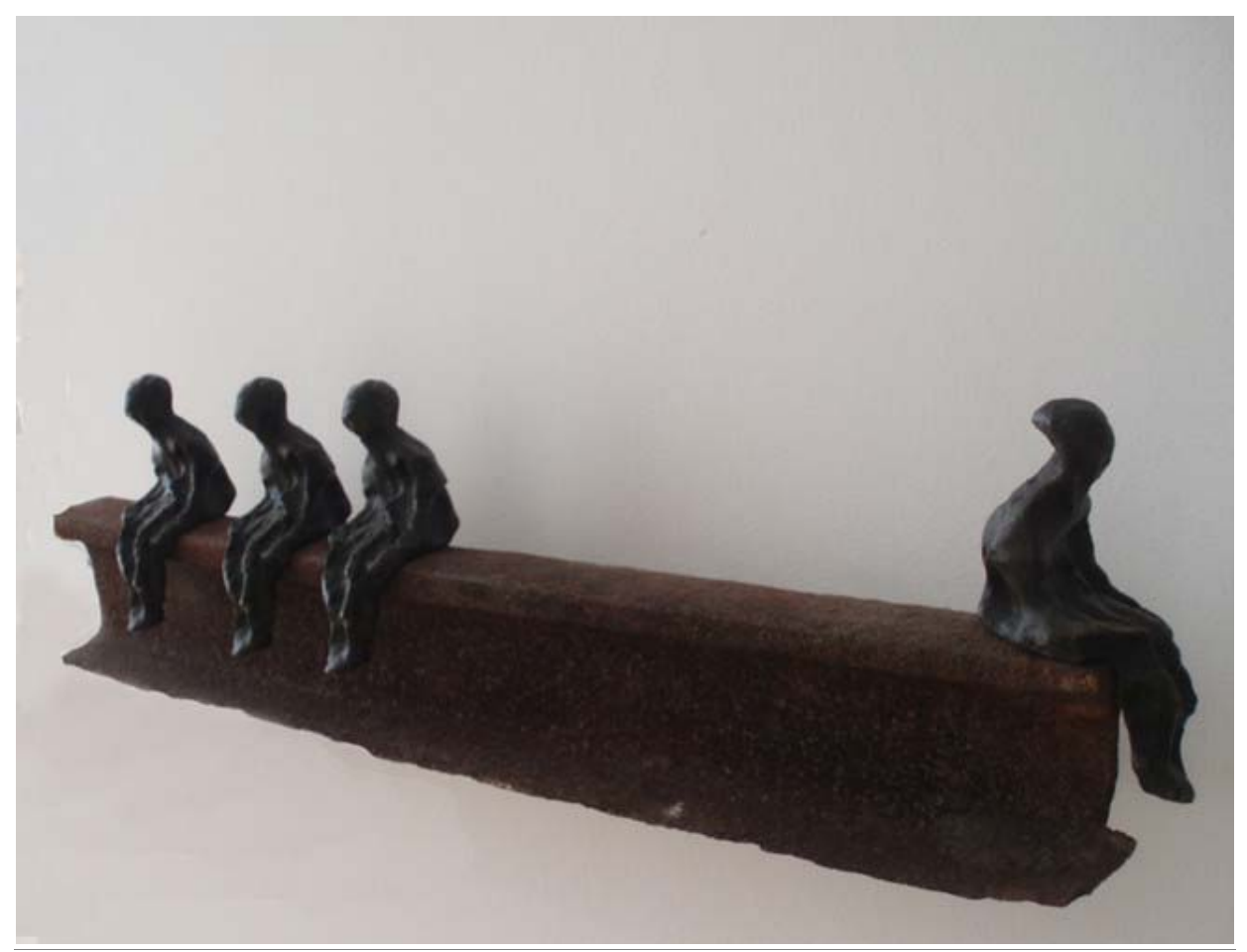

Figura 97: O Sentado. Escultura en bronce, 11x 6x 4cm. Edição de 50 peças (Fundição Teixeira Lopes)

\section{¿En qué consisten sus trabajos?}

Mi trabajo ha pasado por varias fases, pero son tres las más importantes. La primera fase, a partir de los años 1998/2000, que creé varios acuarios, o mejor, receptáculos de vidrio, donde introducía objetos como manos, brazos que sujetaban objetos,

297 En los años 1992-94, frecuentó el curso de design de interior, y en 2003 termina la licenciatura en Artes Plásticas/Dibujo en la Escola Superior Artística do Porto. Su primera exposición individual ha sido en 1994, Coarctações, en Vila Do Conde; en 1995, realizó la exposición, Outras mentes, outros corpos, en Vila do Conde; en 2004, Casulo da alma, en la Galería Asterisco, en Oporto; en 2006, Projecto "Casulo II", Galeria Símbolo, Oporto y Projecto "Casulo II", en Penafiel. Desde 1983 hasta 2007, ha realizado 33 exposiciones colectivas, tanto nacionales como internacionales, además de participar en varios eventos de creación artística. En 1995, ha ganado el Prémio de Escultura do "9 Encontro com Arte"- Maia y en 2002, el $2^{\circ}$ Prémio de artes plásticas, en Maia. Desde 2006, es propietario del espacio "João Pedro Rodrigues", que consiste en galería, oficina y atelier de artes Plásticas, en Oporto. Participó y realizó varios workshop de escultura, dibujo y pintura, además de haber sido docente de las asignaturas de dibujo, escultura, geometría y vitrinismo en varias instituciones de Oporto y otras ciudades del norte del país. 
plantas, vidrio, etc. Por ejemplo, el trabajo con más repercusión de esta fase, fue presentado en la galería del espacio Laberinto en Oporto.

Era una instalación constituida por un conjunto de cinco receptáculos con $77 \mathrm{~cm}$ de altura por 35 de largo, rectángulos dinámicos con estructura de hierro de un metro. Una de las piezas tenía una cabeza griega dividida por la mitad, donde había un globo de vidrio con un cerebro de vaca, introducidos dentro del agua, donde de la parte inferior se soltaba un gas que a su vez en la superficie se transformaba en fuego, retratando el pensamiento humano: la inspiración divina y humana. Con relación a este objeto, existían cuatro piezas más que completaban la idea: una segunda pieza con una planta, un pez que se alimentaba de la planta, la planta y el agua creaban, de esta forma, un ecosistema; una tercera pieza que tenía que ver con el arte, el pensamiento y la creatividad; una cuarta que tenía que ver con la informática y la inteligencia artificial; y una última pieza que tenía que ver con la polución. Todos los elementos de las obras estaban introducido dentro del agua, que significaba el liquido puro, que, al mismo tiempo, nos da la vida o nos puede destruir, que podrá igualarse a un envoltorio.

La segunda fase tiene como base la gran preocupación por la protección del medio ambiente, y que consiste en un trabajo más bidimensional. Uno de los puntos principales era el 'yo'.

En el presente, estoy en la tercera fase, con relación con el mundo infantil, que también se refleja en el 'yo'.

\section{¿Cuál es el peso de la vertiente conceptual en su obra?}

Mis trabajos siempre han tenido una vertiente humanista y moralista. En el caso concreto de la instalación en el Laberinto, he tenido una preocupación muy grande con la naturalaza y el espacio envolvente, y el impacto que el ser humano tuvo, tiene y tendrá en el futuro y la consciencia de eso. Para mi es fundamental pensar en la transformación, ciclo de vidas, etc.

El concepto de la obra es fundamental, no hago nada sin significado. El arte es como la literatura, la música, como el teatro el baile, tiene que hablar, es como ser una persona, hay que tener contenido para ser alguien.

\section{¿Proyecta y ejecuta sus obras?}

¡Yo las conceptualizo! Yo llevo seis meses o un año pensando en ellas y después unos meses concretándolas. No me gusta trabajar sobre presión, pero siempre ha sido así hasta hoy.

¿Firma las obras?

A veces firmo. Es una cuestión que tiene que ser pensada ante la obra. La obra es algo muy propio y en este sentido ya tiene su firma, siempre posible fírmala en el reverso, pero no me parece esencial. 
¿Cataloga todas sus obras?

Hago registro fotográfico. Antiguamente no daba tanta importancia al registro y por eso tengo algunos trabajos que no están documentados.

¿De qué materiales está constituida su obra?

Normalmente utilizo resina, fibra de vidrio, mucha agua, mucho hierro corrugado, mucho vidrio temperado, etc.

¿Dónde adquiere los materiales?

En fábricas o tiendas especializadas.

¿Aplica alguna protección a la obra?

Depende de la obra... funciona como en la pintura, dependiendo del resultado final aplico o no barniz, teniendo más atención al lado estético que protector.

Ahora una cosa que me gusta es la resistencia, siento que los trabajos deben ser resistentes, por eso, yo tengo mucho cuidado con los materiales.

¿Conoce bien los materiales con que trabaja?

Conozco y siento que es muy importante. Puedo decir que domino el material, y en ese sentido ya tengo mis fórmulas, para que no tenga sorpresas a la hora de concretar la obra.

¿Busca nuevos materiales para sus trabajos?

Si, pienso que es importante buscar nuevos materiales, para que no sea un caminar limitado sino una forma de avanzar en el trabajo.

¿Usted se preocupa con el deterioro de los materiales y de sus obras?

¡Si y no! ¡Depende! Me da pena mirar un trabajo perderse, pero, por otro lado es muy bueno observar el paso del tiempo en la obra, la obra entendida como objeto. El tiempo da a la obra una intensidad inmensa. Pero como obra de arte no se debe perder por el hecho de que es un registro de un tiempo o de alguien. Todavía si eso ocurre es porque es parte de las cosas, hay trabajos que ni duran días.

¿Su obra es efímera?

Algunas lo son. Hay obras que me dejan satisfecho cuando las muestro, y después desmonto y se acabó.

¿Dónde están ubicadas sus obras?

¡No soy internacional! Pero tengo obras por todo el país, Lisboa, Algarve, Porto, etc.

¿Cómo almacena sus obras? 
Algunas obras están en el jardín, otras embaladas, otras las dejo en el espacio donde tengo el atelier... están por ahí, y cuando las necesito para una exposición, las reparo, repinto, etc.

¿Y en cuanto a su exhibición?

Para mis trabajos soy un poco despreocupado.

¿Y el transporte de las obras como se realiza?

Normalmente soy yo que hago el transporte y tengo los cuidados básicos con las obras.

¿Ya alguna obra ha tenido que ser restaurada?

Si, iya restauré muchas obras! No sé... yo comprendo mi trabajo, el material... me gusta ser yo quien haga la restauración.

¿Entonces está de acuerdo con que sea el propio artista quien haga las restauraciones de sus obras?

Yo pienso que no tiene que ser el artista quien haga la restauración, dependiendo de los trabajos. Yo hago la restauración de mis obras porque conozco muy bien los materiales con que trabajo. Además, hago restauraciones para otros artistas, y siempre me preocupo mucho de los materiales y por eso antes de intervenir en la obra pregunto al artista para percibir al máximo la obra y el material constituyente.

¿Confiará sus obras para que fuesen restauradas?

Las dejaría si conociera el trabajo del restaurador.

¿Cómo ve la disciplina de la conservación/restauración?

Yo pienso que la restauración es importante. Hay obras que deben ser restauradas y otras no, y para esas obras que deben ser restauradas es importante que existe una disciplina específica. Además, acredito que todas las escuelas de arte deberían tener una disciplina con el objetivo de profundizar el conocimiento de los materiales, tener consciencia de las características de los diferentes materiales. Por ejemplo, por un lado, yo considero el paso del tiempo importante en las obras, por eso digo que hay obras que no deben ser restauradas, por otro lado, tengo obras que las quiero totalmente blancas, por eso cuando las expongo nuevamente tendrán de ser repintadas.

Entrevista realizada en Enero de 2008. 


\section{Rui Pedro Fonseca}

Porto, 1979298

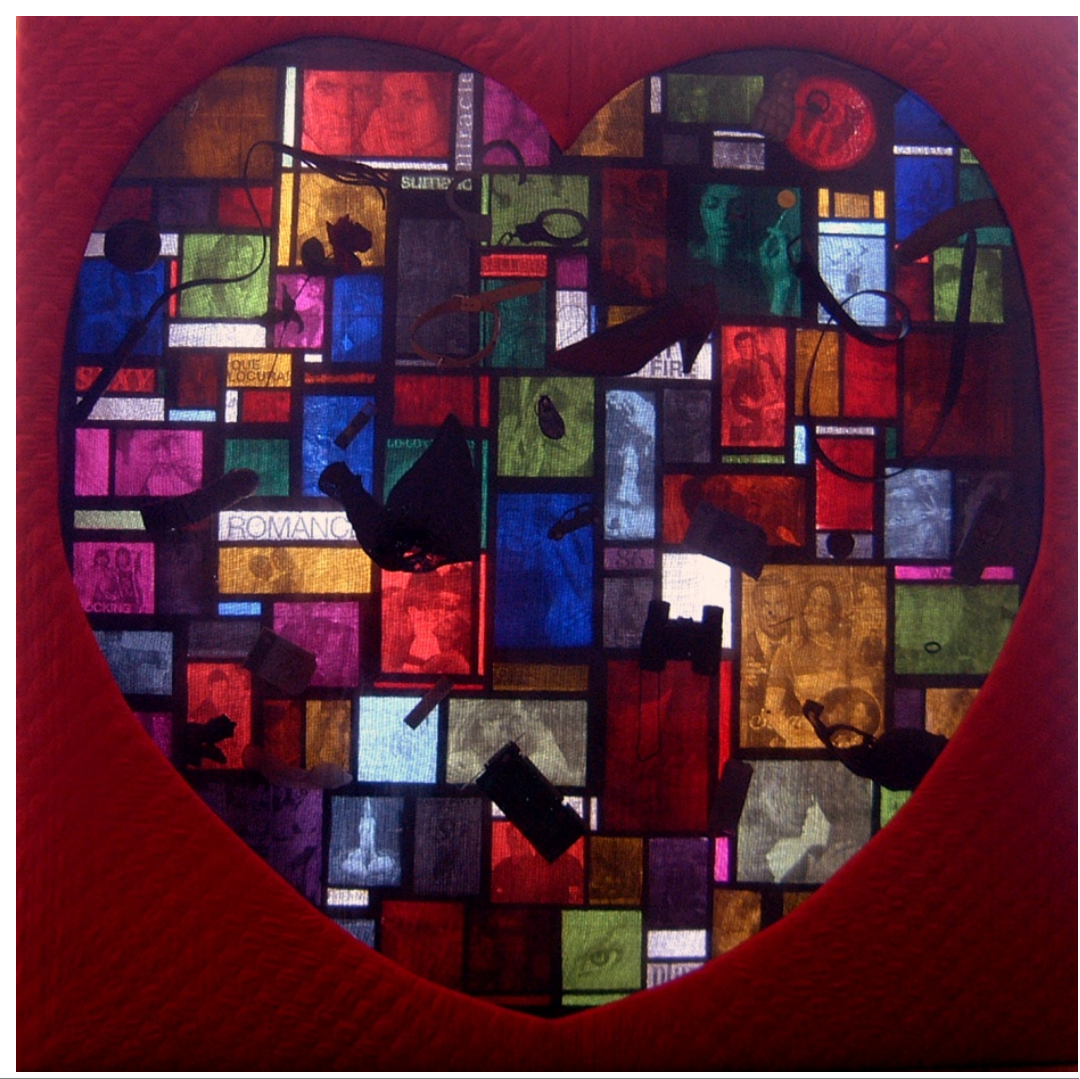

Figura 98: Love Shop, 2003. Caja de luz, 150x150x 34cm.

\section{¿En qué consiste su obra?}

En general, mi obra es un producto de reflexión, alusivo a cuestiones que suscitan interés de análisis y opinión. Resulta de la investigación que llevo realizando con

298 Licenciado, en 2003, en Artes Plásticas en la Escola Superior Artística do Porto y desde 2004 cursa el doctorado: Espacios de Representación y Lugar de la escultura, en la Universidad del País Vasco, Bilbao; en que su investigación está basada en Os Géneros no Meios de Comunicação: Representações Artísticas - anos 50 - 90. Realizó su primera exposición individual en 2002, Faith To Contents, Galería Arterisco, Oporto; en 2003, Projecto Re-Live, Igreja Envanjelica de Belomonte, Oporto, y la exposición, ...Me To My Love - Project, en la Galería Por Amor à Arte, Oporto; en 2004, ...The World Of Mr. Pat.- Project, en la Galería Por Amor à Arte, Oporto. Desde 2001 hasta 2003 ha realizado 11 exposiciones colectivas, tanto nacionales como internacionales. Y su obra se encuentra representada en varias colecciones privadas. 
alguna insistencia en las normativas culturales de representación de los géneros y a los procesos de estructuración de los valores reproductibles. Además, por su importancia, intento crear discusiones alrededor a otros temas como de orden política 0 ética.

\section{¿Proyecta y ejecuta sus obras?}

Todas las obras que idealizo son proyectadas y ejecutadas por mí, pero ya he recurrido a un técnico especializado para realizar alguno de los componentes. Es cierto que si fuera posible, lo ideal sería que cada parte del trabajo estuviera bajo la responsabilidad de técnicos especializados; si el presupuesto lo permitiese, estaban de esta forma garantizados los mejores acabados y materiales más adecuados para expresar de forma clara una determinada idea. Pero no siempre los presupuestos lo permiten.

¿Qué materiales normalmente emplea en sus obras?

Para las cajas de luz, recojo objetos específicos (objetos masculinos o femeninos), objetos infantiles, tejidos "masculinos o femeninos", imágenes en papel, placas de acrílico o vidrio, utilizo maderas, desde contra-chapados, placas de mdf o pino, barrotes de pino, acetatos, redes, bombillas, metales, pegamientos, tintas, barnices, etc.

\section{¿Cree que son materiales estables?}

Las tintas industriales y el MDF (tablero de fibra de densidad media), por ejemplo, cambian su aspecto, estabilidad y fuerza con el paso del tiempo. Un trabajo que realicé en 2003 - Icon, fue compleja su construcción: pesado, muy grande, con un sistema de iluminación, con un sistema de sustentación, con muchos materiales y al mismo tiempo muy frágil; lo que resultó fue que en cada transporte y montaje que hacía de la obra, surgían fallas, aunque, muy pequeñas. Si durante 2 años la obra fuese transportada para varias exposiciones, seguro que tendría de restaurarla algunas veces debido a la propia trepidación del transporte a que estaría sujeta. Si se quedase en una pared por cien años imagino que no sería suficiente cambiar únicamente las bombillas. Por ejemplo, el hecho de poseer placas acrílicas por delante, me hace pensar en un aumento de humedad en el interior de la caja.

¿Cuáles son las cualidades que valora en los materiales que emplea en sus obras?

En mi trabajo de escultura creo que existen dos categorías de materiales: una primera categoría, que está compuesta por los materiales estructurales que tienen esencialmente la función de sustentar la obra, y lo ideal es que sean resistentes al tiempo y a las propias condiciones que la obra suporta (como el calor de la luz interna, 0 la humedad en el exterior). Lo mejor sería que los materiales estructurales fuesen siempre los más resistentes al tiempo y las trepidaciones. 
En la otra categoría de materiales están los que considero de "estéticos-simbólicos". Son aquellos que quedan a la vista del público y que dan cuerpo al significado cuando son combinados entre sí. Por ejemplo, el tejido militar me interesa cuando quiero dar a una pieza escultórica un carácter militar, o alusivo al género masculino.

¿Dónde adquiere los materiales?

Los materiales estructurales son adquiridos en: carpinterías, tiendas de acrílicos, tiendas de electricidad, tiendas de tejidos, droguerías, tiendas de metales, etc. Los materiales "estéticos-simbólicos": en tiendas de juguetes, boutiques, súper-mercados, tiendas de tejidos, etc.

¿A usted le gusta experimentar nuevos materiales?

Me gustaría sobre todo experimentar materiales con más calidad, pudiendo, de partida, garantizar una mayor calidad en lo que respecta a la durabilidad y eficiencia conceptual de la obra.

¿Tiene por hábito pensar en cuestiones como: durabilidad, pureza, permanencia del color y compatibilidad de los materiales que utiliza en sus obras?

Principalmente me preocupo con la compatibilidad de los materiales en términos simbólicos. En cuanto a la durabilidad y pureza, dependen de muchos factores y confieso que los intento comprender al máximo, con la experiencia que voy acumulando.

¿Aplica alguna capa de protección en sus obras? ¿Cómo es el acabado?

Por ejemplo, en la obra Composition X (2) de 2004, fue aplicada sobre la madera una tinta brillante propia para madera. Esta tinta celulósica sólo adquiría determinado brillo si era aplicada sobre una sub-capa de barniz celulósico, o una sub-capa de la misma tinta. Opté por la utilización de la tinta como capa de preparación para proceder al acabado final brillante. Pero en gran parte de los trabajos no hay capas de protección, pues la madera de la obra es revestida con tejido.

¿Firma sus obras? ¿En qué lugar?

Nunca firmo. Algunas obras pueden tener mi nombre, pero nunca está accesible al espectador, puede estar por dentro en una viga o en la tapa de la caja, por bajo de un tejido, pero nunca de modo visible.

Entiendo que la "firma" puede ser un elemento perturbador en la composición de los elementos morfológicos de la obra, y por otro lado es un elemento individualizado que no tengo intención de utilizar. Si lo hiciese, sería un procedimiento paradoxal, ya que quiero que mi obra tenga un carácter esencialmente colectivo.

¿Cataloga sus obras? ¿Dónde se encuentran sus obras? 
Todas las obras están debidamente catalogadas e informatizadas. En cuanto a su ubicación, solamente tengo algunas obras en colecciones privadas.

¿Cuánto tiempo inverste en la ejecución de una obra? Y ¿Cuándo las considera terminadas?

Depende. Desde el proyecto a la total ejecución de una obra puedo tardar entre 30/45 horas de trabajo, desde la parte del dibujo hasta la ejecución. Hay otras 4 horas de investigación, además de escribir sobre la obra y su tema. Es en la fase de proyección cuando establezco los objetivos pretendidos.

¿Conoce el estado de conservación de sus obras? Y ¿Le preocupa esta cuestión?

Tengo una idea. Por lo menos pienso que, relativamente a las cajas de luz, les limpian el polvo y cambian las bombillas cuando es necesario.

Si las obras están conmigo me preocupo, pero a partir del momento en que son adquiridas, pienso que la preocupación es parte de quien realizó la adquisición, a quién, si me lo pide, doy todos los consejos de mantenimiento de la obra. Claro que me alegra saber que quien adquirió las obras tiene procedimientos de conservación, pues eso significa que las respetan.

¿Tiene conocimiento de algún tipo o nivel de deterioro en su obra?

Hace poco tiempo un coleccionista me ha dicho que «no sabía cambiar la bombilla de la caja de luz», y me ha pedido que lo hiciera. En este caso la obra se ha deteriorado temporalmente, una vez que quedó sin luz y dejó de ser la "obra" en su plenitud. Este caso no es preocupante, pues solamente se tiene que proceder al cambio de la bombilla.

Es más preocupante cuando, por ejemplo, un acrílico de una caja, o un vidrio se rompen, o un tornillo que sustenta la obra se suelta porque la madera empieza a deteriorarse con la humedad; 0 aún, que las placas de madera empiecen a ondular debido al calor de las bombillas. Son estas cuestiones las que en un futuro implicarán volver a montar la obra.

¿A qué cree que es resultado ese deterioro?

Calor, humedad, transporte con trepidación, etc.

¿Cómo almacena, exhibe y transporta sus obras?

En relación a las cajas, las almaceno y transporto siempre con aquel plástico de burbujas de aire, con la preocupación de que el traslado de la pieza se haga en la misma orientación y posición que cuando son expuestas.

Para exponer las cajas, es necesario estructurar con detalle un plano de exposición, pues son obras muy pesadas y que están sujetas por tornillos bien espesos, que posteriormente encajan en las argollas de acero que están por detrás de los trabajos. Después de sujetadas las obras hay que efectuar las conexiones eléctricas de 
acuerdo con el espacio, y por fín procurar jugar con la iluminación exterior de las obras.

¿Tiene algún tipo o recomendación para la conservación de sus obras?

Pienso que cada obra debe tener cuidados específicos de conservación. Una pintura al óleo sobre tela, ciertamente exige un principio de conservación distinto de una pintura al óleo sobre madera. Me parece que cambian los procedimientos de conservación conforme los materiales que componen y se conjugan en la obra.

Teniendo en cuenta el concepto de degradación, ¿considera usted sus obras efímeras?

En lo que respecta el concepto de degradación "natural" no considero mis obras (cajas) efímeras. ¡Pueden ser restauradas durante los próximos 200 años! Si no lo son, siempre quedan los registros fotográficos y los textos alusivos a sus temas. La propia condición de esculturas efímeras, implica, en mi perspectiva, una menor eficacia de su valor simbólico, ya que deja de existir la posibilidad de ser expuesta en espacios donde el público pueda acceder, además, deja de consistir en objeto de cambio económico, y por ello, se pierde su valor de mercado.

¿Cuál es su actitud frente a una intervención de conservación/restauración?

Tengo un profundo respeto por el proceso de restauración de una obra de arte, cuando el restaurador respeta integralmente las especificidades y características de la obra, lo que a veces puede ser una tarea muy difícil.

¿Le parece a usted necesaria la consulta previa del artista?

El restaurador que procure actuar con las mejores intenciones y cumplir con la recuperación original de la obra, puede siempre conseguirlo de la mejor forma. Podrá suceder como justificación, no poder hablar con el artista por cuestiones temporales, 0 aún no tener acceso a los elementos caracterizadores y fieles del aspecto original de la obra.

Pero en el caso que el restaurador viva en la misma época del artista, (y en un escenario ideal, con la posibilidad de acceder a los elementos caracterizadores de su obra) me parece importante la consulta al artista. Este último, representa la autoridad máxima y responsable de la concepción de la obra, la persona que le proporcionó y dio forma para que su existencia material adquiera valor simbólico y de mercado. El artista vivo, debe, si es necesario acompañar e intervenir en el proceso de restauración. Lo principal, es el respeto del contenido conceptual de la obra, lo que pasa necesariamente por respetar su aspecto y los materiales constituyentes.

¿Quién cree que debe realizar la restauración de las obras? 
Si es posible ambos, el artista como aquel que concibió el original, y el restaurador como técnico especializado. En la ausencia del artista, creo que el restaurador puede hacerlo con las adecuadas investigaciones.

¿Alguna obra suya ya ha sido restaurada?

$\mathrm{Si}$, una y por mí.

¿Le parece a usted útil pedir a los artistas una ficha explicativa con todos los datos técnicos sobre cada obra? ¿O le parece un proyecto irrealizable y pretencioso?

Más que pedir una ficha explicativa con todos los datos técnicos de la obra, me parece más útil pedir una ficha explicativa sobre el contenido conceptual. Hablo de una "ficha", o memoria descriptiva de la obra que debería ser patentada en simultáneo en una exposición y ser accesible al público. A pesar de no ser una medida suficiente para crear en el público mecanismos de discusión alrededor del arte y de sus valores. Pero quizás, podría ayudar a mejorar la integración de los públicos en la propia producción del arte, y en que las instituciones de arte convirtiesen sus espacios en locales más ricos en intercambios y discusiones culturales.

¿Cómo ve a los conservadores/restauradores?

Las funciones de los restauradores y conservadores son en cuanto a mi, muy complejas y extremamente exigentes. Y cuanto más cercana a los mercados centrales del arte la restauración se sitúa, más elevada es la responsabilidad del restaurador. Restaurar un "Van Gohg" es restaurar la plasticidad de la obra (a través de los mejores recursos tecnológicos y de los mejores profesionales) pero es también especular y aumentar su valor en la bolsa del mercado del arte. Añadida a este caso, por ejemplo, hay una enorme responsabilidad por parte del profesional de la restauración.

Entrevista realizada en marzo de 2006. 


\section{Índice de figuras}

- Figura 1: Isaque Pinheiro, Adanarg, 2000. Fotografia de Isaque Pinheiro. [p.37]

- Figura 2: João Pedro Rodrigues, instalación Duplicidades. Fuente: $<$ http://www.joaopedrorodrigues.com/>. [p.41]

- Figura 3: João Pedro Rodrigues, instalación $\operatorname{Ar} e$ terra. Fuente: $<$ http://www.joaopedrorodrigues.com/>. [p.41]

- Figuras 4, 5, 6 y 7: Isaque Pinheiro, detalles de la instalación MAE. Fotografias de Isaque Pinheiro. [p.46]

- Figura 8: Rui Pedro Fonseca, Cowlandcape, 2007. Fuente: <www.geocities.com/ruipedro _fonseca>. [p.51]

- Figura 9: Cildo Meireles, Inserciones en circuitos ideológicos: Proyecto Coca-Cola, 1970 Fuente: < http://www.artnexus.com/ArtistHome.aspx?Artistld=472>, 25.may.2009. [p.53]

- Figuras 10: El artista Isaque Pinheiro. Fuente: Fotografía de Joana Teixeira. [p.56]

- Figuras 11: El artista Isaque Pinheiro. Fuente: Fotografía de Joana Teixeira. [p.56]

- Figura 12: Leonardo da Vinci, La adoración de los magos. Fuente: <http://pt.wikipedia.org/wiki/Leornado_da_vinci>, en 3. Jul.2009. [p. 59]

- Figura 13: Katsushika Hokusai. South Wind at Clear Dawn (Gaifu kaisei). Fuente: <http://es.wikipedia.org/wiki/Katsushika_Hokusai>, en 25 may.09. [p.62]

- Figura 14: Van Gogh, detalle de Campos en Cordeville. Fuente: <http://es.wikipedia.org/wiki/Vincent_van_Gogh>, 25.may.2009. [p.65]

- Figura 15: Paul Gauguin, detalle de Jinete en la Playa. Fuente: $<$ http://es.wikipedia.org/wiki/Paul_Gauguin>, 25.mayo.2009. [p.65]

- Figura 16: Paul Cezanne, detalle de La montaña Sainte-Victoire. Fuente: <http://es.wikipedia.org/wiki/C\%C3\%A9zanne>, 25.may.2009. [p.65]

- Figura 17: La artista Ana Cardoso en su atelier. Fotografía de Ana Cardoso. [p.69]

- Figura 18: Isaque Pinheiro, instalación Amo-te, 2003. Fotografía de Isaque Pinheiro. [p.71]

- Figura 19: Isaque Pinheiro, instalación Hoje Amo-te, 2003. Fotografía de Isaque Pinheiro. [p.71]

- Figura 20: Isaque Pinheiro, escultura Só Ihe faltava falar, 2008. Fotografía de Isaque Pinheiro. [p.74]

- Figura 21: Ana Cardoso, Know everybody knows, 2005. Fotografía de Ana Cardoso. [p.78] 
- Figura 22: João Pedro Rodrigues, instalación Casulo II. Fuente: <http://www.joaopedrorodrigues.com/>. [p.81]

- Figura 23: Isaque Pinheiro, instalación Em cima da Terra debaixo do Céu, 2008. Fotografía de Isaque Pinheiro. [p.84]

- Figura 24: Fotografia de Lucio Fontana por Ugo Mulas. Fuente: < http://en.wikipedia.org/ wiki/Lucio_Fontana>, 25.may.2009. [p.90]

- Figura 25: Concepto Espacial, 1967. Fuente: <http://www.fondazionelucio fontana.it/galleria.html>, 25.may.2009. [p.90]

- Figura 26: Isaque Pinheiro, São Rosas Señor... São Rosas!, 2002. Fotografía de Isaque Pinheiro. [p.92]

- Figura 27: Rui Pedro Fonseca, instalación Adoro-te Avó... que Vivas Para Sempre!, 2002. Fotografía de Rui Pedro Fonseca. [p.95]

- Figuras 28: João Pedro Rodrigues en la ejecución del trabajo, Toca-me, 2007. Fuente: João Pedro Rodrigues. [p.98]

- Figuras 29: João Pedro Rodrigues,Toca-me, 2007. Fuente: $<$ <ttp://www.joaopedrorodrigues.com/>. [p.98]

- Figura 30: Isaque Pinheiro, instalación MAE (Más altas esferas), 2004. Fotografía de Isaque Pinheiro. [p.105]

- Figura 31: Isaque Pinheiro, detalle de Contacto, 2004. Fotografía de Isaque Pinheiro. [p.107]

- Figura 32: João Pedro Rodrigues, instalación Anemona. Fuente: $<$ <ttp://www.joaopedrorodrigues.com/>. [p.108]

- Figura 33: João Pedro Rodrigues, instalación Ele... Fuente: <http://www.joaopedrorodrigues.com/>. [p.108]

- Figura 34: Ana Cardoso, Back Away, 2004. Figura 43: Ana Cardoso, S/ título, 2006. Acrílico sobre tela, 8 piezas de 30x30cm (4 dípticos). [p.111]

- Figura 35: Rui Pedro Fonseca, Summer Delight, 2007. Fuente: <www.geocities.com/ruipedro _fonseca>. [p.116]

- Figura 36: Isaque Pinheiro, instalación S/Titulo, 2007. Fotografía de Isaque Pinheiro. [p.119]

- Figura 37: Isaque Pinheiro, detalle de S/Titulo, 2007. Fotografía de Isaque Pinheiro. [p.119]

- Figura 38: Ana Cardoso, Blind date, 2008. Fotografía de Ana Cardoso. [p.123]

- Figura 39: Isaque Pinheiro, escultura Planeta Piercing \#2, 2006. Fotografía de Isaque Pinheiro. [p.127]

- Figuras 40: Rui Pedro Fonseca, detalle de Serie X, 2002. Fotografía de Rui Pedro Fonseca. [p.132]

- Figuras 41: Rui Pedro Fonseca, instalación Serie X, 2002. Fotografía de Rui Pedro Fonseca. [p.132] 
- Figura 42: João Pedro Rodrigues, Performace perteneciente al Proyecto Casulo II, realizada en la Galeria Craesbeeck -Porto 2003. Fuente: <http://www.joaopedrorodrigues.com/>. [p.137]

- Figura 43: Ana Cardoso, S/ título, 2006. Fotografía de Ana Cardoso. [p.144]

- Figuras 44: Rui Pedro Fonseca, Performance 1Move. Fotografía de Rui Pedro Fonseca. [p.146]

- Figura 45: Fotografía del final de la performance. Fotografía de Rui Pedro Fonseca. [p.146]

- Figura 46: Isaque Pinheiro, instalación 1/3, 2007. Fotografía de Isaque Pinheiro. [p.149]

- Figura 47: Isaque Pinheiro, detalle de 1/3. Fotografía de Isaque Pinheiro. [p.149]

- Figura 48: Anselm Kiefer, The ridge way, 1983. Fuente: < http://www.artnet.com/Artists>, en 25.mayo.2009. [p.152]

- Figura 49: João Pedro Rodrigues, instalación S/Título. Fuente: $<$ <ttp://www.joaopedrorodrigues.com/>. [p.158]

- Figura 50: Exposición_de Ana Cardoso y co-autoria con Kasia Gubernat, My Life on sale, Caves Calém, Oporto. 2005. Fotografía de Joana Teixeira. [p.162]

- Figura 51: João Pedro Rodrigues en la inauguración de la exposición conmemorativa del $1^{0}$ cumpleaños de su galería, 2008. Fuente: <http://www.joaopedrorodrigues.com/>. [p.167]

- Figura 52: Rui Pedro Fonseca, instalación Mr Pat, 2005. Fotografía de Rui Pedro Fonseca. [p.170]

- Figura 53: Rui Pedro Fonseca, instalación Composition X, 2005. Fotografía de Rui Pedro Fonseca. [p.170]

- Figura 54: Ana Cardoso, Dreamland, 2008. Fotografía de Ana Cardoso. [p.175]

- Figura 55: Isaque Pinheiro, escultura Em cima da Terra debaixo do Céu, 2008. Fotografía de Isaque Pinheiro. [p.180]

- Figuras 56: Detalles de Em cima da Terra debaixo do Céu. Fotografía de Isaque Pinheiro. [p.180]

- Figuras 57: Detalles de Em cima da Terra debaixo do Céu. Fotografía de Isaque Pinheiro. [p.180]

- Figura 58: João Pedro Rodrigues, instalación en la playa de S/Titulo. Fuente: $<$ http://www.joaopedrorodrigues.com/>. [p.188]

- Figura 59: Ana Cardoso, Think Pink, 2007. Fotografía de Ana Cardoso. [p.192]

- Figura 60: Rui Pedro Fonseca, instalación Confort, 2004. Fotografía de Rui Pedro Fonseca. [p.194]

- Figura 61: Exposición individual de Ana Cardoso, Muito Pouco ou Nada. Galeria João Lagoa, Porto, 2006. Fotografía de Ana Cardoso. [p.205] 
- Figura 62: Isaque Pinheiro, instalación Sapatos de pedra e um horizonte que está sempre mais além, 2006. Fotografía de Isaque Pinheiro. [p.210]

- Figura 63: Detalle de Sapatos de pedra e um horizonte que está sempre mais além, 2006. Fotografía de Isaque Pinheiro. [p.210]

- Figura 64: Isaque Pinheiro, detalle de Sapatos de pedra e um horizonte que está sempre mais além, 2006. Fotografía de Isaque Pinheiro. [p.215]

- Figura 65: Ana Cardoso, Splash, 2008. Fotografía de Ana Cardoso. [p.218]

- Figura 66: Montaje de la exposición del proyecto Barbarybabyzation de Rui Pedro Fonseca. Oporto, 2007. Fuente: <www.geocities.com/ruipedro_fonseca>. [p.220]

· Figura 67: João Pedro Rodrigues, !!??!!!. Fuente: <http://www.joaopedrorodrigues.com/>. [p.224]

- Figura 68: João Pedro Rodrigues, Atolado. Fuente: <http://www.joaopedrorodrigues.com/>. [p.224]

- Figura 69: Ana Cardoso, Time over nothing, 2004. Fotografía de Ana Cardoso. [p.229]

- Figura 70: Rui Pedro Fonseca, cartel Mc Organs. Fuente: <www.geocities.com/ruipedro _fonseca>. [p.233]

- Figura 71: Ana Cardoso, Urban Chic, 2008. Fotografía de Ana Cardoso. [p.235]

- Figura 72: Ana Cardoso, How can I miss you, 2007. Fotografía de Ana Cardoso. [p.239]

- Figura 73: Isaque Pinheiro, instalación Apego a um lugar, 2007. Fotografía de Isaque Pinheiro. [p.241]

- Figura 74: Ana Cardoso, S/Titulo, Serie diarios, 2005. Fotografía de Ana Cardoso. [p.247]

- Figura 75: João Pedro Rodrigues, Banho no lago. Fuente: $<$ <ttp://www.joaopedrorodrigues.com/>. [p.253]

- Figura 76: João Pedro Rodrigues, Bipolar. Fuente: <http://www.joaopedrorodrigues.com/>. [p.253]

- Figura 77: Ana Cardoso, S/Titulo, Série diários, 2005. Fotografía de Ana Cardoso. [p.262]

- Figura 78: Gráfica 1, No artistas. [p.266]

- Figura 79: Gráfica 2, Categorias. [p.267]

- Figura 80: Gráfica 3, Firma. [p.268]

- Figura 81: Gráfica 4, Catalogación. [p.268]

- Figura 82: Gráfica 5, Ubicación. [p.269]

- Figura 83: Gráfica 6, Obra efímera. [p.270]

- Figura 84: Gráfica 7, Estado de conservación. [p.271]

- Figura 85: Gráfica 7a, Estado de conservación. [p.271]

- Figura 86: Gráfica 7b, Estado de conservación. [p.271]

- Figura 87 : Gráfica 8, Intervención conservación/restauración. [p.272] 
- Figura 88: Gráfica 8a, Intervención conservación/restauración. [p.272]

- Figura 89: Gráfica 9, Por quien. [p.273]

- Figura 90: Gráfica 10, Obra restaurada. [p.273]

- Figura 91: Gráfica 11, Conservación/restauración. [p.274]

- Figura 92: Isaque Pinheiro, detalle de la instalación Em cima da terra debaixo do céu, 2008. Fotografía de Isaque Pinheiro. [p.276]

- Figura 93: Ana Cardoso, Somam-se-me dias, 2006. Acrílico sobre tela, 150x150cm. Fotografía de Ana Cardoso. [p.320]

- Figura 94 y 95: Carlos Mesquita. Vistas de la exposición individual 'Paying my rent everyday in the tower of light', 2003. Galeria Fuga Pela Escada, Guimarães. Fuente:

$<$ http://www.fugapelaescada.com/>. [p.324]

- Figura 96: Isaque Pinhiero, instalación MAE (Mais Altas Esferas) o tempo não para, 2006. Dimensiones variables. Fotografía de Isaque Pinheiro. [p.331]

- Figura 97: João Pedro Rodrigues, O Sentado. Escultura en bronce, 11x 6x 4cm. Edição de 50 peças (Fundição Teixeira Lopes). Fuente: <http://www.joaopedrorodrigues.com/> [p.335]

- Figura 98: Rui Pedro Fonseca, Love Shop, 2003. Caja de luz, 150x150x 34cm. Fotografía de Rui Pedro Fonseca. [p.339] 
Este trabajo de investigación finalizó

en julio de 2009. 